\title{
Lokaal of nationaal? : het lokale karakter van de gemeenteraadsverkiezingen in Nederlandse gemeenten (1974-1990)
}

Citation for published version (APA):

van Tilburg, M. (1993). Lokaal of nationaal? : het lokale karakter van de gemeenteraadsverkiezingen in Nederlandse gemeenten (1974-1990). [Doctoral Thesis, Maastricht University]. VNG-Uitgeverij. https://doi.org/10.26481/dis.19930416mt

Document status and date:

Published: 01/01/1993

DOI:

10.26481/dis.19930416mt

Document Version:

Publisher's PDF, also known as Version of record

Please check the document version of this publication:

- A submitted manuscript is the version of the article upon submission and before peer-review. There can be important differences between the submitted version and the official published version of record.

People interested in the research are advised to contact the author for the final version of the publication, or visit the DOI to the publisher's website.

- The final author version and the galley proof are versions of the publication after peer review.

- The final published version features the final layout of the paper including the volume, issue and page numbers.

Link to publication

\footnotetext{
General rights rights.

- You may freely distribute the URL identifying the publication in the public portal. please follow below link for the End User Agreement:

www.umlib.nl/taverne-license

Take down policy

If you believe that this document breaches copyright please contact us at:

repository@maastrichtuniversity.nl

providing details and we will investigate your claim.
}

Copyright and moral rights for the publications made accessible in the public portal are retained by the authors and/or other copyright owners and it is a condition of accessing publications that users recognise and abide by the legal requirements associated with these

- Users may download and print one copy of any publication from the public portal for the purpose of private study or research.

- You may not further distribute the material or use it for any profit-making activity or commercial gain

If the publication is distributed under the terms of Article 25fa of the Dutch Copyright Act, indicated by the "Taverne" license above, 


\section{LOKAAL OF NATIONAAL?}

Het lokale karakter van de gemeenteraadsverkiezingen

in Nederlandse gemeenten (1974-1990) 


\section{LOKAAL OF NATIONAAL?}

Het lokale karakter van de gemeenteraadsverkiezingen in Nederlandse gemeenten (1974-1990)

\section{PROEFSCHRIFT}

ter verkrijging van de graad van doctor aan de Rijksuniversiteit Limburg te Maastricht, op gezag van de Rector Magnificus, Prof.mr. M.J. Cohen, volgens het besluit van het College van Dekanen, in het openbaar te verdedigen op vrijdag 16 april 1993 om 16.00 uur

door

MARIO FRANCISCLS JOSEPHUS VAN TILBURG 


\section{WOORD VOORAF}

Een afgerond proefschrift geeft al snel de indruk dat het beschreven onderzoek zonder veel problemen tot stand is gekomen. Iedere promovendus is zich echter bewust van de ongelijkmatige voortgang van het promotie-onderzoek, waarbij elke belangrijke inhoudelijke beslissing de grens vormt tussen een trage en een snelle voortgang van het onderzoek.

Zo is dit onderzoek gestart als een AIO-project binnen de Faculteit der Rechtsgeleerdheid van de Rijksuniversiteit Limburg met als titel: gemeenteraadsverkiezingen 1962-1974-1986. Het project maakte onderdeel uit van het onderzoeksprogramma van de Werkgroep lokale politiek van de Rijksuniversiteit Limburg, waarin naast de aandacht voor het functioneren van de Limburgse lokale politiek enig zicht nodig werd geacht op de landelijke electorale ontwikkelingen bij de gemeenteraadsverkiezingen in de periode 1962-1986. In de oorspronkelijke opzet zou op basis van de databestanden die ten grondslag lagen aan het promotie-onderzoek Partijpolitieke verhoudingen in Nederlandse gemeenten 1962-1974 van K.L.L.M. Dittrich, een overzicht worden gemaakt van de electorale ontwikkelingen bij de gemeenteraadsverkiezingen in de periode 1962-1974. Met name omdat deze bestanden niet meer beschikbaar waren, werd besloten het onderzoek te richten op de electorale ontwikkelingen in de periode 1974-1990. Tevens werd gekozen voor het centraal stellen van het lokale karakter van de gemeenteraadsverkiezingen.

Bij de keuze van dit thema is in het bijzonder de samenwerking met Pieter Tops van groot belang geweest. Ik ben hem zeer erkentelijk voor de inspirerende wijze waarop hij mij in deze beginfase heeft ondersteund. Van grote betekenis voor de totstandkoming van dit proefschrift was tevens de inhoudelijke inbreng van de leden van de Werkgroep lokale politiek. Hierbij wil ik met name Wim Kuiper en Huub Spoormans noemen. Van hun kennis en ervaring heb ik gedurende de gehele onderzoeksperiode dankbaar gebruik gemaakt. Ook dienen in dit kader Karl Dittrich en Arno Korsten genoemd te worden, die in hun leidende rol binnen respectievelijk de Werkgroep lokale politiek en het Centrum voor Euregionale, Lokale en Provinciale Studies (CELS) het mogelijk hebben gemaakt dat ik mij verder kon ontwikkelen in het wetenschappelijk onderzoek.

Het schrijven van een politicologisch onderzoek aan een juridische faculteit betekende in mijn geval onder meer dat een promotor aan een andere universiteit gezocht moest worden. Ik ben Galen Irwin zeer erkentelijk dat hij de moeilijke taak op zich genomen heeft om midden in de uitvoering van het project zowel mijn promotor als begeleider te worden. Dat vervolgens binnen twee jaar het manuscript van dit proefschrift kon worden afgerond, is met name aan zijn inbreng te danken.

Bij de uitvoering van het onderzoek heeft de operationele ondersteuning van verschillende personen een rol van betekenis gespeeld. Zo was Erik Knippenberg niet alleen een prettige collega, maar heeft hij tevens de eerste aanzet gegeven tot het overzicht van lokaal kiezersonderzoek in het laatste deel van dit proefschrift Marc Hermans wil ik bedanken voor zijn bijdrage aan het invoeren van gegevens in de computer, zodat ik in staat was om de verschillende analyses uit te voeren. Marie-Thérèse Velraad ben ik zeer erkentelijk voor haar redactionele ondersteuning en voor haar opbeurende woorden op momenten dat het nodig 
was. In de laatste afrondende fase hebben Ton Kapteijns en Gaston Moonen mijn taak verlicht door respectievelijk de algehele lay-out en de vertaling van de samenvatting op zich te $n \in m e n$. Bij het schrijven van het proefschrift bestaat de neiging om je geheel af te zonderen van je omgeving. Gelukkig hebben mijn mede-bestuursleden van de Aio Vereniging Rijksuniversiteit Limburg (AVRL) mij op een zeer prettige wijze hiervoor behoed. Dat alle AVRLrbestuursleden van het eerste uur reeds zijn gepromoveerd of binnenkort gaan promoveren, geeft aan dát een kritische beschouwing van het functioneren van het AIO-stelsel het schrijven var een proefschrift niet in de weg staat.

Het is al bijna een cliché om het dankwoord bij een proefschrift af te sluiten met het bedanken van de partner voor de morele ondersteuning. In heb mogen ervaren dat het een cliche is waarvan de inhoud in de praktijk volledig wordt waargemaakt. Vandaar dat ik Henny wil bedanken voor de eigen wijze waarop zij heeft bijgedragen aan de totstandkoming vạn dit proefschrift, zonder haar betekenis voor mij tot deze bijdrage te willen beperken. Dit proefschrift draag ik daarom aan haar op.

Den Haag, januari 1993

Mario van Tilburg 


\section{Promotor:}

Prof. G.A Irwin Ph.D. (RUL)

\section{Beoordelingscommissie:}

Prof. dr. A.F.A. Korsten, voorzitter (OU en RL)

Prof. dr. H. Daalder (RLiL)

Dr. KLLM. Dittrich (RL)

Dr. P.W. Tops (KUB)

Omslagontwerp : : Bertine Colsen

Lay-out :Ton Kapteijns

Vertaling samenvatting : Gaston Moonen

Van dit proefschrift is tevens een handelseditie verschenen bij de VNG-uitgeverij te 'sGravenhage. ISBN 9032271032 


\section{INHOUDSOPGAVE}

Woord vooraf

pagina

Lijst van tabellen $\quad$ XIII

I INLEIDING

1. Probleemstelling en onderzoeksopzet 3

$\begin{array}{ll}\text { Noten } & 13\end{array}$

2. Het formele kader en de variabelen. 15

2.1 Het formele kader.

2.2 Indeling van gemeenten. 20

2.3 Indeling van lijsten. 22

Noten 28

II DE ELECTORALE POSITIE VAN DE LOKALE EN NATIONALE LUJSTEN 31 $1974-1990$

3. Deelname aan de gemeenteraadsverkiezingen 33

3.1 Deelname van lokale en nationale lijsten. 34

3.2 Deelname van politieke stromingen $\quad 40$

3.3 Kiezers en deelname van lijsten $\quad 44$

3.4 Samenvattende conclusies 48

$\begin{array}{ll}\text { Noten } & 50\end{array}$

4. Verkiezingsresultaten 51

4.1 Verkiezingsresultaten van lokale en nationale lijsten 51

4.2 Verkiezingsresultaten van de politieke stromingen 55

4.3 Communale, nationale en gemengde gemeenten 60

$\begin{array}{ll}4.4 \text { Conclusies en nabeschouwing } & 63\end{array}$

$\begin{array}{ll}\text { Noten } & 66\end{array}$ 
III ANALYSE VAN PLAATSELJKE VERKIEZINGSUITSLAGEN 1974-1990 67

Inleiding

5. Analyse van de plaatselijke stempercentages.

5.1 Verschillen tussen lokale- en niet-lokale verkiezingen 71

5.2 De samenhang tussen de plaatselijke stempercentages $\quad 80$

5.3 De berekende lokale factor bij de plaatselijke stempercentages $\quad 85$

5.4 Gemeenten met uitzonderlijke stempercentages $\quad 100$

$\begin{array}{ll}5.5 \text { Samenvatting en conclusies } & 107\end{array}$

$\begin{array}{ll}\text { Noten } & 110\end{array}$

6. Analyse van de plaatselijke trends. 113

6.1 De spreiding van de plaatselijke trends $\quad 115$

$\begin{array}{ll}\text { 6.2 De samenhang tussen de plaatselijke trends } & 118\end{array}$

6.3 Het verschil tussen de plaatselijke en de landelijke trend 121

6.4 Gemeenten met uitzonderlijke trends $\quad 130$

6.5 Samenvatting en conclusies 139

Noten 142

IV KIEZERS EN DE GEMEENTERAADSVERKIEZINGEN 143

7. Lokaal kiezersonderzoek en lokaal kiesgedrag $\quad 145$

$\begin{array}{ll}7.1 \text { Kiesgedrag bij lokale en nationale verkiezingen } & 145\end{array}$

$\begin{array}{ll}\text { 7.2 Motieven voor kiesgedrag bij de gemeenteraadsverkiezingen } & 153\end{array}$

$\begin{array}{ll}\text { 7.3 Samenvattende conclusies } & 156\end{array}$

$\begin{array}{ll}\text { Noten } & 158\end{array}$

8. De betrokkenheid van kiezers bij de lokale politiek 161

8.1 Interesse in lokale en landelijke politiek $\quad 165$

$\begin{array}{ll}8.2 \text { Kennis van lokale en landelijke politiek } & 171\end{array}$

8.3 Politieke activiteiten op lokaal en landelijk niveau 174

8.4 Politiek (zelf)vertrouwen op lokaal en landelijk niveau 177

$\begin{array}{ll}8.5 \text { Belang van de lokale en landelijke politiek } & 183\end{array}$

8.6 De perceptie van het politieke karakter van de lokale politiek $\quad 185$

$\begin{array}{ll}\text { 8.7 Samenvattende conclusies } & 189\end{array}$

$\begin{array}{ll}\text { Noten } & 191\end{array}$

9. Samenvatting, conclusies en nabeschouwing 195

$\begin{array}{ll}9.1 \text { Samenvatting } & 195\end{array}$

$\begin{array}{lr}9.2 \text { Eindconclusies } & 199\end{array}$

9.3 Nabeschouwing 201

$\begin{array}{ll}\text { Noten } & 208\end{array}$ 
Bibliografie

Bijlagen.

1. Extra tabellen hoofdstuk 3

226

2. Extra tabellen hoofdstuk 4

230

3. Extra tabellen hoofdstuk 5

232

4. Extra tabellen hoofdstuk 6

235

5. Extra tabellen hoofdstuk 7

239

6. Overzicht gebruikt kiezersonderzoek 241

7. Overzicht verkiezingsuitslagen 1974-1990 247

8. Overzicht methoden deel III 248

Curriculum Vitae. 


\section{LIJST VAN TABELLEN}

2.1 Aantal raadsleden per categorie van gemeentegrootte.

2.2 Aantal gemeenten per provincie, 1974-1990.

2.3 Indeling van gemeenten naar gemeentegrootte, 1974-1990, in procenten.

3.1 Gemiddeld aantal deelnemende lokale en nationale lijsten per gemeente, 1974-1990.

3.2 Gemiddeld aantal deelnemende lokale en nationale lijsten per gemeente, per provincie, 1974 en 1990.

3.3 Gemiddeld aantal deelnemende lokale en nationale lijsten per gemeente, per categorie van gemeentegrootte, 1974 en 1990.

3.4 Percentage gemeenten waar lokale c.q. nationale lijsten aan de gemeenteraadsverkiezingen deelnemen, 1974-1990

3.5 Spreidingscijfers voor lokale c.q. nationale lijsten, per provincie, 1974 en 1990, in procenten.

3.6 Spreidingscijfers voor lokale c.q. nationale lijsten, per categorie van gemeentegrootte, 1974 en 1990, in procenten.

3.7 Spreidingscijfers voor de landelijke politieke stromingen, 1974-1990, in procenten.

3.8 Spreidingscijfers voor de landelijke politieke stromingen, per provincie, 1974 en 1990, in procenten.

3.9 Spreidingscijfers voor de landelijke politieke stromingen,per categorie van gemeentegrootte, 1974 en 1990, in procenten.

3.10 Percentage gemeenten waar alle drie landelijke politieke stromingen aan deverkiezingen deelnemen, 1974-1990.

3.11 Percentage kiezers dat op een lokale of een nationale lijst kon stemmen, 1974-1990.

3.12 Percentage kiezers dat niet op een lokale of een nationale lijst kon stemmen, per provincie, 1974 en 1990.

3.13 Percentage kiezers dat niet op een lokale of een nationale lijst kon stemmen, per categorie van gemeentegrootte, 1974 en 1990.

3.14 Percentage van de kiesgerechtigde bevolking naar deelname van het aantal politieke stromingen bij de gemeenteraadsverkiezingen in hun gemeente, 1974-1990.

3.15 Percentage kiezers dat niet op één van de politieke stromingen kon stemmen, 1974-1990

4.1 Percentage stemmen op de lokale en nationale lijsten 1974-1990.

4.2 Percentage stemmen op lokale lijsten, per provincie 1974-1990.

4.3 Percentage stemmen op lokale lijsten, voor Noord-Brabant en Limburg en de rest van Nederland 1974-1990.

4.4 De plaatselijke stempercentages in 1990 vergeleken met die in 1974, in Noord-Brabant en Limburg en de rest van Nederland, in percentages van het aantal gemeenten.

4.5 Percentage stemmen op lokale lijsten, per categorie van gemeentegrootte, 1974-1990.

4.6 Percentage stemmen op de drie politieke stromingen, 1974-1990. 
4.7 De plaatselijke stempercentages in 1990 vergeleken met die in 1974, voor de drie politieke stromingen, in percentages van het aantal gemeenten.

4.8 Percentage stemmen op de drie politieke stromingen, in Noord-Brabant, Limburg en de rest van Nederland, 1974-1990.

4.9 De plaatselijke stempercentages in 1990 vergeleken met die in 1974 , voor de drie politieke stromingen, in Noord-Brabant, Limburg en de rest van Nederland, in percentages van het aantal gemeenten.

4.10 Percentage stemmen op de drie politieke stromingen, per categorie van gemeentegrootte, 1974 en 1990.

4.11 Percentage communale, gemengde en nationale gemeenten, 1974-1990.

4.12 Vergelijking van de indeling van gemeenten in 1974 met die in 1990, in absolute aantallen en in percentages.

4.13 Percentage communale, gemengde en nationale gemeenten, per provincie, 1974 en 1990.

4.14 Percentage communale, gemengde en nationale gemeenten, per categorie van gemeentegrootte, 1974 en 1990.

5.1 Percentage stemmen op CDA, PvdA en VVD bij de gemeenteraads- dan wel Staten- of Tweede Kamerverkiezingen, 1974-1990.

5.2 Percentage gemeenten waar het CDA, de PvdA en de VVD aan de gemeenteraadsverkiezingen deelnamen en het percentage kiezers in deze gemeenten, 1974-1990.

5.3 Percentage stemmen in 1990 voor CDA, PvdA, VVD zoals gehaald in gemeenten waar men in 1974 wel c.q. niet heeft deelgenomen aan de gemeenteraadsverkiezingen.

5.4 Percentage stemmen op CDA, PvdA en VVD bij de lokale en niet-lokale verkiezingen in gemeenten waar de partijen hebben deelgenomen aan de gemeenteraadsverkiezingen, $1974-1990$.

5.5 De berekende invloed van de deelname van partijen aan de gemeenteraadsverkiezingen op het verschil tussen de landelijke uitslagen bij de lokale- en niet-lokale verkiezingen, in procenten, 1974-1990.

5.6 Percentage stemmen op de lokale lijsten, 1974-1990.

5.7 Opkou - mercentages bij lokale- en niet-lokale verkiezingen in de periode 1974-1990.

5.8 Plaatselijke stempercentages voor een partij bij gemeenteraads-, Staten- en Tweede Kamerverkiezingen in acht denkbeeldige gemeenten.

5.9 De correlatie tussen de plaatselijke uitslagen bij de lokale- en niet-lokale verkiezingen, 1974-1990.

5.10 De correlatie tussen de plaatselijke uitslagen bij lokale en niet-lokale verkiezingen voor gemeenten waar geen lokale lijsten aan de verkiezingen deelnemen, 1974-1990.

5.11 Voorbeeld van een berekening van het verschil tussen het landelijk stempercentage en de plaatselijke stempercentages bij een gemeenteraads- en een Tweede Kamerverkiezing in een achttal denkbeeldige gemeenten, in percentages.

5.12 De gemiddelde en mediane waarde van de lokale factor per partij per gemeenteraadsverkiezing, in stempercentages, 1974-1990.

5.13 Coëfficient of variation van de lokale factor per gemeenteraadsverkiezing, 1974-1990.

5.14 De gemidddelde en mediane waarde van de lokale factor per partij per gemeenteraadsverkiezing, in gemeenten zonder lokale lijsten, in stempercentages, 1974-1990. 
5.15 Coëfficient of variation van de lokale factor per gemeenteraadsverkiezing, in gemeenten zonder lokale lijsten, 1974-1990.

5.16 Voorbeeld van de berekening van de relatieve factor in een achttal denkbeeldige gemeenten, in percentages.

5.17 De gemiddelde en mediane waarde van de relatieve lokale factor per partij per gemeenteraadsverkiezing, in procenten, 1974-1990.

5.18 Coëfficient ofvariation van de relatieve lokale factor perpartij per gemeenteraadsverkiezing, 1974-1990.

5.19 De gemiddelde en mediane waarde van de relatieve lokale factor per partij per gemeenteraadsverkiezing, in gemeenten zonder lokale lijsten, in procenten, 1974-1990.

5.20 Coëfficient ofvariation van de relatieve lokale factor per partij per gemeenteraadsverkiezing, in gemeenten zonder lokale lijsten, 1974-1990.

5.21 De gemiddelde en mediane waarde van de (absolute) lokale factor per gemeente, in alle gemeenten en gemeenten zonder lokale lijsten, in stempercentages, 1974-1990.

5.22 Decoëfficient of variation van de (absolute) lokale factor per gemeente, in alle gemeenten en gemeenten zonder lokale lijsten, 1974-1990.

5.23 De gemiddelde en mediane waarde van de relatieve lokale factor per gemeente, in alle gemeenten en gemeenten zonder lokale lijsten, 1974-1990.

5.24 De coëfficient of variation van de relatieve lokale factor per gemeente, in alle gemeenten en gemeenten zonder lokale lijsten, 1974-1990.

5.25 Lijstvan gemeenten met uitzonderlijke plaatselijke stempercentages voor het CDA, 19741990.

5.26 Lijstvan gemeenten met uitzonderlijke plaatselijke stempercentages voor de PvdA, 19741990.

5.27 Lijst van gemeenten met uitzonderlijke plaatselijke stempercentages voor de VVD, 19741990.

5.28 Uitzonderlijke plaatselijke stempercentages ingedeeld naar verklaring, voor alle gemeenten inclusief gemeenten met lokale lijsten, 1974-1990.

6.1 Voorbeeld van de berekening van de plaatselijke trend in een achttal denkbeeldige gemeenten, in percentages.

6.2 De standaardafwijking van de plaatselijke trends bij de lokale-en niet-lokale verkiezingen, $1974-1990$.

6.3 De standaardafwijking van de plaatselijke trends bij de lokale-en niet-lokale verkiezingen voor gemeenten zonder lokale lijsten, 1974-1990.

6.4 De correlatie tussen de plaatselijke trends, voor lokale-en niet-lokale verkiezingen, 1974 1990.

6.5 De correlatie tussen de plaatselijke trends in gemeenten zonder lokale lijsten, voor lokale- en niet-lokale verkiezingen, 1974-1990.

6.6. Voorbeeld van het berekenen van de afwijking van de plaatselijke trends ten opzichte van de landelijke trend voor zowel lokale- als niet-lokale verkiezingen, in percentages.

6.7 De gemiddelde en mediane waarde van het verschil tussen de landelijke trend en de plaatselijke trends per partij en per lokale- en niet-lokale verkiezing, 1974-1990.

6.8 De coëfficient of variation van de afwijking van de plaatselijke trends, voor lokale- en nietlokale verkiezingen, 1974-1990. 
6.9 De gemiddelde en mediane waarde van het verschil tussen de landelijke trend en de plaatselijke trends per partij en per lokale- en niet-lokale verkiezing, in gemeenten zonder lokale lijsten, 1974-1980.

6.10 De coëfficient of variation van de afwijking van de plaatselijke trend, voor lokale- en nietlokale verkiezingen, in gemeenten zonder lokale lijsten, 1974-1990.

6.11 De gemiddelde en mediane waarde van het verschil tussen de landelijke trend en de plaatselijke trends per gemeente en per lokale-en niet-lokaleverkiezing, in alle gemeenten en gemeenten zonder lokale lijsten, 1974-1990.

6.12 De coëfficient of variation van de afwijking van de plaatselijke trend per gemeente, voor lokale en niet-lokale verkiezingen, in alle gemeenten en gemeenten zonder lokale lijsten, 1974-1990.

6.13 Lijst van gemeenten met uitzonderlijke plaatselijke trends voor het CDA bij de gemeenteraadsverkiezingen 1974-1990.

6.14 Lijst van gemeenten met uitzonderlijke plaatselijke trends voor het CDA bij de niet-lokale verkiezingen, 1974-1990.

6.15 Lijst van gemeenten met uitzonderlijke plaatselijke trends voor de PvdA bij de gemeenteraadsverkiezingen, 1974-1990.

6.16 Lijst van gemeenten met uitzonderlijke plaatselijke trends voor de PvaA bij de niet-lokale verkiezingen, 1974-1990.

6.17 Lijst van gemeenten met uitzonderlijke plaatselijke trends voor de VVD bij gemeenteraadsverkiezingen, 1974-1990.

6.18 Lijst van gemeenten met uitzonderlijke plaatselijke trends voor de VVD bij de niet-lokale verkiezingen, 1974-1990.

6.19 Uitzonderlijke trends bijde gemeenteraadsverkiezingen ingedeeld naarverklaringsgrond, voor alle gemeenten, 1978-1990.

7.1 Vergelijking van hetkiesgedrag tussen gemeenteraads-en de Tweede Kamerverkiezingen in 1986, met de Tweede Kamerverkiezingen als uitgangspunt.

7.2 Vergelijking van het kiesgedrag tussen gemeenteraads- en de Tweede Kamerverkiezingen in 1986, met de gemeenteraadsverkiezingen als uitgangspunt.

7.3 Percentage kiezers dat bij de Tweede Kamerverkiezingen hetzelfde stemt als bij de Tweede Kamerverkiezingen per gemeentegrootte, 1986.

7.4 Kiesgedrag Tweede Kamerverkiezingen gerelateerd aan de gemeenteraadsverkiezingen, zeven gemeenten, 1991, in percentages.

7.5 Invloed van lokale en landelijke politiek op de partijkeuze bijgemeenteraadsverkiezingen, 1982-1990, in percentages.

7.6 Invloed van lokale en landelijke politiek op de partijkeuze bijgemeenteraadsverkiezingen, per gemeentegrootte, 1982-1990, in percentages.

7.7 Percentage kiezers in zeven gemeenten dat een lokaal of nationaal motief geeft voor de partijkeuze bij de gemeenteraadsverkiezingen, en het percentage kiezers dat bij deze verkiezingen hetzelfde motief heeft als bij de verkiezingen voor de Tweede Kamer, 1991.

8.1 Opkomst bij gemeenteraads-en Tweede Kamerverkiezingen per urbanisatiegraad, 19821986 , in percentages.

8.2 Interesse in lokale en landelijke politiek, 1982-1990, in percentages. 
8.3 Percentage kiezers met zeer veel of tamelijk veel interesse in de lokale dan wel landelijke politiek, 1982-1990.

8.4 Percentage kiezers in een aantal gemeenten dat zegt interesse te hebben in problemen die de gemeentelijke of landelijke politiek betreffen.

8.5 Percentage (zeer of tamelijk) geinteresseerden in de lokale politiek of de politiek in zijn algemeenheid, in een tiental gemeenten, 1991.

8.6 Antwoord op de vraag of men een grotere interesse heeft in de lokale of de nationale politiek, in een tiental gemeenten, in percentages, 1989-1991.

8.7 Percentages inwoners (16-74-jarigen) dat vaak of (bijna) altijd binnenlands nieuws of nieuws over de eigen woonplaats leest in de krant, 1975-1987.

8.8 Percentage kiezers dat in een aantal gemeenten de naam van de burgemeester, minstens één wethouder, minstens éen raadslid of de grootste partij in de gemeenteraad weet, 1974.

8.9 Kennis van de naam van de burgemeester en minstens één wethouder in een aantal gemeenten, 1982-1990, in percentages.

8.10 Percentage inwoners (16-74-jarigen) dat zich ingezet heeft voor een (inter)nationale dan wel lokale kwestie, 1980-1989.

8.11 Percentage inwoners (16-74-jarigen) dat zich heeft ingezet voor een (inter) nationale of lokale kwestie in vijf denkbeeldige gemeenten, 1975-1986.

8.12 Percentage inwoners (16-74-jarigen) dat contact heeft gezocht met een minister of kamerlid dan wel burgemeester, wethouder of raadslid, 1973-1986.

8.13 Percentage kiezers in een aantal gemeenten dat zegt contact gehad te hebben met de burgemeester, een wethouder of een raadslid, 1974.

8.14 Percentage kiezers in een aantal gemeenten dat vertrouwen heeft in de gemeentelijke overheid, 1974.

8.15 Percentage inwoners (16-74-jarigen) datvan mening is dat men geen enkele invloed heeft op regering of gemeentelijk, 1975-1989.

8.16 Percentage inwoners (16-74-jarigen) die van mening zijn dat zij geen invloed kunnen uitoefenen op de regering of in de gemeentepolitiek, voor vijf denkbeeldige gemeenten, 1975-1986.

8.17 Percentage kiezers in zeven gemeenten dat het eens dan wel oneens is met de stelling dat men persoonlijk wel degelijk invloed kan uitoefenen op de poltiek van het gemeentebestuur/de regering, 1991.

8.18 Percentage inwoners (16-74-jarigen) dat van mening is dat Kamerleden en ministers dan wel gemeenteraadsleden niet veel geven om hun mening, 1975-1989.

8.19 Percentage inwoners (16-74-jarigen) dat van mening is dat Kamerleden en ministers dan wel gemeenteraadsleden niet veel geven om hun mening, voor vijf denkbeeldige gemeenten 1975-1986.

8.20 Percentage kiezers in zeven gemeenten dat het eens dan wel oneens is met de stelling dat gemeenteraadsleden dan wel kamerleden zich niet bekommeren om de mening van mensen zoals zij, 1991.

8.21 De ervaren invloed van beslissingen op lokaal of landelijke niveau op het dagelijkse leven, 1986 en 1987, in percentages.

8.22 De in zeven gemeenten ervaren invloed van beslissingen op lokaal en nationaal niveau op het dagelijkse leven, in 1991, in percentages. 
8.23 Percentage kiezers in zeven gemeenten dat het eens dan wel oneens is met de stelling dat er nauwelijks verschillen te zien zijn tussen de partijen die in de gemeenteraad/ Tweede Kamer vertegenwoordigd zijn, 1991.

8.24 Percentage kiezers in zeven gemeenten dat het eens dan wel oneens is met de stelling dat het eerlijk gezegd voor hen nooit zo duidelijk is waar het om gaat bij de gemeenteraadsverkiezingen, 1991.

8.25 Percentage kiezers in zeven gemeenten dat het eens dan wel oneens is met de stelling dat het voor hen niet uitmaakt welke partijen het in de gemeenteraad voor het zeggen hebben, 1991.

8.26 Percentage kiezers in zeven gemeenten dat het eens dan wel oneens is met de stelling dat de gemeentepolitiek een stuk interessanter zou worden als partijen hun onderlinge verschillen duidelijker zouden maken, 1991.

8.27 Percentage kiezers in zeven gemeenten dat het eens dan wel oneens is met de stelling dat voor het functioneren van de gemeente de kwaliteit van de wethouders belangrijker is dan hun politieke kleur, 1991.

Tabellen in de bijlagen

Bijlage 1 Extra tabellen hoofdstuk 3

3.2 Gemiddeld aantal deelnemende lokale en nationale lijsten, per provincie, 1978-1986.

3.3 Gemiddeld aantal deelnemende lokale en nationale lijsten, per categorie van gemeentegrootte, 1978-1986.

3.5 Spreidingscijfers voor lokale en nationale lijsten, per provincie, 1978-1986, in procenten.

3.6 Spreidingscijfers van lokale en nationale lijsten, per categorie van gemeentegrootte, 1978-1986, in procenten.

3.8 Spreidingscijfers voor de landelijke politieke stromingen, per provincie, 1978-1986, in procenten.

3.9 Spreidingscijfers voor de landelijke politieke stromingen, per categorie van gemeentegrootte, 1978-1986, in procenten.

Bijlage 2 Extra tabellen hoofdstuk 4

4.10 Percentage stemmen op de drie politieke stromingen, per categorievan gemeentegrootte, 1978-1986.

4.13 Percentage communale en nationale gemeenten, per provincie, 1978-1986.

4.14 Percentage communale en nationale gemeenten, per categorie van gemeentegrootte, $1978-1986$.

\section{Bijlage 3 Extra tabellen hoofdstuk 5}

1. Standaardafwijking van het gemiddelde stempercentage bij de lokale- en niet-lokale verkiezingen, 1974-1990.

2. Standaardafwijking van het gemiddelde stempercentage bij de lokale- en niet-lokale verkiezingen in gemeentenzonder lokale lijsten, 1974-1990.

3. Correlatie tussen de plaatselijke stempercentages bij lokale- en niet-lokale verkiezingen, per gemeentegrootte, 1974-1990. 
4. Correlatie tussen de plaatselijke stempercentages bij lokale- en niet-lokale verkiezingen in gemeenten zonder lokale lijsten, per gemeentegrootte, 1974-1990.

Bijlage 4 Extra tabellen hoofdstuk 6

1. Correlatie tussen de plaatselijke stempercentages bij twee opeenvolgende gemeenteraadsverkiezingen, per gemeentegrootte, 1974-1990.

2. Correlatie tussen de plaatselijke stempercentages bij twee opeenvolgende niet-lokale verkiezingen, per gemeentegrootte, 1974-1990.

3. Correlatie tussen de plaatselijke stempercentages bij twee opeenvolgende gemeenteraadsverkiezingen in gemeenten zonder lokale lijsten, per gemeentegrootte, 1974-1990.

4. Correlatie tussen de plaatselijke stempercentages bij twee opeenvolgende niet-lokale verkiezingen in gemeentenzonder lokale lijsten, per gemeentegrootte, 1974-1990.

Bijlage 5 Extra tabellen hoofdstuk 7

1. Vergelijking van het stemgedrag bij de gemeenteraads-en de TweedeKamerverkiezingen in 1986, met de Tweede Kamerverkiezingen als uitgangspunt.

2. Vergelijking van het stemgedrag bij de gemeenteraads- en de Tweede Kamerverkiezingen in 1986, met de gemeenteraadsverkiezingen als uitgangspunt.

Bijlage 7 Overzicht verkiezingsuitslagen 1974-1990

1. Percentage stemmen op politieke groeperingen en landelijke politieke stromingen bij de gemeenteraadsverkiezingen, 1974-1990. 
Deel 1

INLEIDING 

Hoofdstuk 1

\section{PROBLEEMSTELLING EN ONDERZOEKSOPZET}

\section{De discussie}

Verkiezingen spreken tot de verbeelding. Kiezers nemen het heft in handen terwijl politici buiten spel lijken te staan. Dit geldt voor alleverkiezingen. Maar met name bij de gemeenteraadsverkiezingen lijken politici ook nog op een andere manier buiten spel te staan. De vraag is immers in hoeverre kiezers bij de gemeenteraadsverkiezingen het gevoerde beleid, de kandidaten en de verkiezingsprogramma's van de verschillende plaatselijke politieke groeperingen beoordelen? Of anders gezegd, wordt bij deze verkiezingen niet over de hoofden van de lokale politici een oordeel geveld over het functioneren van de landelijke politici?

Dergelijke vragen waren in 1986 (en 1990) de achtergrond voor een discussie over de invloed van de landelijke politiek op de gemeenteraadsverkiezingen (Lieske, 1986; Scholten, 1986, 1987a, 1987b; Elzinga, 1986; Verplanke, 1986, 1990; Drijber, 1987; Hendrikx, 1987; Derksen, 1989a, 1990a, 1990b; van der Laan, 1990). De aanleiding tot deze discussie was vooral gelegen in de omstandigheid dat in dat jaar de gemeenteraadsverkiezingen ongeveer twee maanden vóór de Tweede Kamerverkiezingen plaatsvonden. Men veronderstelde dat door de nabijheid van de Tweede Kamerverkiezingen, de gemeenteraadsverkiezingen teveel gebruikt zouden worden als een graadmeter voor de landelijke politieke verhoudingen. Aldus stond niet de plaatselijke maar de landelijke politiek in de belangstelling. Dit zou de gemeenteraadsverkiezingen teveel nationaliseren. Daarmee werd aangeduid dat het kiesgedrag bij de gemeenteraadsverkiezingen in grote mate bepaald werd door de landelijke politiek. Als mogelijke oorzaken voor deze ontwikkeling werd onder meer de aandacht van de landelijke partijen en landelijke media voor de gemeenteraadsverkiezingen genoemd (Scholten, 1986, 1987a, 1987b; Drijber, 1987; Hendrikx, 1987; Derksen, 1990a). De landelijke partijen zouden de gemeenteraadsverkiezingen gebruiken als graadmeter voor de Tweede Kamerverkiezingen door nationale items en nationale kopstukken op de voorgrond te schuiven bij de campagnes voor de gemeenteraadsverkiezingen. De landelijke media, en met name de landelijke T.V., werd verweten dit proces te ondersteunen. Voorts werden ook de strakke partij-organisatie en de modelverkiezingsprogramma's van de landelijke partijen genoemd als factoren die van nadelige invloed waren op het lokale karakter van de gemeenteraadsverkiezingen (Scholten, 1986; Elzinga, 1986; Hendrikx, 1987; Derksen, 1990a). Als mogelijke oplossing werd vooral een spreiding van de gemeenteraadsverkiezingen voorgesteld (Drijber, 1987; Scholten, 1986, 1987a, 1987b; Elzinga, 1986; Derksen, 1990a). De gemeenteraadsverkiezingen zouden dus niet meer in alle gemeenten tegelijkertijd moeten plaatsvinden. Daardoor zou het voor de landelijke politici en in hun kielzog de landelijke media minder interessant worden om zich bezig te houden met de gemeenteraadsverkiezingen. De plaatselijke politiek zou daarmee meer aandacht krijgen, waardoor kiezers op grond van de plaatselijke politieke situatie hun stem zouden uitbrengen. Tevens werd een vrijwillige beperking van de activiteiten van de landelijke 
partijen en media genoemd als een bijdrage aan de vermindering van de invloed van de landelijke politiek op de gemeenteraadsverkiezingen (Scholten, 1986; Hendrikx, 1987). Hendrikx (1987) noemde tevens een vergroting van de gemeentelijke belangen van de burgers, door een vergroting van de financiële ruimte van de gemeenten, als een mogelijke versterking van het lokale karakter van de gemeenteraadsverkiezingen.

Bovenstaande discussie over de invloed van de landelijke politiek op de gemeenteraadsverkiezingen werd ingegeven door de omstandigheid dat in 1986 de gemeenteraadsverkiezingen twee maanden voor de. Tweede Kamerverkiezingen gepland waren. Wij kunnen ons echter afvragen of onafhankelijk van een dergelijke omstandigheid de invloed van de landelijke politiek op de gemeenteraadsverkiezingen groot is. Kortom, is het niet een 'normale' situatie dat plaatselijke factoren slechts een geringe rol spelen bij de partijkeuze bij de gemeenteraadsverkiezingen? Anders gezegd: hoe lokaal zijn de lokale verkiezingen?

Voordat wij ons met deze vraag gaan bezighouden, richten wij ons op een andere vraag, namelijk: waarom zouden wijhet mogelijke geringe lokale karaktervan de gemeenteraadsverkiezingen als een probleem moeten ervaren?

\section{Het probleem}

Of en in hoeverre een gering lokaal karakter van de gemeenteraadsverkiezingen als problematisch wordt ervaren, hangt af van hetgeen wij zien als de belangrijkste functie van verkiezingen. Een mogelijke invalshoek is dat het belang van de verkiezingen gelegen is in de mogelijkheid van burgers om hun volksvertegenwoordigers te vervangen. Aangezien de gemeenteraadsverkiezingen deze functie vervullen, is er vanuit deze invalshoek geen reden om het geringe lokale karakter van de gemeenteraadsverkiezingen.als een probleem te zien. Waarom kiezers bij de gemeenteraadsverkiezingen op een bepaalde partij stemmen en of er dus sprake is van een lokaal karakter van de gemeenteraadsverkiezingen is immers binnen deze benadering irrelevant.

Vanuit een minder strikte opvatting kunnen wij ons echter afvragen of de functie van verkiezingen niet meer inhoudt dan de mogelijkheid om volkvertegenwoordigers te vervangen. Moeten verkiezingen ook niet een inhoudelijke betekenis hebben, in de zin dat er een relatie is tussen het gedrag van kiezers (stemgedrag) en het gedrag van de lokale politici. Vanuit deze invalshoek wordt het geringe lokale karakter van de gemeenteraadsverkiezingen wel als een probleem ervaren. Immers, een gering lokaal karakter van de gemeenteraadsverkiezingen geeft immers aan dat kiezers bij hun partijkeuze zich nauwelijks laten leiden door plaatselijk (politieke) overwegingen. De kiezers geven geen oordeel over het gevoerde beleid of de beleidsvoomemens van de lokale politici. Of lokale politici het goed of slecht doen, maakt voor hun verkiezingsresultaat relatief weinig uit. Daarmee zijn de gemeenteraadsverkiezingen een betrekkelijk willekeurige interventie in de lokale politieke verhoudingen. In wezen hebben de kiczers de gekozen volksvertegenwoordigers daarmee een formeel en geen materieel mandaat gegeven om hun beleidsvoornemens ten uitvoer te brengen.

Deze ontkoppeling tussen het gedrag van kiezers en gekozenen kan op verschillende wijzen het functioneren van de lokale democratie beinvloeden. De al genoemde omstandigheid dat de gemeenteraadsverkiezingen geen uitdrukking zijn van de beoordeling van de kandidaten door de kiezers kan tevens het gedrag van de lokale politci beïnvloeden. Als men bij de 
gemeenteraadsverkiezingen niet wordt beloond of bestraft voor de prestaties in de afgelopen periode, vervalt voor een deel de noodzaak voor lokale politici om zich te richten naar de wensen van de burgers. De burgers bepalen immers toch niet hun partijkeuze op basis van de verrichtingen van de lokale politici. Natuurlijk zijn er grenzen aan het verontachtzamen van de wensen van de burgers. In een dergelijke situatie ontstaat de mogelijkheid dat een nieuwe (lokale) partij haar intrede doet in de lokale politiek, waardoor de positie van de bestaande partijen bedreigd wordt. In ieder geval gaat van het geringe lokale karakter van de gemeenteraadsverkiezingen geen stimulans uit om de afstand tussen politici en kiezers te verkleinen.

Gezien het voor de lokale politiek inhoudsloze karakter van de partijkeuze bij de gemeenteraadsverkiezingen, bestaat tevens het risico dat een groot deel van de kiezers op termijn geen stem meer gaan uitbrengen bij de gemeenteraadsverkiezingen. Daannee wordt duidelijk dat het gezag van de lokale overheid aan erosie onderhevig is. In ieder geval in de ogen van de betrokken politici, zoals de discussies over het functioneren van de lokale en provinciale politiek na de laatste verkiezingen met relatief lage opkomsten lieten zien. Al met al is er reden genoeg om nader te onderzoeken in hoeverre er sprake is van een lokaal karakter van de gemeenteraadsverkiezingen.

\section{De probleemstelling}

Opvallend in de discussie over het lokale karakter van de gemeenteraadsverkiezingen is dat er door bijna alle participanten vanuit wordt gegaan dat de gemeenteraadsverkiezingen bepaald worden door de landelijke politiek. Men vraagt zich niet af of dat een nieuw fenomeen is en of de invloed van de landelijke politiek altijd even groot is geweest. Wel gaat men er vanuit dat in 1986 de gemeenteraadsverkiezingen in relatief sterke mate werden beinvloed door de landelijke politiek, omdat de landelijke partijen in hun campagnes sterk hierop de nadruk legden in verband met de te volgen Tweede Kamerverkiezingen.

In dit onderzoek zullen wij trachten te bepalen in hoeverre de gemeenteraadsverkiezingen een eigen lokaal karakter dragen. De centrale probleemstelling luidt dan ook:

In hoeverre is er bij de gemeenteraadsverkiezingen in de periode 1974-1990 sprake van lokaal kiesgedrag dat karakteristiek is voor deze verkiezingen?

Uit de probleemstelling blijkt dat niet het stemgedrag maar het kiesgedrag bij de gemeenteraadsverkiezingen centraal staat. Dat betekent dat in deze studie alleen de keuze van de politieke groepering bij de gemeenteraadsverkiezingen centraal staat, en niet de keuze om wel of niet te gaan stemmen.

In principe zullen wijvia twee benaderingen het kiesgedrag bij de gemeenteraadsverkiezingen analy seren om het lokale karakter hiervan te achterhalen. De eerste betreft een onderzoek van het individuele kiesgedrag, terwijl de tweede benadering het kiesgedrag op geaggregeerd niveau (gemeentelijk, provinciaal, landelijk) onderzoekt. In het eerste geval is daarbij sprake van een secundaire analyse van kiezersonderzoek op het gebied van de lokale en nationale politiek in de periode 1974-1990. In het tweede geval betreft het verkiezingsonderzoek; een analyse van de verkiezingsuitslagen bij de lokale- en niet-lokale verkiezingen in de periode 1974-1990. Niezing (1966:65) spreekt in dit kader ook wel over het onderscheid tussen 
kiezersonderzoek en resultatenanalyse. Een nadeel van een resultatenanalyse is dat zij niet doordringt tot de subjectieve invloeden op het kiesgedrag omdat de individuele kiezer niet het uitgangspuntvan de analyse is. Daarmee samenhangend is het nadeel dat een resultatenanalyse op basis van de veranderingen in de verkiezingsresultaten alleen de netto-verschuivingen in het kiesgedrag waarneemt (Niezing, 1966:68). De werkelijke verschuivingen in het kiesgedrag zijn waarschijnlijk groter dan hetgeen in de verandering van de verkiezingsresultaten tot uitdrukking komt. Aangezien echter in de periode 1974-1990 relatief weinig kiezers onderzoek ten aanzien van de lokale politiek en de gemeenteraadsverkiezingen verricht is, is een analyse van de verkiezingsresultaten het enige bruikbare instrument om het lokale karakter van de gemeenteraadsverkiezingen te bepalen. Op basis van de zo verkregen gegevens en het beschikbare lokale kiezersonderzoek kunnen wij de ontwikkelingen in het lokale kiesgedrag bij de gemeenteraadsverkiezingen in de periode 1974-1990 in kaart brengen. Een tweede aspect van de centrale probleemstelling dat nadere uitleg behoeft, is de wijze waarop wij bepalen dat er sprake is van een lokaal kiesgedrag dat karakteristiek is voor de gemeenteraadsverkiezingen. Dat zal op drie verschillende manieren gebeuren, waarbij steeds het onderscheid tussen 'het lokale' en het 'nationale' centraal staat. Door dit onderscheid te hanteren wordt immers duidelijk in hoeverre het kiesgedrag bij de gemeenteraadsverkiezingen toe te wijzen is aan het specifieke lokale karakter van de gemeenteraadsverkiezingen. De eerste manier betreft het in kaart brengen van de electorale positie van de lokale en nationale lijsten. Vervolgens zullen wij door een analy se van de plaatselijkeverkiezingsuitslagen het lokale karakter van de gemeenteraadsverkiezingen bepalen. Tenslotte zal dit gebeuren door een analyse van (lokaal) kiezersonderzoek.

\section{Electorale positie lokale en nationale lijsten}

De eerste manier betreft een overzicht van de electorale ontwikkeling van de lokale en nationale lijsten bij de gemeenteraadsverkiezingen in de periode 1974-1990. Het lokale element bestaat uit de lokale lijsten en het nationale element uit de nationale lijsten. Uitgangspunt hierbij is dat de lokale lijsten per definitie alleen aan de gemeenteraadsverkiezingen deelnemen. Daarmee kunnen wij de verkiezingsresultaten van deze lijsten kenmerken als een uiting van lokaal kiesgedrag bij de gemeenteraadsverkiezingen. ${ }^{2} \mathrm{Wij}$ zullen zowel nagaan in hoeveel gemeenten de twee soorten lijsten in de periode 1974-1990 aan de gemeenteraadsverkiezingen deelnemen als de verkiezingsresultaten in deze gemeenten bepalen. In het verlengde van Dittrich (1978:215-218) zullen wij daarbij het begrip "lokalisering van de gemeenteraadsverkiezingen" gebruiken. De lokalisering van de gemeenteraadsverkiezingen kan bestaan uit verschillende aspecten. Zo spreken wij ten aanzien van de deelname van de gemeenteraadsverkiezingen onder meer van lokalisering van de gemeenteraadsverkiezingen als de lokale lijsten in relatief meer gemeenten aan de gemeenteraadsverkiezingen gaan deelnemen. Ten aanzien van de stempercentages is er sprake van een lokalisering van de gemeenteraadsverkiezingen als het totaal aan lokale lijsten een hoger stempercentage halen bij de gemeenteraadsverkiezingen in de onderzochte periode. Als dit daarentegen voor de nationale lijsten geldt, spreken wij van een nationalisering van de gemeenteraadsverkiezingen. Het meest uitgebreide onderzoek naar de verkiezingsuitslagen bij de gemeenteraadsverkiezingen in Nederlandse gemeenten is het onderzoek van Dittrich (1978) naar de partijpolitieke verhoudingen in Nederlandse gemeenten in de periode 1962-1974. In zijn onderzoek wordt veel aandacht geschonken aan de positie van de lokale lijsten bij de gemeenteraadsverkiezingen in de onderzochte periode. Mede naar aanleiding van het 
onderzoek van Dittrich zijn de laatste jaren verschillende onderzoeken verricht naar de electorale positie en het functioneren van de lokale lijsten. Zo heeft de Werkgroep Lokale Politiek van de Rijksuniversiteit Limburg in verschillende publicaties aandacht geschonken aan de electorale positie van de lokale lijsten in Limburg, vanouds een bolwerk van de lokale lijsten bij de gemeenteraadsverkiezingen. Dittrich (1983) heeft onder meer bericht over de opkomst van de landelijke lijsten en de aantasting van de positie van de lokale lijsten bij de herindelingsverkiezingen van 1981/1982 in Zuid-Limburg. Daarnaast is zowel in 1986 (Werkgroep Lokale Politiek RL) en 1990 (Korsten/Kuiper) aandacht geschonken aan de electorale ontwikkelingen bij de Limburgse gemeenteraadsverkiezingen. Voorts is bij de herindelingsverkiezingen in 1990 in Midden-Limburg de onverminderd sterke positie van de lokale lijsten in kaart gebracht (Kuiper e.a., 1991). Ook naar het functioneren van de lokale lijsten is onderzoek verricht. Uit een enquête onder lijsttrekkers bij de gemeenteraadsverkiezingen in 1981/1982 bleek onder meer de grote aandachtvan lijsttrekers van lokale lijsten voor hun ombudsfunctie (Kuiper, 1987). Ook uit een tweetal monografieën over de lokale politiek in een tweetal Limburgse gemeenten blijkt dat de lokale lijsten tot in de jaren zeventig een eigen manier van functioneren hadden (Custers, 1988; Boogers/Keizers, 1991). Voorts is gebleken dat in ieder geval tot 1974 in gemeenten met een meerderheid van raadsleden van lokale lijsten in de gemeenteraad minder afspiegelingscolleges worden gesloten dan in gemeenten waar gemeenteraadsleden van de landelijke partijen in de meerderheid zijn. Tevens blijken de steunpercentages voor de gekozen wethouders in de eerstgenoemde gemeenten geringer dan in de laatstgenoemde gemeenten (Tops, 1991:73-75). In de gemeenten met een meerderheid voor de lokale lijsten worden ook tussentijds relatief veel wethouders ontslagen, zoals uit een onderzoek van Knippenberg (1987) blijkt. Kortom, de positie en het functioneren van de lokale lijsten in Nederlandse gemeenten heeft in de afgelopen tien jaar sterker dan voorheen in de belangstelling gestaan.

\section{Analyse plaatselijke verkiezingsuitslagen}

De tweede manier om te bepalen of er sprake is van voor de gemeenteraadsverkiezingen karakteristiek lokaal kiesgedrag, bestaat uit een analyse van de plaatselijke verkiezing suitslagen voor de drie grootste landelijke partijen. ${ }^{3}$ De achtergrond voor dit accent op de analyse van de verkiezingsresultaten van landelijke partijen is dat kiezers ook op deze partijen kunnen stemmen op basis van puur plaatselijke overwegingen. Als dergelijke overwegingen zo sterk zijn dat zij leiden tot een ander kiesgedrag bij de gemeenteraadsverkiezingen in vergelijking met het kiesgedrag bij de niet-lokale verkiezingen, dan komen de netto-verschuivingen die hiervan het gevolg zijn tot uitdrukking door een vergelijking van de plaatselijk verkiezingsresultaten bij deze twee soorten verkiezingen.

Uitgangspunt hierbij is dat de plaatselijke verkiezingsresultaten bij de gemeenteraadsverkiezingen in essentie door drie factoren beheerst worden. In de eerste plaats speelt de samenstelling van het lokale electoraat een rol van betekenis. Met name de sociaal-economische klasse en godsdienstige overtuiging van het electoraat zijn hierbij van belang, al is de invloed van deze twee factoren sinds het midden van de jaren zestig verminderd (Irwin/van Holsteyn, 1989). In de tweede plaats gaan wij ervan uit dat de plaatselijke uitslagen bij de gemeenteraadsverkiezingen bepaald kunnen worden door allerlei lokale factoren. Wij kunnen daarbij denken aan allerlei lokale politieke gebeurtenissen en omstandigheden. Het kan hierbij niet alleen gaan om het gevoerde beleid in de afgelopen raadsperiode, maar tevens om het door de partijen gepresenteerde verkiezingsprogramma en de naar voren geschoven 
kandidaten. Ten aanzien van de kandidaten speelt niet alleen de partijpolitieke profilering een rol maar kunnen tevens meer persoonlijke kenmerken zoals de plaatselijke bekendheid van de kandidaat, de activiteiten van een kandidaat in de lokale gemeenschap en de woonplaats van de kandidaat in een bepaald deel van de gemeente van invloed zijn. In de derde plaats kunnen allerlei nationale factoren van invloed $z$ ijn op de verkiezingsresultaten van de gemeenteraadsverkiezingen. Dat is het geval als kiezers op basis van landelijke politieke ontwikkelingen op een partij stemmen bij de gemeenteraadsverkiezingen.

Het zal duidelijk zijn dat wij vooral geïnteresseerd zijn in het achterhalen van de betekenis van de verschillende lokale factoren, aangezien zij ons iets vertellen over het functioneren van de lokale politiek. Het is echter niet mogelijk om met de ons beschikbare gegevens de betekenis van de verschillende lokale factoren in kaart te brengen. Wel kunnen wij door een vergelijking van de plaatselijke verkiezingsuitslagen bij de gemeenteraadsverkiezingen met de plaatselijke verkiezingsuitslagen bij de niet-lokale verkiezingen de betekenis van de invloed van lokale factoren als geheel bepalen. Immers, bij de niet-lokale verkiezingen zijn zowel de samenstelling van het lokale electoraat als ook nationale factoren van invloed op de plaatselijke verkiezingsuitslagen, maar is het onwaarschijnlijk dat lokale politieke gebeurtenissen systematisch een rol van betekenis spelen bij de partijkeuze bij de Tweede Kamerverkiezingen.

In het verlengde van het verkiezingsonderzoek van Dittrich is in de jaren tachtig meer aandacht geschonken aan de analyse van electorale ontwikkelingen bij de gemeenteraadsverkiezingen in Nederlandse gemeenten. Naast de reeds genoemde activiteiten van de Werkgroep Lokale Politiek, waarbij met name de Limburgse ontwikkelingen centraal staan, is er tevens onderzoekverricht naar de plaatselijke verschillen in deverkiezingsuitslagen bij gemeenteraadsverkiezingen (Tops, 1990; van Tilburg/Tops, 1990). In het verlengde hiervan is ook het provinciale karakter van de verkiezingsuitslagen bij Statenverkiezingen in kaart gebracht (van Tilburg, 1991). Daarnaast is in onderzoek ook aandacht geschonken aan de betekenis en ontwikkeling van regionale verschillen in verkiezingsuitslagen (Aarts/ Horstman, 1991; Johnston e.a., 1983; Knippenberg/de Pater, 1988:166-168 en 192-194). Al deze onderzoeken kunnen beschouwd worden als een onderdeel van de politieke geografie, die wij in navolging van Dekker (1988:256) omschrijven als de wetenschap van de ruimtelijke achtergronden en de ruimtelijke neerslag van het politieke gedrag van individuen en collectiviteiten. Van Amersfoort e.a. (1981:13) gaan zelfs uit van de verkiezingsgeografie als apart onderdeel van de politieke geografie. Verkiezingsgeografie wordt daarbij omschreven als de analyse van lokale en regionale politieke verschillen met behulp van verkiezingsstatistieken. Ten aanzien van de buitenlandse literatuur kan ondermeer verwezen worden naar de studie van Taylor en Johnston (1979). Meer specifiek gericht op de lokale en regionale verschillen in de verkiezingsuitslagen bij lokale en regionale verkiezingen zijn de onderzoeken van Dolive (1976), Waller (1980), Denver (1986), Gallagher (1986), Håkansson (1986) en Miller (1988).

\section{Lokaal kiezersonderzoek}

De derde manier om hetvoor de gemeenteraadsverkiezingen karakteristieke lokale kiesgedrag te bepalen, bestaat uit de secundaire analyse van lokaal kiezersonderzoek in deze periode. Het betreft enquêtes waarbij vragen zijn gesteld die betrekking hebben op het kiesgedrag bij de gemeenteraadsverkiezingen. In deze studie wordt allereerst, als indicatievoor lokaal kiesgedrag, nagegaan in hoeverre bij de verkiezingen in 1986 de kiezers op dezelfde partij hebben gestemd bij de gemeenteraads- en Tweede Kamerverkiezingen in dat jaar. Tevens wordt voor de 
gemeenteraadsverkiezingen in de periode 1982-1990 nagegaan in hoeverre de lokale en de landelijke politiek bepalend is geweest voor de partijkeuze bij de gemeenteraadsverkiezingen. Vervolgens zal de betrokkenheid van burgers bij de lokale politiek geschetst worden. In feite valt dit overzicht van de betrokkenheid van kiezers bij de lokale politiek buiten de centrale probleemstelling. Deze richt zich immers alleen op het kiesgedrag en niet op de politieke betrokkenheid van kiezers. Wij brengen de betrokkenheid bij de lokale politiek desondanks in kaart, omdat daarmee een beeld ontstaat van de mogelijke oorzaken van het geconstateerde lokale karakter van de gemeenteraadsverkiezingen.

In vergelijking met nationaal kiezersonderzoek, is er weinig kiezersonderzoek verricht naar aanleiding van de gemeenteraadsverkiezingen. Er bestaat dan ook, analoog aan het Nationaal Kiezersonderzoek (NKO), geen Lokaal Kiezersonderzoek bij de gemeenteraadsverkiezingen. Het bestaande lokale kiezersonderzoek is in de regel beperkt tot een aantal grote gemeenten. Zo is in 1973 in een twaalftal (middel) grote gemeenten een onderzoek verricht naar de relatie overheid-burgers (Veldkamp Marktonderzoek, 1974). Een dergelijk onderzoek in een zevental grote gemeenten is in 1991 verricht (Onderzoeksgroep lokale democratie, 1991). Daarnaast zijn sporadisch enkele (beperkte) enquêtes in verschillende, meest grote gemeenten verricht. Zie voor een overzicht hiervan bijlage 6 . Naast deze gegevens zijn soms ook gegevens van landelijke enquêtes bruikbaar. Dit geldt met name voor de door het Sociaal en Cultureel Planbureau verzamelde gegevens in het kadervan het onderzoek "culturele veranderingen in Nederland". Zie ook het hierop gebaseerde onderzoek van Dekker (1988) naar de lokale en regionale verscheidenheid in politieke cultuur in Nederland. Ten aanzien van de buitenlandse literatuur kan als onderzoek naar de betrokkenheid van burgers bij de lokale politiek de uitgebreide studie van Miller (1988) voor Groot-Brittannië genoemd worden.

De periode

Uit het bovenstaande blijkt al dat deze studie zich zal beperken tot de analyse van de periode 1974-1990. Alle gemeenteraadsverkiezingen in deze periode zullen bij de analyse betrokken worden. De keuze om bij de gemeenteraadsverkiezingen van 1974 te beginnen is bepaald door een tweetal overwegingen.

In de eerste plaats werd in 1974 een periode van grote politieke en maatschappelijke veranderingen afgesloten. De Nederlandse samenleving werd tot in het begin van de jaren zestig gekenmerkt door een sterke verzuiling. Iedere zuil werd vertegenwoordigd door éen of meerdere politieke partijen. De politieke verhoudingen waren daardoor ook betrekkelijk stabiel (Daalder, 1974; Lijphart, 1979). De tweede helft van de jaren zestig werd echter gekenmerkt door onrust. Er ontstonden protestbewegingen zoals Provo en de Kabouters, die $z$ ich richtten op andere waarden en normen. Men eiste een democratisering van de samenleving en verzette zich tegen de bestaande machtsverhoudingen. Tevens werden nieuwe politieke groeperingen zoals D'66 en de PPR opgericht. Binnen de PvdA was er sprake van de opkomst van Nieuw Links die deze partij van binnenuit probeerde te vernieıwen. Als reactie. hierop onstond DS'70. Tegelijkertijd bleken de godsdienstige kiezers steeds minder automatisch te stemmen op de partij van hun zuil. Deze deconfessionalisering zorgde voor een instabiele politieke situatie omdat de (godsdienstige) partijen niet meer vanzelfsprekend om een vast electoraat konden rekenen (Andeweg, 1982; van der Eijk/Niemöller, 1983; Dittrich e.a., 1986). De drie grote confessionale partijen (KVP, ARP, CHU) verloren bij de Tweede: 
Kamerverkiezingen in de periode 1962-1972 dan ook een groot deel van hun aanhang. In 1963 haalde zij bij de Tweede Kamerverkiezingen nog 49,2 procent van de stemmen terwijl dat in 1972 was teruggelopen naar 31,3 procent. Mede op grond hiervan besloten deze partijen de mogelijkheden voor een fusie te onderzoeken, hetgeen in 1978 formeel leidde tot de oprichting van het:CDA. In 1974 nam al in veel gemeenten een gezamenlijke lijst van KVP, ARP en CHU aan de gemeenteraadsverkiezingen deel. Met de oprichting van het CDA werd een periode van grote veranderingen in Nederlandse politiek afgesloten.

Een tweede reden om het onderzoek te beginnen met de gemeenteraadsverkiezingen van 1974 is dat wij hiermee aansluiten bij het onderzoek van Dittrich (1978) naar de electorale ontwikkelingen bij de gemeenteraadsverkiezingen in de periode 1962-1974. Zo kunnen wij nagaan of de door Dittrich in deze periode geconstateerde lokaliserings- en nationaliserings tendensen zich voortzetten na 1974.

\section{De onderzoeksgegevens}

De gegevens die bij dit onderzoek gebruikt worden zijn afkomstig van het databestand van het Centrum voor Euregionale, Lokale en Provinciale Studies (CELS) van de Open Üniversiteit en de Rijksuniversiteit Limburg.

In de bestanden van de gemeenteraadsverkiezingen zijn voor elke gemeente gegevens verzameld over het totaal aantal kiesgerechtigden, het totaal aantal uitgebrachte stemmen, het aantal geldige en ongeldige stemmen, het aantal stemmen per deelnemende partij, per partij het aantal stemmen op andere dan de eerste kandidaat (tot aan 1982), per partij het aantal mannelijke en vrouwelijke gemeenteraadsleden. Deze gegevens zijn gebaseerd op de officiële statistieken van de gemeenteraadsverkiezingen van het CBS (Statisticken der verkiezingen 1974, 1978, 1982, 1986, gemeenteraden). De gegevens van 1990 zijn gebaseerd op de door het ANP verzamelde Officieuze uitslagen van de gemeenteraadsverkiezingen op 21 maan 1990. Wat betreft de indeling van de lijsten in lokale en nationale lijsten zijn de CBS-gegevens in enkele gevallen aangepast. Daarbij is in 1974 gebruik gemaakt van de door de gemeenten aan het CBS verstrekte gegevens. Op basis van de indeling in lokale en nationale lijsten in 1974 en 1990 , waarbij dus de basisgegevens van de gemeenten gebruikt zijn, zijn de CBS-gegevens van 1978, 1982 en 1986 voor zover nodig aangepast. Wat de gemeenteraadsverkiezingen in Limburg betreft, is hierbij tevens gebruik gemaakt van het door de voormalige Werkgroep Lokale Politiek van de Rijksuniversiteit Limburg verzamelde materiaal.

Wat de niet-lokale verkiezingen betreft, maken wij gebruik van zowel de uitslagen van Provinciale Staten- als Tweede Kamerverkiezingen. De gebruikte plaatselijke verkiezingsuitslagen zijn gebaseerd op de officiële statistieken van het CBS (Statistieken der verkiezingen 1982, 1986, 1989, Tweede Kamer der Staten-Generaal en Statistieken der verkiezingen 1974 en 1978, Provinciale Staten). De gebruikte gegevens van de plaatselijke uitslagen van de Provinciale Statenverkiezingen in 1974 en 1978 en van de Tweede Kamerverkiezingen in 1982, 1986 en 1989 bestaan per gemeente uit het aantal geldig uitgebrachte stemmen en de door het CDA, PvdA en VVD behaalde aantal stemmen."

Aangezien het CDA bij de Tweede Kamerverkiezingen van 1972 in het geheel niet en bij de gemeenteraadsverkiezingen van 1974 slechts in beperkte mate aan deze verkiezingen deelnam, zijn hierbij de gezamenlijke stemmen van KVP, ARP en CHU (en CDA) opgeteld. 
Naast bovenstaande gegevens is in het bestand ook opgenomen in welke provincie elke gemeente gelegen is. Op basis hiervan zijn in het eerste deel van deze studie analyses per provincie uitgevoerd. Hetzelfde is gedaan voor de grootte van de gemeenten. De grootte van de gemeenten is bepaald op grond van het aantal zetels in de gemeenteraad van elke gemeente. Het aantal gemeenteraadszetels in een gemeente wordt immers bepaald door het aantal inwoners in de gemeente. Dit betekent onder meer dat door een afname of toename van het aantal inwoners in een gemeente het aantal raadszetels verhoogd dan wel verlaagd kan worden. Een gemeente kan op grond hiervan in de loop van de onderzochte periode in een andere categorie van gemeentegrootte worden ingedeeld. Met name de herindeling van gemeenten heeft bijgedragen aan dergelijke veranderingen. ${ }^{5}$

\section{De indeling}

Deze studie bestaat uit verschillende delen waarbij in elk deel een aspect van het lokale kiesgedrag aan de orde komt. Allereerst zal echter, om de plaats van de gemeenteraadsverkiezingen in het Nederlandse staatsbestel te bepalen, in het tweede hoofdstuk het formele kader waarbinnen de gemeenteraadsverkiezingen plaatsvinden geschetst worden. Tevens zullen de verschillende variabelen gepresenteerd worden, gebaseerd op een territoriale en politieke indeling.

Vervolgens zal in deel 2 van deze studie de positie van de lokale en nationale lijsten in de periode 1974-1990 aan de orde worden gesteld. In hoofdstuk drie zal aandacht geschonken worden aan de deelname van nationale en lokale lijsten aan de gemeenteraadsverkiezingen. Vervolgens zullen in hoofdstuk 4 de verkiezingsresultaten van de verschillende lijsten aan bod komen. Op basis hiervan zullen de gemeenten worden ingedeeld, waardoor de ontwikkelingen in de electorale positie van de lokale en nationale lijsten op gemeente-niveau in kaart worden gebracht.

In deel 3 staat de analyse van de plaatselijke verkiezingsuitslagen van de gemeenteraadsverkiezingen centraal. Zoals reeds gesteld zullen wij ons daarbij beperken tot een analyse van de uitslagen van het CDA, de PvdA en de VVD. In de twee hoofdstukken van dit deel zullen de plaatselijke verkiezingsuitslagen van de gemeenteraads- en Tweede Kamerverkiezingen geanalyseerd worden om via een vergelijking van de resultaten de invloed van lokale factoren op de gemeenteraadsverkiezingen te bepalen. In hoofdstuk 5 zullen overigens de plaatselijke stempercentages geanalyseerd worden terwijl in hoofdstuk 6 de plaatselijke trends van de drie partijen bij de gemeenteraadsverkiezingen onderzocht worden.

In het vierde deel van deze studie zal op basis van een een secundaire analyse van lokaal kiezersonderzoek een beeld worden geschetst van de betrokkenheid van kiezers bij de lokale politiek. Allereerst $z$ al in hoofdstuk 7 worden nagegaan in hoeverre kiezers bij de gemeenteraadsverkiezingen van 1986 bij de gemeenteraads- en Tweede Kamerverkiezingen op dezelfde partij hebben gestemd. Ook de motieven van de kiezers voor hun partijkeuze bij de gemeenteraadsverkiezingen in de periode $1982-1990$ komen in dit hoofdstuk aan bod. Om een beter beeld te krijgen van de oorzaken van het geconstateerde lokale karakter van de gemeenteraadsverkiezingen zal vervolgens in hoofdstuk 8 de betrokkenheid van de burgers bij de lokale en nationale politiek in beeld worden gebracht.

Tenslotte zal in hoofdstuk 9 een samenvatting worden gegeven van de belangrijkste bevindingen, op basis waarvan een conclusie wordt getrokken omtrent het lokale karakter van de 
gemeenteraadsverkiezingen in de periode 1974-1990. Tevens zal naar aanleiding van de discussie omtrent de mogelijke versterking van het lokale karakter van de gemeenteraadsverkiezingen, een aantal voorstellen in deze richting aan de orde worden gesteld. 


\section{NOTEN}

'Bijdeze analyse moeten wij ons realiseren dat met het beoordelen van het functioneren van de lokale democratie gezien het geringe lokale karakter van de gemeenteraadsverkiezingen, slechts én aspect van de relatie burgeroverheid aan de orde is, namelijk die tussen kjezers en gekozenen. In wezen beoordelen wij dus het functioneren van de lokale democratie in het licht van de functie van de verkiezingen. Dit betekent dat op men grond van deze analyse geen algemeen negatief oordeel kan vellen over de relatie tussen burger en overheid en daarmee het functioneren van de lokale democratie.

2Zelfs al zou een deel van de kiezers op de lokale lijsten op deze lijsten stemmen uit onvrede met de politiek van één of meerdere landelijke partijen, dan nog is een stem voor de lokale lijsten te bestempelen als een uiting van lokaal kiesgedrag. Immers, in de meeste gemeenten heeft men de mogelijkheid om op een andere landelijke partij te stemmen. Daarnaast heeft men in alle gemeenten de mogelijkheid om in het geheel niet of blancote stemmen. Deze twee mogelijkheden staan natuurlijk ook open voor kiezers die bij de gemeenteraadsverkiezingen alleen een keuze kunnen maken uit lokale lijsten. Zoals uit hoofdstuk drie zal blijken heeft slechts een zeer klein percentage kiezers in de periode 1974-1990 niet de mogelijkheid hun stem uit te brengen op een nationale partij. ${ }^{3}$ De reden om deze analyse te beperken tot de drie grootste landelijke partijen (CDA, PvdA, VVD) is dat alleen deze partijen in meer dan 50 procent van de gemeenten hebben deelgenomen aan de gemeenteraadsverkiezingen in de onderzochte periode (1974-1990).

'De reden voor het gebruik van de uitslagen van de Provinciale Statenverkiezingen in 1974 en 1978 en de Tweede Kamerverkiezingen in 1982, 1986 en 1989 is dat deze verkiezingen kort vóbr of na de gemeenteraadsverkiezingen hebben plaatsgevonden. In verband met de analyse van de plaatselijke verkiezingsuitslagen is dit van belang. Voor een nadere uitleg verwijs ik naar de inleiding bij deel drie van dit proefschrift.

s In hoofdstuk 2 wordt nader ingegaan op de indeling van gemeenten in provincies en categorieiin van gemeentegrootte en de veranderingen hierin in de periode 1974-1990. 



\section{HET FORMELE KADER EN DE VARIABELEN}

De uitslagen van de gemeenteraadsverkiezingen worden indirect beïnvloed door het formele kader waarbinnen deze verkiezingen plaatsvinden. Zo bepaalt bijvoorbeeld de Kieswet welke ingezetenen van Nederland aan de gemeenteraadsverkiezingen mogen meedoen. Het kiesstelsel en de omvang van de gemeenteraad bepalen het percentage stemmen dat men moet halen om een zetel in de gemeenteraad te bemachtigen. Dit is voor de lijsten en partijen een factor van betekenis bij de beslissing om wel of niet aan de gemeenteraadsverkiezingen deel te nemen. Hiermee wordt duidelijk dat het van belang is om het formele kader waarbinnen de gemeenteraadsverkiezingen plaats vinden, in kaart te brengen.

Voor een analyse van de gemeenteraadsverkiezingen is tevens van belang dat via verschillende variabelen electorale ontwikkelingen zichtbaar worden gemaakt. Het gaat hierbij met name om een indeling van gemeenten en een indeling van de lijsten die aan de gemeenteraadsverkiezingen deelnemen.

\subsection{Het formele kader.}

Nederland wordt wel omschreven als een gedecentraliseerde eenheidsstaat. Daarmee wordt aangegeven dat enerzijds van de gemeenten verwacht wordt dat zij als onderdeel van een groter geheel het beleid van dat groter geheel mee helpen uitvoeren, terwijl er anderszijds ruimte is voor het formuleren van een eigen beleid. In de praktijk blijkt daarmee de beleidsvrijheid van de gemeenten niet erg groot. Daarbij is onder meer van belang dat steeds meer taken door de centrale overheid zijn overgenomen, waarbij de gemeenten opgedragen wordt deze in medebewind uit te voeren (SCP, 1987:29-61). Ook de eigen financiële ruimte van de gemeenten is betrekkelijk gering, zeker als wij deze vergelijken met de ons omliggende landen (Havermans, 1989:93-113). Daar staat tegenover dat de laatste tijd, onder meer in het kader van de sociale vernieuwing, de vergroting van de gemeentelijke beleidsruimte sterk in de belangstelling is gekomen. ${ }^{1}$ Tevens moeten wij ons in navolging van Toonen realiseren dat als uitgegaan wordt van een minder formeel-juridische benadering en er meer aandacht geschonken wordt aan beleidsprocessen waarbij meerdere overheden zijn betrokken, de feitelijke mogelijkheden van gemeenten groter zijn dan verwacht (Toonen, 1987:175-176).

\section{Positie gemeenteraad}

Ook ten aanzien van de positie van de gemeenteraad binnen de gemeentelijke organisatie, kunnen wij constateren dat deze in de loop van de tijd verzwakt is (Hoekema, 1978: Elzinga, 1979; van Vugt, 1987; Ringeling, 1989). Formeel is de raad het hoogste orgaan van de gemeente. Immers, volgens artikel 125 van de Grondwet staat de gemeenteraad aan het hoofd van de gemeente. Tevens bepaalt artikel 148 van de Gemeentewet dat alle bevoegdheden die 
niet aan andere gemeentelijke organen zijn opgedragen, tot de gemeenteraad behoren. In de praktijk blijkt echter de invloed van de gemeenteraad niet zo groot als men op grond van de wettelijke bepalingen zou verwachten. Ringeling noemt terverklaring vier factoren (Ringeling, 1989:121-124). In de eerste plaats komt naar zijn mening de gemeenteraad betrekkelijk laat in het besluitvormingsproces aan bod. In de tweede plaats beschikken de gemeenteraden niet altijd over voldoende informatie, aangezien zij geen ambtelijk apparaat tot hun beschikking hebben. Tevens speelt hierbij een rol dat de meeste raadsleden als amateurs hun tijd niet volledig aan het raadswerk kunnen besteden. Als derde verklaring noemt Ringeling de sterke positie van het College van $B \& W$ ten opzichte van de gemeenteraad. De wethouders, die onderdeel blijven van hun fracties, zijn in de regel veel eerder en intensiever betrokken bij de gemeentelijke beslissingen. Tevens speelt in dit kader een rol dat slechts de minderheid van de gemeenteraad die niet in het College vertegenwoordigd is, daadwerkelijk het College van $B \& W$ controleert. De meerderheid van de raad die wel in het College vertegenwoordigd is, zal immers in de regel het College willen ondersteunen en in stand willen houden. Als vierde factor wordt de toenemende specialisatie op beleidsterreinen door de gemeenteraadsleden genoemd. De intensiteit van het lokaal bestuur zou hen daartoe dwingen. Het gevolg is echter dat het overzicht over het gemeentelijk beleid voor een deel verloren gaat, hetgeen de positie van de gemeenteraad als beleidsbepalend orgaan verzwakt. Concluderend kunnen wij stellen dat de positie van de gemeenteraad in de besluitvorming minder sterk is dan men op grond van de wet zou vermoeden. Vooral het College van $B \& W$ neemt binnen de gemeente een sterke positie in. Door deze ontwikkelingen lijkt het belang van de gemeenteraadsverkiezingen verminderd te zijn. Immers, de invloed van de hierbij gekozen gemeenteraadsleden is minder dan men van de leden van het hoogste gemeentelijke orgaan zou verwachten. Daar staat tegenover dat wethouders door en uit de gemeenteraad gekozen worden. Succesvolle gemeenteraadsverkiezingen zijn daarmee de eerste stap op weg naar een wethouderschap, en daarmee naar een sterke positie in het gemeentelijk beleidsvormingsproces.

\section{Tijdstip van de gemeenteraadsverkiezingen}

De gemeenteraad wordt volgens artikel 129 lid 4 van de Grondwet gekozen voor een periode van 4 jaar, 'behoudens bij de wet te bepalen uitzonderingen.' Uit artikel F1 en J1 van de Kieswet volgt dat de verkiezingen plaatsvinden op de woensdag in de periode 2-8 maart van het jaar van de verkiezingen. Ook als in hetzelfde jaar Tweede Kamerverkiezingen plaatsvinden, worden de gemeenteraadsverkiezingen in maart gehouden. De Tweede Kamerverkiezingen verschuiven dan naar mei. ${ }^{2}$ Het bovenstaande geeft aan dat spreiding van de gemeenteraadsverkiezingen volgens de huidige wettelijke bepalingen niet mogelijk is. Zoals in hoofdstuk 1 is aangegeven, is de spreiding van de gemeenteraadsverkiezingen één van de voorstellen geweest terversterking van het lokale karaktervan de gemeenteraadsverkiezingen. Dit voorstel is bij de behandeling van de wijziging van de Kieswet door de Tweede Kamer besproken en afgekeurd. De regering en met haar het parlement betwijfelde of een dergelijke spreiding zou leiden tot een verkleining van de landelijke invloed op de gemeenteraadsverkiezingen. Immers, de landelijke politici zouden zich bij de gemeenteraadsverkiezingen op een kleiner gebied kunnen concentreren. Tevens werd de verwachting uitgesproken dat de spreiding van de gemeenteraadsverkiezingen gepaard zou gaan met een daling van de opkomst. Daarnaast werden enkele praktische bezwaren naar voren gebracht. ${ }^{3} \mathrm{Op}$ basis hiervan werd een voorstel om een onderzoek te houden naar de mogelijke effecten van een 
spreiding van de gemeenteraadsverkiezingen met ruime meerderheid in de Tweede Kamer verworpen. ${ }^{4}$

\section{Aantal raadsleden}

Zoals reeds in de inleiding gesteld, is het ledental van de gemeenteraad, naast het kiesstelsel, van belang voor de hoogte van het stempercentage dat lijsten en partijen moeten halen om één of meerdere zetels in de gemeenteraad te bemachtigen. In gemeenten met minder dan 3.000 inwoners bestaat de gemeenteraad uit zeven leden, terwijl in de gemeenten met meer dan 200.000 inwoners 45 raadsleden gekozen kunnen worden. ${ }^{5}$ Tabel 2.1 geeft een overzicht van het aantal raadsleden per categorie van gemeentegrootte.

Tabel 2.1: Aantal raadsleden per categorie van gemeentegrootte.

\begin{tabular}{lrrr}
\hline beneden & 3.000 inwoners & & 7 raadsleden \\
van & 3.000 tot en met & 6.000 & 11 \\
& 6.001 & 10.000 & 13 \\
10.001 & 15.000 & 15 \\
15.001 & 20.000 & 17 \\
20.001 & 25.000 & 19 \\
25.001 & 30.000 & 21 \\
& 30.001 & 35.000 & 23 \\
& 35.001 & 40.000 & 25 \\
& 40.001 & 45.000 & 27 \\
& 45.001 & 50.000 & 29 \\
& 50.001 & 60.000 & 31 \\
& 60.001 & 70.000 & 33 \\
& 70.001 & 80.000 & 35 \\
boven & 80.001 & 100.000 & 37 \\
& 100.001 & 200.000 & 39 \\
& 200.000 & & 45
\end{tabular}

Bron: Artikel 5 Gemeentewet.

Door het geringe aantal raadsleden is in de kleinste gemeenten een relatief hoog stempercentage nodig om een gemeenteraadszetel te halen. In de onderzochte periode is het in deze gemeenten nooit voorgekomen dat een partij met minder dan 10,7 procent van de stemmen een gemeenteraadszetel haalde. ${ }^{6}$ In de grootste gemeenten (meer dan 100.000 inwoners) is in de praktijk echter al $2,1 \%$ van de stemmen genoeg voor een gemeenteraadszetel. Hoe groter de gemeente wordt, des te lager is dus het relatieve aantal benodigde stemmen voor het behalen van één zetel.

Daarentegen is in een kleine gemeente het absolute aantal stemmen voor éen zetel veel geringer is dan in een grote gemeente. Zo behaalde bij de gemeenteraadsverikiezingen van 1974 in Katwoude de lijst Berger met 20 stemmen een gemeenteraadszetel. In de gemeente Amsterdam had D'66 bij dezelfde verkiezingen 7278 stemmen nodig voor één zetel. Vanuit dit oogpunt lijkt het dus eenvoudiger om in Katwoude een gemeenteraadszetel te halen, omdat het nu eenmaal gemakkelijker is om 20 mensen van je gelijk te overtuigen dan 7278 mensen. Dergelijke overwegingen kunnen van invloed zijn op de keuze om wel of niet als lijst aan de 
gemeenteraadsverkiezingen deel te nemen. In hoeverre de gemeentegrootte van belang is voor het aantal deelnemende lijsten zal in hoofdstuk drie aan de orde komen.

\section{Kuiesrecht}

Een ander belangrijk onderdeel van het formele kader waarbinnen de gemeenteraadsverkiezingen plaatsvinden is het actief en passief kiesrecht bij dezeverkiezingen. Om te mogen stemmen (actief kiesrecht) moet men aan de volgende eisen voldoen:

- Het Nederlanderschap (art. 129 GW). Daarnaast hebben buitenlanders sinds 1986 bij de gemeenteraadsverkiezingen stemrecht indien zij ten minste vijfjaren onafgebroken ingezetene van Nederland zijn geweest?;

- Op grond van artikel 54 lid 1 (GW) en artikel 129 lid 1 (GW) dient men 18 jaar of ouder te zijn; - Men dient niet uitgesloten te zijn van het kiesrecht op grond van de in artikel 54 lid 2 (GW) in artikel 129 lid 1 (GW) geformuleerde uitsluitingsgronden. ${ }^{8}$

Voor de verkiesbaarheid (passief kiesrecht) gelden dezelfde voorwaarden als voor het actief kiesrecht. In dit kader is het van belang dat de Kieswet niet uitgaat van het bestaan van politieke partijen. Er wordt enkel gesproken over 'groeperingen'. Wel worden aan groeperingen enkele eisen gesteld als voorwaarde voor deelname. Zo moeten groeperingen aan een aantal eisen voldoen, willen zij de naam van hun lijst boven het stembiljet zetten. Landelijke of provinciale partijen moeten daarvoor toestemming hebben van de eigen partij-organisatie als deze partij tenminste provinciaal of landelijk geregistreerd is. Lokale groeperingen moeten zich laten registreren, waarbij registratie bij de voorgaande verkiezingen voldoende is om zonder registratie aan de volgende gemeenteraadsverkiezingen deel te kunnen nemen. Lokale groeperingen die voor de eerste maal in de betreffende gemeente aan de gemeenteraadsverkiezingen deelnemen dienen zich dus te laten registreren om de eigen naam boven de kandidatenlijst geplaatst te krijgen. Een voorwaarde voor registratie is dat men een vereniging met volledige rechtsbevoegdheid is (art.G3 lid 1 Kieswet). Deze voorwaarde is ingevoerd omdat bij een vereniging duidelijk is wie de naam van de vereniging mag gebruiken. Dat is immers bij de oprichting van de vereniging vastgelegd. Op deze manier wil men voorkomen dat bij de kandidaatstelling verschillende personen claimen namens eenzelfde vereniging te opereren. ${ }^{9}$

Tevens zijn er financiële consequenties verbonden aan het meedoen aan de gemeenteraadsverkiezingen. Bij de registratie dient men in elke gemeente Fl. 250,-te voldoen. Dit bedrag krijgt men vervolgens terug indien men daadwerkelijk een kandidatenlijst indient (art.G3 lid 2 Kieswet). Groeperingen die nog niet in de betreffende gemeenteraad vertegenwoor-

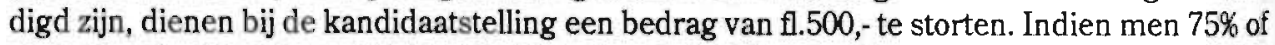
meer van de kiesdeler haalt bij de verkiezingen, krijgt men dit bedrag terug (art.H14 lid 4 Kieswet). Uit bovenstaande financiële regels kunnen wij afleiden dat geregistreerde partijen die al in de betreffende gemeenteraad vertegenwoordig $\mathrm{d}$ zijn, zonder financiële consequenties onder eigen naam een kandidatenlijst kunnen indienen, terwijl (nieuwe) niet geregistreerde (lokale) lijsten die niet in de gemeenteraad vertegenwoordigd zijn in totaal fl.750,- moeten betalen om een kandidatenlijst met de eigen naam te kunnen indienen. Deze financiële regels voor de gemeenteraadsverkiezingen zijn bij de wijziging van de Kieswet van 1989 voor het eerst ingevoerd. De belangrijkste reden hiervoor was dat men op deze manier wil verkomen dat nietserieuze lijsten zich laten registreren en mee gaan doen aan de gemeenteraadsverkiezingen. ${ }^{10}$ 


\section{Zetelverdeling}

Tenslotte stellen wij de wijze waarop de uitslag van de gemeenteraadsverkiezingen vertaald wordt in gemeenteraadszetels aan de orde. In Nederland wordt het stelsel van evenredige vertegenwoordiging gehanteerd (art. 129 lid 2 Grondwet), hetgeen inhoudt dat de gemeenteraadszetels worden verdeeld naar verhouding van het behaalde aantal stemmen van de verschillende deelnemende groeperingen. Ten aanzien van de hoogte van de kiesdrempel en de methode voor restzetelverdeling wordt bij de gemeenteraadsverkiezingen een onderscheid gemaakt tussen gemeenten met meer dan 20.000 inwoners ( 19 of meer raadsleden) en gemeenten die 20.000 of minder inwoners hebben (minder dan 19 raadsleden). Volgens artikel P7 lid 1 van de Kieswet wordt bij de restzetelverdeling in de grotere gemeenten uitgegaan van het systeem van de grootste gemiddelden. Dit betekent dat de restzetels achtereenvolgens worden toegekend aan de lijst die na toekenning van de zetel het grootste gemiddelde aantal stemmen per toegekende zetel zou hebben. Bij de restzetelverdeling wordt geen kiesdrempel gehanteerd. Bij de kleinere gemeenten wordt volgens artikel P8 lid 2 van de Kieswet wel een kiesdrempel gehanteerd. Alleen lijsten die tenminste het aantal stemmen hebben gehaald dat gelijk is aan $75 \%$ van de kiesdeler, mogen meedoen aan de restzetelverdeling. Bij die restzetelverdeling wordt het stelsel van de grootste overschotten gehanteerd (art. P7 lid 2 van de Kieswet). Dit houdt in dat de restzetels achtereenvolgens worden toebedeeld aan de partijen die na de verdeling van de hele zetels het grootste overschot aan stemmen hebben. Het kan bij deze verdeling voorkomen dat er nog zetels over blijven als alle in aanmerking komende groeperingen al een restzetel hebben ontvangen. In dat geval wordt volgens artikel P8 lid 3 de resterende restzetels volgens het systeem van de grootste gemiddelden over de groeperingen verdeeld. Geen van de groeperingen kan echter op deze wijze meer dan én restzetel toebedeeld krijgen. Ter afsluiting is vermeldenswaardig dat in artikel P9 geregeld wordt dat een partij die de absolute meerderheid van de stemmen heeft gehaald, maar niet de meerderheid van de zetels heeft gekregen, een extra zetel toebedeeld krijgt. Deze zetel gaat dan ten koste van de lijst die als laatste een restzetel heeft toegewezen gekregen.

De Kieswetwijziging van 1989 heeft geen ingrijpende veranderingen teweeg gebracht in de wijze waarop de verkiezingsuitslagen bij de gemeenteraadsverkiezingen worden vertaald in zetels voor de deelnemende groeperingen. Wel is er in de Tweede Kamer geprobeerd het bestaande systeem aan te passen. Zo werd in een PvdA-amendement voorgesteld om bij alle verkiezingen een kiesdrempel van één maal de kiesdeler in te stellen, hetgeen betekende dat alleen lijsten die één of meer zetels haalden, mee zouden mogen doen aan de restzetelverdeling. Dit zou ten koste gaan van veel kleinere groeperingen bij de gemeenteraadsverkiezingen. ${ }^{11} \mathrm{Na}$ een hevig protest van de kleinere groeperingen in de Tweede Kamer werd het betreffende amendement gewijzigd, in die zin dat de kiesdrempel van éénmaal de kiesdeler alleen zou gelden voor gemeenten met meer dan 20.000 inwoners. Maar ook dit amendement werd door een meerderheid van de Tweede Kamer afgewezen. ${ }^{12}$

Een ander voorstel kwam van de D66-fractie in de Tweede Kamer. Zij stelde voor om bij de restzetelverdeling gebruik te maken van een variant op het zogenaamde systeem van Webster. Het effect van invoering van dit systeem zou zijn dat de zetelverdeling meer evenredig zou plaatsvinden dan bij de huidige systemen van restzetelverdeling. Door invoering van het systeem-Webster zou aan de bevoordeling van de grote partijen bij het systeem van de grootste gemiddelden en de bevoordeling van de kleine partijen door het systeem van de grootste overschotten een einde worden gemaakt. ${ }^{13}$ Het voorstel werd echter door een kleine meerderheid van de Tweede Kamerverworpen. ${ }^{14}$ Als argumenten tegen hetvoorstel werden ingebracht 
dat de ervaring met het bestaande stelsel, de geringe problemen die zich hierbij voordeden en de geringe voordelen van toepassing van de voorgestelde restzetelverdeling verandering van het bestaande systeem niet wenselijk maakten. ${ }^{15}$

\subsection{Indeling van gemeenten.}

Uit het onderzoek van Dittrich (1978) blijkt dat de electorale positie van de lokale lijsten en de verschillende landelijke lijsten niet in alle categorieën van gemeenten hetzelfde is. Zo was er bijvoorbeeld een duidelijk verschil tussen de electorale positie van de lokale lijsten in de provincies Noord-Brabant en Limburg in vergelijking met de overige provincies. Hetzelfde gold ook voor de kleinste gemeenten in vergelijking met de grootste gemeenten. Daarom zal nu nader worden ingegaan op de indeling van gemeenten in provincies en in categorieën van gemeentegrootte in de periode 1974-1990.

\subsubsection{Provinciale indeling}

In 1974 waren er in Nederland nog 841 gemeenten, terwijl dit er per 1 januari 1991 nog slechts 647 waren. Aangezien Nederland in 1962 nog 977 gemeenten kende, heeft de herindeling van gemeenten $z$ ich in de periode 1974-1990 voortgezet. Daaruit mag niet worden geconcludeerd dat herindeling van gemeenten onomstreden is. Integendeel, verschillende grootschalige herindelingsoperaties zijn steeds meer ter discussie komen te staan. ${ }^{16} \mathrm{Zo}$ is in 1986 afgezien van een herindeling van gemeenten in de Bommelerwaard en Midden-Betuwe. De weerstand tegen grootschalige herindelingen vindt ook zijn weerslag in het regeerakkoord van het kabinet Lubbers-Kok waarin gesteld wordt datprovincies zelfkunnen bepalen of er grootschalige herindelingen zullen plaatsvinden op hun grondgebied. ${ }^{17}$ In de periode 1974-1990 hebben overigens grootschalige herindelingen plaatsgevonden in Noord-Holland (1978, 1989 en 1990), Zuid-Limburg(1981), Friesland(1983), Utrecht (1988), Groningen(1989), MiddenLimburg en Zuid-Holland(1990).

In tabel 2.2 geven wij een overzicht van het aantal gemeenten per provincie in de periode 1974 1990 , zoals opgenomen in het gebruikte databestand. 
Tabel 2.2: Aantal gemeenten per provincie, 1974-1990.

\begin{tabular}{|c|c|c|c|c|c|}
\hline & 1974 & 1978 & 1982 & 1986 & 1990 \\
\hline Groningen & 51 & 51 & 50 & 50 & 25 \\
\hline Friesland & 44 & 44 & 44 & 31 & 31 \\
\hline Drenthe & 34 & 34 & 34 & 34 & 34 \\
\hline Overijssel & 47 & 47 & 47 & 45 & 45 \\
\hline Gelderland & 104 & 95 & 93 & 86 & 86 \\
\hline Utrecht & 48 & 48 & 48 & 48 & 38 \\
\hline Noord-Holland & 96 & 95 & 81 & 81 & 70 \\
\hline Zuid-Holland & 151 & 151 & 144 & 103 & 95 \\
\hline Zeeland & 30 & 30 & 30 & 30 & 30 \\
\hline Noord-Brabant & 131 & 131 & 131 & 131 & 131 \\
\hline Limburg $^{18}$ & 104 & 103 & 69 & 69 & 56 \\
\hline Flevoland ${ }^{19}$ & 1 & 1 & 3 & 6 & 6 \\
\hline Nederland & 841 & 830 & 774 & 714 & 647 \\
\hline
\end{tabular}

Bron: Databestand CELS.

Uit de tabel blijkt dat in 1974 de provincies Zuid-Holland en Noord-Brabant de meeste gemeenten hadden. Het aantal gemeenten in Zuid-Holland is in de periode 1974-1990 echter sterk teruggelopen terwijl Noord-Brabant stabiel blijft op 131 gemeenten. Ook de provincies Drenthe, Zeeland en Overijssel blijven op ongeveer hetzelfde peil. De provincies Groningen, Limburg, Noord-Holland en in mindere mate Friesland, Gelderland en Utrecht kennen een sterke achteruitgang van het aantal gemeenten. Flevoland is de enige provincie die een toename van het aantal gemeenten kende.

\subsubsection{Indeling naar gemeentegrootte.}

Naast een indeling van gemeenten in provincies, zullen wij ook gebruik maken van een indeling van gemeenten naar hun inwonertal. Zo ontstaat een indeling in categorieën van gemeentegrootte. Zoals reeds gesteld, is het aantal raadszetels in een gemeente gekoppeld aan het inwonertal van de gemeenten. Op basis van het aantal raadszetels kunnen wij dus de gemeenten indelen naar de grootte van hun inwonertal. Tabel 2.3 geeft een overzicht van de indeling van de gemeenten naar gemeentegrootte in de periode 1974-1990. 
Tabel 2.3: Indeling van gemeenten naar gemeentegrootte, in procenten, 1974-1990.

\begin{tabular}{|c|c|c|c|c|c|c|}
\hline \multirow{2}{*}{$\begin{array}{l}\text { inwoners } \\
\times 1000\end{array}$} & & \multirow[t]{2}{*}{1974} & \multirow[t]{2}{*}{1978} & \multirow[t]{2}{*}{1982} & \multirow[t]{2}{*}{1986} & \multirow[t]{2}{*}{1990} \\
\hline & & & & & & \\
\hline & 3 & 19,4 & 17,8 & 14,5 & 9,1 & 3,9 \\
\hline 3 & 10 & 43,5 & 43,3 & 46,4 & 39,5 & 35,5 \\
\hline 10 & $\begin{array}{l}-\quad 25 \\
\end{array}$ & 24,7 & 25,2 & 29,1 & 33,5 & 39,4 \\
\hline 25 & - $\quad 50$ & 7,4 & 8,6 & 10,5 & 10,8 & 13,0 \\
\hline \multirow[t]{2}{*}{50} & -100 & 3,1 & 3,1 & 3,6 & 4,8 & 5,6 \\
\hline & $>100$ & 1,9 & 2,0 & 2,2 & 2,4 & 2,6 \\
\hline $\mathrm{N}$ & & 841 & 830 & 774 & 714 & 647 \\
\hline
\end{tabular}

Bron: Databestand CELS.

In 1974 had $19,4 \%$ van de gemeenten minder dan 3.000 inwoners, terwijl $43,5 \%$ van de gemeenten tussen de 3.000 en 10.000 inwoners had. Dus meer dan 60\% van de gemeenten had minder dan 10.000 inwoners. Relatief veel van deze gemeenten kwamen voor in de provincies Groningen (tot 1990), Drenthe, Noord-Brabant en Limburg (tot 1982).

De grote steden (meer dan 100.000 inwoners) worden gevormd door Groningen (Gr.), Enschede (Ov.), Arnhem, Nijmegen, Apeldoorn (Gld.), Utrecht (Ut), Zaanstad, Amsterdam, Haarlem (NH), Den Haag, Rotterdam, Dordrecht $(\mathrm{ZH})$, Breda, Tilburg, Eindhoven (NB) en Maastricht (Lb). In 1978 voegde Leiden $(\mathrm{ZH})$ zich bij deze gemeenten.

In 1990 is het aandeel van de kleinste gemeenten zeer sterk gedaald. Slechts 3,9\% van de gemeenten heeft minder dan 3.000 inwoners. Het aandeel van de overige gemeenten met minder dan 10.000 inwoners is gedaald tot $35,5 \%$. In 1990 heeft dus iets meer dan $40 \%$ van de gemeenten minder dan 10.000 inwoners. De overige categorieën laten een stijging zien, zowel in absolute als relatieve $z$ in. De stijging is het grootst in de categorie gemeenten met tussen de 10.000 en 25.000 inwoners. Het aandeel van deze categorie stijgt van $24,7 \%$ naar $37,7 \%$.

Bovenstaande veranderingen zijn van belang bij de interpretatie van de onderzoeksresultaten in dit proefschrift. Met name de categorie gemeenten met minder dan 3.000 inwoners is door de afname van het aantal gemeenten in deze categorie in de onderzochte periode zo veranderd dat een vergelijking van onderzoeksgevevens van 1974 met die van 1990 aan belang inboet. Zonodig zal hierop gewezen worden.

\subsection{Indeling van lijsten.}

Aan de gemeenteraadsverkiezingen neemt een groot aantal partijen en lijsten deel. In 1990 betrof het in totaal 3252 lijsten. Daarbij gaat het zowel om lokale als nationale lijsten. Tevens bestaat een deel van de deelnemende lijsten uit lokale samenwerkingsverbanden van landelijke partijen. Door deze samenwerkingsverbanden en de deelname van de lokale lijsten is er bij de gemeenteraadsverkiezingen sprake van een grotere verscheidenheid aan lijsten dan bij de niet-lokale verkiezingen. Voor de analyse van het lokale karakter van de 
gemeenteraadsverkiezingen is het natuurlijk in eerste instantie van belang om te bepalen welke lijsten getypeerd kunnen worden als 'lokaal' en welke als 'nationaal'.

\subsubsection{Lokale en nationale lijsten}

Essentieel voor het onderscheid in lokale en nationale lijsten is dat lokale lijsten niet officieel verbonden zijn met landelijke partijen. Daarmee lijkt het betrekkelijk eenvoudig om deze twee soorten lijsten van elkaar te onderscheiden. Maar naast de verschillende plaatselijke lijsten van landelijke partijen nemen ook nog verschillende samenwerkingsverbanden van landelijke partijen deel aan de gemeenteraadsverkiezingen. In de periode 1974-1990 kan men daarbij de volgende categorieën onderscheiden:

PAK: Progressief AKkoord: Indien een gecombineerde lijst is uitgekomen van éen of meer der algemeen bekende groeperingen D66, PPR, PSP, CPN in kombinatie met de PvdA, eventueel in samenwerking met onafhankelijke kandidaten;

LC: Linkse Combinatie: Indien een gecombineerde lijst is uitgekomen van twee of meer der algemeen bekende groeperingen PPR, PSP, CPN, EVP echter zonder de PvdA, eventueel in samenwerking met onafhankelijke kandidaten;

PCG:Protestantse Christelijke Gecombineerde lijst: Indien twee of meer van de protestantschristelijke groeperingen GPV, RPF of SGP gezamenlijk zijn opgetreden, eventueel in combinatie met andere protestants-christelijke groepen;

GP: Gemengd Protestantse lijst: Indien ARP en/of CHU een combinatie zijn aangegaan met het SGP, de GPV of een lokale protestantse groepering;

OV: Overige landelijke lijsten en combinaties van landelijke lijsten, eventueel in combinatie met een of meerdere lokale lijsten.

Zoals in het eerste hoofdstuk is gesteld, zijn de uitslagen van de gemeenteraadsverkiezingen die in dit onderzoek worden gebruikt, gebaseerd op de gegevens van het CBS. Dit betekent overigens niet dat bovenstaande indeling van landelijke samenwerkingsverbanden overeenkomt met die van het CBS. Een verschil is onder meer dat het CBS geen onderscheid maakt tussen hetgeen hierboven als PAK en LC gerubriceerd is. Door dit onderscheid vanaf 1974 te maken, kan worden duidelijk gemaakt in hoeverre combinaties van progressieve partijen een algemeen progressief dan wel radikaal-links karakter hadden. Bij de gemeenteraadsverkiezingen van 1990 nemen de radikaal-linkse lijsten in de meeste gemeenten aan de gemeenteraadsverkiezingen deel onder de naam Groen Links.

Ten aanzien van de PCG-lijsten wordt dezelfde indeling gebruikt als het CBS sinds 1982 hanteert. Tot 1982 werden ook combinaties met de ARP en/of de CHU tot deze categorie gerekend. In $1978 \mathrm{kwamen}$ deze combinaties nog maar amper voor. In 1974 was dat nog in 176 gemeenten het geval. Vandaar dat deze samenwerkingsverbanden in 1974 en 1978 als een aparte categorie (GP) beschouwd kunnen worden.

De categorie overige landelijke lijsten wordt onder andere gevormd door DS70, de Centrumpartij, de Centrum Democraten en God Met Ons. Tevens vallen hieronder combinaties van landelijke lijsten met lokale lijsten, zoals bijvoorbeeld VVD-Gemeentebelangen. Dergelijke combinaties haalden gezamenlijk in de onderzochte periode op landelijk niveau nooit meer dan $0,3 \%$ van de stemmen. 
De bovenstaande lijsten kunnen allen als 'nationaal' gekarakteriseerd worden. Dat betekent overigens niet dat geen ruimte werd geschapen voor onafhankelijke lokale kandidaten binnen deze lijsten. Met name bij de LC-lijsten, maar ook de PAK-lijsten kwam een dergelijke opzet voor.

De lokale lijsten bestaan naast de onafhankelijke plaatselijke lijsten de lijsten die door het CBS als Rooms-Katholiek en Protestants-Christelijk zijn gerubriceerd. Van deze laatste categorie is sprake indien een protestants-christelijke groepering een lijst heeft ingediend en niet is gebleken dat deze geldt als de officiële respectievelijk hoofdlijst van eén der bekende protestants-christelijke groeperingen (CBS; 1974:11). De karakterisering van de zogenaamde rooms-katholieke lijsten als 'lokaal' is gebaseerd op Dittrich (1978:19-20) die terecht stelt dat men vraagtekens kan zetten bij het rooms-katholieke karakter van een groot deel van deze lijsten in een tijd van toenemende ontzuiling en deconfessionalisering. Tevens is van hierbijvan belang dat deze door het CBS als rooms-katholiek gerubriceerde lijsten in bijna alle gevallen afkomstig waren uit gemeenten in provincies en streken waar het merendeel van de bevolking rooms-katholiek was. Met ingang van de gemeenteraadsverkiezingen van 1990 laat het CBS overigens de afzonderlijke categorie van rooms-katholieke lijsten vallen.

Tenslotte dient vermeld te worden dat ook de Fryske Nasjonale Partij als een niet-landelijke groepering met een sterk lokaal karakter bij de lokale lijsten is ingedeeld.

\subsubsection{Landelijke politieke stromingen}

Ten behoeve van de analyse van de electorale positie van de lokale en landelijke lijsten bij de gemeenteraadsverkiezingen zullen in de volgende hoofdstukken ten aanzien van de nationale lijsten drie landelijke politieke stromingen worden onderscheiden, namelijk de confessionele, de progressieve en de liberale stroming. Deze politieke stromingen zijn uit de volgende groeperingen samengesteld:

Confessioneel: ARP, CDA, CHU, GP, GPV, KVP, PCG, RPF en SGP. Progressief: CPN, D66, EVP, GL, LC, PAK, PPR, PSP en PvdA. Liberaal: VVD.

Van de nationale lijsten is alleen de categorie 'overige lijsten' dus niet in éen van de politieke stromingen opgenomen. De reden hiervoor is dat deze categorie in ideologisch opzicht zo divers van samenstelling is dat zij niet bij éen van de politieke stromingen is in te delen. Daarbij speelt tevens een rol dat in deze categorie ook samenwerkingsverbanden van lokale en landelijke lijsten zijn opgenomen.

Uit de indeling blijkt voorts dat wij de VVD als enige liberale partij beschouwen. De vraag is echter of ook D66 niet tot de liberale stroming gerekend dient te worden. Hiervan is om een tweetal redenen afgezien. In de eerste plaats heeft D66 zich nooit tot de sociaal-democratische, liberale of welke politieke stroming dan ock willen bekennen. Men heeft zich in de regel geprofileerd als een pragmatische partij die zich zowel door liberale als sociaal-democratische noties liet inspireren. Vanuit deze optiek heeft men zich opgeworpen als een verdediger van het liberale gedachtengoed, waarbij kwesties als abortus, euthanasie en de media-politiek een belangrijke rol speelden. D66 heeft zich echter nooit beschouwd of gepresenteerd als een 
liberale partij. Daarentegen heeft zij zich wel altijd gepresenteerd als een gematigd-progressieve partij.

In de tweede plaats kunnen wij constateren dat D66, met name in de jaren'70, in verschillende gemeenten in PAK-verband aan de gemeenteraadsverkiezingen heeft deelgenomen. Ook al nam D66 in de jaren tachtig doorgaans onafhankelijk aan de gemeenteraadsverkiezingen deel, als er sprake was van een lokale samenwerking bij de gemeenteraadsverkiezingen, betrof het een samenwerking met andere progressieve partijen in PAK-verband. Lokale samenwerkingsverbanden met de VVD kwamen ook in deze jaren niet voor.

\subsubsection{Lokale lijsten}

De lokale lijsten kunnen per definitie nog minder dan de nationale lijsten als een eenheid worden beschouwd. Wel is het mogelijk om de lokale lijsten in te delen in verschillende typen. ${ }^{20}$ Om een beter beeld te krijgen van de verschillende soorten lokale lijsten, zullen wij in deze paragraaf tevens aandacht schenken aan de aard en het functioneren van de lokale lijsten en de veranderingen die zich daarbij hebben voorgedaan.

In de literatuur komen verschillende indelingen van typen lokale lijsten voor. De eerste onderverdeling van lokale lijsten is afkomstig van Dittrich (1978:112-115). Hij onderscheidt de volgende vijf soorten lokale lijsten:

- Lijsten van kerkdorpen en buurtschappen. Veel gemeenten bestaan uit verschillende kernen. De bewoners van deze kernen zijn dikwijls sterk gericht op de eigen gemeenschap. Tussen de verschillende kernen is de rivaliteit dikwijls groot, vooral als het gaat op het voorzieningenniveau in de eigen kern. Onvrede over verschillen in voorzieningenniveau's leidde vaak tot de vorming van een eigen politieke organisatie;

- Standslijsien. Dit zijn meestal lijsten van boeren, arbeiders en middenstanders;

- Lijsten rond local leaders'. Plaatselijke notabelen zoals artsen, advocaten en onderwijzers bepaalde dikwijls in samenspraak met de geestelijkheid de lokale politiek. Ook de 'grote' boeren hadden dikwijls een belangrijke plaats in de lokale politiek;

- Lijsten als algemeen of plaatselijk, gemeentelijk belang. Dit zijn vaak lijsten die proberen om de vaak felle lokale tegenstellingen te overbruggen door het gemeenschapsbelang te benadrukken; - Persoonslijsten. Populaire plaatselijke grootheden proberen een rol te spelen in de lokale politiek. Ook ruzies tussen personen en families kunnen leiden tot de oprichting van persoonslijsten.

Volgens Kuiper kan men echter moeilijk onderscheid maken tussen lijsten van 'local leaders' en persoonslijsten, zodat hij deze lijsten in eén categorie, persoonslijsten, onderbrengt. Tevens onderscheidt hij culturele lijsten, waarbij de rivaliteit tussen verschillende verenigingen in een gemeente de basis vormt van een lokale lijst. Naar zijn mening zijn ook ideologische en issuegerichte lijsten een belangrijke categorie. In deze categorie vallen ook de lokale lijsten die zich sterk afzetten tegenover de landelijke partijen en de belangen van de gemeenten voorop stellen. Hij spreekt in dit kader van een 'ideologisch communalisme' (Kuiper, 1986:3).

Tops daarentegen gaat uit van een tweedeling, waarbij de aard en het functioneren van de lokale lijsten het criterium is (Tops, 1990:123-126). De eerste groep lokale lijsten, vaak 'Gemeentebelangen' geheten, komt met name voor in een door de nationale partijen gedomi- 
neerde gemeenteraad, terwijl de tweede groep lokale lijsten zich voornamelijk voordoet in een omgeving waar lokale lijsten (nagenoeg) alleen andere lokale lijsten aantreffen. Met name in de periode tot 1974 zouden de verschillen tussen deze twee soorten lokale lijsten aanwezig zijn. $\mathrm{Na} 1974$ spreekt Tops van het 'gemengde communalisme', omdat lokale en nationale lijsten steeds meer elkaars concurrent zijn in de verschillende gemeenten.

Kenmerkend voor de eerste groep lokale lijsten zou zijn dat $z$ ij in de regel eenzelfde structuur kennen als de plaatselijke afdelingen van de landelijke partijen. Dit betekent dat er in de meeste gevallen sprake is van een ledenvergadering en een bestuur. Tevens is vergelijkbaar dat men op basis van een verkiezingsprogramma de verkiezingen ingaat. Voorts worden deze lijsten gekenmerkt door enige duurzaamheid; men probeert in de regel bij elke gemeenteraadsverkiezing met een kandidatenlijst te komen.

De tweede groep lokale lijsten zou zich zowel in haar structuur als in haar functioneren onderscheiden van zowel de plaatselijke lijsten van de landelijke groeperingen als de overige lokale lijsten. Dikwijls kennen zij geen afdelingsvergadering of bestuur. Uit een onderzoek van Kuiper (1988:19) blijkt dat in 1981/1982, in de periode van het zogenaamde gemengde communalisme dus, 58 procent van de onderzochte Limburgse lokale lijsten geen bestuur had en dat in 45 procent van de gevallen er geen mogelijkheid is om lid te worden van deze groeperingen. Deze lokale lijsten hebben dikwijls geen (uitgewerkt) verkiezingsprogramma. En omdat $z$ ij in veel gevallen bestaan uit een verzameling kandidaten met als middelpunt de lijsttrekker, hebben zij in vergelijking met de landelijke partijen een veel minder duurzaam karakter. Bij het wegvallen van eén of enkele personen houdt de lijst dikwijls op te bestaan. Hierbij is tevens van belang dat het een vrij normale verschijning is dat kandidaten en raadsleden naar een andere groepering overstappen (Kuiper, 1986:27). Tevens blijkt dat in communale gemeenten veel vaker dan in niet-communale gemeenten persoonlijke motieven een rol speelden bij het ontslag van een wethouder. ${ }^{\prime 1}$ Voorts ging in meer dan $2 / 3$ van het aantal ingediende moties van wantrouwen tegen wethouders in communale gemeenten gepaard met het overlopen van een raadslid, waardoor de oppositie de meerderheid van raadszetels bemachtigde (Knippenberg, 1987:8).

Personen spelen bij deze lokale lijsten ook bij de verkiezingen een belangrijke rol, hetgeen blijkt uit het relatief hoge percentage voorkeurstemmen dat op deze lijsten wordt uitgebracht. Zo was bij de gemeenteraadsverkiezingen van 1974 in Limburg, waar lokale lijsten een zeer sterke electorale positie innamen, zelfs 52 procent van de stemmen een voorkeurstem, terwij] dat landelijk slechts 26 procent was. In 1981/82 en in 1986 is het percentage voorkeurstemmen in Limburg gestegen tot 56 procent en in 1990 tot 60 procent. (Kuiper/Koning, 1991:198). Hiermee wordt duidelijk dat zelfs in de periode van het 'gemengde communalisme' de voorkeurstem bij Limburgse gemeenteraadsverkiezingen dominant is.

Zoals gesteld, geeft Tops aan dat bovenstaande verschillen tussen de lokale lijsten in een comnunale politieke omgeving enerzijds en de landelijke partijen en de overige lokale lijsten anderzijds, na 1974 aan het vervagen zijn. In het verlengde van Welten (1987:45) constateert hij dat steeds meer lokale lijsten een structuur krijgen die vergelijkbaar is met de plaatselijke afdelingen van landelijke partijen. Tevens maken zij ook steeds meer via een verkiezingsprogramma hun standpunten bekend. De professionalisering van de lokale lijsten wordt ook duidelijk uit de omstandigheid dat een deel van hen zich in Noord-Brabant en Limburg aaneengesluten heeft in bovenlokale samenwerkingsverbanden. Opvallend is overigens dat ook de landelijke partijen in de gemengd-communale omgeving zich aanpassen aan de lokale lijsten. Zo constateert Welten (1987:6) dat deze landelijke partijen in toenemende mate 
proberen bekende lokale persoonlijkheden te recruteren voor hun kandidatenlijst. In dit kader is het opmerkelijk dat ook op deze partijen steeds meer voorkeurstemmen werden uitgebracht bij de Limburgse gemeenteraadsverkiezingen. In 1990 was het percentage voorkeurstemmen voor het CDA, de PvdA en de VVD respectievelijk 67, 50 en 55 procent tegenover 65 procent voor de lokale lijsten (Kuiper/Koning, 1991:201).

Of de lokale lijsten, mede door bovenstaande veranderingen, hun electorale positie hebben kumnen handhaven, $z$ al in de volgende twee hoofdstukken aan de orde komen. 


\section{NOTEN}

${ }^{1}$ Met name kan hier melding worden gemaakt van de zogenaamde Decentralisatie Impuls. Deze houdt in dat het kabinet bereid is om F1.8,5 miljard over te hevelen naar de gemeenten en provincies. Tevens is er sprake van een mogelijke vergroting van het gemeentelijke belastinggebied door het overhevelen van de overdrachtsbelasting naar het lokale niveau. Tevens heeft de cie. De Kam in dit kader voorgesteld om door verschillende maatregelen de eigen inkomsten van de gemeenten te verhogen van 5,7 miljard naar 10,7 miljard.

${ }^{2}$ Uit de Handelingen van de Tweede Kamer blijkt overigens niet dat men zich heeft gerealiseerd dat als in hetzelfde jaar de gemeenteraadsverkiezingen in maart en de Tweede Kamerverkiezingen in mei worden gehouden, de gemeenteraadsverkiezingen waarschijnlijk in sterkere mate in het teken zullen staan van de landelijke politiek.

${ }^{3}$ Hierbij werd ondermeer genoemd dat er vaker sprake zou zijn van een samenloop van verschillende verkiezingen. Tevens werd gesteld dat de ene verkiezing de andere zou kunnen beünvloeden. In de derde plaats werd eropgewezen dat bijhet bedrijfsleven - door het gelegenheid geven om te stemmen-zich problemen zouden kunnen voordoen. Zie: Hand.II, nr. 20264, nr.3, p.19-21. Zie ook: nr.7, p.15-17; nr.8, p.19-21 en nr.18, p.17-18. ${ }^{4}$ Hand.II, 1988/1989, p. 5692, 5702, 5783, 5798, 5849/5850. De door D66 ingediende motie (20264, nr.50) werd ondersteund door D66, PPR en PSP.

${ }^{5}$ In de nieuwe Gemeentewet is in artikel 10 het zetelaantal van de gemeenteraden enigszins gewijzigd. Het verschil met de gemeentewet die in de onderzochte periode gold, is dat gemeenten met minder dan 3001 inwoners 9 in plaats van 7 gemernteraadsleden kriigen.

${ }^{6}$ Het betreft hier cen stempercentage van de CPN bij de gemeenteraadsverkiezingen van 1974 in Jisp.

${ }^{7}$ Gebaseerd op art. $130 \mathrm{GW}$ en artikel B3 van de Kieswet. Zie voor de overige eisen en uitzonderingen hierop artikel B3 lid 2, 3 en 4 van de Kisswet.

'Art. 54 lid 2 van de Grondwet luidt: 'Van kiesrecht is uitgesloten:

a. Hij die wegens het begaan van enn daartoe bij de wet aangewezen delict bij onherroepelijke rechterlijke uitspraak is veroordeeld toteen vrijheidsstraf van tenminste een jaar en hierbij tevens is ontzet van het kiesrecht; b. Hij die krachtens onherroepelijke rechterlijke uitspraak wegens een geestelijke stoomis onbekwaam is rechtshandelingen te verrichten.'

' Zie hiervoor: Hand.II, nr.20264, nr.3, p.29. Opmerkelijk is dat niet aangetoond is of en in hoeverre er bij de gemeenteraadsverkiezingen problemen waren met het plaatsen van de naam van de lijst boven het stembiljet.

${ }^{10}$ Hand II, nr. 20264, nr. 3, p.29. Ook hierbij werd niet duidelijk of er sprake was van een sterke stijging in de deelname van zogenaamde niet-serieuze lijsten, waardoor een dergelijke verandering van de Kieswet zou worden gerechtvaardigd.

1'Zie: Hand П, 1988/1989, p.5680-5682, 5811-5812. Zie ook: van Tilburg en Knippenberg (1989).

${ }^{12}$ Hand.II, 1988/1989, p.5811-5813 en p.5941.

${ }^{13}$ Idem, p.58245826.

"Idem, p.5795. Het amendement-Kohnstamm werd gesteund door de fracties van D66, VVD, SGP, GPV, RPF, RPF, PPR en PSP.

${ }^{15}$ Hand.II, nr.20264, nr.7, p.40-44 en Hand.II, 1988/1989, p.5660-5661 en 5801.

${ }^{18}$ Voor een overzicht van de discussie over gemeentelijk herindeling, zie: Derksen, Gemeentelijke herindeling en pluriformiteit, 1989 , pp. 414-428.

"Zie hiervoor het regeerakkoord van het kabinet Lubbers-Kok in: Hand. II, 1989/1990, nr. 21132, nr. 8, p.49. ${ }^{18}$ In 1978 zijn er in de Limburgse gemeente Stevensweert geen gemeenteraadsverkiezingen gehouden omdat het aantal kandidaten overeenkwam met het aantal gemernteraadszetels.

${ }^{18}$ De provincie Flevoland is pas op 28 juni 1985 ingesteld. Tot die tijd waren er echter al wel enkele gemeenten op het huidige grondgebied van Flevoland. Zo is Dronten per 1-1-1972 ingesteld. Voor Lelystad was dat per 1-11980 het geval. Almere en Zeewolde zijn op 1-1-1984 ingesteld. Deze gemeenten zijn in de tabel opgenomen onder Flevoland. Bij de instelling van de provincie Fevoland zijn de gemeenten Noordoostpolder en Urk overgegaan van Overijssel naar Flevoland.

Bij de gemeenteraadsverkiezingen van 1982 is overigens tevens de uitslag van de adviesraad van de Zuidelijke Usselmeer Polders (ZUP), waaruit later Almere en Zeewolde ontstonden, in de analyse meegenomen.

${ }^{20}$ Omdat in het gebruikte databestand echter geen gegevens zijn verzameld over de verschillende typen lokale lijsten, is het niet mogelijk om aan te geven in welke matc lokale lijsten van de verschillende typen aan de gemeenteraadsverkiezingen deelnamen, en of zich in de onderzochte periode hierin verschuivingen voordeden. 
${ }^{24}$ De term communatal is ontleend aan Dittrich (1978:105). Hij maakt een onderscheid tussen communalistische en niet-communalistische gemeenten. In zijn onderzoek is ecn gemeente communalistisch als zowel bij de gemeenteraadsverkiezingen van 1962 als 197490 procent of meer van de stemmen zijn uitgebracht op de lokale lijsten. In de aangehaalde studie van Knippenberg wordt de term gebruikt voor gemeenten waar de meerderheid van de raadszetels wordt bezet door leden van lokale groeperingen (Knippenberg, 1988:6). 



\section{Deel 2}

DE ELECTORALE POSITIE VAN DE LOKALE EN NATIONALE LIJSTEN 



\section{DEELNAME AAN DE GEMEENTERAADSVERKIEZINGEN}

In vergelijking met de niet-lokale verkiezingen nemen de partijen en lijsten niet in alle gemeenten deel aan de gemeenteraadsverkiezingen. De deelname aan de gemeenteraadsverkiezingen is daardoor van grote betekenis voor de verkiezingsresultaten van de lokale en nationale lijsten. Daarmee is de deelname van deze lijsten van belang voor het bepalen van de mate waarin van lokaal kiesgedrag dat karakteristiek is voor de gemeenteraadsverkiezingen sprake is. Naast de deelname van de lokale lijsten zal ook de deelname van nationale lijsten aan de gemeenteraadsverkiezingen in de periode 1974-1990 in kaart worden gebracht. Hiermee wordt niet alleen het nationale element bij de gemeenteraadsverkiezingen zichtbaar, maar worden tevens de ontwikkelingen in de deelname van de lokale lijsten in een duidelijker perspectief geplaatst.

In navolging van Dittrich (1978:215-219) zullen wij ter beoordeling van de ontwikkelingen ten aanzien van de deelname van lokale en nationale lijsten aan de gemeenteraadsverkiezingen de begrippen 'lokalisering' en 'nationalisering' hanteren. Zoals in hoofdstuk 1 is uiteengezet kunnen aan het begrip 'Iokalisering' verschillende aspecten worden onderscheiden. In dit hoofdstuk concentreren wij ons op het aspect van de deelnamevan de lokale en nationale lijsten aan de gemeenteraadsverkiezingen. In dit kader spreken wij van een lokalisering van de gemeenteraadsverkiezingen als het percentage lokale lijsten op het totaal aantal deelnemende lijsten toeneemt of als de lokale lijsten in relatief meer gemeenten aan cle gemeenteraadsverkiezingen gaan deelnemen. Het zal duidelijk zijn dat sprake is van een nationalisering van de gemeenteraadsverkiezingen als de nationale partijen hun aandeel in het totaal aantal deelnemende lijsten verhogen en in meer gemeenten aan de gemeenteraadsverkiezingen gaan deelnemen. Uit het bovenstaande volgt dat wat de deelname aan de gemeenteraadsverkiezingen betreft, tegelijkertijd van een nationalisering als een lokalisering van de gemeenteraadsverkiezingen sprake kan zijn. Dit is bijvoorbeeld het geval als zowel de lokale ais nationale lijsten in grotere mate gaan deelnemen aan de gemeenteraadsverkiezingen. Bij een delokalisering of denationalisering van de gemeenteraadsverkiezingen zijn respectievelijk de lokale dan wel de nationale lijsten in minder gemeenten aan de gemeenteraadsverkiezingen gaan deelnemen.

Volgens Dittrich heeft zich in de periode 1962-1974 zowel een proces van lokalisering als van nationalisering voorgedaan in de Nederlandse lokale politiek (Dittrich, 1978:215-219). Lokalisering, omdat in steeds meer gemeenten lokale lijsten deelnamen aan de gemeenteraadsverkiezingen, waardoor ook steeds meer kiezers de mogelijkheid kregen om op een lokale lijst hun stem uit te brengen. Nationalisering, omdat in dezelfde periode in steeds meer gemeenten nationale lijsten aan de gemeenteraadsverkiezingen deelnamen. In steeds meer gemeenten waren daarom lijsten van de drie grootste landelijke politieke stromingen vertegenwoordigd. ${ }^{1}$ In dit hoofdstuk staat de vraag centraal of en in hoeverre deze ontwikkelingen zich in de periode 1974-1990 hebben voortgezet. 


\subsection{Deelname van lokale en nationale lijsten}

De betekenis van de deelname van de lokale en nationale lijsten aan de gemeenteraadsverkiezingen kan in essentie op twee manieren in kaart worden gebracht. Zoals uit de inleiding blijkt gaat het hierbij om het aandeel van de lokale en nationale lijsten op het totaal aantal deelnemende lijsten en de mate waarin deze lijsten in de verschillende gemeenten aan de verkiezingen deelnemen.

\subsubsection{Aantal deelnemende lijsten}

Uit het onderzoek van Dittrich (1978:100) blijkt dat in de periode 1962-1974 het gemiddeld aantal deelnemende lijsten per gemeente is toegenomen van 4.99 naar 5.84. Uit tabel 3.1 wordt duidelijk dat deze stijging zich na 1974 niet heeft voortgezet.

Tabel 3.1: Gemiddeld aantal deelnemende lokale en nationale lijsten per gemeente, 1974-1990.

\begin{tabular}{lccccc} 
& 1974 & 1978 & 1982 & 1986 & 1990 \\
lokaal & 2,37 & 2,03 & 1,68 & 1,53 & 1,29 \\
nationaal & 3,47 & 3,57 & 4,11 & 4,03 & 4,08 \\
totaal & $\overline{5,83}$ & $\overline{5,61}$ & $\overline{5,79}$ & $\overline{5,56}$ & $\overline{5,37}$ \\
$N$ & 841 & 830 & 774 & 714 & 647 \\
\hline
\end{tabular}

Bron: Databestand CELS.

In de onderzochte periode is het gemiddeld aantal ingediende lijsten per gemeente gedaald van 5,83 bij de gemeenteraadsverkiezingen van 1974 naar 5,37 in 1990. Deze daling heeft zich niet geleidelijk voltrokken, aangezien zich in 1982 een lichte stijging heeft voorgedaan. Opvallend is dat de daling van het gemiddeld aantal deelnemende lijsten per gemeente veroorzaakt wordt door de geringere deelname van lokale lijsten aan de gemeenteraadsverkiezingen. Immers, in de periode 1974-1990 loopt het gemiddeld aantal lokale lijsten per gemeente terug van 2,37 naar 1,29 , terwijl het gemiddeld aantal nationale lijsten stijgt van 3,47 naar $4,08 .^{2}$ Vooral 1982 was er een duidelijke stijging van het gemiddeld aantal deelnemende nationale lijsten per gemeente. Deze ontwikkelingen betekenen dat in 1974 gemiddeld nog ruim 40 procent van de deelnemende lijsten per gemeente lokaal was, terwijl dat in 1990 nog maar geldt voor gemiddeld 24 procent van de deelnemende lijsten per gemeente.

Deze toename van de deelname van nationale lijsten is des te opmerkelijk als wij ons realiseren dat in de onderzochte periode steeds meer combinaties van landelijke partijen aan de gemeenteraadsverkiezingen zijn gaan deelnemen. Het gaat hierbij met name om de samenwerking van de ARP, de CHU en de KVP in het CDA, dat in 1978 in 640 gemeenten aan de gemeenteraadsverkiezingen deelnam, terwijl dit in 1974 slechts in 250 gemeenten het geval was. Tegelijkertijd zien wij een grote toename van het percentage gemeenten waar een zogenaamde Linkse Combinatie-lijst aan de gemeenteraadsverkiezingen deelneemt, waarbij de vorming van Groen Links het sluitstuk vormt. In dezelfde periode was tevens sprake van een afname van het aantal kleinere christelijke lijsten dat aan de gemeenteraadsverkiezingen deelnam. Ook deze lijsten hebben zich in toenemende mate in gezamenlijk verband aan de 
kiezer gepresenteerd. Tegenover deze toename van verschillende lijstencombinaties staat wel een afname van het aantal PAK-lijsten dat aan de gemeenteraadsverkiezingen deelnam. Al met al is in de periode 1974-1990 het percentage lijstencombinaties toegenomen ten koste van de deelname van afzonderlijke landelijke partijen. ${ }^{3}$ De stijging van het gemiddeld aantal deelnemende nationale lijsten getuigt hiermee van een substantile versterking van de positie van de nationale lijsten.

\section{Aantal deelnemende lijsten per provincie}

Tot nu toe hebben wij ons beperkt tot de analyse van de deelname van de lokale en nationale lijsten aan de gemeenteraadsverkiezingen vanuit landelijk perspectief. Uit het onderzoek van Dittrich blijkt dat er echter grote verschillen zijn in de deelname van lokale en nationale lijsten in de verschillende provincies. Vandaar dat het voor een beter inzicht in de electorale positie van de lokale en nationale lijsten noodzakelijk is om de verschillen tussen de provincies in de periode 1974-1990 in kaart te brengen. Daarmee wordt duidelijk of de reeds geconstateerde ontwikkelingen in de deelname van de lokale en nationale lijsten zo substantieel zijn, dat zij zich voordoen in alle provincies."

Tabel 3.2: Gemiddeld aantal deelnmende lokale en nationale lijsten per gemeente, per provincie, 1974 en 1990.

\begin{tabular}{|c|c|c|c|c|c|c|c|c|}
\hline & & & & 1974 & & & & 1990 \\
\hline & lok & nat & tot & $\mathrm{N}$ & lok & nat & tot & $\mathrm{N}$ \\
\hline GR. & 0,82 & 4,04 & 4,86 & 51 & 0,76 & 5,08 & 5,84 & 25 \\
\hline FR. & 1,16 & 4,18 & 5,34 & 44 & 1,39 & 4,00 & 5,39 & 31 \\
\hline DR. & 1,00 & 4,47 & 5,47 & 34 & 0,94 & 3,85 & 4,79 & 34 \\
\hline OV. & 1,21 & 4,85 & 6,06 & 47 & 0,71 & 4,36 & 5,07 & 45 \\
\hline GL. & 2,15 & 3,69 & 5,85 & 104 & 1,13 & 4,12 & 5,24 & 86 \\
\hline UT. & 1,06 & 5,06 & 6,12 & 48 & 0,47 & 5,16 & 5,63 & 38 \\
\hline NH. & 1,25 & 4,33 & 5,58 & 96 & 0,96 & 4,46 & 5,42 & 70 \\
\hline $\mathrm{ZH}$. & 0,85 & 4,46 & 5,32 & 151 & 0,62 & 4,93 & 5,55 & 95 \\
\hline ZL. & 1,77 & 4,20 & 5,97 & 30 & 0,73 & 4,20 & 4,93 & 30 \\
\hline NB. & 4,75 & 1,63 & 6,38 & 131 & 2,26 & 3,04 & 5,30 & 131 \\
\hline LB. & 5,81 & 0,81 & 6,62 & 104 & 2,54 & 3,16 & 5,70 & 56 \\
\hline FL. & 2,00 & 4,00 & 6,00 & 1 & 1,00 & 5,50 & 6,50 & 6 \\
\hline NL & 2,37 & 3,47 & 5,83 & 841 & 1,29 & 4,08 & 5,37 & 647 \\
\hline
\end{tabular}

Bron: Databestand CELS.

Het meest opvallend in tabel 3.2 zijn de gegevens voor Noord-Brabant en Limburg. Meteen valt op dat de daling van het gemiddeld aantal deelnemende lijsten per gemeente in deze twee provincies is veroorzaakt door de sterke daling van de deelnemende lokale lijsten. Toch was het gemiddeld aantal deelnemende lokale lijsten per gemeente in Noord-Brabant en Limburg ook in 1990 nog hoger dan in de andere provincies, al is het verschil met de andere provincies kleiner dan in 1974. Wat de deelnemende nationale lijsten betreft, zien wij overigens het tegenovergestelde beeld. In 1974 was de deelname van nationale lijsten opvallend gering. Door een relatief sterke stijging is in 1990 het verschil met de andere provincies verkleind. Toch is 
de gemiddelde deelname van nationale lijsten per gemeente in Noord-Brabant en Limburg nog steeds op een lager niveau dan in de andere provincies.

Wat de overige provincies betreft, zien wij in 1990 ten opzichte van 1974 dat drie provincies, namelijk Groningen, Zuid-Holland en Flevoland een lichte stijging kenden van het gemiddeld aantal deelnemende lijsten per gemeente. Voorts kunnen wij constateren dat zowel in 1974 als in 1990 in Groningen en Zuid-Holland relatief weinig lokale lijsten aan de gemeenteraadsverkiezingen deelnamen. Alleen in Friesland is sprake van een lichte stijging in het aantal deelnemende lokale lijsten per gemeente. Een relatief sterke daling daarentegen heeft zich voorgedaan in Gelderland, Zeeland en Utrecht. Opvallend hierbij is dat in 1974 Gelderland en Zeeland na Noord-Brabant en Limburg het hoogste aantal deelnemende lokale lijsten per gemeente hadden. Dittrich (1978:105) heeft er in zijn onderzoek al op gewezen dat in de katholieke streken van Nederland de lokale lijsten een sterke electorale positie hadden in de periode 1962-1974. In Gelderland en Zeeland betreft het respectievelijk het Land van Maas en Waal en Zeeuws-Vlaanderen. De conclusie is gerechtvaardigd dat de daling in de deelname van de lokale lijsten aan de gemeenteraadsverkiezingen zich in ieder geval sterk heeft voorgedaan in de traditionele bolwerken van de lokale lijsten.

Wat de nationale lijsten betreft, kunnen wij constateren dat buiten Noord-Brabant en Limburg alleen in Friesland, Drenthe en Overijssel in de periode 1974-1990 het gemiddeld aantal deelnemende lijsten is gedaald. De andere provincies kenden in deze periode in de regel een stijging, waarbij Groningen de grootste stijging laat zien.

Aantal deelnemende lijsten per categorie van gemeentegrootte

Niet alleen per provincie maar ook per urbanisatiegraad waren er, zo blijkt uit onderzoek van Dittrich (1978:100), in de periode 1962-1974 verschillen ten aanzien van de deelname van lokale en nationale lijsten aan de gemeenteraadsverkiezingen. Vandaar dat een analyse van de dcelname van lokale en nationale lijsten van de door ons gebruikte indeling naargemeentegrootte belangrijke informatie kan opleveren over de relatieve omvang van de geconstateerde stijging van het percentage nationale lijsten op het totaal aantal deelnemende lijsten. ${ }^{5}$

Tabel 3.3: Gemiddeld aantal deelnemende lokale en nationale lijsten per gemeente, per categorie van gemeentegrootte, 1974 en 1990.

\begin{tabular}{|c|c|c|c|c|c|c|c|c|c|}
\hline \multirow{2}{*}{$\begin{array}{l}\text { inwoners } \\
\times 1000\end{array}$} & & \multicolumn{4}{|c|}{1974} & \multicolumn{4}{|c|}{1990} \\
\hline & & lok & nat & tot & $\mathrm{N}$ & lok & nat & tot & $\mathrm{N}$ \\
\hline & 3 & 2,02 & 1,95 & 3,96 & 163 & 1,80 & 1,84 & 3.64 & 25 \\
\hline 3 & - 10 & 2,70 & 2,70 & 5,40 & 359 & 1,27 & 3,14 & 4,40 & 230 \\
\hline 10 & - $\quad 25$ & 2,39 & 4,21 & 6,61 & 209 & 1,31 & 4,17 & 5,48 & 255 \\
\hline 25 & - $\quad 50$ & 1,66 & 5,98 & 7,64 & 62 & 1,19 & 5,26 & 6,45 & 84 \\
\hline 50 & - 100 & 1,12 & 7,92 & 9,04 & 26 & 0,92 & 6.42 & 7,33 & 36 \\
\hline & $>100$ & 2,81 & 9,63 & 12,44 & 16 & 1,82 & 8,12 & 9,94 & 17 \\
\hline Tot. & & 2,37 & 3,47 & 5,83 & 841 & 1,29 & 4,08 & 5,37 & 647 \\
\hline
\end{tabular}

Bron: Databestand CEIS. 
Uit de tabel blijkt dat het totaal aantal deelnemende lijsten per gemeente toeneemt naar mate de gemeente meer inwoners heeft. Eén van de mogelijke oorzaken hiervan is de omstandigheid dat in de grotere gemeenten een kleiner stempercentage nodig is om een raadszetel te bemachtigen dan in een kleine gemeente. Doordat daardoor ook kleinere partijen eerder in staat zullen zijn een raadszetel te bemachtigen, zullen zij in grotere getale aan de gemeenteraadsverkiezingen deelnemen. Tevens bevestigen onze bevindingen onderstaande stelling van Dahl en Tufte:

"Among political units within a democratic country where a system of proportional representation obtains, the number of parties (orparty lists) presented to the voters at election increases with unit size, degree of urbanisation, degree of specialization, and differentiation of labor and other resources." (Dahl/Tufte, 1973: 100)

Opvallend is dat de daling van het gemiddeld aantal deelnemende lijsten per gemeente in de periode 1974-1990 relatief zwak is in de gemeenten met minder dan 3.000 inwoners en daarentegen relatief sterk is in gemeenten met meer dan 100.000 inwoners. Het verschil in het gemiddeld aantal deelnemende lijsten per gemeente tussen de laagste en de hoogste categorie van gemeentegrootte is daardoor verkleind. Daarbij moet wel aangetekend worden dat met name de samenstelling van de categorie gemeenten met minder dan 3.000 inwoners sterk veranderd is in de onderzochte periode.

De lokale lijsten blijken relatief weinig aan de gemeenteraadsverkiezingen deel te nemen in de gemeenten met 25.000 tot 100.000 inwoners. De sterkste daling van het gemiddeld aantal deelnemende lokale lijsten doet zich overigens voor in gemeenten met tussen de 3.000 en 25.000 inwoners. Ook in de grootste gemeenten is een relatief sterke daling te constateren. Voor de nationale lijsten geldt in tegenstelling tot de lokale lijsten dat zij in sterkere mate aan de gemeenteraadsverkiezingen deelnemen naarmate het inwonertal van de gemeenten stijgt. Er blijkt overigens alleen in de gemeenten met 3.000 tot 10.000 inwoners sprake te zijn van een stijging van het aantal deelnemende nationale lijsten. Bovenstaande ontwikkelingen hebben ertoe bijgedragen dat in 1990 in geen enkele categorie van gemeentegrootte gemiddeld meer lokale dan nationale lijsten aan de gemeenteraadsverkiezingen deelnamen. In 1974 was dat nog het geval in de kleinste gemeenten, en hielden de lokale en nationale lijsten elkaar in evenwicht in de categorie gemeenten met 3.000 tot 10.000 inwoners.

\subsubsection{Spreidingscijfers}

De nationalisering van de gemeenteraadsverkiezingen in de periode $1974-1990 \mathrm{kan}$ niet alleen bepaald worden door het gemiddeld aantal deelnemende lokale en nationale lijsten per gemeente in kaart te brengen, maar tevens door het bepalen van het percentage gemeenten waar één of meerdere lokale dan wel nationale lijsten aan de gemeenteraadsverkiezingen hebben deelgenomen. In wezen meten wij daardoor de spreiding van deze lijsten over de verschillende gemeenten. Vandaar dat het percentage gemeenten waar lokale of nationale lijsten aan de gemeenteraadsverkiezingen deelnemen ook wel het spreidingscijfer wordt genoemd. ${ }^{6}$

Dittrich constateerde in zijn onderzoek naar de partijpolitieke verhoudingen bij de gemeenteraadsverkiezingen in de periode 1962-1974 dat zowel de lokale als de nationale lijsten in relatief meer gemeenten gingen deelnemen in deze periode. In hoeverre dat geldt voor de periode 1974-1990, wordt duidelijk uit tabel 3.4 . 
Tabel 3.4: Percentage gemeenten waar lokale c.q. nationale lijsten aan de gemeenteraadsverkiezingen deelnemen, 1974-1990.

\begin{tabular}{lrrrrr} 
& 1974 & 1978 & 1982 & 1986 & 1990 \\
lokaal & 79,9 & 77,8 & 75,3 & 72,7 & 70,8 \\
nationaal & 83,7 & 88,8 & 95,1 & 97,3 & 98,6 \\
N & 841 & 830 & 774 & 714 & 647 \\
\hline
\end{tabular}

Bron: Databestand CELS.

Uit de tabel blijkt duidelijk dat in de periode 1974-1990 sprake is van een voortzetting van de trend van de nationale lijsten om in relatief meer gemeenten aan de gemeenteraadsverkiezingen deel te nemen, terwijl dat niet geldt voor de lokale lijsten. Bij deze lijsten zien wij in deze periode een geleidelijke daling van het percentage gemeenten waar zij aan de verkiezingen deelneemt van 79,9 procent in 1974 tot 70,8 procent in 1990 . Omdat het spreidingscijfer van de nationale lijsten stijgt van 83,7 procent in 1974 tot 98,6 procent in 1990 , is het verschil in spreidingscijfers tussen de twee soorten lijsten vergroot. Dezevergroting van hetverschil geldt met name voor de gemeenteraadsverkiezingen van 1978 en 1982, omdat bij deze verkiezingen het spreidingscijfer van de nationale lijsten relatief sterk stijgt.

\section{Spreidingscijfers per provincie}

In de vorige paragraaf hebben wij kunnen constateren dat wat de deelname van het aantal lokale en nationale lijsten betreft, de provincies Noord-Brabant en Limburg een afwijkend beeld laten zien. Door de spreidingscijfers per provincie te bekijken, kan worden nagegaan of Noord-Brabant en Limburg ook op dit punt een afwijkend beeld laten zien.

Tabel 3.5: Spreidingscijfers voor lokale c.q. nationale lijsten, per provincie, 1974 en 1990, in procenten.

\begin{tabular}{lrrrrrr}
\hline & \multicolumn{2}{c}{1974} & & & 1990 \\
& lok. & nat. & $\mathrm{N}$ & lok. & nat. & $\mathrm{N}$ \\
Gr. & 62,7 & 100,0 & 51 & 60,0 & 100,0 & 25 \\
Fr. & 84,1 & 97,7 & 44 & 93,5 & 96,8 & 31 \\
Dr. & 79,4 & 100,0 & 34 & 82,4 & 100,0 & 34 \\
Ov. & 76,6 & 100,0 & 47 & 68,9 & 100,0 & 45 \\
Gl. & 78,8 & 87,5 & 104 & 64,0 & 100,0 & 86 \\
Ut. & 72,9 & 100,0 & 48 & 39,5 & 100,0 & 38 \\
NH. & 71,9 & 100,0 & 96 & 70,0 & 100,0 & 70 \\
ZH. & 65,6 & 99,3 & 151 & 48,4 & 100,0 & 95 \\
Zl. & 70,0 & 96,3 & 30 & 40,0 & 100,0 & 30 \\
NB. & 98,5 & 58,8 & 131 & 96,2 & 94,1 & 131 \\
Lb. & 100,0 & 35,6 & 104 & 85,7 & 98,2 & 56 \\
Fl. & 100,0 & 100,0 & 1 & 66,7 & 100,0 & 6 \\
& & & & & & \\
NL. & 79,9 & 83,7 & 841 & 70,8 & 98,6 & 647 \\
Bron: Databestand CELS. & & & & & \\
\end{tabular}


Uit tabel 3.5 kunnen wij opmaken dat Noord-Brabant en Limburg ook ten aanzien van de spreidingscijfers in de periode 1974-1990 een aparte plaats innemen. Zo blijkt bijvoorbeeld dat zowel in 1974 als in 1990 het spreidingscijfer voor de lokale lijsten in deze provincies opmerkelijk hoog is in vergelijking met met de overige provincies, al is in Limburg wel sprake van een daling. Tegenover de hoge spreidingscijfers voor de lokale lijsten stonden in 1974 opmerkelijk lage spreidingscijfers voor de nationale lijsten in deze provincies. In 1990 zijn deze daarentegen gestegen tot meer dan 90 procent. Samen met Friesland zijn Noord-Brabant en Limburg in 1990 de enige provincies met gemeenten waarin geen nationale lijsten aan de gemeenteraadsverkiezingen deelnamen. In totaal gaat het om negen gemeenten, waarvan zeven uit Noord-Brabant, namelijk Beers, Chaam, Hooge en Lage Mierde, Lith, Luyksgestel, Nieuw Vossemeer en Westerhoven. In Limburg betreft het enkel de gemeenten Kessel en in Friesland de gemeente Schiermonnikoog. Noord-Brabant is overigens de enige provincie waar zowel in 1974 als in 1990 in meer gemeenten lokale dan nationale lijsten aan de gemeenteraadsverkiezingen deelnamen. In 1974 gold hetzelfde ook voor Limburg. Uit tabel 3.5 kunnen wij dus opmaken dat de stijging van het landelijke spreidingscijfer van de nationale lijsten grotendeels is veroorzaakt door de toename van de deelname van de nationale lijsten in Noord-Brabant en Limburg.

Wat de overige provincies betreft, laten Utrecht, Zuid-Holland en Zeeland in de periode 19741990 een duidelijke daling van het spreidingscijfer voor de lokale lijsten zien. In de andere provincies blijft het spreidingscijfer in deze periode op ongeveer hetzelfde niveau. De nationale lijsten namen buiten Noord-Brabant en Limburg in zowel 1974 als in 1990 in bijna alle gemeenten deel aan de gemeenteraadsverkiezingen. Zoals gesteld, was Friesland de enige overige provincie waar in 1990 in niet alle gemeenten één of meerdere nationale lijsten aan de gemeenteraadsverkiezingen deelnamen. Uit bovenstaande bevindingen is af te leiden dat het verschil in spreidingscijfers tussen de provincies is vergroot bij de lokale lijsten en sterk is verkleind bij de nationale lijsten. Kortom, er is op dit punt sprake van een duidelijke nationalisering van de gemeenteraadsverkiezingen in de periode 1974-1990.

\section{Spreidingscijfers per gemeentegrootte}

Wat het aantal deelnemende lijsten betreft, is gebleken dat het aantal nationalc lijsten toenam naarmate het inwonertal van de gemeenten steeg, terwijl bij de lokale lijsten eerder sprake was van een tegenovergestelde ontwikkeling. Uit tabel 3.6 wordt duidelijk in hoeverre dat ook geldt voor de spreidingscijfers. 
Tabel 3.6: Spreidingscijfers van lokale c.q. nationale lijsten, per categorie van gemeentegrootte, 1974 en 1990, in procenten.

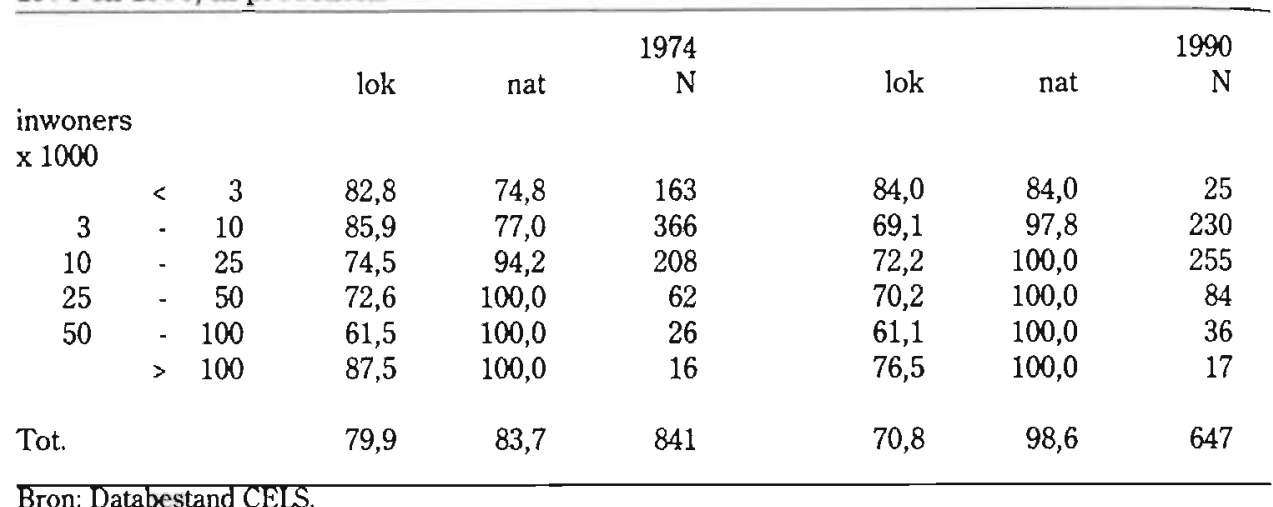

De tabel laat zien dat in ieder geval voor de nationale lijsten het spreidingscijfer toeneemt naar mate het inwonertal van de gemeenten stijgt. Zo nam in 1974 in alle gemeenten met meer dan 25.000 inwoners een nationale lijst deel aan de gemeenteraadsverkiezingen. In 1990 was dat zelfs het geval voor alle gemeenten met meer dan 10.000 inwoners. Tevens blijkt, zover nog mogelijk, in elke categorie van gemeentegrootte het spreidingscijfer gestegen te zijn in de onderzochte periode.

Dat geldt niet voor de lokale lijsten. In alle categorieën van gemeentegrootte behalve die met minder dan 3.000 inwoners is het spreidingscijfer gedaald. Deze daling is het sterkst in de gemeenten met 3.000 tot 10.000 inwoners en de grootste gemeenten. Er is dus in bijna alle categorieën van gemeentegrootte sprake van de delokalisering van de gemeenteraadsverkiezingen. Tevens kunnen wij constateren dat in 1990, in tegenstelling tot in 1974, in geen enkele categorie van gemeentegrootte het spreidingscijfer voor de lokale lijsten hoger is dan dat voor des nationale lijsten.

\subsection{Deelname van politieke stromingen}

Tot nu toe hebben wij de nationale lijsten als éen geheel beschouwd. Het totaal aan nationale lijsten wordt echter gevormd door lijsten van verschillende landelijke politieke stromingen. Wij onderscheiden daarbij een confessionele, een progressieve en een liberale stroming.

In de vorige paragraaf hebben wij meerdere malen geconstateerd dat in de periode 1974-1990 de nationale lijsten in relatief steeds meer gemeenten aan de gemeenteraadsverkiezingen hebben deelgenomen. Daarmee konden wij concluderen dat er in deze periode sprake is van een nationalisering van de gemeenteraadsverkiezingen. De vraag is of deze nationalisering alleen geldt voor éen van de landelijke politieke stromingen, of dat meerdere politieke stromingen in sterkere mate aan de gemeenteraadsverkiezingen zijn gaan deelnemen. Door de aandacht te richten op de verschiliende landelijke politieke stromingen bepalen wij de relatieve omvang van de geconstateerde nationalisering van de gemeenteraadsverkiezingen. 
Voor de periode 1962-1974 constateerde Dittrich (1978:102) dat de liberale en de progressieve stroming in steeds sterkere mate aan de gemeenteraadsverkiezingen deelnamen, terwijl de confessionele stroming ten aanzien van de deelname aan de gemeenteraadsverkiezingen op ongeveer hetzelfde (hoge) niveau bleef. ${ }^{7}$ Tabel 3.7 geeft aan in hoeverre deze ontwikkelingen zich na 1974 hebben voortgezet.

Tabel 3.7: Spreidingscijfers voor de landelijke politieke stromingen, 1974-1990, in procenten.

\begin{tabular}{lrrrrr}
\hline & 1974 & 1978 & 1982 & 1986 & 1990 \\
Confessioneeel & 71,0 & 79,4 & 92,5 & 95,1 & 97,4 \\
Progressief & 74,2 & 82,2 & 87,7 & 89,2 & 93,0 \\
Liberaal & 61,4 & 73,6 & 81,3 & 85,0 & 88,7 \\
N & 841 & 830 & 774 & 714 & 647 \\
\hline
\end{tabular}

Bron: Databestand CELS.

Uit de tabel komt duidelijk naar voren dat de spreidingscijfers van alle landelijke politieke stromingen in de periode 1974-1990 zijn gestegen. De liberale stoming blijkt door de jaren heen het laagste spreidingscijfer te hebben, hetgeen onder meer te wijten is aan de omstandigheid dat deze stroming in tegenstelling tot de confessionele en progressieve stroming maar uit én partij bestaat. ${ }^{8}$ Tegenover deze relatief lage spreidingscijfers staat wel de grootste stijging van deze cijfers in de onderzochte periode. Ook de confessionele stroming boekte een aanzienlijke vooruitgang en is daarmee sinds 1982 de stroming die in de meeste gemeenten vertegenwoordigd is. De progressieve stroming kende de geringste stijging van het spreidingscijfer. Wij kunnen dus de conclusie trekken dat op het punt van de deelname aan de gemeenteraadsverkiezingen de nationalisering van deze verkiezingen door alle drie de landelijke politieke stromingen gedragen wordt. De nationalisering van de gemeenteraadsverkiezingen is daarmee substantieel van aard.

\section{Spreidingscijfers per provincie}

De gegevens van tabel 3.5 gaven aan dat met name in Noord-Brabant en Limburg de nationale lijsten in de periode 1974-1990 in relatief meer gemeenten aan de gemeenteraadsverkiezingen zijn gaan deelnemen. De vraag is of deze doorbraak beperkt is gebleven tot eén van de landelijke politieke stromingen of dat zij alle hun spreidingscijfer verhoogd hebben in deze provincies. 
Tabel 3.8: Spreidingscijfers voor de landelijke politieke stromingen, per provincie, 1974 en 1990 , in procenten.

\begin{tabular}{|c|c|c|c|c|c|}
\hline & $\begin{aligned} & \text { conf. } \\
& 1974 \quad 1990\end{aligned}$ & $\begin{array}{rl} & \text { prog. } \\
1974 & 1990\end{array}$ & $\begin{array}{rr}\text { lib. } \\
1974 \quad 1990\end{array}$ & 1974 & $\begin{array}{r}\mathrm{N} \\
1990\end{array}$ \\
\hline Gr. & $90,2 \quad 96,0$ & $100,0100,0$ & $52,9 \quad 92,0$ & 51 & 25 \\
\hline Fr. & $95,5 \quad 93,5$ & $93,2 \quad 96,8$ & $72,5 \quad 93,5$ & 44 & 31 \\
\hline Dr. & $91,2 \quad 100,0$ & $97,1 \quad 97,1$ & $91,2100,0$ & 34 & 34 \\
\hline Ov. & $100,0100,0$ & $87,2 \quad 97,8$ & $66,0 \quad 88,9$ & 47 & 45 \\
\hline Gl. & $74,0 \quad 97,7$ & $86,5100,0$ & $67,3 \quad 91,9$ & 104 & 86 \\
\hline Ut. & $100,0100,0$ & $72,9 \quad 97,4$ & $75,0 \quad 100,0$ & 48 & 38 \\
\hline NH. & $91,7100,0$ & $87,5100,0$ & $69,8 \quad 98,6$ & 96 & 70 \\
\hline $\mathrm{ZH}$. & $97,4100,0$ & $90,7 \quad 100,0$ & $81,5100,0$ & 151 & 95 \\
\hline Zl. & $90,0 \quad 100,0$ & $80,0 \quad 90,0$ & $50,0 \quad 86,7$ & 30 & 30 \\
\hline NB. & $27,5 \quad 93,1$ & $45,8 \quad 75,6$ & $46,6 \quad 72,5$ & 131 & 131 \\
\hline Lb. & $6,7 \quad 94,6$ & $26,0 \quad 91,1$ & $21,2 \quad 73,2$ & 104 & 56 \\
\hline Fl. & $100,0100,0$ & $100,0 \quad 83,3$ & $100,0 \quad 83,3$ & 1 & 6 \\
\hline
\end{tabular}

\section{Bron: Databestand CELS.}

Uit tabel 3.8 kunnen wij nietalleen opmaken dat de drie landelijke politieke stromingen in bijna alle provincies hun spreidingscijfer verhoogd hebben, maar dat dat met name geldt voor Noord-Brabant en Limburg. Bij deze sterke stijging is opmerkelijk dat met name de confessionele stroming haar positie in deze provincies verbeterd heeft. Men zou immersverwachten dat deze politieke stroming in deze katholieke gebieden van oudsher een sterke positie zou hebben bij de gemeenteraadsverkiezingen. De sterke ondervertegenwoordiging van de confessionele politieke stroming wordt grotendeels veroorzaakt door de sterke positie van de lokale lijsten in deze provincies. Dittrich (1978:115-116) heeft er reeds op gewezen dat de katholieke mono-cultuur in deze provincies ertoe bijgedragen heeft dat de KVP zich niet genoodzaakt voelde om ten koste van de lokale lijsten aan de gemeenteraadsverkiezingen deel te nemen. Een concurrentie met de lokale lijsten zou immers alleen maar kunnen leiden tot meningsverschillen binnen de katholieke aanhang. En zolang andere landelijke partijen niet massaal deelnamen aan de gemeenteraadsverkiezingen in deze provincies, was er tevens geen enkele noodzaak aanwezig om zich officieel te mengen in de lokale politiek. In de jaren zeventig en tachtig slaagden lijsten van de andere landelijke politieke stromingen er echter in toenemende mate in hun positie in de zuidelijke provincies te verbeteren. Deelname van deze lijsten aan de gemeenteraadsverkiezingen dwong het CDA om ook aan deze verkiezingen deel te nemen (Welten, 1987:44). Dit had tot gevolg dat het CDA in 1978 in veel meer gemeenten in Noord-Brabant en Limburg aan de gemeenteraadsverkiezingen ging deelnemen. Ook in 1982 was de stijging van het aantal CDA-lijsten in Limburg aanzienlijk. ${ }^{9}$ Ditverklaart dan tevens voor een deel de eerder geconstateerde stijging van het spreidingscijfervan de nationale lijsten in 1982. Deze stijging wordt mede veroorzaakt door een duidelijk stijging van de deelname van de VVD en de progressieve lijsten in Limburg. De herindelingsverkiezingen van 1981 in ZuitLimburg hebben waarschijnlijk evenzeer een stimulerende rol vervuld. In de bij deze herindeling ontstane grotere gemeenten was de kiesdrempel immers relatief laag, waardon! voor landelijke lijsten de kans op een gemeenteraadszetel vergroot werd. Tevens werd door de herindeling van gemeenten de organisatiegraad van de partijen vergroot (Dittrich, 1983:49). 
Al met al geldtvoor elk van de landelijke politieke stromingen dat bij stijgende spreidingscijfers in 1990 het verschil tussen de spreidingscijfers van de provincies kleiner is dan in 1974 . Hetgeen opnieuw een aanwijzing is dat de nationalisering van de gemeenteraadsverkiezingen van substantile aard is.

\section{Spreidingscijfers per gemeentegrootte}

Wij hebben in tabel 3.6 kunnen constateren dat in 1990 alleen in de categorieën gemeenten met minder dan 10.000 inwoners gemeenten voorkomen waar geen nationale lijsten aan de gemeenteraadsverkiezingen hebben deelgenomen. In hoeverre dat ook geldt voor de drie afzonderlijke landelijke politieke stromingen, wordt duidelijk uit tabel 3.9.

Tabel 3.9: Spreidingscijfers voor de landelijke politieke stromingen, per categorie van gemeentegrootte, 1974 en 1990 , in procenten.

\begin{tabular}{|c|c|c|c|c|c|c|c|c|}
\hline & & $\begin{array}{r}\text { conf } \\
19741990\end{array}$ & 1974 & $\begin{array}{l}\text { prog. } \\
1990\end{array}$ & 1974 & $\begin{array}{r}\text { lib. } \\
1990\end{array}$ & $1974^{\circ}$ & $\begin{array}{r}\mathrm{N} \\
1990\end{array}$ \\
\hline \multicolumn{9}{|c|}{$\begin{array}{l}\text { inwoners } \\
\text { x } 1000\end{array}$} \\
\hline & 3 & $64,4 \quad 56,0$ & 56,4 & 56,0 & 25,2 & 52,0 & 163 & 25 \\
\hline 3 & 10 & $62,3 \quad 97,4$ & 67,8 & 86,1 & 56,3 & 79,6 & 366 & 230 \\
\hline 10 & 25 & $78,8100,0$ & 86,5 & 99,2 & 80,3 & 94,5 & 208 & 255 \\
\hline 25 & - 50 & $93,5100,0$ & 100,0 & 100,0 & 98,4 & 100,0 & 62 & 84 \\
\hline \multirow[t]{2}{*}{50} & - 100 & $100,0100,0$ & 100,0 & 100,0 & 96,2 & 100,0 & 26 & 36 \\
\hline & $>100$ & $100,0100,0$ & 100,0 & 100,0 & 100,0 & 100,0 & 16 & 17 \\
\hline Tot. & & $71,0 \quad 97,4$ & 74,2 & 93,0 & 61,4 & 88,7 & 841 & 647 \\
\hline
\end{tabular}

Bron: Databestand CELS.

Uit de tabel blijkt dat alleen de confessionele stroming in 1990 in alle gemeenten met meer dan 10.000 inwoners aan de gemeenteraadsverkiezingen heeft deelgenomen. Voor de progressieve stroming geldt dat niet in twee gemeenten, namelijk Eersel en Urk. Voor de drie onderscheiden landelijke politieke stromingen geldt wel dat zij in alle categorien van gemeentegrootte, behalve die met gemeenten met minder dan 3.000 inwoners, zover nog mogelijk hun spreidingscijfer verhoogd hebben. Met name bij de liberale stroming is de stijging van het spreidingscijfer opmerkelijk. Tevens blijkt voor elk van de politieke stromingen te gelden dat het spreidingscijfer stijgt naar mate het inwonertal van de gemeenten stijgt. Daarmee wordt de eerder aangehaalde stelling van Dahl en Tufte tevens onderschreven op het punt van de diversiteit van politieke partijen. Immers, hoe groter de gemeente, des te groter de kans dat een kiezer uit elk van de drie landelijke politieke stromingen zijn keuze kan maken.

Voor de periode 1962-1974 constateerde Dittrich (1978:104) dat er zich een grote stijging heeft voorgedaan in het percentage gemeenten waar lijsten van alle landelijke politieke stromingen aan de gemeenteraadsverkiezingen hebben deelgenomen. Tabel 3.10 geeft een overzicht van de resultaten in de periode 1974-1990. 
Tabel 3.10: Percentage gemeenten waar alle drie landelijke politieke stromingen aan de gemeenteraadsverkiezingen deelnamen, 1974-1990.

\begin{tabular}{lllll}
1974 & 1978 & 1982 & 1986 & 1990 \\
52,7 & 66,9 & 77,4 & 81,2 & 86,4 \\
\hline
\end{tabular}

Bron: Databestand CELS.

Uit de tabel kunnen wij opmaken dat de trend van een verdere pluralisering van de gemeenteraadsverkiezingen zich na 1974 in sterke mate heeft voortgezet. Het zal nietverbazen dat vooral in Noord-Brabant en Limburg de stijging van het percentage gemeenten waar lijsten van alle drie de politieke stromingen aan de gemeenteraadsverkiezingen hebben deelgenomen aanzienlijk is. In Noord-Brabant betreft het een stijging van 21,4 naar 66,4 procent, en in Limburg van 5,8 naar 69,6 procent. Daarmee blijven de cijfers van deze provincies echter nog onder het landelijk gemiddelde.

\subsection{Kiezers en deelname van lijsten}

Of er in de periode 1974-1990 sprake is van kiesgedrag dat karakteristiek is voor de gemeenteraadsverkiezingen, wordt mede bepaald door de mogelijkheden die kiesgerechtigden (of eenvoudigweg: kiezers) hebben om in hun kiesgedrag daaraan uiting te geven. Vandaar dat het niet alleen van belang is of lokale en landelijke lijsten aan de gemeenteraadsverkiezingen deelnemen, maar tevens in hoeverre kiezers de mogelijkheid hebben hun stem uit te brengen op een lokale of nationale lijst. Kortom, wij bepalen dus hoe groot het percentage kiezers is in de gemeenten waar lokale dan wel nationale lijsten aan de gemeenteraadsverkiezingen deelnemen. Dus niet het percentage gemeenten maar het percentage kiezers staat in deze paragraaf centraal.

Gezien de toenamevan het percentage gemeenten met nationale lijsten, mogen wijverwachten dat ook een groter percentage kiezers in de onderzochte periode de mogelijkheid heeft op een dergelijke lijst hun stem uit te brengen.

Tabel 3.11: Percentage kiezers dat op een lokale of nationale lijst kon stemmen, 1974-1990.

\begin{tabular}{|c|c|c|c|c|c|}
\hline & 1974 & 1978 & 1982 & 1986 & 1990 \\
\hline lokaal & 79,7 & 80,9 & 80,1 & 77,9 & 71,7 \\
\hline nationaal & 95,1 & 97,4 & 99,0 & 99,7 & 99,8 \\
\hline
\end{tabular}

Bron: Databestand CELS.

Blijkens de tabel had in 1974 al 95,1\% van de kiezers de mogelijkheid op althans één nationale lijst te stemmen. Sinds 1974 is dit percentage geleidelijk verhoogd, zodat in 1990 bijna alle kiezers hun stem konden uitbrengen op tenminste één nationale lijst. Het percentage kiezers dat op een lokale lijst kon stemmen is voor alle verkiezingen geringer dan het percentage 
kiezers dat op de nationale lijsten kon stemmen. Tevens is er sinds 1978 sprake van een dalende tendens in deze cijfers. Vooral in 1990 was er sprake van een achteruitgang.

\section{Resultaten per provincie}

Gezien onze eerder bevindingen mogen wij verwachten dat met name in de provincies NoordBrabant en Limburg een relatief groot deel van de kiezers in 1974 niet de mogelijkheid hebben gehad op een landelijke lijst te stemmen.

Tabel 3.12: Percentage kiezers dat niet op een lokale of nationale lijst kon stemmen, per provincie, 1974 en 1990.

$\begin{array}{lrrrr} & & \begin{array}{r}1974 \\ \text { nat. }\end{array} & \text { lok. } & \begin{array}{r}1990 \\ \text { nat. }\end{array} \\ & \text { lok. } & & & \\ \text { Gr. } & 35,3 & 0,0 & 27,8 & 0,0 \\ \text { Fr. } & 14,8 & 0,2 & 5,8 & 0,2 \\ \text { Dr. } & 25,5 & 0,0 & 41,0 & 0,0 \\ \text { Ov. } & 44,9 & 0,0 & 30,3 & 0,0 \\ \text { Gl. } & 29,5 & 3,2 & 31,5 & 0,0 \\ \text { Ut. } & 28,6 & 0,0 & 76,2 & 0,0 \\ \text { NH. } & 24,1 & 0,0 & 20,3 & 0,0 \\ \text { ZH. } & 15,7 & 0,1 & 30,8 & 0,0 \\ \text { Zl. } & 40,6 & 2,5 & 71,3 & 0,0 \\ \text { NB. } & 3,0 & 16,2 & 12,8 & 1,0 \\ \text { Lb. } & 0,0 & 29,3 & 11,8 & 0,3 \\ \text { Fl. } & 0,0 & 0,0 & 30,5 & 0,0 \\ \text { Nl. } & & & & \\ \text { N. } & 20,3 & , 9 & 28,3 & 0,2 \\ \text { Br. } & & & \end{array}$

Bron: Databestand CELS.

Uit tabel 3.12 blijkt dat dat inderdaad het geval is. In 1974 kon 16,2 procent van de kiezers in Noord-Brabant en 29,3 procent van de kiezers in Limburg op geen enkele nationale lijst stemmen bij de gemeenteraadsverkiezingen. In 1990 zijn deze percentages sterk gedaald tot respectievelijk 1,0 en 0,3 procent. In dezelfde periode konden bijna alle kiezers in NoordBrabant en Limburg op lokale lijsten stemmen, al gold dat in 1990 in mindere mate dan in 1974 . Ook in de provincie Friesland konden relatief veel kiezers op een lokale lijst stemmen in de periode 1974-1990, hetgeen grotendeels veroorzaakt wordt door de deelname van de FNP aan de gemeenteraadsverkiezingen. In de meeste overige provincies hadden in 1990 minder kiezers dan in 1974 de mogelijkheid om op een lokale lijst te stemmen. Vooral in Utrecht en Zeeland zien wij een grote stijging van het percentage kiezers die bij de gemeenteraadsverkiezingen niet op een lokale lijst kon stemmen.

\section{Resultaten per categorie van gemeeentegrootte}

In paragraaf 3.1 hebben wij geconstateerd dat de lokale lijsten met name minder in gemeenten met 3.000 tot 10.000 inwoners en in gemeenten met meer dan 100.000 inwoners zijn gaan deelnemen aan de gemeenteraadsverkiezingen. Uit tabel 3.13 blijkt dan ook dat in deze twee 
gemeentecatgorieën er een relatief grote stijging is van het percentage kiezers dat niet op een lokale lijst kan stemmen. Maar ook in de ander categorieën van gemeentegrootte is er sprake van een stijging.

Tabel 3.13: Percentage kiezers dat niet op een lokale of nationale lijst kon stemmen, per categorie van gemeentegrootte, 1974 en 1990.

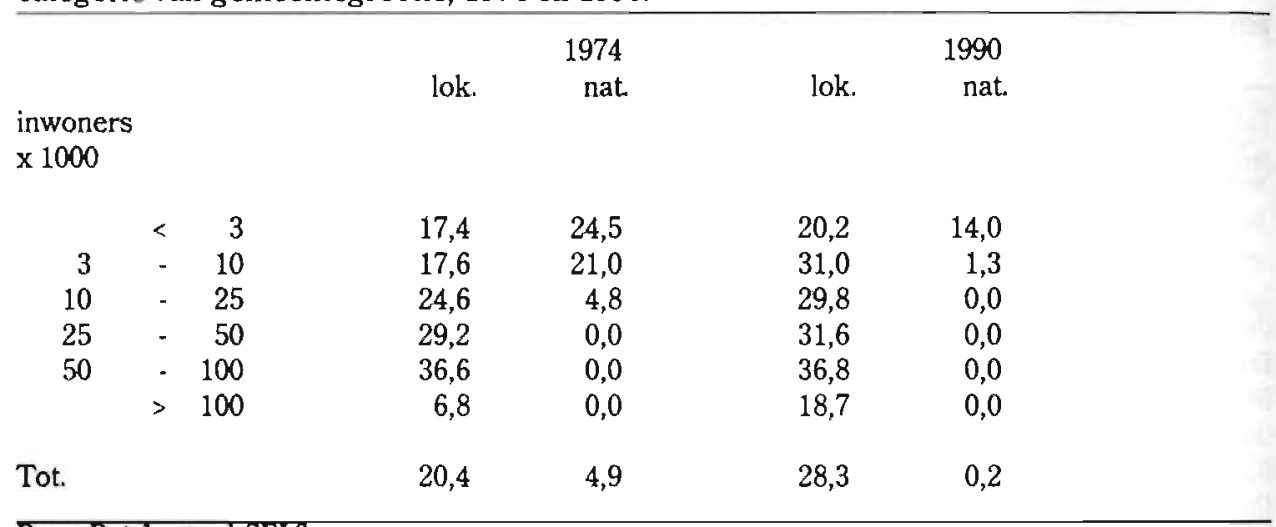

Bron: Databestand CELS.

Ten opzichte van de gemeenteraadsverkiezingen van 1974 zien wij in 1990 in alle categorieën van gemeentegrootte een daling van het percentage kiezers dat niet op een nationale lijst kan stemmen. Daarmee konden in 1990 alleen nog in de categorieën gemeenten met minder dan 10.000 inwoners een deel van de kiezers op geen enkele nationale lijst stemmen. In 1990 gold in tegenstelling tot de gemeenteraadsverkiezingen van 1974 dat in alle categorieën van gemeentegrootte meer kiezers op een nationale lijst dan op een lokale lijst konden stemmen.

Kiezers en deelname van politieke stromingen

In de vorige paragraaf hebben wij laten zien in hoeverre de verschillende landelijke politieke stromingen in meer gemeenten aan de gemeenteraadsverkiezingen zijn gaan deelnemen. Het achterliggende idee hierbij was om daarmee de relatieve omvang van de opkomst van de nationale lijsten te bepalen. Aldus constateerden wij dat in de periode 1974-1990 de gemeenteraadsverkiezingen onder meer gekenmerkt werden docr een verdere pluralisering, aangezicn in steeds meer gemeenten lijsten van de drie grote landelijke politieke stromingen aan de gemeenteraadsverkiezingen zijn gaan deelnemen. Uit tabel 3.14 blijkt in hoeverre het percontage kiezers dat een dergelijke keuze kon maken, is gestegen. 
Tabel 3.14: Percentage van de kiesgerechtigde bevolking naar deelname van het aantal deelnemende politieke stromingen bij de gemeenteraadsverkiezingen in hun gemeente, 19741990.

\begin{tabular}{lrrrrr}
\hline & 1974 & 1978 & 1982 & 1986 & 1990 \\
geen stroming & 4,9 & 2,6 & 1,0 & 0,3 & 0,2 \\
eén stroming & 4,0 & 2,7 & 1,2 & 1,4 & 0,9 \\
twee stromingen & 8,3 & 4,9 & 3,8 & 2,9 & 2,7 \\
drie stromingen & 82,6 & 89,9 & 94,0 & 95,5 & 96,3 \\
Total & 100,0 & 100,1 & 100,0 & 100,1 & 100,1 \\
\hline
\end{tabular}

Bron: Databestand Werkgroep lokale politiek RL.

In 1974 kon $82,6 \%$ van de kiesgerechtigde bevolking zijn stem uitbrengen op elk van de drie landelijke politieke stromingen. In 1990 is dit percentage verhoogd tot 96,3\%. In de periode 1974-1990 zijn de politieke stromingen er dus in geslaagd om zich aan bijna alle kiezers bij de gemeenteraadsverkiezingen te presenteren. Voorts kunnen wij constateren dat met name in 1978 en 1982 de keuzemogelijkheden voor relatief veel kiezers uitgebreid zijn. Daarmee geven deze cijfers zeer duidelijk aan dat de positie van de nationale lijsten en de afzonderlijke politieke stromingen in de onderzochte periode versterkt is.

Als wij deze cijfers vergelijken met de eerder gepresenteerde gegevens over het percentage gemeenten waarin alle drie de politieke stromingen aan de verkiezingen deelnamen, dan blijkt in elke verkiezingsjaar het percentage kiezers dat de mogelijkheid had om op elk van de drie landelijke politieke stromingen te stemmen, aanzienlijk hoger te zijn. Daaruit kunnen wij concluderen dat in de periode 1974-1990 vooral in veel kleinere gemeenten kiezers in staat zijn gesteld op drie landelijke politieke stromingen te stemmen. Immers, hetpercentage gemeenten waarin deze drie politieke stromingen aan de gemeenteraadsverkiezingen deelnemen, stijgt in veel sterkere mate dan het aantal kiezers dat een keuze kon maken uit deze politieke stromingen.

Bovenstaande bevindingen wijzen er tevens op dat een deel van de kiezers niet de mogelijkheid heeft gehad op een lijst van éen of meerdere landelijke politieke stromingen te stemmen. In welke mate daarin verandering komt in de periode 1974-1990 blijkt uit tabel 3.15.

Tabel 3.15: Percentage kiezers dat niet op één van de politieke stromingen kon stemmen, 1974 1990.

\begin{tabular}{lrrrrr} 
& 1974 & 1978 & 1982 & 1986 & 1990 \\
$\begin{array}{lrrr}\text { ontbrekende } \\
\text { stroming: }\end{array}$ & & & & & \\
& & & & & \\
confessionele & 11,2 & 6,7 & 1,5 & 0,6 & 0,1 \\
progressieve & 8,1 & 4,3 & 2,7 & 2,2 & 1,2 \\
liberale & 12,2 & 7,2 & 5,0 & 3,7 & 3,2 \\
\hline
\end{tabular}


In 1974 is het percentage kiezers dat niet op een lijst van de liberale of confessionele stroming kon stemmen hoger dan het percentage kiezers dat niet op een lijst van de progressieve stroming kon stemmen. Bij de daarop volgende verkiezingen, vooral die van 1978 en 1982, was er sprake van een sterke daling van het percentage kiezers dat niet op een confessionele lijst kon stemmen, zodat vanaf 1982 bijna alle kiezers de mogelijkheid hebben hun stem uit te brengen op een lijst van deze stroming. Daarmee wordt nogmaals de betekenis onderstreept van de expliciete deelname van de confessionele stroming aan de gemeenteraadsverkiezingen in Noord-Brabant en Limburg. Ook de andere politieke stromingen bereikten in de periode 1974-1990 meer kiezers. In 1990 kon dan daarmee bijna iedere kiezer zijn stem uitbrengen op de liberale en progressieve stroming.

Samenvattend kunnen wij stellen dat al in 1974 een zeer groot deel van de kiezers konden stemmen op een lijst van één van de drie landelijke politieke stromingen. In de periode 19741990 zijn zij erin geslaagd om bij de gemeenteraadsverkiezingen nog meer kiezers te bereiken. Dat geldt niet voor de lokale lijsten. In dezelfde periode hebben minder kiezers de kans gekregen hun stem uit te brengen op eén van de lokale lijsten.

\subsection{Samenvattende conclusies}

In dit hoofdstuk hebben wij de deelname van de lokale en nationale lijsten aan de gemeenteraadsverkiezingen in de periode 1974-1990 in kaart gebracht. De reden hiervoor is dat hiermee een aspect van het lokale karakter van de gemeenteraadsverkiezingen aan de orde wordt gesteld. Immers, de lokale lijsten kunnen wij beschouwen als een kenmerkend lokaal element in de gemeenteraadsverkiezingen.

In de inleiding hebben wij gesteld dat wij ten aanzien van de deelnamevan lokale lijsten spreken van een delokalisering van de gemeenteraadsverkiezingen als het percentage lokale lijsten op het totaal aantal deelnemende lijsten afneemt of als de lokale lijsten in minder gemeenten aan de gemeenteraadsverkiezingen gaan deelnemen. Aangezien in de periode 1974-1990 beide ontwikkelingen zich voordoen, kunnen wij dus concluderen dat in de periode 1974-1990 een proces van delokalisering van de gemeenteraadsverkiezingen heeft plaatsgevonden. De afname van het aandeel van de lokale lijsten is met name sterk in de provincies Noord-Brabant en Limburg en gemeenten met 3.000 à 25.000 inwoners. De deelname van de lokale lijsten viel met name terug in de provincies Utrecht, Zuid-Holland en Zeeland.

Naast een delokalisering van de gemeenteraadsverkiezingen kunnen wij constateren dat in de periode 1974-1990 zich een proces van nationalisering heeft voltrokken. Dat blijkt niet alleen uit de toename van het aandeel van de nationale lijsten op het totaal aantal deelnemende lijsten. maar met name ook uit de stijging van het percentage gemeenten waarin de nationale lijsten zich aan de kiezers presenteren. Deze stijging is met name in de provincies Noord-Brabant en Limburg te constateren. Tevens blijft deze stijging niet beperkt to één politieke stroming, maar geldt zij voor de drie grootste landelijke politieke stromingen, en weer met name in NoordBrabant en Limburg.

De geconstateerde processen van delokalisering en nationalisering van de gemeente raadsverkiezingen, doen zich ook voor als wij het percentage kiezers in ogenschouw nemen dat op een lokale of nationale lijst kan stemmen. Voorts geldt voor elk van de drie landelijke politieke stromingen dat $z \mathrm{ij}$ in de periode 1974-1990 een hoger percentage van de kiezers bereiken. Tevens is er sprake van een stijging van het percentage kiezers dat bij de 
gemeenteraadsverkiezingen een keuze kan maken uit de drie landelijke politieke stromingen, zodat wij kunnen spreken van een proces van partijpolitieke pluralisering van de gemeenteraadsverkiezingen in de periode 1974-1990. Gezien de afnemende deelname van de lokale lijsten aan de gemeenteraadsverkiezingen kunnen wij echter niet in $z^{\prime} n$ algemeenheid spreken van een pluralisering van de gemeenteraadsverkiezingen in deze periode.

Het bovenstaande betekent dat in 1974 een periode van lokalisering van de gemeenteraadsverkiezingen is afgesloten. Dittrich constateerde immers dat in de periode 1962-1974 sprake is van een lokalisering van de gemeenteraadsverkiezingen, onder andere wat de deelname van de lokale lijsten betreft. De door hem geconstateerde nationalisering van de gemeenteraadsverkiezingen in de periode 1962-1974, voor wat de deelname van de nationale lijsten betreft, zet zich na 1974 wel verder door (Dittrich, 1978:216-217;46-47). Wat de mogelijke oorzaken zijn van deze nieuwe ontwikkelingen, zal in hoofdstuk vier aan de orde komen. Daarin zullen de verkiezingsresultaten van de lokale en nationale lijsten in kaart worden gebracht. 


\section{NOTEN}

${ }^{1}$ Dittrich onderscheidt in zijn proefschrift nog vier politieke hoofdstromingen, namelijk de katholieke, de protestantse, de liberale en de socialistische. In 1962 had 65,2\% van de kiesgerechtigde bevolking de mogelijkheid een keuze te maken uit de deze vier politieke stromingen. In 1974 was dit gestegen tot 72,8\% (Dittrich, 1978:98). ${ }^{2}$ Dit beeld wordt nog enigszins vertekend door de afzonderlijke deelname van lijsten van de KVP, ARP en CHU aan de gemeenteraadsverkiezingen van 1974. Als wij deze lijsten in alle gemeenten waar zij aan de gemeenteraadsverkiezingen deelnamen als een lijst beschouwen, dan daalt het gemiddeld aantal deelnemende nationale lijsten tot 3.37 .

${ }^{3}$ Zie voor een meer gedetaileerd overzicht van de deelname van combinaties van kleine landelijke partijen hoofdstuk 5 paragraaf 1.2 .

" Om de gepresenteerde gegevens enigszins overzichtelijk te houden is er voor gekozen om bij een groot deel van de tabellen in dit hoofdstuk de gegevens van de gemeenteraadsverkiezingen van 1978, 1982 en 1986 op te nemen in aparte tabellen in bijlage 1.

"In tegenstelling tot Dittrich maken wij in dit onderzoek gebruik van een indeling naar gemeentegrootte in plaats van een indeling naar urbanisatiegraad. Dat deze twee indelingen eenzelfde ontwikkeling laten zien, wordt in het onderzoek van Dittrich ondermeer treffend aangetoond in de tabellen 8.3 en 8.4. (Dittrich, 1978:156 en 158). ${ }^{8}$ Deze term is geïntroduceerd door Dittrich (1978:37).

"Hierbij moet wel aangetekend worden dat bij Dittrich de zogenaamde RK-lijsten deel uit maken van het confessionele blok, terwijl in deze studie zij tot het lokale blok gerekend worden.

${ }^{3}$ Als wij de spreidingscijfers van de VVD vergelijken met die van de grootste partijen in de andere twee politieke stromingen- het CDA en de PudA - dan blijkt dat de VVD bij alle gemeenteraadsverkiezingen in de onderzochte periode een hoger spreidingscijfer heeft dan de PvdA en een lager spreidingscijfer heeft dan het CDA. Als wi] ook de gemeenten met: een PAK-lijst: meetellen bij de score van de PvdA, dan blijkt de PvdA echter in meer gemeenten dan de VVD deel te nemen aan de gemeenteraadsverkiezingen. Aangezien de VVD bij alle gemeenteraadsverkiezingen, behalve die van 1982, ongeveer 9 á 13 procent minder stemmen heeft gekregen dan de PvdA en het PAK gezamenlijk, kunnen wij de deelname van de VVD aan de gemeenteraadsverkiezingen opmerkelijk groot noemen.

'Daarbij moeten wij ons realiseren dat een deel van de CDA-lijsten tot stand zijn gekomen door de overstap van lokale politici van de lokale lijsten, of de overstap van lokale lijsten als geheel naar het CDA. Zie hiervoor: Werkgroep Lokale Politiek (1986:43); Kuiper (1991:110-111); Kuiper e.a. (1991:54,58); Kuiper en Knippenberg (1990:147). 


\section{Hoofdstuk 4}

\section{VERKIEZINGSRESULTATEN}

In het vorige hoofdstuk hebben wij kunnen zien dat in de periode 1974-1990 sprake is van een daling van zowel het gemiddeld aantal deelnemende lokale lijsten als van de spreidingscijfers van de lokale lijsten. De positie van de lokale lijsten is dus onder druk komen te staan. In hoeverre gaat deze ontwikkeling gepaard met een daling van het percentage stemmen voor de lokale lijsten in de onderzochte periode? Deze vraag zal in dit hoofdstuk beantwoord worden. Daarmee wordt een compleet overzicht gegeven van de electorale positie van de lokale lijsten. Aangezien wij de deelname van en electorale steun voor de lokale lijsten beschouwen als een voorbeeld van lokaal kiesgedrag bij de gemeenteraadsverkiezingen, kunnen wij op basis van onze bevindingen een eerste conclusie trekken omtrent de mate waarin wij kunnen spreken van een eigenstandig lokaal karakter van de gemeenteraadsverkiezingen. Daarbij zullen wij, evenals in hoofdstuk drie, gebruik maken de door Dittrich (1978:215-219) geïntroduceerde begrippen "lokalisering" en "nationalisering". In dit hoofdstuk zullen wij ons richten op eén aspect van deze begrippen, namelijk de ontwikkeling van de stempercentages van de lokale en nationale lijsten. Er is sprake van een lokalisering van de gemeenteraadsverkiezingen als de stempercentages van de lokale lijsten in de onderzochte periode stijgen. Bij een toename van de stempercentages van de nationale lijsten is er daarentegen sprake van een nationalisering van de gemeenteraadsverkiezingen.

Evenals in het vorige hoofdstuk zal bij de analyse van de verkiezingsresultaten van de lokale en nationale lijsten niet alleen een landelijk, maar ook een provinciaal beeld worden geschetst. Tevens zullen de resultaten per categorie van gemeentegrootte in kaart worden gebracht. Voorts zal ook op gemeente-niveau worden nagegaan in welke richting de stempercentages van de lokale en nationale lijsten zich hebben ontwikkeld in de onderzochte periode. Op deze manier wordt de relatieve omvang van de geconstateerde ontwikkelingen in de onderzochte periode duidelijk. Vervolgens zullen wij aandacht schenken aan de verkiezingsresultaten van de verschillende politieke stromingen. Ook hierbij is de achterliggende gedachte inzicht te krijgen in de relatieve omvang van de geconstateerde ontwikkelingen, in dit geval ten aanzien van de electorale ontwikkelingen van de nationale lijsten.

\subsection{Verkiezingsresultaten van de lokale en nationale lijsten}

In paragraaf 3.1 hebben wijgeconstateerd dat de lokale lijsten in de periode $1974-1990$ in relatief minder gemeenten aan de gemeenteraadsverkiezingen zijn gaan deelnemen. Tevens bleek dat daardoor uiteindelijk minder kiezers de mogelijkheid kregen op een lokale lijst te stemmen. Op grond hiervan kunnen wij verwachten dat ook het percentage stemmen dat op de lokale lijsten wordt uitgebracht een daling laat $z$ ien. 
Tabel 4.1: Percentage stemmen op de lokale en nationale lijsten, 1974-1990.

\begin{tabular}{lrrrrr}
\hline & 1974 & 1978 & 1982 & 1986 & 1990 \\
lokaal & 18,9 & 14,8 & 13,0 & 12,0 & 13,3 \\
nationaal & 81,1 & 85,2 & 87,0 & 88,0 & 86,7 \\
Totaal & 100 & 100 & 100 & 100 & 100 \\
\hline Bron: Databestand CELS. & & &
\end{tabular}

Uit tabel 4.1 blijkt dat de lokale lijsten inderdaad een deel van hun aanhang verliezen. Vooral bij de gemeenteraadsverkiezingen van 1978 is het verlies relatief groot. In de daaropvolgende verkiezingen is het verlies echter minder. Uit de tabel blijkt tevens dat bij de gemeen. teraadsverkiezingen van 1990 het stemmenpercentage van de lokale lijsten weer stijgt. Daarmee hebben deze lijsten in 1990 weer het niveau van 1982 bereikt. Sinds 1982 zijn de lokale lijsten, uitgaande van de in totaal uitgebrachte stemmen, er dus in geslaagd om zich op ongeveer hetzelfde electorale niveau te handhaven.

In hoeverre zijn deze ontwikkelingen zichtbaar op gemeente-niveau? Of anders gezegd, in hoeveel gemeenten is het stempercentage van de gezamenlijke lokale lijsten in 1990 lager dan in 1974? Dat blijkt in 346 gemeenten het geval te zijn. Daarentegen is het stempercentage voor de lokale lijsten in 1990 in 175 gemeenten hoger dan in 1974. In de overige 84 gemeenten is het stempercentage gelijk gebleven, hetgeen in bijna alle gevallen inhoudt dat in deze gemeenten zowel in 1974 als in 1990 geen lokale lijsten aan de gemeenteraadsverkiezingen hebben deelgenomen. ${ }^{1}$ In een ruime meerderheid van de gemeenten hebben de gezamenlijke lokale lijsten dus in 1990 een lager stemperentage gehaald dan bij de gemeenteraadsverkiezingen in 1974.

\section{Uitslagen per provincie}

In hoofdstuk drie is geconstateerd dat in 1974 in alle provincies in meer dan 60 procent van de gemeenten een lokale lijst aan de gemeenteraadsverkiezingen heeft deelgenomen. In 1990 is het verschil in de provinciale spreidingscijfers vergroot van 39,5 procent in Utrecht tot 96,2 procent in Noord-Brabant. Of daarmee ook het verschil in de provinciale stemprecentages vergroot is, blijkt uit tabel 4.2 . 
Tabel 4.2: Percentage stemmen op lokale lijsten, per provincie, 1974- 1990.

$\begin{array}{lrrrrr} & 1974 & 1978 & 1982 & 1986 & 1990 \\ \text { Gr. } & 5,1 & 5,0 & 6,5 & 5,7 & 5,9 \\ \text { Fr. } & 10,5 & 9,2 & 9,9 & 9,2 & 12,7 \\ \text { Dr. } & 8,5 & 8,9 & 9,3 & 9,1 & 12,0 \\ \text { Ov. } & 10,6 & 6,5 & 6,6 & 6,1 & 9,4 \\ \text { Gl. } & 16,7 & 13,0 & 11,2 & 10,4 & 12,1 \\ \text { Ut. } & 5,3 & 3,2 & 3,1 & 3,7 & 4,9 \\ \text { NH. } & 6,4 & 4,9 & 6,4 & 6,8 & 7,9 \\ \text { ZH. } & 4,7 & 3,3 & 4,6 & 4,5 & 4,6 \\ \text { Zl. } & 15,8 & 13,2 & 11,4 & 9,0 & 10,7 \\ \text { NB. } & 51,3 & 37,0 & 31,7 & 28,1 & 30,0 \\ \text { Lb. } & 71,8 & 61,9 & 41,0 & 36,1 & 34,2 \\ \text { Fl. } & 6,3 & 4,7 & 2,8 & 5,2 & 5,7 \\ \text { Nl. } & 18,9 & 14,8 & 13,0 & 12,0 & 13,3\end{array}$

Bron: Databestand CELS.

De stempercentages van de lokale lijsten in de verschillende provincies laten in eerste instantie grote verschillen zien. Verreweg het hoogste percentage stemmen halen de lokale lijsten in 1974 in Noord-Brabanten Limburg. Daarnaast zijn ook de verkiezingsresultaten in Gelderland en Zeeland relatief goed. Als vervolgens de cijfers van 1974 vergeleken worden met die van 1990, dan blijkt dat juist in deze vier provincies de grootste achteruitgang te constateren is. Tegenover deze achteruitgang staat overigens een vooruitgang in een vijftal provincies. Daarmee zijn de verschillen tussen de verschillende provincies in 1990 kleiner dan in 1974.

De grootste achteruitgang in het percentage stemmen op de lokale lijsten vinden wij overigens in Limburg en Noord-Brabant. In 1978 lijden de Jokale lijsten als geheel een groot verlies in Noord-Brabant, terwijl in 1982 Limburg een aanzienlijke daling van het percentage stemmen laat zien. In de periode 1974-1990 wordt zo het percentage stemmen op alle lokale lijsten gezamenlijk in Noord-Brabant met $41,2 \%$ verminderd en in Limburg zelfs met $56,7 \%$. Kortom, het verlies van de lokale lijsten in de periode 1974-1990 lijkt voor een groot gedeelte veroorzaakt door het grote verlies van aanhang in de provincies Noord-Brabant en Limburg. Dat wordt vooral duidelijk als wij de stemmenpercentages voor de lokale lijsten voor NoordBrabant en Limburg enerzijds en de rest van Nederland anderzijds berekenen. Zie hiervoor tabel 4.3 .

Tabel 4.3: Percentage stemmen op lokale lijsten, voor Noord-Brabant en Limburg en de rest van Nederland, 1974-1990.

\begin{tabular}{lrrrrr} 
& 1974 & 1978 & 1982 & 1986 & 1990 \\
NB+Lb & 58,9 & 46,1 & 35,1 & 31,0 & 31,5 \\
rest & 8,3 & 6,4 & 6,9 & 6,7 & 8,0 \\
Bron: & & & & & \\
\hline
\end{tabular}

Bron: Databestand CELS. 
Zoals uit de tabel blijkt is het percentage stemmen op de lokale lijsten in de periode 1974-1990 met name sterk verminderd in Noord-Brabant en Limburg. In 1990 is het percentage stemmen van de lokale lijsten in deze provincies ongeveer de helft van het percentage stemmen dat men in 1974 haalde. In de rest van Nederland is het verkiezingsresultaat van de lokale lijsten in 1990 op bijna hetzelfde niveau als in 1974. In de tussenliggende periode is echter sprake van een verlies van ongeveer 15 á 25 procent. Vooral in 1978 is er een relatief grote achteruitgang in het percentage stemmen op de lokale lijsten in de rest van Nederland.

Ook op gemeente-niveau blijkt dat de gezamenlijke lokale lijsten met name in Noordbrabantse en Limburge gemeenten in 1990 een lager stempercentage gehaald hebben dan in 1974. Zie hiervoor tabel 4.4 .

Tabel 4.4: De plaatselijke stempercentages van de lokale lijsten in 1990 vergeleken met die in 1974, in Noord-Brabant en Limburg en de rest van Nederland, in percentages van het aantal gemeenten.

\begin{tabular}{lrrrr} 
& lager & hoger & gelijk & N \\
NB+Lb & 85,3 & 9,8 & 4,9 & 184 \\
rest & 44,9 & 37,2 & 17,8 & 421 \\
\hline
\end{tabular}

Bron: Databestand CELS

Terwijl de lokale lijsten in 85,3 procent van de Noordbrabantse en Limburgse gemeenten in 1990 een lager stempercentage hadden in 1990 in vergelijking met 1974, geldt dat voor de rest van Nederland maar voor 44,9 procent van de gemeenten. In deze laatste groep gemeenten is met 37,2 procent het aantal gemeenten dat een stijging van het stempercentage van de lokale lijsten kende, zelfs bijna even groot als het aantal gemeenten dat een daling kende. ${ }^{2}$ In NoordBrabant en Limburg is dit met een percentage van 9,8 procent zeker niet het geval. Uit het percentage gemeenten waarin het stempercentage van de lokale lijsten gelijk bleef, blijkt dat buiten Noord-Brabant en Limburg in relatief veel gemeenten zowel in 1974 als in 1990 geen lokale lijsten aan de gemeenteraadsverkiezingen hebben deelgenomen.

\section{Uitslagen per grootte van de gemeente}

Uit een vergelijking van het bovenstaande met de resultaten uit hoofdstuk drie kunnen wij opmaken dat er op provinciaal niveau geen eenduidige relatie is tussen de spreidingscijfers en de stempercentages voor de lokale lijsten. Immers, in de provincies Groningen en NoordHolland gaat de daling van het spreidingscijfer voor de lokale lijsten in 1990 ten opzichte van 1974 gepaard met een verhoging van het stempercentage, terwijl in de andere provincies met een dalend spreidingscijfer in deze periode ook het stempercentage daalt. Tevens kunnen wij constateren dat in Drenthe de stijging van het spreidingspercentage veel geringer is dan de stijging van het stempercentage, terwijl in Utrecht de daling van het spreidingspercentage veel sterker is dan de daling van het stempercentage.

Of hetzelfde geldt voor gemeenten van verschillende grootte, wordt duidelijk als wij de gegevens van tabel 4.5 in relatie brengen met die van tabel 3.6. Uit deze laatste tabel blijkt dat voor alle gemeenten behalve de gemeenten tot 3.000 inwoners geldt dat de spreidingsciffers in 1990 iets lager zijn dan in 1974. 
Tabel 4.5: Percentage stemmen op lokale lijsten, per categorie van gemeentegrootte, 19741990.

\begin{tabular}{|c|c|c|c|c|c|c|}
\hline \multicolumn{7}{|c|}{$\begin{array}{l}\text { Inwoners } \\
\times 1000\end{array}$} \\
\hline & 3 & 44,9 & 42,3 & 38,7 & 42,1 & 50,0 \\
\hline 3 & 10 & 42,8 & 35,2 & 25,8 & 23,1 & 25,7 \\
\hline 10 & $-\quad 25$ & 27,7 & 20,4 & 19,3 & 17,9 & 19,7 \\
\hline 25 & $\begin{array}{l}-50 \\
\end{array}$ & 14,0 & 10,0 & 10,0 & 10,8 & 13,3 \\
\hline 50 & -100 & 5,3 & 4,6 & 5,0 & 6,2 & 6,5 \\
\hline & $>100$ & 2,4 & 2,1 & 3,0 & 2,6 & 2,1 \\
\hline
\end{tabular}

Bron: Databestand CELS.

Opvallend is allereerst dat voor alleverkiezingen geldt dat de aanhang van de lokale lijsten daalt naarmate de categorie van gemeentegrootte meer inwoners telt. Vergeleken met 1974 stijgt bij de gemeenteraadsverkiezingen van 1990 de aanhang van de lokale lijsten in de gemeenten met minder dan 3.000 inwoners en die met 50.000 tot 100.000 inwoners. In het eerste geval geldt dat overigens alleen voor 1990 en moeten wij rekening houden met de grote veranderingen in deze categorie van gemeentegrootte in de onderzochte periode. De sterkste daling van de stempercentages van de lokale lijsten doet zich voor in gemeenten met tussen de 3.000 en 25.000 inwoners. Vooral in gemeenten met 3.000 tot 10.000 inwoners is het verlies groot. De relatief grote achteruitgang van het stempercentage van de lokale lijsten in de gemeenten met 10.000 tot 25.000 inwoners is opvallend gezien de geringe achteruigang van de spreidingscijfers in deze categorie gemeenten. Daar staat tegenover dat in de categorie gemeenten met 50.000 tot 100.000 inwoners het stempercentage van de lokale lijsten een stijging kent, terwijl het spreidingscijfer ongeveer stabiel blijft. Al met al lijkt ook voor de verschillende categorieën van gemeentegrootte geen sterke relatie te bestaan tussen de spreidingscijfers en de stempercentages voor de lokale lijsten. Vermeldenswaardig is tevens dat het stempercentage van de lokale lijsten in 1990 ten opzichte van 1986 in alle categorien van gemeentegrootte behalve die van de grote steden gestegen is. En uit een analyse op gemeente-niveau blijkt dat in alle categorieën van gemeentegrootte er meer gemeenten zijn waar het stempercentage van de gezamenlijke lokale lijsten daalt dan er gemeenten zijn waar dit stempercentage in 1990 stijgt ten opzichte van de gemeenteraadsverkiezingen van 1974 .

\subsection{Verkiezingsresultaten van de politieke stromingen}

Uit de voorgaande paragraaf is ons gebleken dat de stempercentages van de lokale lijsten in de periode 1974-1990 gedaald zijn. Dat betekent automatisch dat de stempercentages van de landelijke lijsten in deze periode gestegen zijn. In die zin kunnen wij dus spreken van een nationalisering van de gemeenteraadsverkiezingen. Als wij echter willen achterhalen wat de relatieve omvang van de stijging van de stempercentages van de landelijke lijsten is, moeten wij ons nader richten op de electorale ontwikkelingen binnen het totaal van de nationale lijsten. Daarbij gaat het om de vraag in hoeverre de verschillende landelijke politieke stromingen erin geslaagd zijn hun electorale positie te verbeteren in de periode $1974-1990$. Tabel 4.6 geeft hiervoor de nodige gegevens. 
tabel 4.6: Percentage stemmen op de drie politieke stromingen, 1974- 1990.

\begin{tabular}{llllll} 
& 1974 & 1978 & 1982 & 1986 & 1990 \\
& & & & & \\
confessioneel & 30,7 & 34,9 & 33,3 & 32,2 & 33,9 \\
progressief & 33,6 & 35,5 & 33,1 & 37,9 & 36,9 \\
liberaal & 14,8 & 14,1 & 19,5 & 16,0 & 13,5 \\
\hline
\end{tabular}

Bron: Databestand CEIS.

In de periode 1974-1990 hebben zowel de confessionele als de progressieve stromingen hun electorale positie verbeterd. De confessionele stroming heeft in alle verkiezingen na 1974 een beter resultaat gehaald dan in 1974 , al is er geen sprake van een gelijkmatige ontwikkeling. Ook bij de progressieve stroming is dat niet het geval. Tevens is bij deze stroming deverkiezingsuitslag van 1982 lager dan die van 1974.

In tegenstelling tot de progressieve en confessionele stroming kent de liberale stroming in 1990 een slechter verkiezingsresultaat dan in 1974. De uitslagen van deze stroming in 1982 en 1986 zijn echter wel aanzienlijk beter dan die van $1974 .^{3}$

Tabel 4.7: De plaatselijke stempercentages van de lokale lijsten in 1990 vergeleken met die in 1974 , voor de drie politieke stromingen, in percentages van het aantal gemeenten.

\begin{tabular}{lrrrr} 
& lager & hoger & gelijk & $\mathrm{N}$ \\
confessioneel & 46,6 & 50,7 & 2,6 & 605 \\
progressief & 23,6 & 69,8 & 6,6 & 605 \\
liberal & 46,1 & 43,6 & 10,2 & 605 \\
\hline
\end{tabular}

Bron: Databestand Cels.

De vergelijking van de stempercentages op gemeente-niveau, zoals in tabel 4.7, geeft aan dat zowel de de confessionele stroming als de progressieve stroming in meer gemeenten een hoger dan een lager stempercentage haalden bij de gemeenteraadsverkiezingen van 1990 ten opzichte van 1974. Met name bij de progressieve stroming is dit verschil groot. De liberale stroming daarentegen kent iets meer gemeenten met een daling van het stempercentage dan met een sti.jging van het stempercentage. De eerder geconstateerde stijging van het landelijke stempencentage van de liberale stroming is dus veroorzaakt door een toename van plaatselijke stempercentages in relatief weinig gemeenten.

\section{Verkiezingsresultaten op provinciaal niveau}

In de vorigre paragraaf hebben wij geconstateerd dat de lokale lijsten voornamelijk in NoordBrabant en Limburg een groot deel van hun aanhang hebben verloren bij de gemeenteraadsverkiezingen in de periode 1974-1990. Bij een overzicht van de verkiezingsresultaten van de drie onderscheiden politieke stromingen zullen wij ons daarom concentreren op deze twee provincies. De verkiezingsresultaten in de overige provincies worden bij deze analyse samengevoegd. 
Tabel 4.8: Percentage stemmen op de drie politieke stromingen, in Noord-Brabant, Limburg en de rest van Nederland, 1974-1990.

\begin{tabular}{lrrrrrr}
\hline \multirow{5}{*}{ confessioneel } & & 1974 & 1978 & 1982 & 1986 & 1990 \\
& NB & 21,8 & 32,1 & 32,0 & 31,7 & 33,1 \\
& Lb & 11,4 & 17,7 & 32,6 & 31,2 & 34,3 \\
rest & 34,1 & 37,1 & 33,8 & 32,3 & 34,0 \\
progressief & NB & 15,4 & 20,4 & 20,2 & 25,8 & 23,7 \\
& Lb & 11,3 & 14,8 & 17,0 & 23,8 & 23,6 \\
& rest & 38,7 & 40,1 & 37,1 & 41,6 & 40,7 \\
liberaal & NB & 9,7 & 9,9 & 14,5 & 11,9 & 10,1 \\
& Lb & 5,1 & 5,5 & 8,6 & 8,1 & 6,9 \\
& rest & 16,5 & 15,6 & 21,4 & 17,6 & 14,9 \\
\hline
\end{tabular}

Bron: Databestand CELS.

Uit tabel 4.8 blijkt dat in de provincies Noord-Brabant en Limburg alle drie de politieke stromingen in de periode 1974-1990 hun aanhang onder de kiezers wisten te vergroten. De confessionele stroming weet vooral in Limburg met een toename van haar stempercentage van 22,9 procent haar electorale positie te versterken. De grootste vooruitgang wordt in 1982 geboekt. In de provincie Noord-Brabant is dat in 1978 het geval, waarna men zich stabiliseert. In de restvan Nederland blijft de confessionele stroming op ongeveer hetzelfde niveau van 1974 tot en met 1990. Daarmee kunnen wij concluderen dat de eerder geconstateerde vooruitgang van de confessionele stroming voornamelijk veroorzaakt wordt door de betere verkiezingsresultaten in Noord-Brabant en Limburg.

Ook de progressieve stroming boekt een aanzienlijke winst in Noord-Brabant en Limburg. In Noord-Brabant wordt bij de gemeenteraadsverkiezingen van 1978 en 1986 de grootste winst geboekt. In Limburg neemt het percentage stemmers op de progressieve stroming geleidelijk toe, met een relatief sterke vooruitgang in 1986. In de rest van Nederland wordt een lichte winst geboekt.

De liberale stroming kent een minder grote vooruitgang in de provincies Noord-Brabant en Limburg. De beste uitslag haalt zij in 1982 , waarna zij bij de gemeenteraadsverkiezingen van 1986 en 1990 weer een deel van haar aanhang verliest. Hetzelfde beeld zien wij ook bij de uitslag van de liberale stroming in de rest van Nederland, al is daar de uitslag van 1990 zelfs lager dan die van 1974. In Noord-Brabant en Limburg is de uitslag van 1990 nog wel iets hoger dan die van 1974. 
Tabel 4.9: De plaatselijke stempercentages van de lokale lijsten in 1990 vergeleken met die in 1974 , voor de drie politieke stromingen, in Noord-Brabant, Limburg en de rest van Nederland, in percentages van het aantal gemeenten.

\begin{tabular}{lrrrrr}
\hline & & lager & hoger & gelijk & N \\
confessioneel & Lb & 17,6 & 75,6 & 6,9 & 131 \\
& rest & 60,6 & 86,8 & 5,7 & 53 \\
& & & 38,5 & 1,0 & 421 \\
progressief & NB & 9,2 & 70,2 & 20,6 & 131 \\
& Lb & 0,0 & 90,6 & 9,4 & 53 \\
& rest & 31,1 & 67,0 & 1,9 & 421 \\
liberaal & & & & & \\
& NB & 27,5 & 45,8 & 26,7 & 131 \\
& Lb & 22,6 & 54,7 & 22,6 & 53 \\
& rest & 54,9 & 41,6 & 3,6 & 421 \\
\hline
\end{tabular}

Bron: Databestand CELS.

Uit tabel 4.9 blijkt dat ook op gemeente-niveau alle drie de politieke stromingen betere resultaten hebben gehaald in Noord-Brabant en Limburg dan in de rest van Nederland. Dit geldt met name voor de confessionele stroming. Terwijl buiten Noord-Brabant en Limburg in 60,6 procent van de gemeenten de confessionele stroming in 1990 een slechter verkiezingsresultatat haalde dan in 1974 , is daarentegen in 75,6 procent van de Noordbrabantse gemeenten en zelfs in 86,8 procent van de Limburgse gemeenten sprake van een verhoging van het plaatselijke stempercentage in 1990 ten opzichte van dat bij de gemeenteraadsverkiezingen van 1974.

Bij de progressieve stroming is opvallend dat zij in geen enkele Liburgse gemeente in 1990 een lager stempercentage haalde dan in 1974. In Noord-Brabant is dat in 9,2 procent van de gemeenten wel het geval, terwijl in de rest van Nederland in 31,1 procent van de gemeenten de progressieve stroming in 1990 een lager stempercentage haalde dan in 1974. Het verschil tussen de drie onderscheiden categorieën gemeenten is minder opvallend als wij ons richten op het percentage gemeenten waar de plaatselijke stempercentages van de progressieve stroming gestegen zijn in 1990 ten opzichte van 1974. Met name het percentage in NoordBrabant $(70,2 \%)$ benadert het percentage in de rest van Nederland $(67,0 \%)$.

Ook bij de liberale stroming zijn er meer gemeenten met een stijging dan met een daling van het stempercentage in de periode 1974-1990. De drie onderscheiden categorieën gemeenten hebben een ongeveer even hoog percentage gemeenten waar het stempercentage is gestegen. In Noord-Brabant en Limburg zijn er in vergelijking met de rest van Nederland echter relatief weinig gemeenten waar de plaatselijke stempercentages voor de liberale stroming dalen in de periode 1974-1990. Deze cijfers zijn mogelijk beïnvloed door het hoge percentage gemeenten in Noord-Brabant en Limburg waar het stempercentage gelijk bleef. Dit zijn gemeenten waar de liberale stroming zowel in 1974 als in 1990 niet heeft deelgenomen aan de gemeenteraadsverkiezingen.

Concluderend kunnen wij stellen dat vooral de confessionele en progressieve stroming en in mindere mate de liberale stroming in de periode 1974-1990 hun aanhang in de provincies Noord-Brabant en Limburg hebben vergroot. In deze periode kent alleen de progressieve 
stroming ook een (lichte) vooruitgang in de rest van Nederland. De confessionele stroming weet zich te stabiliseren en de liberale stroming verliest een deel van haar aanhang in de rest van Nederland. De progressieve stroming is tevens de enige landelijke poltieke stroming waar buiten Noord-Brabant en Limburg meer gemeenten een stijging dan een daling kennen van het plaatselijke stempercentage, uitgaande van een vergelijking van de plaatselijke stempercentages van de gemeenteraadsverkiezingen van 1990 met die van 1974 .

\section{Verkiezingsresultaten per grootte van de gemeente}

In de vorige paragraaf hebben wij geconstateerd dat de lokale lijsten vooral in de gemeenten met tussen de 3.000 en 25.000 inwoners een relatief groot deel van hun aanhang hebben verloren. Welke politieke stromingen hebben in deze gemeenten betere verkiezingsuitslagen gehaald? Dat wordt duidelijk in tabel 4.10.

Tabel 4.10: Percentage stemmen op de drie politieke stromingen, per categorie van gemeentegrootte, 1974 en $1990 .^{4}$

\begin{tabular}{|c|c|c|c|c|c|c|c|}
\hline \multirow{3}{*}{$\begin{array}{l}\text { inwoners } \\
\times 1000\end{array}$} & & \multicolumn{2}{|c|}{ confessioneel } & \multicolumn{2}{|c|}{ progressief } & \multicolumn{2}{|c|}{ liberaal } \\
\hline & & 1974 & 1990 & 1974 & 1990 & 1974 & 1990 \\
\hline & & & & & & & \\
\hline & 3 & 30,3 & 22,9 & 18,9 & 15,6 & 5,4 & 11,5 \\
\hline 3 & - 10 & 26,7 & 35,5 & 19,5 & 23,4 & 9,8 & 13,5 \\
\hline 10 & $\begin{array}{l}-\quad 25 \\
\end{array}$ & 34,0 & 38,9 & 23,4 & 27,8 & 13,7 & 12,9 \\
\hline 25 & - 50 & 36,3 & 37,2 & 32,1 & 34,7 & 16,3 & 13,8 \\
\hline 50 & -100 & 34,4 & 31,0 & 39,3 & 44,5 & 18,3 & 14,7 \\
\hline & $>100$ & 25,4 & 24,4 & 51,3 & 53,4 & 17,3 & 13,4 \\
\hline
\end{tabular}

Bron: Databestand CELS.

Uit de tabel blijkt dat de confessionele stroming haar positie in de gemeenten met 3.000 à 25.000 inwoners heeft versterkt. In de gemeenten waar de lokale lijsten hun positie sterk verbeterd hebben - de gemeenten met minder dan 3.000 inwoners - heeft de confessionele stroming daarentegen in 1990 een slechter resultaat gehaald dan in 1974. Maar met name in deze categorie van gemeentegrootte zijn de veranderingen in de periode 1974-1990 zo sterk dat een vergelijking tussen de resultaten van 1974 en 1990 van minder betekenis is. Dit geldt in veel minder mate voor de gemeenten met meer dan 50.000 inwoners waar sprake is van een lichte achteruitgang van de confessionele stroming.

Ook de progressieve stroming heeft haar aanhang vergroot in de gemeenten waar de stempercentages van de lokale lijsten sterk zijn gedaald. Alleen in de categorie met minder dan 3.000 inwoners is het verkiezingsresultaat van de progressieve stroming in 1990 slechter dan in $1974 .^{5}$ Voor de progressieve stroming geldt overigens, hoe groter de categorie van gemeentegrootte, des te hoger is het stempercentage.

De liberale stroming heeft alleen in de categorieën gemeenten met minder dan 10.000 inwoners een hoger stempercentage in 1990 dan in 1974. Uit tabel 4.7 in bijlage 2 blijkt echter dat met name in 1982 en ook nog in 1986 de stempercentages van de liberale stroming in de verschillende categorieën van gemeentegrootte hoger zijn dan die in 1974 . Opvallend is voorts 
dat deverkiezingsuitslagen van de liberale stroming opvallend gelijkmatig over deverschillende gemeenten verdeeld $z$ ijn.

Kortom, alle stromingen hebben in de periode 1974-1990 in de categorie met gemeenten tussen de 3.000 en 10.000 inwoners hun aanhang vergroot. Voor de confessionele en progressieve stroming geldt dat tevens voor de gemeenten met 10.000 à 25.000 inwoners. Juist in deze twee categorieën hebben de lokale lijsten een groot deel van hun aanhang verloren.

\subsection{Communale, nationale en gemengde gemeenten}

Electorale ontwikkelingen bij de gemeenteraadsverkiezingen worden ook inzichtelijk door voor elke gemeente de structuur van de electorale verhoudingen te bepalen. Hierbij maken wij gebruik van een indeling van gemeenten in communale, nationale en gemengde gemeenten. In communale gemeenten is 60 procent of meer van de stemmen uitgebracht op lokale lijsten. In nationale gemeenten is 60 procent of meer van de stemmen uitgebracht op de nationale lijsten. Alle overige gemeenten noemen wij gemengde gemeenten. ${ }^{6}$ Veranderingen in het percentage gemeenten in deze categorieën in de periode $1974-1990$ geven aan in hoeverre de electorale positie van de lokale en nationale lijsten op gemeenteniveau veranderd is. Daarmee wordt duidelijk of er op gemeenteniveau sprake is van een lokalisering dan wel nationalisering van de gemeenteraadsverkiezingen. Om de relatieve omvang van deze electorale ontwikkelingen te bepalen zal tevens de indeling van de gemeenten per provincie en categorie van gemeentegrootte aan de orde komen. Tenslotte zal worden nagegaan in welke mate op gemeente-niveau veranderingen plaatsvinden.

Tabel 4.11: Percentage communale, gemengde en nationale gemeenten,

$1974-1990$.

\begin{tabular}{lrrrrr}
\hline & 1974 & 1978 & 1982 & 1986 & 1990 \\
communaal & 28,7 & 21,2 & 11,5 & 8,4 & 7,9 \\
gemengd & 6,4 & 6,7 & 9,2 & 10,9 & 9,7 \\
nationaal & 64,9 & 71,1 & 79,3 & 80,7 & 82,4 \\
N & 841 & 830 & 774 & 714 & 647 \\
\hline
\end{tabular}

Bron: Databestand CEIS.

Uit tabel 4.11 blijkt dat in de periode 1974-1990 het percentage communale gemeenten zeer sterk is afgenomen van 28,7 naar 7,9 procent. Het percentage nationale gemeenten en in mindere mate het percentage gemengde gemeenten is in dezelfde periode sterk toegenomen. De afname van het percentage communale gemeenten was het sterkst in 1978 en 1982 Opvallend is overigens dat ondanks een licht herstel van het landelijke stempercentage van de lokale lijsten in 1990, de daling van het percentage communale gemeenten zich doorzet. Daarmee wordt duidelijk dat de lokale lijsten zich in 1990 versterkt hebben in gemeenten waar men geen dominante positie heeft. 
Tabel 4.12: Vergelijking van de indeling van gemeenten in 1974 met die in 1990, in absolute aantallen en in percentages van gemeenten.

\begin{tabular}{llrr}
\hline & & abs. & $\%$ \\
Van communaal naar & communaal & 45 & 26,8 \\
& gemengd & 77 & 45,8 \\
& nationaal & 46 & 27,4 \\
Van nationaal naar & communaal & 1 & 0,2 \\
& gemengd & 7 & 1,7 \\
Van gemengd naar & nationaal & 400 & 98,0 \\
& communaal & 1 & 3,4 \\
& gemengd & 9 & 31,0 \\
& nationaal & 19 & 65,5
\end{tabular}

Bron: Databestand CELS.

Tabel 4.12 laat zien dat bijna de helft van de communale gemeenten in 1974 in 1990 een gemengde gemeente is geworden. Ruim een kwart van de communale gemeenten van 1974 zijn in 1990 zelfs een nationale gemeente geworden. Bijna alle nationale gemeenten van 1974 zijn daarentegen ook in 1990 nog nationaal. Slechts één gemeente (Belfeld) is veranderd van nationaal in 1974 naar communaal in 1990. En slechts 1,7 procent ( 7 gemeenten) zijn in 1990 van de categorie nationale gemeenten in de categorie gemengde gemeenten terecht gekomen. Het merendeel van de gemengde gemeenten van 1974 is in 1990 een nationale gemeente geworden. Ook hier is er eén gemeente (Halsteren) die de overstap maakt naar de categorie communale gemeenten. Uit het bovenstaande wordt duidelijk dat op gemeenteniveau een groot aantal gemeenten in de periode 1974-1990 de overstap maakt van de categorie communale gemeenten naar de categorieën gemengde en nationale gemeenten en van de categorie gemengde gemeenten naar de nationale gemeenten. 
Indeling van gemeenten op provinciaal niveau

Tabel 4.13: Percentage communale, gemengde en nationale gemeenten, per provincie, 1974 en 1990.

\begin{tabular}{|c|c|c|c|c|c|c|}
\hline & $\begin{array}{l}1974 \\
\text { com. }\end{array}$ & gem. & $\mathrm{N}$ & $\begin{array}{l}1990 \\
\text { com. }\end{array}$ & gem. nat. & $\mathrm{N}$ \\
\hline $\mathrm{Gr}$ & 2,0 & $-98,0$ & 51 & - & $-100,0$ & 25 \\
\hline $\mathrm{Fr}$ & 4,5 & $4,5 \quad 91,0$ & 44 & 3,2 & $3,2 \quad 93,5$ & 31 \\
\hline Dr & - & $2,9 \quad 97,1$ & 34 & - & $2,9 \quad 97,1$ & 34 \\
\hline Ov & - & $10,6 \quad 89,4$ & 47 & - & $2,2 \quad 97,8$ & 45 \\
\hline $\mathrm{Gl}$ & 25,0 & $10,6 \quad 64,4$ & 104 & 2,3 & $9,3 \quad 88,4$ & 86 \\
\hline $\mathrm{Ut}$ & 2,1 & $2,1 \quad 95,8$ & 48 & - & $-100,0$ & 38 \\
\hline NH & 8,3 & $16,7 \quad 75,0$ & 96 & - & $2,9 \quad 97,1$ & 70 \\
\hline $\mathrm{ZH}$ & 2,6 & $4,6 \quad 92,7$ & 151 & - & $-100,0$ & 95 \\
\hline $\mathrm{Zl}$ & 13,3 & $6,780,0$ & 30 & 3,3 & $10,0 \quad 86,7$ & 30 \\
\hline NB & 74,8 & $6,1 \quad 19,1$ & 131 & 23,7 & $28,2 \quad 48,1$ & 131 \\
\hline $\mathrm{Lb}$ & 93,3 & $1,0 \quad 5,8$ & 104 & 28,6 & $17,9 \quad 53,6$ & 56 \\
\hline F] & - & $-100,0$ & 1 & - & $-100,0$ & 6 \\
\hline
\end{tabular}

Bron: Databestand CELS.

Uit tabel 4.13 blijkt dat in 1974 vooral in de provincies Noord-Brabant en Limburg relatief veel communale gemeenten voorkomen. Ook de provincies Gelderland en Zeeland scoren relatief hoog. De provincie Noord-Holland valt op door het hoge percentage gemengde gemeenten. Als wij de situatie in 1974 vergelijken met die van 1990, dan blijkt dat zoals te verwachten in Noord-Brabant en Limburg het percentage communale gemeenten zeer sterk is.teruggelopen. In Noord-Brabant is tevens sprake van een sterke toename van het percentage gemengde gemeenten. Buiten Noord-Brabant en Limburg komen overigens nauwelijks nog communale gemeenten voor. In de provincies Gelderland en Zeeland zijn nog wel relatief veel gemengde gemeenten.

Indeling van gemeenten per categorie van gemeentegrootte

Tabel 4.14: Percentage communale, gemengde en nationale gemeenten, per categorie van gemeentegrootte, 1974 en 1990.

inwoners

$\begin{array}{lll}1974 & 1990 \\ \text { com gem nat } \mathrm{N} & \text { com gem nat } \mathrm{N}\end{array}$

$\mathrm{x} 1000$

\begin{tabular}{|c|c|c|c|c|c|c|c|c|}
\hline & $<$ & 34,4 & 12,9 & 52,8 & 163 & 44,0 & $8,0 \quad 48,0$ & 25 \\
\hline 3 & 10 & 36,3 & 5,2 & 58,5 & 366 & 12,2 & 73,5 & 230 \\
\hline 10 & 25 & 23,1 & 5,3 & 71,6 & 208 & 4,3 & 86,7 & 255 \\
\hline 25 & 50 & 6,5 & 3,2 & 90,3 & 62 & 1,2 & 92,9 & 84 \\
\hline 50 & - 100 & - & 3,8 & 96,2 & 26 & 一 & $-100,0$ & 36 \\
\hline & $>100$ & - & & 100,0 & 16 & - & $-100,0$ & 17 \\
\hline
\end{tabular}

Bron: Databestand CELS. 
De gegevens in tabel 4.14 geven aan dat in 1974 vooral bij gemeenten met minder dan 10.000 inwoners relatief veel communale gemeenten voorkomen. Nationale gemeenten komen relatief veel voor bij gemeenten met meer dan 25.000 inwoners.

In 1990 is het percentage communale gemeenten sterk teruggelopen in de categoriein gemeenten met 3.000 tot 25.000 inwoners. Alleen bij de kleinste gemeenten komen in 1990 relatief meer communale gemeenten voor dan in 1974, al moet hierbij de kanttekening worden geplaatst dat het aantal gemeenten in deze categorie zeer sterk is teruggelopen. Het percentage nationale gemeenten is het sterkst gestegen bij gemeenten met 3.000 tot 25.000 inwoners. In categorieën gemeenten met meer dan 25.000 inwoners is dat amper het geval, hetgeen ook te wijten is aan het al relatief hoge percentage nationale gemeenten in deze categorieën in 1974 . Het percentage gemengde gemeenten is in de periode 1974-1990 alleen gestegen in gemeenten met 3.000 tot 25.000 inwoners.

Concluderend kunnen wij stellen dat in de periode 1974-1990 het percentage communale gemeenten sterk gedaald is, terwijl het percentage gemengde en nationale gemeenten gestegen is. Deze daling doet zich in bijna alle provincies voor, maar zeer sterk in NoordBrabant en Limburg. Daarnaast is met name bij gemeenten met 3.000 tot 25.000 inwoners sprake van daling van het aantal communale gemeenten.

\subsection{Conclusies en nabeschouwing}

De lokale lijsten kunnen wij beschouwen als een kenmerkend lokaal element van de gemeenteraadsverkiezingen. Vandaar dat wij de door deze lijsten behaalde stemmen in de gemeenteraadsverkiezingen in de periode 1974-1990 beschouwen als een aspectvan het lokale karakter van de gemeenteraadsverkiezingen. Op grond van de bevindingen in dit hoofdstuk moeten wij concluderen dat de electorale positie van alle lokale lijsten gezamenlijk in de periode 1974-1990 is verslechterd, zodat wij kunnen spreken van een nationalisering van de gemeenteraadsverkiezingen en daarmee van een vermindering van het lokale karakter van de gemeenteraadsverkiezingen. De afname van de aanhang van de lokale lijsten doet zich overigens voor in bijna alle categorien van gemeentegrootte, maar vooral bij gemeenten met 3.000 tot 25.000 inwoners. Tevens blijkt dat vooral in de provincies Noord-Brabant en Limburg de positie van alle lokale lijsten gezamenlijk verzwakt is. De verbetering van de positie van de nationale lijsten is grotendeels ten goede gekomen aan de confessionele en de progressieve stroming, terwijl de liberalen met name in 1982 een hoog stemmenpercentage haalden. De confessionelen en de progressieven hebben hun electorale positie zeer sterk verbeterd in Noord-Brabant en Limburg. Ook de liberale stroming verbeterde in deze provincies haar positie enigszins. Ten aanzien van de electorale verhoudingen per gemeente zien wij eenzelfde beeld. Er is een duidelijke afname van het percentage communale gemeenten en een toename van het percentage gemengde en vooral het percentage nationale gemeenten in de periode 1974-1990. In zeer sterke mate is dit het geval in de provincies Noord-Brabant en Limburg en bij de gemeenten met 3.000 tot 25.000 inwoners.

\section{Nabeschouwing}

De bevindingen van hoofdstuk drie en vier betekenen dat in 1974 een periode van lokalisering van de gemeenteraadsverkiezingen is afgesloten. Dittrich constateerde immers dat in de periode 1962-1974 sprake is van een lokalisering van de gemeenteraadsverkiezingen, zowe] 
wat de deelname als deverkiezingsresultaten van de lokale lijsten als de electorale verhoudingen in de gemeenten betreft (Dittrich, 1978:46-47 en 216-217). De door hem geconstateerde nationalisering van de gemeenteraadsverkiezingen in de periode 1962-1974, voor wat de deelname van de nationale lijsten betreft, zet zich na 1974 verder door en breidt zich dus uit tot de verkiezingsresultaten van de nationale lijsten alsmede de electorale verhoudingen op gemeenteniveau. Wat zijn de mogelijke oorzaken van deze ontwikkelingen? Laten wij allereerst nader ingaan op hetgeen Dittrich dienaangaande stelde. In hetverlengde van Hofstee (1962:4852) maakt hij melding van een 'moderniseringstheorie' van de gemeentepolitiek. In dit kader stelt hij onder meer:

“(...) in het traditionalistische zuiden, waarvoor de katholieken de noodzaak ontbrak om een afweer tegen socialisten en liberalen op te bouwen, zijn de gemeenteraadsvcrkiezingen lang een een zaak geweest van traditionalistische, niet op ideologie gebasecrde, lijsten." (Dittrich, 1978:214)

Pas na 1962 zou voor het eerst sprake $z$ ijn van een doordringing van de niet-traditionalistische, nationaal georganiseerde partijen. Daarbij zou van belang zijn:

"(...) dat in de meeste Brabantse en Limburgse plattelands-gemeenschappen een sterke gemeenschapszin leeft, die er onder andere toe leidt dat er sprake is van vrij hechte, traditionalistische en gesloten gemeenschappen. (...) Door de toenemende mobiliteit van de bevolking, de sterk verbeterde kommunikatiemogelijkheden, en ook door de (vanwege de tcruglopende werkgelegenheid in de agrarische sektor) vaak noodgedwongen grotere beroepsmobiliteit van de bevolking, zijn de traditionalistische, gesloten gemeenschappen van weleer echter voor een groot gedeelte "opengebroken'." (Dittrich, 1978:215)

Deze ontwikkeling beantwoordt ook aan hetgeen van der Loo en van Reijen (1991:114)) als een belangrijk gevolg van 'modernisering' beschouwen, namelijk het vergroten van de verschillen binnen een groep, en tegelijkertijd het verkleinen van de verschillen tussen de leden van de diverse groepen.

Op grond van onze bevindingen kunnen wij aannemen dat deze modernisering, wat de lokale politieke verhoudingen betreft, zich heeft doorgezet in de periode 1974-1990. De nationalise ring van de gemeenteraadsverkiezingen wijst daar immers op. De vraag is of en waarom de mogelijke oorzaken van de lokalisering van de gemeenteraadsverkiezingen in de periode $196:$ 1974 zich niet hebben doorgezet. Dittrich (1978:216-218) noemt als mogelijke verklaring van de lokalisering onder meer dat het een effect is van de politisering van de lokale politiek in die periode. ${ }^{7}$ De daardoor ontstane actiegroepen zouden zich mogelijk als onafhankelijke groepering bij de gemeenteraadsverkiezingen gemanifesteerd hebben. Concrete gegevens over de deelname van actiegroepen aan de gemeenteraadsverkiezingen in de periode 1962-1974 of de periode 1974-1990 ontbreken, zodat de betekenis van deze factor onduidelijk blijft. Uit gegevens van het NKO blijkt dat er in de periode 1972-1989 geen grote schommelingen zijp in het percentage kiezers dat zegt geparticipeert te hebben in een actiegroep. ${ }^{8}$ Daarmee wordt nog niet duidelijk of en in hoeverre actiegroepen hebben deelgenomen aan de gemeenteraadsverkiezingen. Op basis hiervan kunnen wij echter wel stellen dat als de opkomst van de actiegroepen een factor van betekenis is geweest voor de stijging van de stempercentages van de lokale lijsten in de periode 1962-1974, deze factor waarschijnlijk van weinig betekenis is geweest voor de daling van de stempercentages van de lokale lijsten in de periode 1974-1990. 
Als mogelijke verklaring voor de lokalisering van de gemeenteraadsverkiezingen noemat Dittrich tevens de ontzuiling. Op gemeentelijk niveau zouden lokale lijsten voor een deel van de kiezers als intermediair kunnen dienen tussen de identificatie met de ene en de overgang naar de andere landelijke partij, temeer daar de keuzemogelijkheid bij de gemeenteraadsverkiezingen kleiner is dan bij de Tweede Kamerverkiezingen. Dit laatste geldt natuurlijk ook in de periode 1974-1990, al kunnen wij tegelijkertijd constateren dat steeds meer kiezers de mogelijkheid hebben om een stem uit te brengen op éen van de landelijke politieke stromingen. De intermediaire functie van de lokale lijsten boet daardoor aan waarde in. Voorts kan men zich afvragen of er in de periode 1974-1990 een zodanige band bestaat tussen kiezers en politieke partijen, dat de lokale lijsten een vanzelfsprekende intermediair zijn tussen de overstap van de ene naar de andere politieke partij. Zoals Andeweg (1989:89-90) stelt, schijnt in de Nederlandse situatie partij-identificatie eerder het gevolg dan de oorzaak van een bepaalde partijkeuze. Anders gezegd, omdat de identificatie met de landelijke partijen gering is, is een overstap naar een andere landelijke partij voor veel kiezers betrekkelijke eenvoudig, waardoor de mogelijke intermediaire functie van lokale lijsten betekenisloos wordt. Dit functieverlies kan voor een deel de afnemende electorale betekenis van de lokale lijsten verklaren.

Wijkunnen dus concluderen dat gezien de nationalisering van de gemeenteraadsverkiezingen in de periode 1974-1990 de door Dittrich genoemde 'moderniseringstheorie van de gemeenteraadsverkiezingen' nog steeds geldt. De relatief grote vooruitgang van de nationale lijsten in Noord-Brabant en Limburg wijst hierop. Tegelijkertijd blijken de mogelijke oorzaken van een lokalisering van de gemeenteraadsverkiezingen aan betekenis te hebben ingeboet. Met name de intermediare functie van de lokale lijsten heeft in de ontzuilde samenleving aan betekenis verloren. Uit onze bevindingen blijkt dan ook dat de electorale positie van de lokale lijsten ook buiten de traditionele bolwerken van de lokale lijsten onder druk is komen te staan. Dat de lokale lijsten desondanks bij de gemeenteraadsverkiezingen van 1990 een lichte vooruitgang kennen is mogelijk voor een deel te wijten aan de lage opkomst. Wellicht dat de voor de lokale politiek meer gemotiveerde aanhang van de lokale lijsten in grotere mate hun stem heeft uitgebracht bij deze gemeenteraadsverkiezingen dan de aanhang van de landelijke politieke partijen (van Tilburg/Ohlenforst, 1991:181-184). Maar niet alleen in Limburg, maar voor heel Nederland geldt dat de opkomst, in elke categorie van gemeentegrootte, in communale gemeenten hoger is geweest dan in gemengde en nationale gemeenten. In vergelijking met de opkomst in 1986 is tevens sprake van een meer dan gemiddelde opkomst: in de communale gemeenten en een minder dan gemiddelde opkomst in de nationale gemeenten. ${ }^{9}$ Kiezersonderzoek zal echter moeten uitwijzen of in hoeverre aanhangers van. lokale lijsten bij de gemeenteraadsverkiezingen van 1990 in sterkere mate zijn gaan stemmen dan aanhangers van nationale lijsten. 


\section{NOTEN}

${ }^{2}$ Het totaal aantal gemeenten in deze analyse is 605 . In 42 gemeenten is niet nagegaan in hoeverre de lokale lijsten hun stempercentage verhongd of verlaagd hebben t.o.v. 1974. Het betreft nieuwgevormde gemeenten die in de periode 19741990 door herindelingen ontstaan zijn.

${ }^{2}$ In de provincies Friesland, Drenthe en Noord-Holland waren er overigens meer gemeenten waar het stempercentage van de lokale lijsten steeg dan gemeenten waar het stempercentage van 1990 t.o.v. 1974 daalde. ${ }^{3} \mathrm{Bij}$ deze resultaten moeten wij ons realiseren dat de liberale stroming in tegenstelling tot de confessionele en progressieve stroming uit slechts éen partij bestaat. In tegenstelling tot de andere politieke stromingen kan de liberale stroming een verlies van éen partij dus niet compenseren met de winst van een andere partij in dezelfde stroming. In bijlage 6 is overigens een overzichtopgenomen van de verkiezingsresultaten van de te onderscheiden groeperingen die deel uitmaken van de landelijke politieke stromingen in de periode 1974-1990.

- Vanwege de overzichtelijkheid van de gepresenteerde gegevens zijn de vergelijkbare gegevens van de gemeenteraadsverkiezingen van 1978 tot en met 1986 opgenomen in tabel 4.10 in bijlage 2. Hetzelfde geldt overigens voor de tabellen 4.13 en 4.14 .

${ }^{5}$ In de periode 1974-1990 is het percentage stemmen van de progressieve stroming in de categorie gemeenten met minder dan 3.000 inwoners overigens alleen in 1990 slechter dan in 1974. Zie hiervoor tabel 4.10 in bijlage 2.

${ }^{6}$ Deze indeling van gemeenten is vergelijkbaar met die van Dittrich (1978:44-45 en 105). Hij maakt onder meer een onderscheid tussen communalistische en niet-communalistische gemeenten. De eerste categorie omvat alle gemeenten waar meer dan 90 procent van de stemmen op lokale lijsten zijn uitgebracht. De tweede categorie bestaat uitalle overige gemeenten. In een andere indeling worden door hem gemengdegemeenten gekarakteriseerd als gemeenten waar 40 tot 60 procent van de stemmen zjjn uitgebracht op landelijke lijsten. Andere categorieèn zijn dan zuiver-nationale, sterk-nationale, gemengd-nationale, gemengd-lokale, sterk-lokale gemeenten en zuiver-lokale gemeenten. Ten behoeve van onze analyse van de periode 19741990 zijn de eerste drie categoriën samengevoegd als nationale gemeenten en de laatste drie categorieën als communale gemeenten.

" Dittrich noemt naast de twee besproken mogelijke oorzaken van de lokalisering van de gemeenteraadsverkiezingen, ook nog de opkomst van lokale samenwerkingsverbanden van landelijke lijsten en de samenwerking tussen een lokale en een nationale lijst. Deze mogelijke oorzaken zijn echter niet van belang, aangezien dergelijke samenwerkingsverbanden in deze studie niet als een lokale lijst beschouwd worden.

"Het percentage kiezers dat zegt aan een actiegroep te hebben deelgenomen is voor de versehillende jaren als volgt: $1972-14,8 \% ; 1977-7,9 \% ; 1981-12,2 \% ; 1982-14,2 \% ; 1986$ - 12,0\%; 1989 - 16,2\%. Gebaseerd op: (van Deth/) Horstman, 1989:106) voor 1972-1986 en (CBS, 1990:53) voor 1989.

"Het verschil tussen de gemiddelde opkomst in elke categorie van gemeentetegrootte en de opkomstcijfers vour de drie soorten gemeenten zijn voor 1986 en 1990 als volgt:

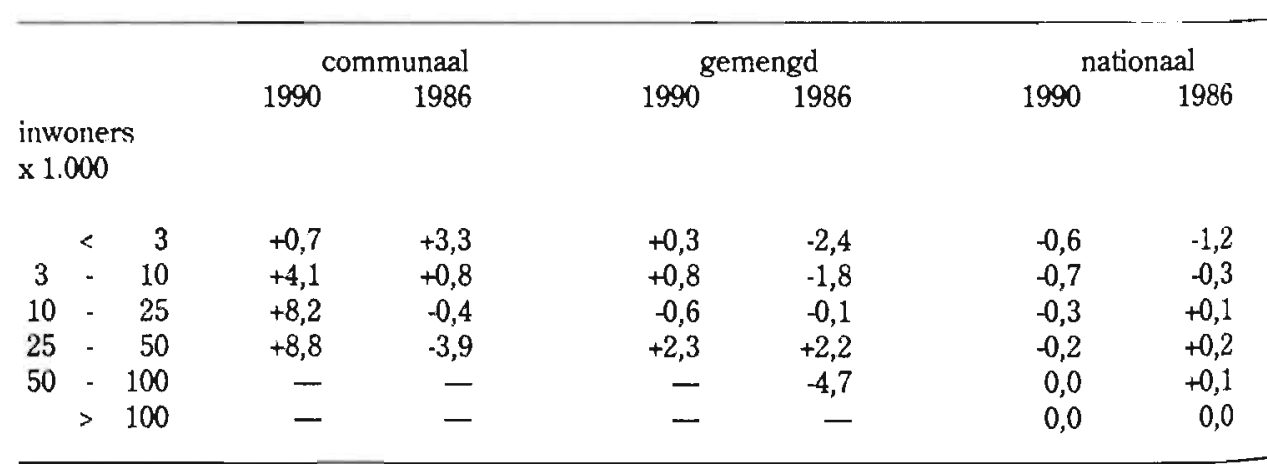

Bron: Databestand CELS. 
Deel 3

ANALYSE VAN DE PLAATSELIJKE VERKIEZINGSUITSLAGEN 



\section{INLEIDING}

In deel I isvia een overzichtvan de electorale ontwikkelingen bij de gemeenteraadsverkiezingen duidelijk geworden dat de positie van de lokale lijsten in de periode $1974-1990$ verzwakt is terwijl de positie van de nationale lijsten, en de verschillende politieke stromingen die onderdeel uitmaken van de nationale lijsten, versterkt is. Op grond hiervan hebben wij dan ook geconcludeerd dat in de periode $1974-1990$ sprake is van een afname van het lokale karakter van de gemeenteraadsverkiezingen.

Niet alleen de electorale positie van de lokale en nationale lijsten geeft inzicht in het lokale karakter van de gemeenteraadsverkiezingen. Het is mogelijk dat ook in de plaatselijke uitslagen en trends van de landelijke partijen lokaal kiesgedrag bij de gemeenteraadsverkiezingen tot uitdrukking komt. ${ }^{1}$ Vandaar dat wij in dit deel van het onderzoek ons vervolgens richten op de analyse van deze plaatselijke uitslagen en trends van de nationale partijen. Bij deze analyse van de gemeenteraadsverkiezingen zullen echter alleen de drie grootste landelijke partijen - het CDA, de PvdA en de WVD - betrokken worden. De reden hiervoor is dat alleen deze drie partijen vanaf 1974 bij alle gemeenteraadsverkiezingen in een meerderheid van de gemeenten aan deze verkiezingen hebben deelgenomen.

Via een vergelijking van de uitslagen en trends voor de drie grootste landelijke partijen bij de lokale-en niet-lokaleverkiezingen zal worden bepaald in hoeverre op nationaal en lokaal niveau het kiesgedrag bij de gemeenteraadsverkiezingen overeenkomt met dat van de niet-lokale verkiezingen. Bij grote verschillen in de uitslagen en trends op plaatselijk niveau kunnen wij spreken van een sterk lokaal karakter van de gemeenteraadsverkiezingen. Achtergrond van de vergelijking tussen lokale- en niet-lokale verkiezingen is dat wij daarmee rekening houden met de invloed van de sociaal-economische, godsdienstige en demografische heterogeniteit van de gemeenten op de uitslagen van zowel de lokale-als niet-lokale verkiezingen. Als wij alleen de lokale verkiezingen zouden analyseren, zou deze heterogeniteit van de gemeenten de gevonden uitkomsten beïnvloeden, waardoor niet het specifieke lokale karakter van de gemeenteraadsverkiezingen gemeten wordt. Het is bijvoorbeeld voorstelbaar dat in gemeenten met relatief veel godsdienstige kiezers de uitslagen van de gemeenteraadsverkiezingen zich anders ontwikkelen dan in gemeenten waar relatief veel kiezers niet godsdienstig zijn. Door een vergelijking van de verkiezingsuitslagen van de gemeenteraadsverkiezingen met die van de niet-lokale verkiezingen wordt rekening gehouden met de invloed van de samenstelling van het lokale electoraat op de verkiezingsuitslag. Zoals in hoofdstuk 1 gesteld, gaan wij er vanuit de uitslagen van de gemeenteraadsverkiezingen tevens beïnvloed worden door landelijke factoren. Door de vergelijking van de uitslagen van de lokale-met de niet-lokale verkiezingen wordt tevens rekening gehouden met de mogelijke invloed van deze landelijke factoren op de gemeenteraadsverkiezingen.

Deze vergelijking met niet-lokale verkiezingen brengt wel een probleem met zich mee. In de Nederlandse situatie worden immers de lokale en niet-lokale verkiezingen niet op dezelfde data gehouden. Wel komt het dikwijls voor dat lokale en niet-lokale verkiezingen in hetzelfde jaar plaatsvinden, waarbij tussen deze verkiezingen slechts enkele maanden liggen. Daarmee is er een basis om de ontwikkelingen bij deze verkiezingen met elkaar te vergelijken. Een 
vergelijking tussen ontwikkelingen bij Tweede Kamer- en gemeenteraadsverkiezingen ligt daarbijvoor de hand. Echter, in de jaren zeventig zijn de Tweede Kamerverkiezingen in andere jaren gehouden dan de gemeenteraadsverkiezingen. In deze periode hebben Tweede Kamerverkiezingen plaatsgevonden in november 1972 en mei 1977, terwijl de gemeenteraadsverkiezin. gen plaatsvonden in mei 1974 en mei 1978. Gezien het relatief grote tijdsverschil, is voor de jaren zeventig gekozen voor een vergelijking van de gemeenteraadsverkiezingen met de Statenverkiezingen, die wel in dezelfde jaren plaatsvonden als de raadsverkiezingen. Doorslaggevend bij deze keuze was dat uit onderzoek bleek dat de provinciale factor bij de Provinciale Statenverkiezingen zeer gering was (van Tilburg, 1991; van der Eijk/Visser, 1992:90). Daarmee waren de ontwikkelingen bij de Statenverkiezingen in de jaren zeventig beter vergelijkbaar met de gemeenteraadsverkiezingen dan de Tweede Kamerverkiezingen die in andere jaren dan de raadsverkiezingen plaatsvonden.

Dit deel van het onderzoek naar het lokale karakter van de gemeenteraadsverkiezingen bestaat uit twee hoofdstukken. In hoofdstuk vijf zullen wij het lokale karakter van de gemeenteraadsverkiezingen bepalen door de stempercentages van de gemeenteraadsverkiezingen te vergelijken met die van de niet-lokale verkiezingen. In hoofdstuk zes zullen vervolgens de trends bij de lokale- en niet-lokale verkiezingen met elkaar vergeleken worden.? Er zijn twee redenen waarom zowel de plaatselijke stempercentages als de plaatselijke trends worden geanalyseerd. In de eerste plaats omdat het aanwezig zijn van ongeveer dezelfde trends bij de verschillende partijen bij de gemeenteraadsverkiezingen bij uitstek wordt gezien als een bewijs van het geringe lokale karakter van de gemeenteraadsverkiezingen. ${ }^{3}$ De tweede reden is dat het mogelijk is dat ten aanzien van het lokale karakter van de gemeenteraadsverkiezin. gen zich niet dezelfde ontwikkelingen voordoen bij de plaatselijke trends als bij de plaatselijke stempercentages. Het is bijvoorbeeld voorstelbaar dat in een gemeente bij de gemeenteraadsverkiezingen een uitzonderlijke trend zich voordoet, hetgeen wijst op de aanwezigheid van kiesgedrag dat karakteristiek is voor de gemeenteraadsverkiezingen. Deze uitzonderlijke trend kan er echter tevens betekenen dat daardoor het behaalde stempercentage bij de gemeenteraadsverkiezingen in veel sterkere mate dan voorheen overeenkomt met het plaatselijke stempercentage bij de Tweede Kamerverkiezingen, hetgeen wijst op een afname van kiesgedrag dat karakteristiek is voor de gemeenteraadsverkiezingen. Vandaar dat zowel de plaatselijke stempercentages als de plaatselijke trends bij de gemeenteraadsverkiezingen worden geanalyseerd. 


\section{ANALYSE VAN DE PLAATSELLJKE STEMPERCENTAGES}

Via een analyse van de verschillen in de plaatselijke stempercentages van de drie grote landelijke partijen kan het lokale karakter van de gemeenteraadsverkiezingen bepaald worden. Tenminste als wordt uitgaan van een vergelijking van de uitslagen bij de lokale- en nietlokaleverkiezingen. Inzicht in de belangrijksteverschillen tussen deze twee soorten verkiezingen vormt daarbij de basis van een analyse van de plaatselijke uitslagen bij de gemeenteraadsverkiezingen.

Deze analyse zal op verschillende manieren zijn beslag krijgen. Allereerst zal getracht worden een antwoord te geven op de vraag of er een sterke overeenkomst is tussen de plaatselijke stempercentages bij de lokale en de niet-lokale verkiezingen. Daarmee weten wij nog niet welk effect lokale factoren hebben op de hoogte van de plaatselijke stempercentages. Via een berekening zal de invloed van dit effect in kaart worden gebracht. Tenslotte zal de vraag beantwoord worden welke lokale factoren een grote invloed uitoefenen op de plaatselijke stempercentages van elk van de drie grote landelijke partijen bij de gemeenteraadsverkiezingen. Dit zal gebeuren via een analyse van de in verschillende gemeenten voorkomende uitzonderlijke stempercentages voor deze partijen.

\subsection{Verschillen tussen lokale en niet-lokale verkiezingen}

Bijde bepaling van het lokale karaktervan de gemeenteraadsverkiezingen door een vergelijking van de lokale-met de niet-lokale verkiezingen, is het van belang om aandacht te schenken aan de factoren die van betekenis zijn voor het verschil in de landelijke uitslagen van de lokale en niet-lokale verkiezingen. Anders gezegd, wat zijn de kenmerkende verschillen tussen de lokale- en niet-lokale verkiezingen die bijdragen tot een verschillende verkiezingsuitslag bij deze twee soorten verkiezingen? Laten wij allereerst vaststellen hoe groot de verschillen zijn tussen de verkiezingsuitslagen bij deze verkiezingen. In tabel 5.1 wordt daartoe een overzicht gegeven van de landelijke percentages voor de drie partijen bij de lokale- en niet-lokale verkiezingen in de periode $1974-1990 .^{4}$ 
Tabel 5.1: Percentage stemmen op CDA, PvdA en VVD bij de gemeenteraads- dan wel Statenof Tweede Kamerverkiezingen, 1974-1990.

\begin{tabular}{lrrrrrr}
\hline & \multicolumn{2}{c}{ CDA } & \multicolumn{2}{c}{ PvdA } & \multicolumn{2}{c}{ VVD } \\
& GR & PS/TK & GR & PS/TK & GR & PS/TK \\
& & & & & & \\
1974 & 27,1 & 30,9 & 21,6 & 30,0 & 14,8 & 19,0 \\
1978 & 31,7 & 35,1 & 24,4 & 33,9 & 14,1 & 16,9 \\
1982 & 28,9 & 29,4 & 20,9 & 30,4 & 19,5 & 23,1 \\
1986 & 28,0 & 34,6 & 29,0 & 33,3 & 16,0 & 17,4 \\
$1989 / 1990$ & 29,0 & 35,3 & 22,0 & 31,9 & 13,5 & 14,6 \\
\hline
\end{tabular}

Bron: Databestand Cels.

Leesvoorbeeld: Bij de gemeenteraadsverkiezingen van 1974 haalde het CDA 27,1 procent van het totaal aantal geldig uitgebrachte stemmen, terwijl dat 30,9 procent was bij de Statenverkiezingen in dat jaar.

Opvallend is allereerst dat bij alle drie de partijen de uitslagen voor de Staten- en Tweede Kamerverkiezingen voor alle jaren hoger zijn dan dievoor de gemeenteraadsverkiezingen. Het grootste verschil treffen wij in de regel aan bij de PvdA. De VVD heeft, met name in 1986 en 1990, het kleinsteverschil. In de tweede plaats kunnen wij constateren dat de VVD ook de enige partij is waarbij het verschil in de landelijke percentages voor de lokale- en niet-lokale verkiezingen in de periode 1974-1990 geringer wordt. Bij het CDA en de PvdA zien wij geen duidelijke vermindering. Voor deze partijen geldt dat het verschil tussen de landelijke uitslagen van beide soorten verkiezingen in 1990 zelfs groter is dan in 1974 .

\subsubsection{Verschillen in deelname van partijen aan de verkiezingen}

Welke factoren beïnvloeden nu de verschillen in uitslagen voor de drie grootste partijen in de periode 1974-1990? Laten wij ons in de eerste plaats richten op die factoren die direct met de aard van de gemeenteraadsverkiezingen te maken hebben. Het gaat hierbij bijvoorbeeld om de deelname van de drie landelijke politieke partijen aan de gemeenteraadsverkiezingen. Zoals wij in hoofdstuk 3 hebben gezien is een verschil tussen de gemeenteraadsverkiezingen enerzijds en Tweede Kamer- en Statenverkiezingen anderszijds, dat bii gemeenteraadsverkiezingen de drie grote landelijke partijen niet in alle gemeenten aan deze verkiezingen deelnemen. Wel is er sprake van een ontwikkeling in de richting van een deelname aan de gemeenteraadsverkiezingen in relatief meer gemeenten. In dit kader is tevens van belang dat de partijen daarmee een groter deel van de kiezers bereiken. Tabel 5.2 geeft een overzicht van de mate waarin de drie partijen aan de gemeenteraadsverkiezingen hebben deelgenomen en de mate waarin kiezers op hen hebben kunnen stemmen. 
Tabel 5.2: Percentage gemeenten waar het CDA, de PvdA en de VVD aan de gemeenteraadsverkiezingen deelnamen en het percentage kiezers in deze gemeenten, 19741990 .

\begin{tabular}{|c|c|c|c|}
\hline the & $\begin{array}{c}\text { CDA } \\
\text { gem. kiezers }\end{array}$ & $\begin{array}{c}\text { PvdA } \\
\text { gem. kiezers }\end{array}$ & $\begin{array}{c}\text { VVD } \\
\text { gem. kiezers }\end{array}$ \\
\hline 1974 & 88,1 & $57,9 \quad 73,6$ & $61,4 \quad 87,8$ \\
\hline 1978 & $78,8 \quad 92,8$ & $68,7 \quad 84,4$ & $73,6 \quad 92,8$ \\
\hline 1982 & $92,1 \quad 98,4$ & $75,1 \quad 88,4$ & $81,3 \quad 95,0$ \\
\hline 1986 & $94,7 \quad 99,3$ & $79,1 \quad 92,5$ & $85,0 \quad 96,3$ \\
\hline 1990 & $97,4 \quad 99,7$ & $85,8 \quad 95,0$ & $88,7 \quad 96,6$ \\
\hline
\end{tabular}

\section{Bron: Databestand CELS.}

Bij de drie partijen blijkt sprake van een toename van het percentage gemeenten waar men aan de gemeenteraadsverkiezingen deelneemt. Deze toename blijkt bij alle drie ongeveer 28 procent te bedragen. Het CDA is van de drie partijen in de periode 1974-1990 in relatief de meeste gemeenten vertegenwoordigd. Tevens hebben meer kiezers de mogelijkheid om op het CDA te stemmen dan op de PvdA of de VVD. Het verschil met de VVD en de PvdA is echter gering. Gezien het feit dat in 1974 duidelijk minder kiezers de mogelijkheid hadden op de PvdA te stemmen dan op het CDA en de VVD, is vooral de PvdA erin geslaagd om met een eigen lijst meer kiezers te bereiken bij de gemeenteraadsverkiezingen in de periode $1974-1990 .{ }^{5}$

Het belang van een grotere deelname van partijen als een factor van betekenis bij het verklaren van het verschil tussen de landelijke uitslagen bij de lokale- en niet-lokale verkiezingen wordt duidelijk in tabel 5.3, waarin uiteengezet wordt hoeveel procent van de stemmen elk van de drie partijen bij de gemeenteraadsverkiezingen in 1990 heeft gehaald in de gemeenten waar men in 1974 al wel, dan wel niet aan de gemeenteraadsverkiezingen deelnam. ${ }^{6}$

Tabel 5.3: Percentage stemmen in 1990 voor CDA, PvdA, VVD zoals gehaald in gemeenten waar men in 1974 wel c.q. niet heeft deelgenomen aan de gemeenteraadsverkiezingen.

\begin{tabular}{lrrr} 
& CDA & PvdA & VVD \\
in 1974 aanwezig & 24,7 & 17,5 & 12,6 \\
in 1974 niet aanwezig & 4,2 & 4,5 & 1,0 \\
Totaalscore 1990 & 28,9 & 22,0 & 13,6 \\
\hline
\end{tabular}

Bron: Databestand CELS.

Wij kunnen constateren dat het CDA en de PvdA ruim vier procent van hun landelijk stempercentage in 1990 gehaald hebben in gemeenten waar men in 1974 nog niet aan de gemeenteraadsverkiezingen deelnam. Vooral voor de PvdA is dat een relatief groot gedeelte van het bij de gemeenteraadsverkiezingen van 1990 behaalde stempercentage. Immers 20 procent van de in 1990 bij de gemeenteraadsverkiezingen behaalde stemmen (4,5\% op 22,0\%) is afkomstig uit gemeenten waar de PvdA in 1974 nog niet als zodanig aan de gemeenteraadsverkiezingen deelnam. Hiermee wordt duidelijk dat een grotere deelname aan de gemeenteraads- 
verkiezingen ook van betekenis is voor het behaalde landelijke stempercentage bij deze verkiezingen.

Nu wij bepaald hebben dat de deelname van de drie landelijke partijen aan de gemeente raadsverkiezingen van invloed is op het verschil tussen de landelijke uitslagen bij de lokale en niet-lokale verkiezingen, is het de vraag hoe groot deze invloed is. Om deze invloed te kunnen meten is het allereerst nodig te bepalen hoe hoog het stempercentage voor iedere partij zou zijn bij de niet-lokale verkiezingen als wij alleen uitgaan van de uitslagen in de gemeenten waar de betreffende partij aan de gemeenteraadsverkiezingen heeft deelgenomen.

Tabel 5.4: Percentage stemmen op CDA, PvdA en VVD bij de gemeenteraads- en Staten- of Tweede Kamerverkiezingen in gemeenten waar de partijen hebben deelgenomen aan de gemeenteraadsverkiezingen, 1974-1990.

\begin{tabular}{lrrrrrr}
\hline & \multicolumn{2}{c}{ CDA } & \multicolumn{2}{c}{ PvdA } & \multicolumn{2}{c}{ VVD } \\
& GR & PS/Tk & GR & PS/TK & GR & PS/TK \\
1974 & 27,1 & 25,3 & 21,6 & 24,2 & 14,8 & 17,3 \\
1978 & 31,7 & 31,1 & 24,4 & 30,0 & 14,1 & 16,0 \\
1982 & 28,9 & 28,5 & 20,9 & 27,8 & 19,5 & 22,1 \\
1986 & 28,0 & 34,3 & 29,0 & 31,7 & 16,0 & 16,9 \\
$1989 / 1990$ & 29,0 & 34,5 & 22,0 & 30,3 & 13,5 & 14,0
\end{tabular}

Bron: Databestand CEIS.

Leesvoorbeeld: $\mathrm{Bij}$ de gemeenteraadsverkiezingen van 1974 haalde het CDA 27,1 procent van de stemmen, terwijl men in dezelfde gemeenten waar men aan deze gemeenteraadsverkiezingen deelnam het totaal van 25,3 procent van de in totaal geldig uitgebrachte stemmen bij de Statenverkiezingen van dat jaar haalde.

Uit tabel 5.4 blijkt dat in bijna alle gevallen het stempercentage bij de niet-lokale verkiezingen hoger is dan bij de lokale verkiezingen. Opvallende uitzonderingen zijn echter de uitslagen van het CDA in de periode 1974-1982. Wat het verschil in percentages bij de twee soorten verkiezingen betreft, blijkt dit bij het CDA in de periode 1974-1982 het geringst te zijn. Bij de verkiezingen van 1986 en 1989/90 geldt dat voor de VVD. Voor zowel het CDA als de PvdA is het verschil tussen de uitslagen bij de lokale-en niet-lokale verkiezingen in 1990 groter dan in 1974. Bij de VVD is er sprake van een duidelijke vermindering van dit verschil in de periode 1974-1990.

Vervolgens kunnen wij op basis van de gegevens in tabel 5.1 en 5.4 vaststellen in welke mate de deelname van de partijen van invloed is op het verschil in de uitslagen bij de lokale- en nietlokale verkiezingen. Wij berekenen deze factor door de stempercentages voor de partijen bij de niet-lokale verkiezingen in tabel 5.1 te vergelijken met die in tabel 5.4. Immers, de stempercentages in tabel 5.1 zijn gebaseerd zijn op de uitslagen in alle gemeenten, terwijl de percentages in tabel 5.4 gebaseerd zijn op alleen die gemeenten waar de betreffende partij aan de gemeenteraadsverkiezingen heeft deelgenomen. Ervan uitgaande datalle andere bepalende factoren voor de uitslag bij de verkiezingen gelijk zijn, kunnen wij zo vaststellen in welke mate de geringere deelname bij de gemeenteraadsverkiezingen van invloed is op de samengestelde landelijke uitslag bij deze verkiezingen. Wij zullen echter in dit hoofdstuk zien dat ook andere factoren dan de deelname van de partijen een rol van betekenis spelen bij het verschil in landelijke uitslagen bij lokale- en niet-lokale verkiezingen. Het gevonden percentage in tabel 
5.5geeft daarom slechts een indicatie van de invloed van de geringere deelnamevan de partijen aan de gemeenteraadsverkiezingen op het verschil tussen de landelijke uitslagen van de lokaleen niet-lokale verkiezingen. Ten aanzien van de PvdA is het wel noodzakelijk om een correctie aan te brengen. Deze partij doet immers ook in PAK-verband mee aan de gemeenteraadsverkiezingen. De score van de PvdA is daarom verminderd met het percentage stemmen dat de PAK-lijsten bij de verschillende gemeenteraadsverkiezingen hebben gehaald.

Tabel 5.5: De berekende invloed van de deelname van partijen aan de gemeenteraadsverkiezingen op het verschil tussen de landelijke uitslagen bij de lokale-en nietlokale verkiezingen, in procenten, 1974-1990.

\begin{tabular}{lrrr}
\hline & CDA & PvdA & VVD \\
1974 & 5,6 & 1,4 & 1,7 \\
1978 & 3,8 & 1,1 & 0,9 \\
1982 & 0,9 & 0,8 & 1,0 \\
1986 & 0,3 & 0,4 & 0,5 \\
$1989 / 1990$ & 0,8 & 0,8 & 0,6
\end{tabular}

Bron: Databestand CELS.

Leesvoorbeeld: Bij het CDA is in 1974 5,6 procent van het verschil tussen de landelijke uitslagen bij de lokaleen niet-lokale verkiezingen veroorzaakt door de geringere deelname van deze partij aan de gemeenteraadsverkiezingen.

Meteen valt op dat in grote lijnen bij alle drie de partijen de berekende invloed van de deelname van partijen aan de gemeenteraadsverkiezingen op het verschil tussen de landelijke uitslagen bij de lokale- en niet-lokale verkiezingen vermindert. Dat is ook niet verwonderlijk als wij ons realiseren dat de partijen niet alleen in steeds meer gemeenten aan de gemeenteraadsverkiezingen zijn gaan deelnemen, maar dat daarmee ook steeds meer kiezers bereikt werden, zoals uit tabel 5.2 bleek. Dit bevestigt nogmaals de conclusie dat een grotere deelname van de drie partijen zich vertaalt in een hoger stempercentage en dat daarmee de deelname van de partijen aan de gemeenteraadsverkiezingen éen van de factoren is die het verschil tussen de landelijke uitslagen van de lokale- en niet-lokale verkiezingen bepaalt.

\subsubsection{Verschillen in concurrentie}

Een tweede factor van betekenis voor het verklaren van het verschil tussen de landelijke uitslagen bij de de lokale- en niet-lokale verkiezingen is het verschil in concurrentie. Bij de Tweede Kamer- en Statenverkiezingen doen (bijna) alle landelijke partijen mee aan deze verkiezingen in (bijna) alle gemeenten. Bij de gemeenteraadsverkiezingen is dat, zoals wij in hoofdstuk 3 en de vorige paragraaf zagen niet het geval. Dat betekent dat partijen op plaatselijk niveau geconfronteerd worden met verschillende concurrentieverhoudingen. Van groot belang hierbij is de deelname van de lokale lijsten aan de gemeenteraadsverkiezingen. ${ }^{7}$ Deze lijsten, die per definitie niet aan de niet-lokale verkiezingen deelnemen, kunnen op zeer verschillende wijze de uitslagen van de landelijke partijen op lokaal niveau beïnvloeden. ${ }^{8}$ In de volgende paragrafen zullen wij hierop terugkomen. Aangezien het niet mogelijk is om de exacte invloed van de lokale lijsten op de afzonderlijke landelijke uitslagen van de landelijke partijen te bepalen, zullen wij moeten volstaan met een overzichtvan de deelname van de lokale 
lijsten aan de gemeenteraadsverkiezingen en het door hen daarbij behaalde percentage stemmen.

In hoofdstuk drie hebben wij al geconstateerd dat in de periode 1974-1990 bij elke gemeenteraadsverkiezing in 70 à 80 procent van de gemeenten één of meerdere lokale lijsten hebben deelgenomen. In tabel 5.6 wordt een overzicht gegeven van het door de gezamenlijke lokale lijsten in totaal behaalde percentage stemmen.

Tabel 5.6: Percentage stemmen op de lokale lijsten, 1974-1990.

\begin{tabular}{lllll}
1974 & 1978 & 1982 & 1986 & 1990 \\
18,9 & 14,8 & 13,0 & 12,0 & 13,3 \\
\hline
\end{tabular}

Bron: Databestand CELS.

Uit deze tabel blijkt dat het stemmenpercentage van de lokale lijsten tot 1986 daalde, al verminderde die daling gaandeweg. In 1990 is het percentage stemmen weer iets gestegen, waarmee het stemmenpercentage van de gezmanelijke lokale lijsten weer op het niveau van $1982 \mathrm{kwam}$. Het zal duidelijk zijn dat dergelijke stemmenpercentages van invloed kunnen zijn op de door de drie landelijke partijen behaalde stempercentages. In de volgende paragrafen van dit hoofdstuk zullen wij zien dat de lokale lijsten een grote invloed uitoefenen op de plaatselijke uitslagen van de afzonderlijke landelijke partijen.

\section{Geringere concurrentie van kleinere partijen}

Terwijl de lokale lijsten door hun deelname aan de gemeenteraadsverkiezingen op plaatselijk niveau in vergelijking met de niet-lokale verkiezingen zorgen voor een toename van de concurrentie tussen partijen, is het tegendeel het geval ten aanzien van de kleine landelijke partijen. Deze partijen nemen immers in (bijna) alle gemeenten aan de niet-lokale verkiezingen deel, terwijl dat dikwijls niet het geval is bij de gemeenteraadsverkiezingen.

D66 bijvoorbeeld is in 1974 in maar 4,0procentvan de gemeenten met een lijstvertegenwoordigd bij de gemeenteraadsverkiezingen. Bij de overige verkiezingen in de periode 1974-1990 waren de deelnamecijfers achtereenvolgens $24,3,42,9,31,0$ en 36,5 procent. Ook de kleinere christelijke lijsten (SGP, GPV, RPF) nemen in relatief weinig gemeenten deel aan de gemeenteraadsverkiezingen. Bij de achtereenvolgende verkiezingen is in respectievelijk 33,8 , $35,7,40,7,40,2$ en 38,9 procentvan de gemeenten een kleinere christelijke lijstvertegenwoordigd. Opvallend is dat de kleine christelijke partijen steeds minder afzonderlijk en steeds meer in een samenwerkingsverband aan de gemeenteraadsverkiezingen deelnemen. Bij de lokale verkiezingen in de periode 1974-1990 was dat in achtereenvolgens $3,2,14,2,31,9,32,9$ en 43,3 procent van het totaal aantal ingediende lijsten van de kleine christelijke partijen het geval. Tegelijkertijd met de toename van samenwerkingsverbanden zien wij een toename van het percentage gemeenten waar de kleine christelijke lijsten succesvol aan de gemeenteraadsverkiezingen deelnemen. Zo is in 197456,9 procent van de kleine christelijke lijsten succesvol, terwijl dat in 1990 stijgt tot 85,3 procent. ${ }^{10}$

Evenals de kleinere christelijke lijsten waren de gezamenlijke klein-linkse lijsten (CPN, PSP, PPR, EVP) slechts in een minderheid van de gemeenten aanwezig bij de raadsverkiezingen. Bij de achtereenvolgende gemeenteraadsverkiezingen in de periode 1974-1990 is het percent- 
age gemeenten waar minstens èen klein-linkse lijst aan de gemeenteraadsverkiezingen deelneemt respectievelijk 28,5, 31,3, 33,6, 27,9 en 27,7 procent. Bij de klein-linkse partijen kunnen wij nog duidelijker dan bij de kleine christelijke partijen constateren dat men steeds minder afzonderlijk en steeds meer in een samenwerkingsverband aan de verkiezingen gaat deelnemen. In 1974 was 14,8 procent van de klein-Linkse lijsten een samenwerkingsverband, terwijl dit percentage in 1986 is gestegen tot 67,2 procent. Hiermee wordt duidelijk dat de CPN, de PSP, de PPR en de EVP op lokaal niveau al in veel gemeenten gezamenlijk aan de gemeenteraadsverkiezingen hebben deelgenomen, al is hierbij sprake van verschillende smanestellingen van partijen. In dezelfde periode stijgt het percentage succesvolle lijsten van 55,8 procent naar 74,7 procent. In 1990 zijn 91,9 procent van de Groen-Linkse lijsten succesvol. Op grond van het bovenstaande kunnen wij stellen dat de relatief geringe deelname van de kleine landelijke partijen aan de gemeenteraadsverkiezingen een kenmerkend element is van deze verkiezingen. Deze partijen hebben daardoor bij de gemeenteraadsverkiezingen minder mogelijkheden om stemmen te vergaren. Daar staat tegenover dat kleinere landelijke partijen mogelijk profiteren van de omstandigheid dat bij de gemeenteraadsverkiezingen de machtsvraag - wie gaat met wie regeren - in veel mindere mate aan de orde is dan bij de Tweede Kamerverkiezingen. Op grond hiervan is het mogelijk dat een deel van de kiezers dat bij de Tweede Kamerverkiezingen op éen van de grote partijen stemt, bij de gemeenteraadsverkiezingen op éen van de kleinere landelijke partijen stemt. Hierover zijn echter geen landelijke gegevens bekend. ${ }^{11}$ Tevens moeten wij ons realiseren dat zich hetzelfde voor kan doen bij de Statenverkiezingen.

Naast deze samenwerkingsverbanden van de kleinere partijen aan de linkerkant van het partijpolitieke spectrum, hebben in de jaren zeventig ook de PAK-lijsten een rol gespeeld bij de gemeenteraadsverkiezingen. Deze samenwerkingsverbanden van de PvdA met andere progressieve partijen - naast de eerder genoemde Groen-Linkse partijen kan ook D66 daartoe gerekend worden - nemen in de periode 1974-1990 in achtereenvolgens 15,2, 11,9, 11,9, 9,5 en 7,0 procent van de gemeenten deel aan de gemeenteraadsverkiezingen. Men haalt bij deze verkiezingen daarmee respectievelijk $4,4,2,8,1,8,1$,2 en 0,8 procent van de stemmen. Daarmee kan door deze samenwerkingsverbanden op lokaal niveau een deel van het verschil tussen de uitslagen van de PvdA bij de lokale- en niet-lokale verkiezingen verklaard worden.

\subsubsection{Verschillen in opkomst}

Een opvallend verschil tussen lokale en niet-lokale verkiezingen is het verschil in opkomst. Uit tabel 5.7 kunnen wij opmaken dat er een groot verschil is tussen de opkomstpercentages bij de gemeenteraads- en Statenverkiezingen enerzijds en de Tweede Kamerverkiezingen anderzijds. Tevens is dit verschil in 1990 groter dan ooit tevoren. 
Tabel 5.7: Opkomstpercentages bij lokale-en niet-lokale verkiezingen in de periode 1972-1990.

\begin{tabular}{|c|c|c|c|c|c|c|c|c|c|c|c|}
\hline & '72 & 74 & 77 & 78 & '81 & '82 & '86 & '87 & '89 & '90 & '91 \\
\hline lokaal & & 69,1 & & 73,7 & & 68,3 & 73,2 & & & 62,3 & \\
\hline TK & 83,5 & & 88,0 & & 87,0 & 81,0 & 85,8 & & 80,3 & & \\
\hline PS & & 75,1 & & 79,6 & & 68,4 & & 66,3 & & & 52,3 \\
\hline
\end{tabular}

Bron: CBS, Statistieken der verkiezingen.

* De onderstreepte percentages geven de niet-lokale verkiezingen aan die bij de analyse in dit deel van het proefschrift worden gebruikt. In 1974 en 1978 betreft het de Provinciale Statenverkiezingen, in 1982, 1986 en 1989 de Tweede Kamerverkiezingen.

Belangrijk in dit kader is echter of het verschil in opkomstpercentages nadelige gevolgen heeft voor éen van de drie grote landelijke politieke partijen. Hierover is er echter maar zeer weinig bekend. Uit onderzoek van Inter/View uit 1990 bleek dat bij deze verkiezingen wel verschillen waren in de opkomst van de aanhang van de verschillende partijen, maar dat deze verschillen geen grote invloed hadden op de uitslag. ${ }^{12}$ Daaruit

bleek tevens dat indien op dat moment Tweede Kamerverkiezingen zouden zijn gehouden, meer kiezers zouden zijn gaan stemmen. Dit zou tevens de uitslagen van de verschillende partijen benvloed hebben. Vooral de PvdA, maar ook D66 zou een hogere uitslag gehaald hebben, terwijl voor het CDA het tegendeel gold. Relatief gezien hebben vooral de kleine christelijke lijsten en in iets mindere mate Groen-Links geprofiteerd van de geringe opkomst. Blijkbaar hebben zij een relatief trouwe aanhang. Voor de VVD maakte het geen verschil. ${ }^{13} \mathrm{Bij}$ deze vergelijking moeten wij ons wel realiseren dat een dergelijk onderzoek niet alleen meet in hoeverre een verhoging van de opkomst tot een andere uitslag zou leiden, maar tevens of de omstandigheid dat men voor de Tweede Kamer zou gaan stemmen in plaats van de voor gemeenteraad van invloed is geweest op het stemgedrag. Het is bijvoorbeeld voorstelbaar, zoals reeds eerder gesteld, dat een deel van de kiezers bij de Tweede Kamerverkiezingen eerder op één van de grotere partijen stemt dan bij de gemeenteraadsverkiezingen, omdat bij de Tweede Kamerverkiezingen ook de mogelijkheid van regeringsdeelname van de partijen op het spel staat. Kortom, gezien deze kanttekeningen en het ontbreken van onderzoek naar de motivering van de partijkeuze bij de gemeenteraadsverkiezingen in de periode 1974-1986 is het onmogelijk om definitieve conclusies te trekken over de invloed van het verschil in opkomstpercentages bij de lokale- en niet-lokale verkiezingen op de verkiezingsuitslag. De gepresenteerde beschikbare gegevens maken wel duidelijk dat deze factor geen al te grote rol speelt bij het verschil tussen de landelijke uitslagen bij de lokale-en niet-lokale verkiezingen.

\subsubsection{Deelname van buitenlanders aan de gemeenteraadsverkiezingen}

In hoofdstuk 2 is reeds aangegeven dat met ingang van de gemeenteraadsverkiezingen van 1986 buitenlanders die langer dan vijf jaar legaal in Nederland verblijven stemrecht hebben bij de gemeenteraadsverkiezingen. Deze mogelijkheid bestaat niet bij de Staten- en Tweede Kamerverkiezingen. Daarmee is de deelname van buitenlanders aan de gemeenteraadsverkiezingen een karakteristiek element van deze verkiezingen. De vraag is in hoeverre het 
kiesgedrag van niet-Nederlanders van invloed is op verschil tussen de landelijke uitslagen van de lokale- en niet-lokale verkiezingen?

Aangezien er geen landelijk kiezersonderzoek is gehouden naar de opkomst en partijkeuze van buitenlandse kiesgerechtigden bij de gemeenteraadsverkiezingen van 1986 en 1990, is op deze vraag geen direct antwoord te geven. Uit een aantal plaatselijke kiezersonderzoeken blijkt echter dat zowel in 1986 als in 1990 de opkomst van de buitenlandse kiesgerechtigden lager is geweest dan die van de Nederlandse kiesgerechtigden (Veldkamp Marktonderzoek b.v., 1986:14; Boosten, 1990:11; Buijs en Rath, 1986:22; Rath, 1990:50). Alleen in een onderzoek naar de gemeenteraadsverkiezingen van 1990 in Den Haag kwam naar voren dat niet-Nederlandse kiesgerechtigden in ongeveer dezelfde mate zijn gaan stemmen dan Nederlandse kiesgerechtigden.(Luijten, 1990:9).

Naast het relatief geringe aantal niet-Nederlandse kiesgerechtigden op het totaal aantal kiesgerechtigden bij de gemeenteraadsverkiezingen, (in Den Haag in 1990 bijvoorbeeld 4,3\% van het electoraat) draagt de relatief lage opkomst van de niet-Nederlanders ertoe bij dat de plaatselijke uitslagen van de verschillende partijen in slechts geringe mate worden benvloed door het kiesgedrag van de niet-Nederlanders. Door middel van een secundaire analyse van de voorhanden gegevens over het kiesgedrag bij de gemeenteraadsverkiezingen van 1986 in Rotterdam en het kiesgedrag bij de gemeenteraadsverkiezingen van 1990 in Den Haag en Rooterdam kunnen wij achterhalen in hoeverre niet-Nederlandse kiezers de plaatselijke stempercentages van de partijen in deze gemeenten hebben beïnvloed. Daaruit blijkt dat de plaatselijke uitslagen van de PvdA het sterkst worden beïnvloed door de deelname van buitenlandse kiezers aan de gemeenteraadsverkiezingen. Zonder deze deelname zou het stempercentage van de PvdA in 1986 in Rotterdam ongeveer 2,5 procent lager zijn geweest. In 1990 is dat nog ongeveer 1,7 procent. In Den Haag zou het stempercentage van de PvdA bij de gemeenteraadsverkiezingen in 1990 ongeveer 2,5 lager zijn geweest. De stempercentages van het CDA zouden daarentegen respectievelijk 0,4 procent, 0,5 procent en 0,5 procent hoger zijn geweest als buitenlanders hun stem niet konden uitbrengen bij de gemeenteraadsverkiezingen. Ook de VVD zou in dat geval haar stempercentage verhoogd hebben. Het verschil bedraagt ongeveer 0,4 procent in 1986 in Rotterdam en 0,4 en 0,8 procent in 1990 in respectievelijk Rotterdam en den Haag.

Afsluitend kunnen wij concluderen dat de deelname van buitenlanders aan de gemeenteraadsverkiezingen in de grote steden de plaatselijke stempercentages van de drie grootste partijen in geringe mate heeft beinvloed. Daarmee is de invloed van het kiesgedrag van de niet-Nederlandse kiezers op de verkiezingsresultaten van de gemeenteraadsverkiezingen in heel Nederland zeer gering.

\section{Verschillende verkiezingsdata}

Een laatste mogelijke factor ter verklaring van het verschil tussen de landelijke uitslagen van de lokale- en niet-lokale verkiezingen is de omstandigheid dat de verkiezingen voor de Provinciale Staten, de Tweede Kamer en de gemeenteraden niet op dezelfde dag plaatsvinden. In de tijd tussen de verschillende verkiezingen kan sprake zijn van electorale ontwikkelingen die van invloed zijn op de verkiezingsuitslagen. Tevens kan in de tussenliggende periode de samenstelling van het electoraat in de gemeenten enigszins veranderen. Hoe groot de invloed van deze factoren is, is met behulp van de voorhanden gegevens niet te achterhalen. Waarschijnlijk spelen ze slechts een geringe rol omdat er maar twee of drie maanden ligt tussen de twee verkiezingen die met elkaar vergeleken worden. Bij de verkiezingen van $1989 / 90$ is 
het verschil echter ruim zes maanden. Vooral voor de PvdA was dit van betekenis, aangezien zij in de periode tussen de verkiezingen geconfronteerd werd met een sterke afname van de eigen aanhang. Deze ontwikkeling, die van invloed is op het verschil tussen de landelijke uitslagen van de PvdA in 1989/90voor de gemeenteraads- en Tweede Kamerverkiezingen, kan daarmee de analyse van de plaatselijke uitslagen beïnloeden en is dus een factor waar bij de analyse rekening mee moet worden gehouden. De methoden die in dit hoofdstuk worden gebruikt zijn echter gekozen of ontwikkeld met het uitgangspunt dat zij zo min mogelijk worden beïnvloed door tussentijdse ontwikkelingen in de kiezersvoorkeur. ${ }^{14}$ Enige invloed van dergelijke ontwikkelingen is echter niet uit te sluiten.

\subsubsection{De kenmerkende verschillen tussen de lokale- en niet-lokale verkiezingen}

Afsluitend kunnen wij concluderen dat hetverschil tussen de landelijke uitslagen van de lokaleen niet-lokale verkiezingen in ieder geval veroorzaakt wordt door een viertal factoren. Het betreft de geringere deelname van de landelijke partijen aan de gemeenteraadsverkiezingen, de verschillen in de plaatselijke partijpolitieke concurrentie, en in mindere mate de deelname van niet-Nederlandse kiezers aan de gemeenteraadsverkiezingen en de electorale ontwikkelingen in de periode tussen de lokale-en niet-lokale verkiezingen. De verschillen in deelname en concurrentie en de deelname van niet-Nederlandse kiezers zijn specifiek verbonden met de gemeenteraadsverkiezingen en bepalen daarmee het lokale karakter van deze verkiezingen. Aangezien wij aangetoond hebben dat de geringere deelname van de drie landelijke partijen in steeds mindere mate een rol speelt bij de bepaling van de landelijke uitslag van deze partijen bij de gemeenteraadsverkiezing en dat de deelname van niet-Nederlandse kiezers in zeer geringe mate de landelijke uitslagen van de partijen beïnvloeden, zijn de verschillen in de concurrentie tussen partijen steeds meer de bepalende factor geworden bij het lokale karakter van de gemeenteraadsverkiezingen. Vooral de concurrentie van de lokale lijsten lijkt daarbij een rol van betekenis te spelen. Vandaar dat bij de analyse van de plaatselijke stempercentages van de drie landelijke partijen expliciet aandacht zal worden geschonken aan deze factor.

\subsection{De samenhang tussen de plaatselijke stempercentages}

Niet alleen op landelijk maar ook op plaatselijk niveau is er voor de drie grote landelijke partijen een verschil tussen de uitslagen bij de lokale-en niet-lokale verkiezingen. Een analyse van deze verschillen verschaft ons informatie over het lokale karakter van de gemeenteraadsverkiezingen. Daarom zullen wij in de rest van dit hoofdstuk het lokale karakter van de gemeenteraadsverkiezingen in kaart brengen door de vergelijking van de plaatselijke uitslagen bij de lokaleen niet-lokale verkiezingen.

Op verschillende manieren kan een dergelijke vergelijking informatie verschaffen over het lokale karakter van de gemeenteraadsverkiezingen. Allereerst zullen wij bepalen in hoeverre er een samenhang bestaat tussen de mate waarin in de verschillende gemeenten de plaatselijke stempercentages bij de lokale verkiezingen afwijken van de plaatselijke stempercentages bij de niet-lokale verkiezingen. Een voorbeeld kan het een en ander verduidelijken. 
Tabel 5.8: Plaatselijke stempercentages voor een partij bij gemeenteraads-, Staten- en Tweede Kamerverkiezingen in acht denkbeeldige gemeenten.

\begin{tabular}{lrrr}
\hline gemeente & GR & PS & TK \\
1 & 12,3 & 8,4 & 13,8 \\
2 & 13,4 & 15,2 & 14,9 \\
3 & 14,5 & 6,7 & 16,0 \\
4 & 15,6 & 21,8 & 17,1 \\
5 & 16,7 & 6,9 & 18,2 \\
6 & 17,8 & 15,3 & 19,3 \\
7 & 18,9 & 19,6 & 20,4 \\
8 & 20,0 & 20,4 & 21,5 \\
\hline
\end{tabular}

In dit voorbeeld zien wij dat er tussen de stempercentages van de gemeenteraadverkiezingen en de Provinciale Statenverkiezingen geen relatie bestaat. In enkele gemeenten is het plaatselijke stempercentage bij de gemeenteraadsverkiezingen hoger dan bij de Provinciale Statenverkiezingen, terwijl in een aantal andere gemeenten precies het omgekeerde het geval is. Vergelijken wij echter de plaatselijke stempercentages van de gemeenteraadsverkiezingen met de plaatselijke stempercentages van de Tweede Kamerverkiezingen, dan blijkt van een zeer sterke relatie sprake te $z i j n$. Immers, in alle gemeenten is het stemmenpercentage bij de Tweede Kamerverkiezingen 1,5 procent hoger dan die bij de gemeenteraadsverkiezingen.

De betekenis van het meten van deze samenhang is, dat een sterke samenhang erop duidt dat lokale factoren die specifiek zijn voor de gemeenteraadsverkiezingen, slechts in geringe mate van invloed zijn op de uitslagen van de gemeenteraadsverkiezingen. Immers, als in de verschillende gemeenten lokale factoren een belangrijke rol zouden spelen, dan zouden er ook grote positieve of negatieve verschillen moeten zijn tussen de afwijkingen van de plaatselijke stempercentages bij de gemeenteraadsverkiezingen ten opzichte van de plaatselijke stempercentages bij de niet-lokale verkiezingen. In de ene gemeente zou de betreffende partij door de invloed van lokale factoren een veel hoger stempercentage halen bij de gemeenteraadsverkiezingen in vergelijking met de niet-lokale verkiezingen, terwijl in de andere gemeente het omgekeerde het geval zou kunnen zijn. Als deze verschillen er niet zijn en er dus sprake is van een sterke samenhang tussen het verschil in plaatselijke stempercentages bij de lokale- en niet-lokale verkiezingen in de verschillende gemeenten, kunnen wij nauwelijks spreken van een lokaal karakter van de gemeenteraadsverkiezingen.

\subsubsection{Het meten van de samenhang tussen plaatselijke stempercentages}

De samenhang tussen de plaatselijke stempercentages bij de lokale-en niet-lokale verkiezingen in de periode 1974-1990 wordt bepaald door het berekenen van de Pearson produkt-moment correlatiecoëfficiënt tussen deze twee stempercentages. ${ }^{15}$ Een voordeelvan deze maatvoor het meten van de samenhang tussen twee variabelen is dat deze veel gebruikt wordt en daardoor algemeen bekend is. Daarbij is van betekenis dat de waarden van de correlatiecoëfficiënt tussen een vastgesteld minimum en maximum liggen, hetgeen de interpretatie van de gevonden gegevens eenvoudiger maakt.

Een nadeel van de berekening van de correlatie tussen twee variabelen is echter wel dat de hoogte van de correlatiecoëfficint beïnvloed wordt door de diversiteit van de plaatselijke 
stempercentages in de gemeenten (Achen, 1977). Deze invloed betekent in dit onderzoek dat als de plaatselijke stempercentages van een partij sterk van elkaar verschillen, dit een positief effect kan hebben op de correlatiecoëfficiënten. Om hier zonodig rekening mee te houden, is het noodzakelijk dat voor elk van de drie partijen bekend is wat de verschillen zijn tussen de plaatselijke stempercentages. Als maat hiervoor gebruiken wij de standaardafwijking van de plaatselijke stempercentages. Zie hiervoor tabel 1 en 2 in bijlage 3. Daaruit blijkt dat voor zowel de lokale- als de niet-lokale verkiezingen het CDA de grootste standaardafwijking heeft, gevolgd door de PvdA. De standaardafwijking van de VVD is bij alle verkiezingen duidelijk het geringst. Uitgaande van de stelling van Achen betekent dit dat de correlatiecoëfficiënten van het CDA en de PvdA ten opzichte van die van de VVD in opwaartse richting beinvloed zijn doordat deze twee partijen een grotere spreiding van plaatselijke stempercentages kennen dan de VVD. Bij de interpretatie van de gegevens moeten wij dus hiermee enigszins rekening houden. Aangezien bij elk van de drie partijen de verschillen in de standaardafwijkingen over de verschillende verkiezingen betrekkelijk gering zijn, levert een vergelijking van de correlatiecofficinten over de verschillende verkiezingen in ieder geval geen interpretatieproblemen op.

\subsubsection{Resultaten}

Voor elk van de drie landelijke partijen hebben wij voor alle verkiezingen in de periode 19741990 de correlatie berekend tussen de plaatselijke uitslagen van de lokale- en niet-lokale verkiezingen in alle gemeenten waar de betreffende partij heeft meegedaan aan de gemeenteraadsverkiezingen. De resultaten van deze analyse staan in tabel 5.9.

Tabel5.9: Decorrelatie tussen de plaatselijke uitslagen bij de lokale-en niet-lokaleverkiezingen, 1974-1990.

\begin{tabular}{lllllll}
\hline & CDA & N & PvdA & N & VVD & N \\
1974 & .79 & 583 & .87 & 483 & .84 & 511 \\
1978 & .73 & 637 & .82 & 577 & .90 & 606 \\
1982 & .67 & 688 & .84 & 563 & .84 & 608 \\
1986 & .69 & 669 & .79 & 558 & .87 & 600 \\
$1989 / 90$ & .71 & 584 & .68 & 513 & .81 & 534 \\
\hline
\end{tabular}

Bron: Databestand CEIS.

Opvallend is dat bij de VVD de sterkste samenhang bestaat tussen de plaatselijke uitslagen bij de lokale- en niet-lokale verkiezingen. Aangezien de standaardafwijking van het gemiddelde plaatselijke stempercentage voor de VVD duidelijk kleiner is, zouden wij immers kunnen verwachten dat de gegevens voor de VVD een relatief laag verband tussen de plaatselijke. uitslagen zou aangeven. Blijkbaar spelen lokale factoren een zeer geringe rol. In dat kader is het ook opvallend dat de partij met de hoogste standaardafwijking, het CDA, de laagste correlaties heeft. Het CDA is ook de enige partij waarbij de correlatiecoëfficiënten zelfs altijd lager zijn dan .80. De PvdA laat tot 1986 nog wel een sterk verband zien voor de plaatselijke uitslagen bij de lokale- en niet-lokale verkiezingen.

Wat de ontwikkelingen over de verschillende verkiezingsjaren voor de afzonderlijke partijen betreit, zien wij enkele kenmerkende verschillen tussen de drie partijen. Bij de PudA kunnen 
wij een duidelijke neiging tot een minder sterk verband tussen de plaatselijke uitslagen constateren. Lokale factoren winnen dus iets aan betekenis bij de PvdA Bij het CDA is aanvankelijk ook sprake van een daling, maar met ingang van 1986 is er weer een sterker verband tussen de plaatselijke uitslagen van de vergeleken verkiezingen. Bij de VVD tenslotte is er geen eenduidige ontwikkeling over de verschillende verkiezingsjaren te ontdekken. Tevens valt op dat in 1990 vooral bij de PvdA, maar ook bij de VVD sprake is van een zwakkere relatie tussen de plaatselijke uitslagen van de lokale- en niet-lokale verkiezingen dan bij de andere verkiezingen. Lokale factoren spelen dus bij deze verkiezingen voor deze partijen een grotere rol van betekenis dan bij voorgaande verkiezingen. Hierbij moeten wij wel de kanttekening maken dat het relatief grote tijdsverschil tussen beide vergeleken verkiezingen mogelijk enige invloed heeft uitgeoefend op de uitkomsten van 1990. Dit geldt dan echter niet voor het CDA, aangezien de correlatie in 1990 nauwelijks afwijkt van die van 1986.

Voor alle partijen geldt dat de correlaties van 1990 lager zijn dan die van 1974. Dus bij alle partijen spelen lokale factoren een grotere rol bij de gemeenteraadsverkiezingen van 1990 dan bij de gemeenteraadsverkiezingen van 1974 .

\section{Resultaten in gemeenten zonder lokale lijsten}

Zowel in deel 2 van deze studie als in paragraaf 5.1 .2 hebben wij aandacht geschonken aan de electorale positie van de lokale lijsten. Daaruit bleek dat deze lijsten nog steeds van relatief grote betekenis zijn bij de gemeenteraadsverkiezingen, ook al lijken de nationale partijen een steeds grotere rol te spelen bij deze verkiezingen. Daarmee zijn de lokale lijsten waarschijnlijk éen van de belangrijkste oorzaken voor de verschillen in de uitslagen bij de lokale en niet-lokale verkiezingen. Op basis hiervan kan men ervan uitgaan dat de lokale lijsten de in tabel 5.9 gevonden samenhang tussen de plaatselijke stempercentages van de lokale- en niet-lokale verkiezingen beïnvloeden. Immers, lokale lijsten zijn een lokale factor die in verschillende gemeenten op zeer verschillende wijze de verkiezingsuitslagen voor de landelijke partijen kunnen beïnvloeden. Daarom is in tabel 5.10 tevens de correlatie gegeven in gemeenten waar geen lokale lijsten aan de verkiezingen deelnemen. ${ }^{16}$

Tabel 5.10: De correlatie tussen de plaatselijke uitslagen bij lokale-en niet-lokale verkiezingen voor gemeenten waar geen lokale lijsten aan de verkiezingen deelnemen, 1974-1990.

\begin{tabular}{lllllll}
\hline & CDA & N & PvdA & N & VVD & N \\
1974 & .93 & 180 & .93 & 146 & .92 & 167 \\
1978 & .96 & 194 & .92 & 168 & .93 & 190 \\
1982 & .95 & 198 & .87 & 170 & .93 & 198 \\
1986 & .95 & 195 & .92 & 171 & .93 & 194 \\
$1989 / 90$ & .92 & 184 & .82 & 168 & .88 & 181 \\
\hline
\end{tabular}

Bron: Databestand CELS.

Het meest opvallende gegeven in tabel 5.10 in vergelijking met de gegevens in tabel 5.9 is de grote toename van de sterkte van het verband tussen de plaatselijke uitslagen bij de lokale-en niet-lokale verkiezingen voor het CDA. Dit betekent dat de plaatselijke uitslagen van het CDA bij de gemeenteraadsverkiezingen in relatief sterke mate worden beïnvloed door de stempercentages van de lokale lijsten. Ook bij de PvdA en de VVD geven de uitkomsten aan dat er 
in gemeenten zonder lokale lijsten sprake is van een sterker verband tussen de plaatselijke uitslagen van deze partijen hij de lokale- en niet-lokale verkiezingen. Dus de lokale lijsten hebben ook de plaatselijke stempercentages van deze partijen bij de gemeenteraadsverkiezingen enigszins beïnvloed.

Bij ten vergelijking van de resultaten van de afzonderlijke partijen blijkt dat de plaatselijke uitslagen van het CDA bij de lokale- en niet-lokale verkiezingen de sterkste samenhang vertonen. Dit geldt voor alle verkiezingen in de periode 1974-1990. Het CDA wordt overigens op de voet gevolgd door de VVD.

De ontwikkelingen bij de verkiezingen in de periode 1974-1990 zijn ook nu verschillend voor de afzonderlijke partijen. Het CDA kent bij de verkiezingen van 1978, 1982 en 1986 een sterk en stabiel verband tussen de plaatselijke uitslagen bij de lokale- en niet-lokale verkiezingen. In 1974 en 1990 daarentegen is dit verband iets zwakker. Lokale factoren spelen bij deze twee verkiezingen een iets sterkere rol dan bij de overige verkiezingen. Bij de PvdA zien wij dat er sprake is van een vermindering van de sterkte van het verband tussen de plaatselijke uitslagen tot 1986. In 1990 is, evenals in tabel 5.8, sprake van een relatief zwak verband. Dus ook in de gemeenten zonder lokale lijsten is de invloed van lokale factoren op de plaatselijke stempercentages bij de gemeenteraadsverkiezingen van 1990 hoger dan voorheen. Hetzelfde geldt ook voor de VVD, die echter in de periode 1974-1986 een sterk en stabiel verband tussen de plaatselijke uitslagen laat zien.

\section{Resultaten per categorie van gemeentegrootte}

Bovenstaande analysen hebben wij tevens uitgevoerd per categorie van gemeentegrootte. De reden hiervoor is dat wij in deel 2 van deze studie hebben gezien dat de deelname van lokale lijsten verschilt in de verschillende categorieën van gemeentegrootte. Door een dergelijke analyse uit te voeren, wordt duidelijk in hoeverre de invloed van lokale factoren verschilt in gemeenten van verschillende grootte.

Gezien de hoge correlaties, met name bij de analyse voor gemeenten waar geen lokale lijsten aan de gemeenteraadsverkiezingen deelnemen, $z$ ijn de verschillen tussen de verschillende categorieën van gemeentegrootte niet groot. Zie hiervoor de tabellen 3 en 4 in bijlage 3 . Een aantal van de meer opmerkelijke resultaten is echter interessant genoeg om vermeld te worden.

Zo is bij het CDA opvallend dat bij de analyse in alle gemeenten vanaf 1978 de correlaties in de gemeenten met meer dan 25.000 inwoners opmerkelijk hoger zijn dan die met minder dan 25.000 inwoners. In de gemeenten zonder deelnemende lokale lijsten ligt een dergelijke grens bij 3.000 inwoners. Vooral bij de categorieën van gemeentegrootte met 3.000 tot 10.000 inwoners en 10.000 tot 25.000 inwoners is de samenhang tussen de plaatselijke uitslagen bij lokale en niet-lokale verkiezingen in gemeenten zonder lokale lijsten opmerkelijk hoger dan in alle gemeenten, inclusief die met lokale lijsten. Kortom, vooral in deze categorien van gemeentegrootte worden de plaatselijke stempercentages van het CDA relatief sterk beïnvloed door de lokale lijsten. Dit zijn tevens de categorieën van gemeentegrootte waar de confessionele partijen in de periode 1974-1990 hun electorale positie versterkt hebben. Gezien de relatief sterke electorale positie van de lokale lijsten in deze categorieën, kan men verwachten dat de lokale lijsten een relatief grote invloed hebben op de plaatselijke stempercentages van het CDA in deze gemeenten.

De PvdA heeft in 1974 in alle categorieën van gemeentegrootte een relatief hoge correlatie. hetgeen nogmaals aangeeft dat bij deze verkiezingen lokale factoren van minder invloed zijn 
op de plaatselijk stempercentages van de PvdA dan bij de latere verkiezingen. Met ingang van 1986 lijken de lokale lijsten een grotere invloed uit te oefenen op de plaatselijke stempercentages van de PvdA dan voorheen. De eerder geconstateerde sterke beïnvloeding door lokale factoren van de gemeenteraadsverkiezingen van 1990 komt met name sterk voor in gemeenten met tussen de 3.000 en 10.000 inwoners en in gemeenten met meer dan 100.000 inwoners.

Bij de VVD kunnen wij constateren dat in de gemeenten met meer dan 10.000 inwoners de correlatie bij alle verkiezingen opmerkelijk hoger is dan in gemeenten met minder dan 10.000 inwoners. Vanaf 1978 is in de categorie gemeenten met 3.000 tot 10.000 inwoners de correlatie hoger dan die in gemeenten met minder dan 3.000 inwoners maar tegelijkertijd lager dan die in gemeenten met meer dan 10.000 inwoners. De lokale lijsten blijken de plaatselijke stempercentages voor de VVD het sterkste te beinvloeden in de gemeenten met minder dan 3.000 inwoners. Dat is tevens de categorie van gemeentegrootte waar de VVD haar electorale positie in de periode 1974-1990 sterk heeft verbeterd. Vooral met ingang van de gemeenteraadsverkiezingen van 1982 is de invloed van de lokale lijsten op de plaatselijke stempercentages van de VVD relatief sterk.

\subsection{De berekende lokale factor bij de plaatselijke stempercentages}

Een sterke samenhang tussen de plaatselijke uitslagen bij de lokale-en niet-lokaleverkiezingen, geeft aan dat de plaatselijke stempercentagesvan de drie landelijke partijen bij de gemeenteraadsverkiezingen slechts in geringe mate beïnvloed worden door lokale factoren. De vraag is nu hoe wij op basis van een analyse van de plaatselijke stempercentages van de drie landelijke partijen de invloed van lokale factoren op deze stempercentages kunnen meten. Anders gezegd, in hoeverre is de hoogte van een plaatselijk stempercentage van elk van de drie grote landelijke partijen in absolute zin verhoogd of verlaagd onder invloed van lokale factoren. Laten wij deze invloed de 'absolute lokale factor' noemen. De term 'lokale factor' staat hierbij voor dat deel van het verschil tussen de plaatselijke uitslagen bij beide soorten verkiezingen dat toe te wijzen is aan het lokale karaktervan de gemeenteraadsverkiezingen. Voor een goed begrip is het van belang dat wij ons realiseren dat lokale factoren niet alleen bestaan uit politieke factoren, zoals bijvoorbeeld de mate waarin verkiezingsprogramma's of de beoordeling van de prestaties van plaatselijke politici de uitslag van de gemeenteraadsverkiezingen beïnvloeden. Ook de mate waarin de lokale politici actief zijn in hun gemeenschap, en persoonlijke kenmerken zoals het wonen in een bepaald kern binnen een gemeente, zijn lokale factoren die van invloed kunnen zijn op het kiesgedrag bij de gemeenteraadsverkiezingen.

\subsubsection{Het meten van de absolute lokale factor}

De wijze waarop wij de invloed van lokale factoren op de plaatselijke stempercentages van de drie grote landelijke partijen willen meten, is gebaseerd op een vergelijking van de plaatselijke uitslagen bij de lokale- en niet-lokale verkiezingen. De eerste stap bestaat uit het bepalen van de landelijke uitslag bij zowel de lokale als de niet-lokale verkiezingen in alle gemeenten waar de betreffende partij aan de betreffende gemeenteraadsverkiezingen deelneemt. ${ }^{17}$ Dit doen wij door in deze gemeenten de stemmen van de betreffende partij te delen door het totaal aantal geldig uitgebrachte stemmen. 
De tweede stap houdt in dat wij vervolgens in alle gemeenten het verschil berekenen tussen het landelijke stempercentage en het plaatselijke stempercentage voor de betreffende partij bij de betreffende gemeenteraadsverkiezing en de betreffende niet-lokale verkiezing. Om deze stap te verduidelijken wordt in tabel 5.11 een voorbeeld gegeven van deze berekeningen in een achttal denkbeeldige gemeenten.

Tabel5.11:Voorbeeld van een berekening van hetverschil tussen het landelijke stempercentage en de plaatselijke stempercentages bij een gemeenteraads- en een Tweede Kamerverkiezing in een achttal denkbeeldige gemeenten, in percentages.

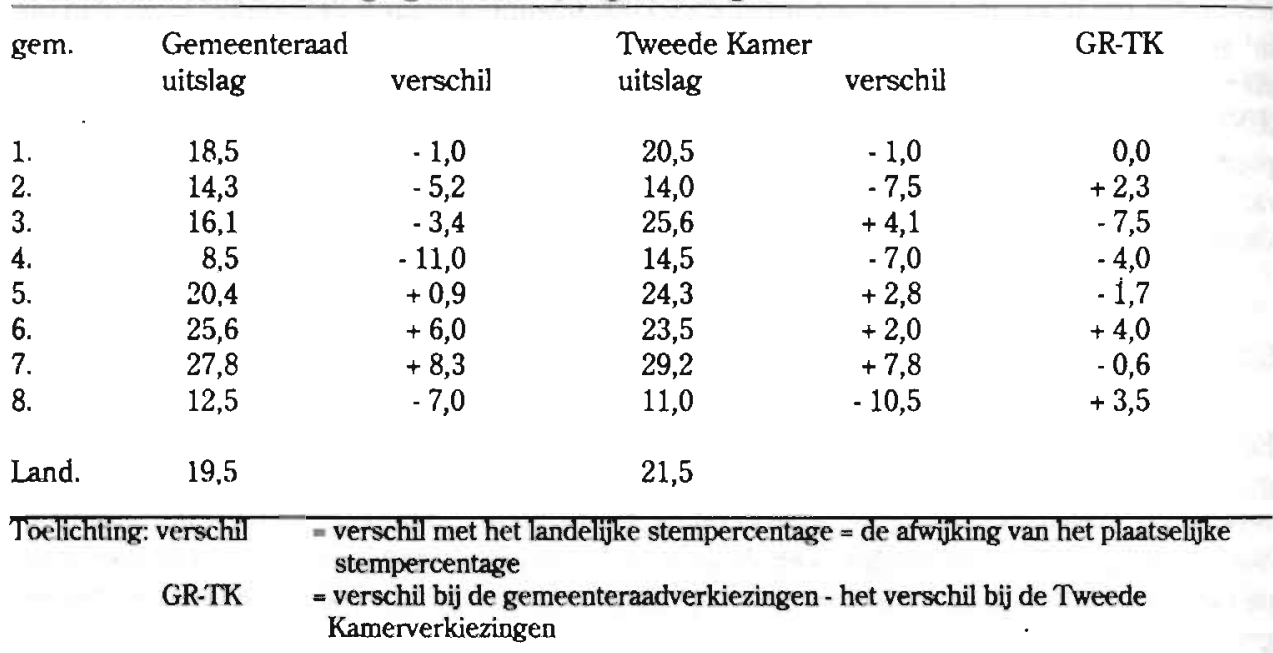

De tabel laat ons zien dat voor zowel de gemeenteraadsverkiezingen als voor de Tweede Kamerverkiezing in elk van de acht gemeenten het verschil wordt berekend tussen de landelijke uitslag en de plaatselijke uitslag. Dit verschil, dat bijvoorbeeld bij de gemeenteraadsverkiezingen in de eerste gemeente-1,0 procent bedraagt $(18,5 \%-19,5 \%)$, zullen wij vervolgens de afwijking van het plaatselijke stempercentage noemen. Aangezien wij voor zowel de lokale-als de niet-lokale verkiezingen in de gemeenten een dergelijke afwijking berekenen, spreken wij van de afwijking van het plaatselijke stempercentage bij de lokale verkiezingen en een afwijking van het plaatselijke stempercentage bij de niet-lokale verkiezingen.

$\mathrm{Na}$ deze berekening bestaat de volgende stap uit het berekenen van het verschil tussen dé gevonden afwijkingen van de plaatselijke stempercentages bij de lokale- en niet-lokale verkiezingen. Dit betekent dus dat wij voor alle gemeenten de afwijking van het plaatselijke stempercentage bij de gemeenteraadsverkiezingen in verband brengen met de afwijking van het plaatselijke stempercentage bij de niet-lokale verkiezingen. Het resultaatvan een dergelijke berekening kunnen wij zien in het laatste kolom van ons voorbeeld (GR-TK) in tabel 5.11. Z0 is bijvoorbeeld in de eerste gemeente bij zowel de gemeenteraads-als de Tweede Kamerverkiezingen het plaatselijk stempercentage 1 procent lager dan het landelijk stempercentage. $\mathrm{Er}$ is dus geen verschil aanwezig tussen de afwijking van het plaatselijke stempercentage bij de gemeenteraadsverkiezingen en de afwijking van het plaatselijke stempercentage bij de niet- 
lokale verkiezing. In de tweede gemeente daarentegen is er wel een verschil tussen de afwijking van het plaatselijke stempercentage bij de lokale- en niet-lokale verkiezingen. Bij de gemeenteraadsverkiezingen is deze afwijking $-5,2$ procent $(14,3 \%-19,5 \%)$, terwijl dat bij de Tweede Kamerverkiezingen $-7,5$ procent is $(14,0 \%-21,5 \%)$. Hetverschil tussen beide afwijkingen is 2,3 procent. Aangezien de uitslag bij de gemeenteraadsverkiezingen minder onder het landelijk gemiddelde ligt dan de uitslag bij de Tweede Kamerverkiezingen, kunnen wij stellen dat hetverschil ten voordele is van de gemeenteraadsverkiezingen $(-5,2 \%--7,5 \%=+2,3 \%)$. Vanuit ons model gaan wij er vanuit dat dit verschil wordt veroorzaakt door lokale factoren. De uitkomst van 2,3 procent is dan ook de berekende (absolute) lokale factor. Wel moet rekning gehouden worden met een foutenmarge. Omdat de gemeenteraads- en Tweede Kamerverkiezingen niet op dezelfde datum plaatsvinden, kunnen wij hierbij bijvoorbeeld denken aan de veranderingen in het kiesgedrag tussen de twee verkiezingen die niet toe te wijzen zijn aan lokale factoren. Het bovenstaande kan al volgt in een formule worden weeergegeven:

$$
\mathrm{LF}+\mathrm{e}=\mathrm{GR}-\mathrm{TK}
$$

$L F$ - de (absolute) lokale factor bij de gemeenteraadsverkiezingen

GR - het verschil tussen het plaatselijke en landelijke stempercentage bij de gemeenteraadsverkiezingen

TK - het verschil tussen het plaatselijke en landelijke stempercentage bij de niet-lokale verkiezingen

e $=$ error-factor

Bij deze berekening gaan wij ervan uit dat de uitslagen bij de gemeenteraadsverkiezingen bepaald worden door zowel lokale als nationale factoren. De uitslagen van de niet-lokale verkiezingen worden bepaald door nationale factoren. Bij beiden speelt natuurlijk de samenstelling van het lokale electoraat een belangrijke rol. Het gaat hierbij onder meer om de godsdienstige en de sociaal-economische samenstelling van het lokale electoraat. Door de GRscore te vergelijken met de TK-score berekenen wij voor iedere partij in iedere gemeente de lokale factor in de plaatselijke uitslag die toe te wijzen is aan het specifieke karakter van de. gemeenteraadsverkiezingen. Natuurlijk moeten wij hierbij rekening houden met de genoende: foutenmarge, hetgeen de ' $\mathrm{e}$ ' in de formule verklaart.

Wij zien dus dat de plaatselijke afwijking van het landelijk stempercentage bij de lokale verkiezingen in relatie wordt gebracht met dezelfde afwijking bij de niet-lokale verkiezingen. Door bij deze vergelijking niet uit te gaan van de werkelijke stempercentages maar van de afwijking van het plaatselijke stempercentage ten opzichte van het landelijke stempercentage, vermijden wij dus een directe vergelijking van de plaatselijke stempercentages bij de twee verkiezingen. De reden hiervoor is dat deze verkiezingen niet op dezelfde data plaatsvinden waardoor tussentijdse electorale ontwikkelingen een te grote invloed kunnen uitoefenen op de berekende scores voor de lokale factor. Door uit te gaan van de plaatselijke afwijking van het landelijk stempercentage wordt de invloed van deze electorale ontwikkelingen verkleind, al blijt een zekere vertekening mogelijk. 
De vierde en laatste stap bestaat uit het berekenen van de gemiddelde lokale factor voor de betreffende partij bij de betreffende gemeenteraadsverkiezing. Deze berekening ziet er dus als volgt uit:

$$
\text { Uitgaande van } L F+e-G R-T K \quad \frac{\sum|(L F+e)|}{n}
$$

$L F=$ de lokale factor bij de gemeenteraadsverkiezingen

$\mathrm{GR}=$ het verschil tussen het plaatselijke en landelijke stempercentage bij de gemeenteraadsverkiezingen

TK - het verschil tussen het plaatselijke en landelijke stempercentage bij de niet-lokale verkiezingen

e $=$ error-factor

$\mathrm{n}=$ aantal deelnemende gemeenten

Wij gaan bij het berekenen van deze lokale factor overigens uit van de absolute waarde van de berekende plaatselijke lokale factor, omdat het voor ons onderzoek niet van belang is of de lokale factor positief of negatief is. Een positieve lokale factor geeft uitdrukking aan de omstandigheid dat de betreffende partij bij de betreffende gemeenteraadsverkiezing door de lokale omstandigheden die toe te schrijven zijn aan het specifieke karakter van de gemeenteraadsverkiezingen een hoger stempercentage heeft gehaald dan men zonder deze. lokale omstandigheden had gehaald. Met andere woorden, de betreffende partij heeft het door lokale omstandigheden beter gedaan dan verwacht mocht worden. Voor een negatieve plaatselijke lokale factor geldt natuurlijk het omgekeerde. Wij zijn echter in dit stadium van het onderzoek niet geïnteresseerd in de omstandigheid of een partij het beter dan wel slechter heeft gedaaan dan men mocht verwachten. Het gaat ons om het feit of er überhaupt lokale factoren een rol hebben gespeeld bij de gemeenteraadsverkiezingen. Vandaar dat wij voor iedere partij bij iedere gemeenteraadsverkiezingen het gemiddelde berekenen van de absolute plaatselijke factoren. Deze werkwijze heeft als nadeel dat hiermee ook de door ons onderscheiden error-factorverabsoluteerd wordt. Deze verabsolutering leidt ertoe dat de error-factor niet zoals normaal bij het berekenen van een gemiddelde waarde naar 0 neigt. Immers, de positieve en negatieve waarden van de error-factor vallen door de absolutering niet tegen elkaar weg. De per partij per verkiezingsjaar berekende gemiddelde lokale factor wordt dus enigszins 'vervuild' door de in de berekening meegenomen error-factor, hetgeen betekent dat de lokale factoren in werkelijkheid iets geringer zijn dan berekend.

Door de berekening van de gemiddelde lokale factor is het mogelijk om over een bepaalde periode de grootte van de lokale factor bij de gemeenteraadsverkiezingen te bepalen. Uitgaande van ons voorbeeld in tabel 5.11 zou de gemiddelde lokale factor 2,95 procent bedragen. Deze score betekent dat de hoogte van de plaatselijke stempercentages gemiddeld met 2,95 procent verhoogd of verlaagd is onder invloed van lokale factoren. Wij moeten ons realiseren dat het hierbij gaat om een absolute verandering. Anders gezegd, wij hebben het verschil tussen het plaatselijk stempercentage met de invloed van lokale factoren en het plaatselijk stempercentage zonder invloed van lokale factoren berekend. In paragraaf 5.3.3 zullen wij overigens de relatieve invloed van de berekende absolute lokale factor op de hoogte van de plaatselijke stempercentages berekenen. Dit noemen wij de relatieve lokale factor. 


\subsubsection{Resultaten}

Op basisvan bovenstaande methode hebben wijvoor de drie partijen voor alle verkiezingsjaren de gemiddelde en mediane waarde van de lokale factor berekend. De resultaten hiervan staan in tabel 5.12.

Tabel 5.12: De gemiddelde en mediane waarde van de lokale factor per partij per gemeenteraadsverkiezing, in stempercentages, 1974-1990

\begin{tabular}{|c|c|c|c|c|c|c|c|c|c|}
\hline \multirow[b]{2}{*}{1974} & \multicolumn{2}{|c|}{$\begin{array}{r}\text { CDA } \\
\text { gemid. med. }\end{array}$} & \multirow{2}{*}{$\begin{array}{r}N \\
583\end{array}$} & \multicolumn{2}{|c|}{$\begin{array}{r}\text { PvdA } \\
\text { gemid. med. }\end{array}$} & \multirow{2}{*}{$\begin{array}{r}N \\
483\end{array}$} & \multicolumn{2}{|c|}{$\begin{array}{r}\text { VVD } \\
\text { gemid. med. }\end{array}$} & \multirow{2}{*}{$\begin{array}{r}N \\
511\end{array}$} \\
\hline & 6,0 & 3,6 & & 4,4 & 3,3 & & 3,3 & 2,5 & \\
\hline 1978 & 6,2 & 3,2 & 637 & 5,4 & 4,5 & 577 & 2,5 & 1,8 & 606 \\
\hline 1982 & 6,6 & 3,6 & 688 & 4,9 & 3,9 & 563 & 3,6 & 3,1 & 608 \\
\hline 1986 & 6,8 & 4,4 & 669 & 5,3 & 4,0 & 558 & 2.8 & 2.1 & 600 \\
\hline 1990 & 6,8 & 4,6 & 584 & 6,3 & 5,2 & 513 & 3,0 & 2,2 & 534 \\
\hline
\end{tabular}

Bron: Databestand CELS.

Leesvoorbeeld: Bij de gemeenteraadsverkiezingen van 1974 zijn onder invloed van lokale factoren de plaatselijke stempercentages van het CDA gemiddeld 6,0 procent hoger of lager dan zonder de invloed van lokale factoren het geval zou zijn.

Het CDA blijkt bij alle verkiezingsjaren de grootste gemiddelde lokale factor te hebben. Dat betekent dat de plaatselijke uitslagen van het CDA gemiddeld in absolute zin het sterkst benvloed zijn door lokale factoren bij de gemeenteraadsverkiezingen. Tevens kunnen wij uit de tabel opmaken dat zowel bij het CDA als de VVD de lokale factor bij de verschillende verkiezingen redelijk stabiel blijft. Bij de PvdA is vooral de in vergelijking met de andere verkiezingen hogere lokale factor bij de gemeenteraadsverkiezingen van 1990 opvallend. Wellicht dat hierbij het relatief grote verschil tussen de stempercentages van de Tweede Kamerverkiezingen van 1989 en de gemeenteraadsverkiezingen van 1990 van invloed is geweest. Als wij ons vervolgens richten op de ontwikkeling door de jaren heen van de lokale factoren van de afzonderlijke partijen, dan blijkt alleen bij het CDA sprake te zijn van een eenduidige trend. In dit geval is dat een licht stijgende trend. Daarmee is de lokale factor bij het CDA in 1990 ook hoger dan die in 1974 . Hetzelfde geldt ook voor de PvdA, waarbij de lokale factor bij alle verkiezingen na 1974 hoger is dan die in 1974. Bij de VVD is behalve in 1982 de lokale factor kleiner dan die in 1974.

In tabel 5.12 is naast de gemiddelde waarde ook de mediane waarde van de lokale factor opgenomen. De reden hiervoor is dat hetverschil tussen de gemiddelde en de mediane waarde (of: middelste waarde) aangeeft in welke mate de gemiddelde lokale factor door extreme waarden beinvloed wordt. Als wij de mediane waarden vergelijken met de gemiddelde waarden dan blijkt dat met name bij het CDA sprake is van een groot verschil. Terwijl het CDA bij alle verkiezingen de hoogste gemiddelde lokale factor heeft, is dat bij de mediane waarden alleen nog maar het geval bij de gemeenteraadsverkiezingen van 1974 en 1986 . Bij de overige verkiezingen heeft de PvdA de hoogste mediane waarde voor de lokale factor. Een aantal plaatselijke stempercentages van het CDA wordt dus blijkbaar zeer sterk beïnvloed door lokale factoren. Als wij voorbij gaan aan de invloed hiervan, door uit te gaan van de mediane waarde, 
dan blijken de plaatselijke stempercentages van de PvdA bij drie gemeenteraadsverkiezingen zelfs sterker dan die van het CDA beïnvloed te zijn door lokale factoren.

Niet alleen de gemiddelde en mediane waarde van de lokale factor van een partij bij de lokale verkiezingen geven ons informatie over de mate waarin lokale factoren de stempercentages van een partij beïnvloeden. Ook de spreiding van deze lokale factoren is van betekenis voor de wijze waarop lokale factoren een rol spelen bij de gemeenteraadsverkiezingen. Een grote spreiding betekent immers dat er grote verschillen zijn tussen de mate waarin lokale factoren van invloed zijn op de plaatselijke stempercentages. Vandaar dat wij voor elk van de drie landelijke partijen de spreiding van lokale factoren bepaald hebben. Daarvoor hebben wij gebruik gemaakt van de door Blalock voorgestelde coëfficiënt of variation (Blalock, 1979:84). Het voordeel van deze maat voor het berekenen van de spreiding is dat zij rekening houdt met de hoogte van het gemiddelde waarover de spreiding berekend wordt. ${ }^{18}$ De ratio achter het gebruik van deze maat is dat een zeer lage gemiddelde waarde per definitie niet een hoge spreiding kan hebben, terwijl de spreiding relatief gezien - ten opzichte van het gemiddelde hoog kan zijn. Door de coëfficiënt of variation te gebruiken komt een in relatieve zin grote spreiding toch uit de analyse naar voren, ook al is die spreiding in absolute zin gering.

Tabel 5.13: Coëfficiënt of variation van de lokale factor per gemeenteraadsverkiezing, 19741990.

\begin{tabular}{lrrrrrr}
\hline & \multicolumn{2}{c}{ CDA } & \multicolumn{2}{c}{ PvdA } & \multicolumn{2}{c}{ VVD } \\
& c.v. & $\mathrm{N}$ & c.v. & $\mathrm{N}$ & c.v. & $\mathrm{N}$ \\
& & & & & & \\
1974 & 1,16 & 583 & 0,88 & 483 & 0,86 & 511 \\
1978 & 1,32 & 637 & 0,79 & 577 & 0,93 & 606 \\
1982 & 1,23 & 688 & 0,82 & 563 & 0,87 & 608 \\
1986 & 1,05 & 669 & 0,89 & 558 & 0,92 & 600 \\
1990 & 1,04 & 584 & 0,76 & 513 & 1,03 & 534 \\
\hline
\end{tabular}

Bron: Databestand CELS.

Opvallend is allereerst dat de spreiding bij het CDA duidelijk hoger is dan bij de andere twee partijen. Blijkbaar worden de plaatselijke stempercentages van het CDA zeer verschillend beinvloed door lokale factoren. In 1986 en 1990 is dat echter in mindere mate het geval dan bij de voorgaande verkiezingen. De PvdA heeft bij de meeste verkiezingen de laagste spreiding, in 1990 zelfs de allerlaagste. De hogere lokale factor bij de gemeenteraadsverkiezingen in dat jaar in vergelijking met de andere verkiezingen is dus blijkbaar niet veroorzaakt door enkele extreme waarden. Bij de VVD is de spreiding van de lokale factoren bij de gemeenteraadsverkiezingen van 1990 daarentegen wel groter dan voorheen.

\section{De lokale factor in gemeenten zonder lokale lijsten}

Wij hebben kunnen zien dat de deelnamevan lokale lijsten aan de gemeenteraadsverkiezingen van relatief grote invloed is op het lokale

karakter van de gemeenteraadsverkiezingen. Om nader te bepalen wat de invloed van lokale lijsten op de plaatselijke stempercentages van de landelijke partijen is geweest, zullen wij nu 
de invloed van de lokale factoren berekenen voor gemeenten waar geen lokale lijsten aan de gemeenteraadsverkiezingen hebben deelgenomen. Zie hiervoor tabel 5.14.

Tabel 5.14: De gemiddelde en mediane waarde van de lokale factor per partij per gemeenteraadsverkiezing, in gemeenten zonder lokale lijsten, in stempercentages, 1974-1990

CDA

gemid. med. $\mathrm{N}$

1974

1978

1982

1986

1990
PvdA

gemid. med. $\mathrm{N}$

$2,8 \quad 2,0 \quad 146$

$3,6 \quad 3,0 \quad 168$

$4,2 \quad 3,5 \quad 170$

$\begin{array}{lll}2,9 & 2,3 & 171\end{array}$

$5,3 \quad 4,3 \quad 168$

VVD

\section{Bron: Databestand CELS.}

Voor alle drie de partijen geldt dat bij alle gemeenteraadsverkiezingen de berekende gemiddelde Jokale factoren geringer zijn dan die in tabel 5.12 waar in de analyse wel gemeenten met lokale lijsten meegenomen zijn. Een ander kenmerkend verschil met de uitkomsten van tabel 5.12 is dat alle berekende lokale factoren van het CDA van na 1974 lager zijn dan die van 1974 . Bij het CDA is tevens het verschil tussen de hoogte van de gemiddelde lokale factoren in alle gemeenten en in gemeenten zonder lokale lijsten het grootst. Behalve in 1974 is de lokale factor in deze gemeenten zelfs minder dan de helft van de gemiddelde lokale factor voor alle gemeenten. Daarmee hebben wij opnieuw een aanwijzing dat de plaatselijke stempercentages van het CDA het sterkst benvloed worden door de aanwezigheid van de lokale lijsten. Door de daling van gemiddelde waarden van het CDA zijn in de gemeenten zonder lokale lijsten de gemiddelde lokale factoren van de PvdA na 1974 hoger zijn dan die van het CDA. In overeenstemming met de gegevens in tabel 5.10 blijven de berekende lokale factoren van de WD het laagst. Bij de VVD is nu wel, evenals bij de PvdA, de berekende lokale factor in 1990 hoger dan die bij de voorgaande verkiezingen. Bij het CDA is alleen de lokale factor in 1974 hoger dan die in 1990.

De mediane waarden in tabel 5.14 zijn zoals verwacht lager dan de gemiddelde waarden. De verschillen tussen deze twee waarden zijn echter niet zo groot als bij de anlayse voor de categorie alle gemeenten. Daarmee kunnen wij de conclusie trekken dat de eerder geconstateerde invloed van extreme waarden van lokale factoren op de gemiddelde lokale factor van het CDA voor een groot deel veroorzaakt wordt door de deelname van lokale lijsten aan de gemeenteraadsverkiezingen. Immers, in gemeenten zonder lokale lijsten is de invloed van extreme lokale factoren op de gemiddelde lokale factor veel geringer dan in alle gemeenten, inclusief die met lokale lijsten. 
Tabel 5.15 : Coëfficiënt of variation van de lokale factor per gemeenteraadsverkiezing, in gemeenten zonder lokale lijsten, 1974-1990.

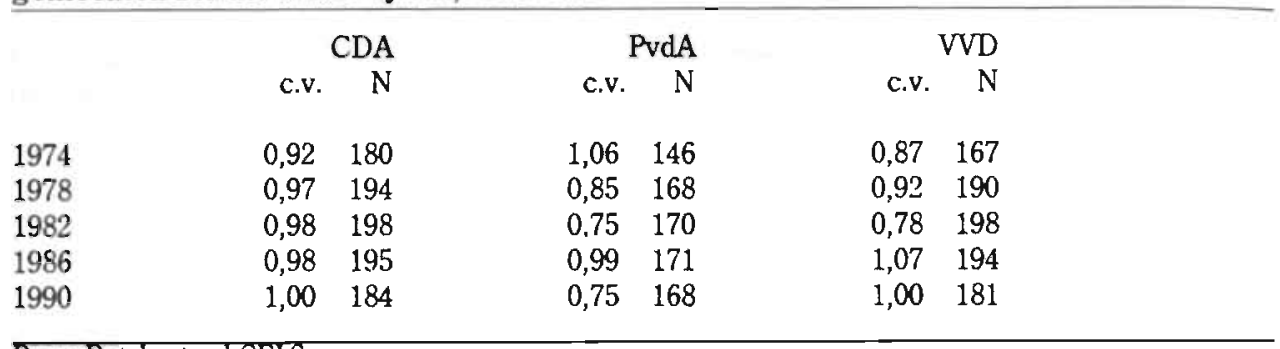

Bron: Databestand CELS.

Ondanks de relatief lage gemiddelde lokale factor voor het CDA in gemeenten zonder lokale lijsten, is de spreiding van de lokale factoren in vier van de vijf verkiezingen de grootste. Al met al is in de periode 1974-1990 de spreiding van de lokale factoren van het CDA licht toegenomen. Bij de PvdA daarentegen is geen duidelijke trend te ontdekken, al is in vergelijking met de andere partijen bij bijna alle gemeenteraadsverkiezingen de spreiding van de lokale factoren het geringst. Verder valt de relatief hoge spreiding in 1974 en 1986 op. Bij de VVD is de spreiding van de lokale factoren sinds 1986 op een iets hoger niveau is komen te liggen.

\subsubsection{De relatieve lokale factor}

De lokale factor die wij tot nu toe berekend hebben, geeft in wezen de invloed van de lokale factoren op de plaatselijke stempercentages van een partij, onafhankelijk van de electorale positie van de betreffende partij op lokaal niveau. Bij de berekening wordt dus geen rekening gehouden met de betekenis van de hoogte van de berekende lokale factor voor het plaatselijke stempercentage van de betreffende partij. Anders gezegd, de berekende lokale factor geeft niet aan in hoeverre op plaatselijk niveau lokale factoren van belang zijn geweest voor de hoogte van het percentage stemmen dat de betreffende partij in de betreffende gemeente bij de gemeenteraadsverkiezingen heeft gehaald. Eenvoorbeeld kan het een en anderverduidelijken.

Tabel 5.16: Voorbeeld van de berekening van de relatieve factor in een achttal denkbeeldige gemeenten, in percentages.

$\begin{array}{lrrr}\text { gem. } & \text { GR } & \text { LF } & \text { rel.LF } \\ \text { 1. } & 18,5 & 0,0 & 0,00 \\ 2 . & 14,3 & 2,3 & 16,08 \\ \text { 3. } & 16,1 & 7,5 & 46,58 \\ 4 . & 8,5 & 4,0 & 47,05 \\ 5 . & 20,4 & 1,7 & 8,33 \\ 6 . & 25,6 & 4,0 & 13,67 \\ 7 . & 27,8 & 0,6 & 2,10 \\ 8 . & 12,5 & 3,5 & 32,00\end{array}$

$\begin{array}{cl}\text { Toelichting: GR } & =\text { Plaatselik stempercentage bij de gemeenteraadsverkiezingen } \\ \text { LF } & =\text { Berekende (absolute) lokale factor } \\ \text { rel. LF } & =\text { Berekende relatieve lokale factor }\end{array}$


Uit tabel 5.16 kunnen wij dat opmaken een hoge absolute lokale factor van zeer verschillende belang kan zijn voor het plaatselijke stempercentage. Zo hebben zowel de vierde als de zesde gemeente een absolute lokale factorvan 4,0 . De berekende relatieve lokale factoren verschillen echter aanzienlijk, omdat een absolute lokale factor van 4,0 gerelateerd aan het plaatselijk stempercentage een veel grotere invloed heeft op het plaatselijk stempercentage van 8,5 procent dan op het plaatselijk stempercentage van 25,6 procent. Anders gezegd, in het eerste geval hebben lokale factoren relatief gezien een veel grotere invloed gehad op het plaatselijke stempercentage dan in het tweede geval. Vandaar dat wij in elke gemeente de berekende absolute lokale factor delen door het plaatselijke stempercentage van de betreffende partij, en deze breuk vervolgens met 100 vermenigvuldigen zodat wij de procentuele invloed van de lokale factor op het plaatselijke stempercentage berekend hebben. Dit noemen wij de relatieve lokale factor. Evenals bij de berekening van de absolute lokale factor, zijn wij bij de relatieve lokale factor geïnteresseerd in een vergelijking van de resultaten van deze berekening over de verschillende verkiezingsjaren. Daarom zullen wij voor elke partij per verkiezingsjaar de gemiddelde relatieve lokale factor berekenen. Deze berekening kan als volgt worden voorgesteld:

Uitgaande van $\mathrm{LF}+\mathrm{e}=\mathrm{GR}-\mathrm{TK}$ $\frac{\Sigma(\mid \mathrm{LF}+\mathrm{el} / \mathrm{LP}) \star 100}{\mathrm{n}}$

$\mathrm{LF}=$ de lokale factor bij de gemeenteraadsverkiezingen

GR - het verschil tussen het plaatselijke en landelijke stempercentage bij de gemeenteraadsverkiezingen

$\mathrm{TK}=$ het verschil tussen het plaatselijke en landelijke stempercentage bij de nict-lokale verkiezingen

$\mathrm{LP}=$ lokaal stempercentage voor de betreffende partij

$\mathrm{e}=$ error-factor

$\mathrm{n}=$ aantal deelnemende gemeenten

Evenals bij de absolute lokale factor wordt de gemiddelde relatieve lokale factor dus berekend door de som van de plaatselijke relatieve lokale factoren te delen door het aantal gemeenten waar deze relatieve lokale factor berekend is. In onsvoorbeeld is de gemiddelde relatieve lokale factor op deze manier 20.73 procent. Dit betekent dus dat de plaatselijke stempercentages van de betreffende partij gemiddeld voor ruim 20 procent bepaald zijn door lokale factoren. Dus gemiddeld is bijna 80 procent van de plaatselijke stempercentages toe te wijzen aan niet-lokale factoren. In het algemeen geldt dus dat hoe hoger de berekende gemiddelde relatieve lokale factor is, des te groter is de invloed van lokale factoren op de plaatselijke stempercentages. Op basis van bovenstaande berekening hebben wij voor de drie landelijke partijen voor de gemeenteraadsverkiezingen in de periode 1974-1990 de gemiddelde en mediane waarde van de relatieve lokale factor berekend. De resultaten hiervan staan in tabel 5.17. 
Tabel 5.17: De gemiddelde en mediane waarde van de relatieve lokale factor per partij per gemeenteraadsverkiezing, in procenten, 1974-1990

\begin{tabular}{lrrrrrr}
\hline & $\begin{array}{r}\text { CDA } \\
\text { gemid. med. }\end{array}$ & $\begin{array}{r}\text { PvdA } \\
\text { gemid. med. }\end{array}$ & $\begin{array}{r}\text { VVD } \\
\text { gemid. med. }\end{array}$ \\
1974 & 19,6 & 10,8 & 24,6 & 12,8 & 27,5 & 16,2 \\
1978 & 21,6 & 8,9 & 30,9 & 17,3 & 19,9 & 12,5 \\
1982 & 26,0 & 11,2 & 29,3 & 18,2 & 23,0 & 13,0 \\
1986 & 27,8 & 13,7 & 27,5 & 15,2 & 20,2 & 12,1 \\
1990 & 24,5 & 14,6 & 34,6 & 25,1 & 22,4 & 15,5 \\
\hline
\end{tabular}

Bron: Databestand CEIS.

Leesvoorbeeld: Gemiddeld zijn de plaatselijke stempercentages van het CDA bij de gemeenteraadsverkiezingen van 1974 voor 19,6 procent bepaald door de invloed van lokale factoren.

In vergelijking met de gegevensvan tabel 5.12 is het opvallend dat de plaatselijke stempercentages van de PvdA bij vier van de vijf gemeenteraadsverkiezingen in relatieve zin in sterkere mate bepaald $z$ ijn door lokale factoren dan die van het CDA. Alleen in 1986 is de gemiddelde relatieve lokale factor van het CDA (iets) hoger dan die van de andere partijen. De plaatselijke stempercentages van de VVD zijn bij alle gemeenteraadsverkiezingen, behalve bij die van 1974 , in de minste mate beïnvloed door lokale factoren.

Bij het CDAen de PvdA is de gemiddelde relatieve lokale factor hoger in 1990 dan in 1974. Zoals reeds gesteld kan de berekende lokale factorvan de PvdA in 1990 enigszins beïnvloed zijn door de electorale ontwikkelingen tussen de Tweede Kamerverkiezingen van 1989 en de gemeenteraadsverkiezingen van 1990.De drie partijen laten overigens in de periode 1974-1990 verschillende ontwikkelingen in de hoogtevan de gemiddelde relatieve lokale factor zien. Voor zowel het CDA als de PvdA geldt dat de relatieve lokale factor bij alle verkiezingen hoger is dan die van 1974. Voor de VVD geldt precies het omgekeerde. Bij het CDA is opvallend dat in 1974 en 1978 de invloed van lokale factoren op een lager niveau ligt dan bij de gemeenteraadsverkiezingen daarna. Bij de VVD valt op dat de plaatselijke stempercentages van deze partij na de gemeenteraadsverkiezingen van 1974 in ongeveer gelijke mate bepaald worden door lokale factoren.

De mediane waarden van de relatieve lokale factoren liggen in vergelijking met de gemiddelde waarden vooral bij het CDA op een lager niveau. Bijviervan de vijf gemeenteraadsverkiezingen is de mediane waarde zelfs het laagste in vergelijking met de andere twee partijen. Daarmee wordt duidelijk dat in een aantal gemeenten de plaatselijke stempercentages in zeer sterke mate bepaald zijn door lokale factoren, die een relatief sterke invloed uitoefenen op de berekende gemiddelde relatieve lokale factor. Eenzelfde conclusie kunnen wij ook trekken ten aanzien van de PvdA. Immers, ook al zijn de mediane waarden in tabel 5.17 bij de meeste verkiezingen het hoogst, tegelijkertijd kunnen wij constateren dat deze mediane waarden veel lager zijn dan de gemiddelde waarden voor de PvdA. De berekende relatieve lokale factor van de VVD daarentegen wordt tenslotte het minst beïnvloed door extreme waarden van de berekende relatieve lokale factor in gemeenten.

In hoeverre voor elke partij de hoogte van de relatieve lokale factoren in de gemeenten met elkaar overeenkomen wordt duidelijk bij een analyse van de gegevens in tabel 5.18. 
Tabel 5.18: Coëfficiënt of variation van de relatieve lokale factor per partij per gemeenteraadsverkiezing, 1974-1990.

\begin{tabular}{rrrr} 
CDA & PvdA & VVD \\
c.v. & c.v. & c.v. \\
& & & \\
1974 & 2,28 & 1,97 & 1,40 \\
1978 & 2,17 & 1,61 & 1,14 \\
1982 & 2,45 & 1,71 & 1,36 \\
1986 & 1,80 & 1,84 & 1,41 \\
1990 & 1,35 & 1,11 & 1,03 \\
\hline
\end{tabular}

Bron: Databestand CELS.

Evenals in tabel 5.13 kunnen wij in tabel 5.18 constateren dat de spreiding het sterkst is bij het CDA, nu gevolgd door de PvdA en tenslotte de VVD. Wel is bij het CDA een sterke daling te constateren in 1986, die zich in 1990 nog verder doorzet. Dit wijst erop dat de relatieve lokale factoren van het CDA in de verschillende gemeenten steeds meer met elkaar overeenkomen. Bij de andere twee partijen zien wij geen duidelijke trend in de spreiding van de lokale factoren in de periode 1974-1990. Zij laten in vergelijking met het CDA een stabieler beeld zien, waarbij in 1990 de lokale factoren van deze partijen het meest met elkaar overeenkomen.

De relatieve lokale factor in gemeenten zonder lokale lijsten

In hoeverre in gemeenten zonder lokale lijsten lokale factoren van invloed zijn op de plaatselijke stempercentages van de landelijke partijen, wordt duidelijk als wij de gemiddelde relatieve lokale factoren berekenen. In tabel 5.19 staan de resultaten van deze analyse van de gemeenteraadsverkiezingen in de periode 1974-1990.

Tabel 5.19: De gemiddelde en mediane waarde van de relatieve lokale factor per partij per gemeenteraadsverkiezing, in gemeenten zonder lokale lijsten, in procenten, 1974-1990

\begin{tabular}{|c|c|c|c|c|}
\hline \multirow[b]{2}{*}{1974} & \multicolumn{2}{|c|}{$\begin{array}{l}\text { CDA } \\
\text { gemid. med. }\end{array}$} & $\begin{array}{r}\text { PvdA } \\
\text { gemid. med. }\end{array}$ & $\begin{array}{r}\text { VVD } \\
\text { gemid. med. }\end{array}$ \\
\hline & 12,3 & 9,9 & 9,8 & $12,4 \quad 10,2$ \\
\hline 1978 & 7,4 & 5,2 & $12,5 \quad 10,8$ & $10,7 \quad 8,5$ \\
\hline 1982 & 8,6 & 6,9 & $16,6 \quad 14,9$ & 11,0 \\
\hline 1986 & 8,1 & 6,0 & 10,2 & 9,5 \\
\hline 1990 & 10,1 & 7,0 & 19,2 & $15,5 \quad 12,5$ \\
\hline
\end{tabular}

Bron: Databestand CELS.

De gemiddelde relatieve lokale factor blijkt voor alle drie de partijen bij al]e gemeenteraadsverkiezingen lager in gemeenten zonder lokale lijsten dan in alle gemeenten. Tevens blijkt dat vanaf 1982 bij het CDA het grootste verschil optreedt tussen de uitslagen van de relatieve lokale factoren bij alle gemeenten en de gemeenten zonder lokale lijsten, hetgeen opnieuw een aanwijzing is dat de plaatselijke uitslagen van het CDA in sterkere mate dan die 
van de andere twee partijen benvloed worden door de aanwezigheid van lokale lijsten. Met ingang van 1978 zijn van de drie partijen de plaatselijke stempercentages van het CDA bij alle gemeenteraadsverkiezingen het minst beïnvloed door lokale factoren. Tevens kunnen wij uit tabel 5.19 opmaken dat bij vier van de vijf gemeenteraadsverkiezingen de plaatselijke stempercentages van de PvdA het sterkst beïnvloed zijn door lokale factoren. Alleen in 1974 is dat voor de VVD het geval.

Wat de ontwikkelingen in de periode 1974-1990 betreft, zijn er bij de drie partijen geen eenduidige trends te ontdekken. Wel kunnen wij bij de VVD tot aan 1990 een lichte daling van de invloed van lokale factoren op de plaatselijke stempercentages constateren. In 1990 is de invloed van deze factoren echter hoger dan voorheen. Hetzelfde geldt voor de PvdA, waar de plaatselijke stempercentages in 1990 in vergelijking met andere verkiezingen in zeer sterke mate benvloed zijn door lokale factoren.

Tevens kunnen wijvaststellen dat er geen opmerkelijk grote verschillen zijn tussen de mediane en de gemiddelde waarde van de berekende relatieve lokale factoren. Deze worden dan ook niet in sterke mate beïnvloed door extreme waarden van de relatieve lokale factoren in de gemeenten. Aangezien dat in de categoriealle gemeenten nog wel het geval was, kunnen wij de conclusie trekken dat de berekende extreme relatieve lokale factoren, die vooral voorkomen bij het CDA en de PvdA, waarschijnlijk veroorzaakt zijn door de deelname van de lokale lijsten aan de gemeenteraadsverkiezingen.

Tabel 5.20: Coëfficiënt of variation van de relatieve lokale factor per partij per gemeenteraadsverkiezing, in gemeenten zonder lokale lijsten, 1974-1990.

\begin{tabular}{rrrr}
\hline & CDA & PvdA & VVD \\
c.v. & c.v. & \\
1974 & 0,97 & 0,94 & 1,12 \\
1978 & 1,12 & 0,76 & 0,83 \\
1982 & 0,89 & 0,79 & 0,97 \\
1986 & 1,04 & 1,13 & 0,89 \\
1990 & 1,11 & 0,77 & 0,88
\end{tabular}

Bron: Databestand CELS.

Opvallend is dat met uitzondering van de gemeenteraadsverkiezingen van 1986 de PvdA de laagste spreiding van de relatieve lokale factoren heeft. Bij alle partijen zien wij geen duidelijk trend in de ontwikkeling van de hoogte van de coëfficiënt of variation. Wel kunnen wij in vergelijking met de gegevens in tabel 5.18 constateren dat er sprake is van een veel lagere spreiding van de relatieve lokale factoren in gemeenten zonder lokale lijsten. Blijkbaar zijn de verschillen in de mate waarin lokale factoren van invloed zijn op de plaatselijke stempercentagesvan de landelijke partijen voor een groot deel het gevolg is van de invloed van de deelname van lokale lijsten aan de gemeenteraadsverkiezingen.

\subsubsection{Resultaten per gemeente}

Doelvan dit onderzoek is het bepalen van het lokale karaktervan de gemeenteraadsverkiezingen in de periode $1974-1990$. Via een analyse van de plaatselijke stempercentages van de drie grote landelijke partijen wordt duidelijk in welke mate de plaatselijke uitslagen van deze partijen 
beinvloed worden door lokale factoren die specifiek zijn voor de gemeenteraadsverkiezingen. Wij hebben tot nu toe alleen voor elke partij afzonderlijk de invloed van lokale factoren gemeten. Maar, uiteindelijk zijn wij niet alleen geïnteresseerd in de invloed van lokale factoren op de plaatselijke stempercentages van ieder van de partijen afzonderlijk. Om op een eenvoudige manier een totaalbeeld te krijgen van de ontwikkelingen in de invloed van lokale factoren op de plaatselijke stempercentages in de periode 1974-1990, is het nuttig om in elke gemeente de gemiddelde afwijking per partij te berekenen. Kortom, wij richten ons niet op ieder partij afzonderlijk, maar proberen te achterhalen wat in iedere gemeente de gemiddelde absolute lokale factor bij de betreffende verkiezingen is. De zo berekende lokale factor noemen wij de absolute lokale factor per gemeente.

De methode om de lokale factor per gemeente te bepalen is zeer eenvoudig. Nadat voor elk van de drie partijen in een gemeente de lokale factor is berekend, worden deze berekende lokale factoren bij elkaar opgeteld, waarna het resultaat door drie wordt gedeeld. Wij hebben dus het gemiddelde van de berekende lokale factoren voor de drie partijen genomen. Een dergelijke berekening is alleen mogelijk als in een gemeente alle drie de landelijke partijen aan de gemeenteraadsverkiezingen hebben deelgenomen. Dit betekent dat bij elke verkiezing alleen die gemeenten in de analyse worden betrokken waarin de drie landelijke politieke partijen aan de betreffende gemeenteraadsverkiezing hebben deelgenomen. Conform bovenstaande werkwijze hebben wij de lokale factor per gemeente per gemeenteraadsverkiezing berekenend. Zie hiervoor tabel 5.21 .

Tabel 5.21: De gemiddelde en mediane waarde van de (absolute) lokale factor per gemeente, in alle gemeenten en gemeenten zonder lokale lijsten, in stempercentages, 1974-1990

\begin{tabular}{lcccccc}
\hline \multicolumn{3}{c}{ alle gemeenten } & \multicolumn{4}{l}{ zonder lokale lijsten } \\
& gemid. & med. & $\mathrm{N}$ & gemid. & med. & $\mathrm{N}$ \\
1974 & 3,7 & 3,1 & 329 & 2,8 & 2,5 & 128 \\
1978 & 4,2 & 3,4 & 455 & 2,5 & 2,5 & 147 \\
1982 & 4,2 & 3,7 & 497 & 3,1 & 2,9 & 161 \\
1986 & 4,3 & 2,4 & 509 & 2,4 & 2,0 & 166 \\
1990 & 4,8 & 4,2 & 481 & 3,7 & 3,5 & 165 \\
\hline
\end{tabular}

Bron: Databestand CELS.

Er blijken geen grote verschillen te zijn tussen de berekende lokale factoren per gemeente bij de gemeenteraadsverkiezingen in de periode 1974-1990. Wel is er sprake van een stijgende tendens van iets minder dan 4 procent tot bijna 5 procent. Lokale factoren hebberi de gemeenteraadsverkiezingen het sterkst benvloed in 1990, hetgeen het meest duidelijk tot uitdrukking komt bij de waarde van de lokale factor voor de gemeenten zonder lokale lijsten, al moeten wij hierbij weer wel enigszins rekening houden met de reeds eerder genoemde omstandigheid dat de gemeenteraadsverkiezingen van 1990 meer dan zes maanden na de vergelijkbare Tweede Kamerverkiezingen van 1989 plaatsvonden.

Als wij de berekende lokale factoren per gemeente voor alle gemeenten vergelijken met die voor gemeenten zonder lokale lijsten, dan blijkt zoals verwacht dat de lokale factor bij de laatste groep gemeenten geringer is dan bij de eerste groep. Opvallend is wel dat er bij beide groepen sprake is van verschillende ontwikkelingen. Alleen in 1990 zien wij bij beide een stijging van 
de lokale factor. Bij de andere gemeenteraadsverkiezingen is er sprake van tegengestelde ontwikkelingen. Het verschil tussen de twee stempercentages was met bijna 2 procent in 1978 en 1986 iets groter dan bij de andere gemeenteraadsverkiezingen $( \pm 1 \%)$. Dit duidt erop dat in 1978 en 1986 andere factoren dan de aanwezigheid van de lokale lijsten een iets groter deel uitmaakten van de berekende lokale factor dan bij de andere gemeenteraadsverkiezingen. Wat de invloed van extreme waarden voor de berekende lokale factoren per gemeente betreft, valt uit de vergelijking van gemiddelde en mediane waarden op te maken dat deze van iets grotere invloed zijn in alle gemeenten dan in gemeenten zonder lokale lijsten. Immers, bij deze eerste categorie gemeenten laten de mediane waarden een iets groter verschil zien met de gemiddelde waarde dan bij de laatste categorie gemeenten. Dit betekent dat een deel van de extreme lokale factoren veroorzaakt wordt door de deelname van de lokale lijsten aan de gemeenteraadsverkiezingen.

In hoeverre er grote verschillen zijn tussen de berekende lokale factoren per gemeente in de verschillende gemeenten, wordt duidelijk uit de analyse van de spreiding van deze lokale factoren. Zie hiervoor tabel 5.22.

Tabel 5.22: De coëfficiënt of variation van de (absolute) lokale factor per gemeente, in alle gemeenten en gemeenten zonder lokale lijsten, 1974-1990.

\begin{tabular}{rrrrr} 
& \multicolumn{2}{c}{ alle gemeenten } & \multicolumn{2}{c}{ zonder lokale lijsten } \\
& c.v. & $\mathrm{N}$ & c.v. & $\mathrm{N}$ \\
1974 & & 329 & 0,53 & 128 \\
1978 & 0,68 & 455 & 0,51 & 147 \\
1982 & 0,75 & 497 & 0,55 & 161 \\
1986 & 0,65 & 509 & 0,61 & 166 \\
1990 & 0,69 & 481 & 0,56 & 165 \\
\hline
\end{tabular}

Bron: Databestand CELS.

Allereerst valt op dat de spreiding van de berekende lokale factoren bij alle gemeenten uiteindelijk een dalende trend laat zien, terwijl bij de gemeenten zonder lokale lijsten eerder sprake lijkt te zijn van een licht stijgende trend. In 1990 is zelfs de spreiding bij deze laatste categorie gemeenten iets hoger dan bij alle gemeenten. Tevens kunnen wij constateren dat daardoor het verschil in spreiding tussen deze twee categorieën gemeenten sterk verminderd is. Daarom kunnen wij de conclusie trekken dat de invloed van de deelname van lokale lijsten op de spreiding van de lokale factoren per gemeente sterk vermindert in de periode 1974-1990. In deze periode zijn de extreme waarden van de berekende lokale factoren in steeds mindere mate het gevolg van de deelname van lokale lijsten aan de gemeenteraadsverkiezingen.

\section{De relatieve lokale factor per gemeente}

Het is natuurlijk ook mogelijk per gemeenteraadsverkiezing de relatieve lokale factor per gemeente te berekenen. Dit gebeurt op dezelfde wijze als de berekening van de absolute lokale factor per gemeente. Dat betekentonder meer dat wijonze analyse beperken tot die gemeenten waar elk van de drie landelijke partijen aan de gemeenteraadsverkiezingen heeft deelgenomen. Vervolgens berekenen wij voor iedere partij de relatieve lokale factor. De derde stap bestaat uit het berekenen van het gemiddelde van de drie berekende relatieve lokale factoren. De zo 
berekende relatieve lokale factor per gemeente geeft aan in hoeverre de plaatselijke stempercentagesvan de drie grote landelijke partijen gezien de hoogte van deze stempercentages beinvloed zijn door lokale factoren. Aangezien wij een totaalbeeld willen krijgen van de invloed van lokale factoren op de plaatselijke stempercentages van de drie landelijke partijen in de verschillende gemeenten, zullen wij vervolgens de gemiddelde en mediane waarde van de berekende relatieve lokale factor per gemeente berekenen. Daarmee hebben wij de mogelijkheid om de ontwikkeling in de invloed van lokale factoren op de plaatselijke stempercentages van dedrie grote landelijke partijen bij de gemeenteraadsverkiezingen in de periode 1974-1990vast te stellen. In tabel 5.23 wordt een overzicht gegeven van de resultaten van de berekening van de gemiddelde en mediane waarde van de relatieve lokale factor per gemeente.

Tabel 5.23: De gemiddelde en mediane waarde van de relatieve lokale factor per gemeente, in alle gemeenten en gemeenten zonder lokale lijsten, in procenten, 1974-1990.

alle gemeenten

gemid. med.

1974

1978

1982

1986

1990

$\begin{array}{ll}17,6 & 13,1 \\ 20,1 & 13,6 \\ 21,9 & 15,3 \\ 22,3 & 14,3 \\ 24,3 & 19,8\end{array}$

zonder lokale lijsten

gemid. med.

$\begin{array}{lll}3,1 & 10,8 & 9,8\end{array}$

$\begin{array}{lrr}13,6 & 9,7 & 8,7\end{array}$

$11,7 \quad 10,8$

$9,0 \quad 7,4$

$15,8 \quad 14,3$

Bron: Databestand CELS.

Wij zien dat de relatieve lokale factor bij alle gemeenten in de periode 1974-1990 een geleidelijke toename kent van 17,6 naar 24,3 procent. Zoals verwacht zijn de berekende relatieve lokale factoren per gemeente in deze categorie gemeenten duidelijk hoger dan van de gemeenten zonder lokale lijsten. Bij de gemeenten zonder lokale lijsten is sprake van een op- en neergaande lijn van de invloed van de lokale factoren op de plaatselijke stempercentages van de drie landelijke partijen. Vooral in 1990 is met een berekend gemiddeld percentage van bijna 16 procent de relatieve invloed van lokale factoren op de plaatselijke stempercentages van de drie landelijke partijen groot. Het verschil in de gemiddelde waarden van de berekende relatieve lokale factor per gemeente tussen beide categoriën gemeenten is het grootst in 1986 en het kleinst in 1974. In dat jaar maakt de aanwezigheid van de lokale lijsten dus blijkbaar een relatief klein deel uit van de lokale factoren die een rol spelen bij de gemeenteraadsverkiezingen.

De mediane waarden bij de categorie alle gemeenten zijn duidelijk lager dan de gemiddelden, hetgeen duidt op een relatief grote invloed van extreme waarden van de relatieve lokale factor per gemeente. Bij de gemeenten zonder lokale lijsten is dit verschil gering. Daarmee kunnen wij concluderen dat de geconstateerde invloed van de extreme waarden van de relatieve lokale factor per gemeente voor een relatief groot deel het gevolg is van de deelname van de lokale lijsten aan de gemeenteraadsverkiezingen. 
Tabel 5.24: De coëfficiënt of variation van de relatieve lokale factor per gemeente, in alle gemeenten en gemeenten zonder lokale lijsten, 1974-1990.

\begin{tabular}{lcc}
\hline & alle gemeenten & zonder lokale lijsten \\
1974 & 1,20 & 0,57 \\
1978 & 1,11 & 0,53 \\
1982 & 1,30 & 0,60 \\
1986 & 1,38 & 0,68 \\
1990 & 0,76 & 0,61 \\
\hline
\end{tabular}

Bron: Databestand CELS.

Uit tabel 5.24 blijkt dat in de analyse voor alle gemeenten de spreiding van de relatieve lokale factoren per gemeente tot 1990 een stijgende tendens kent. In 1990 is echter sprake van een sterke daling. In de gemeenten zonder lokale lijsten zien wij een dergelijke verandering niet. Daar is sprake van een licht stijgende tendens in de periode 1974-1990. Met uitzondering van de gemeenteraadsverkiezing van 1990 is er dus een groot verschil in de spreiding van de relatieve lokale factoren per gemeente in alle gemeenten in vergelijking met de gemeenten zonder lokale lijsten. Dit wijst er opnieuw op dat de deelname van lokale lijsten aan de gemeenteraadsverkiezingen voor een relatief groot deelverantwoordelijk is voor deverschillen in de relatieve lokale factoren per gemeente in de verschillende gemeenten.

\subsection{Gemeenten met uitzonderlijke stempercentages}

Tot nu toe is in dit hoofdstuk geen aandacht geschonken aan de plaatselijke stempercentages in de afzonderlijke gemeenten. Wij hebben alleen uitspraken gedaan over het verschil tussen de plaatselijke stempercentages bij de lokale- en niet-lokale verkiezingen voor alle gemeenten gezamenlijk. In deze paragraaf zullen daarentegen de gemeenten met uitzonderlijke plaatselijke stempercentages bij de gemeenteraadsverkiezingen in kaart worden gebracht. Door middel van een analyse van deze lijst van gemeenten kunnen wij immers een beter beeld kriigen van de aard en betekenis van de lokale factoren bij de gemeenteraadsverkiezingen. Op basis van deze analyse krijgen wij dus enig zicht op de meer kwalitatieve aspecten van de lokale factoren.

\subsubsection{Het bepalen van een uitzonderlijke plaatselijke stempercentages}

Voordat wij de verschillende gemeenten met uitzonderlijke plaatselijke stempercentages bij de gemeenteraadsverkiezingen kunnen analyseren, is het nodig een methode toe te passen waardoor bepaald wordt welke gemeenten een dergelijke uitslag hebben. In dit onderzoek zal dit gebeuren door een regressie-analyse uit te voeren, waarbij voor elk verkiezingsjaar de plaatselijke stempercentages bij de lokale- en niet-lokale verkiezingen de variabelen zijn. Vervolgens hebben wij op basis van deze regressie-analyse de residuen aan een nader onderzoek onderworpen. In alle gevallen waar de waarde van het residu hoger was dan een 
gestandaardiseerde score van 3 of meer, conludeerden wij dat er sprake is van een uitzonderlijk plaatselijke stempercentage. ${ }^{19}$

Het is mogelijk dat ook eenheden met een geringe waarde van het residu een relatief grote invloed uitoefenen op de regressie-waarden die bepalend zijn voor de loop van de regressielijn en daarmee voor de gevonden opmerkelijke gemeenten. Dergelijke invloedrijke eenheden kunnen worden opgespoord met behulp van 'Cooks afstandsmaat (Cd)'. Daarbij wordt gesteld dat een $C d$ in de buurt van 1 groot te noemen is (van Snippenburg, 1986:123). Op basis van dit criterium zou echter geen enkele eenheid aangemerkt kunnen worden als invloedrijke eenheid. In deze analyse houden wij daarom rekening met de gemiddelde grootte van de $\mathrm{Cd}$ bij de verschillende eenheden. Dit betekent in concreto dat alleen een eenheid met een $\mathrm{Cd}$ van groter dan . 25 uit de analyse wordt genomen, waarna via een nieuwe analyse bekeken wordt of nog nieuwe eenheden met extreme waarden optreden. Ook deze gemeenten werden vervolgens gerekend tot de gemeenten met een uitzonderlijke uitslag. Het betreft overigens slechts twee gemeenten, namelijk Breukelen in 1974 en Oude Pekela in 1986, beiden bij de PvdA.

\subsubsection{Resultaten}

Op basis van bovenstaande werkwijze hebben wij voor de drie partijen, voor alle verkiezingen bepaald welke gemeenten uitzonderlijke uitslagen te zien geven. Zie hiervoor de tabellen 5.25 $\mathrm{t} / \mathrm{m}$ 5.27. In deze paragraaf zullen wij vervolgens deze lijst van gemeenten nader analyseren. 
Tabel 5.25: Lijstvan gemeenten met uitzonderlijke plaatselijke stempercentages voor het CDA, 1974-1990.

$\begin{array}{lllr}1974 & \text { Alle gemeenten } & & \text { Zonder lokale lijsten } \\ \text { Losser } & \text { Duiven } & \text { Dussen } & \text { Leerbroek }^{\star} \\ \text { Bemmel } & \text { Groesbeek } & \text { Leerbroek } & \text { Tienhoven }^{*} \\ \text { Bergh } & \text { Obdam } & \text { Polsbroek } & \end{array}$

1978

$\begin{array}{llll}\text { Zegveld } & \text { Hoeven } & \text { Waspik } & \text { Vuren * } \\ \text { Baarlo-Nassau } & \text { Reusel } & \text { Wouw } & \\ \text { Bergeijk } & \text { Schaijk } & \text { Vaals } \\ \text { Halsteren } & \text { Vlijmen } & & \end{array}$

1982

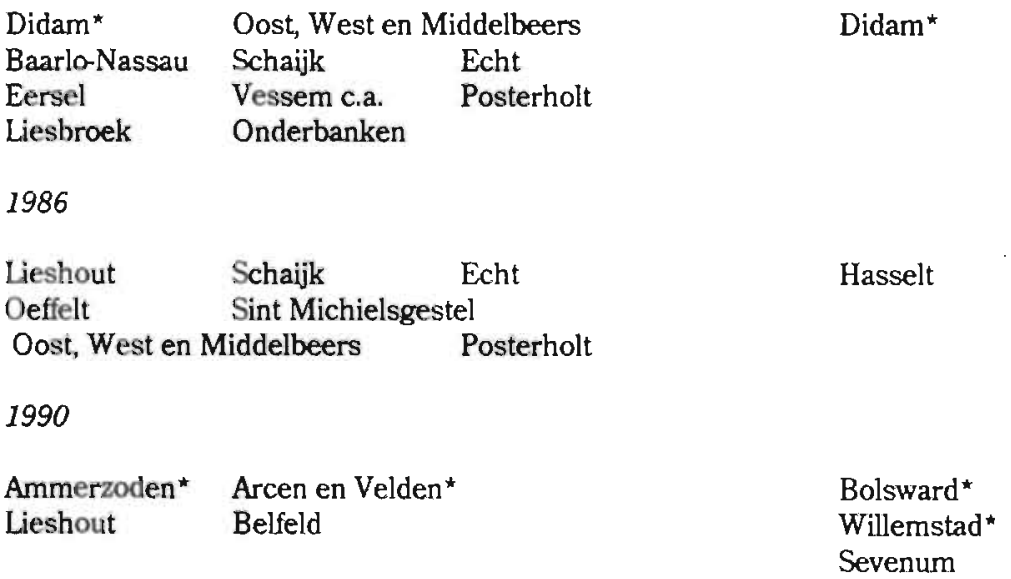

Bron: Databestand CELS.

* Het betreft een positieve residu-waarde. De overige waarden zijn negatief. 
Tabel 5.26: Lijstvan gemeenten met uitzonderlijke plaatselijke stempercentages voor de PvdA, 1974-1990.

\section{4}

Gasselte

Maurik

Twisk*

1978

Heerewaarden

Twisk*

Geertruidenberg

1982

Vlagtwedde

Hulst

Nieuw-Vossemeer

1986

Nieuw-Vossemeer

Rucphen

Landgraaf

1990

Berghem

Rucphen

Bron: Databestand CELS.

${ }^{\star}$ Het betreft een positieve residu-waarde. De overige waarden zijn negarief.

Amerstol

$\begin{array}{lll}\text { Rucphen } & \text { Vaals } & \text { Marken } \\ \text { Hoensbroek } & & \text { Twisk }^{*}\end{array}$

Nieuwenhagen

Rucphen Echt

Onderbanken

Landgraaf

Born

Echt

Simpelveld

Susteren

Beerta

Oude Pekela

Terheijden

Terheijden
Simpelveld

\section{Zonder lokale lijsten}

Twisk*

Oud en Nieuw Gastel

Schaesberg 
Tabel 5.27: Lijst van gemeenten met uitzonderlijke plaatselijke stempercentages voor cle VVD, 1974-1990.

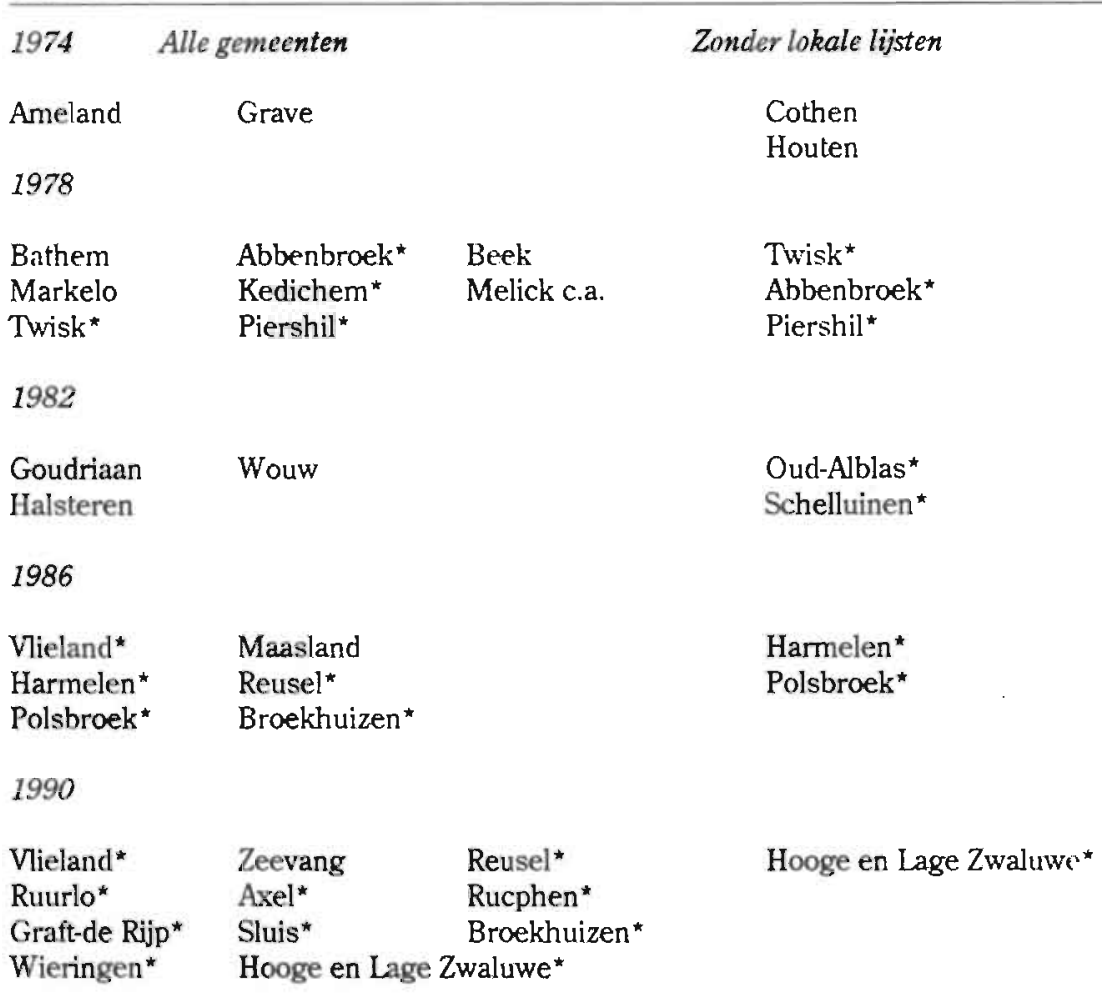

Bron: Databestand CELS.

* Het betreft een positieve residu-waarde. De overige waarden zijn negatief.

Uit het overzicht van de gemeenten met uitzonderlijke plaatselijke stempercentages blijkt dat deze meer voorkomen als alle gemeenten worden geanalyseerd dan in het geval dat alleen de gemeenten zonder lokale lijsten worden geanalyseerd. Houden wij echter rekening met het aantal gemeenten dat bij deze twee afzonderlijke analyses betrokken is, dan blijkt het verschil minimaal te zijn. Bij de analyse getaseerd op alle gemeenten blijkt dat ongeveer 1,2 procent van de gemeenten een uitzonderlijk plaatselijk stempercentage heeft, terwijl dat bij de gemeenten zonder lokale lijsten voor ongeveer 1,0 procent van de gemeenten geldt. Bij deze laatste groepgemeenten kunnen wij overigens een vermindering van het percentage gemeenten met een uitzonderlijk stempercentage constateren. In 1974 had immers nog 1,2 procent van deze gemeenten een dergelijke uitslag, terwijl dat in 1990 in nog maar 0,8 procent van de gemeenten het geval is. Bij de analyses die gebaseerd zijn op alle gemeenten valt alleen 1978 
op, aangezien in dat jaar 1,4 procent van de gemeenten een uitzonderlijke uitslag vertoont. In alle andere verkiezingsjaren is dat 1,0 of 1,1 procent.

Richten wij ons op de verschillende partijen dan blijkt het CDA zowel in absolute als relatieve zin in de meeste gemeenten een uitzonderlijk plaatselijk stempercentage te hebben. In de periode 1974-1990 gaat het om 41 gemeenten $(1,3 \%)$ tegenover 30 voor de PvdA en de VVD (1,1 en 1,0\%). Alle drie de partijen hebben ongeveer evenveel gemeenten met een uitzonderlijk stempercentages als het de gemeenten zonder lokale lijsten betreft. Dit betekent dat in relatieve zin het CDA hier enigszins achterblijft met 0,8 procentvan het totaal aantal gemeenten waar het CDA aan de gemeenteraadsverkiezingen heeft deelgenomen tegenover 1,0 en 1,1 procent voor respectievelijk de PvdA en de VVD. Kortom, de verschillen in het aantal gemeenten met uitzonderlijke plaatselijk stempercentages zijn betrekkelijk gering.

De gevonden waarden voor de gestandaardiseerde residuen voor de verschillende eenheden kunnen zowel uitzonderlijk positief als negatief zijn. Bij een uitzonderlijk positieve waarde is het plaatselijke stempercentage bij de gemeenteraadsverkiezingen hoger dan die bij de vergelijkbare niet-lokale verkiezingen. Uit het overzicht van de gemeenten met uitzonderlijke stempercentages blijkt dat vooral bij gemeenten zonder lokale lijsten relatief veel positieve uitslagen voorkomen. In 65 procentvan de uitzonderlijke stempercentag es bij deze gemeenten is dat het geval, terwijl dat bij alle gemeenten, dus inclusief die waar lokale lijsten aan de gemeenteraadsverkiezingen deelnemen, slechts in 25 procent het geval is. Ten aanzien van dit puntis tevens een grootverschil te constateren tussen het CDAen de PvdA enerzijds en de VVD anderzijds. Vooral bij de VVD is in relatief veel gevallen bij de analyse in de categorie alle gemeenten sprake van positieve waarden, namelijk in 63 procent van de uitzonderlijke stempercentages van deze partij. Bij het CDA en de PvdA is dat in minder dan 10 procent het geval. Opmerkelijk hierbij is tevens dat de VVD in 1990 in maar liefst 10 gemeenten een uitzonderlijk positieve uitslag heeft bij de gemeenteraadsverkiezingen. De oorzaak hiervan is op basis van de verkiezingsuitslagen niet te bepalen.

\section{Verwikkelingen in afzonderlijke gemeenten}

Het blijkt dat in maar weinig gemeenten meer dan één partij een uitzonderlijk plaatselijk stempercentage heeft. In 1978 is dat alleen het geval in Vaals, waar zowel het CDA als de PvdA bij de gemeenteraadsverkiezingen met respectievelijk 8,1 en 4,6 procent een veel lager stempercentage halen dan bij de Statenverkiezingen in dat jaar (resp. 45,0 en 33,1\%). Dit grote verschil wordt veroorzaakt door de sterke electorale positie van de lokale lijsten in deze gemeente. Voor de gemeenten zonder lokale lijsten is er in 1978 sprake van twee partijen met een uitzonderlijk stempercentages in de gemeente Twisk, waar PvdA en VVD een zeer positieve uitslag halen bij de gemeenteraadsverkiezingen. In 1982 hebben het CDA en de PvdA een opmerkelijk laag stempercentage in Onderbanken en Echt. Ook in dit geval is de sterke electorale positie van de lokale lijsten hiervoorverantwoordelijk. In 1990 is het stempercentage van de PvdA uitzonderlijk laag in Rucphen, terwijl de VVD bij deze gemeenteraadsverkiezing juist een opmerkelijke hoog stempercentage heeft gehaald.

Het komt zelden voor dat een gemeente een uitzonderlijk plaatselijk stempercentage heeftvoor een partij bij zowel de analyse voor alle gemeenten als ook de analyse van gemeenten zonder lokale lijsten. Dat is slechts 10 maal het geval. In al deze gemeenten betreft het een uitzonderlijk positieve uitslag voor de betreffende partij. Het geringe aantal van 10 gemeenten heeft waarschijnlijk te maken met de omstandigheid dat in de categorie alle gemeenten, de 
deelname van lokale lijsten in veel gemeenten zo'n grote (negatieve) invloed heeft op de plaatselijke stempercentages van de drie landelijke partijen dat de extreme waarden in de categorie alle gemeenten voornamelijk voorkomen in gemeenten met lokale lijsten.

Door na te gaan of en hoe de verschillende partijen in bepaalde gemeenten opvallen door opvallende stempercentages, krijgen wij een indruk van welke lokale factoren van invloed zijn op de plaatselijke stempercentages van die partijen. Als wij het overzicht van de gemeenten bekijken dan valt bij het CDA op dat vanaf 1978 vooral Noord-Brabantse en ook wel Limburgse gemeenten een uitzonderlijk stempercentage geven. Ook bij de PvdA is dat het geval, al zijn daar de Limburgse gemeenten iets sterker vertegenwoordigd. Wij zullen zien dat met name de deelname van lokale lijsten aan de gemeenteraadsverkiezingen in deze gemeenten hieraan een bijdrage leveren.

\section{Plaatselijke concurrentie-verhoudingen: mogelijke verklaringen}

Eén van de doeleinden van deze analyse van de gemeenten met uitzonderlijke uitslagen voor eén van de drie landelijke partijen, is het bepalen van de aard van de invloed van de lokale factoren op de plaatselijke stempercentages. Een verklaring van de uitzonderlijke uitslagen in de verschillende gemeenten geeft aan welke specifieke lokale factoren van belang $z$ ijn. Het is echter ondoenlijk om alle factoren die van invloed kunnen zijn op de uitslag bij de gemeenteraadsverkiezingen te achterhalen. Met behulp van de verkiezingsuitslagen is het wel mogelijk te bepalen in hoeverre de plaatselijke concurrentieverhoudingen van invloed zijn op de aanwezigheid van uitzonderlijke uitslagen. Op deze manier kunnen wij twee oorzaken hiervan bepalen.

In de eerste plaats kan de deelname van éen of meerdere lokale lijsten van invloed zijn op de plaatselijke stempercentages van de landelijke partijen. Als lokale lijsten aan de gemeenteraadsverkiezingen deelnemen en meer dan 10 procent van de stemmen halen, kunnen wij ervan uitgaan dat zij een belangrijke rol spelen bij het aanwezig zijn van negatieve uitzonderlijke uitslagen voor één van de drie landelijke partijen. Daarbij is het niet noodzakelijk dat de plaatselijke stempercentages van alle landelijke partijen in de betreffende gemeenten uitzonderlijk zijn. Of een partij in een gemeente een uitzonderlijk stempercentages heeft, hangt immers samen met de stempercentages in de andere gemeenten, die per definitie per partijeen verschillende beeld vertonen. Tevens is het mogelijk dat een landelijke partij in de betreffende gemeente niet aan de gemeenteraadsverkiezingen heeft deelgenomen. Tenslotte moet rekening worden gehouden met de omstandigheid dat een lokale lijst de stempercentages van de deelnemende landelijke partijen in een gemeente in verschillende mate kan beïnvloeden.

In de tweede plaats kan het gebrek aan plaatselijke partijpolitieke concurrentie van invloed zijn op de plaatselijke stempercentages van de landelijke partijen. In tegenstelling tot de deelname van lokale lijsten is er bij een gebrek aan concurrentie echter sprake van een uitzonderlijke positieve uitslag voor een landelijke partij. Alleen als er sprake is van slechts twee deelnemende partijen bij de gemeenteraadsverkiezingen in een gemeente zullen wij uitgaan van een gebrek aan partijpolitieke concurrentie als oorzaak voor een uitzonderlijk positieve uitslag voor een landelijke partij.

Het zal duidelijk zijn dat met deze twee oorzaken voor de aanwezigheid van uitzonderlijke plaatselijke stempercentages slechts een gedeelte van de uitzonderlijk stempercentages 
verklaard kan worden. De overige uitzonderlijke stempercentages zullen wij daarom classificeren als 'niet-verklaard'. Tabel 5.28 geeft een overzicht van de resultaten van deze indeling van gemeenten met uitzonderlijke plaatselijke stempercentages.

Tabel 5.28: Uitzonderlijke plaatselijke stempercentages ingedeeld naar verklaring, voor alle gemeenten inclusief gemeenten met lokale lijsten, 1974-1990.

\begin{tabular}{lrrrrrrrrrr}
\hline & \multicolumn{3}{c}{ CDA } & \multicolumn{4}{c}{ PvdA } & \multicolumn{4}{c}{ VVD } \\
& I & II & III & I & II & III & I & II & III \\
1974 & 8 & 0 & 1 & & 5 & 1 & 0 & 2 & 0 & 0 \\
1978 & 2 & 0 & 0 & 6 & 1 & 0 & 4 & 1 & 3 \\
1982 & 9 & 0 & 1 & 7 & 0 & 0 & 3 & 0 & 0 \\
1986 & 7 & 0 & 0 & 7 & 0 & 0 & 1 & 1 & 4 \\
1990 & 2 & 1 & 1 & 3 & 0 & 0 & 1 & 1 & 9 \\
7490 & 37 & 1 & 3 & 28 & 2 & 0 & 11 & 3 & 16
\end{tabular}

Verklaring: I $\begin{aligned} & \text { = uitzonderlijke uitslag veroorzaakt door de deelname van lokale lijsten } \\ & \text { II } \text { = uitzonderlijke uitslag veroorzaakt door zeer geringe partijpolitieke concurrentie } \\ & \text { III }=\text { uitzonderlijke uitslag onverklaard }\end{aligned}$

Gebaseerd op: Databestand CELS.

Uit de op basis van bovenstaande werkwijze uitgevoerde analyse blijkt datvan de uitzonderlijke stempercentages in alle gemeenten, inclusief de gemeenten met lokale lijsten, ongeveer 75 procent verklaard wordt door de deelname van lokale lijsten. Voor het CDA en de PvdA ligt dit percentage boven de 90 , terwijl dat voor de VVD slechts 37 procent is. Bij de VVD is daarmee een relatief hoog percentage van de uitzonderlijke stempercentages niet-verkJaard, namelijk 53 procent. Vooral in 1990 is dat het geval, namelijk in 9 van de 11 gemeenten met uitzonderlijke stempercentages. Daarbij is het tevens opvallend dat in veel gemeenten de VVD een positieve uitzonderlijke uitslag laat zien.

Bij de gemeenten zonder lokale lijsten bleek in 7 van de 26 gevallen (27\%) waarbij sprake was van een uitzonderlijk stempercentage, de zeer geringe concurrentie de oorzaak te zijn. Alle andere uitzonderlijke stempercentages zijn op basis van de verkiezingsuitslagen niet te verklaren. Dit betekent dat vooral een nadere analyse van deze gemeenten extra informatie zou moeten geven over welke lokale factoren van invloed zijn in gemeenten zonder lokale lijsten.

\subsection{Samenvatting en conclusies}

In dit hoofdstuk hebben wij de invloed van lokale factoren op de plaatselijke stempercentages van de gemeenteraadsverkiezingen gemeten om zo het lokale karakter van de gemeenteraadsverkiezingen te bepalen. Daarbij is rekening gehouden met de omstandigheid dat ook de niet-lokale verkiezingen in zekere zin worden beïnvloed door lokale factoren. Daarmee doelen wij met name op de invloed van de samenstelling van het lokale electoraat op de uitslagen van zowel lokale-als niet-lokale verkiezingen. Door de plaatselijke stempercentages van de lokale verkiezingen in verband te brengen met de plaatselijke stempercentages bij de niet-lokale verkiezingen wordt echter rekening gehouden met deze factor. Tevens wordt op deze wijse rekening gehouden met de mogelijke invloed van landelijke politieke factoren op de 
verkiezingsuitslagen. Op basis van de vergelijking van de plaatselijke stempercentages bij de lokale- en niet-lokale verkiezingen wordt dus het lokale karakter dat specifiek is voor de gemeenteraadsverkiezingen tot uitdrukking gebracht. Daarbij moeten wij ons wel realiseren dat de zo berekende invloed van lokale factoren niet gelijk gesteld mag worden met de invloed van de lokale politiek op de uitslagen van de gemeenteraadsverkiezingen. Ook factoren die niet in verband staan met de lokale politiek kunnen immers de plaatselijke uitslagen bij de gemeenteraadsverkiezingen beïnvloeden. Wij kunnen hierbij bijvoorbeeld denken aan de betekenis van de woonplaats van de kandidaten in de gemeente.

Uit de analyse van de landelijke uitslagen van de lokale en niet-lokale verkiezingen blijkt dat drie factoren van belang zijn bij de gemeenteraadsverkiezingen. Het betreft de geringere deelname van de partijen aan de gemeenteraadsverkiezingen, deverschillen in de plaatselijke concurrentieverhoudingen en in mindere mate de electorale ontwikkelingen in de periode tussen de lokale-en niet-lokale verkiezingen. Bij de concurrentieverhoudingen blijkt met name de deelname van de lokale lijsten een factor van betekenis.

Op basis van met name de sterke samenhang tussen de plaatselijke stempercentages bij de lokale-en niet-lokale verkiezingen kunnen wij concluderen dat de invloed van lokale factoren op de gemeenteraadsverkiezingen betrekkelijk gering is. In die zin kan men stellen dat er slechts sprake is van een gering lokaal karakter van de gemeenteraadsverkiezingen in de periode 1974-1990. Wel lijkt er in deze periode een licht stijgende tendens te zijn in de mate waarin de plaatselijke stempercentages van de drie grote landelijke partijen door lokale factoren beïnvloed worden. Metname in 1990 is deze invloed in vergelijking met de voorgaande gemeenteraadsverkiezingen sterk.

De mate waarin de plaatselijke stempercentages van de verschillende partijen worden beïnvloed door lokale factoren is niet erg groot. In absolute zin blijken de plaatselijke stempercentages van het CDA in iets sterkere mate dan de andere twee partijen door lokale factoren beïnvloed te worden, gevolgd door de PvdA en tenslotte de VVD. Daarbij is wel van betekenis dat de stempercentages van het CDA hoger zijn dan die van de PvdA en zeker die van de VVD. Als wij hiermee rekening houden, en dus de relatieve invloed van lokale factoren op de plaatselijke stempercentages berekenen, dan blijken de plaatselijke stempercentages van de PudA het sterkst beïnvloed te zijn door lokale factoren, gevolgd door het CDA en tenslotte de VVD.

Een tweede conclusie is dat de lokale lijsten in belangrijke mate verantwoordelijk zijn voor de geconstateerde invloed van lokale factoren op de plaatselijke stempercentages van de drie grote landelijke partijen in de periode 1974-1990. Dat blijkt zowel bij de analyse van de samenhang tussen de plaatselijke stempercentages van lokale- en niet-lokale verkiezingen, als bij de berekende invloed van lokale factoren op de plaatselijke stempercentages bij de gemeenteraadsverkiezingen en bij de analysevan de uitzonderlijke uitslagen in de gemeenten. Dat de berekende invloed van lokale factoren voor een groot deel wordt bepaald door de deelname van lokale lijsten aan de gemeenteraadsverkiezingen wordt tevens duidelijk uit de omstandigheid dat een deel van de extreme waarden van de berekende invloed van lokale factoren $0 \mathrm{D}$ de plaatselijke stempercentages is terug te voeren op de deelname van deze lijsten. Ook de analy se van de lijst van uitzonderlijke plaatselijke stempercentages van de drie partijen wijst in dezelfde richting. Immers, ongeveer 75 procent van deze uitslagen kan verklaard worden door de deelname van de lokale lijsten aan de gemeenteraadsverkiezingen. Met name geldt dat voor het CDA en de PvdA, die overigens in relatief veel Noord-Brabantse en Limburgse gemeenten een uitzonderlijke (negatieve) uitslag hebben. DeVVD heeft daarentegen 
relatief veel positieve uitzonderlijke uitslagen, die overigens in veel gevallen niet verklaard konden worden.

Ook ten aanzien van de invloed van lokale lijsten op de plaatselijke stempercentages zijn er lichte verschillen tussen de drie partijen. De plaatselijke stempercentages van het CDA blijken in vergelijking met die van de andere twee partijen in sterkere mate beïnvloed te worden door de deelname van de lokale lijsten aan de gemeenteraadsverkiezingen. Dat kunnen wij onder meer opmaken uit het grote verschil in de samenhang van de plaatselijke stempercentages bij de lokale- en niet-lokale verkiezingen voor alle gemeenten in vergelijking met de gemeenten waar geen lokale lijsten aan de gemeenteraadsverkiezingen deelnemen. In het laatste geval is deze samenhang duidelijk hoger dan in het eerste geval. Voor de PvdA en vooral de VVD is dit verschil minder groot. Eenzelfde beeld zien wij bij de hoogte van de berekende absolute lokale factor bij de gemeenteraadsverkiezingen. Deze daling van de berekende absolute lokale factor van het CDA in gemeenten zonder lokale lijsten leidt er mede toe dat in deze gemeenten de PvdA de hoogste absolute lokale factor heeft, gevolgd door het CDA en tenslotte de VVD. In de gemeenten zonder lokale lijsten is dus de hoogte van de plaatselijke stempercentages van de PydA in sterkere mate veranderd onder invloed van lokale factoren dan die van het CDA en de VVD. Ook als de berekende lokale factor gerelateerd wordt aan de hoogte van het plaatselijke stempercentage, en wij dus de relatieve invloed van lokale factoren op de plaatselijke stempercentages berekenen, blijkt dat de plaatselijke stempercentages van het CDA het sterkst beïnvloed worden door de deelname van de lokale lijsten, al is het verschil met de PvdA niet groot. In de gemeenten zonder lokale lijsten blijkt tevens weer dat de plaatselijke stempercentages van de PvdA in de sterkste mate zijn beïnvloed door lokale factoren.

Tenslotte is vermeldenswaard dat bij het CDA de spreiding van de berekende lokale factoren in de gemeenten dikwijls hoger is dan bij de andere twee partijen, vooral bij de analyse in alle gemeenten. Tevens blijkt in vergelijking met de ander twee landelijke partijen een groot deel van deze spreiding veroorzaakt te worden door de deelname van lokale lijsten aan de gemeenteraadsverkiezingen. Ook uit de analyse van de spreiding van de relatieve lokale factor per gemeente blijkt dat deze spreiding voor een groot gedeelte is terug te voeren naar de deelname van lokale lijsten. Kortom, de verschillen in de plaatselijke stempercentages van het CDA worden in sterkere mate dan bij de andere twee landelijke partijen bepaald door de invloed van de deelname van lokale lijsten aan de gemeenteraadsverkiezingen. 


\section{NOTEN}

${ }^{1}$ Onder trend verstaan wij het verschil tussen de plaatselijke stempercentages van een lijst in een gemeente bij twee opeenvolgende verkiezingen.

${ }^{2}$ In bijlage 8 wordt een overzicht gegeven van de methoden die bij de analyse van de plaatselijke stempercentages en plaatselijke trends worden gebruikt.

${ }^{3}$ Niet alleen in de media maar ook in de politicologische literatuur gaat men ervan uit dat de grote overeenkomsten in de plaatselijke trends bij de verschillende verkiezingen aangeven dat er nauwelijks sprake is van subnationale factoren bij subnationale verkiezingen. Zie bijvoorbeeld: Denver(1987), Gallagher(1987), Håkansson(1987), Tops/van Tilburg (1989) en Tops(1991).

${ }^{4}$ Conform het gestelde in de Inleiding geldt voor alle tabellen in dit hoofdstuk, tenzij anders aangegeven, dat de stempercentages voor de niet-lokale verkiezingen in 1974 en 1978 gebaseerd zijn op de uitslagen van de Statenverkiezingen, terwijl zij in 1982, 1986 en 1989 gebaseerd zijn op de uitslagen van de Tweede Kamerverkiezingen.

De stempercentages van de PvdA in dit hoofdstuk bestaan alleen uit de stemmen van de PvdA-lijsten en niet die van de PAK-lijsten. Hierbij moet wel aangetekend worden dat in 1974 en 1978 een PAK-lijst meedeed aan de Statenverkiezingen in de provincie Utrecht.

De percentages voor het CDA in 1974 zijn samengesteld door de stemmen voor de ARP, de CHU, de KVP, het CDA en combinaties waarbij deze partijen betrokken zijn, bij elkaar te voegen.

${ }^{5}$ Dat de PvdA als tweede partij in Nederland in minder gemeenten met minder kiezers dan de VVD aan de gemeenteraadsverkiezingen deelneemt is voor een deel te verklaren door de deelname van de PvdA aan de gemeenteraadsverkiezingen in PAK-verband. De PAK-lijsten namen in de periode 1974-1990 achtereenvolgens in $15,2,11,9,11,9,9,5$ en 7,0 procent van de gemeenten deel aan de gemeenteraadsverkiezingen.

'De in de periode 1974-1990 door gemeentelijke herindelingen nieuw gevormde gemeenten zijn niet in deze analyse meegenomen.

${ }^{7}$ Evenals in de vorige hoofdstukken worden hier onder de lokale lijsten verstaan: de onafhankelijke lokale lijsten en de PC-lijsten.

"Hierbij wordt gemakshalve voorbijgegaan aan het feit dat bij de Statenverkiezingen in 1986 en 1990 in verschillende provincies samenwerkingsverbanden van lokale lijsten aan deze verkiezingen deelnamen. Zie hiervoor: van Tilburg (1991).

- De relatief lage score voor $1974(3,2 \%)$ is waarschijnlijk mede veroorzaakt doordat de kleinere christelijke partijen bij deze gemeenteraadsverkiezingen ook nog samenwerkingsverbanden zijn aangegaan met de ARP en de CHU.

${ }^{19}$ Deze toename van het percentage gemeenten waar de kleine christelijke partijen succesvol aan de gemeenteraadsverkiezingen hebben deelgenomen is wellicht niet alleen te wijten aan de toename van samenwerkingsverbanden van deze partijen. Mogelijk is ook een daling van de kiesdrempel door gemeentelijke herindelingen en een verandering in het stemmenpercentage van invloed geweest.

4. Gevraagd naar het waarom van de verschillende partijkeuze bij de gemeenteraads- en de Tweede Kamerverkiezingen antwoordden in een Interview-onderzoek in 1986 in Breda alle respondenten die bij de gemeenteraadsverkiezingen op een 'klein-linkse' lijst stemde terwij] men bij de Tweede Kamerverkiezingen op de PvdA had gestemd, dat de reden hiervoor was dat bij de gemeenteraadsverkiezingen de machtsvraag niet aan de orde was. Het betrof echter slechts vijf respondenten. Zie hiervoor: Interview (1986). Ander onderzoek is niet bekend.

${ }^{2}$ Zie hiervoor: de Hond (1990). De opkomst van de aanhang van CDA, PvdA, VVD, D66, Groen Links en de kleine christelijke partijen was respectievelijk $71,3,64,9,67,9,66,4,70,3$ en 85,4 procent, uitgaande van het stemgedrag bij de Tweede Kamerverkiezingen van 1989.

${ }^{13}$ Zie hiervoor: Irwin en Andeweg (1990). Uitgaande van een fictieve zetelverdeling in de Tweede Kamer, zou de PvdA bijeen hoge opkomst vier zetels meer gekregen hebben dan bij de lage opkomst. D66 zou éen zetel meer gewonnen hebben. Het CDA en de kleine christelijke partijen zouden allebij twee zetels minder gehaald hebben en Groen links én.

"Zie hiervoor ook het overzicht van de in dit hoofdstuk gebruikte methoden in bijlage 8 .

${ }^{15}$ De Pearson moment-produkt correlatiecoefficiènt is het getal dat de aard en sterkte van de relatie tussen twee variabelen samenvat. Zij geeft aan in hoeverre de relatie tussen beide variabelen in een grafiek lijkt op een rechte lijn. De waarde van de correlatiecofficint ligt altijd tussen 1 en-1. Een waarde van 1 of 1 duidt erop dat in een grafiek de scores van beide variabelen precies op een rechte lijn liggen. Een negatieve correlatie betekent dat de hoge 
waarden van de ene variabele samengaan met lage waarden van de andere variabele. Een positieve correlatie geeft aan dat de hoge waarden van de ene variabele samengaan met hoge waarden van de andere variabele. Als de correlatiecoëffiënt 0 is, is er geen sprake van een rechtlijnig verband.

${ }^{16} \mathrm{Bij}$ de analyse van de plaatselijke stempercentages en trends worden zowel de onderzoeksresultaten in alle gemeenten als de resultaten in gemeenten waar de lokale lijsten niet aan de gemeenteraadsverkiezingen hebben deelgenomen, gepresenteerd. Dat wij niet de onderzoeksresultaten in gemeenten met en gemeenten zonder lokale lijsten presenteren, heeft als reden dat de onderzoeksresultaten in gemeenten met lokale lijsten in zeer sterke mate overeenkomen met de onderzoeksresultaten in alle gemeenten. Door de onderzoeksresultaten in de categorie alle gemeenten te presenteren, kan dus zowel het verschil tussen gemeenten met en gemeenten zonder lokale lijsten in kaart worden gebracht terwijl gelijkertijd een uitspraak kan worden gedaan over het lokale karakter van de gemeenteraadsverkiezingen als geheel, omdat de plaatselijke stempercentages in alle gemeenten in de analyse zijn meegenomen.

"Bij de analyse van de plaatselijke uitslagen van de drie landelijke partijen, zijn de gemeenten waar ten tijde van de betrefffende verkiezingen herindelingsverkiezingen hebben plaatsgevonden, niet in de analyse meegenomen. De reden hiervoor is dat de veranderde samenstelling van het electoraat van de heringedeelde gemeente, bij een vergelijking van de plaatselijke uitslagen van de lokale-en niet-lokale verkiezingen van invloed kan zijn op de resultaten van de analyse.

Het spreekt voor zich dat wij bij de berekening van de invloed van de lokale factoren op de plaatselijke stempercentages enkel kunnen uitgaan van de gemeenten waar de betreffende partijaan de gemeenteraadsverkiezingen heeft deelgenomen. Vandaar dat als wij in dit hoofdstuk spreken over "alle gemeenten", wij alle gemeenten bedoelen waar de betreffende partij aan de gemeenteraadsverkiezingen heeft deelgenomen, met uitzondering van de gemeenten waar in het kader van een herindeling gemeenteraadsverkiezingen hebben plaatsgevonden. ${ }^{13}$ De coëfficiènt of variation (CV) wordt dan ook berekend door de standaardafwijking te delen door de gemiddelde waarde.

"De achtergrond van een dergelijke analyse is het volgende:

Als wij de stempercentages bij de lokale- en niet-lokale verkiezingen in een grafiek tegenover elkaar zouden zetten, zouden wij een rechtlijnig verband kunnen ontdekken. Het is dan ook mogelik een (regressie)lijn te trekken die de gegevens in de tabel zo goed mogelijk beschrijft. Deze lijn wordt zo getrokken dat het kwadraat van de afstanden van alle punten tot die lijn zo klein mogelijk is, hetgeen het kleinste kwadraten criterium wordt genoemd. Uitgaande van dit criterium kan wiskundig de vergelijking voor de beste lijn worden afgeleid. Het belang van deze lijn is dat op basis hiervan voor elke waarde van de afhankelijke variabele de afstand tussen die waarde en de door de regressielijn voorspelde waarde berekend kan worden. Dit noemen wijhet residu. Van deze residuen kan het gemiddelde en de standaardafwijking van de residuen berekend worden. Vervolgens is het mogelijk om elke waarde van het residu uit te drukken in het aantal malen dat de waarde van het residu de standaardafwijking van het gemiddelde afligt. Stel dat bijvoorbeeld de gemiddelde waarde van de residuen 5 procent, en de standaardafwijking 3 procent is, dat ligt een residuele waarde van 14 procent drie standaardafwijkingen vau het gemiddelde. Het gestandaardiseerde residu (de zogenaamde Z-score) heeft in dat geval een waarde van 3. In het algemeen gaat met ervan uit dat bij eenheden warvan het gestandaardiseerde residu een (positieve of negatieve) waarde heeft van 3 of meer, er sprake is van een extreme waarde. In dit onderzoek zullen daarom alle gemeenten die bij één van de verkiezingen voor éen van de partijen een dergelijke extreme waarde laten zien, gekenmerkt worden als een gemeente met een uitzonderlijke uitslag. 
, 


\section{ANALYSE VAN DE PLAATSELJJKE TRENDS}

In de regel krijgt in geen enkele gemeente een partij bij twee opeenvolgende verkiezingen hetzelfde stempercentage. Er is bijna altijd sprake van winst en verlies tussen tweeverkiezingen. In Groot-Brittannië, waar onder meer door het kiesstelsel twee partijen de boventoon voeren, spreekt men in dit kader ook wel van de "swing" tussen de twee grote partijen. Doordat kiezers van de ene partij naar de andere overlopen (de "swing"), ontstaan er verschillen in de stempercentages bij twee opeenvolgende verkiezingen. In de Engelse situatie spreekt men in dit kader ook wel van een landelijke "swing", een percentage partijwisselaars dat gelijk is over het gehele land en ervoor zorgt dat in bepaalde districten de parlementszetel door de andere partij gewonnen wordt.

In Nederland is er geen met "swing" vergelijkbare term. Toch zijn er ook in Nederland factoren die ervoor zorgen dat er een landelijke "trend" is die voor of tegen een partij werkt. Een partij zit electoraal in de lift en wint overal een bepaald stempercentage terwijl een andere partij electoraal in een dal zit en overal een bepaald stempercentage verliest bij de verkiezingen. In dit hoofdstuk proberen wij via een analyse van de plaatselijke trends in de verschillende gemeenten het lokale karakter van de gemeenteraadsverkiezingen te bepalen. Een "trend" definiëren wij als het verschil tussen twee plaatselijke stempercentages bij twee opeenvolgende verkiezingen. In tabel 6.1 worden een aantal hypothetische voorbeelden uitgewerkt.

Tabel 6.1: Voorbeeld van de berekening van de plaatselijke trend in een achttal denkbeeldige gemeenten, in percentages.

$\begin{array}{lrrr}\text { gem. } & \text { \%verkiezing } 1 & \text { \% verkiezing } 2 & \text { pl. trend } \\ 1 . & 12,4 & 13,5 & \\ 2 . & 16,5 & 16,8 & +1,1 \\ 3 . & 20,1 & 19,2 & +0,3 \\ 4 . & 17,7 & 22,4 & -0,9 \\ 5 . & 11,8 & 10,0 & +4,7 \\ 6 . & 15,6 & 18,3 & -1,8 \\ 7 . & 18,2 & 18,5 & +2,7 \\ 8 . & 19,3 & 17,0 & +0,3 \\ & & & -2,3\end{array}$

Uit de tabel blijkt dat plaatselijke trends zowel positief als negatief kunnen zijn. Een positieve waarde geeft aan dat men bij de tweede verkiezing een hoger stempercentage heeft gehalald dan bij eerste verkiezing. Voor een negatieve waarde geldt vanzelfsprekend het tegendeel. Als de factoren die de winst of verlies van een partij beïnvloeden slechts landelijke factoren zijn, dan zal de trend in de verschillende gemeenten in grote mate overeenkomen. Dit is het idee van de Engelse "swing". Zoals gezegd komt het ook in Nederland voor dat partijen in bijna alle 
gemeenten winnen dan wel verliezen. Bij de gemeenteraadsverkiezingen van 1990 was bijvoorbeeld opvallend dat de PvdA in 87 procent van de gemeenten haar stempercentage zag dalen.

De vraag is nu of en hoeveel invloed plaatselijke factoren - zoals de prestaties van wethouders en raadsleden, het gemeentelijk beleid, maar mogelijk ook niet-politieke factoren zoals de woonplaats en de activiteiten van een politicus in de lokale gemeenschap - hebben op de verkiezingsresultaten van de partijen bij de gemeenteraadsverkiezingen. Als dergelijke plaatselijke factoren van belang zijn dan moet dit tot uitdrukking komen in de de plaatselijke trendcijfers. Anders gezegd, in dat geval moeten de plaatselijke trends van elkaar verschillen. Er kan natuurlijk nog wel sprake zijn van een landelijke trend, maar de politieke situatie binnen een gemeente en verschillende plaatselijke factoren kunnen ervoor zorgen dat een partij het beter (of slechter) doet dan de landelijke trend.

Ook voor twee niet-lokale verkiezingen kunnen wij de plaatselijke trends berekenen. Het ligt voor de hand dat deze plaatselijke trends voor het grootste deel veroorzaakt worden door landelijke factoren. In ieder geval mogen wij er vanuit gaan dat de plaatselijke trends bij de nietlokale verkiezingen in veel mindere mate door lokale factoren beïnvloed worden dan de plaatselijke trends bij de gemeenteraadsverkiezingen. Door deze twee plaatselijke trends te vergelijken zullen wij trachten te bepalen in welke mate lokale factoren die specifiek zijn voor degemeenteraadsverkiezingen van invloed zijn op de plaatselijke trends bij deze verkiezingen. In hoofdstuk 5 hebben wij voor elke gemeente het stempercentage bij de gemeenteraadsverkiezingen direct in verband gebracht met het stempercentage bij de nietlokale verkiezingen. De basis voor onze analyse was dus een vergelijking van beide stempercentages op lokaal niveau. Nadat deze vergelijking in elke gemeente was gemaakt, werd vervolgens om een landelijk beeld te krijgen de gemiddelde waarde van deze plaatselijke vergelijkingen berekend. In dit hoofdstuk gaan wij bij onze analyse echter niet uit van een directe vergelijking van de plaatselijke trends op lokaal niveau. De plaatselijke trends bij de gemeenteraadsverkiezingen zullen apart van de plaatselijke trends bij de niet-lokale verkiezingen worden geanalyseerd. Nadat dit gebeurd is zullen de uitkomsten van deze twee analyses naast elkaar gezet worden. Dit betekent dus dat wij op basis van de verschillen tussen de resultaten van de twee aparte analyses vervolgens de invloed van lokale factoren op de plaatselijke trends bij de gemeenteraadsverkiezingen bepalen.

De reden hiervoor is dat meer factoren van invloed zijn op een analyse van de plaatselijke trends dan op een analyse van de plaatselijke stempercentages. Als de plaatselijke stempercentages bij de lokale-en niet-lokale verkiezingen met elkaar in verband worden gebracht, spelen alleen deze twee stempercentages een rol bij de analyse. Gaan wij echter de plaatselijke trends bij de lokale verkiezingen vergelijken met die van de niet-lokale verkiezingen, dan spelen tenminste vier stempercentages een rol van betekenis. Immers, zowel de plaatselijke trend bij de lokaleals de plaatselijk trend bij de niet-lokale verkiezingen, wordt bepaald door de plaatselijke stempercentages bij twee opeenvolgendeverkiezingen. Door devergelijking van de plaatselijke trends bij de gemeenteraadsverkiezingen met de plaatselijke trends bij de niet-lokale verkiezingen, zijn dus vier plaatselijke stempercentages van invloed op de resulaten van de analyse. Door deze toename van het aantal van invloed zijnde factoren zijn de gegevens van een analyse van de plaatselijke trends niet te vergelijken met de gegevens van een analyse van de plaatselijke stempercentages. Vandaar dat in dit hoofdstuk gekozen is voor een andere benadering, waarbij na een aparte analyse van beide soorten verkiezingen alleen de resultaten hiervan met elkaar vergeleken worden. Dat een dergelijke benadering van grote betekenis is 
voor het bepalen van het lokale karakter van de gemeenteraadsverkiezingen, wordt in de volgende paragrafen duidelijk.

\subsection{De spreiding van de plaatselijke trends}

Uit het voorgaande volgt dat wij er vanuit gaan dat er verschillen zijn tussen de plaatselijke trends van een partij, als tenminste lokale factoren een rol spelen bij de gemeenteraadsverkiezingen. Of, en in welke mate dat het geval is, blijkt als wij voor deze partijen de spreiding van de plaatselijke trends bepalen. Deze informatie geeft ons een eerste aanwijzing omtrent het lokale karakter van de gemeenteraadsverkiezingen.

\subsubsection{Het meten van de spreiding van de plaatselijke trends}

Wij zullen in dit onderzoek de spreiding van de plaatselijke trends bepalen door het berekenen van de standaardafwijking van deze trends. Hoe hoger de standaardafwijking, hoe sterker de trends onderling van elkaar verschillen en afwijken van het gemiddelde. ${ }^{1}$

Wij gaan ervan uit dat de plaatselijke uitslagen en daarmee ook de plaatselijke trends worden beînvloed door lokale factoren, waaronder lokale factoren die specifiek met de gemeenteraadsverkiezingen verbonden zijn. De lokale factoren die samenhangen met de gemeenteraadsverkiezingen verschillen per definitie per gemeente, hetgeen enige extra variatie in de plaatselijke trends bij de gemeenteraadsverkiezingen teweeg zal brengen. Als deze veronderstelling juist is, zal in de regel de standaardafwijking bij de lokale verkiezingen groter zijn dan die bij de niet-lokale verkiezingen. Uiteindelijk zijn wij echter geinteresseerd in de invloed van lokale factoren die specifiek met de gemeenteraadsverkiezingen verbonden $z$ zijn. Vandaar dat wij de spreiding bij de lokale verkiezingen vergelijken met de spreiding bij de niet-lokale verkiezingen. De ontwikkeling van het berekende verschil tussen de standaardafwijking bij lokale-en niet-lokale verkiezingen geeft aan of lokale factoren bij deverschillende gemeenteraadsverkiezingen in de periode 1974-1990 hun invloed vergroten of verkleinen.

Het zal duidelijk zijn dat wij ten behoeve van de vergelijking van de standaardafwijking bij lokale- en niet-lokale verkiezingen, de berekening van de standaardafwijking bij niet-lokale verkiezingen gebaseerd hebben op dezelfde gemeenten als bij lokale verkiezingen. ${ }^{2}$

\subsubsection{Resultaten}

Volgens bovenstaande werkwijze hebben wij voor het CDA, de PvdA en de VVD de standaardafwijking van de plaatselijke trends bij de lokale- en niet-lokale verkiezingen berekend. De resultaten staan in tabel 6.2. 
Tabel 6.2: De standaardafwijking van de plaatselijke trends bij de lokale en niet-lokale verkiezingen, 1974-1990.

\begin{tabular}{|c|c|c|c|c|c|c|c|c|c|}
\hline & & $\mathrm{CDA}$ & & & $\mathrm{vdA}$ & & & VVD & \\
\hline & lok & -lok & $\mathrm{N}$ & lok & -lok & $N$ & lok & n-lok & $\mathrm{N}$ \\
\hline 7478 & 8,0 & 3,1 & 559 & 4,7 & 3,7 & 459 & 2,9 & 2,4 & 500 \\
\hline $78-82$ & 6,2 & 3,3 & 597 & 4,2 & 2,5 & 507 & 3,1 & 2,6 & 558 \\
\hline $82-86$ & 5,0 & 2,8 & 627 & 3,9 & 3,0 & 502 & 3,3 & 2.0 & 558 \\
\hline $86-89 / 90$ & 4,6 & 1,6 & 578 & 4,7 & 1,3 & 483 & 3,0 & 1,6 & 526 \\
\hline
\end{tabular}

Bron: Databestand CEIS.

Zoals verwacht is de spreiding van de plaatselijke trends groter bij de lokale- dan bij de nietlokale verkiezingen. Met name bij het CDA is dat het geval. Blijkbaar zijn de plaatselijke trends van het CDA bij de gemeenteraad sverkiezingen het sterkst beïnvloed door lokale factoren. Bij het CDA is tevens opmerkelijk dat in de periode 1974-1990 sprake is van een relatief sterke daling van de spreiding van de plaatselijke trends bij de gemeenteraadsverkiezingen. Voor een juiste beoordeling van deze ontwikkeling is het wel van belang dat wij ons realiseren dat de relatief grote spreiding voor de verkiezingen van 1974-1978 mede veroorzaakt kan zijn door de omstandigheid dat in 1974 de partijen die deel uitmaken van het CDA-KVP, CHU en ARP-in een groot deel van de gemeenten nog afzonderlijk aan de gemeenteraadsverkiezingen hebben deelgenomen. In 1978 daarentegen neemt in bijna alle gemeenten alleen een CDA-lijst aan de gemeenteraadsverkiezingen deel.

Nietalleen bij de lokale- maar ook bij de niet-lokaleverkiezingen is sprakevan een ontwikkeling in de richting van een geringere spreiding van de plaatselijke trends. Dit geldt overigens voor alle drie de partijen. Maar alleen voor het CDA geldt dat het verschil in spreiding tussen de lokale en niet-lokale verkiezingen in de periode 1974-1990 kleiner is geworden. Deze vermindering van hetverschil in de spreiding bij de lokale- en niet-lokaleverkizingen geeft aan dat de invloed van lokale factoren op de plaatselijke trends van het CDA is verminderd. Bij de PvdA is de invloed van lokale factoren op de plaatselijke trends eerder toegenomen. Vooral door de grotere spreiding van de plaatselijke trends bij de gemeenteraadsverkiezingen van 1990 ten opzichte van de voorgaande verkiezingen en de relatief lage spreiding van de plaatselijke trends bij de Tweede Kamerverkiezingen van 1989 is bij de PvdA het verschil tussen beide vergroot. Dit kan een aanwijzing zijn voor een relatief grote invloed van lokale factoren op de plaatselijke trends van de PvdA bij de gemeenteraadsverkiezingen van 1990. A moeten wij ook hier rekening houden met de mogelijke invloed van het eerder genoemde relatief grote tijdsverschil tussen de Tweede Kamerverkiezingen van 1989 en de gemeenteraadsverkiezingen van 1990. De uitslag voor de gemeenteraadsverkiezingen wijst er echter op dat in ieder geval ook specifieke lokale factoren een rol hebben gespeeld. Ook bij de VVD is het verschil in spreiding van de plaatselijke trends bij de lokale- en niet-lokale verkiezingen in de periode 1974-1990 vergroot. Dit komt met name door de daling bij niet-lokale verkiezingen, terwijl de spreiding van de plaatselijke trends bij gemeenteraadsverkiezingen redelijk stabiel blijft. 
De spreiding van plaatselijke trends in gemeenten zonder lokale lijsten

In het vorige hoofdstuk hebben wij kunnen constateren dat de aanwezigheid van de lokale lijsten een relatief grote invloed uitoefent op de plaatselijke stempercentages bij de gemeenteraadsverkiezingen. De aanwezigheid van lokale lijsten is dus een belangrijke lokale factor. Men kan zich voorstellen dat de lokale lijsten ook een grote invloed uitoefenen op de spreiding van de plaatselijke trends bij de gemeenteraadsverkiezingen. De spreiding bij deze verkiezingen zal daarom in gemeenten zonder lokale lijsten sterker gedaald zijn ten opzichte van de spreiding in de categorie alle gemeenten dan het geval zal zijn bij de niet-lokale verkiezingen. Per saldo zal daardoor het verschil tussen beide verminderen. Of dat inderdaad het geval is, wordt duidelijk uit een analyse van de gegevens in tabel $6.3 .^{3}$.

Tabel 6.3: De standaardafwijking van de plaatselijke trends bij de lokale- en niet-lokale verkiezingen voor gemeenten zonder lokale lijsten, 1974-1990.

\begin{tabular}{|c|c|c|c|c|c|c|c|c|c|}
\hline & lok & $\begin{array}{l}\text { CDA } \\
\text { rlok }\end{array}$ & $\mathrm{N}$ & lok & $\begin{array}{l}\text { vdA } \\
\text {-lok }\end{array}$ & $\mathrm{N}$ & lok & $\begin{array}{l}\text { VD } \\
\text {-lok }\end{array}$ & $\mathrm{N}$ \\
\hline 74.78 & 4,4 & 2,8 & 121 & 3,3 & 2,8 & 100 & 2,6 & 2,4 & 120 \\
\hline $78-82$ & 3,9 & 3,1 & 134 & 3,3 & 2,0 & 110 & 3,1 & 2,3 & 131 \\
\hline $82-86$ & 3,2 & 2,5 & 141 & 3,2 & 2,5 & 115 & 2,7 & 1,7 & 141 \\
\hline $86-89 / 90$ & 3,4 & 1,6 & 147 & 4,3 & 1,2 & 124 & 2,9 & 1,6 & 144 \\
\hline
\end{tabular}

Bron: Databestand CEIS.

Uit een vergelijking van de gegevens in tabel 6.2 en 6.3 valt meteen op dat voor de drie partijen en bijna alle verkiezingen geldt dat de spreiding van de plaatselijke trends in de gemeenten zonder lokale lijsten geringer is dan in de categorie alle gemeenten. Deze afname van de spreiding doet zich, zoals verwacht, in sterkere mate voor bij de gemeenteraadsverkiezingen. Met name bij het CDA is dit het geval, gevolgd door de PvdA en tenslotte de VVD. Dit geeft aan dat vooral bij het CDA de lokale lijsten van relatief grote invloed zijn op de spreiding van de plaatselijke trends van deze partij.

Door de sterkere daling van de spreiding bij de gemeenteraadsverkiezingen zijn voor alle drie de partijen de verschillen tussen de spreiding van de plaatselijke trends bij lokale-en niet-lokale verkiezingen in de periode 1974-1990verkleind. Opmerkelijk is tevens datvoor elke partij geldt dat in gemeenten zonder lokale lijsten dezelfde ontwikkeling te constateren is ten aanzien van deverschillen tussen spreiding van de plaatselijke trends bij lokale- en niet-lokale verkiezingen als in alle gemeenten.

Zo zien wij bij het CDA dat na een aanvankelijke daling van het verschil in spreiding tussen de plaatselijke trends van de lokale- en niet-lokale verkiezingen sprake is van een stijging. Bij de PvdA is er geen eenduidige ontwikkeling. Wel valt op dat in $1989 / 90$ het verschil duidelijk groter is dan voorheen. Opvallend daarbij is dat de spreiding bij de gemeenteraadsverkiezingen in dat jaar ongeveer even groot is als bij de analyse in alle gemeenten bij deze verkiezingen. Ook bijde VVD is hetverschil in de plaatselijke trendsvan de lokale-en niet-lokaleverkiezingen in 1989/90 groter dan bij andere verkiezingsjaren, maar daarmee wordt bij deze partij een ontwikkeling van geleidelijke stijging van dit verschil voortgezet. Wij kunnen dus constateren dat voor elke partij geldt dat in 1989/90 het verschil tussen de spreiding van de plaatselijke trends bij de lokale-en niet-lokale verkiezingen groter is dan in voorgaande verkiezingsjaren. 
Mogelijk dat ook hier het relatief grote tijdsverschil tussen de Tweede Kamerverkiezingen van 1989 en de gemeenteraadsverkiezingen van 1990 van invloed is. Al kunnen wij op basis van de opmerkelijke spreiding in 1990 in ieder geval voor de PvdA uitgaan van een rol van betekenis van de specifiek lokale factoren.

\subsection{De samenhang tussen de plaatselijke trends}

Uit de bevindingen van de voorgaande paragraaf blijkt dat er een verschil is tussen de spreiding van de plaatselijke trends van lokale-en niet-lokale verkiezingen. Daarmee wordt duidelijk dat lokale factoren een rol spelen bij de gemeenteraadsverkiezingen. Welke betekenis wij moeten hechten aan de gevonden verschillen en daarmee aan de invloed van lokale factoren op de plaatselijke trends is niet duidelijk. In deze paragraaf willen wij door het meten van de samenhang tussen de plaatselijke trends bij twee opeenvolgende verkiezingen hierin duidelijkheid scheppen. Bij het bepalen van het lokale karakter van de gemeenteraadsverkiezingen neemt een dergelijke analyse van de plaatselijke trends een belangrijke plaats in. Zo heeft bijvoorbeeld Tops (1990:182-187) de samenhang berekend tussen de plaatselijke uitslagen bij twee opeenvolgende gemeenteraadsverkiezingen, om daarmee te bepalen in welke mate sprake is van een relatie tussen het gedrag van lokale kiezers en lokale politici. Ook in de buitenlandse literatuur maakt men gebruik van dergelijke analyses (Denver, 1987; Håkansson, 1987).

In dit deel van het onderzoek zullen wij op een vergelijkbare manier de plaatselijke trends bij de gemeenteraadsverkiezingen analyseren. Door in elke gemeente de plaatselijke stempercentages bij twee opeenvolgendeverkiezingen tegenover elkaar te zetten, en vervolgens na te gaan in hoeverre de relatie tussen deze twee stempercentages overeenkomt met die in andere gemeenten, meten wij in wezen de samenhang tussen de plaatselijke trends bij de gemeenteraadsverkiezingen. Bij een sterke samenhang tussen de plaatselijke trends in de gemeenten, is er weinig verschil tussen de winst- of verliescijfers in de verschillende gemeenten. Lokale factoren oefenen blijkbaar een geringe invloed uit op de plaatselijke trends. Bij een zwakke samenhang tussen de plaatselijke trends daarentegen, zijn er grote verschillen tussen de plaatselijke winst- of verliescijfers voor de betreffende partij bij de verkiezingen in kwestie. In dat geval is duidelijk dat lokale factoren een grote invloed uitoefenen op de plaatselijke trends.

Een dergelijke analyse zullen wij uitvoeren voor zowel de lokale-als de niet-lokale verkiezingen. Door vervolgens op landelijk niveau de geconstateerde samenhangen bij deze twee soorten verkiezingen met elkaar te vergelijken, wordt duidelijk in hoeverre lokale factoren die specifiek zijn voor de gemeenteraadsverkiezingen van invloed zijn op de plaatselijke trends van de drie grootste landelijke partijen bij de gemeenteraadsverkiezingen in de periode 1974-1990.

\subsubsection{Het meten van de samenhang tussen de plaatselijk trends}

Wij zullen de samenhang tussen de plaatselijke trends bij zowel lokale- als niet-lokale verkiezingen meten door het berekenen van de Pearson product-moment correlatiecoëfficiënt tussen de plaatselijke uitslagen bij twee opeenvolgende verkiezingen. Wij gaan ervan uit dat bijde berekende correlaties tussen de plaatselijke uitslagen bij twee opeenvolgende verkiezingen sprake is van een (positief) verband. Hoe meer de berekende scores de waarde 1 naderen, hoe sterker de samenhang tussen de plaatselijke uitslagen en hoe geringer de invloed van lokale 
factoren op de plaatselijke uitslagen. In verband met de vergelijking van de samenhang van de plaatselijke trends voor enerzijds de gemeenteraadsverkiezingen en anderzijds de niet-lokale verkiezingen, zullen de correlaties bij deze twee verkiezingen worden gemeten voor dezelfde gemeenten. Dat zijn alle gemeenten waar de betreffende partij aan de gemeenteraadsverkiezingen heeft deelgenomen. Ook bij deze analyse moeten wij ons realiseren dat de hoogte van de correlatiecoëfficiënt beïnvloed wordt door de diversiteit van de plaatselijke uitslagen in de verschillende gemeenten (zie §5.2.1). Bij de interpretatie van de gegevens zal hiermee zo nodig rekening worden gehouden.

\subsubsection{Resultaten}

Voor elk van de drie landelijke partijen hebben wij voor alle lokale- en niet-lokale verkiezingen in de periode 1974-1990 de samenhang tussen de plaatselijke trends gemeten. De resultaten hiervan staan in tabel 6.4.

Tabel 6.4: De correlatie tussen de plaatselijke trends, voor lokale- en niet-lokale verkiezingen, 1974-1990.

\begin{tabular}{lccccccccc}
\hline & \multicolumn{3}{c}{$\begin{array}{c}\text { CDA } \\
\text { lok n-lok }\end{array}$} & $\mathrm{N}$ & lok & $\begin{array}{c}\text { PvdA } \\
\text { n-lok }\end{array}$ & $\mathrm{N}$ & \multicolumn{3}{c}{ VVD } \\
& & & & & & & & & \\
$74-78$ & .84 & .97 & 559 & .92 & .93 & 459 & .93 & .94 & 500 \\
$78-82$ & .89 & .98 & 597 & .93 & .97 & 507 & .92 & .93 & 558 \\
$82-86$ & .91 & .97 & 627 & .94 & .96 & 502 & .92 & .96 & 558 \\
$86-89 / 90$ & .92 & .99 & 578 & .89 & .99 & 483 & .92 & .98 & 526
\end{tabular}

Bron: Databestand CELS.

Wij kunnen constateren dat de correlaties bij de niet-lokale verkiezingen hoger zijn dan die bij de lokale verkiezingen. Dit betekent dat de trends bij de gemeenteraadsverkiezingen meer beïnvloed worden door lokale factoren dan de trends bij de niet-lokale verkiezingen. Bij de nietlokale verkiezingen kunnen wij zelfs bij alle drie de partijen een lichte stijging zien van de samenhang tussen de plaatselijke trends. De lokale invloeden op de plaatselijke trends worden dus nog geringer en zijn gezien de zeer hoge correlaties in feite afwezig. Bij de gemeenteraadsverkiezingen zien wij een dergelijk stijging alleen bij het CDA De PvdA kent tot en met 1986 een licht stijgende samenhang, waarna in 1990 sprake is van een duidelijke daling van de samenhang tussen de plaatselijke trends. Lokale invloeden hebben dus bij de gemeenteraadsverkiezingen in dat jaar een grotere invloed gehad op de plaatselijke trends van deze partij dan in voorgaande jaren. De VVD laat van de drie partijen bij de gemeenteraadsverkiezingen het meest stabiele beeld zien.

Om een juist beeld te krijgen van de invloed van lokale factoren op de plaatselijke trends bij de gemeenteraadsverkiezingen, is het noodzakelijk om het verschil tussen de berekende correlatiecoëfficiënten van de lokale- en de niet-lokale verkiezingen nader in kaart te brengen. Daarbij valt op dat voor elke partij de ontwikkeling van dit verschil in de periode 1974-1990 overeenkomt met die van het verschil in de standaardafwijkingen bij de lokale- en niet-lokale verkiezingen, zoals die in de vorige paragraaf beschreven is. Bij het CDA is tot en met 1986 sprake van een daling van het verschil tussen de berekende correlaties. Wij kunnen dus 
concluderen dat in deze periode de plaatselijke trends van het CDA in steeds mindere mate beïnvloed worden door lokale factoren die specifiek zijn voor de gemeenteraadsverkiezingen. In 1989/90 is er echter sprake van een zeer lichte stijging. Bij de PvdA zien wij een op- en neergaande lijn, waarbijvooral in 1990 hetverschil groter is dan bij devoorgaandeverkiezingen. De stijgende lijn bij de VVD wijst op een lichte vergroting van de invloed van lokale factoren op deplaatselijke trends. Het is overigens opvallend hoe hoog de gevonden correlatiecoëfficiënten voor de VVD zijn, gezien het feit dat bij deze partij ten opzichte van de andere twee partijen de diversiteitvan de plaatselijke uitslagen geringer is, hetgeen een matigende invloed kan hebben op de sterkte van de gevonden samenhang tussen de plaatselijke uitslagen bij twee opeenvolgende verkiezingen. Daarmee wordt duidelijk dat de plaatselijke trends van de VVD het minst beïnvloed worden door lokale factoren.

\section{De samenhang bij gemeenten zonder lokale lijsten}

Bovenstaande analyse is ook uitgevoerd de gemeenten waar geen lokale lijsten aan de gemeenteraadsverkiezingen deelnemen. Zie hiervoor tabel 6.5.

Tabel 6.5: De correlatie tussen de plaatselijke trends in gemeenten zonder lokale lijsten, voor lokale-en niet-lokale verkiezingen, 1974-1990.

\begin{tabular}{|c|c|c|c|c|c|c|c|c|c|}
\hline \multirow{3}{*}{$74-78$} & \multicolumn{3}{|c|}{ CDA } & \multicolumn{3}{|c|}{ PvdA } & \multicolumn{3}{|c|}{ VVD } \\
\hline & \multicolumn{2}{|c|}{ lok n-lok } & \multirow{2}{*}{$\begin{array}{r}\mathrm{N} \\
121\end{array}$} & \multicolumn{2}{|c|}{ lok n-lok } & \multirow{2}{*}{$\begin{array}{r}\mathrm{N} \\
100\end{array}$} & \multicolumn{2}{|c|}{ lok n-lok } & \multirow{2}{*}{$\begin{array}{r}\mathrm{N} \\
120\end{array}$} \\
\hline & .95 & .97 & & .95 & .96 & & .94 & .95 & \\
\hline $78-82$ & .95 & .98 & 134 & .94 & .98 & 110 & .92 & .94 & 131 \\
\hline $82-86$ & .96 & .97 & 141 & .94 & .97 & 115 & .94 & .97 & 141 \\
\hline $86-89 / 90$ & .96 & .99 & 147 & .89 & .99 & 124 & .93 & .98 & 144 \\
\hline
\end{tabular}

\section{Bron: Databestand CELS.}

Allereerst valt op dat de verschillen tussen de correlaties van de lokale- en niet-lokale verkiezingen zeer gering zijn. Dit duidt erop dat lokale factoren een zeer geringe invloed uitoefenen op de plaatselijke trends bij de gemeenteraadsverkiezingen in gemeenten zonder lokale lijsten. De verschillen zijn overigens zo gering doordat in vergelijking met de gegevens in tabel 6.4 vooral bij de gemeenteraadsverkiezingen sprake is van een toename van de samenhang tussen de plaatselijke trends. Vooral bij het CDA is dit het geval, hetgeen erop duidt dat de plaatselijke trends van deze partij in vergelijking met de andere twee landelijke partijen in sterkere mate worden beïnvloed door de aanwezigheid van lokale lijsten bij de gemeenteraadsverkiezingen.

Bij de niet-lokale verkiezingen is overigens sprake van een nog licht stijgende tendens in de samenhang tussen de plaatselijke trends. De lokale verkiezingen laten wat dat betreft in de onderzochte periode een redelijk stabiel beeld zien. Wel is opvallend dat bij de PvdA in 1990 een relatief sterke daling te zien is van de samenhang tussen de plaatselijke trends. Daarmee is het verschil met de vergelijkbare niet-lokale verkiezingen van 1989 groter dan bij de andere. verkiezingen. Eenzelfde resultaat zagen wij ook al bij onze analyse van de gegevens in tabel 6.4. De zwakkere samenhang tussen de plaatselijke trends bij de gemeenteraadsverkiezingen geeft aan dat ditverschil in ieder geval voor een deel te wijten is aan lokale factoren die specifiek 
verbonden zijn met de gemeenteraadsverkiezingen, al kan ook het eerder genoemde tijdsverschil tussen de twee betrokken verkiezingen hierop van invloed zijn geweest.

\section{De samenhang van plaatselijke trends per categorie van gemeentegrootte}

Bij de analyse van de samenhang tussen de plaatselijke trends hebben wij tevens onderzocht in hoeverre er verschillen zijn tussen gemeenten van verschillende grootte. De reden hiervoor is dat wij in deel 2 van deze studie hebben gezien dat de deelname van lokale lijsten verschilt in de verschillende categorieën van gemeentegrootte. Door een dergelijke analyse uit te voeren, wordt duidelijk in hoeverre de invloed van lokale factoren verschilt in gemeenten van verschillende grootte.

Uit de gegevens van de tabellen in bijlage 4 blijkt dat in de regel voor beide verkiezingen geldt dat de verschillen tussen gevonden correlaties in de verschillende categorieën van gemeentegrootte niet erg groot zijn. Bij het CDA kunnen wij zien dat de samenhang tussen de plaatselijke trends in de kleinste gemeenten in 1978 en 1982 relatief zwak is. Bij de PvdA zien wij een dergelijke zwakke samenhang in deze categorie van gemeentegrootte in 1990, en bij de VVD in 1982. Dit betekent dat de plaatselijke trends van deze partijen bij deze verkiezingen in sterkere mate dan bij de andere verkiezingen beivloed zijn door lokale factoren. Aangezien in slechts éen of twee verkiezingsjaren hiervan sprake is, kunnen wij niet spreken van een structurele beinvloeding van de plaatselijke trends van deze partijen. Opvallend is wel dat alleen in de kleinste gemeenten met minder dan 3.000 inwoners een dergelijke beïnloeding van de plaatselijke trends te constateren is.

Een andere opvallende uitslag is in 1990 de relatief geringe samenhang tussen de plaatselijke trends bij de gemeenteraadsverkiezingen voor de PvdA in de categorie grootste gemeenten. Blijkbaar hebben in deze gemeenten lokale politieke factoren een relatief grote rol gespeeld bij de trend van de PvdA bij de gemeenteraadsverkiezingen van 1990.

\subsection{Het verschil tussen de plaatselijke en de landelijke trend}

Op grond van een analyse van de samenhang tussen de plaatselijke trends weten wij nog niet welk deel van de plaatselijke verandering in de stempercentages te wijten is aan de invloed van lokale factoren. Vandaar dat wij in deze paragraaf inzicht proberen te krijgen in dit effect van de lokale factoren op de plaatselijke trends bij de lokale- en niet-lokale verkiezingen.

\subsubsection{De bepaling van de afwijking van de plaatselijke trends}

De eerste stap om de afwijking van de plaatselijke trends ten opzichte van de landelijke trend te meten, is het berekenen van de landelijke trend bij deze twee soorten verkiezingen. Laten wij de berekening van de landelijke trend bij de gemeenteraadsverkiezingen als voorbeeld nemen. De landelijke trend wordt bepaald op basis van de landelijke stempercentages bij twee opeenvolgende gemeenteraadsverkiezingen. Daarbij is allereerst van belang dat alleen de uitslagen in de gemeenten waar de betreffende partij aan beide opeenvolgende gemeenteraadsverkiezingen heeft deelgenomen, meetellen voor de berekening van het landelijke stempercentage. Het landelijke stempercentage van elk van de twee opeenvolgende gemeenteraadsverkiezingen wordt berekend door het totaal aantal stemmen op een partij te delen door het totaal aantal geldig uitgebrachte stemmen. De landelijke trend wordt nu bepaald 
door het landelijke stempercentage bij de tweede verkiezing af te trekken van het landelijk stempercentage bij de eerste verkiezing. Als dus bijvoorbeeld het berekende landelijke stempercentage van een partij hoger is in 1978 dan in 1974, is er dus sprake van een positieve landelijke trend.

Als wij de afwijking van de plaatselijke trends ten opzichte van de landelijke trend willen bepalen, moeten wij natuurlijk ook de plaatselijke trend berekenen. De tweede stap bestaat dus uit het bepalen van de plaatselijke trends in elke deelnemende gemeente. Deze wordt op eenzelfde wijze berekend als de landelijke trend. Dat betekent dus dat het plaatselijke stempercentage bij de tweede gemeenteraadsverkiezing wordt afgetrokken van het plaatselijke stempercentage bij de eerste gemeenteraadsverkiezing.

De derde stap bestaat uit het in elke deelnemende gemeente bepalen van het verschil tussen de landelijke trend en de plaatselijke trend bij de betreffende gemeenteraadsverkiezing. In elke gemeente wordt daartoe de landelijke trend afgetrokken van de plaatselijke trend, waarmee wij in elke gemeente de afwijking van de plaatselijke trend bepaald hebben.

Uiteindelijk willen wij een overzicht hebben van de berekende afwijkingen van de plaatselijke trends in de verschillende gemeenten. De vierde stap bestaat daarom uit het berekenen van de gemiddelde afwijking van de plaatselijke trend ten opzichte van de landelijke trend. Bij deze berekening gaan wij uit van het absolute verschil tussen beide trends. Het is dus nietvan belang of er sprake is van een positieve of negatieve afwijking van de plaatselijke trend, omdat de hoogte en niet de richting van de afwijking ons nuttige informatie verschaft. Immers, als wij wel rekening zouden houden met de positieve en negatieve uitslagen, dan zou de gemiddelde afwijking per definitie 0 naderen. Om het een en ander duidelijk te maken is in tabel 6.6 een voorbeeld gegeven van de berekening.

Tabel 6.6: Voorbeeld van het berekenen van de afwijking van de plaatselijke trends ten opzichte van de landelijke trend voor zowel lokale- als niet-lokale verkiezingen, in percentages.

genn.

lokale verkiezingen

plaats. land.

trend trend

1. $\quad+5,2$

$2 .+1,3$

3. $\quad-4,0$

4. $\quad+8,6$

$5 . \quad+3,4$

$6 .-5,1$

7. $\quad+7,6$

8. $\quad+2,6$

Gemid. afwijking

Gemid. (abs.) afwijking
$+2,3$

$+2,3$

$+2,3$

$+2,3$

$+2,3$

$+2,3$

$+2,3$

$+2,3$ afwijking

$+2,9$

$-1,0$

$-6,3$

$+6,3$

$+1,1$

$-7,4$

$+5,3$

$+0,3$

$+0,15$

4,75 niet-lokale verkiezingen

plaats. land.

trend trend afwijking
$+2,1 \quad-1,0 \quad+3,1$

$-4,3 \quad-1,0 \quad-3,3$

$-0,5 \quad-1,0 \quad+0,5$

$\begin{array}{lll}-6,6 & -1,0 & -5,6\end{array}$

$+2,9 \quad-1,0 \quad+3,9$

$-2,9 \quad-1,0 \quad-1,9$

$+1,9 \quad-1,0 \quad+2,9$

$\begin{array}{lll}-0,2 & -1,0 \quad+0,8\end{array}$ 
UIt het voorbeeld blijkt dat zowel positieve als negatieve afwijkingen kunnen voorkomen. Als wij bij de berekening van de gemiddelde afwijking hiermee rekening zouden houden, dan zou het gemiddelde verschil bij de lokale verkiezingen $+0,15$ procent en bij de niet-lokale verkiezingen $+0,05$ procent zijn. Gaan wij echter uit van de absolute afwijkingen in elke gemeente, dan zijn de gevonden gemiddelden respectievelijk 4,75 procent en 2,75 procent. Dit betekent dat bij de lokale verkiezingen de plaatselijke trends sterker afwijken van de landelijke trend dan bij de niet-lokale verkiezingen. Wij gaan er vanuit dat door de invloed van lokale factoren, de afwijking van de plaatselijke trend bij de lokale verkiezingen in de regel groter is dan de afwijking van de plaatselijke trend bij de niet-lokale verkiezingen. Immers, lokale. factoren die specifiek verbonden zijn met de gemeenteraadsverkiezingen zorgen voor een grotere variatie in de plaatselijke uitslagen en daarmee de plaatselijke trends. De laatste stap bestaat daarom uit het berekenen van het verschil in de gemiddelde afwijking van de plaatselijke trend bij de lokale verkiezingen en de gemiddelde afwijking van de plaatselijke trend bij de niet-lokale verkiezingen. Daardoor krijgen wij immers een globaal beeld van de grootte van de invloed van lokale factoren op de plaatselijke trend, waarmee het lokale karakter van de gemeenteraadsverkiezingen tot uitdrukking wordt gebracht.

\subsubsection{Resultaten}

Voor de drie landelijke partijen hebben wij voor zowel de lokale-als de niet-lokale verkiezingen de gemiddelde afwijking van de plaatselijke trend ten opzichte van de landelijke trend berekend. Tabel 6.7 geeft een overzicht van de resultaten van deze analyse.

Tabel 6.7: De gemiddelde en mediane waarde van het verschil tussen de landelijke trend en de plaatselijke trends per partij en per lokale- en niet-lokale verkiezing, 1974-1990.

\begin{tabular}{|c|c|c|c|c|c|c|c|c|c|}
\hline \multirow[t]{2}{*}{ Gemid. } & \multicolumn{3}{|c|}{$\mathrm{CDA}$} & \multicolumn{3}{|c|}{ PvdA } & \multicolumn{3}{|c|}{ VVD } \\
\hline & lok & lok & $\mathrm{N}$ & lok & -lok & $N$ & lok & r-lok & $\mathrm{N}$ \\
\hline 74.78 & 5,1 & 2,4 & 559 & 3,5 & 3,0 & 459 & 2,3 & 1,9 & 500 \\
\hline $78-82$ & 4,1 & 2,7 & 597 & 3,4 & 2,2 & 507 & 2,4 & 2,1 & 558 \\
\hline 82.86 & 3,2 & 2,3 & 627 & 3,0 & 2,2 & 502 & 2,5 & 1,6 & 558 \\
\hline $86-89 / 90$ & 3,1 & 1,2 & 578 & 4,8 & 1,4 & 483 & 2,2 & 1,2 & 526 \\
\hline \multirow[t]{2}{*}{ Med. } & \multicolumn{3}{|c|}{$\mathrm{CDA}$} & \multicolumn{3}{|c|}{ PvdA } & \multicolumn{3}{|c|}{ WD } \\
\hline & lok. & & n-lok. & lok. & & n-lok. & lok & & n-lok \\
\hline $74-78$ & 3,1 & & 2,1 & 2,7 & & 2,6 & 1,8 & & 1,6 \\
\hline $78-82$ & 2,7 & & 2,2 & 2,8 & & 1,8 & 2,0 & & 1,7 \\
\hline $82-86$ & 2,0 & & 2,0 & 2,4 & & 1,9 & 1,9 & & 1,4 \\
\hline $86-89 / 90$ & 2,0 & & 0,9 & 4,4 & & 1,3 & 1,6 & & 1,0 \\
\hline
\end{tabular}

Bron: Databestand CELS.

Zoals verwacht is bij alle verkiezingsjaren de gemiddelde afwijking van de plaatselijke trend groter bij lokale-dan bij niet-lokale verkiezingen. Daarmee wordt nogmaals duidelijk dat lokale factoren een rol spelen bij de gemeenteraadsverkiezingen. 
Als wij ons richten op de ontwikkelingen in de periode 1974-1990, dan blijkt bij de niet-lokale verkiezingen in grote lijnen sprake te zijn van een daling van de grootte van de gemiddelde afwijking van de plaatselijke trend. Bij de niet-lokale verkiezingen komen de plaatselijke trends dus steeds meer overeen met de landelijke trend. Bij de gemeenteraadsverkiezingen zien wij verschillende ontwikkelingen bij de drie partijen. Het CDA kent een duidelijke vermindering van de afwijking van de plaatselijke trend. Voor de PvdA geldt hetzelfde tot 1990 . In dat jaar zien wij een opmerkelijk sterke stijging, hetgeen eropduidt dat bij deze gemeenteraadsverkiezingen lokale factoren in grotere mate dan voorheen van invloed zijn geweest op de plaatselijke trends. De VVD tenslotte had tot 1990 een licht stijgende ontwikkeling in de gemiddelde afwijking van de plaatselijke trend. In 1990 was er sprake van een daling, waarmee de VVD haar laagste score in de periode 1974-1990 haalde.

Wat betekenen deze verschillende ontwikkelingen voor het verschil tussen de afwijkingen van de plaatselijke trend bij de lokale- en de niet-lokale verkiezingen? Hierin zijn wij immers met name geïnteresseerd omdat daarmee tot uitdrukking wordt gebracht in hoeverre lokale factoren die specifiek zijn voor de gemeenteraadsverkiezingen de plaatselijke trends beïnvloed hebben. Er zijn op dit punt duidelijke verschillen tussen de drie partijen. In drie van de vier gevallen is het verschil tussen lokale- en niet-lokale verkiezingen het grootst bij het CDA, gevolgd door de PvdA en tenslotte de VVD. Bij het CDA oefenen dus de lokale factoren de grootste invloed uit op de plaatselijke trends bij de gemeenteraadsverkiezingen. Ook de ontwikkelingen in de periode 1974-1990 blijken voor de partijen verschillend te zijn. Het CDA kent tot 1990 een daling van het verschil tussen de gemiddelde afwijking van de plaatselijke trend bij de lokale- en de niet-lokale verkiezingen. In 1986 is dit verschil zelfs minder dan 1 procent. In 1990 is er echter bijna sprake van een verdubbeling tot 1,9 procent. De PvdA kent een op-en neergaande lijn, waarbij vooral het grote verschil in $1990(3,4 \%)$ opvallend is. Bij de VVD zien wij een licht stijgende ontwikkeling. Bij deze partij wordt de invloed van de lokale factoren op de plaatselijke trends dus iets vergroot. Het gemiddelde verschil tussen lokale-en niet-lokale verkiezingen is echter nooit hoger dan éen procent. Daarmee wordt duidelijk dat de invloed van lokale factoren op de plaatselijke trends van de VVD gering blijft.

Wat het verschil in de mediane waarden bij de lokale- en niet-lokale verkiezingen betreft, is er bij het CDA sprake van een duidelijke daling hiervan tot aan de verkiezingen van $1989 / 90$. Bij de PvdA daarentegen zien wij een stijging van dit verschil, met name in 1989/90. Bij de gemeenteraadsverkjezingen van 1990 waren dus lokale factoren die specifiek zijn voor deze verkiezingen in sterke mate van invloed op de plaatselijke trends van de PvdA dan bij de andere verkiezingen. Bij de VVD zien wij overigens ook een dergelijke ontwikkeling in een zwakkere vorm.

Door een vergelijking van de mediane en gemiddelde waarden van de drie partijen, wordt duidelijk in hoeverre bij de drie partijen extreme afwijkingen van de plaatselijke trends optreden. Zo kunnen wij onder meer constateren dat extreme afwijkingen in sterkere mate voorkomen bij lokale verkiezingen dan bij niet-lokale verkiezingen, omdat in de regel bij lokale verkiezingen het verschil tussen de mediane en gemiddelde waarden het grootst is. Tevens blijkt dat bij het CDA in sterkere mate extreme afwijkingen van de plaatselijke trend voorkomen dan bij de andere partijen. De betekenis hiervan blijkt in de periode 1974-1990 wel enigszins af te nemen. Opmerkelijk is overigens dat bij de lokale verkiezingen in 1990 zowel de mediane als de gemiddelde waarde bij de PvdA opmerkelijk hoog is. De hoge gemiddelde afwijking van de plaatselijke trend bij deze verkiezingen is dus niet veroorzaakt door enkele extreme afwijkingen van de plaatselijke trend. 
Ook de analyse van de spreiding van de afwijking van de plaatselijke trends bij de lokale-en niet-lokale verkiezingen, geeft ons informatie omtrent de wijze waarop lokale factoren een rol spelen bij de gemeenteraadsverkiezingen. Een groot verschil tussen de spreiding bij de lokale verkiezingen in vergelijking met de niet-lokale verkiezingen, geeft immers aan dat er grote verschillen zijn tussen de mate waarin lokale factoren de plaatselijke trends bij de gemeenteraadsverkiezingen benvloeden. Als maat van spreiding gebruiken wij de coëfficiënt of variation.

Tabel 6.8: De coëfficiènt of variation van de afwijking van de plaatselijke trends, voor lokaleen niet-lokale verkiezingen, 1974-1990.

\begin{tabular}{lcccccc}
\hline & \multicolumn{2}{c}{ CDA } & \multicolumn{2}{c}{ PvdA } & \multicolumn{2}{c}{ VVD } \\
& lok. & n-lok. & lok. & n-lok. & lok. & n-lok. \\
& & & & & & \\
$74-78$ & 1,26 & 0,85 & 0,91 & 0,79 & 0,87 & 0,78 \\
$78-82$ & 1,15 & 0,80 & 0,86 & 0,76 & 0,87 & 0,82 \\
$82-86$ & 1,17 & 0,71 & 0,85 & 0,90 & 1,00 & 0,74 \\
$86-89 / 90$ & 1,12 & 0,88 & 0,70 & 0,65 & 0,94 & 0,84 \\
\hline
\end{tabular}

Bron: Databestand CELS.

De gegevens in de tabel laten zien dat het CDA het grootste verschil in spreiding tussen de lokale en niet-lokale verkiezingen heeft. Dit betekent dat de plaatselijke trends van het CDA op zeer verschillende wijze worden beinvloed door lokale factoren bij de gemeenteraadsverkiezingen. Bij de andere partijen is dat duidelijk in mindere mate het geval. Bij met name het CDA, maar ook de PvdA wordt het verschil in spreiding van de afwijking van de plaatselijke trend tussen de lokale- en niet-lokale verkiezingen minder in de periode 1974-1990. Bij de VVD zien wij met uitzondering van 1986 een redelijk stabiel beeld. Bij de PvdA valt op dat in 1989/ 90 bij zowel de lokale- als de niet-lokale verkiezingen de spreiding van de afwijking van de plaatselijke trend relatief gering is. 
De afwijking van de plaatselijke trends in gemeenten zonder lokale lijsten

Tabel 6.9: De gemiddelde en mediane waarde van het verschil tussen de landelijke trend en de plaatselijke trends per partij en per lokale- en niet-lokale verkiezing, in gemeenten zonder lokale lijsten, 1974-1990.

\begin{tabular}{|c|c|c|c|c|c|c|c|c|c|}
\hline \multirow{3}{*}{$\begin{array}{l}\text { Gemid. } \\
74-78\end{array}$} & \multicolumn{3}{|c|}{ CDA } & \multicolumn{3}{|c|}{ PvdA } & \multicolumn{3}{|c|}{ VVD } \\
\hline & lok & n-lok & $\mathrm{N}$ & lok & 1-lok & $\mathrm{N}$ & lok & n-lok & $N$ \\
\hline & 3,3 & 2,4 & 121 & 2,5 & 2,3 & 100 & 2,0 & 1,8 & 120 \\
\hline $78-82$ & 3,2 & 2,4 & 134 & 2,8 & 1,6 & 110 & 2,6 & 1,9 & 131 \\
\hline $82-86$ & 2,1 & 2,1 & 141 & 2,4 & 1,5 & 115 & 2,2 & 1,4 & 141 \\
\hline $86-89 / 90$ & 2,4 & 1,2 & 147 & 3,8 & 1,0 & 124 & 2,2 & 1,3 & 144 \\
\hline \multirow[t]{2}{*}{ Med. } & \multicolumn{3}{|c|}{$\mathrm{CDA}$} & \multicolumn{3}{|c|}{ PvdA } & \multicolumn{3}{|c|}{ VVD } \\
\hline & lok. & & n-lok. & lok. & & n-lok. & lok. & & n-lok. \\
\hline $74-78$ & 2,3 & & 2,2 & 2,2 & & 1,7 & 1,6 & & 1,4 \\
\hline $78-82$ & 3,1 & & 2,0 & 2,3 & & 1,3 & 2,0 & & 1,6 \\
\hline $82-86$ & 1,4 & & 1,9 & 2,1 & & 1,2 & 1,8 & & 1,2 \\
\hline $86-89 / 90$ & 1,6 & & 0,9 & 3,3 & & 0,9 & 1,7 & & 1,1 \\
\hline
\end{tabular}

Bron: Databestand CELS.

Ook in gemeenten zonder lokale lijsten blijkt dat bij de lokale verkiezingen een grotere gemiddelde afwijking van de plaatselijke trend voorkomt dan bij de niet-lokale verkiezingen. Met uitzondering van de score voor de PvdA in 1986 is het verschil tussen de lokale-en de nietlokale verkiezingen echter nu duidelijk geringer dan bij de analyse van alle gemeenten. In negen van de twaalf gevallen is hetverschil in gemeenten zonder lokale lijsten zelfs minder dan 1 procent, hetgeen duidt op een zeer geringe invloed van lokale factoren op de plaatselijke trends van de drie landelijke partijen bij de gemeenteraadsverkiezingen.

In de periode 1974-1990 zien wij bij zowel de lokale-als de niet-lokale verkiezingen dezelfde ontwikkelingen als bij de analyse van alle gemeenten. Hetzelfde geldt ook voor het verschil tussen de afwijking van de plaatselijke trend bij de lokale- en de niet-lokale verkiezingen. Opmerkelijk is wel dat de aanwezigheid van de lokale lijsten bij het CDA een relatief groot deel uitmaakt van de invloed van de lokale factoren op de plaatselijke trends. Immers, vergeleken met de analyse in alle gemeenten zijn bij de analyse in gemeenten zonder lokale lijsten de verschillen tussen de berekende gemiddelde afwijking bij de lokale verkiezingen in vergelijking met de niet-lokale verkiezingen bij het CDA in sterkere mate gedaald dan bij de andere partijen. Bij de PvdA is er ook bij de gemeenten zonder de lokale lijsten sprake van een op en neergaande lijn ten aanzien van het verschil tussen de afwijking van de plaatselijke trend bij de lokale- en de niet-lokale verkiezingen. Opnieuw valt op dat het verschil in 1989/90 opmerkelijk groot is. Bij de VVD zijn de verschillen, die altijd minder dan éen procent zijn, daarentegen het geringst, al is er weer sprake van een licht stijgende tendens van dit verschil tussen de lokale en niet-lokale verkiezingen.

De mediane waarden van de afwijking van de plaatselijke trend zijn bij de lokale verkiezingen hoger dan bij de niet-lokale verkiezingen. Het verschil hiertussen wordt vooral bij de PvdA en ook wel bij de VVD groter. Bij deze partijen wordt de invloed van lokale factoren op de 
plaatselijke trends dus vergroot in de onderzochte periode. Het CDA laat ten aanzien van dit punt een wisselend beeld zien.

Extreme afwijkingen van de plaatselijke trend hebben een betrekkelijk geringe invloed op de gemiddelde afwijking van de plaatselijke trend van elke partij. Het verschil tussen de mediane en gemiddelde waarde is in de regel immers bij elk van de drie partijen niet groot. Behalve bij de PvdA bij de gemeenteraadsverkiezingen in 1990 zijn er geen grote verschillen tussen de mediane waarden in alle gemeenten in vergelijking met de gemeenten zonder lokale lijsten. Dit betekent dat in de regel lokale lijsten niet van groot belang zijn in het totaal aan lokale factoren dat de afwijking van de plaatselijk trend bij de lokale en niet-lokale verkiezingen heeft beïnvloed, als wij de extreme afwijkingen tenminste uitzonderen.

Tabel 6.10: De coëfficiënt of variation van de afwijking van de plaatselijke trend, voor lokaleen niet-lokale verkiezingen, in gemeenten zonder lokale lijsten, 1974-1990.

\begin{tabular}{lcccccc}
\hline CV & \multicolumn{2}{c}{ CDA } & \multicolumn{2}{c}{ PvdA } & \multicolumn{2}{c}{ WDD } \\
& lok. & n-lok. & lok. & n-lok. & lok. & n-lok. \\
& & & & & & \\
$74-78$ & 0,98 & 0,65 & 0,82 & 0,89 & 0,89 & 0,84 \\
$78-82$ & 0,75 & 0,83 & 0,83 & 0,80 & 0,82 & 0,80 \\
$82-86$ & 1,16 & 0,66 & 0,82 & 1,32 & 0,89 & 0,76 \\
$86-89 / 90$ & 0,99 & 0,89 & 0,79 & 0,73 & 0,84 & 0,74 \\
\hline
\end{tabular}

Bron: Databestand CELS.

De spreiding van de afwijking van de plaatselijke trend in gemeenten zonder lokale lijsten is in de regel groter bij de lokale- dan bij niet-lokale verkiezingen. Dit geldt echter bij het CDA nietvoor de verkiezingen van 1982 en bij de PvdA niet voor de verkiezingen van 1978 en 1986. Vooral in 1986 is het verschil opmerkelijk groot. De oorzaak van deze grote spreiding van de afwijking van de plaatselijke trends is op basisvan het beschikbare materiaal niet te achterhalen. Wat niet veranderd is in vergelijking met de analyse van alle gemeenten, is dat bij het CDA het verschil in spreiding bij de lokale-en niet-lokale verkiezingen het grootst is van de drie partijen. Het CDA kent dus relatief grote verschillen tussen de afwijkingen van de plaatselijke trend bij de lokale- en niet-lokale verkiezingen.

\subsubsection{De afwijking van de plaatselijke trend per gemeente}

Het eigenstandig lokale karakter van de gemeenteraadsverkiezingen kan worden bepaald door de analyse van de plaatselijke trends van de drie grote partijen bij de lokale-en niet-lokale verkiezingen. Maar, uiteindelijk zijn wij niet alleen geïnteresseerd in de invloed van lokale factoren op de plaatselijke trends van iedervan de partijen afzonderlijk. Om op een eenvoudige manier een totaalbeeld te krijgen van de ontwikkelingen in de invloed van lokale factoren op de plaatselijke trends in de periode 1974-1990, is het nuttig om in elke gemeente de gemiddelde afwijking per partij te berekenen. Kortom, wij richten ons niet op ieder partij afzonderlijk, maar proberen te achterhalen wat in iedere gemeente de gemiddelde afwijking van de plaatselijke trend ten opzichte van de landelijke trend bij de betreffende verkiezingen is. Een dergelijke afwijking noemen wij de afwijking van de plaatselijke trend per gemeente.

Hoe berekenen wij nu de afwijking van de plaatselijke trend per gemeente? Hierbij is allereerst van belang dat alleen gemeenten waar alle drie de landelijke partijen aan beide voor de 
berekening van de plaatselijke trend betrokken gemeenteraadsverkiezingen hebben deel. genomen, in de analyse worden meegenomen. Zo wordt alleen in gemeenten waar zowel in 1982 als in 1986 alle drie de partijen gezamenlijk aan de gemeenteraadsverkiezingen hebben deelgenomen, de afwijking van de plaatselijke trends per gemeente bij de gemeenteraadsverkiezingen van 1986 berekend. In de betreffende gemeenten wordt de afwijking van de plaatselijke trend per gemeente berekend door de afwijkingen van de plaatselijke trend van ieder van de drie landelijke partijen bij elkaar op te tellen en vervolgens deze som te delen door drie. Wij hebben dan het gemiddelde genomen van de drie afwijkingen van de plaatselijke trend in een gemeente.

Om een overzicht te krijgen de resultaten van een dergelijke analyse in de verschillende gemeenten berekenen wij de gemiddelde en de mediane waarde van de berekende afwijkingen van de plaatselijke trend in alle gemeenten. In tabel 6.11 zijn de resultaten van deze analyse opgenomen, voor zowel de lokale als de niet-lokale verkiezingen, in zowel alle gemeenten als in gemeenten waar geen lokale lijsten aan de betrokken gemeenteraadsverkiezingen deelnemen.

Tabel 6.11: De gemiddelde en mediane waarde van het verschil tussen de landelijke trend en de plaatselijke trends per gemeente en per lokale- en niet-lokale verkiezing, in alle gemeenten en gemeenten zonder lokale lijsten, 1974-1990.

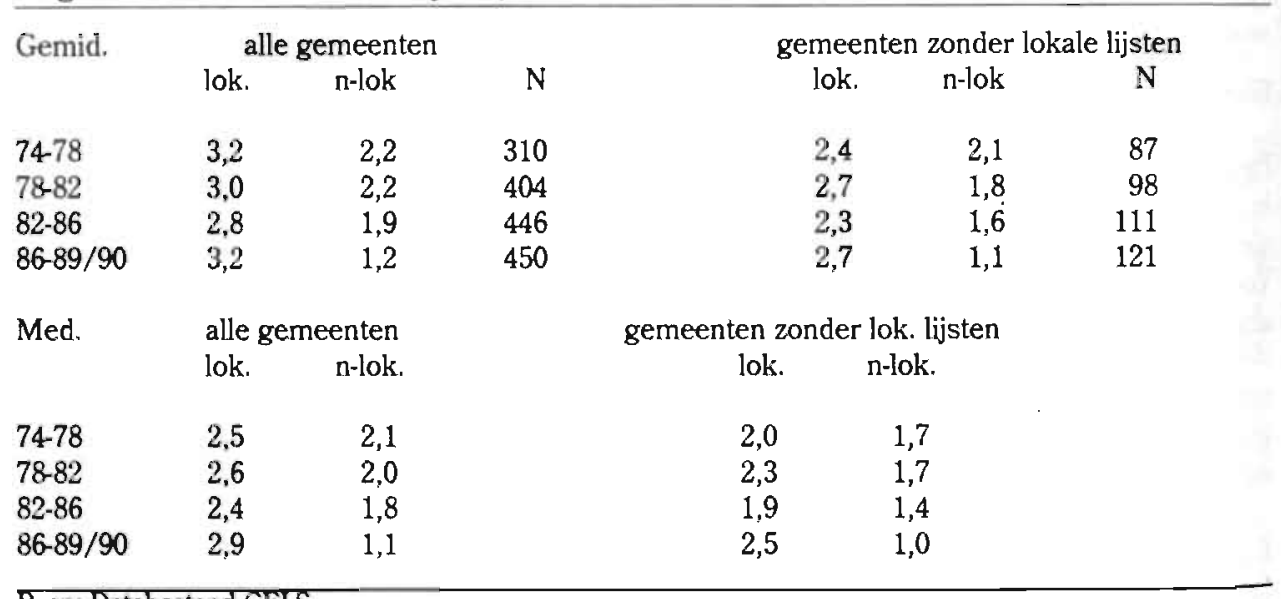

Bron: Databestand CELS.

De gegevens over de gemiddelde afwijking van de plaatselijke trend per gemeente in alle gemeenten laten tot aan de gemeenteraadsverkiezingen van 1990 een daling van deze afwijking zien. In 1990 is er echter sprake van een duidelijke stijging. Bij de niet-lokale verkiezingen zijn de percentages zoals verwacht lager dan bij de lokale verkiezingen. Tevens is hier sprake van een consequent dalende tendens in de periode 1974-1990. Op basis van de ontwikkelingen bij de lokale- en de niet-lokale verkiezingen kunnen wij door een vergelijking constateren dat tot en met de gemeenteraadsverkiezingen van 1990 hetverschil in de afwijking van de plaatselijke trend bij de twee soorten verkiezingen ongeveer 1 procent bedraagt. In 1990 is dit echter gegroeid tot 2 procent, hetgeen aangeeft dat bij de gemeenteraadsverkiezingen 
in dat jaar lokale factoren een grotere invloed hebben gehad op de plaatselijke trends van de drie partijen dan bij voorgaande verkiezingen.

Bij de gemeenten zonder lokale lijsten kunnen wij constateren dat lokale factoren bij de achtereenvolgende gemeenteraadsverkiezingen iets aan invloed hebben gewonnen, al blijft deze invloed gering. Immers, terwijl bij de lokale verkiezingen in deze gemeenten sprake is van een op- en neergaande lijn van de afwijking van de plaatselijke trend, zien wij bij de nietlokale verkiezingen een consequent dalende lijn. Daarmee is bij het verschil tussen de beide uitslagen sprake van een stijgende tendens, vooral in 1990 met een verschil van 1,6 procent. Om nader te bepalen in hoeverre de aanwezigheid van de lokale lijsten van invloed is op de hoogte van de lokale factor bij de gemeenteraadsverkiezingen, is het nodig voor elke verkiezing de resultaten in alle gemeenten te vergelijken met die in gemeenten zonder lokale lijsten. Uit een dergelijke vergelijking blijkt dat, zoals verwacht, deze verschillen groter zijn bij de lokale dan bij de niet-lokale verkiezingen, waarmee de invloed van de lokale lijsten zichtbaar wordt. Bij beide verkiezingen valt op dat vooral in 1990 sprake is van een relatief groot verschil tussen de afwijking van de plaatselijke trend in alle gemeenten en de gemeenten zonder lokale lijsten. Bij deze verkiezingen hebben de lokale lijsten dus in vergelijking met de voorgaande verkiezing weer een grotere rol gespeeld bij de beïnvloeding van de plaatselijke trends bij de gemeenteraadsverkiezingen.

Bij de mediane waarden in zowel alle gemeenten als de gemeenten zonder lokale lijsten is opvallend dat hetverschil tussen de lokale-en niet-lokale verkiezingen sterk toeneemt in 1989/ 90. Bij de gemeenteraadsverkiezing van 1990 hebben lokale factoren dus een grotere invloed uitgeoefend op de plaatselijke trends van de drie landelijke partijen dan bij de voorgaande verkiezingen. Een vergelijking tussen de resultaten in alle gemeenten en de resultaten in gemeenten zonder lokale lijsten, laat geen grote verschillen zien. Dit betekent dat lokale lijsten een niet zo groot aandeel hebben in het totaal aan lokale factoren, als wij de extreme waarden buiten beschouwing hebben gelaten. Uit een vergelijking tussen de mediane en gemiddelde waarden blijkt dat de extreme afwijkingen van de plaatselijke trend per gemeente sterker voorkomen bij de lokale- dan bij de niet-lokale verkiezingen, en sterker in alle gemeenten dan in gemeenten zonder lokale lijsten. De lokale lijsten zijn dus wel van betekenis voor de aanwezigheid van extreme afwijkingen van de plaatselijke trend per gemeente.

Tabel 6.12: De coëfficiënt of variation van de afwijking van de plaatselijke trend per gemeente, voor lokale-en niet-lokale verkiezingen, in alle gemeenten en gemeenten zonder lokale lijsten, 1974-1990.

\begin{tabular}{|c|c|c|c|c|}
\hline & \multicolumn{2}{|c|}{ alle gemeenten } & \multicolumn{2}{|c|}{ gemeenten zonder lok. lijsten } \\
\hline & lok. & n-lok. & lok. & n-lok. \\
\hline 74.78 & 0,76 & 0,57 & 0,65 & 0,56 \\
\hline $78-82$ & 0,66 & 0,55 & 0,57 & 0,58 \\
\hline $82-86$ & 0,61 & 0,48 & 0,62 & 0,53 \\
\hline $86-89 / 90$ & 0,58 & 0,55 & 0,54 & 0,46 \\
\hline
\end{tabular}

Bron: Databestand CEIS. 
De spreiding van de afwijking van de plaatselijke trend per gemeente is met name in alle gemeenten hoger bij de lokale dan bij de niet-lokale verkiezingen. Bij de gemeenten zonder lokale lijsten is ditverschil in de regel geringer. Dit betekent dat een deel van de lokale factoren bij de gemeenteraadsverkiezingen bestaat uit de aanwezigheid van lokale lijsten. Wel kunnen wij tevens constateren dat dit in grotere mate geldt voor de verkiezingen van 1978 en 1982 dan deverkiezingen van 1986 en 1990 . Immers, bij de eerste twee verkiezingen is de geconstateerde spreiding van de afwijking van de plaatselijke trend per gemeente in alle gemeente duidelijk groter in alle gemeenten dan in gemeenten zonder lokale lijsten. Bij de laatste tweeverkiezingen geldt dat in mindere mate. Daarmee wordt duidelijk dat de invloed van de lokale lijsten op de spreiding van de afwijking van de plaatselijke trend afneemt na de verkiezingen van 1982.

\subsection{Gemeenten met uitzonderlijke trends}

Het is niet alleen interessant om de mate waarin lokale factoren de plaatselijke trends beïnvloeden te onderzoeken, maar tevens om de aard van de lokale factoren te bepalen. Daarmee wordt een beter inzicht verkregen in welke lokale factoren bijdragen aan het lokale karakter van de plaatselijke trends. Kortom, duidelijk wordt wat bijdraagt tot een lokaal kiesgedrag bij de gemeenteraadsverkiezingen. De aard van de lokale factoren kan alleen achterhaald worden als de afzonderlijke gemeenten de basis zijn van de analyse. Immers, de aard van de lokale factor die van invloed is op een plaatselijke trend wordt immers bepaald door de plaatselijke politieke verhoudingen. Wij proberen de aard van de lokale factoren te bepalen door een analyse van de gemeenten met uitzonderlijke verkiezingsuitslagen, in dit geval de gemeenten met uitzonderlijke trends. Op basis hiervan zal een beter inzicht ontstaan in de betekenis van uitzonderlijke trends.

De uitzonderlijke trends zullen bepaald worden door een regressie-analyse uit te voeren. De variabelen bestaan uit de plaatselijke stempercentages bij twee opeenvolgende verkiezingen. De waarden van de residuen met een gestandaardiseerde score van 3 of meer worden beschouwd als een uitzonderlijke plaatselijke trend. ${ }^{5}$

\subsubsection{Resultaten}

Op basis van bovenstaande werkwijze hebben wij voor de drie partijen voor alle verkiezingen vanaf 1974 bepaald welke gemeenten uitzonderlijke trends te zien gaven. Zie hiervoor de tabellen $6.13 \mathrm{t} / \mathrm{m} 6.18$. 
Tabel 6.13: Lijst van gemeenten met uitzonderlijke plaatselijke trends voor het CDA bij de gemeenteraadsverkiezingen, 1974-1990.

\section{4-1978}

Losser*

Heumen *

Lichtenvoorde *

Kockengen

Langbroek

1978-1982

Ammerzoden *

Kockengen *

Langbroek*

Polsbroek*

Snelrewaard ${ }^{*}$

Zegveld*

Harenkarspel *

Limmen

1982-1986

Lichtenvoorde

Dinteloord

Eersel*

Haaren*

Hooge en Lage $Z$ waluwe

Leende *

Oploo c.a.

$1986-1990$

Zeewolde

Borne

Aalburg

Hooge en Lage Zwaluwe*

Oost, West en Middelbeers *

Waspik ${ }^{\star}$

Putte

Vessem *

Onderbanken *

Maasbracht*

Margraten*

Roggel

Susteren

Domburg

Oirschot*

Raamsdonk *

Haastrecht *

gestein ${ }^{*}$

Dussen *

Hoeven *

Oirschot

Woudrichem *

Arcen en Velden*

Meerssen *

Schinnen*

Stein

Vaals*

\section{Zonder lokale lijsten}

Hoevelaken *

Gouderak

Klaaswaal

Zwartsluis

Marken

Nederhorst den Berg

Bron: Databestand CELS

" Het betreft een positieve residu-waarde. De overige waarden zijn negatief.

Zeeland Zeewolde 
Tabel 6.14: Lijst van gemeenten met uitzonderlijke plaatselijke trends voor het CDA bij de nietlokale verkiezingen, 1974-1990.

1974-1978

Urk

Voorhout*

Aalburg

1978-1982

Doniawerstal *

Hennarderadeel ${ }^{*}$

Hedel

Houten

Polsbroek *

1982-1986

Zegveld*

1986-1990

Zeewolde

Urk

Groenlo*
Alle gemeenten

Oirschot*

Woudrichem

Kerkrade
Zonder lokale lijsten

\section{Houten}

Molenaarsgraaf*

Renswoude *

Molenaarsgraaf*

Wijngaarden *

's Gravenmoer

Haaren *

Bron: Databestand CELS.

* Het betreft een positieve residu-waarde. De overige waarden zijn negatief.

Warnsveld

Zeewolde

Reeuwijk $^{*}$

Voerendaal* 
Tabel 6.15: Lijst van gemeenten met uitzonderlijke plaatselijke trends voor de PvdA bij de gemeenteraadsverkiezingen, 1974-1990.

$\begin{array}{lll}\text { 1974-1978 } & \text { Alle gemeenten } & \text { Zonder lokale lijsten } \\ \text { Leek } & \text { Maurik }^{\star} \\ \text { Hindelopen } & \text { Callantsoog } \\ \text { Anloo } & \text { Marken }{ }^{*} \\ \text { Gasselte* } & \text { Oudekerk a/d IJssel }\end{array}$

1978-1982

Muntendam Hardinxveld-Giessendam

Heerewaarden * Zevenhuizen

Ammerstol *

$1982-1986$

$\begin{array}{lll}\text { Finsterwolde }^{\star} & \text { Oosterhesselen } & \text { Westervoort* } \\ \text { Nieuweschans }^{\star} & \text { Westervoort* } & \\ \text { Weststellingwerf }^{*} & \text { Bakel c.a. } & \end{array}$

$1986-1990$

Winschoten 's Gravenmoer

Diepenheim * Mill en St. Hubert

Wieringen *

Bron: Databestand CELS.

" Het betreft een positieve residu-waarde. De overige waarden zijn negatief. 
Tabel 6.16: Lijst van gemeenten met uitzonderlijke plaatselijke trends voor de PvdA bij de nietlokale verkiezingen, 1974-1990.

1974-1978

Schijnde ${ }^{*}$

Eijgelshoven *

1978-1982

Sloten*

1982-1986

Beerta*
Finsterwolde*

1986-1990

Almere

Spijkenisse
Alle gemeenten

Zonder lokale lijsten

Hoensbroek *

Kerkrade*

Beesel

Bron: Databestand CELS.

* Het betreft een positieve residu-waarde. De overige waarden zijn negatief.
Beerta*

Westervoort*

Spijkenisse
Maarheeze* 
Tabel 6.17: Lijst van gemeenten met uitzonderlijke plaatselijke trends voor de VVD bij de gemeenteraadsverkiezingen, 1974-1990.

\begin{tabular}{|c|c|}
\hline $1974-1978$ & Alle gemeente \\
\hline Montfoort* & Heenvliet $^{\star}$ \\
\hline Twisk ${ }^{*}$ & Mijnsheerela \\
\hline $1978-1982$ & \\
\hline $\begin{array}{l}\text { Graft-de Rijp* } \\
\text { Nederhorst den Berg* }\end{array}$ & Heinenoord \\
\hline Berkenwoude & Meerkerk \\
\hline Bleskensgraaf c.a. & Oud-Alblas \\
\hline Everdingen & Huijbergen \\
\hline
\end{tabular}

1982-1986

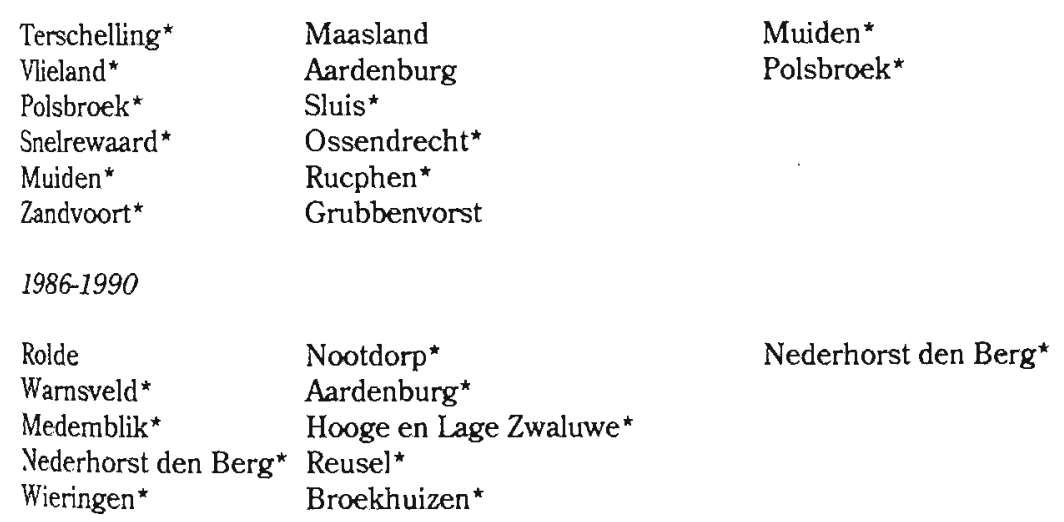

Maasland Aardenburg

Sluis *

Ossendrecht *

Rucphen *

Grubbenvorst

Snelrewaard *

Muiden*

Zandvoort*

$1986-1990$

Rolde

Warnsveld *

Medemblik*

Vederhorst den Berg

Wieringen *

Nootdorp*

Aardenburg *

Hooge en Lage Zwaluwe*

Reuse]*

Broekhuizen *

Muiden*

Polsbroek *

Nederhorst den Berg ${ }^{\star}$

\section{Zonder lokale lijsten}

Twisk ${ }^{\star}$

\section{Bron: Databestand CEIS.}

" Het betreft een positieve residu-waarde. De overige waarden zijn negatief. 
Tabel 6.18: Lijst van gemeenten met uitzonderlijke plaatselijke trends voor de VVD bij de nietlokale verkiezingen, 1974-1990.

\begin{tabular}{lll}
\hline 1974-1978 & Alle gemeenten & Zonder lokale lijsten \\
Barsingerhorn* & Noordwijkerhout & Barsingerhorm \\
Midwoud & Voorhout & Midwoud* \\
Mijnsheereland & &
\end{tabular}

1978-1.982

Leimuiden * Woensdrecht*

Bergen op Zoom*

Halsteren ${ }^{\star}$ Melick c.a.

$1982-1986$

Goudswaard

$1986-1990$

$\begin{array}{lll}\text { Almere }^{\star} & \text { Wateringen } & \text { Zeewolde } \\ \text { Zeewolde }^{\star} & \text { Aardenburg } & \text { Wateringen } \\ \text { Zeevang }^{\star} & \text { Son en Breugel } & \\ \text { Reeuwijk } & \text { Voerendaal } & \end{array}$

Bron: Databestand CEIS.

* Het betreft een positieve residu-waarde. De overige waarden zijn negatief.

Zowel in absolute als relatieve zin komen meer uitzonderlijke trends voor in alle gemeenten als in gemeenten waar lokale lijsten niet aan de gemeenteraadsverkiezingen deelnemen. Dit geldt zowel voor de lokale- als de niet-lokale verkiezingen. Bij de lokale verkiezingen komen overigens zowel in absolute als in relatieve zin meer uitzonderlijke trends voor dan bij de nietlokale verkiezingen, hetgeen een indicatie is voor het lokale karakter van de gemeenteraads. verkiezingen.

Uit een vergelijking tussen de partijen blijkt dat bij beide verkiezingen het CDA in relatief de meeste gemeenten een uitzonderlijke trend heeft. Het gaat om 2,0 procent van alle gemeenten in de analyse van de gemeenteraadsverkiezingen en 0,8 procent van de gemeenten bij de nietlokale verkiezingen. Voor de PvdA zijn deze percentages respectievelijk 1,0 en 0,6 procent. De VVD scoort iets hoger met respectievelijk 1,5 en 0,9 procent. Het zal niet verbazen dat bij alle drie de partijen het percentage voor de gemeenteraadsverkiezingen bij de analyse voor alle gemeenten hoger is dan bij de analyse voor enkel de gemeenten zonder deelnemende lokale lijsten. Dat dit verschil veel geringer is bij de niet-lokale verkiezingen geeft aan dat een deel van de uitzonderlijke trends veroorzaakt wordt door de deelname van de lokale lijsten.

Het percentage positieve uitzonderlijke trends op het totaal aantal uitzonderlijke trends blijkt bij de gemeenteraadsverkiezingen met 64 procent 10 procent hoger te zijn dan bij de niet-lokale verkiezingen. Blijkbaar is het gemakkelijker om bij de gemeenteraadsverkiezingen een betere trend dan gemiddeld te halen dan bij de niet-lokale verkiezingen. Bij de gemeenteraads. verkiezingen heeft de PvdA met 54 procent relatief de minste positieve uitzonderlijke trends, 
gevolgd door het CDA met 65 procent en de VVD met 71 procent. Bij de niet-lokale verkiezingen ishet het $C D A$ dat relatief de minste uitzonderlijk positieve trends heeft met 44 procentvan het aantal uitzonderlijke trends. De VVD neemt met53 procent de middenpositie in, terwijl de PvdA met 75 procent duidelijk de meeste uitzonderlijk positieve trends heeft. Opvallend is overigens dat bij de gemeenteraadsverkiezingen het percentage positieve uitzonderlijke trends toeneemt in de periode 1974-1990. Vooral bij de verkiezingen van 1982 is dat het geval. Dit hangt waarschijnlijk samen met de terugval van de lokale lijsten bij deze gemeenteraadsverkiezingen, waardoor de landelijke partijen in relatief veel gemeenten een grote toename van hun stempercentage kennen.

\section{Verwikkelingen in afzonderlijke gemeenten}

Het komt zelden voor dat twee partijen bij dezelfde verkiezingen in dezelfde gemeente een uitzonderlijke trend hebben. Bij de gemeenteraadsverkiezingen van 1978 was dat met het CDA en de VVD het geval in Mijnsheerenland. In deze gemeente ging het CDA van 48,4 naar 21,4 procent van de stemmen. Daarbij speelt waarschijnlijk een rol dat bij de gemeenteraadsverkiezingen van 1974 sprake was van een protestant-christelijk gecombineerde lijst. Het stemmenpercentage van de VVD in Mijnsheereland steeg van 25,0 naar 34,7 procent. Bij de gemeenteraadsverkiezingen van $1990 \mathrm{zijn}$ er twee gemeenten waar twee partijen een uitzonderlijke plaatselijke trend hebben. In de gemeente Hooge en Lage Zwaluwe voor het $C D A$ en de VVD. In deze gemeente ging het CDA van 21,7 naar 41,1 procent van de stemmen. Het stemmenpercentage van de VVD steeg van 7,9 naar 30,4 procent. In Wieringen hadden de PvdA en de VVD in 1990 een uitzonderlijke trend. Terwijl de PvdA bij de gemeenteraadsverkiezingen in deze gemeente in 198636,1 procent van de stemmen haalde, is dat in 1990 gestegen tot 42,2 procent. De VVD steeg bij dezelfde verkiezingen van 29,8 naar 38,6 procent van de stemmen. In zowel Hooge en Lage Zwaluwe als Wieringen zijn de uitzonderlijke plaatselijke trends waarschijnlijk te wijten aan het niet meer deelnemen van lokale lijsten aan de gemeenteraadsverkiezingen van 1990 . Bij de niet-lokale verkiezingen zien wij twee partijen met uitzonderlijke trends bij de Statenverkiezingen van 1978 in Voorhout en Kerkrade en bij de Tweede Kamerverkiezingen van 1989 in Zeewolde, Almere, Reeuwijk en Voerendaal. De extreme negatieve trends van de PvdA en het CDA in Zeewolde en Almere zijn wellichtveroorzaakt door de standpunten van deze twee partijen ten aanzien van de herziening van het reiskostenforfait, hetgeen vanwege de kabinetscrisis op dit punt een belangrijk item was bij de Tweede Kamerverkiezingen in 1989. Men kan immers veronderstellen dat een deel van het relatief grote aandeel forensen in deze gemeenten, de negatieve financiële gevolgen van de voorgestelde maatregelen heeft laten meewegen bij de partijkeuze bij de verkiezingen. Vooral ook omdat de afstand tussen deze gemeenten en de wat gemeenten waar de forensen werken relatief hoog. ${ }^{6}$ Vandaar dat de VVD, die een tegengesteld standpunt innam, in deze gemeenten een uitzonderlijk hoog stempercentage haalde (Visscher, 1989:51-52). Het komt overigens weinig voor dat een partij bij zowel de lokale-als niet-lokale verkjezingen in dezelfde gemeente een uitzonderlijke trend laat zien. In totaal gaat het om zeven gevallen. Daarbij ging het om uitzonderlijke trends die bij beide verkiezingen in dezelfde (positieve of negatieve) richting gingen. Juist omdat, zoals in deze paragraaf duidelijk zal worden, de lokale lijsten van grote betekenis zijn voor de aanwezigheid van uitzonderlijke trends bij de gemeenteraadsverkiezingen is het begrijpelijk dat in betrekkelijk weinig gemeenten zowel bij lokale- als nietlokale verkiezingen een partij een uitzonderlijke trend heeft. 
Door na te gaan in welke gemeente er voor een partij sprake is van een uitzonderlijke trend, kunnen wij een aantal interessante ontwikkelingen in kaart brengen. Bij het CDA is zowel bij de gemeenteraadsverkiezingen van 1986 als die van 1990 sprake van veel Noord-Brabantseen Limburgse gemeenten met uitzonderlijke trends. Uit een nadere analyse blijkt dat in deze gemeenten sprake is van een opmerkelijke terugval of een opmerkelijke opkomstvan de lokale lijsten. Opvallend is tevens dat in 1982 de VVD in zes Zuidhollandse gemeenten uitzonderlijke trends kent. Hetzelfde geldt voor het CDA in vijf Utrechtse gemeenten. In beide gevallen was met behulp van de uitslagen in deze gemeenten geen duidelijke overeenkomst tussen deze gemeenten te destilleren. Wel was ook in deze gevallen bij een groot deel van de betrokken gemeenten de opkomst of neergang van de lokale lijsten opvallend.

\section{Plaatselijke concurrentieverhoudingen: mogelijke verklaringen}

Met behulp van de analyse van de plaatselijke verkiezingsuitslagen kunnen wij proberen te achterhalen welke factoren van beslissende invloed zijn geweest op de aanwezigheid van een uitzonderlijke trend bij de gemeenteraadsverkiezingen (zie ook $\$ 5.4 .2$ ).

Bij deze analyse zullen wij gebruik maken van vier mogelijke verklaringen. In de eerste plaats kunnen lokale trends beïnvloed worden door het volledig verdwijnen of het opkomen van lokale lijsten op plaatselijk niveau. Of er kan sprake zijn van een ingrijpende verandering van de stempercentages van de aanwezige lokale lijsten. Het zal duidelijk zijn dat al deze ontwikkelingen die in verband staan met de lokale lijsten, van invloed kunnen zijn op de plaatselijke stempercentages en daarmee de plaatselijke trends van de landelijke partijen. Bekeken zal worden of er redelijkerwijs van kan worden uitgegaan dat een uitzonderlijketrend van één van de landelijke partijen te wijten is aan één van de genoemde factoren met betrekking tot de electorale positie van lokale lijsten.

De tweede verklaring bestaat uit een verandering in de politieke concurrentie tussen landelijke politiek partijen. Landelijke partijen nemen immers niet in alle gemeenten aan de gemeenteraadsverkiezingen deel. Zodra een landelijke partij voor de eerste keer aan de gemeenteraadsverkiezingen in een gemeente gaat deelnemen, kan dit van grote invloed zijn op de electorale positie van andere landelijke partijen in de betrefffende gemeente. De electorale positie van de bestaande landelijke partijen kan zelfs zo negatief worden beïnvloed dat er sprake is van een (negatieve) uitzonderlijke plaatselijke trend.

In de derde plaats is het mogelijk dat landelijke factoren van grote betekenis zijn voor de opgetreden uitzonderlijke trend. Dit zou moeten blijken uit de aanwezigheid van een uitzonderlijke trend bij dezelfde gemeente voor de betreffende partij bij de niet-lokale verkiezingen.

In de vierde plaats is het mogelijk dat de plaatselijke uitslagen en trends van het CDA beïnvloed worden door een confessionele hergroepering. Dit is niet alleen mogelijk in 1978, als in bijna alle gemeenten de KVP, ARP en CHU met een CDA-lijst aan de gemeenteraadsverkiezingen gaan deelnemen. Tevens kan in de daaropvolgende verkiezingen de opkomst of neergang van een plaatselijke confessionele partij van invloed zijn op de trend van het CDA in de betreffende gemeente.

Indien tenslotte alle genoemde verklaringen niet opgaan, zullen wij de betreffende trend als onverklaard classificeren. Tabel 6.19 geeft een overzicht van de indeling volgens bovenstaande verklaringen. 
Tabel 6.19: Uitzonderlijke trends bij de gemeenteraadsverkiezingen ingedeeld naar verklaringsgrond, voor alle gemeenten, 1978-1990.

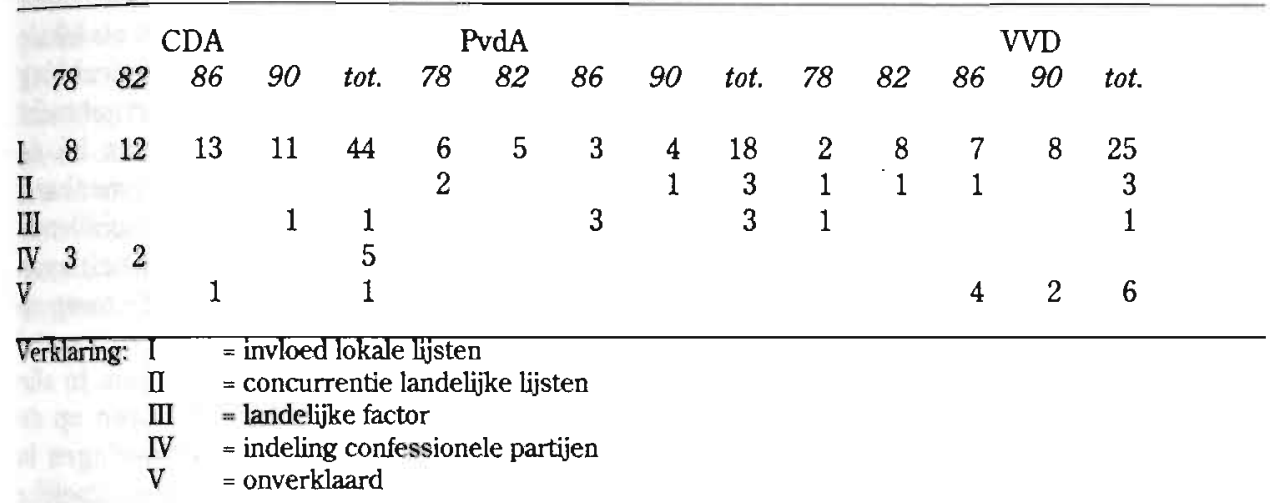

Uit de tabel blijkt dat in bijna 80 procent van de voorkomende uitzonderlijke plaatselijke trends, deze veroorzaakt zijn door schommelingen in de stempercentages van de lokale lijsten. Immers, 87 van de 110 uitzonderlijke plaatselijke trends kunnen hierdoor verklaard worden. Bijhet CDA geldt dit in de sterkste mate met een percentage van 86 procent, gevolgd door de PvdA met 75 procent en de VVD met 71 procent. Bij het CDA is overigens in 63 procent van het totaal aantal uitzonderlijke trends het wegvallen van de lokale lijsten dan wel een sterke achteruitgang van deze lijsten de reden voor een uitzonderlijk (positieve) trend. Voor de VVD is dit percentage 46 procent en voor de PvdA 38 procent. Uit deze gegevens blijkt dat de lokale lijsten in sterkere mate concurreren met het CDA dan met de andere twee landelijke partijen. Dat vooral Noord-Brabantse en Limburgse gemeenten een uitzonderlijke trend voor het CDA laten zien, is in dit licht niet opmerkelijk gezien de grote electorale achteruitgang van de lokale lijsten in deze twee provincies. In vergelijking met de andere partijen blijken de plaatselijke trends van de PvdA in grotere mate beinvloed te zijn door een verandering in de plaatselijke concurrentieverhoudingen en door landelijke factoren. Bij de VVD is opvallend dat een relatief groot deelvan de uitzonderlijke trends nietverklaard kan worden. Met 17 procent is dit immers veel groter dan die van het CDA (2\%) en de PvdA (0\%).

\subsection{Samenvatting en conclusies}

In hoofdstuk zes staat de invloed van lokale factoren op de plaatselijke trends van de drie grote landelijke partijen centraal. Deze lokale factoren kunnen zeer divers van karakter zijn. Het kan hierbij bijvoorbeeld gaan om de waardering van het gevoerde beleid van de partijen in de afgelopen raadsperiode, maar tevens om niet-politieke factoren zoals de activiteiten van een lokaal politicus in de lokale gemeenschap. Op basis van een landelijke vergelijking van de resultaten van de analyse van de plaatselijke trends van lokale- en niet-lokale verkiezingen is de invloed van de lokale factoren, in zoverre deze specifiek zijn voor de gemeenteraadsverkiezingen, bepaald. De ratio achter deze vergelijking is dat plaatselijke trends verschillend kunnen zijn omdat het lokale electoraat in de verschillende gemeenten van elkaar verschilt. $0 \mathrm{~m}$ in ieder geval met deze factor en landelijke politieke factoren rekening te houden, wordt 
zichtbaar in hoeverre wij kunnen spreken van een eigenstandig lokaal karakter van de plaatselijke trends van de drie landelijke partijen.

Allereerst is onderzocht in hoeverre de spreiding van de plaatselijke trends bij de lokale-ende niet-lokale verkiezingen van elkaar verschilt. Het achterliggende idee hierbij is dat als lokale factoren inderdaad een rol spelen bij de gemeenteraadsverkiezingen, dit ook tot uitdrukking moet komen in de spreiding van de plaatselijke trends. Vervolgens hebben wij in kaart gebrachi in hoeverre lokale factoren een invloed uitoefenen op de plaatselijke trends bij de gemeenteraadsverkiezingen. Dit is gedaan doorvoor beide soorten verkiezingen de samenhang tussen de plaatselijke uitslagen bij twee opeenvolgende verkiezingen in de verschillende gemeenten te bepalen. Door de gemiddelde afwijking van de plaatselijke trend ten opzichtevan. de landelijke trend te berekenen hebben wij de grootte van het effect van lokale factoren of de plaatselijke trend gemeten, waarna een analyse van de opmerkelijke trends in een aantal gemeenten ons informatie gaf over de aard en de betekenis van de lokale factoren. In alle gevallen zijn de resultaten van deze manieren om de invloed van lokale factoren op de plaatselijke trends te meten zoals verwacht. Dit betekent, dat bij lokale verkiezingen in vergelijking met niet-lokale verkiezingen, sprake is van een grotere spreiding van de plaatselijke trends, een geringere samenhang tussen de plaatselijke uitslagen bij twee opeenvolgende verkiezingen en een groter verschil tussen de plaatselijke trends en de landelijke trend. Dit geldt in de regel voor alle drie de partijen en zowel in alle gemeenten als in gemeenten zonder lokale lijsten. De geconstateerde invloed van lokale factoren blijkt echter niet erg groot. Van de drie partijen worden de plaatselijke trends van het CDA nog het sterkst door lokale factoren beïnvloed, gevolgd door de PvdA en de VVD.

Voor elk van de drie partijen geldt tevens dat de gevonden verschillen tussen de lokale-en de niet-lokale verkiezingen, en daarmee de invloed van de lokale factoren, groter zijn in alle gemeenten dan in de gemeenten zonder lokale lijsten. Met name bij het CDA is er dikwijls sprake van een relatief groot verschil in de uitkomsten bij deze twee categorieën gemeenten. Daarmee wordt duidelijk dat de plaatselijke trends van deze partij in sterkere mate dan de andere twee partijen worden beïnvloed door de aanwezigheid van de lokale lijsten bij de gemeenteraadsverkiezingen.

Opmerkelijk is tevens dat voor elk van de drie partijen, maar met name de PvdA, geldt dat in $1989 / 90$ de invloed van lokale factoren op de plaatselijke trends is toegenomen in vergelijking met de vorige verkiezingen. Voor een deel kan dit te wijten zijn aan het relatief grote tjjdsverschil tussen de Tweede Kamerverkiezingen van 1989 en de gemeenteraadsverkiezingen van 1990. In de tussenliggende periode kunnen zich immers nieuwe electorale ontwikkelingen voordoen die van invloed zijn op de resultaten van de analyse. De geconstateerde vergroting van de invloed van lokale factoren op de plaatselijke trends van de PvdA is echter zo opmerkelijk, ook in vergelijking met de andere twee landelijke partijen, dat wij kunnen concluderen dat lokale factoren in sterkere mate dan voorheen van betekenis zijn voor de verklaring van de gevonden verschillen tussen de lokale- en niet-lokale verkiezingen in 1989/ 90.

Om niet afhankelijk te zijn van de bevindingen voor elke partij, hebben wij tevens een totaalbeeld gegeven door de gemiddelde afwijking van de plaatselijke trend per gemeente berekend. Uit de analyse van deze gegevens komt naar voren dat tot aan de verkiezingen in $1989 / 90$ de invloed van lokale factoren op een betrekkelijk laag niveau blijft, waarna deze invloed op een iets hoger niveau komt. Dit geldt voor zowel alle gemeenten als de gemeenten zonder lokale lijsten. 
De in enkele gemeenten voorkomende extreme plaatselijke trends, blijken voor bijna 80 procent te wijten te zijn aan schommelingen in de stempercentages van lokale lijsten. Vooral het CDA heeft bij de gemeenteraadsverkiezingen van 1986 en 1990 relatief veel uitzonderlijk positieve trends. In veel gevallen betreft het Noord-Brabantse en Limburgse gemeenten. Opmerkelijk is tevens dat de VVD in relatief veel gemeenten een uitzonderlijk positieve trend heeft, waarvoor echter op grond van de analyse van de verkiezingsuitslagen geen verklaring gevonden kan worden.

$\mathrm{Al}$ al met al kunnen wij concluderen dat lokale factoren een betrekkelijk geringe invloed uitoefenen op de plaatselijke trends van de drie landelijke partijen. Daarbij wordt een deel van deze invloed bepaald door de aanwezigheid van de lokale lijsten bij de gemeenteraadsverkiezingen. 


\section{NOTEN}

${ }^{1}$ De keuze voor de standaardafwijking in plaats van de door Blalock (1979:84) voorgestelde coëfficiënt of variation is ingegeven door de omstandigheid dat wij hier trends analyseren in plaats van stempercentages. Fen kenmerkend verschil daarbij is dat trends zowel positief als negatief kunnen zijn en dus niet gebonden zijn aan een nulpunt zoals stempercentages. Dat betekent dat in principe een lage gemiddelde plaatselijke trend samen kan gaan met een hoge spreiding van plaatselijke trends. Bij stempercentages is dat niet mogelijk, waardoor het inderdaad nuttig is de berekende standaardafwijking in relatie te brengen met het gemiddelde stempercentage. ${ }^{2} \mathrm{Het}$ aantal gemeenten wordt overigens niet alleen beperkt omdat de verschillende partijen niet in alle gemeentei aan de gemeenteraadsverkiezingen hebben deelgenomen. Evenals in het vorige hoofdstuk zijn ook nu weer de gemeenten waar herindelingsverkiezingen hebben plaatsgevonden in de periode tussen de twee betrokken gemeenteraadsverkiezingen niet in de analyse meegenomen, aangezien zij de resultaten oneigenlijk zouden kunnen beïnvloeden. Door de herindeling kan immers de samenstelling van het lokale electoraat sterk veranderd zijn, waardoor de uitslagen alsmede de trends tussen twee gemeenteraadsverkiezingen sterk beïnvloed kurnen worden.

${ }^{3}$ Alleen gemeenten waar lokale lijsten niet deelnamen aan beide aan de orde zijnde gemeenteraadsverkiezingen, worden betrokken bij de analyse. Evenals in de vorige hoofdstukken worden hier onder lokale lijsten verstaar: de onafhankelijke lokale lijsten en de PC-lijsten.

- Vandaar dat wij ook bij deze analyse zullen spreken van de samenhang tussen de plaatselijke trends, in plaats van de de samenhang tussen plaatselijke stempercentages bij twee opeenvolgende verkiezingen.

${ }^{5} \mathrm{Bij}$ de analyse is voorts van belang dat rekening wordt gehouden met de aanwezigheid van gemeenten die in sterke mate de regressielijn beïnvloeden. Evenals bij de analyse van de plaatselijke uitslagen is hierbij een waarde van Cook's D van groter dan. 25 als criterium genomen. Opgrond hiervan zijn twee gemeenten met uitzonderlijkr trends aan de lijst toegevoegd. Het betreft bij de gemeenteraadsverkiezingen van 1978 voor het CDAde gemeente Raamsdonk en bij de Tweede Kamerverkiezingen van 1986 voor de PvdA, in gemeenten zonder lokale lijsten, de gemeente Westervoort. Voor een uitgebreidere uiteenzetting van de gebruikte methode verwijs ik nalar paragraaf 5.4.1.

'De omstandigheid dat het percentage volmachten bij verkiezingen in Flevoland het hoogst is van alle provincies kan immers worden beschouwd als een aanwijzing dat veel kiezers in Flevoland relatief ver van hun woonplats werken. Voor hen is het waarschijnlijk moeilijk om tijdens de opening van het stembureau persoonlijk hun stem uit te brengen. 
Deel 4

KIEZERS EN DE GEMEENTERAADSVERKIEZINGEN 



\section{LOKAAL KIEZERSONDERZOEK EN LOKAAL KIESGEDRAG}

Tot nu toe hebben wij het lokale karakter van de gemeenteraadsverkiezingen bepaald op grond van de analyse van verkiezingsuitslagen op landelijk of plaatselijk niveau. Daarbij hebben wij de electorale positie van de lokale lijsten in kaart gebracht en de plaatselijke stempercentages en trends van de drie grote landelijke partijen geanalyseerd. Het belang van deze analyse van de gemeenteraadsverkiezingen op landelijk of plaatselijk niveau is dat wij daarmee inzicht krijgen in het kiesgedrag van kiezers. Maar daarmee is nog geen juist beeld geschetst van het kiesgedrag op individueel niveau. Zelfs als zouden de landelijke of plaatselijke uitslagen van alle partijen bij twee opeenvolgende verkiezingen hetzelfde zijn, dan nog is het waarschijnlijk dat een deel van de kiezers van partij veranderd is. Deze uitslagen geven dus alleen aan dat de partijen per saldo op landelijk of plaatselijk niveau dezelfde steun hebben gekregen van de kiezers. Vandaar dat het nuttig is om na te gaan in welke mate individuele kiezers bij de gemeenteraadsverkiezingen een werkelijk lokale keuze maken bij de gemeenteraadsverkiezingen. Bij deze analy se van het individueel kiesgedrag bij de gemeenteverkiezingen zullen wijgebruik maken van de beschikbare gegevens van lokaal kiezersonderzoek dat in de periode $1974-1991$ is verricht. $^{1}$

7.1 Kiesgedrag bij lokale en nationale verkiezingen

Een indicatie van het lokale karakter van het kiesgedrag bij gemeenteraadsverkiezingen is de mate waarin de kiezers dezelfde partij stemmen bij de gemeenteraads- en Tweede Kamerverkiezingen. Als kiezers bij de gemeenteraadsverkiezingen in relatief sterke mate op een andere partij stemmen dan bij de niet-lokale verkiezingen, kunnen wij stellen dat er sprake is van kiesgedrag dat karakterestiek is voor de gemeenteraadsverkiezingen. Een dergelijke vergelijking kan echter niet meer dan een indicatie zijn voor het lokale kiesgedrag bij de gemeenteraadsverkiezingen omdat het niet uit te sluiten is dat ook bij kiezers die bij beide verkiezingen op dezelfde partij stemmen, lokale overwegingen een rol van betekenis spelen bij de partijkeuze bij de gemeenteraadsverkiezingen.

Voordat wij het kiesgedrag bij beide verkiezingen met elkaar vergelijken is het belangrijk dat wij ons realiseren dat wij ons in dit hoofdstuk, in het verlengde van de centrale probleemstelling, richten op het kiesgedrag in plaats van het stemgedrag. Het verschil is dat wij onder het stemgedrag het gedrag van alle stemgerechtigden verstaan, terwijl het kiesgedrag zich richt op degenen die daadwerkelijk op een bepaalde partij hebben gestemd bij de verkiezingen. In het kader van de vergelijking van het kiesgedrag bij de gemeenteraads- en Tweede Kamerverkiezingen is het belangrijkste verschil dat geen rekening wordt gehouden met degenen die niet zijn gaan stemmen bij én van deze verkiezingen. ${ }^{2}$ 
Op landelijk niveau zijn in de periode $1974-1990$ maar twee onderzoeken verricht waarbij het stemgedrag bij de gemeenteraadsverkiezingen vergeleken werd met het stemgedrag bij de Tweede Kamerverkiezingen. Beide onderzoeken - het Nationaal Kiezers Onderzoek (NKO) en een AVRO/ NIPO-enquête - zijn uit 1986. Dat alleen in dat jaar gevraagd is naar het stemgedrag bij de twee verkiezingen, heeft waarschijnlijk te maken met de omstandigheid dat in 1986 zowel gemeenteraadsverkiezingen als verkiezingen voor de Tweede Kamer gepland waren. ${ }^{3}$ In tabel 7.1 wordt voor de verschillende partijen aangegeven in hoeverre men bij de gemeenteraadsverkiezingen hetzelfde heeft gestemd als bij de Tweede Kamerverkiezingen. Uit de tabel kunnen wij opmaken dat er vooral bij het NKO grote verschillen zijn tussen partijen wat het percentage kiezers betreft dat bij de gemeenteraadsverkiezingen hetzelfde heeft gestemd als bij de Tweede Kamerverkiezingen. Met name de kiezers van de PvdA en de christelijk-rechtse partijen blijken zeer trouw te zijn. Ongeveer 80 procent van de kiezers op deze partijen bij de Tweede Kamerverkiezingen in 1986, stemmen hetzelfde bij de gemeenteraadsverkiezingen. Ook bij de VVD en het CDA heeft een groot deel van de kiezers bij beide verkiezingen hetzelfde gestemd. Bij de AVRO/NIPO-enquête zijn de verschillen tussen de genoemde partijen geringer. Voor alle vier de genoemde partijen geldt dat 70 à 75 procent van de kiezers bij de Tweede Kamerverkiezingen van 1986 ook op deze partijen heeft gestemd bij de gemeenteraadsverkiezingen. 
Tabel 7.1: Vergelijking van het kiesgedrag bij de gemeenteraads- en de Tweede Kamerverkiezingen in 1986, met de Tweede Kamerverkiezingen als uitgangspunt.

NKO

CDA PvdA VVD $\begin{array}{lllll}\text { Tweede Kamer } & \text { G6 } & \text { GL } & \text { CR } & \text { ov. }\end{array}$

$\begin{array}{lrrrrrrr}\begin{array}{l}\text { Gemeen- } \\ \text { teraad }\end{array} & & & & & & & \\ \text { CDA } & 68,0 & 2,4 & 6,5 & 11,1 & 4,3 & 13,5 & 7,1 \\ \text { PvdA } & 7,9 & 80,4 & 3,2 & 25,0 & 10,9 & 2,7 & 21,4 \\ \text { VVD } & 6,2 & 1,1 & 75,3 & 5,6 & 2,2 & 0,0 & 0,0 \\ \text { D66 } & 2,3 & 1,1 & 2,2 & 38,9 & 2,2 & 0,0 & 0,0 \\ \text { GL } & 0,9 & 3,5 & 0,5 & 0,0 & 45,7 & 0,0 & 14,3 \\ \text { CR } & 1,8 & 0,3 & 0,5 & 0,0 & 0,0 & 81,1 & 7,1 \\ \text { Lok/ov. } & 12,9 & 11,1 & 11,8 & 19,4 & 34,8 & 2,7 & 50,0 \\ \text { Tot } & 100,0 & 99,9 & 100,0 & 100,0 & 100,1 & 100,0 & 99,9 \\ \text { N } & 341 & 368 & 186 & 72 & 48 & 37 & 14\end{array}$

\section{AVRO/NIPO}

Gemeen-

VVD

teraad

CDA

$74,4 \quad 1,2$

1,2

72,6

2,1

6,1

1,5

73,0

3,0

0,9

1,6

66,7

1,9

0,0

0,0

0,0

0,0

22,9

22,8

22,7

GL

CR

ov.

Lok/ov. 18,8

100,0

100,0

100,0

\section{0,0 \\ 19,4}

5,3

0,0

0,0

50,0

3,2

0,0

0,0

3,2

0,0

0,0

45,2

0,0

0,0

0,0

71,0

0,0

29,0

23,7

50,0

To

$100,0 \quad 100,0$

394

581

189

66

100,0

100,0

100,0

Bron: Secundaire analyse NKO 1986 en AVRO/NIPO 1986.

Toelichting: GL $\quad$ Groen-Linkse partijen (PPR,PSP,CPN,EVP)

Lok/ov. = Lokale lijsten en overige partijen

$\mathrm{CR} \quad=$ kleinere christelijke partijen (SGP,GPV,RPF)

Leesvoorbeeld: Volgens het NKO heeft 80,4 procent van de PvdA-stemmers bij de Tweede Kamerverkiezingen die ook bij de gemeenteraadsverkiezingen stemde, weer op de PvdA gestemd. Bij de AVRO/NIPO is dit percentage 72,6 procent.

Opvallend is dat D66 en de gezamenlijke Groen-Linkse partijen in vergelijking met de andere partijen minder constante kiezers hebben. Volgens de AVRO/NIPO-enquête heeft $2 / 3$ deel van de D66-stemmers bij de Tweede Kamerverkiezingen in 1986 ook op deze partij gestemd 
bij de gemeenteraadsverkiezingen. Maar volgens het NKO geldt dat voor slechts 39 procent. Met 45 procent stabiele kiezers bij beide kiezersonderzoeken zijn de Groen-Linkse kiezers bii de Tweede Kamerverkiezingen hun partijkeuze het minst trouw bij de gemeenteraadsverkiezingen. Daarmee lijkt het op het eerste gezicht dat de kiezers van D66 en Groen Links het meest lokale overwegingen betrekken bij hun partijkeuze bij de gemeenteraadsverkiezingen. Bij deze conclusie moeten wij echter een aantal kanttekeningen plaatsen. In de eerste plaats moeten wij ons realiseren dat een deel van de kiezers op deze partijen bij de Tweede Kamerverkiezingen niet de mogelijkheid heeft gehad op deze partijen te stemmen bij de gemeenteraadsverkiezingen. In vergelijking met de drie grote landelijke partijen nemen D66 en de Groen-Linkse partijen immers in relatief weinig gemeenten aan de gemeenteraadsverkiezingen deel. Een deel van de aanhang van deze partijen is daarom gedwongen, als zij tenminste gaan stemmen, bij de gemeenteraadsverkiezingen op een andere partij te stemmen. In de tweede plaats moeten wij laten meewegen dat uit onderzoek blijkt dat deze partijen in vergelijking met andere partijen een minder stabiele aanhang hebben (Daudt 1977:140-141, van der Kaap 1987:173). De andere partijkeuze bij de gemeenteraadsverkiezingen geeft daarom nog geen uitsluitsel over de mate waarin lokale overwegingen hierbijvan invloed zijn geweest. In de derde plaats kan ten aanzien van de Groen-Linkse partijen een rol hebben gespeeld dat zij in plaatselijke samenwerkingsverbanden aan de gemeenteraadsverkiezingen hebben meegedaan. Een deel van deze samenwerkingsverbanden is waarschijnlijk in de categorie lokale lijsten ondergebracht. Het relatief hoge aandeel van de Groen Links-kiezers bij de Tweede Kamerverkiezingen dat bij de gemeenteraadsverkiezingen op een lokale lijst heeft gestemd is hiervoor een aanwijzing.

Ook bij de andere partijen, behalve de kleinere christelijke partijen (volgens het NKO), zien wij overigens dat het grootste deel van de kiezers dat bij de gemeenteraadsverkiezingen opeen andere partij heeft gestemd dan bij de Tweede Kamerverkiezingen, zijn stem heeft uitgebracht op een lokale lijst (of een overige landelijke partij). Daarnaast hebben. de stemmers op de kleinere christelijke partijen - vooral volgens het NKO - bij de gemeenteraadsverkiezingen relatief vaak op het CDA gestemd. Van degenen die bij de Tweede Kamerverkiezingen op een Groen-Linkse lijst stemmen blijkt een relatief groot deel bij de gemeenteraadsverkiezingen op de PvdA te stemmen. De D66-kiezers hebben bij de gemeenteraadsverkiezingen in relatie! grote mate op het CDA en volgens het NKO ook op de PydA gestemd. Voor het CDA zijn naast de lokale lijsten de PvdA en de VVD de belangrijkste concurrenten, terwijl voor de VVD hel CDA dit blijkt te zijn.

Tot nu toe hebben wij bepaald in welke mate kiezers hetzelfde stemmen bij de gemeenteraadsverkiezingen als bij de Tweede Kamerverkiezingen. Het is tevens mogelijk om uitgaande van de gemeenteraadsverkiezingen, na te gaan wat de betreffende kiezers hebben gestemd bij de Tweede Kamerverkiezingen. In dat geval nemen wij de gemeenteraadsverkiezingen als uitgangspunt voor onze analyse. Een voordeel van dezr zienswijze is dat daardoor de lokale lijsten geen invloed uitoefenen op de gevonden percentages stabiele kiezers bij beide verkiezingen. In tabel 7.2 staan per partij de gegevens over het percentage kiezers dat bij de Tweede Kamerverkiezingen hetzelfde heeft gestemd als bij de gemeenteraadsverkiezingen. 
Tabel 7.2: Vergelijking van het kiesgedrag bij de gemeenteraads- en de Tweede Kamerverkiezingen in 1986, met de gemeenteraadsverkiezingen als uitgangspunt.

\begin{tabular}{lrrrrrrrrr} 
NKo & \multicolumn{10}{c}{ Tweede Kamer } \\
\multicolumn{1}{c}{ CDA PvdA VVD } & D66 & GL & CR & Lok/ov & Tot. & N \\
$\begin{array}{l}\text { Gemeen- } \\
\text { teraad }\end{array}$ & & & & & & & & & \\
CDA & 86,2 & 3,3 & 4,5 & 3,0 & 0,7 & 1,9 & 0,4 & 100,0 & 356 \\
PvdA & 7,6 & 83,1 & 1,7 & 5,1 & 1,4 & 0,3 & 0,8 & 100,0 & 269 \\
WD & 12,4 & 2,4 & 82,4 & 2,4 & 0,6 & 0,0 & 0,0 & 100,2 & 170 \\
D66 & 17,8 & 8,9 & 8,9 & 62,2 & 2,2 & 0,0 & 0,0 & 100,0 & 45 \\
GL & 7,5 & 32,5 & 2,5 & 0,0 & 52,5 & 0,0 & 5,0 & 100,0 & 40 \\
CR & 15,4 & 2,6 & 2,6 & 0,0 & 0,0 & 76,9 & 2,6 & 100,1 & 39 \\
Lok/ov & 30,3 & 28,3 & 15,2 & 9,7 & 11,0 & 0,7 & 4,8 & 100,1 & 145 \\
& & & & & & & & &
\end{tabular}

\section{AVRO/NIPO}

\begin{tabular}{|c|c|c|c|c|c|c|c|c|c|}
\hline \multirow{4}{*}{$\begin{array}{l}\text { Gemeen- } \\
\text { teraad }\end{array}$} & \multicolumn{9}{|c|}{ Tweede Kamer } \\
\hline & \multicolumn{3}{|c|}{ CDA PvdA VVD } & D66 & GL & $\mathrm{CR}$ & Lok/ov & \multirow[t]{2}{*}{ Tot. } & \multirow[t]{2}{*}{$\mathrm{N}$} \\
\hline & & & & & & & & & \\
\hline & 94,5 & 2,3 & 1,3 & 1,3 & 0,0 & 0,6 & 0,0 & 100,0 & 310 \\
\hline PvdA & 2,3 & 95,3 & 0,2 & 0,2 & 1,4 & 0,0 & 0,7 & 100,1 & 343 \\
\hline VVD & 5,8 & 3,2 & 89,0 & 1,3 & 0,6 & 0,0 & 0,0 & 99,9 & 155 \\
\hline D66 & 7,3 & 5,5 & 5,5 & 80,0 & 1,8 & 0,0 & 0,0 & 100,1 & 55 \\
\hline GL & 0,0 & 44,0 & 0,0 & 0,0 & 66,0 & 0,0 & 0,0 & 100,0 & 25 \\
\hline $\mathrm{CR}$ & 12,9 & 0,0 & 0,0 & 0,0 & 0,0 & 87,1 & 0,0 & 100,0 & 31 \\
\hline Lok/ov & 25,9 & 46,5 & 15,0 & 5,2 & 3,1 & 3,1 & 1.0 & 99,8 & 286 \\
\hline
\end{tabular}

Bron: Secundaire analyse NKO 1986 en AVRO-NIPO 1986.

Toelichting: GL = Groen-Linkse partijen (PPR,PSP,CPN,EVP)

Lok/ov = Lokalc lijsten en overige partijen

CR = Kleinere christelijke partijen (SGP,GPV,RPF)

Leesvorbeeld: Volgens het NKO heeft 86,1 procent van de de CDA-stemmers bij de gemeenteraadsverkiezingen die ook bij de Tweede Kamerverkiezingen stemde, weer op het CDA gestemd. Bij de AVRO-NIPO is dit percentage 94,5 procent.

In vergelijking met de vorige tabel valt op dat bij zowel het NKO als de AVRO/NIPO-enquête het percentage stabiele kiezers voor bijna iedere partij verhoogd is. Aangezien de lokale lijsten in tabel 7.2 geen invloed uitoefenen op de gevonden percentages stabiele kiezers voor iedere partij, is deze verhoging begrijpelijk.

In hoeverre slagen de verschillende partijen erin om hun kiezers bij de gemeenteraadsverkiezingen eveneens op hen te laten stemmen bij de Tweede Kamerverkiezingen? Wat dat betreft zijn er geen grote verschillen tussen de PvdA en het CDA. Uit beide kiezersonderzoeken blijkt dat CDA en PvdA er het beste in slagen om hun kiezers bij de gemeenteraadsverkiezingen ook bij de Tweede Kamerverkiezingen op hen te laten stemmen. Zij worden daarbij gevolgd door de VVD, die bij de AVRO/NIPO-enquête iets achterblijft, en de kleinere christelijke partijen, die iets lager scoren bij het NKO. Bij beide onderzoeken blijken D66 en de Groen Linkse partijen er het minst in te slagen om hun kiezers aan zich te 
binden bij beide verkiezingen, al is het D66-percentage van 80 procent bij het NKO opmerkelijk hoog.

De deelname van lokale lijsten aan de gemeenteraadsverkiezingen betekent een toenamevan de concurrentie bij deze verkiezingen voor de landelijke partijen. Op basis van bovenstaande gegevens kunnen wij tevens nagaan in hoeverre deze deelname de stempercentages van de landelijke partijen heeft beïnvloed. In wezen geven wij daarmee aan in hoeverre op landelijk niveau een duidelijk lokaal element bij de gemeenteraadsverkiezingen - de deelname van lokale lijsten - van invloed is op een duidelijk nationaal element bij deze verkiezingen - de stempercentages voor de landelijke partijen. Volgens het NKO zou het stempercentage van het CDA relatief gezien 16,9 procent hoger (van 24,8 procent naar 29,0 procent) zijn geweest als de betreffende stemmers op de lokale lijsten op de partij hadden gestemd die ze bij de Tweede Kamerverkiezingen hebben gesteund. Voor de PvdA en de VVD zijn deze percentages respectievelijk 11,9 en 13,1 procent. Door de sterke oververtegenwoordiging van stemmers op de lokale lijsten, zijn deze laatste twee percentages bij de AVRO/NIPO-enquête meer dan het dubbele van die van het NKO. De stempercentages van het CDA, de PvdA en de VVD zouden volgens de AVRO/ NIPO-enquête een relatieve stijging kennen van respectievelijk 28,6, 34,6 en 32,4 procent als de stemmers op de lokale lijsten dezelfde partij hadden gestemd als men bij de Tweede Kamerverkiezingen van plan was."

Op basis van het percentage constante kiezers per partij kunnen wij natuurlijk ook voor het betreffende verkiezingsjaar berekenen in hoeverre kiezers hetzelfde gestemd hebben bij de gemeenteraadsverkiezingen als bij de Tweede Kamerverkiezingen. Daarmee krijgen wij een beeld van het lokale kiesgedrag bij de gemeenteraadsverkiezingen van $1986 .{ }^{5}$ Volgens het NKO heeft in 198670,9 procent van de kiezers bij beide verkiezingen op dezelfde partij gestemd. Bij de AVRO/NIPO-enquête is dit percentage 72,1 procent. Hieruit volgt dus dat ongeveer zeven van de 10 kiezers bij beide verkiezingen dezelfde partijkeuze maken. Het spreekt voor zich dat de deelname van de lokale lijsten aan de gemeenteraadsverkiezingen deze gegevens beïnvloeden omdat kiezers op deze lijsten per definitie niet op dergelijke lijsten kunnen stemmen bij de Tweede Kamerverkiezingen. Om een juist beeld te krijgen van het percentage kiezers dat bij de gemeenteraadsverkiezingen en de Tweede Kamerverkiezingen op dezelfde landelijke partij stemt, moeten wij de kiezers op de lokale lijsten dus buiten beschouwing laten. Dit heeft tot resultaat dat volgens het NKO 81,9 procent van de kiezers bij beide verkiezingen dezelfde landelijke partij stemt. Bij de AVRO/NIPO-enquête is dit percentage zelfs 92,3 procent. ${ }^{6}$ Uit een vergelijking van deze percentages met de eerder genoemde percentages waarbij de stemmen op de lokale lijsten zijn meegeteld, kunnen wij concluderen dat volgens het NKO 1/3 van het verschillende kiesgedrag veroorzaakt is door het stemmen op lokale lijsten bij de gemeenteraadsverkiezingen. Volgens de AVRO/NIPO-enquéte is zelfs meer dan $2 / 3$ van het verschillend kiezen bij beide verkiezingen te wijten aan het stemmen op lokale lijsten.

\section{Kiesgedrag per gemeentegrootte}

In deel één van dit onderzoek hebben wij ondermeer geconstateerd dat lokale lijsten in de regel sterker vertegenwoordigd zijn in de kleine dan in de grotere gemeenten. Dit betekent waarschijnlijk dat in de kleinere gemeenten in geringere mate bij degemeenteraadsverkiezingen op dezelfde partij wordt gestemd als bij de Tweede Kamerverkiezingen. Maar geldt dit ook nog als wij de kiezers op de lokale lijsten buiten beschouwing laten? Of dat het geval is in 1986 blijkt uit tabel 7.3. 
Tabel 7.3: Percentage kiezers dat bij de Tweede Kamerverkiezingen hetzelfde stemt als bij de gemeenteraadsverkiezingen, per gemeentegrootte, 1986.

\begin{tabular}{|c|c|c|c|c|c|}
\hline \multirow{2}{*}{$\begin{array}{l}\text { inwoners } \\
x 1.000\end{array}$} & & \multicolumn{2}{|c|}{ met lokale lijsten } & \multicolumn{2}{|c|}{ zonder lokale lijsten } \\
\hline & & NKO & AVRO/NIPO & NKO & AVRO/NIPO \\
\hline$<$ & 5 & 54,8 & 59,4 & 88,5 & 95,0 \\
\hline 5 & 10 & 64,6 & 57,5 & 74,5 & 85,7 \\
\hline 10 & 20 & 66,8 & 63,5 & 80,7 & 88,5 \\
\hline 20 & - $\quad 50$ & 71,5 & 77,1 & 79,3 & 94,8 \\
\hline 50 & -100 & 71,6 & 71,6 & 78,9 & 91,8 \\
\hline 100 & -400 & 80,3 & 76,0 & 84,5 & 91,2 \\
\hline$>$ & 400 & 78,2 & 82,5 & 88,5 & 93,7 \\
\hline
\end{tabular}

Bron: Secundaire analyse NKO 1986 en AVRO/NIPO 1986.

Volgens met name het NKO en in minder mate de AVRO/NIPO-enquête geldt in grote lijnen dat, hoe groter de gemeente is, hoe hoger het percentage kiezers dat bij gemeenteraads- en Tweede Kamerverkiezingen hetzelfde stemt. Laten wij echter de stemmen op de lokale lijsten buiten beschouwing, dan blijkt niet alleen dat het percentage stabiele kiezers over de gehele linie sterk is toegenomen, maar tevens dat de verschillen tussen de gemeenten van verschillende grootte sterk verkleind zijn. In grote lijnen kunnen wij nu een tweedeling constateren. Volgens het NKO is het percentage stabiele kiezers het hoogst in de kleinste gemeenten (minder dan 5.000 inwoners) en in de gemeenten met meer dan 100.000 inwoners. In de overige gemeenten is dat in iets mindere mate het geval. In die gemeenten is dus het lokale kiezersgedrag bij de gemeenteraadsverkiezingen wat hoger. Bij de AVRO/NIPO-enquête zijn deverschillen tussen de gemeenten van verschillende grootte nog kleiner. Behalve in de gemeenten met 5.000 à 10.000 inwoners en in mindere mate in die met 10.000 à 20.000 inwoners is er nauwelijks verschil in het percentage stabiele kiezers in gemeenten van verschillende grootte. Op basis van een vergelijking van de gegevens met en zonder lokale lijsten kunnen wij vervolgens wel concluderen dat op landelijk niveau in grote lijnen geldt, hoe kleiner de gemeente hoe groter de invloed van de lokale lijsten op het kiesgedrag bij de gemeenteraadsverkiezingen is.

\section{Lokale kiezersonderzoeken}

Naast deze twee onderzoeken op landelijk niveau, zijn er ook nog enkele lokale kiezersonderzoeken met gegevens over het kiesgedrag in een aantal afzonderlijke gemeenten. Het betreft een onderzoek naar de adviesraadsverkiezingen in Lelystad in 1974, een onderzoek in Roosendaal en Breda in 1986 en de zeven gemeenten uit het onderzoek "lokale democratie en bestuurlijke vernieuwing' in 1991'. Uit al deze onderzoeken blijkt dat van degenen die bij beide verkiezingen gaan stemmen of hebben gestemd, in de regel in meer dan negen van de tien gevallen op dezelfde partij stemmen. In Lelystad stemde in 197491 procent van de kiezers bij de adviesraadsverkiezingen op vergelijkbare partijen bij de Tweede Kamerverkiezingen. Van de kiezers op de KVP en de ARP/CHU-combinatie was dit percentage 88 procent. Voor de PAK-lijst en de VVD zijn de percentages respectievelijk 95 en 100 procent. Ook in Roosendaal en Breda vinden wij voor de verkiezingen in 1986 vergelijkbare percentages. Uitgaande van de landelijke partijen stemt ongeveer 86 procent van de stemmers bij de 
gemeenteraadsverkiezingen in Roosendaal ook op hun partij van keuze bij de Tweede Kamerverkiezingen. Voor het CDA is dit percentage 87 procent. De PvdA haalt met 97 procent weer een opmerkelijk hoog percentage. De VVD slaagt erin om 91 procent van haar stemmers bij de Tweede Kamerverkiezingen te behouden. In Breda zijn deze percentages voor deze partijen respectievelijk 97, 98 en 95 procent. Het onderzoek 'lokale democratie en bestuurlijke vernieuwing' uit 1991 geeft vergelijkbare gegevens. Zie hiervoor tabel 7.4.

Tabel 7.4: Kiesgedrag Tweede Kamerverkiezingen gerelateerd aan de gemeenteraadsverkiezingen, zeven gemeenten, 1991, in percentages.

\begin{tabular}{lrrrrrr}
\hline & Tot. & CDA & PvdA & VVD & D66 & GL \\
Amsterdam & 89 & 95 & 94 & 100 & 92 & 84 \\
Den Haag & 92 & 94 & 98 & 97 & 94 & 94 \\
Eindhoven & 88 & 95 & 87 & 93 & 86 & 50 \\
Nijmegen & 89 & 92 & 88 & 94 & 100 & 86 \\
Tilburg & 88 & 89 & 89 & 93 & 94 & 88 \\
Utrecht & 86 & 95 & 88 & 92 & 84 & 89 \\
Zwolle & 84 & 98 & 85 & 97 & 92 & 73
\end{tabular}

Bron: Onderzoeksgroep Lokale Democratie (1991).

Leesvoorbeeld: Van de stemmers die bij beide verkiezingen hun partijkeuze bepaald hebben, stemt in Amsterdam 89 procent dezelf́de partij bij de Tweede Kamerverkiezingen als bij de gemeenteraadsverkiezingen. Voor de CDA-stemmers bij de gemeenteraadsverkiezingen in Amsterdam is dat percentage 95 procent. $^{8}$

Voor alle gemeenten geldt dat gemiddeld bijna 90 procentvan de kiezers bij beide verkiezingen op dezelfde partij stemt. Dit geldt in nog sterkere mate voor de vier grootste partijen, aangezien 85 tot 100 procent van de stemmers op deze partijen bij de Tweede Kamerverkiezingen hetzelfde stemt als bij de gemeenteraadsverkiezingen. ${ }^{9} \mathrm{Al}$ zijn de verschillen tussen de grote partijen gering, met name de kiezers van het CDA en de VVD blijken bijzonder trouw. Evenals uit de landelijke onderzoeken blijkt dat Groen Links er in de minste mate in slaagt om haar kiezers bij de gemeenteraadsverkiezingen te behouden bij de Tweede Kamerverkiezingen. Uii een nadere beschouwing blijkt dat een relatief groot deel van de kiezers van Groen Links die een andere partij stemt bij de Tweede Kamerverkiezingen, op de PvdA stemt. Hetzelfde zagen wij al bij de landelijke kiezersonderzoeken. Bij deze andere partijkeuze bij de Tweede Kamerverkiezingen speelt waarschijnlijk een rol dat men op nationaal niveau door een stem uit te brengen op de PvdA de positie van de PvdA in de coalitie-onderhandelingen en in een mogelijke regering wilversterken. Op lokaal niveau spelen dergelijke machtspolitieke argumenten wellicht veel minder een rol, waardoor men eerder de partij van eerste keuze stemt. ${ }^{10} \mathrm{De}$ genoemde reden voor het verschillende kiesgedrag bij de gemeenteraadsverkiezingen heef dus wel te maken met het karakter van de gemeenteraadsverkiezingen maar niet met de plaatselijke politiek in de betreffende gemeente.

Al met al kunnen wij concluderen dat als lokale overwegingen al een rol spelen bij het kiesgedrag bij de gemeenteraadsverkiezingen, dit in zeer weinig gevallen leidt tot een andere partijkeuze. 


\subsection{Motieven voor kiesgedrag bij de gemeenteraadsverkiezingen}

Verreweg de meeste kiezers hebben in 1986 dezelfde partij gekozen bij de gemeenteraads- en Tweede Kamerverkiezingen. Daarbij kunnen wij dus concluderen dat er slechts in geringe mate sprake is van een lokaal kiesgedrag bij de gemeenteraadsverkiezingen. Dit betekent echter niet dat lokale overwegingen geen enkele rol hebben gespeeld bij de partijkeuze bij de gemeenteraadsverkiezingen. Ook al is het kiesgedrag bij de gemeenteraadsverkiezingen niet anders dan bij de Tweede Kamerverkiezingen, de attitude van de kiezer kan wel zeer verschillend zijn. Een kiezer kan bijvoorbeeld op grond van strikt lokale overwegingen toch dezelfde partij stemmen bij de gemeenteraadsverkiezingen als bij de Tweede Kamerverkiezingen. Het is dus noodzakelijk om te achterhalen in hoeverre bij de kiezers een lokale attitude heeft geleid tot een partijkeuze bij de gemeenteraadsverkiezingen.

Op twee manieren heeft men in lokaal kiezersonderzoek geprobeerd te achterhalen in hoeverre lokale overwegingen een rol hebben gespeeld bij de partijkeuze bij de gemeenteraadsverkiezingen. In de meeste gevallen wordt dit op een directe manier gevraagd aan de respondenten. Dit was bijvoorbeeld het geval in de AVRO/NIPO-enquêtes van 1982, 1986 en 1990. De resultaten hiervan staan in tabel 7.5.

Tabel 7.5: Invloed van lokale en landelijke politiek op de partijkeuze bij gemeenteraadsverkiezingen, 1982-1990, in percentages.

\begin{tabular}{lrrr}
\hline & 1982 & 1986 & 1990 \\
$\begin{array}{l}\text { Partijkeuze } \\
\text { bepaald door: }\end{array}$ & & \\
& 44 & 51 & 34 \\
Landelijke politiek & 20 & 18 & 33 \\
Lokale politiek & 14 & 15 & 9 \\
Beide ongeveer evenveel & 22 & 16 & 24 \\
Geen oordeel & &
\end{tabular}

Bron: AVRO/NIPO-nquétes 1982-1990.

Bij de gemeenteraadsverkiezingen in de periode 1982-1990 heeft de lokale politiek slechts bij een minderheid van de kiezers een belangrijke rol gespeeld bij de partijkeuze. Met name in 1986 is de invloed van de landelijke politiek sterk aanwezig. Daarmee wordt duidelijk dat de verwachte grote invloed van de geplande Tweede Kamerverkiezingen op de gemeenteraadsverkiezingen van 1986 zich inderdaad heeft voorgedaan. In 1990 is dit effect echter teniet gedaan, en zien wij zelfs dat bij ongeveer evenveel kiezers de lokale politiek bepalend is geweest voor hun partijkeuze bij de gemeenteraadsverkiezingen als de landelijke politiek. De gemeenteraadsverkiezingen van 1982 nemen een tussenpositie in, hetgeen overeenkomt met de landelijke politieke situatie van dat moment. Terwijl immers in 1986 al van te voren duidelijk was dat na de gemeenteraadsverkiezingen Tweede Kamerverkiezingen zouden volgen, en in 1990 dat niet het geval was, viel kort voor de gemeenteraadsverkiezingen van 1982 het kabinet zodat duidelijk werd dat na de gemeenteraadsverkiezingen van juni in september Tweede Kamerverkiezingen zouden plaatsvinden.

In vergelijking met 1982 zijn er in 1990 tevens meer kiezers die zeggen hun partijkeuze gebaseerd te hebben op de lokale politiek van hun partij. Toch blijft het ook in 1990 , met ruim 
40 procent van de kiezers, een minderheid die aangeeft dat lokale politieke overwegingen (mede) een rol hebben gespeeld bij hun partijkeuze bij de gemeenteraadsverkiezingen."

Wij hebben reeds geconstateerd dat in grote gemeenten het kjesgedrag bij de gemeenteraadsen Tweede Kamerverkiezingen in sterkere mate overeenkomt dan in kleinere gemeenten. Vooral de electorale steun van de lokale lijsten was daarbij van doorslaggevende betekenis. of dit tevens betekent dat in kleinere gemeenten meer kiezers hun partijkeuze bij de gemeenteraadsverkiezingen laten bepalen door de lokale politiek wordt duidelijk in tabel 7.6.

Tabel 7.6: Invloed van lokale en landelijke politiek op de partijkeuze bij de gemeenteraadsverkiezingen, per gemeentegrootte, 1982-1990, in percentages.

Partijkeuze

bepaald door:

inwoners

x 1.000

$\begin{array}{rrr} & < & 5 \\ 5 & - & 10 \\ 10 & - & 20 \\ 20 & - & 50 \\ 50 & - & 100 \\ 100 & - & 400 \\ & > & 400\end{array}$

Partijkeuze

bepaald door:

inwoners

$\mathrm{x} 1.000$ lokale politiek 198219861990 landelijke politiek

198219861990

$\begin{array}{rrrrrrrrr} & < & 5 & 14 & 14 & 0 & 19 & 20 & 50 \\ 5 & - & 10 & 17 & 21 & 17 & 18 & 11 & 27 \\ 10 & - & 20 & 16 & 17 & 7 & 20 & 16 & 27 \\ 20 & - & 50 & 15 & 15 & 11 & 17 & 16 & 24 \\ 50 & - & 100 & 23 & 14 & 6 & 18 & 16 & 24 \\ 100 & - & 400 & 14 & 8 & 6 & 21 & 18 & 19 \\ & > & 400 & 14 & 19 & 10 & 23 & 13 & 26\end{array}$

Bron: Secundaire analyse AVRO/NIPOenquêtes 1982-1990.

Uit de tabel kunnen wij opmaken dat in de regel geldt dat hoe groter de gemeente, hoe hoger het percentage kiezers is waarbij de landelijke politiek bepalend was voor de partijkeuze bij de gemeenteraadsverkiezingen en hoe lager het percentage kiezers is dat zegt het mees: benvloed te zijn door de lokale politiek van de partij van keuze. Opvallend is echter wel dat in de grootste gemeenten (meer dan 400.000 inwoners) meer kiezers hun keuze hebben laten bepalen door de lokale politiek dan in gemeenten met 100.000 à 400.000 inwoners. Voor de invloed van de landelijke politiek op de partijkeuze zien wij ook een dergelijke omslag in omgekeerde richting. Over de reden van deze omslag kunnen wij slechts speculeren. Wellicht 
zijn de grootstedelijke problemen van zo'n groot belang dat men bewuster een partijkeuze makkt bij de gemeenteraadsverkiezingen. Of misschien wordt er in de media meer aandacht geschonken aan de lokale politiek in de grootste steden, waardoor de lokale politiek bij meer kiezers een rol gaat spelen. Tevens kan van belang zijn dat in de grootste steden lokale lijsten een iets grotere rol spelen bij de gemeenteraadsverkiezingen dan in de middelgrote gemeenten. Niet alleen de grootste gemeenten laten een opmerkelijk beeld zien. Met name de allerkleinste gemeenten (met minder dan 5.000 inwoners) wijken over de hele linie sterk af van de overige gemeenten. De kleinste gemeenten hebben aanmerkelijk meer kiezers waarbij de lokale politiek van groot belang is voor de partijkeuze bij de gemeenteraadsverkiezingen. Tevens is het percentage kiezers dat een partijkeuze maakt op basis van de landelijke politiek veel geringer, met name in 1990 . Voor alle drie verkiezingen geldt dan ook dat alleen in de kleinste gemeenten meer kiezers zich bij hun partijkeuze laten leiden door de lokale politiek dan de landelijke politiek bij de gemeenteraadsverkiezingen. In 1990, als de lokale politiek een ongeveer even grote invloed uitoefent op de partijkeuze als de landelijke politiek, is overigens in alle gemeenten met minder dan 50.000 inwoners de lokale politiek van groter belang voor de partijkeuze dan de landelijke politiek.

\section{Lokale kiezersonderzoeken}

Ook in een aantal lokale kiezersonderzoeken op plaatselijk niveau is gevraagd naar de invloed van de lokale en landelijke politiek op de partijkeuze bij de gemeenteraadsverkiezingen. Uit een onderzoek naar de gemeenteraadsverkiezingen van 1986 in Breda blijkt dat ongeveer 12 procent van de kiezers zich bij de partijkeuze liet leiden door de politieke situatie in Breda. Ongeveer 68 procent liet zich leiden door de landelijke politieke voorkeur, terwijl bij 8 procent beide een rol speelden. Uit een onderzoek in Nijmegen in 1986 blijkt daarentegen dat 26 procent van de kiezers zich voornamelijk laat leiden door de gemeentelijke opstelling bij de partijkeuze bij de gemeenteraadsverkiezingen. Voor 23 procent gaf de landspolitieke opstelling van de partij van keuze de doorslag, terwijl 41 procent aangaf dat beide een even grote rol speelden. Dat dit laatste percentage zo hoog is in vergelijking met de resultaten van de andere kiezersonderzoeken komt waarschijnlijk door de vraagstelling ${ }^{12}$. Tenslotte is er nog in één onderzoek, in Nijmegen in 1982, gevraagd of en zo ja welke lokale gebeurtenissen van invloed zijn geweest bij de stemkeuze bij de gemeenteraadsverkiezingen. Ongeveer 23 procent van van de ondervraagden antwoordde hierop positief. Van deze 23 procent wist 23 procent nog niet wat men ging stemmen en 22 procent ging niet stemmen door een lokale gebeurtenis. Van de stemmers noemde aldus 20 procent een lokale gebeurtenis.

Naast de meer directe manier van vragen naar de lokale dan wel landelijke overwegingen om op de partij van keuze te stemmen bij de gemeenteraadsverkiezingen, is ook op een meer indirecte manier getracht de invloed van lokale overwegingen op de partijkeuze te achterhalen. In het onderzoek 'lokale democratie en bestuurlijke vernieuwing' van 1991 is nagegaan in hoeverre de stemmotieven bij de gemeenteraads- en Tweede Kamerverkiezingen met elkaar overeenkomen. ${ }^{13}$ Tevens is op basis van de antwoorden de aard van de stemmotieven bepaald. De resultaten van dit onderzoek staan in tabel 7.7. 
Tabel 7.7: Percentage kiezers in zeven gemeenten dat een lokaal of nationaal motief geeft voor de partijkeuze bij de gemeenteraadsverkiezingen en het percentage kiezers dat bij deze verkiezingen hetzelfde motief heeft als bij de verkiezingen voor de Tweede Kamer, 1991.

\begin{tabular}{lrcr}
\hline Motief: & lokaal & national & 2x hetzelfde m \\
Amsterdam & 3 & 4 & 63 \\
Den Haag & 2 & 4 & 60 \\
Eindhoven & 4 & 9 & 56 \\
Nijmegen & 6 & 7 & 45 \\
Tilburg & 3 & 6 & 42 \\
Utrecht & 4 & 12 & 44 \\
Zwolle & 5 & 11 & 39
\end{tabular}

Bron: Onderzoek 'lokale democratie en bestuurlijke vernieuwing' 1991.

Als alleen naar de stemmotieven bij de gemeenteraadsverkiezingen wordt gekeken, dan valt op dat in de zeven onderzochte gemeenten in de regel minder dan 5 procent van de ondervraagden een expliciet lokaal motief als belangrijkste reden noemt, terwijl tussen de 4 en 12 procent een expliciet nationaal motief noemt. Toch blijkt niettemin uit hetzelfde onderzoek dat bij ongeveer 50 procent van de ondervraagden het motief voor het kiesgedrag bij de gemeenteraadsverkiezingen niet overeenkomt met die bij de Tweede Kamerverkiezingen. Aangezien nauwelijks plaatselijke politieke motieven worden genoemd, is waarschijnlijk de andere aard van de genneenteraadsverkiezingen daarbij van belang. ${ }^{14}$ In dit kader is tevens opvallend dat in de zeven onderzochte gemeenten relatief veel kiezers geen reden wisten te noemen voor hun partijkeuze bij de gemeenteraadsverkiezingen. Hiermee komt tot uitdrukking dat voor relatief veel kiezers de lokale politiek van minder betekenis is.

Op grond van de bovenstaande onderzoeksresultaten kunnen wij concluderen dat maar weinig kiezers naar eigen zeggen uit expliciet lokale overwegingen op de partij van hun keuze stemmen bij de gemeenteraadsverkiezingen. Toch lijkt bij ongeveer de helft van de kiezers het helangrijkste motief voor hun partijkeuze bij de gemeenteraadsverkiezingen niet overeen te komen met die bij de Tweede Kamerverkiezingen. Mede op grond van een globale analy se van de verschillen in deze motieven voor de partijkeuze lijkt de aard van de gemeenteraadsverkie zingen daarbij een factor van betekenis te zijn. In die zin kunnen wij stellen dat de gemeente raadsverkiezingen op zich wel een zeker lokaal karakter hebben, maar dat de plaatselijke politiek daarbij van weinig betekenis is.

\subsection{Samenvattende conclusies}

In dit hoofdstuk hebben wij via het beschikbare lokale kiezersonderzoek een beeld geschetst van de mate waarin er bij de gemeenteraadsverkiezingen sprake is van lokaal kiesgedrag en de motieven voor het kiesgedrag bij deze verkiezingen. Daarbij moeten wij ons wel realiseren dat dit materiaal ons slechts in staat stelt om een voorlopig antwoord te geven op de vraag in hoeverre lokale overwegingen een rol spelen bij de partijkeuze bij dt gemeenteraadsverkiezingen. Immers, er is in de periode 1974-1990 relatief weinig kiezersonderzoek gedaan naar het kiesgedrag en de motieven hiervoor bij de 
gemeenteraadsverkiezingen. De conclusies van dit hoofdstuk zijn dan ook voornamelijk gebaseerd op kiezersonderzoek uit de tweede helft van de jaren tachtig en 1990/1991.

In 1986 heeft een meerderheid van de kiezers die bij zowel de gemeenteraads al Tweede Kamerverkiezingen gestemd heeft, op dezelfde partij gestemd. Dat geldt voor ongeveer 70 procent van de kiezers als wij een keuze voor een lokale lijst in de analyse betrekken, en voor 80 à 90 procent van de kiezers als wij ons enkel richten op degenen die een landelijke partij stemmen bij de gemeenteraadsverkiezingen. In 1991 blijkt uit een onderzoek in een zevental grote gemeenten dat ongeveer 90 procent van de kiezers die zegt bij beide verkiezingen te stemmen, een stem uitbrengt op dezelfde partij. De verschillen tussen de grootste vier partijen -CDA, PvdA, VVD,D66 - zijn op dit punt gering. Wij kunnen dus concluderen dat als lokale overwegingen al een rol hebben gespeeld bij de partijkeuze bij de gemeenteraadsverkiezingen, dit in slechts weinig gevallen leidt tot een andere partijkeuze.

Tevens kunnen wij uit het beschikbare kiezersonderzoek opmaken dat voor slechts een minderheid van de kiezers de lokale politiek doorslaggevend was bij hun partijkeuze bij de gemeenteraadsverkiezingen. Bij de onderzochte verkiezingen in de periode 1982-1990 gaf zelfs een groter deelvan de kiezers aan dat de landelijke politiek van hun partij de doorslag heeft gegeven bij hun partijkeuze. Dit is met name in 1986 het geval. In 1990 zien wij echter voor het eerst dat volgens ongeveer evenveel kiezers de lokale-als de landelijke politiek bepalend is geweest voor hun partijkeuze bij de gemeenteraadsverkiezingen. Uit het onderzoek in 1991 in zeven grote gemeenten blijkt dat minder dan 5 procent van de kiezers een expliciet lokaal motief noemt voor de partijkeuze bij de gemeenteraadsverkiezingen. Er zijn zelfs meer kiezers die bij deze verkiezingen een landelijk motief noemen als belangrijkste reden voor hun partijkeuze. Dat er waarschijnlijk voor veel kiezers wel een verschil is tussen de gemeenteraads- en de Tweede Kamerverkiezingen blijkt uit het feit dat in de zeven onderzochte gemeenten ongeveer de helft van de kiezers bij deze verkiezingen verschillende motieven geeft voor hun partijkeuze. Waarschijnlijk is dit onder meer te wijten aan de in de ogen van de kiezers andere aard van de gemeenteraadsverkiezingen. Plaatselijke politieke motieven werden immers nauwelijks genoemd. 


\section{NOTEN}

' Zie voor een overzicht van het gebruikte lokale kiezersonderzoek bijlage zes. Dat tevens kiezersonderzoek uit 1991 wordt gebruikt, is met name te wijten aan het onderzoek 'lokale democratie en bestuurlijke vernieuwing' dat in 1991 in zeven gemeenten is uitgevoerd. De reden voor de opname van dit onderzoek is dat dit een grootschalig kiezersonderzoek is dat zich speciaal richt op de betekenis van de lokale politiek voor de burgers in meerdere (grote) gemeenten.

2 Wel zal in bijlage vijf een overzicht worden gegeven van de resultaten van een vergelijking van het stemgedrag bij de gemeenteraads en Tweede Kamerverkiezingen. Zie hiervoor tabel 1 en 2.

3ierbij moet worden aangetekend dat bij het NKO het daadwerkelijke stemgedrag bij beide verkiezingen vergeleken is, terwijl bij de AVRO/ NIPO-enquête het stemgedrag bij de gemeenteraadsverkiezingen van 1906 vergeleken is met het voorgenomen stemgedrag bij de Tweede Kamerverkiezingen van 1986. Bij het NKO is dt vraag naar het kiesgedrag bij de onderscheiden verkiezingen direct na deze twee verkiezingen gesteld.

- Dat niet zoals in deel II nadrukkelijker de invloed van de lokale lijsten op het CDA tot uitdrukking komt, ligt mogelijk aan de relatief sterke ondervertegenwoordiging van CDA-stemmers en de lichte oververtegen woordiging van PvdA-stemmers in het NKO en de AVRO/NIPO-enquête. Tevens moet men rekening houden met de omstandigheid dat de berekende invloed van lokale lijsten op plaatselijke stempercentages niet hetzelfde is als de berekende invloed op het landelijke stempercentage.

${ }^{5} \mathrm{Bij}$ de berekening van de percentage constante kiezers gaan wij alleen uit van die respondenten die bij beide verkiezingen hebben gestemd, dan wel gingen stemmen en in het laatste geval ook wisten wat ze gingen stemmen. De categorie 'weet niet' is dus niet in de berekening meegenomen. De reden hiervoor is dat bij het NK0 en de AVRO/NIPO-enquête gevraagd is wat men heeft gestemd bij de gemeenteraadsverkiezingen en wat men zou gaan stemmen bij de verkiezingen voor de Tweede Kamer (AVRO/NIPO) of wat men bij deze verkiezingen heeft gestemd (NKO). Bij hetonderzoek Tokale democratie en bestuurlijke vernieuwing' is daarentegen bij beide verkiezingen gevraagd wat men zou gaan stemmen. Dit verschil is van belang omdat de categorie 'weet nie' groter is als men vraagt wat men gaat stemmen dan als men vraagt wat men onlangs heeft gestemd. Daarom is het onderzoek 'lokale democratie en bestuurlijke vernieuwing' moeilijk vergelijkbaar met de andere twee onderzoeken als wij tenminste de categorie 'weet niet' meenemen bij de berekening van het percentage kiezers dat bij de Tweede Kamerverkiezingen hetzelfde stemt als bij de gemeenteraadsverkiezingen. Om de vergelijkbaarheid te vergroten hebben wij ons dus beperkt tot de kiezers die bij beide verkiezingen hebben gestemd dan wel zouden stemmen en wisten wat men had gestemd dan wel wat men ging stemmen.

'Het verschil tussen het percentage van het NKO en de AVRO/NIPO-enquête wordt waarschijnlijk veroorzaakt door de relatief grote oververtegenwoordiging van kiezers in de AVRO/NIPO-enquête die op de lokale lijsten hebben gestemd bij de gemeenteraadsverkiezingen.

${ }^{7}$ In Roosendaal betrof het overigens een onderzoek in een wijk in deze gemeente. Zie hiervoor ook bijlage zes. - In de betreffende enquêtes is gevraagd wat men op dat moment zou stemmen als er gemeenteraads dan wel Tweede Kamerverkiezingen zouden zijn.

- De berekende percentages constante kiezers per gemeente zijn in verhouding met de percentages voor te afzonderlijke partijen relatief laag omdat de categorieën 'overige partijen' en 'weet niet' niet opgenomen zijn in de tabel, terwijl deze relatief laag scoren wat het percentage constante kiezers betreft. Opmerkelijk is dat men in het betreffende onderzoek de categorie 'weet niet' betrokken heeft bij de berekening van het percentage stabiele kiezers. Wij kunnen immers veronderstellen dat juist in deze categorie veel kiezers zitten met een wisselend kiesgedrag. Vandaar dat deze categorie niet meegenomen moet worden bij de berekening van het percentage constante kiezers bij de gemeenteraads- en Tweede Kamerverkiezingen. De berekende percentages zouden daarmee tot maximaal 4 procent verhoogd worden.

${ }^{10}$ Het enige onderzoek dat deze visie ondersteunt is een in 1986 gehouden kiezersonderzoek in Breda. Bij dit onderzoek is aan alle respondenten die bij de gemeenteraadsverkiezingen van 1986 op een ander partij stemden dan bij de Tweede Kamerverkiezingen gevraagd welke reden men daarvoor had. Van degenen die bij beide verkiezingen wisten wat ze gingen stemmen, bij de Gemeenteraadsverkiezingen Groen-Links hadden gestemi en bij de Tweede Kamerverkiezingen PvdA gingen stemmen, gaven allen als reden op dat ze het belangrijk vonden dat op nationaal niveau een partij met meer invloed sterk zou staan. Op lokaal niveau was dat niet 20 belangrijk waardoor men daar op de partij van eerste voorkeur stemde. Het betrof echter slechts vij. respondenten.

1: Tevens moeten wij bij de analyse van de gegevens rekening houden met de mogelijkheid dat een deel van de respondenten een sociaal-wenselijk antwoord geeft bij een dergelijke directe vraag. In dit geval zou dat betekenen 
dat een deel van de respondenten onterecht antwoordt dat de lokale politiek doorslaggevend was voor hun partijkeuze bij de gemeenteraadsverkiezingen. In dit kader is het interessant dat Miller in zijn onderzoek naar de Britse lokale politiek constateerde dat er een groot verschil is tussen het percentage kiezers dat zegt dat lokale. onderwerpen een rol hebben gespeeld bij de partijkeuze bij de gemeenteraadsverkiezingen, en het percentage kiezers dat daadwerkelijk een lokaal onderwerp kan noemen, toen daar naar gevraagd werd (Miller, 1988:15-23). i: Het verschil met de andere onderzoeken wordt waarschijnlijk veroorzaakt door de omstandigheid dat alleen. bijhet onderzoek in Nijmegen nadrukkelijk de mogelijkheid werd genoemd om te antwoorden dat zowel de lokale als de landelijke politiek van belang waren bij de partijkeuze bij de gemeenteraadsverkiezingen. Veel respondenten omzeilde door deze antwoordcategorie de keuze tussen de lokale of landelijke politiek als beslissende factor bij de partijkeuze. Bij de andere onderzoeken werd niet de mogelijkheid genoemd om te antwoorden dat zowel de lokale als de landelijke politiek in ongeveer gelijke mate van invloed zijn geweest.

${ }^{13}$ De antwoorden op de vraag waarom men op een bepaalde partij heeft gestemd, werden in 8 categorien ingedeeld, namelijk: belangenbehartiging, beginselen, partij, politicus, beleid, traditie, weet niet en overige motieven. Als bij de vraag naar de reden van de partijkeuze bij beiden verkiezingen een antwoord werd gegeven dat in dezelfde categorie viel, werd geconcludeerd dat het motief voor de partijkeuze bij beide verkiezingen hetzelfde is.

"In dit kader is het tevens van belang dat bij dit onderzoek aan de respondenten alleen gevraagd werd wat het belangrijkste motief was voor hun partijkeuze bij de twee verkiezingen. Men had dus slechts de mogelijkheid om én motief te noemen. Zeker als een kiezer meerdere redenen heeft om op een partij te stemmen, is het niet uitte sluiten dat bij toeval of door de aard van de verkiezingen bij de gemeenteraadsverkiezingen een ander motief wordtgegeven voor de partijkeuze dan bij de Tweede Kamerverkjezingen. Wellicht dat als, zoals in het Nationaal Kiezersonderzork, de mogelijkheid was geschapen om meerdere redenen voor de partijkeuze te noemen, er minder verschillen waren tussen de gegeven motieven bij beide verkiezingen. 



\section{DE BETROKKENHEID VAN KIEZERS BIJ DE LOKALE POLITIEK}

Uit de voorgaande hoofdstukken is gebleken dat wij op basis van het kiesgedrag bij de gemeenteraadsverkiezingen het lokale karakter van deze verkiezingen betrekkelijk laag moeten inschatten. Daarmee komt de vraag op waarom kiezers lokaal-politieke overwegingen slechts een betrekkelijk geringe rol laten spelen bij hun partijkeuze bij de gemeenteraadsverkiezingen. Om deze vraag te kunnen beantwoorden is het noodzakelijk een beter beeld te krijgen van de betrokkenheid van de kiezers bij de lokale politiek.

Politieke betrokkenheid is overigens een begrip in de politicologie waarmee een complex van gedragingen, meningen en houdingen van de burgers ten aanzien van de politiek wordt aangeduid. Er worden dan ook verschillende aspecten van politieke betrokkenheid onderscheiden. In een overzicht van lokaal kiezersonderzoek uit de periode 1974-1991 zullen wij daarom verschillende aspecten van betrokkenheid van kiezers bij de lokale politiek in kaart brengen. ${ }^{1}$ Om de gegevens van dit kiezersonderzoek in het juiste perspectief te zien, zullen wij deze zoveel als mogelijk vergelijken met gegevens van vergelijkbaar kiezersonderzoek naar de betrokkenheid van kiezers bij de landelijke politiek. Daarmee wordt duidelijk op welke gebieden en in welke mate de betrokkenheid bij de lokale politiek zich onderscheidt van die bij de landelijke politiek. Dat de betrokkenheid van kiezers bij de lokale politiek vanuit meerdere invalshoeken onderzocht dient te worden, wordt onder meer duidelijk als we de resultaten van twee benaderingswijzen naast elkaar zetten.

De eerste benadering neemt de opkomstcijfers bij de verkiezingen als uitgangspunt. Een mogelijke aanwijzing dat de betrokkenheid bij de lokale politiek geringer is dan de betrokkenheid bij de landelijke politiek zijn de lagere opkomstcijfers bij de gemeenteraadsverkiezingen. In de periode 1974-1990 was de opkomst bij de gemeenteraadsverkiezingen gemiddeld ongeveer 14 procent lager dan bij de Tweede Kamerverkiezingen. Uit tabel 8.1 kunnen wij tevens opmaken dat dit verschil niet voor alle gemeenten hetzelfde is. ${ }^{2}$ 
Tabel 8.1: Opkomst bij gemeenteraads- en Tweede Kamerverkiezingen per urbanisatiegraad, 1982-1986, in percentages.

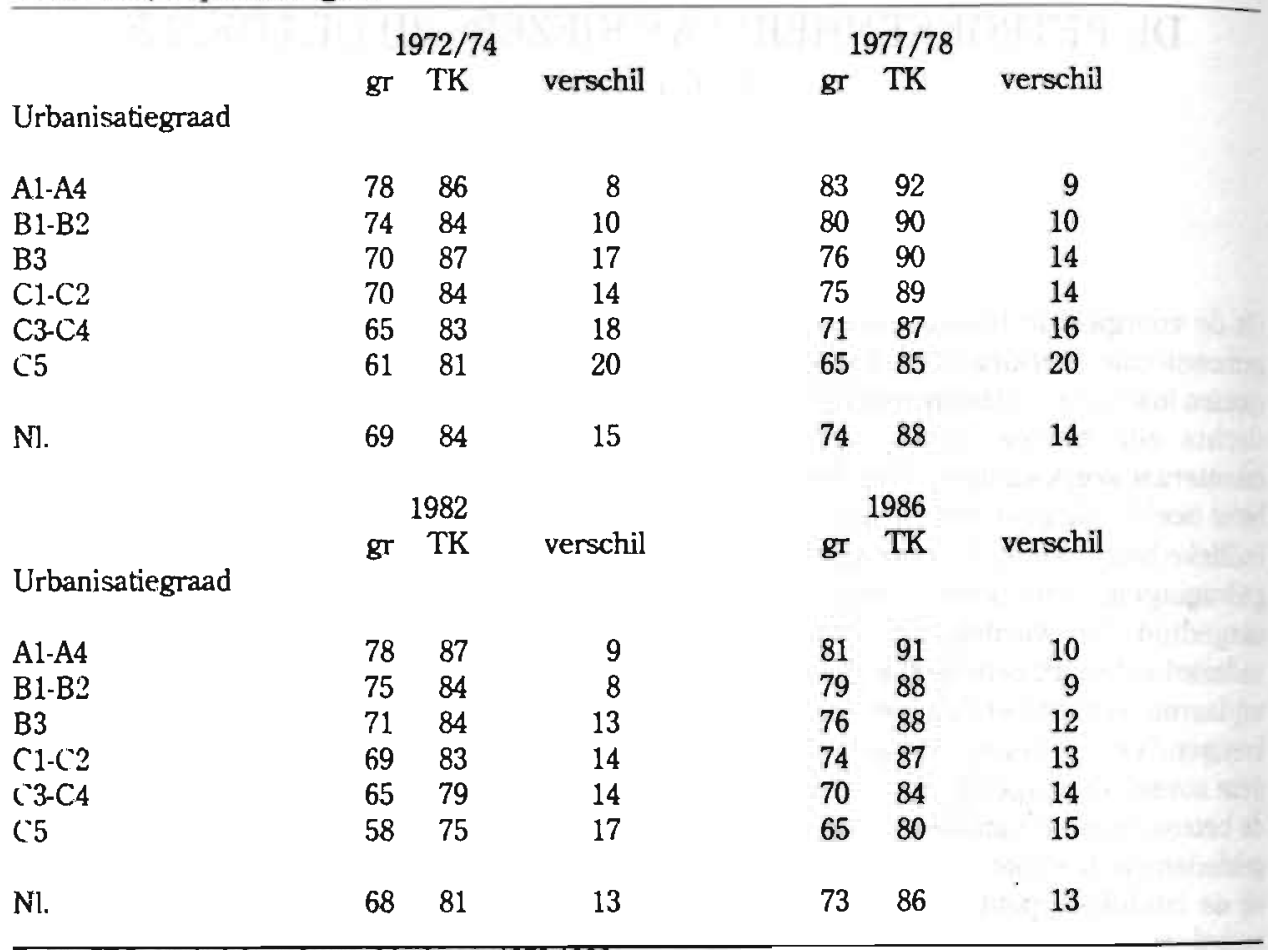

Bron: CBS, statistieken der verkiezingen 1972-1986.

Bij zowel de gemeenteraads- als de Tweede Kamerverkiezingen kunnen wij constateren dat in grote lijnen de opkomst hoger is als de gemeente minder inwoners telt. Met name bij de gemeenteraadsverkiezingen kunnen wij dit duidelijk constateren. Bij deze verkiezingen is het verschil tussen de hoogste en laagste opkomst bij de gemeentecategorieën dan ook duidelijk hoger dan bij de Tweede Kamerverkiezingen. Het bovenstaande leidt tot de conclusie dat hoe groter de gemeente, des te hoger het verschil in opkomst is tussen de gemeenteraads- en Tweede kamerverkiezingen. Wel lijken deze verschillen in de onderzochte periode enigszins kJeiner te worden. Zo was bij de verkiezingen van 1972/1974 het verschil tussen het hoogste en laagste verschil in opkomstcijfer bij beide verkiezingen 12 procentpunten ( 8 tegenover 20 procent). In 1986 was dit verschil verminderd tot 6 procentpunten ( 9 tegenover 15 procent). Kortom, als wij de opkomst bij de gemeenteraads- en Tweede Kamerverkiezing als maat van betrokkenheid bij de lokale en nationale politiek nemen, dan blijkt de betrokkenheid bij nationale politiek groter dan bij de lokale politiek. Dit geldt in sterkere mate in de grotere gemeenten dan in de kleinere gemeenten, al loopt het verschil tussen de verschillende categorieën gemeenten in de periode 1972-1986 enigszins terug.

De betrokkenheid van burgers kan niet alleen tot uitdrukking komen door de opkomst bij de verkiezingen maar ook door het uitbrengen van een voorkeurstem. Bij deze benadering wordi iedere stem op een andere kandidaat dan de lijsttrekker beschouwd als een bewuste keuze, 
hetgeen getuigt van een zekere betrokkenheid bij de lokale politiek en in ieder geval van een betrokkenheid bij éen van de lokale politici. Het CBS heeft tot aan de verkiezingen van 1982 het aantal voorkeurstemmen bij de verschillende verkiezingen geregistreerd. In tabel 8.2 wordt een overzicht gegeven van het percentage voorkeurstemmen bij de gemeenteraads-, Provinciale Staten- en Tweede Kamerverkiezingen in de periode 1972-1982.

Tabel 8.2: Percentage voorkeurstemmen bij de gemeenteraads-, Provinciale Staten-en Tweede Kamerverkiezingen in de periode 1972-1982.

\begin{tabular}{|c|c|c|c|c|c|}
\hline & 1972 & 1974 & 1977 & 1978 & 1982 \\
\hline Gr. & & 26,3 & & 27,0 & 28,4 \\
\hline PS. & & 21,7 & & 24,5 & 23,3 \\
\hline TK & 11,7 & & 8,3 & & 9,6 \\
\hline
\end{tabular}

Bron: CBS, Statistieken der verkiezingen 1972-1982.

Uit de tabel blijkt dat bij de gemeenteraadsverkiezingen relatief de meeste voorkeurstemmen worden uitgebracht, gevolgd door de Provinciale Statenverkiezingen. De Tweede Kamerverkiezingen blijven met ongeveer 10 procent voorkeurstemmen ver achter bij de 26 tot 30 procent bij de gemeenteraadsverkiezingen en de 21 tot 25 procent bij de Statenverkiezingen. Op basis van deze gegevens zouden wij dus moeten concluderen dat de betrokkenheid bij de lokale poltitiek groter is dan die bij de provinciale politiek en deze weer groter dan de betrokkenehid bij de nationale politiek. Deze volgorde is daarmee dus tegengesteld aan de volgordevan de drie soorten verkiezingen met betrekking tot de opkomst bij deze verkiezingen. In hoofdstuk 5 hebben wij namelijk gezien dat in de periode 1972-1982 de Tweede Kamerverkiezingen de hoogste opkomst kennen, gevolgd door de Statenverkiezingen en tenslotte de gemeenteraadsverkiezingen. Wellicht geven deze cijfers aan dat de Tweede Kamerverkiezingen belangrijker en interessanter worden gevonden, terwijl de afstand tot de politici geringer is bij de gemeenteraadsverkiezingen.

Opvallend is overigens dat met name in de provincie Limburg de percentage voorkeurstemmen zeer hoog zijn. Bij de gemeenteraadsverkiezingen ligt het percentage voorkeurstemmen in Limburg boven de 50 procent, terwijl het op eén na hoogste percentage met ongeveer 30 procent afkomstig is van de provincie Noord-Brabant. De oorzaak van ditverschil tussen deze twee provincies met allebij een sterke traditie van lokale (persoons) lijsten is onduidelijk. Mogelijk is hierbij van enige betekenis dat in Limburg relatief veel gemeenten bestaan uit meerdere dorpskernen, waarbij kiezers een voorkeurstem uitbrengen op een kandidaat uit hun eigen kern (Koning/Kuiper, 1991:201). Tevens mag niet uit het oog worden verloren dat in 1974 in Noord-Brabant het percentage kiezers dat op een lokale lijst heeft gestemd 20 procent lager was dan dat in Limburg.

In 1990 is het percentage voorkeurstemmen bij de gemeenteraadsverkiezingen in Limburg overigens gestegen tot 59,9 procent. Naast de stemmers op de lokale lijsten, brachten met name de stemmers op het CDA relatief veel voorkeurstemmen uit. In 1990 was het percentage voorkeurstemmen op een CDA-kandidaat 67,0 procent en op een kandidaat van een lokale lijst 64,8 procent (Koning/Kuiper, 1991:200-201). Op basis hiervan kunnen wij ons afvragen of nationale lijsten een even hoog percentage voorkeurstemmen kennen dan lokale lijsten. Tabel 8.3 geeft een overzicht van de percentages voorkeurstemmen voor de twee soorten lijsten bij 
de gemeenteraadsverkiezingen in de periode 1974-1982. Daarbij zijn de gegevens voor de provincie Limburg buiten beschouwing gelaten omdat het aantal stemmen dat op de lokale lijsten in Limburg is uitgebracht een relatief groot deel uitmaken van het totaal aantal uitgebrachte stemmen op de lokale lijsten in heel Nederland, waardoor het percentage voorkeurstemmen van de lokale lijsten sterk in opwaartse richting wordt beïnvloed. ${ }^{3}$

Tabel 8.3: Percentage voorkeurstemmen voor lokale en nationale lijsten bij de gemeenteraadsverkiezingen, 1974-1982.

\begin{tabular}{llll} 
& 1974 & 1978 & 1982 \\
Lokaal & 34,3 & 31,5 & 30,9 \\
Nationaal & 22,9 & 24,2 & 25,4 \\
Totaal & 24,5 & 25,0 & 26,0 \\
\hline
\end{tabular}

Bron: Databestand CELS.

Bij alle drie de gemeenteraadsverkiezingen is het percentage voorkeurstemmen op de lokale lijsten hoger dan die op de nationale lijsten. Het verschil wordt echter wel geringer in de onderzochte periode omdat het percentage voorkeurstemmen op de lokale lijsten iets daalde terwijl gelijkertijd het percentage voorkeurstemmen op de nationale lijsten een stijging kende. Wij kunnen op grond van deze gegevens de conclusie trekken dat de band tussen de stemmers op en de kandidaten van de lokale lijsten sterker lijkt dan de band tussen de stemmers op en de kandidaten van de nationale lijsten, al wordt dit verschil in de onderzochte periode kleiner.

Zoals reeds geconstateerd leidt een analyse van de opkomstcijfers tot een andere conclusie omtrent de mate van betrokkenheid van de kiezers bij de lokale politiek dan een analyse van het percentage voorkeurstemmen. De wijze waarop politieke betrokkenheid wordt gemeten is dus van groot belang voor de beoordeling van de politieke betrokkenheid van kiezers. Ook al staat bij zowel de analyse van de opkomstcijfers als de analyse van het percentage voorkeurstemmen het stemgedrag centraal, deverschillende resultaten geven aan dat in beide gevallen een andere vorm van politieke betrokkenheid wordt gemeten. Bij de analyse van de opkomstcijfers wordt waarschijnlijk het belang van en de interesse voor de verschillende verkiezingen gemeten, terwijl bij de analyse van de voorkeurstemmen de kennis van en afstand tot de politici een belangrijk element kan vormen. Naast (kies)gedrag kunnen dus ook meningen en attitudes van kiezers inzicht geven in de politieke betrokkenheid van kiezers. Via kiezersonderzoek zijn wij in staat om inzicht te krijgen in deze meningen en attitudes waardoor een vollediger beeld kan ontstaan van de politieke betrokkenheid van de burgers bij de (lokale) politiek.

In lokale kiezersonderzoeken wordt meestal niet op een directe manier aan de respondenten gevraagd of men zich betrokken voelt bij de lokale politiek. Een uitzondering is een onderzoek van Schonk in Lelystad in $1973 .{ }^{4}$ Van de ondervraagden gaf 4 procent aan dat men zich sterk betrokken voelde bij politieke zaken in Lelystad. Ongeveer 13 procent voelde zich enigszins betrokken, 5 procent nam een neutrale positie in, 13 procent voelde zich weinig betrokken en 65 procent was helemaal niet betrokken bij politieke zaken in Lelystad. Uit deze gegevens blijkt dat de betrokkenheid bij de lokale politiek in Lelystad gering was. Een tweede onderzoek 
waarin direct naar de betrokkenheid van de kiezers bij de lokale politiek werd gevraagd, betreft een onderzoek in opdracht van het dagblad Trouw in 1991. Daarin werd aan de genterviewden gevraagd of men zich meer betrokken voelde bij de landelijke, provinciale of lokale politiek. De meeste respondenten, namelijk 46 procent, waren het meest betrokken bij de landelijke politiek. Ook de betrokkenheid bij de lokale politiek was nog groot met 39 procent van de kiezers. Slechts 4 procent koos voor de provinciale politiek, terwijl een even groot percentage kiezers zich nergens bij betrokken voelde. Eveneens 4 procent maakte het allemaal niets uit, terwijl 3 procent het niet wist. Kortom, uit deze gegevens blijkt dat de betrokkenheid bij de lokale politiek niet veel minder is dan die bij de landelijke politiek. Het zal duidelijk zijn dat gezien het andere tijdstip, de andere populatie en de andere vraagstelling in beide onderzoeken wij geen duidelijk beeld kunnen krijgen van de betrokkenheid van de kiezers bij de lokale politiek in de periode 1974-1990.

Vandaar dat het noodzakelijk is om de aandacht te richten op lokaal kiezersonderzoek waarbij de politieke betrokkenheid van de kiezers gemeten wordt door verschillende aspecten van deze betrokkenheid aan de orde te stellen. In de volgende paragrafen zullen wij een overzicht geven van de belangrijkste resultaten van deze onderzoeken.

\subsection{Interesse in lokale en landelijke politiek}

In een onderzoek in 1990 gaf ruim 33 procent van de niet-stemmers aan dat desinteresse in de (lokale) politiek een rol heeft gespeeld bij het niet gaan stemmen bij de gemeenteraadsverkiezingen van 1990 (Haagsche Courant,1990). Interesse in de lokale politiek is dus een belangrijke factor bij het bepalen van de betrokkenheid van kiezers bij de lokale politiek.

Op landelijk niveau is er maar én kiezersonderzoek dat een duidelijk onderscheid maakt tussen interesse in lokale en landelijke politiek. Het betreft de eerder vermelde AVRO/NIPOenquêtes. Een overzicht van de resultaten van dit onderzoek staat in tabel 8.2.

De lokale politieke interesse blijkt in de jaren 1982-1990 geringer dan de interesse in de landelijke politiek. Opmerkelijk is overigens dat de interesse in de landelijke politiek duidelijk daalt, terwijl dat nauwelijks geldt voor de lokale politieke interesse. Voorts zien wij bij de landelijke politieke interesse een verschuiving van de categorie zeer geïnteresseerd naar de categorie tamelijk geïnteresseerd. Kortom, er is meer interesse in de landelijke politiek dan in de lokale politiek maar het verschil is in de periode 1982-1990 verminderd door een afnemende interesse in de landelijke politiek. ${ }^{5}$ 
Tabel 8.4: Interesse in lokale en landelijke politiek, 1982-1990, in percentages.

Lokale politiek:

$1982 \quad 1986 \quad 1990$

zeer geïnteresseerd

tamelijk geïnteresseerd

weinig geïnteresseerd

niet geïnteresseerd

11

34

33

22

1982

Landelijke politiek:

zeer geïnteresseerd tamelijk geinteresseerd weinig geïnteresseerd niet geïnteresseerd

$\mathrm{N}$

\section{7}

37

19

17

1108 1986 1990

Bron: AVRO/NIPO-nquêtes 1982-1990.

De opkomstcijfers gaven aan dat in de kleinere gemeenten de opkomst niet alleen hoger is dan in de grotere gemeenten, maar tevens dat dit effect nog sterker is bij de gemeenteraadsverkiezingen dan bij de Tweede Kamerverkiezingen. Betekent dit nu ook dat in de kleinere gemeenten de interesse voor de lokale politiek hoger is dan in de grotere gemeenten?

Tabel 8.5: Percentage kiezers met zeer veel of tamelijk veel interesse in de lokale dan wel landelijke politiek, 1982-1990.

\begin{tabular}{|c|c|c|c|c|c|c|c|c|c|}
\hline $\begin{array}{l}\text { aantal inv } \\
\times 1.000\end{array}$ & $\begin{array}{l}\text { lok. } \\
\text { rs }\end{array}$ & $\begin{array}{l}982 \\
\text { land. }\end{array}$ & $+1-$ & lok. & $\begin{array}{l}1986 \\
\text { land. }\end{array}$ & $+1-$ & lok. & $\begin{array}{l}1990 \\
\text { land. }\end{array}$ & +1 \\
\hline$<5$ & 46 & 65 & -19 & 58 & 55 & +3 & 50 & 33 & +17 \\
\hline $5-10$ & 56 & 69 & -13 & 50 & 65 & -15 & 49 & 45 & +4 \\
\hline 10.20 & 43 & 57 & -14 & 40 & 58 & -18 & 43 & 47 & -4 \\
\hline $20-50$ & 43 & 65 & -22 & 42 & 64 & -22 & 40 & 51 & -11 \\
\hline $50-100$ & 43 & 66 & -23 & 39 & 64 & -25 & 34 & 49 & -15 \\
\hline $100-400$ & 40 & 61 & -21 & 41 & 67 & -26 & 40 & 57 & -17 \\
\hline 400 & 53 & 73 & -20 & 58 & 73 & -15 & 41 & 58 & -17 \\
\hline
\end{tabular}

Bron: Secundaire analyse AVRO/NIPO-enquétes 1982-1990.

Toelichting: lok.= interesse in lokale politiek

land- interesse in landelike politiek

$+/=$ verschil tussen beiden 
Uit de gegevens in tabel 8.5 kunnen wij opmaken dat in 1982 en 1986 de interesse in de lokale politiek in gemeenten met minder dan 10.000 inwoners en met meer dan 400.000 inwoners groter is dan in de overige gemeenten. ${ }^{6}$ Vooral voor de grootste gemeenten is deze conclusie opmerkelijk, aangezien de opkomst in deze gemeenten het laagst is. Ook valt op dat in 1990 de belangstelling voor de lokale politiek in de grootste gemeenten sterk gedaald is, waardoor deze op gemiddeld niveau is komen te liggen. De kiezers in de gemeenten met 50 à 100.000 inwoners blijken in de periode $1982-1990$ het minst geinteresseerd te zijn in de lokale politiek. De belangstelling voor de landelijke politiek blijkt in 1990 in alle gemeenten sterk gedaald in vergelijking met 1986 . Wel blijven de kiezers in de grootste gemeenten het meest geïnteresseerd in de landelijke politiek. In grote lijnen, met uitzondering van de kleinste gemeenten in 1982 en de grootste gemeenten in 1986, kunnen wij constateren dat het verschil in belangstelling voor de lokale en landelijke politiek groter is in de grotere gemeenten dan in de kleinere gemeenten. In de kleinste gemeenten is zelfs vanaf 1986 de interesse in lokale politiek groter. In 1990 geldt dat ook in gemeenten met 5 à 10.000 inwoners. Behalve voor de grootste gemeenten geldt dat in de periode 1982-1990 het verschil in interesse voor de lokale en landelijke politiek gedaald is.

Naast dit landelijk onderzoek is er ook in verschillende gemeenten plaatselijk onderzoek verricht naar de interesse in de lokale politiek. Het merendeel van deze onderzoeken vond plaats in de jaren tachtig en negentig. Een uitzondering hierop is een onderzoek in twaalf gemeenten in $1974 .^{7}$

Tabel 8.6: Percentage kiezers in een aantal gemeenten dat zegt interesse te hebben in problemen die de gemeentelijke of landelijke politiek betreffen, 1974 .

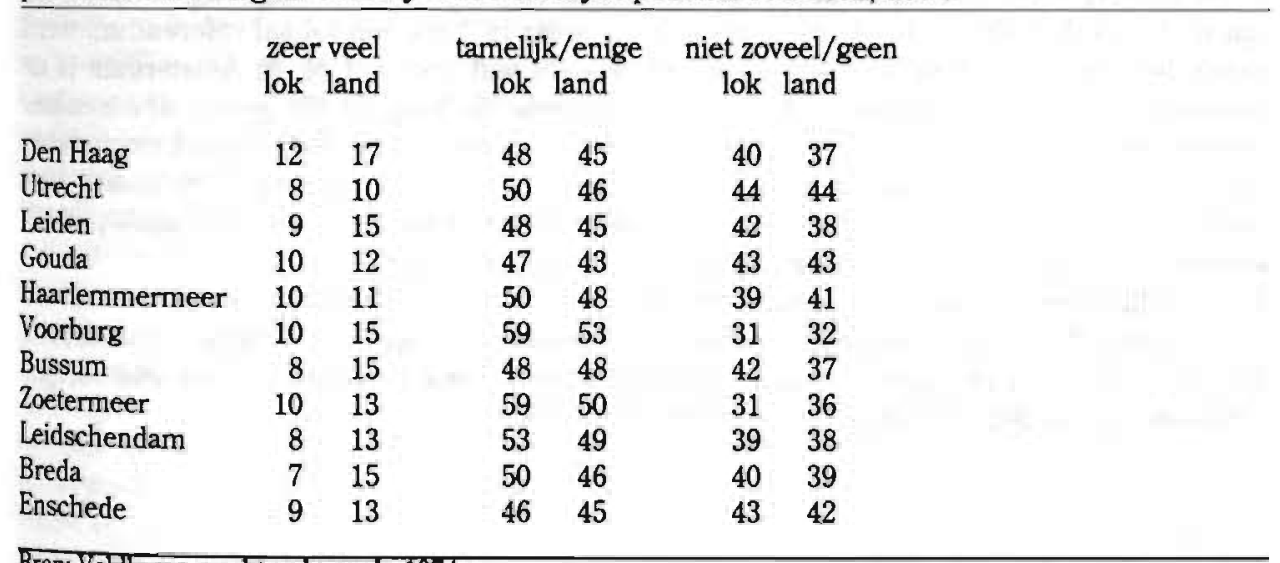

Bron: Veldkamp marktonderzoek, 1974.

Zoals uit tabel 8.6 blijkt, is in deze gemeenten de interesse voor problemen die de landelijke politiek betreffen in de regel wat hoger dan voor problemen die de lokale politiek betreffen. Met name zijn er meer kiezers die zeer veel interesse hebben voor landelijke politieke problemen in vergelijking met lokale politieke problemen.

In 1986 is in een onderzoek in Breda gevraagd in hoeverre men de gemeentepolitiek volgde. Van de ondervraagden gaf 12 procent aan dat men de gemeentepolitiek (vrij) intensief volgde. 
Naar eigen zeggen volgde 41 procent de gemeentepolitiek een beetje, terwijl 47 procent de gemeentepolitiek helemaal niet volgde. Uit een onderzoek in 1987 in Delft blijkt dat 30 procent van de respondenten geïnteresseerd is in plaatselijke politieke onderwerpen. In Nijmegen blijkt uit een lokaal kiezersonderzoek in 1990 dat 53 procent van de ondervraagden zeer of wel wat geïnteresseerd is in de Nijmeegse politiek.

Tabel 8.7: Percentage (zeer of tamelijk) geïnteresseerden in de lokale politiek of de politiek in zijn algemeenheid, in tien gemeenten, 1991.

$$
\text { lokale politiek politiek algemeen }
$$

$\begin{array}{lll}\text { Almere } & 43 & 59 \\ \text { Haarlem } & 63 & 74 \\ \text { Leiden } & 55 & 73 \\ \text { Amsterdam } & 57 & 69 \\ \text { Eindhoven } & 43 & 66 \\ \text { Den Haag } & 48 & 57 \\ \text { Nijmegen } & 47 & 64 \\ \text { Tilburg } & 36 & 59 \\ \text { Utrecht } & 43 & 66 \\ \text { Zwolle } & 45 & 63\end{array}$

Bronnen: VNG (1991), van Holsteyn en Hillebrand (1991), OnderzoeksgToep Lokale Democratie (1991).

Zoals wij uit tabel 8.7 kunnen opmaken blijkt uit de gegevens van een tiental lokale kiezersonderzoeken uit 1991 dat in de regel 40 á 50 procentvan de ondervraagden geïnteresseerd zijn in de lokale politiek. In Haarlem en Leiden, waar in 1991 een lokaal referendum werd gehouden was deze interesse met 63 en 55 procent wat hoger. Ook in Amsterdam is de interesse voor de lokale politiek met 57 procent opmerkelijk hoog. In alle gemeenten is echter de interesse in de politiek in zijn algemeenheid hoger. In Eindhoven, Tilburg en Utrecht is he: verschil met de interesse voor de lokale politiek zelfs meer dan 20 procent. Kortom, ook deze cijfers geven aan dat in ieder geval in de grote gemeenten de interesse voor de lokale polititek achterblijft bij de interesse voor de politiek in zijn algemeenheid.

In verschillende onderzoeken is ook aan de respondenten gevraagd of men meergeinteresseerd is in lokale politiek dan in landelijke politiek. Het betreft onderzoeken in Almere, Dordrecht, Zaanstad en de zeven gemeenten in het onderzoek 'lokale democratie en bestuurlijke vernieuwing” uit 1991. Zie voor de resultaten tabel 8.8 . 
Tabel 8.8: Antwoord op de vraag of men een grotere interesse heeft in de lokale of de nationale poltiek, in 10 gemeenten, in percentages, 1989-1991.

$\begin{array}{lrrrr} & \text { lok. } & \text { land. } & \text { beide } & \text { geen } \\ \text { Dordrecht'89 } & 6 & 30 & 45 & 19 \\ \text { Zaanstad'90 } & 5 & 24 & 40 & 32 \\ \text { Almere '91 } & 12 & 45 & 19 & 24 \\ \text { Amsterdam'91 } & 7 & 41 & 34 & 15 \\ \text { Eindhoven'91 } & 6 & 49 & 27 & 17 \\ \text { Den Haag'91 } & 9 & 35 & 34 & 20 \\ \text { Nijmegen'91 } & 7 & 50 & 26 & 18 \\ \text { Tilburg '91 } & 8 & 43 & 26 & 22 \\ \text { Utrecht '91 } & 8 & 54 & 23 & 14 \\ \text { Zwolle '91 } & 6 & 50 & 33 & 11\end{array}$

Bronnen: Gemeente Dordrecht (1989), Gemeente Zaanstad (1991), VNG (1991), Onderzoeksgroep Lokale Democratie (1991).

Wij kunnen constateren dat maar zeer weinig kiezers een grotere interesse hebben in de lokale politiek dan in de landelijke politiek. Ongeveer 5 à 10 procent van de kiezers is het meest geïnteresseerd in de lokale politiek. Met een percentage van 12 procent is de interesse voor de lokale politiek in Almere het hoogst van de tien gemeenten. Een grotere interesse in de landelijke politiek had in de meeste gemeenten ongeveer 45 a 50 procent van de kiezers. In Dordrecht, Zaanstad en Den Haag is deze voorkeur voor de landelijke politiek in mindere mate aanwezig. In de eerste twee gemeenten is daarentegen met een percentage van 40 en 45 procent een relatief grote groep kiezers in ongeveer dezelfde mate geïnteresseerd in de lokale en landelijke politiek. In de andere gemeenten is dit percentage ongeveer 25 à 35 procent. Ongeveer 10 à 20 procent van de kiezers had helemaal geen belangstelling voor lokale en landelijke politiek. Ook in deze categorie heeft Zaanstad met 32 procent een opmerkelijk hoog percentage.

Opvallend is ook het verschil tussen de interesse in plaatselijke onderwerpen en plaatselijke politieke onderwerpen, zoals dat naar voren komt in het onderzoek in Almere. Daaruit blijkt dat 80 procent van de ondervraagden tamelijk tot zeer geïnteresseerd is in plaatselijke onderwerpen, terwijl dat maar voor 43 procent geldt als het gaat om plaatselijke politieke onderwerpen. In het onderzoek wordt dan ook geconcludeerd dat het lokale politieke bedrijf de burgers niet kan boeien. Overigens gaf 59 procent van de ondervraagden aan dat men tamelijk tot zeer geïnteresseerd is in nationale politieke onderwerpen.

Interesse in de lokale en landelijke politiek is ook te meten door na te gaan in hoeverre men lokaal of nationaal (politiek) nieuws in de kranten leest. Op landelijk niveau is een dergelijke vraag opgenomen in het onderzoek 'culturele veranderingen in Nederland' van het Sociaal en Cultureel Planbureau. De resultaten van dit onderzoek staan in tabel 8.9. 
Tabel 8.9: Percentages inwoners (16-74-jarigen) dat vaak of (bijna) altijd binnenlands nieuws of nieuws over de eigen woonplaats leest in de krant, 1975-1987.

\begin{tabular}{lrrrrrr}
\hline & 1975 & 1980 & 1983 & 1985 & 1986 & 1987 \\
binnenland & 50 & 53 & 54 & - & 48 & 47 \\
woonplaats & 73 & 73 & 70 & 73 & 71 & 72 \\
\hline
\end{tabular}

Bron: SCP, culturele veranderingen in Nederland, 1975-1987

Bij de interpretatie van deze gegevens moeten wij ons wel realiseren dat hier niet gevraagd wordt naar de interesse naar politiek nieuws, maar naar een algemene belangstelling voor binnenlands nieuws of nieuws over de eigen woonplaats. De interesse voor lokaal nieuws in de krant is door de jaren heen ongeveer 20 procent hoger dan de interesse voor binnenlands nieuws. Hieruit kunnen wij concluderen dat er sprake is van een relatief sterke betrokkenheid bij hetgeen in de eigen woonplaats gebeurt. Het SCP is op basis van bovenstaande gegevens voor de periode 1975-1986 nagegaan of er op dit punt duidelijke verschillen zijn tussen verschillende soorten gemeenten. Uit deze analyse blijkt dat in kleine plattelandsgemeenten in het noorden of Zeeland iets minder vaak binnenlands nieuws wordt gelezen dan in andere gemeenten. Daar staat tegenover dat in deze gemeenten en in verstedelijkte plattelandsge. meenten in het zuiden of oosten meer dan gemiddeld nieuws van de eigen woonplaats wordt gelezen. In de grote steden in het westen van het land wordt daarentegen iets minder dan gemiddeld dit nieuws gelezen (SCP,1987:88).

Ook in een aantal lokale kiezersonderzoeken is gevraagd naar de mate waarin men binnenlands nieuws of nieuws over de eigen woonplaats leest in de krant. Uit het onderzoek in Lelystad in 1974 blijkt dat 82 procent van de ondervraagden (bijna) altijd of vaak nieuws over hun woonplaats in de krant lezen. Voor binnenlands nieuws geldt hetzelfde voor slechts 54 procent. In een onderzoek in Tilburg in 1982 geeft 54 procentvan de respondenten aan dat men wel eens wat leest over de plaatselijke politiek. En in Amsterdam antwoordde in 199170 procent van de ondervraagden dat men altijd of tamelijk vaak het nieuws over Amsterdam in de krant leest. In Almere geldt dat voor 60 procentvan de ondervraagden, terwijl maar 32 procent (bijna) altiji Nederlands nieuws in de krant leest. Kortom, uit de beschikbare onderzoeken blijkt dat burgers sterk geïnteresseerd zijn in nieuws over hun eigen woonplaats, zeker in vergelijking met het binnenlandse nieuws.

Concluderend kunnen wij stellen dat kiezers meer geïnteresseerd zijn in de landelijke politiek dan in de lokale politiek. Door de geconstateerde afnemende interesse voor de landelijke politiek wordt dit verschil geringer. Voorts hebben wij geconstateerd dat in de kleinste en de allergrootste gemeenten de belangstelling voor de lokale politiek hoger dan gemiddeld is. In 1990 geldt dat echter niet meer voor de grootste gemeenten. In dat jaar zijn er in de gemeenten met minder dan 10.000 inwoners meer kiezers die interesse hebben in de lokale dan in de nationale politiek. In de andere gemeenten, behalve de grootste gemeenten, is dit verschil in de periode 1982-1990 verkleind. Opvallend is overigens dat meer burgers belangstelling hebben voor het lokale nieuws dan het landelijke nieuws in hun krant. Met name in de plattelandsgemeenten is dit het geval. De interesse in lokaal politiek nieuws lijkt echter wee? duidelijk geringer. Blijkbaar is er wel degelijk sprake van een grote betrokkenheid bij de eigen woonplaats, maar geldt dat in veel mindere mate voor de lokale politiek. 


\subsection{Kennis van lokale en landelijke politiek}

Wij hebben kunnen constateren dat de kiezers in zijn algemeenheid minder geinteresseerd zijn in de lokale- dan in de landelijke politiek. Betekent dit tevens dat men minder kennis heeft van de lokale politiek? Deze vraag kan alleen beantwoord worden door lokaal kiezersonderzoek uit de verschillende gemeenten te beschouwen. Devragen naar de kennis van de kiezers richten zich op drie aspecten. In de meeste kiezersonderzoeken wordt gevraagd naar de kennis van lokale politici. Daarnaast worden wel eens vragen gesteld over de kennis van de lokale politieke situatie. Tenslotte is wel eens gevraagd naar de kennis van lokale politieke onderwerpen. Deze drie aspecten van politieke kennis zullen in deze paragraaf aan bod komen.

In de meeste onderzoeken waarin men de kennis van lokale politiek wil meten, wordt gevraagd de naam te noemen van de burgemeester en de wethouders. Zoals uit de gegevens in tabe] 8.10 blijkt is in 1974 in een aantal gemeenten ook gevraagd of men een raadslid kan noemen en of men weet welke partij de grootste partij in de gemeenteraad is.

Tabel 8.10: Percentage kiezers in een aantal gemeenten dat de naam van de burgemeester, minstens één wethouder, minstens één raadslid of de grootste partij in de gemeenteraad weet, 1974.

\begin{tabular}{lcccc}
\hline & burgemeester & wethouder & raadslid & partij \\
Den Haag & 87 & 34 & 7 & 53 \\
Utrecht & 62 & 44 & 10 & 54 \\
Leiden & 80 & 48 & 17 & 62 \\
Gouda & 85 & 61 & 27 & 56 \\
Haarlemmermeer & 70 & 31 & 26 & 6 \\
Voorburg & 86 & 38 & 47 & 32 \\
Bussum & 74 & 36 & 23 & 28 \\
Zoetermeer & 83 & 57 & 29 & 26 \\
Leidschendam & 94 & 52 & 23 & 50 \\
Breda & 83 & 40 & 22 & 43 \\
Enschede & 82 & 60 & 26 & 65 \\
Bron:Verdkamp & & & &
\end{tabular}

Bron: Veldkamp marktonderzock, 1974.

In de onderzochte elf grote gemeenten blijkt in 1974 de burgemeester veel bekender dan de wethouders. De burgemeester is daarom de meest bekende lokale politicus. Het verschil in bekendheid tussen de burgemeester en én van de wethouders is in Den Haag zelfs meer dan 50 procent. Ook in Voorburg, Leidschendam en Breda is het verschil met meer dan 40 procent opmerkelijk hoog. In de andere gemeenten is het verschil tussen de 20 en 40 procent. Het zal ons nietverbazen dat in alle gemeenten behalve Voorburg meer kiezers een wethouder kennen dan een (ander) raadlid. Behalve Haarlemmermeer is het verschil in alle gemeenten meer dan 20 procent. In het algemeen weten meer kiezers welke partij de grootste is in de gemeenteraad van hun gemeente. Opvallend is hier het lage percentage van 6 procent in Haarlemmermeer. In Zoetermeer, Bussum en Voorburg weet een kwart tot een derde van de kiezers welke partij 
de meeste zetels heeft in de gemeenteraad. In alle andere gemeenten is dat bekend bij meer dan de helft van de kiezers.

In hoeverre zijn bovenstaande gegevens omtrent de politieke kennis van de kiezers veranderd in de periode 1974-1991? Tabel 8.11 geeft ons hiervan enigszins een beeld. Hierin staan de resultaten van kiezersonderzoek dat in de jaren tachtig en 1990/1991 in een aantal grote gemeenten is verricht, waarbij tevens gevraagd werd naar de naam van de burgemeester en de wethouders.

Tabel 8.11: Kennis van de naam van de burgemeester en minstens éen wethouder in een aantal gemeenten, 1982-1990, in percentages.

Burgemeester

$\begin{array}{ll}\text { Tilburg } & ' 82 \\ \text { Nijmegen } & ' 82 \\ \text { Roosendaal } & ' 86 \\ \text { Breda } & ' 86 \\ \text { Leeuwarden } & ' 90 \\ \text { Nijmegen } & ' 90 \\ \text { Almere } & ' 91 \\ \text { Amsterdam } & ' 91 \\ \text { Eindhoven } & ' 91 \\ \text { Den Haag } & ' 91 \\ \text { Nijmegen } & ' 91 \\ \text { Tilburg } & ' 91 \\ \text { Zwolle } & ' 91\end{array}$

wethouder

58

40

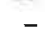

$-$

48

51

35

32

32

29

45

40

45

Bronnen: Biemans (1982), Braat en Gerrichhauzen (1986), de Bock en van der Veen (1986), de Boer e.a. (1900), Biemans en van der Putten (1990), Onderzoeksgroep Lokale Democratie (1991).

Ook in de jaren tachtig en negentig blijkt, in ieder geval in de grotere gemeenten, de burgemeester verreweg de meest bekende lokale politicus te zijn. Het percentage kiezers dat de naam van de burgemeester kent is minstens 20 en in Amsterdam en Eindhoven zelfs 50 procent hoger dan het percentage kiezers dat de naam kent van éen of meerdere wethouders De kennis van de afzonderlijke wethouders is dikwijls nog veel lager dan de percentages in de tabel. Zo blijkt uit het onderzoek 'Lokale democratie en bestuurlijke vernieuwing' dat meer dan de helft van de wethouders in de onderzochte gemeenten bij minder dan 10 procent van de inwoners bekend zijn. Uit het onderzoek in Roosendaal blijkt daarentegen dat elke wethouder bekend was bij 25 á 50 procent van de kiezers, hetgeen een aanwijzing is dat in de kleinere gemeenten relatief meer kiezers de belangrijkste lokale politici kennen.

In enkele onderzoeken is gevraagd of men gemeenteraadsleden dan wel de lijsttrekkers bijde gemeenteraadsverkiezingen kende. In Lelystad was 62 procent van de ondervraagden in star om éen of meer namen te noemen van adviesraadsleden. Uit het onderzoek in Tilburg van 1982 blijkt dat 19 procent van de ondervraagden de naam kon noemen van één of meer raadsledert In Breda waren de lijsttrekkers van de grootste partijen in 1986 maar bekend bij 1 procentvan de kiezers. En ongeveer 25 procent van de respondenten bij het Nijmeegs onderzoek in 1900 wist eén of meer lijsttrekkers te noemen. In Leeuwarden kon in datzelfde jaar maar 18 procent 
van de kiezers de naam noemen van de lijsttrekker van de partij waarop men ging stemmen bij de gemeenteraadsverkiezingen. ${ }^{9}$

Al met al geldt in ieder geval voor de grote gemeenten dat met uitzondering van de burgemeester de lokale politici niet erg bekend zijn bij de lokale kiezers. Daarbij zijn de lijsttrekkers en overige raadsleden waarschijnlijk nog minder bekend dan de wethouders. In zekere zin is dit ook niet verbazingwekkend aangezien de burgemeester in de regel meer naar buiten treedt dan de individuele wethouders en deze weer meer dan individuele raadsleden. Tevens kan een rol spelen dat na elke raadsverkiezing weer andere raadsleden gekozen kunnen worden als wethouder. Er is dus sprake van een grotere doorstroming van wethouders dan van de burgemeester. Dat deze factor mogelijk van invloed is, is ook op te maken uit de tabel. In de kiezersonderzoeken die kort na de gemeenteraadsverkiezingen zijn uitgevoerd, zoals die in Delft en de onderzoeken uit 1991, zien wij immers een relatief laag percentage kiezers dat eén of meer wethouders kan noemen.

Om bovenstaande gegevens op hun waarde te kunnen schatten is een vergelijking met gegevens over de landelijke politiek noodzakelijk. Gezien de verschillen tussen de lokale en landelijke politiek zijn volledig vergelijkbare gegevens niet beschikbaar. Wel is er enige overeenkomst met de vraag bij de nationale kiezersonderzoeken van 1977 en 1981 of men wist wie de landelijk politicus was op een aantal getoonde foto's. Daarbij werd tevens gevraagd naar departij en functie van de betreffende politicus. Uit deze onderzoeken blijkt dat in 1977 en 1981 bijna alle ondervraagden de lijsttrekkers van de drie grootste partijen herkenden en dat ook meer dan 90 procent van hen de partij van de betreffende politicus kon noemen (Irwin,1983:187). Deze cijfers zullen niet verbazen gezien de grote aandacht voor deze politici in de media. Duidelijk zal zijn dat de lokale politiek wat dat betreft sterk in de schaduw staat van de landelijke politiek. De beoordeling van de kennis van de landelijke politici wordtgenuanceerder als wij ons richten op de kennis van anderen dan de lijsttrekkers van de drie grootste partijen. In 1977 waren Terlouw en van Kemenade bekend bij respectievelijk 48 en 31 procent van de kiezers (Verhoef,1977:89). In 1982 herkende bijvoorbeeld 50 procent de foto van kamervoorzitter Dolman, 28 procent die van ex-staatssecretaris Dales en 27 procent die van minister Zeevalking (van der Eijk e.a., 1983:80-87).

Naast de vragen naar de kennis van de lokale politici is in een aantal onderzoeken aandacht geschonken aan de kennis van de lokale politieke situatie. Zo is in het onderzoek naar de lokale. politiek in Nijmegen in 1982 gevraagd of men de namen van de politieke partijen kon noemen die in het College van $B \& W$ vertegenwoordigd waren. Ongeveer de helft van de respondenten gaf als foutief antwoord dat de PvdA éen van de college-partijen was. Meer dan 10 procent van. de kiezers dacht dat de PPR in het college zat, terwijl dat niet het geval was. Voor de PSP gold hetzelfde. En ongeveer 5 procent van de respondenten gaf als foutief antwoord dat de SP of de $\mathrm{CPN}$ in het college vertegenwoordigd waren. Men concludeert dan ook dat blijkbaar veel genterviewden niet het verschil kennen tussen het College van $B \& W$ en de gemeenteraad. In 1990 zien wij echter dat veel meer respondenten de samenstelling van het College van B\&W van Nijmegen kennen. Ruim 70 procent weet aan te geven dat PvdA en CDA deel uit maken van het College van B\&W. In Leeuwarden weet in 199031 procent de juiste samenstelling van het College van $B \& W$. Uit dit onderzoek blijkt voorts dat ongeveer 60 procent van de kiezers wist dat de PvdA de grootste partij was in de gemeenteraad.

In een aantal onderzoeken in 1991 is gevraagd naar de kennis van een aantal actuele politieke onderwerpen in de gemeenten. $Z_{0}$ is in Amsterdam in 1991 gevraagd of men wist dat in Amsterdam een referendum zou worden gehouden. Een minderheid van de ondervraagden, 
namelijk 38 procent, was hiervan op de hoogte. Maar 15 procent wist het onderwerp van he: referendum, het beleid ten aanzien van het autoverkeer in de binnenstad, te noemen. Beter resultaten werden daarentegen bereikt in het onderzoek 'lokale democratie en bestuurlijke vernieuwing'. Als het ging om concrete actuele onderwerpen in de gemeenten, was in de meeste gevallen een ruime meerderheid van de ondervraagden hiervan op de hoogte. ${ }^{10} \mathrm{De}$ kennis van meer algemeen gemeentelijk beleid was daarentegen veel geringer. In de meeste gevallen was slechts een minderheid van de respondenten bekend met het gemeentelijk beleid.

Afsluitend kunnen wij concluderen dat de meeste kiezers weinig kennis hebben van de belangrijkste politici in hun gemeente, de burgemeester uitgesloten. Wel is men redelijk goed op de hoogte van actuele onderwerpen in de gemeente. Dit geldt weer niet voor de lokale politieke situatie. Waarschijnlijk is voor een deel van de kiezers het onderscheid tussen leden van de gemeenteraad en het college van $B \& W$ niet helder. Mede daardoor lijken veel kiezers er niet van op de hoogte te zijn, welke partijen in het college van $B \& W$ vertegenwoordigd zijn. Kortom, in de grotere gemeenten blijkt de kennis van de lokale politiek betrekkelijk gering te zijn. ${ }^{11}$

\subsection{Politieke activiteiten op lokaal en landelijk niveau}

Betekent een geringere interesse voor en kennis van de lokale politiek ten opzichte van de landelijke politiek dat er op lokaal gebied minder politieke activiteiten worden ontplooid dan op landelijk gebied? Uit het eerder aangehaalde SCP-onderzoek is ons al gebleken dat in het algemeen meer (politieke) activiteiten op lokaal dan op nationaal niveau worden ontplooid. Een nadere bestudering van deze gegevens kan ons meer vertellen over de ontwikkeling van de politieke activiteiten op lokaal en nationaal niveau in de periode 1980-1989. Zie hiervoor tabel 8.12.

Tabel 8.12: Percentage inwoners (16-74-jarigen) dat zich ingezet heeft voor een (inter)nationale dan wel lokale kwestie, 1980-1989.

$\begin{array}{lccccccc} & 180 & \prime 83 & \text { '85 } & \text { '86 } & \text { '87 } & \text { '88 } & \text { '89 } \\ \text { (inter)nationaal } & 12 & 17 & 20 & 16 & 14 & 14 & 14 \\ \text { lokaal } & 25 & 21 & 24 & 20 & 22 & 20 & 21\end{array}$

Bron: SCP, Culturele veranderingen in Nederland 1980-1989.

Door de jaren heen lijken meer burgers zich ingezet te hebben voor lokale kwesties dan voor (inter) nationale kwesties, al is het verschil niet erg groot. In de betreffende periode heeft nooit meer dan een kwart van de kiezers zich ingezet voor een lokale kwestie en nooit meer dan een vijfde voor een (inter) nationale kwestie. Wellicht één van de redenen voor de inzet voor lokale kwesties is dat deze zich altijd letterlijk 'dicht bij huis' afspelen, terwijl dat niet altijd geldtroor (inter)nationale kwesties. Blijft staan dat op grond van de ondernomen activiteiten de lokale betrokkenheid groter is dan de (inter) nationale betrokkenheid. 
In hoeverre zijn deze resultaten verschillend voor kiezers in verschillende soorten gemeenten? Het SCP heeft ook ten aanzien van deze vraag een analyse gemaakt van de politieke activiteiten in een vijftal denkbeeldige gemeenten: Weststad (een grote stad in het westen van het land), Bismond (een stad in het zuiden van het land), Slaapdam (een forensenplaats in het westen), Bosdorp (een verstedelijkte plattelandsgemeente in het zuiden of het oosten) en Platkerk (een plattelandsgemeente in het noorden of Zeeland). ${ }^{12}$ Op basis van de gegevens over politieke activiteiten op lokaal of (inter) nationaal niveau in de periode 1975-1986 kunnen wij vaststellen of erverschillen zijn tussen de kiezers in de verschillende gemeenten, zoals uit tabel 8.13 blijkt.

Tabel 8.13: Percentage inwoners (16-74-jarigen) dat zich heeft ingezetvoor een (inter) nationale of lokale kwestie, in vijf denkbeeldige gemeenten, 1975-1986.

Weststad Bismond Slaapdam Bosdorp Platkerk

nationaal

actief

19

15

18

12

14

lokaal

actief

19

20

22

23

26

Bron: SCP, Gemeente, burger, klant (1987) p.88.

Wij kunnen constateren dat de inwoners van Weststad meer dan gemiddeld actief zijn voor een (inter)nationale zaak, en minder dan gemiddeld actief zijn voor een lokale zaak. Alleen voor de inwoners van Weststad geldt dat zij op beide terreinen ongeveer even actief zijn. Voor de inwoners van Platkerk geldt daarentegen dat zij meer dan gemiddeld actief zijn voor iets lokaals. Daardoor is het verschil in deelname aan beide soorten activiteiten het grootst in deze gemeenten. In het algemeen kunnen wij overigens constateren dat het actief zijn voor een (inter)nationale zaak afneemt en het actief zijn voor een lokale zaak toeneemt naarmate de gemeenten kleiner worden.

\section{Contacten met politici}

Een andere manier om lokale betrokkenheid te meten is na te gaan in hoeverre men met een lokaal dan wel nationaal politicus contact heeft gezocht. Tabel 8.14 geeft hiervan een overzicht. ${ }^{13}$

Tabel 8.14: Percentage kiezers dat contact heeft gezocht met een minister of kamerlid dan wel burgemeester, wethouder of raadslid, 1973-1986.

contact met een:

$1977 \quad 1981 / 82 \quad 1986$

nationaal politicus

lokaal politicus

$\begin{array}{rrr}6 & 6 & 8 \\ 18 & 14 & 14\end{array}$

Bron: Nationaal Kiezersonderzoek 1977-1986. 
Er wordt duidelijk meer contact gezocht met een burgemeester, wethouder of raadslid dan met een minister of Tweede Kamerlid. In de jaren'70 werd ongeveer drie keer zoveel contact gezocht met een lokaal politicus dan met een landelijk politicus. In de jaren' 80 is dat gedaald tot ongeveer twee keer zoveel contacten met lokale politici. De contacten met lokale politici zijn immers in de jaren tachtig iets lager dan in 1977, terwijl in 1986 een lichte verhoging zichtbaar is van de contacten met een nationaal politicus. Het lokale kiezersonderzoek in Almere en de onderzoeksgroep 'lokale democratie en bestuurlijke vernieuwing' van 1991 laat overigenszien dat in de onderzochte steden niet meer dan 10 procent van de kiezers contact heeft gehad met een burgemeester of wethouder dan wel gemeenteraadslid. Het verschil met de gegevens van het landelijke onderzoek geeft waarschijnlijk aan dat kiezers in de grotere gemeenten minder contact hebben met lokale politici. Een uitsplitsing van de gegevens naarverschillende soorten gemeenten, geeft inderdaad aan dat in 1973, 1977 en 1986 percentueel meer inwoners in de kleinere gemeenten contact hebben gehad met een lokaal politicus dan in de grotere gemeenten. Opvallend is echter dat in 1981/82 een dergelijk verband niet aanwezig is. Watde contacten met de landelijke politici betreft, zijn in de regel de verschillen tussen de gemeenten niet erg groot (SCP,1987:90).

\section{Plaatselijk kiezersonderzoek}

In 1974 is in het onderzoek in een twaalftal grote gemeenten gevraagd naar de contacten met lokale politici. Uit de gegevens van dit onderzoek blijkt ondermeer dat in deze gemeenten meer kiezers contact hebben gehad met wethouders dan met de burgmeester of een (ander) raadslid.

Tabel 8.15: Percentage kiezers in een aantal gemeenten dat zegt contact gehad te hebben met de burgemeester, een wethouder of een raadslid, 1974.

$\begin{array}{lccc} & \text { burgemeester } & \text { wethouder } & \text { raadslid } \\ \text { Den Haag } & 5 & 11 & 9 \\ \text { Utrecht } & 4 & 15 & 10 \\ \text { Leiden } & 9 & 19 & 15 \\ \text { Gouda } & 15 & 23 & 19 \\ \text { Haarlemmermeer } & 21 & 25 & 22 \\ \text { Voorburg } & 16 & 22 & 21 \\ \text { Bussum } & 19 & 24 & 15 \\ \text { Zoetermeer } & 16 & 28 & 20 \\ \text { Leidschendam } & 16 & 22 & 15 \\ \text { Breda } & 12 & 16 & 18 \\ \text { Enschede } & 9 & 24 & -\end{array}$

Bron: Veldkamp marktonderzoek, 1974.

Uit tabel 8.15 kunnen wij ook opmaken dat de contacten met de burgemeester nog iets geringer zijn dan die met raadsleden. Het relatief geringe percentage kiezers dat contact heeft gehad met een wethouder, de burgemeester en een raadslid in Den Haag en Utrecht, wijst er op dat in de grootste gemeenten dergelijke contacten minder voorkomen dan in de middel-grote gemeenten. 
Meer nog dan voor de ontplooide activiteiten op lokaal en landelijk niveau geld bij de contacten met lokale en landelijke politici dat het in ieder geval in fysieke zin veel gemakkelijker is om in contact te komen met een lokaal politicus dan met een landelijk politicus. Voor de inwoners in kleinere gemeenten zijn daarnaast de drempels voor de contacten met lokale politici geringer dan voor inwoners in de grotere gemeenten. Daar staat tegenover dat, zoals in de vorige paragraaf al is gesteld, kiezers via de media veel meer geconfronteerd worden met landelijke dan plaatselijke politici. In die zin heeft de landelijke politicus dus een grote voorsprong op de lokale politicus.

\subsection{Politiek (zelf)vertrouwen op lokaal en landelijk niveau}

Wellicht dat er, gezien de contacten met de lokale politici, een groter vertrouwen is in het functioneren van de lokale politiek dan in het functioneren van de landelijke politiek. En mogelijk zijn veel kiezers tevens van mening dat zij zelf beter in staat zijn om de lokale- dan om de landelijke politiek te beïnvloeden. Deze twee stellingen staan centraal in deze paragraaf. In eerste instantie richten wij ons op het algemeen vertrouwen in het functioneren van de politieke instituties op lokaal en landelijk niveau. Daarvoor gebruiken wij het SCP-onderzoek 'cultureleveranderingen in Nederland' waarin is nagegaan in hoeverre kiezers van mening zijn dat er op lokaal en nationaal niveau voldoende rekening wordt gehouden met de wensen van de bevolking. In 1986 gaf 23 procent van de ondervraagden aan dat op landelijk niveau voldoende met hun mening rekening wordt gehouden. Op lokaal niveau was dat volgens 33 procent het geval. In 1987 waren deze cijfers respectievelijk 23 procent en 35 procent. Meer kiezers zijn dus van mening dat op lokaal niveau rekening wordt gehouden met de mening van de bevolking dan op landelijk niveau. Uit een onderzoek van de SCP blijkt voorts dat in 1986 in gemeenten met minder dan 50.000 inwoners met 42 procent van de inwoners een veel groter vertrouwen is in de beslissingen van de gemeente dan in grotere gemeenten, waar deze steun 20 à 25 procent bedraagt. Naast kleine plattelandsgemeenten is het vertrouwen in het gemeentebestuur ook opmerkelijk hoog in forensengemeenten (SCP,1987:85).

Uit het referendum-onderzoek in Amsterdam in 1991 blijkt dat 24 procent van de kiezers vindt datervoldoende rekening wordt gehouden met de mening van de mensen. Ongeveer 8 procent had geen oordeel, terwijl 68 procent vond dat er onvoldoende of helemaal geen rekening werd gehouden met de mening van de bevolking. In Haarlem en Leiden zijn respectievelijk 54 en 60 procent van de kiezers het oneens met de stelling dat de gemeenteraad meestal besluiten neemt die in overeenstemming zijn met hetgeen de meerderheid van de bevolking wil. In eerste instantie lijken de resultaten van het onderzoek naar de relatie burger-gemeentelijke overheid uit 1974 in strijd met boenstaande bevindingen. Zoals uit tabel 8.16 blijkt was in de onderzochte elf grotere gemeenten het vertrouwen van de kiezers in de gemeentelijke overheid relatief groot in vergelijking met de voorgaande gegevens. 
Tabel 8.16: Percentage kiezers in een aantal gemeenten datvertrouwen heeft in de gemeentelijke overheid, 1974.

\begin{tabular}{lrccc}
\hline & veel & tamelijk veel/wel & weinig/geen & weet niet \\
Den Haag & 11 & 54 & 31 & 5 \\
Utrecht & 8 & 53 & 34 & 5 \\
Leiden & 5 & 48 & 44 & 3 \\
Gouda & 13 & 56 & 26 & 5 \\
Haarlemmermeer & 8 & 64 & 22 & 5 \\
Voorburg & 9 & 70 & 18 & 2 \\
Bussum & 7 & 60 & 28 & 5 \\
Zoetermeer & 11 & 63 & 21 & 5 \\
Leidschendam & 15 & 63 & 18 & 5 \\
Breda & 9 & 65 & 24 & 3 \\
Enschede & 7 & 65 & 23 & 4 \\
\end{tabular}

Bron: Veldkamp marktonderzoek, 1974.

In alle gemeenten, behalve Leiden, had minder dan 35 procent van de kiezers weinig tot geen vertrouwen in de gemeentelijke overheid. In Leiden had nog altijd een meerderheid van de kiezers (veel) vertrouwen in de gemeentelijke overheid. Aangezien in dit onderzoek gevraagd is naar het vertrouwen in de gemeentelijke overheid in plaats van het vertrouwen in hei gemeentebestuur, zijn de resultaten van dit onderzoek niet vergelijkbaar met de die van de andere gepresenteerde onderzoeken. Immers, tot de gemeentelijke overheid behoort niet alleen het gemeentebestuur maar tevens de dienstverlening van de gemeente. Dat dit van belang is blijkt onder meer uit het onderzoek 'lokale democratie en bestuurlijke vernieuwing'. Daarin wordt duidelijk dat de burgers zich in de regel positiever uitlaten over de gemeentelijke dienstverlening dan over het gemeentebestuur. Dit kan dus verklaren waarom de resultaten van het onderzoek naar de relatie burger - gemeentelijke overheid uit 1974 relatief gunstig zijn in vergelijking met de andere onderzoeken.

Op grond van bovenstaande gegevens kunnen wij concluderen dat in ieder geval in de grotere gemeenten er sprake is van een relatief gering vertrouwen in het gemeentebestuur, al lijkt dit gebrek aan vertrouwen iets minder te zijn dan ten aanzien van de politieke instituties op landelijk niveau. En in gemeenten met minder dan 50.000 inwoners is het gebrek aan vertrouwen ten opzichtevan het gemeentebestuur duidelijk geringer dan in grotere gemeenten.

\section{Politiek zelfvertrouwen}

In verschillende onderzoeken wordt nagegaan in hoeverre kiezers denken dat zij individueet invloed kunnen uitoefenen op politieke instellingen en politieke processen. Dit wordt in de regel aangeduid met het begrip 'politiek zelfvertrouwen'. Politiek zelfvertrouwen word gemeten door de respondenten bij een kiezersonderzoek een aantal stellingen voor te leggen. Twee van dergelijke stellingen zullen hier aan bod komen. Beide stellingen zijn in het SCP. onderzoek 'culturele veranderingen in Nederland' aan respondenten voorgelegd ${ }^{14}$. Bij beide stellingen is er voor enkele jaren een lokale en een nationale variant, zodat wij het zelfver- 
trouwen op lokaal politiek gebied kunnen vergelijken met dat op landelijke gebied. De eerste stelling betreft:

'Mensen als ik hebben geen enkele invloed op wat de regering doet/ op de gemeentepolitiek.'

Tabel 8.17: Percentage inwoners (16-74-jarigen) datvan mening is dat men geen enkele invloed heeft op regering of gemeentepolitiek, 1975-1989.

\begin{tabular}{lcccccc}
\hline $\begin{array}{l}\text { Geen } \\
\text { invloed op: } \\
\text { regering }\end{array}$ & 1975 & 1980 & 1985 & 1986 & 1988 & 1989 \\
$\begin{array}{l}\text { gemeente } \\
\text { politiek }\end{array}$ & 59 & 57 & 59 & 52 & 56 & 48 \\
\hline
\end{tabular}

Bron: SCP, Culturele veranderingen in Nederland 1975-1989.

Uit tabel 8.17 blijkt dat een meerderheid van de kiezers niet denkt enige invloed te kunnen uitoefenen op de regering. Het politiek zelfvertrouwen ten aanzien van de landelijke politiek is dus betrekkelijk gering. Wel is er sprake van een lichte toename van het politiek zelfvertrouwen in de periode 1975-1989. In 1989 denkt voor het eerste minder dan 50 procent van de kiezers dat men geen invloed kan uitoefenen op de regering. Het politiek zelfvertrouwen ten aanzien van de lokale politiek blijkt nauwelijks groter te zijn dan dat ten aanzien van de landelijke politiek. In de beide jaren dat via de betreffende stelling het politiek zelfvertrouwen op lokaal niveau is gemeten, is het verschil maar een paar procent. In 1986 is het een minderheid die van mening is dat men geen invloed kan uitoefenen op de lokale politiek. Met 46 procent van de kiezers blijft het echter een aanzienlijke groep.

Het SCP is ook voor deze stelling op basis van de resultaten in de periode 1975-1986 nagegaan in hoeverre er verschillen zijn tussen de inwoners van verschillende soorten gemeenten. In tabe] 8.18 staan de resultaten van deze analyse.

Tabel 8.18: Percentage inwoners (16-74-jarigen) die van mening zijn dat zij geen invloed kunnen uitoefenen op de regering of het gemeentepolitiek, voor vijf denkbeeldige gemeenten, 1975-1986.

\begin{tabular}{lccccc}
\hline $\begin{array}{l}\text { Geen } \\
\text { invloed op: }\end{array}$ & Weststad & Bismond & Slaapdam & Bosdorp & Platkerk \\
regering & 57 & 63 & 52 & 56 & 62 \\
$\begin{array}{l}\text { gemeente- } \\
\text { politiek }\end{array}$ & 52 & 56 & 39 & 53 & 43 \\
$\begin{array}{l}\text { Bron: SCP, Gemeente, burger, kant (1987) } \\
\text { R. } 94 .\end{array}$
\end{tabular}


In de denkbeeldige forensengemeente Slaapdam en de kleine plattelandgemeente Platkerk blijkt het percentage kiezers dat geen invloed denkt te kunnen uitoefenen op de gemeentepolitiek in vergelijking met de andere gemeenten het geringst. Alleen in deze gemeenten wordt deze stelling door een minderheid onderschreven. Opvallend is dat bij deze twee gemeenten heter een relatief groot verschil is tussen het percentage inwoners dat zegt geen invloed te kunnen uitoefenen op de regering en dat zegt geen invloed te kunnen uitoefenen op de gemeentepolitiek. Met name in Platkerk is dat het geval. Kortom, in de kleine plattelands gemeenten en ook wel de forensengemeenten is het politiek zelfvertrouwen op lokaal niveau duidelijk sterker dan het politiek zelfvertrouwen op nationaal niveau. Wat dit laatste betreft, blijken overigens de verschillen tussen de kiezers van de verschillende gemeenten niet zo groot als bij het politiek zelfvertrouwen op lokaal niveau.

Ook uit kiezersonderzoek op plaatselijk niveau blijkt dat een grote groep kiezers denkt geen invloed te kunnen uitoefenen op de lokale politiek. ${ }^{15}$ In Zaanstad geldt dat in 1990 voor bijvoorbeeld 52 procent van de kiezers, terwijl 25 procent wel denkt invloed te kunnen uitoefenen op het gemeentebestuur. In Dordrecht blijkt het politieke zelfvertrouwen groter. Uit een onderzoek uit 1989 blijkt dat 'slechts' 37 procent van de kiezers denkt geen invloed te kunnen uitoefenen. 42 procent is overigens de tegenovergestelde mening toegedaan. Vergelijkbare cijfers vinden wij in Haarlem en Leiden waar in 1991 respectievelijk 42 en 43 procent van de kiezers van mening is dat het gemeentebestuur niet te beïnvloeden is. Opmerkelijk is overigens, dat uit het onderzoek 'lokale democratie en bestuurlijke vernieuwing' blijkt dat er in de zeven onderzochte gemeenten meer kiezers waren die denken geen invloed te kunnen uitoefenen op de politiek van het gemeentebestuur dan op die van de regering. Zie hiervoor tabel 8.19.

Tabel 8.19: Percentage kiezers in zeven gemeenten dat het eens dan wel oneens is met de stelling dat men persoonlijk wel degelijk invloed kan uitoefenen op de politiek van het gemeentebestuur/de regering, 1991.

invloed:

wel lok. land.

$\begin{array}{lll}\text { Amsterdam } & 37 & 39 \\ \text { Eindhoven } & 38 & 44 \\ \text { Den Haag } & 27 & 30 \\ \text { Nijmegen } & 40 & 52 \\ \text { Tilburg } & 32 & 36 \\ \text { Utrecht } & 36 & 43 \\ \text { Zwolle } & 53 & 48\end{array}$

geen lok. land.

$\begin{array}{ll}51 & 47 \\ 49 & 48 \\ 61 & 58 \\ 50 & 40 \\ 54 & 54 \\ 53 & 48 \\ 40 & 41\end{array}$

weet niet lok. land.

Bron: Onderzoeksgroep Lokale Democratie, 1991

Toelichting: lok. = invloed op gemeentebestuur land. = invloed op de regering

In de gemeenten Amsterdam, Den Haag, Tilburg en Zwolle zijn er ongeveer evenveel kiezers die denken invloed te kunnen uitoefenen op het gemeentebestuur als op de regering. In de andere gemeenten is duidelijker zichtbaar dat meer kiezers denken de regering te kunnen beïnloeden dan het gemeentebestuur. 
Al met al denken dus grote groepen kiezers dat men weinig invloed kan uitoefenen op zowel de lokale als de landelijke politiek. Betekent dit dat er voor de kiezers geen verschil is tussen de mogelijkheden om de lokale of landelijke politiek te beïnvloeden? Een onderzoek van het dagblad Trouw in 1991 geeft in ieder geval aan dat kiezers wat dit betreft wel een verschil ervaren. Aan de respondenten in dit onderzoek is gevraagd waar men denkt de meeste invloed te kunnen uitoefenen, op lokaal, provinciaal of landelijk niveau. Een meerderheid van de kiezers, namelijk 59 procent, noemt hierbij de gemeentelijke politiek. Slechts 2 procent noemt de provinciale politiek, terwijl 19 procent denkt de meeste invloed te kunnen hebben op de landelijke politiek. Ongeveer 10 procent denkt helemaal geen invloed te kunnen uitoefenen, voor 1 procent maakt het niets uit en 10 procent weet het niet. Uit deze cijfers blijkt het volgende: al denkt men niet veel invloed uit te kunnen oefenen op noch de lokale noch de landelijke politiek, de ervaren mogelijkheden daartoe zijn wel veel groter op lokaal niveau dan op landelijk niveau. In die zin is er dus duidelijk een groter politiek zelfvertrouwen ten aanzien van de lokale politiek.

Een tweede stelling die in verschillende lokale kiezersonderzoeken aan de respondenten is voorgelegd om het politiek zelfvertrouwen te meten is de volgende:

'Ik denk niet dat Kamerleden en ministers veel geven om wat mensen als ik denken.' En in de lokale variant:

'Gemeenteraadsleden bekommeren zich niet veel om de mening van mensen zoals ik.'

Tabel 8.20: Percentage inwoners (16-74-jarigen) datvan mening is datKamerleden en minsters dan wel gemeenteraadsleden niet veel geven om hun mening, 1975-1989.

\begin{tabular}{lrrrccc}
\hline & 1975 & 1980 & 1985 & 1986 & 1988 & 1989 \\
$\begin{array}{l}\text { Kamerleden/ } \\
\text { ministers }\end{array}$ & 55 & 56 & 60 & 56 & 55 & 47 \\
$\begin{array}{l}\text { gemeenteraads- } \\
\text { leden }\end{array}$ & 50 & - & - & 52 & - & -
\end{tabular}

Bron: SCP, Culturele veranderingen in Nederland 1975-1989.

Ook deze stellingen worden door een meerderheid van kiezers onderschreven. Tevens zien wij dat in 1989 voor het eerst minder dan 50 procent van de kiezers denkt dat Kamerleden en ministers niet veel geven om hun mening. Een andere overeenkomst met de gegevens uit tabel 8.17 is dat er nauwelijks meer vertrouwen is in gemeenteraadsleden dan in landelijke politici. Ook in dit geval gaat het maar om een verschil van een paar procent. Wellicht dat dit verschil groter is voor de kiezers in kleine plattelandsgemeenten en forensengemeenten. Zie hiervoor tabel 8. 21 . 
Tabel 8.21: Percentage inwoners (16-74-jarigen) dat van mening is dat Kamerleden en ministers dan wel gemeenteraadsleden nietveel geven om hun mening, voor vijf denkbeeldige gemeenten, 1975-1986.

Weststad Bismond Slaapdam Bosdorp Platkerk

Kamerleden/

ministers 58 65 48 57

60

gemeenteraadsleden 52 60 37 53 47

Bron: SCP, Gemeente, burger, klant (1987) p.94.

Wij kunnen constateren dat evenals in tabel 8.18 het politiek zelfvertrouwen op lokaal niveau in de forensengemeente Slaapdam en de kleine plattelandsgemeente Platkerk duidelijk hoger is dan het politiek zelfvertrouwen op landelijk niveau. Voor beide gemeenten geldt slechts dat een minderheid van de inwoners van mening zijn dat gemeenteraadsleden niets geven om hun mening. In Slaapdam is zelfs een minderheid van de kiezers van mening dat kamerleden en ministers niets geven om hun mening. In de andere gemeenten, inclusief Platkerk, ondersteunt een duidelijke meerderheid deze stelling. Het politiek zelfvertrouwen is dus zowel ten aanzien van het lokale als nationale niveau het grootst in de forensengemeenten, terwijl in deze gemeenten en met name in de kleine plattelandsgemeenten er een duidelijk groter politiek zelfvertrouwen is ten aanzien van de lokale politiek dan ten aanzien van de landelijke politiek. Ook plaatselijke kiezersonderzoeken in een aantal grote steden laten overigens zien dat een grote groep kiezers van mening is dat gemeenteraadsleden zich nietveel bekommeren om hun mening.

Tabel 8.22: Percentage kiezers in zeven gemeenten dat het eens dan wel oneens is met de stelling dat gemeenteraadsleden dan wel kamerleden zich niet bekommeren om de mening van mensen zoals zij, 1991.

$\begin{array}{lcc}\text { eens } & \text { oneens } & \text { weet niet } \\ \text { lok. land. } & \text { lok. land. } & \text { lok. land. }\end{array}$

$\begin{array}{lrlllllr}\text { Amsterdam } & 35 & 42 & 49 & 42 & 16 & 16 \\ \text { Eindhoven } & 33 & 44 & 49 & 44 & 18 & 11 \\ \text { Den Haag } & 47 & 48 & 36 & 36 & 16 & 13 \\ \text { Nijmegen } & 35 & 40 & 49 & 46 & 16 & 14 \\ \text { Tilburg } & 45 & 50 & 38 & 41 & 17 & 8 \\ \text { Utrecht } & 35 & 40 & 50 & 48 & 15 & 12 \\ \text { Zwolle } & 33 & 44 & 54 & 47 & 12 & 9\end{array}$

Bron: Onderzoeksgroep Lokale Democratie, 1991.

Toelichting: lok. = stelling over gemeenteraadsleden

land. = stelling over kamerleden 
Uit tabel 8.22 kunnen wij bijvoorbeeld opmaken dat uit het onderzoek 'lokale democratie en bestuurlijke vernieuwing' in 1991 blijkt dat in alle onderzochte gemeenten minstens een derde van de kiezers van mening is dat gemeenteraadsleden zich niet bekommeren om hun mening. In Tilburg en Den Haag laat bijna de helft van de kiezers zich in die zin uit. In Den Haag blijken overigens ongeveer evenveel kiezers van mening dat kamerleden zich niet bekommeren om hun mening. In de andere gemeenten daarentegen is het percentage kiezers dat deze mening aanhangt groter dan datvan mening is dat gemeenteraadsleden zich niet bekommeren om hun mening. Deze cijfers worden wel enigzins vertekend omdat meer kiezers zich niet uitlaten over destelling omtrent de gemeenteraadsleden in vergelijking met de stelling over de kamerleden. Op grond van het bovenstaande kunnen wij concluderen dat in de grote gemeenten in grote lijnen iets meer kiezers van mening zijn dat kamerleden zich niet bekommeren om hun mening dan gemeenteraadsleden.

Bijhet meten van het politiek zelfvertrouwen wordt dikwijls gevraagd of men van mening is dat de eigen stem er niet toe doet omdat er zoveel mensen stemmen. In de periode 1972-1989 blijkt dat tussen de 80 en negentig procent van de kiezers het hier niet mee eens is, als het de Tweede Kamerverkiezingen betreft (van Deth/Horstman,1989:75; CBS,1990:72). Plaatselijke kiezersonderzoeken laten vergelijkbare gegevens zien voor zowel de Tweede Kamer- als de gemeenteraadsverkiezingen (VNG,1991:45-46; Onderzoeksgroep 'Lokale democratie en bestuurlijke verniewing',1991:138-141).

Wij kunnen concluderen dat bij een groot deel van de kiezers sprake is van een gebrek aan vertrouwen ten opzichte van de lokale politiek. Voor de landelijke politiek geldt dat in nog iets sterkere mate. Wat het politiek zelfvertrouwen betreft, blijkt dat de overgrote meerderheid van de kiezers de eigen stem bij de verkiezingen van belang acht. Bij de overige stellingen om het politiek zelfvertrouwen te meten, zien wij echter dat ongeveer de helft van de kiezers daarbij getuigt van een gering politiek zelfvertrouwen ten aanzien van de lokale politiek, al wijzen de gegevens in zeven grote gemeenten in 1991 in een positievere richting. Het politiek zelfvertrouwen ten opzichte van de landelijke politiek is waarschijnlijk nog iets geringer dan dat ten opzichte van de lokale politiek. ${ }^{16}$ Het lokale kiezersonderzoek is echter op dit punt niet eenduidig. Wel hebben wij kunnen vaststellen dat in kleine plattelandsgemeenten en in forensengemeenten er duidelijk meer politiek zelfvertrouwen op lokaal niveau is dan op landelijke niveau. In de andere gemeenten is dit verschil veel geringer.

\subsection{Belang van lokale en landelijke politiek}

Een ander aspect van de betrokkenheid van de burgers bij de lokale politiek betreft de door de kiezers ingeschatte invloed van de beslissingen op lokaal niveau op hun dagelijkse leven. Tervergelijking kan eenzelfde vraag gesteld worden ten aanzien van beslissingen op landelijke niveau. Deze vragen zijn ondermeer aan de orde gekomen in het SCP-onderzoek 'culturele veranderingen in Nederland'. 
Tabel 8.23: De ervaren invloed van beslissingen op lokaal of landelijke niveau op het dagelijkse leven, 1986 en 1987, in percentages.

\begin{tabular}{lrcccc}
\hline & & Lokaal & \multicolumn{2}{c}{ Landelijk } \\
& 1986 & 1986 & 1987 & 1986 & 1987 \\
& NIPO & SCP & SCP & SCP & SCP \\
Veel & 11 & 15 & 17 & & \\
Weinig & 52 & 65 & 62 & 61 & 27 \\
Geen & 37 & 20 & 21 & 14 & 16 \\
\hline
\end{tabular}

Bronnen: SCP, culturele veranderingen in Nederland 1986/1987 en AVRO/NIPO 1986.

Zoals wij in tabel 8.23 kunnen zien, wijzen de SCP-gegevens erop dat er geen erg groot verschil is tussen de ervaren invloed van de beslissingen op landelijk niveau en de beslissingen op lokaal niveau. Het grootste verschil, namelijk 10 procent, zien wij nog bij het percentage ondervraagden dat veel invloed ervaart van de beslissingen van het gemeentebestuur of de regering. Kortom, de beslissingen van het gemeentebestuur worden iets minder belangrijk geacht dan de beslissingen van de regering. In 1986 is ook in de eerder genoemde AVRO/NIPO-enquête gevraagd naar de ervaren invloed van de beslissingen van het gemeentebestuur op het dagelijkse leven. In dit onderzoek zijn er in vergelijking met het SCP-onderzoek meer respondenten die geen invloed ervaren en minder respondenten die aangaven dat er sprake is van weinig invloed. Ook wat de verschillen per gemeentegrootte betreft, zijn er verschillen tussen beide onderzoeken. Volgens de AVRO/NIPO-enquête zijn er in gemeenten met minder dan 5.000 inwoners en meer dan 400.000 inwoners relatief veel kiezers die een grotere invloed van de beslissingen van het gemeentebestuur ervaren. In de grootste gemeenten zijn er tevens relatief weinig kiezers die geen enkele invloed ervaren. Daarentegen komt uit het SCP. onderzoek naar voren dat er op dit punt geen verschillen zijn tussen kiezers van verschillende soorten gemeenten (SCP,1987:85).

Ook in het onderzoek 'lokale democratie en bestuurlijke vernieuwing' uit 1991 is gevraagd naar het belang van beslissingen op lokaal en nationaal niveau op het dagelijkse leven. De resultaten in de verschillende gemeenten staan in tabel 8.24 .

Tabel 8.24: De in zeven gemeenten ervaren invloed van beslissingen op lokaal en nationaal niveau op het dagelijkse leven, 1991, in percentages.

\begin{tabular}{lcccccccc}
\hline & $\begin{array}{c}\text { (zeer) veel } \\
\text { lok. land. }\end{array}$ & $\begin{array}{c}\text { weinig } \\
\text { lok. land. }\end{array}$ & $\begin{array}{c}\text { geen } \\
\text { lok. land. }\end{array}$ & $\begin{array}{c}\text { weet niet } \\
\text { lok. land. }\end{array}$ \\
Amsterdam & 28 & 57 & 44 & 25 & 21 & 8 & 7 & 10 \\
Eindhoven & 22 & 71 & 49 & 24 & 22 & 5 & 7 & 3 \\
Den Haag & 27 & 58 & 45 & 26 & 20 & 9 & 8 & 8 \\
Nijmegen & 24 & 65 & 51 & 31 & 17 & 4 & 8 & 4 \\
Tilburg & 23 & 57 & 47 & 28 & 22 & 9 & 8 & 7 \\
Utrecht & 25 & 55 & 47 & 32 & 21 & 7 & 7 & 5 \\
Zwolle & 22 & 57 & 49 & 31 & 25 & 6 & 5 & 5
\end{tabular}

Bron: Onderzoeksgroep Lokale Democrate, 1991. 
Deze gegevens laten een aanzienlijk groter verschil zien tussen de ervaren invloed van beslissingen van het gemeentebestuur en de ervaren invloed van beslissingen van de regering op het dagelijkse leven. Terwijl ongeveer een kwart van de ondervraagden veel invloed van lokale beslissingen op het dagelijkse leven ervaart, is dat voor landelijke beslissingen tussen de 60 en 75 procent het geval. Daar staat tegenover dat ongeveer 20 á 25 procent van de ondervraagden helemaal geen invloed van beslissingen van het gemeentebestuur op hun dagelijkse leven ervaren. Hetzelfde gold voor beslissingen van de regering maar voor ongeveer 5 procent. Blijkbaar worden de besluiten van de regering van aanmerkelijk groter belang geacht dan die het gemeentebestuur. Aangezien zowel uit het AVRO/NIPO-onderzoek en het SCP-onderzoek van 1986 niet blijkt dat in gemeenten met meer dan 100.000 inwoners sprake is van een veel minder dan gemiddeld ervaren invloed van beslissingen van het gemeentebestuur op het dagelijkse leven, kunnen wij concluderen dat tenminste in de grotere gemeenten na 1986 het percentage kiezers dat van mening is dat beslissingen van het gemeentebestuur van belang zijn voor hun dagelijkse leven verminderd is.

In hoeverre willen kiezers dat verandering wordt gebracht in de machtsverhouding tussen regering en gemeente? In het SCP-onderzoek 'cultureleveranderingen in Nederland' is in 1986 en 1987 aan de respondenten gevraagd of bij een vergelijking van de regering in Den Haag en het gemeentebestuur de regering of het gemeentebestuur meer te zeggen moet krijgen of dat de bestaande situatie gehandhaafd moet worden. Een kleine meerderheid van de ondervraagden $(52 \%)$ vond in beide jaren dat de huidige machtsverhoudingen gehandhaafd moesten worden. Een aanzienlijke minderheid van 40 procent ( $41 \%$ in 1987 ) wilde echter dat de gemeente meer te zeggen kreeg. Slechts 8 procent ( $7 \%$ in 1987) wilde de macht van de regering vergroten ten koste van de gemeente. Al zijn er dus veel meer kiezers die de macht van het gemeentebestuur willen vergroten ten koste van de regering dan andersom, de meerderheid van de kiezers is tevreden over de bestaande machtsverhoudingen.

\subsection{De perceptie van het politieke karakter van de lokale politiek}

Naast de aan de orde gekomen aspecten van de politieke betrokkenheid van burgers bij de lokale politiek, zijn in het onderzoek 'lokale democratie en bestuurlijke vernieuwing' uit 1991 enige vragen gesteld om de opvattingen van de ondervraagden te achterhalen omtrent het functioneren van de lokale politiek. Het gaat hierbij met name om het (partij)politieke karakter van de lokale politiek. Mede omdat de burger minder betrokken zou zijn bij de lokale politiek wordt wel gesteld dat in de ogen van de kiezers de gemeentepolitiek geen partijpolitiek is en dat ook niet zou moeten zijn (SCP,1987:109). In hoeverre dit beeld klopt, zal in deze paragraaf aan de orde worden gesteld.

Aangezien het (partij)politieke karakter van de lokale politiek bepaald wordt door het functioneren van politieke partijen, is het interessant na te gaan in hoeverrekiezers inhoudelijke verschillen zien tussen de politieke partijen. Vandaar dat in het onderzoek 'lokale democratie en bestuurlijke vernieuwing' aan de respondenten in de zeven betrokken gemeenten gevraagd is of men het eens was met de stelling dat er tussen de partijen die in de gemeenteraad vertegenwoordigd zijn, nauwelijks verschillen te zien zijn. Zie voor de antwoorden tabel 8.25. 
Tabel 8.25: Percentage kiezers in zeven gemeenten dat het eens dan wel oneens is met de stelling dat er nauwelijks verschillen te zien zijn tussen de partijen die in de gemeenteraad/ Tweede Kamer vertegenwoordigd zijn, 1991.

\begin{tabular}{lcccccrr}
\hline & \multicolumn{3}{c}{ eens } & \multicolumn{3}{c}{ oneens } & \multicolumn{2}{c}{ weet niet } \\
& gr & TK & & gr & TK & gr & TK \\
& & & & & & & \\
Amsterdam & 39 & 26 & 41 & 62 & 20 & 12 \\
Eindhoven & 45 & 27 & 31 & 66 & 24 & 8 \\
Den Haag & 50 & 28 & 33 & 62 & 17 & 10 \\
Nijmegen & 35 & 18 & 41 & 74 & 24 & 8 \\
Tilburg & 43 & 24 & 33 & 66 & 24 & 9 \\
Utrecht & 41 & 20 & 36 & 73 & 23 & 7 \\
Zwolle & 33 & 14 & 51 & 77 & 16 & 9 \\
& & & & & & &
\end{tabular}

Bron: Onderzoeksgroep Lokale Democratie, 1991.

Ongeveer 35 á 45 procent van de ondervraagden is het eens met de stelling dat er nauwelijks verschillen te zien zijn tussen de partijen in de gemeenteraad, terwijl ongeveer 30 á 40 procent het hiermee oneens was. Ook het relatief groot percentage respondenten dat hierover geen mening heeft $( \pm 20 \%)$, geeft aan dat het voor een relatief groot deel van de kiezers moeilijk is om zich een mening te vormen over het (partij)politieke karakter van de lokale politiek.

Het zal overigens niet verbazen dat de kiezers veel duidelijker de verschillen tussen de partijen in de Tweede Kamer zien. In dat geval is ongeveer 70 procentvan de ondervraagden het oneens met de stelling dat er nauwelijks politieke verschillen te zien zijn. Minder dan 10 procent weet zich hierover geen mening te vormen.

Betekent dit ook dat kiezers niet weten waarover de gemeenteraadsverkiezingen eigenlijk gaan? Om dit te achterhalen is aan de respondenten in de zeven gemeenten gevraagd of men de stelling kon onderschrijven dat men eerlijk gezegd niet precies weet waar het bij de gemeenteraadsverkiezingen om gaat.

Tabel 8.26: Percentage kiezers in zeven gemeenten dat het eens dan wel oneens is met de stelling dat het eerlijk gezegd voor hen nooit zo duidelijk is waar het om gaat bij de gemeenteraadsverkiezingen, 1991.

$\begin{array}{lrrr} & \text { eens } & \text { oneens } & \text { weet niet } \\ \text { Amsterdam } & 43 & 47 & 10 \\ \text { Eindhoven } & 54 & 39 & 7 \\ \text { Den Haag } & 56 & 38 & 6 \\ \text { Nijmegen } & 55 & 39 & 6 \\ \text { Tilburg } & 50 & 32 & 8 \\ \text { Utrecht } & 55 & 38 & 6 \\ \text { Zwolle } & 47 & 48 & 5\end{array}$


Uit tabel 8.26 blijkt dat ruim 50 procent van de kiezers in de zeven gemeenten het eens is met de stelling dat het hen niet duidelijk is waar het om gaat bij de gemeenteraadsverkiezingen. Hieruit blijkt dat een grote groep kiezers moeite heeft om de inhoudelijke betekenis van de gemeenteraadsverkiezingen in te zien. Dat geldt in mindere mate voor kiezers in Amsterdam en Zwolle, waar een relatief grote groep kiezers zegt wel te weten waar het bij de gemeenteraadsverkiezingen in hun gemeente om gaat.

Zoals wij uit de gegevens van tabel 8.27 kunnen opmaken, kunnen wij echter op basis van bovenstaande gegevens niet concluderen dat het voor de kiezers niet uitmaakt welke partij het voor het zeggen heeft in de gemeenteraad.

Tabel 8.27: Percentage kiezers in zeven gemeenten dat het eens dan wel oneens is met de stelling dat het voor hen niet uitmaakt welke partijen het in de gemeenteraad voor het zeggen hebben, 1991.

$\begin{array}{lrrr} & \text { eens } & \text { oneens } & \text { weet niet } \\ \text { Amsterdam } & 23 & 64 & 12 \\ \text { Eindhoven } & 35 & 57 & 9 \\ \text { Den Haag } & 36 & 58 & 6 \\ \text { Nijmegen } & 25 & 68 & 7 \\ \text { Tilburg } & 34 & 56 & 9 \\ \text { Utrecht } & 24 & 68 & 8 \\ \text { Zwolle } & 21 & 73 & 6\end{array}$

Bron: Onderzoeksgroep Lokale Democratie, 1991.

Immers, een ruime meerderheid van de ondervraagden in de onderzochte zeven gemeenten is van mening dat het wel uitmaakt welke partij het voor het zeggen heeft in de gemeenteraad. Het gaat om ongeveer 60 á 70 procent van de kiezers, terwij] 25 á 35 procent het wel eens is met deze stelling. Blijkbaar vindt men dat politieke partijen wel een rol spelen in de lokale politiek, ook al zijn de verschillen tussen de partijen voor veel kiezers nauwelijks zichtbaar. Wellicht dat hiermee ook tot uitdrukking komt dat partijpolitieke verschillen een belangrijkere rol zouden moeten spelen in de lokale politiek.

Tabel 8.28: Percentage kiezers in zeven gemeenten dat het eens dan wel oneens is met de stelling dat de gemeentepolitiek een stuk interessanter zou worden als partijen hun onderlinge verschillen duidelijker zouden maken, 1991.

\begin{tabular}{lrrc}
\hline & eens & oneens & weet niet \\
Amsterdam & 62 & 22 & 16 \\
Eindhoven & 68 & 19 & 13 \\
Den Haag & 70 & 18 & 12 \\
Nijmegen & 66 & 19 & 15 \\
Tilburg & 69 & 16 & 15 \\
Utrecht & 65 & 20 & 14 \\
Zwolle & 70 & 20 & 10
\end{tabular}


Uit tabel 8.28 kunnen wij inderdaad opmaken dat een ruime meerderheid van de kiezers van mening is dat de lokale politiek een stuk interessanter zou worden als de verschillen tussen de partijen duidelijker zouden zijn. Ongeveer 65 á 70 procent was het eens met deze stelling terwijl voor ongeveer 15 à 20 procent het tegendeel gold. Blijkbaar zijn veel kiezers van mening dat het politieke karakter van de lokale politiek versterkt zou moeten worden. Dit lijkt in tegenspraak met het gestelde aan het begin van deze paragraaf dat kiezers vinden dat partijpolitiek geen rol zou moeten spelen in de lokale politiek. Toch vinden wij ook hiervoor enige ondersteuning. Dat in ieder geval de partijpolitiek in de huidige situatie geen belangrijke rol moet spelen, blijkt uit de antwoorden op de stelling dat voor het functioneren van de gemeente de kwaliteit van de wethouder belangrijker is dan de politieke kleur. Zie voor de gegevens hierover tabel 8.29 .

Tabel 8.29: Percentage kiezers in zeven gemeenten dat het eens dan wel oneens is met de stelling dat voor het functioneren van de gemeente de kwaliteit van de wethouders belangrijker is dan hun politieke kleur, 1991.

\begin{tabular}{lrrc}
\hline & eens & oneens & weet niet \\
Amsterdam & 74 & 12 & 14 \\
Eindhoven & 79 & 9 & 12 \\
Den Haag & 72 & 11 & 16 \\
Nijmegen & 77 & 12 & 11 \\
Tilburg & 69 & 14 & 17 \\
Utrecht & 75 & 13 & 12 \\
Zwolle & 81 & 12 & 7 \\
\hline
\end{tabular}

ron: Onderzoeksgroep Lokale Democratie, 1991.

Ongeveer 75 procent van de ondervraagden vindt de kwaliteit van de wethouders belangrijker dan de politiek kleur. Dit is overigens niet verbazingwekkend als wij ons tegelijkertijd realiseren dat een relatief groot deel van de kiezers van mening is dat er nauwelijks verschillen zijn tussen de politieke partijen in de gemeenteraad. Als de politieke kleur aan relevantie inboet, is het immers logisch dat de wethouder en de kwaliteit van de wethouder sterker op de voorgrond treedt.

Uit het bovenstaande kunnen wij afleiden dat het voor veel kiezers wel uitmaakt wie wethouder is. Mogelijk ligt hier ook een gedeeltelijke verklaring voor het feit dat kiezers vinden dat het wel uitmaakt welke partijen het voor het zeggen hebben in de gemeenteraad. Ook al worden de partijpolitieke verschillen tussen de partijen niet als groot ervaren, de partijen leveren wel de wethouders, waarvan de kwaliteit we] van belang wordt geacht.

Al met al kunnen wij dus concluderen dat in ieder geval in de grotere gemeenten een betrekkelijk groot deel van de kiezers nauwelijks verschillen ziet tussen de partijen in de gemeenteraad. Toch vindt een grote meerderheid van hen dat het uitmaakt welke partijen het voor het zeggen hebben in de gemeenteraad. Tevens wil een grote meerderheid van de kiezers dat de verschillen tussen de partijen duidelijker worden. In de huidige situatie echter, vindt men de politieke kleurvan de wethouder minder belangrijk dan de kwaliteit van de wethouder. Kortom, voor veel kiezers in de grotere gemeenten heeft de lokale politiek geen sterk (partij) politiek karakter, al wil men wel dat hierin verandering komt. 


\subsection{Samenvattende conclusies}

In hoofdstuk 7 hebben wij geconcludeerd dat lokale overwegingen geen grote rol hebben gespeeld bijde gemeenteraadsverkiezingen in de periode 1982-1990. De overgrote meerderheid van de kiezers stemt dan ook bij de gemeenteraadsverkiezingen dezelfde partij als bij de Tweede Kamerverkiezingen, als wij de lokale lijsten even buiten beschouwing laten. Vandaar dat wij ons kunnen afvragen in hoeverre de kiezers betrokken zijn bij de lokale politiek. ${ }^{17}$ Uit de resultaten van kiezersonderzoek naar de betrokkenheid van de kiezers bij de lokale en landelijke politiek blijkt ondermeer dat kiezers duidelijk minder geïnteresseerd zijn in de lokale politiek dan in de landelijke politiek. Maar daar staat tegenover dat zij meer geïnteres. seerd zijn in nieuws uit de eigen woonplaats dan in binnenlands nieuws. Blijkbaar is men is wel sterk betrokken bij de eigen woonplaats, maar geldt dat in duidelijk mindere mate voor de lokale politiek. Voor veel kiezers lijkt de lokale politiek geen partijpolitiek karakter te hebben. Om de lokale politiek interessanter te maken is men daar wel voorstander van. In de huidige situatie vraagt een meerderheid van de kiezers zich af waar het nu eigenlijk om gaat bij de gemeenteraadsverkiezingen. Gezien de geringere interesse in de lokale politiek zoals die nu functioneert, is het niet verbazingwekkend dat men in vergelijking met de landelijke politici maar weinig lokale politici kent. Alleen de burgemeester schijnt algemeen bekend te zijn. De geringere interesse kan tevens te maken hebben met de ervaren geringere invloed van beslissingen van het gemeentebestuur op het dagelijkse leven in vergelijking met die van de landelijke regering. De verschillende kiezersonderzoeken geven echter geen eenduidig antwoord op de grootte van dit verschil, zodat onduidelijk blijkt in hoeverre dit van belang is voor de betrokkenheid van de kiezers bij de lokale politiek.

De lokale politiek onderscheidt zich overigens ook op een positieve manier van de landelijke politiek. Zo lijkt er sprake te zijn van een iets groter vertrouwen in de lokale politiek. En in zoverre men denktenige invloed te kunnen uitoefenen op de politiek dan is dat eerder het geval op op lokaal dan op landelijk niveau. In het verlengde hiervan is het niet verbazingwekkend dat men meer contacten heeft met lokale politici dan landelijke politici. Tevens zet men zich meer in voor lokale dan voor (inter) nationale kwesties. In die zin staat de lokale politiek dus dichter bij de burger dan de landelijke politiek.

Welke aanwijzigingen biedt het bovenstaande voor de mogelijke oorzaak van het relatief geringe lokale kiesgedrag bij de gemeenteraadsverkiezingen. Van belang lijkt in ieder geval dat de kiezers wel sterk betrokken zijn bij hetgeen zich in de eigen woonplaats afspeelt, maar dat dit in duidelijk mindere mate geldt voor de lokale politiek. Opvallend is met name dat de lokale politiek voor veel kiezers veel minder interessant is dan de landelijke politiek. Voor veel kiezers zou de lokale politiek interessanter worden als de verschillen tussen de partijen op lokaal niveau veel duidelijker zouden zijn. Kortom, als de lokale politiek een meer partijpolitiek: karakter zou krijgen. Daarmee zou de lokale politiek veel meer tegenwicht geven tegen de algemene (landelijke) politieke noties van de kiezers. Echter, gezien het huidige geringe (partij)politieke karakter van de lokale politiek is het niet opmerkelijk dat voor de meeste kiezers lokale overwegingen slechts een ondergeschikte rol spelen bij de partijkeuze bij de gemeenteraadsverkiezingen, waardoor de partijkeuze bij de gemeenteraads- en Tweede Kamerverkiezingen dikwijls hetzelfde is. 
Bovenstaande conclusies gelden overigens in sterkere mate voor grotere dan voor kl leinere gemeenten. Wij hebben hiervoor verschillende aanwijzingen gevonden. Zo is de opkoimst bij de gemeenteraadsverkiezingen in de kleinere gemeenten relatief hoog in vergelijking ${ }^{\prime}$ met de opkomst in deze gemeenten bij de Tweede Kamerverkiezingen. Hetzelfde kan gesteld $\mathbf{u}_{\text {worden }}$ voor de interesse in de lokale politiek ten opzichte van de interesse in de landelijke politiek. Voorts blijken de inwoners van kleine plattelandsgemeenten in het noorden en Zeelarnd zich meer in te zetten voor een lokale kwestie dan inwoners in andere gemeenten. Samen Imet de inwoners van forensengemeenten in het westen hebben zij ook een groot vertrouwer $I_{n}$ in de lokale politiek in vergelijking met de inwoners van andere gemeenten. Tenslotte is gelbleken dat in de kleinere gemeenten meer kiezers contact hebben gehad met lokale politici dan in grotere gemeenten. De geconstateerde verschillen zijn in de regel echter niet gr'oot en aangezien er geen sprake is van een duidelijke samenhang tussen de verschillen in de gemeenten bij de verschillende aspecten van de betrokkenheid van burgers bij de lokale politiek, kunnen wij niet spreken van verschillende lokale politieke culturen. 


\author{
NOTEN \\ categorieên onderscheiden:

$\begin{array}{ll}\text { A1-A4 } & \text { Plattelandsgemeenten } \\ \text { B1-B3 } & \text { Verstedelijkte plattelandsgemeenten, waarvan } \\ \text { B1-B2 } & \text { geïndustrialiseerde plattelandsgemeenten } \\ \text { B3 } & \text { specifieke forensengemeenten } \\ \text { C1-C5 } & \text { Gemeenten met een stedelijk karakter, waarvan } \\ \text { C1-C2 } & \text { plattelandsstadjes } \\ \text { C3-C4 } & \text { middelgrote steden } \\ \text { C5 } & \text { grote steden }\end{array}$

' Voor een overzicht van het gebruikte lokale kiezersonderzoek verwijzen wij opnieuw naas bijlage zes.

:Om de verschillen in opkomst tussen de gemeenten aan te tonen, gebruiken wij de indeling van gemeenten naar urbansiatiegraad, zoals die op 28 februari 1971 is vastgesteld. Daarbij worden onder meer de volgende

'Als de gegevens van de provincie Limburg wel in de analyse worden meegenomen, wordt het verschil in het percentage voorkeurstemmen tussen de lokale en nationale lijsten bij de gemeenteraadsverkiezingen van 1974, 1978 en 1982 achtereenvolgens vergroot tot 16,3 procent, 14,9 procent en 12,7 procent.

'Het betreft het volgende onderzoek: M.K.A. Schonk, Onderzoek naar tijd- cn ruimtebesteding in Lelystad, Flevobericht nr. 125, Lelystad, 1977. Aangehaald in: Grünfeld en Mejjer (1977:55).

"De daling van de interesse in de landelijke politiek is tevens opmerkelijk als wij deze gegevens vergelijken met de gegevens uit het NKO omtrent de algemene politieke interesse. Daaruit blijkt dat de algemene politieke interesse in de jaren zeventig en tachtig zelfs stijgt. Het percentage kiezers dat zegt geen enkele interesse te hebben in de politiek daalt van 46 procent in 1971 tot 27 procent in 1989. In 1989 is wel een daling te constateren van het percentage kiezers dat zegt zeer geïnteresseerd te zijn in politiek. In 1986 was dat nog 16,5 procent, terwij] dat in 1989 12,2 procent is (vanDeth/Horstman,1989:56; CBS,1990:63).

"Hierbij moet wel aangetekend worden dat in de kleinste gemeenten relatief veel kiezers zeer geinteresseerd zijn, terwijl in de grootste gemeenten relatief veel kiezers tamelijk geinteresseerd zijn. Kortom, er is nog wel een verschil in de intensiteit van de interesse in de lokale politiek.

'In de tabel zijn slechts 11 gemeenten vermeld, aangezien de gegevens van de gemeente Dordrecht niet meer achterhaald konden worden.

${ }^{8}$ Hierbij moet wel worden opgemerkt dat bij de vraag naar het lezen van binnenlands nieuws, in tegenstelling tot die over het lezen van nieuws over Lelystad, een politiek voorbeeld werd genoemd. De viaag luidde: 'En als er in de krant Nederlands nieuws staat, bijvoorbeeld over het loon- en prijsbeleid of regeringsproblemen in Den Haag, leest u dat dan (bijna) altijd, vaak, zo nu en dan of zelden of nooit?'. Zie: Grinfeld en Meijer (1977:122).

' De geringe bekendheid met de lijstrekkers bij de gemeenteraadsverkiezingen wordt wellicht voor een deel veroorzaakt door de omstandigheid dat er alleen tijdens de verkiezingscampagnes sprake is van lijsttrekkers, terwij] wethouders in de regel een aantal jaren in functie zijn.

" Een verschil met het eerdere onderzoek in Amsterdam is dat in het onderzoek lokale democratie en bestuurlijke vernieuwing' de respondenten gevraagd werd of men gehoord had van een bepaald actueel politiek onderwerp. Men hoefde dus niet zelf het betreffende onderwerp te noemen.

"Wellicht is er in de kleinere gemeenten meer kennis aanwezig van de lokale politiek. De resultaten van het gepresenteerde onderzoek uit Roosendaal zijn hiervoor een aanwijzing.

"2ie voor een uitgebreide beschrijving van deze denkbeeldige plaatsen: Sociaal en Cultureel Planbureau (1987:86-87).

${ }^{13}$ Door een andere manier van verzamelen $z$ ijn de gegevens van 1989 niet vergelijkbaar met die van voorgaande jaren. Vandaar dat deze gegevens ook niet zijn opgenomen in de tabel. Zie hiervoor. CBS (1990:49).

"Wij hebben de gegevens van het SCP-onderzoek gebruikt, in plaats van die van de NKO's in de periode 1977 1989 , omdat alleen bij het het onderzoek van het SCP tevens een lokale variant van de stellingen is voorgelegd. Daarmee kunnen wij het politiek zelfvertrouwen ten aanzien van de lokale politiek vergelijken met dat ten aanzien van de landelijke politiek. Omdat bij de gegevens uit het SCP-onderzoek niet de categorie 'weet niet' betrokken is, zijn de gevonden percentages hoger dan bij de de NKO's. De geconstateerde trend in de richting van een verhoging van het politiek zelfvertrouwen ten aanzien van de landelijke politiek zien wij echter bij beide onderzoeken. 
${ }^{15} \mathrm{Bij}$ de interpretatie van de gegevens van de kiezersonderzoeken op plaatselijk niveau is van belang dat men zich realiseert dat er een verschil ontstaat met de cijfers van het SCP omdat het SCP de respondenten die zich niet uitlaten over de stellingen niet meeneemt in de presentatie van de gegevens.

${ }^{16}$ Wel blijkt uit de gegevens van het NKO dat in de periode 1972-1989 het politiek zelfvertrouwen of nationaal niveau iets is toegenomen (van Deth/Horstman,1989:72-76; CBS,1990:72). Tevens zijn er aanwijzingen dat het politieke klimaat en de het optreden van de politieke partij van voorkeur van invloed zijn op he politieke zelfvertrouwen op nationaal niveau (van Dijk,1987:27-34).

${ }^{17}$ Bij de beantwoording van deze vraag moeten wij ons realiseren dat wij op basis van het bfschikbare kiezersonderzoek slechts tentatieve conclusies kunnen trekken omtrent de betrokkenheid van kiejers bij de lokale politiek. Niet alleen is een groot deel van het lokale kiezersonderzoek gehouden in grote gimeenten, tevens is het sterk geconcentreerd in de jaren tachtig en negentig. Voorts moeten wij rekening houcen met de omstandigheid dat de vraagstelling in de verschillende lokale kiezersonderzoeken nogal kan virschillen, hetgeen de resultaten sterk kan beïnvloeden. 


Hoofdstuk 9

\section{SAMENVATTING, CONCLUSIES EN NABESCHOUWING}

$\mathrm{Na}$ de eerste helft van de jaren zeventig, waarin de politisering en polarisering van de lokale politiek voorop stond, ontstond in 1986 weer een zekere belangstelling voor de lokale politiek. Met name het veronderstelde geringe lokale karakter van de gemeenteraadsverkiezingen in dat jaar stond ter discussie. De aanleiding hiervoor was de omstandigheid dat kort na de gemeenteraadsverkiezingen de Tweede Kamerverkiezingen gepland waren. Het idee was dat hierdoor vooral overwegingen van nationale politieke aard de doorslag zouden geven bij de gemeenteraadsverkiezingen. Ook bij de gemeenteraadsverkiezingen van 1990 werd het vermeende geringe lokale karakter van de gemeenteraadsverkjezingen aan de orde gesteld. En de lage opkomst bij deze verkiezingen vergrootte de interessevan politici en wetenschappers voor het functioneren van de lokale democratie.

In deze studie hebben wij ons met name geconcentreerd op het lokale karakter van de gemeenteraadsverkiezingen. De centrale probleemstelling luidt dan ook: In hoeverre is er bij degemeenteraadsverkiezingen in Nederlandse gemeenten in de periode 1974-1990 sprake van lokaal kiesgedrag dat karakteristiek is voor de gemeenteraadsverkjezingen? Allereerst zullen wij de belangrijkste bevindingen van dit onderzoek presenteren, waarna wij een eindconclusie kunnen trekken omtrent het lokale karakter van de gemeenteraadsverkiezingen.

\subsection{Samenvatting}

\section{Lokale lijsten}

Bij het bepalen van het lokale kiesgedrag hebben wij verschillende benaderingen gekozen. In de eerste plaats $z$ ijn wij de ontwikkelingen in de electorale positie van de lokale lijsten nagegaan, mede in relatie tot die van de gezamelijke landelijke lijsten en de drie politieke hoofdstromingen daarbinnen. Het uitgangspunt voor deze benadering was dat het stemmen op een lokale lijst een uiting is van lokaal kiesgedrag. Immers, per definitie heeft men niet de mogelijkheid op deze lijsten te stemmen bij de niet-lokale verkiezingen. ${ }^{1}$

De electorale positie van de lokale lijsten wordt in eerste instantie bepaald door het aantal gemeenten waarin de lokale lijsten aan de gemeenteraadsverkiezingen hebben deelgenomen. In hoofdstuk drie hebben wij op dit punt kunnen constateren dat er sprake is van een afname van het percentage gemeenten waar lokale lijsten aan de gemeenteraadsverkiezingen deelnemen. Dit geldt met name voor de provincies Utrecht, Zuid-Holland en Zeeland en in de categorie gemeenten met 3.000 tot 25.000 inwoners. Tegelijkertijd zien wij een toename van het percentage gemeenten waar de nationale lijsten aan de gemeenteraadsverkiezingen deelnemen, met name in de Noord-Brabant en Limburg. Deze toename geldt voor de drie belangrijke politieke stromingen; de confessionele, de progressieve en de liberale stroming. Op basis van deze twee constateringen is het niet verbazingwekkend dat het percentage lokale 
lijsten op het totaal aantal deelnemende lijsten is afgenomen, met name in de provincies NoordBrabant en Limburg. Deze relatieve afname is sterker in gemeenten met 3.000 tot 25.000 inwoners.

Voor de uitslagen van de partijen op lokaal niveau is het niet alleen van belang in hoeveel gemeenten lijsten aan de gemeenteraadsverkiezingen meedoen, maar vooral ook hoeveel kiezers op basis daarvan op de betreffende partij kunnen stemmen. Er is wat dat betreft een lichte afname van het percentage kiezers dat op een lokale lijst kan stemmen en een lichte toename van het percentage kiezers dat op een nationale lijst kan stemmen. Voorts is er sprake van een toename van het percentage kiezers dat bij de gemeenteraadsverkiezingen een keuze kan maken uit de drie politieke hoofdstromingen. In die zin kunnen wij dus spreken van een pluralisering van de gemeenteraadsverkiezingen.

De uitslagen op landelijk niveau van de lokale lijsten laten in de periode 1974-1990 een daling zien. Deze daling is te constateren in alle categoriën van gemeentegrootte. Nadere analyse bracht aan het licht dat deze achteruitgang met name te wijten is aan de achteruitgang van de lokale lijsten in haar twee bolwerken, de Noord-Brabantse en Limburgse gemeenten. Ten aanzien van de electorale verhoudingen in de gemeenten is er sprake van een afname van het percentage communale gemeenten. Het betreft gemeenten waar 60 procent of meer van de uitgebrachte stemmen op de lokale lijsten zijn uitgebracht. Tegelijkertijd zien wij een relatieve toename van gemengde gemeenten ( 40 á $60 \%$ op de lokale lijsten) en nationale gemeenten ( $40 \%$ of minder voor de lokale lijsten). In zeer sterke mate geldt dit in Noord-Brabant en Limburg en bij de categorie gemeenten met 3.000 tot 25.000 inwoners.

Op basis van het bovenstaande kunnen wij met recht constateren dat de tendens van lokalisering èn nationalisering die Dittrich in de periode 1962-1974 constateerde zich slechts gedeeltelijk heeft doorgezet (Dittrich, 1974:216-217). Immers, er is alleen nog maar sprakevan een nationalisering van de gemeenteraadsverkiezingen. In tegenstelling tot de periode 1962 1974 betreft deze nationalisering niet alleen de deelname van nationale lijsten, maar tevens de verkiezingsresultaten en de electorale verhoudingen in de gemeenten. Hierbij moeten wij wel aantekenen dat de grootste achteruitgang, die in het percentage stemmen, zich voornamelijk heeft voorgedaan in de Noord-Brabantse en Limburgse gemeenten, waar men vanouds zeer sterk stond. De afname van de traditionele voedingsbodem van de lokale lijsten in deze gemeenten door de maatchappelijke ontwikkelingen en de daarmee gepaard gaande toenemende concurrentie van de landelijke lijsten is hiervoor waarschijnlijk verantwoordelijk (van Tilburg, 1991:162-163).

\section{Plaatselijke stempercentages en trends}

Het lokale karakter van de gemeenteraadsverkiezingen wordt echter niet alleen bepaald door de electorale positie van de lokale lijsten. Ook in de verkiezingsresultaten van de landelijke partijen kan een lokale factor zitten. Vandaar dat wij als tweede benadering gekozen hebben voor een vergelijking van de plaatselijke uitslagen van de drie grootste landelijke partijen bij de lokale-en de niet-lokale verkiezingen. Door deze vergelijking zou duidelijk moeten worden in hoeverre er op plaatselijk niveau sprake is van ander kiesgedrag bij beide soorten verkiezingen. Daarmee is niet gesteld dat bij geringe verschillen de lokale verkiezingen genationaliseerd zijn. Daarmee zouden wij immers uitgaan van de on bewezen veronderstelling dat alleen nationale overwegingen de partijkeuze bij de gemeenteraadsverkiezingen bepalen. Wel kunnen wij op basis van de analyse van de uitslagen stellen dat er sprake is van een gering eigenstandig lokaal karakter van de gemeenteraadsverkiezingen. 
Opverschillende manieren hebben wij het lokale karakter van de gemeenteraadsverkiezingen in kaart gebracht. Allereerst bleek dat bij de drie partijen een sterke samenhang bestaat tussen de plaatselijke stempercentages bij de gemeenteraadsverkiezingen en de niet-lokaleverkiezingen. Dit gold in iets sterkere mate voor de PvdA en de VVD dan voor het CDA. Werden de gemeenten waar lokale lijsten aan de gemeenteraadsverkiezingen deelnamen niet in de analyse meegenomen dan werd voor alle partijen maar met name voor het CDA de samenhang tussen de plaatselijke stempercentages nog sterker. Opmerkelijk was dat PvdA en VVD in 1990 ten opzichte van de overige verkiezingsjaren een relatief geringe samenhang tussen de uitslagen lieten zien. ${ }^{2}$

Vervolgens hebben wij bepaald hoe groot de invloed van de lokale factor op de verkiezingsuitslagen is. De gemiddelde invloed hiervan op de plaatselijke stempercentages van het CDA is ongeveer 6 procent. Dit betekent dat onder invloed van lokale factoren de plaatselijke stempercentages van het CDA gemiddeld 6 procent hoger of lager zijn dan zonder de invloed van lokale factoren het geval zou zijn. Bij de PvdA is dit 4 à 6 procent en bij de VVD ongeveer 3 procent. Voorts blijkt de invloed van lokale factoren op de plaatselijke stempercentages van met name het CDA te dalen, tot ongeveer 3 procent, als alleen de gemeenten waar lokale lijsten aan de verkiezingen deelnemen in de analyse werden meegenomen. Opnieuw een bewijs dat de plaatselijke stempercentagesvan het CDA bij de gemeenteraadsverkiezingen relatief sterk beïnvloed worden door de deelname van de lokale lijsten. Als wij de hoogte van de lokale factoren in de verschillende gemeenten relateren aan de plaatselijke stempercentages in deze gemeenten dan blijkt overigens dat de PvdA, vooral in de gemeenten zonder deelnemende lokale lijsten, het sterkst beïnvloed is door lokale factoren. Daarentegen werd het CDA in de gemeenten zonder deelnemende lokale lijsten in nog mindere mate dan de VVD benvloed door lokale factoren. Ook bij het bepalen van de gemiddelde lokale factor voor de verschillende partijen blijkt dat in 1990 met name de plaatselijke stempercentagesvan de PvdA en de VVD in sterkere mate dan voorheen zijn beïnvloed door lokale factoren. Dit betekent ook dat van alle gemeenteraadsverkiezingen in de periode 1974-1990 de plaatselijke stempercentagesvan de drie partijen gezamenlijk in 1990 het sterkst beïnvloed zijn door lokale factoren. De absolute verschillen tussen de verkiezingen in de onderzochte periode zijn echter betrekkelijk gering. De relatieve invloed van de lokale factoren schijnt wel geleidelijk toegenomen te zijn vanaf de gemeenteraadsverkiezingen van 1974.

Uit de analyse van de uitslagen in gemeenten met uitzonderlijke stempercentages bleek dat vanaf 1978 bij het CDA en de PvdA vooral gemeenten in Noord-Brabant en Limburg een dergelijke uitslag lieten zien. De aanwezigheid van de lokale lijsten bleek hierbij de beslissende factor. In $z$ 'n algemeenheid bleek dat driekwart van de uitzonderlijke stempercentages in de periode 1974-1990 verklaard konden worden door de deelname van de lokale lijsten aan de gemeenteraadsverkiezingen. Waarmee nogmaals het belang van deze lijsten voor het lokale karakter van de gemeenteraadsverkiezingen aangetoond wordt.

De analyse van de plaatselijke trends van de drie grote landelijke partijen in de periode 1974$1990 \mathrm{gaf}$ in grote lijnen dezelfde resultaten te zien als de analyse van de plaatselijke uitslagen. Zo bleek ondermeer dat bij de lokale verkiezingen in vergelijking met de niet-lokaleverkiezingen bij de drie partijen sprake was van een grotere spreiding van de plaatselijke trends, een geringere samenhang tussen de plaatselijke stempercentages bij twee opeenvolgendeverkiezingen en een groter verschil tussen de plaatselijke trends en de landelijke trend. De verschilien waren echter betrekkelijk gering. Vooral in de gremeenten zonder deelnemende lokale lijsten was slechts in geringe mate sprake van een lokaal karakter van de plaatseliike trends bij de 
gemeenteraadsverkiezingen. Bij de analyse van de plaatselijke trends bleek ook dat de plaatselijke trends van het CDA relatief het sterkst worden beïnvloed door de deelname van lokale lijsten aan de gemeenteraadsverkiezingen. In het verlengde van de analyse van de plaatselijke stempercentages zien wij bij de analyse van de plaatselijke trends een lichte stijgende tendens bij het gemiddelde verschil tussen de plaatselijke trends en de landelijke trend bij de gemeenteraadsverkiezingen in vergelijking met de niet-lokale verkiezingen. Tevens zien wij dat in 1990 vooral bij de PvdA sprake is van een opmerkelijke stijging van deze afwijking ten opzichte van de gemeenteraadsverkiezingen van 1986 . Vooral bij het CDA was overigens sprake van relatief veel uitzonderlijke trends bij de gemeenteraadsverkiezingen. Een groot deel hiervan is afkomstig uit Noord-Brabantse en Limburgse gemeenten, waar het CDA heeft geprofiteerd van de neergang van de lokale lijsten. In totaal was bijna 80 procentvan de gevonden uitzonderlijke trends bij de drie partijen terug te voeren op plaatselijke electorale verschuivingen van lokale lijsten.

Op basis van de analyse van de plaatselijke stempercentages en trends van de drie grote landelijke partijen kunnen wij concluderen dat in de regel op plaatselijk niveau slechts in geringe mate sprake is van kiesgedrag dat karakteristiek is voor de gemeenteraadsverkiezingen. Zowel de plaatselijke stempercentages als trends bij de gemeenteraadsverkiezingen blijken in sterke mate overeen te komen met die van de niet-lokale verkiezingen. Wel kunnen wij in de periode 1974-1990 een lichte stijging van het lokale karakter van de gemeenteraadsverkiezingen constateren. Opvallend is dat de deelname van de lokale lijsten bijde gemeenteraadsverkiezingen een belangrijke factor bij dit lokale karakter is. Ditgeldt met name voor het CDA, wier plaatselijke stempercentages en trends in grotere mate dan bij de andere partijen beïnvloed worden door de lokale lijsten. Bij de gemeenteraadsverkiezingen van 1990 zien wij vooral bij de PvdA maar ook bij de VVD een sterkere invloed van lokale factoren op hun plaatselijke stempercentages en trends.

\section{Individueel kiesgedrag en lokale overwegingen}

De derde manier om het eigenstandige lokale karakter van de gemeenteraadsverkiezingen te bepalen, bestaat uit een nadere analyse en een overzicht van het beschikbare lokale kiezersonderzoek. Allereerst betrof het hier een analyse van het kiesgedrag bij de lokale-en niet-lokale verkiezingen. De gegevens van landelijke kiezersonderzoeken van 1986 geven aan dat ruim 70 procent van de kiezers bij de twee verkiezingen in dat jaar hetzelfde hebben gestemd dan wel van plan waren te stemmen. Beperken wij ons tot de degenen die bij de gemeenteraadsverkiezingen op de landelijke partijen hebben gestemd, dan blijkt afhankelijk van de partij ruim 80 tot meer dan 90 procent van de kiezers dezelfde partij te hebben gestemd. Hiermee wordt duidelijk dat lokale lijsten van relatief groot belang zijn bij het bepalen van het lokale kiesgedrag bij de gemeenteraadsverkiezingen. Deze gegevens worden ondersteund door de resultaten van lokaal kiezersonderzoek in zeven grote gemeenten in 1991.

Zelfs al stemt men dezelfde partij bij de lokale-en niet-lokale verkiezingen, lokale overwegingen kunnen daarbij een rol hebben gespeeld. Uit landelijk onderzoek blijkt dat in de periode 1982 1990 slechts een minderheid van de kiezers haar partijkeuze bijde gemeenteraadsverkiezingen geheel of gedeeltelijk liet bepalen door de lokale politiek van de partij van keuze. Opmerkelijk is wel dat in 1986 de landelijke politiek van de partij van keuze voor relatief veel kiezers van belang was, terwijl in 1990 juist de lokale politiek aan belang won. Voorts blijkt dat in de regel in kleinere gemeenten de lokale politiek iets meer doorslaggevend was dan in grotere 
gemeenten. Uit lokaal kiezersonderzoek in zeven grote gemeenten in 1991 blijkt overigens dat in deze gemeenten in de regel minder dan 5 procent van de kiezers een expliciet lokaal motief noemt voor de partijkeuze bij de gemeenteraadsverkiezingen. Er worden zelfs meer expliciet nationale motieven gegeven. Wel blijkt dat de motieven bij de gemeenteraads- en Tweede Kamerverkiezingen bijgemiddeld 50 procent van de kiezers niet overeen te komen. Aangezien men bij beide verkiezingen voor het merendeel dezelfde partij stemt en nog meer nationale dan lokale motieven noemt voor de partijkeuze bij de gemeenteraadsverkiezingen, lijken de verschillende motieven bij beide verkiezingen meer samen te hangen met de aard van de gemeenteraadsverkiezingen dan de invloed van de lokale politiek.

Al met al kunnen wij op basis van het lokale kiezersonderzoek concluderen dat er slechts in geringe mate sprake is van lokaal kiesgedrag bij de gemeenteraadsverkiezingen. En ongeveer de helft van de kiezers die verschillend stemmen bij gemeenteraads- en Tweede Kamerverkiezingen hebben bij de gemeenteraadsverkiezingen op een lokale lijst gestemd. Voor een minderheid van de kiezers speelt de lokale politiek van de partij van hun keuze een rol bij de partijkeuze bij de gemeenteraadsverkiezingen. In 1990 geldt dit overigens in duidelijk geringe mate dan in 1986, waar de landelijke politiek een relatief grote rol speelde bij de partijkeuze bij de gemeenteraadsverkiezingen.

\subsection{Eindconclusies}

Uit bovenstaande samenvatting van de belangrijkste resultaten van het onderzoek naar het lokale kiesgedrag bij de gemeenteraadsverkiezingen kunnen wij een aantal conclusies trekken.

De belangrijkste conclusie is dat er slechts in geringe mate gesproken kan worden van een. eigenstandig lokaal kiesgedrag bij de gemeenteraadsverkiezingen in de periode 1974-1990. Dat kunnen wij niet alleen opmaken uit de analyse van de plaatselijke stempercentages en trends bij de gemeenteraadsverkiezingen maar ook uit het beschikbare kiezersonderzoek op ditgebied, ook al heeft dit onderzoek alleen plaatsgevonden in 1986 en 1991. Aanvullend hierbij is de constatering dat in de periode 1982-1990 slecht voor een minderheid van de kiezers de lokale politiek van de partij van keuze van belang is geweest bij de partijkeuze bij de gemeenteraadsverkiezingen.

Een tweede conclusie die wij kunnen trekken is dat de lokale lijsten een belangrijke factor zijn bij het bepalen van het lokale karakter van de gemeenteraadsverkiezingen. In de eerste plaats omdat in de periode 1974-1990 nog altijd 12 á 18 procent van de kiezers haar stem uitbracht op een lokale lijst. De achteruitgang van het percentage stemmen op lokale lijsten na 1974 blijkt voor het grootste deel te wijten aan de achteruitgang in Noord-Brabantse en Limburgse gemeenten, de traditionele bolwerken van de lokale lijsten. Deze achteruitgang kan dus niet als een duidelijk landelijk fenomeen beschouwd worden. In de tweede plaats spelen de lokale lijsten een belangrijke rol bij de gemeenteraadsverkiezingen omdat zij door hun deelname de plaatselijke stempercentages en trends van de drie grote landelijke partijen benvloeden. In de derde plaats blijkt uit het beschikbare lokale kiezersonderzoek dat in ongeveer de helft van de gevallen dat kiezers een andere partijkeuze maken bij de Tweede Kamerverkiezingen in vergelijking met de gemeenteraadsverkiezingen, men bij de gemeenteraadsverkiezingen op een lokale lijst heeft gestemd. 
Een derde conclusie is dat er ten aanzien van het bovenstaande geen grote verschillen tussen de drie grote landelijke partijen zijn. Zo blijkt bijvoorbeeld uit de analyse van de plaatselijke stempercentages en trends dat het CDA in iets grotere mate beïnvloed werd door lokale factoren dan de PvdA en de VVD. Maar dit geldt echter niet meer als wij rekening houden met de hoogte van de plaatselijke stempercentages van de drie afzonderlijke partijen. De plaatselijke stempercentages en trends van de PvdA zijn in dat geval in iets sterkere mate beïnvloed door lokale factoren. De iets sterkere beïnvloeding van de stempercentages en trends van de PvdA kunnen wij ook constateren als wij het lokale karakter van de gemeenteraadsverkiezingen bepalen in de gemeenten waar de lokale lijsten niet aan de gemeenteraadsverkiezingen hebben deelgenomen. Een opmerkelijk verschil is wel dat de plaatselijke stempercentages en trendsvan het CDA in grotere mate beïnvloed werden door de lokale lijsten dan dievan de PvdA en de VVD. Bij de analyse van het individueel kiesgedrag is minder duidelijk een dergelijk verschil te bespeuren. Het CDA blijkt in ongeveer dezelfde mate als de andere grote landelijke partijen erin te slagen haar kiezers op haar te laten stemmen bij zowel de gemeenteraads-als de Tweede Kamerverkiezingen. ${ }^{3}$

\section{Resultaten uit andere Europese landen.}

Uit verschillende onderzoeken blijkt overigens dat ook in andere Europese landen sprake is van een gering lokaal karakter van de gemeenteraadsverkiezingen. Op basis van een grootschalig kiezersonderzoek concludeerde Miller dat in 1986 in Groot-Brittannië 85 procent van de kiezers dezelfde partijvoorkeur had bij de lokale verkiezingen als bij de landelijke verkiezingen. Degenen die kenbaar maakte dat men vanuit lokale overwegingen stemde of, nog sterker, degenen die eerder op een persoon dan op een partij stemde bij de lokale verkiezingen, bleken bij de lokale verkiezingen in meerdere mate een andere partij te kiezen dan kiezers voor wie dit niet gold (Miller, 1988;165-172). Tevens wist hij op basis van de nationale politieke voorkeur ongeveer 80 procent van de variatie in de plaatselijke uitslagen van de Labourparty en de Conservatieven te verklaren. Voor de Liberalen was dit percentage 65 procent. In een analyse van de Ierse lokale verkiezingsuitslagen in 25 kiesdistricten in de periode 1967-1985 komt Callagher tot de conclusie dat er tot op zekere hoogte sprake is van twee verschillende typen van electoraal gedrag bij de Ierse lokale en niet-lokale verkiezingen. Maar gezien de door hem gevonden hoge correlaties tussen de uitslagen van beideverkiezingen is naar zijn mening lokaal electoraal gedrag echter een aangepaste vorm van landelijk electoraal gedrag (Gallagher:1987;11-12). Denver constateert in zijn onderzoek naar de Schotse lokale verkiezingen in de periode 1974-1986 dat er grote overeenkomsten bestaan tussen de uitslagen van de partijen in de verschillende districten bij twee opeenvolgende lokale verkiezingen. Zijn conclusie is dat het stemgedrag bij lokale verkiezingen vooral een product is van de reacties op ontwikkelingen in de landelijke politiek (Denver;1987;14-15). In tegenstelling tot bovenstaande onderzoeken blijkt uit een onderzoek van Håkansson dat bij de Zweedse lokale verkiezingen in de periode $1973-1985$ in toenemende mate sprake is van een lokaal stemgedrag. Hij komt tot deze conclusie op basis van het berekenen van de relatie tussen de nationale en lokale verandering van de plaatselijke stempercentages van de verschillende partijen in de verschillende gemeenten. In 1985 kon bijvoorbeeld maar 30 procent van de variantie in de lokale verandering van de stempercentages voor de verschillende partijen bij de lokale verkiezingen verklaard worden door de verandering van de stempercentages bij de nationale verkiezingen, die overigens op dezelfde dag plaatsvonden (Håkansson, 1987;14-16). 


\section{Mogelijke oorzaken}

Als wij de mogelijke oorzaken van het betrekkelijk geringe lokale karakter van de gemeenteraadsverkiezingen willen bepalen, zijn wij afhankelijk van kiezersonderzoek naar de betrokkenheid van de kiezers bij de lokale politiek. Op grond van een secundaire analyse van het beschikbare lokale kiezersonderzoek uit de periode 1974-1990, kunnen wijechter hoogstens tentatieve conclusies trekken. De resultaten van lokaal kiezersonderzoek geven aan dat kiezers minder geïnteresseerd zijn in de lokale politiek dan in de landelijke politiek. Zij beschikken tevens over relatief weinig kennis over de verschillende aspecten van de lokale politiek. Daar staat tegenover dat burgers een betrekkelijk grote interesse hebben voor de gebeurtenissen in hun woonplaats, al strekt zich dit niet uit tot de lokale politiek. Een groot deel van de kiezers blijkt voorts geen duidelijke verschillen te zien tussen de partijen die in de gemeenteraad vertegenwoordigd zijn. Tevens hebben zij het idee dat de lokale politiek veel interessanter zou zijn als die verschillen wat duidelijker waren. Al met al lijkt het kiezersonderzoek erop te wijzen dat de lokale politiek voor veel kiezers weinig (politieke) betekenis heeft. Vanuit dit gezichtspunt is het dan ook niet opmerkelijk dat bij de gemeenteraadsverkiezingen slechts een beperkte groep kiezers zich laat bij hun partijkeuze laat leiden door overwegingen van lokaal-politieke aard. Als de lokale politiek aan (partijpolitieke) betekenis wint, zal deze meer tegenwicht kunnen geven tegen de algemene (landelijke) politieke noties. Het bovenstaande is in overeenstemming met de zogenaamde echoput-these van Key, die inhoudt dat de keuze van kiezers in eerste instantie bepaald wordt door de voorgelegde alternatieven (Key, 1966:2-3). Als er op lokaal niveau volgens veel kiezers geen duidelijke alternatieven worden voorgelegd, is het logisch dat er ook geen duidelijke lokale keuze wordt gemaakt. Veel kiezers laten hun stem bij de gemeenteraadsverkiezingen in dat geval bepalen door de landelijke politiek, waar kiezers wel duidelijke verschillen zien tussen de partijen. ${ }^{4}$

Lokaal kiezersonderzoek geeft aan dat de betrokkenheid bij de lokale politiek enigszins groter is bij kiezers in de kleinere gemeenten. Het zal duidelijk zijn dat deze grotere betrokkenheid niet veroorzaakt wordt door een sterker partijpolitiek karakter van de lokale politiek in deze gemeenten. Waarschijnlijk is een sterkere band met de directe leefomgeving hierbij van beslissende invloed. Deze zorgt er voor dat men in sterkere mate lokale politici kent en eerder met hen in contact komt. Op deze manier staat de lokale politiek dichter bij de mensen. Daarnaast kan een factor van betekenis zijn dat in de kleinere gemeenten de lokale lijsten relatief sterk vertegenwoordigd zijn. Uit onderzoek blijkt onder meer dat met name op kandidatenlijsten van de lokale lijsten in Limburg van oudsher veel personen staan die een sterke band hebben met de lokale gemeenschap (Werkgroep lokale politiek RL, 1986:27). Vandaar dat in 1990 meer dan 60 procentvan de stemmen op de lokale lijsten voorkeursstemmen zijn (Kuiper/Koning, 1991:201-202). Kortom, ook de bekendheid van en de band met lokale politici kan een factor van betekenis zijn voor de betrokkenheid van kiezers bij de lokale politiek. 


\subsection{Nabeschouwing}

In de in hoofdstuk 1 vermelde discussie over het lokale karaktervan de gemeenteraadsverkiezingen stond niet centraal in hoeverre er werkelijk sprake was van een gering lokaal karakter. De meeste participanten in deze discussie gingen ervan uit dat er sprake was van een gering lokaal karakter en probeerde van daaruit verschillende maatregelen voor te stellen die vanuit hun visie tot verbetering van de situatie zouden leiden. Kortom, allerleivoorstellen werden gedaan om het lokale karakter van de gemeenteraadsverkiezingen te versterken. Wij zullen ter afsluiting enkele voorstellen de revue laten passeren en van kanttekeningen voorzien. Uitgangspunt daarbij is, dat als het geringe lokale karaktervan de gemeenteraadsverkiezingen een negatieve invloed heeft op het democratische gehalte van de lokale politiek, een discussie over mogelijke verbeteringen van het functioneren van de lokale democratie noodzakelijk is. In hoofdstuk acht hebben wij geconstateerd dat burgers in de regel in grote mate betrokken zijn bij hetgeen in hun eigen gemeente gebeurt, maar dat deze betrokkenheid zich niet uitstrekt tot de lokale politiek. En wij hebben geconcludeerd dat door de relatief kleine waarneembare verschillen tussen de partijen op lokaal niveau, het niet opmerkelijk is dat de kiezers zich bij de gemeenteraadsverkiezingen slechts in geringe mate laten leiden door lokale overwegingen bij hun partijkeuze. Uit het bovenstaande is af te leiden dat het versterken van het lokale karaktervan de gemeenteraadsverkiezingen door de betrokkenheid van de burgers bij de lokale politiek te vergroten op twee verschillende manieren inhoud kan worden gegeven. De betrokkenheid van de burgers bij de lokale politiek zou vergroot kunnen worden door de afstand tussen de burgers en de politici op lokaal niveau te verkleinen. Of anders gezegd, door de lokale politiek een duidelijk gezicht te geven. In de tweede plaats kan gedacht worden aan maatregelen die het politieke karakter van de lokale politiek benadrukken. Immers, een groot deel van de burgers is van mening dat dat de lokale politiek voor hen interessanter maakt. Bij de bespreking van de voorstellen ter versterking van het lokale karakter van de gemeenteraadsverkiezingen zullen wij in het verlengde van het onderzoek met name die voorstellen behandelen waarbij lokale verkiezingen en de keuzemogelijkheden van de kiezers centraal staan. ${ }^{5}$

\subsubsection{Andere verkiezingen}

Een aantal veranderingen in het kiesstelsel beogen de band tussen de kiezers en de gekozenen en daarmee het lokale karakter van de gemeenteraadsverkiezingen te versterken. Zo zou bijvoorbeeld de invloed van voorkeurstemmen op de zetelverdeling vergroot kunnen worden. In de huidige Kieswet is een kandidaat met voorkeurstemmen gekozen als hij/zij tenminste de helft van de kiesdeler gehaald heeft. Daarbij worden alle stemmen op de betreffende kandidaat bij elkaar opgeteld. Een vergroting van de invloed van de voorkeurstemmen, bijvoorbeeld door de drempel te verlagen tot 25 procent van de kiesdeler, zou de invloed van de kiezers op de samenstelling van de gemeenteraad kunnen verhogen. Een dergelijke maatregel kan tevens als effect hebben dat kandidaten persoonlijke voorkeursacties gaan voeren (Kuiper/Koning, 1990:198). Een vergroting van de invloed van voorkeurstemmen kan daarmee een bijdrage leveren aan een vergroting van de betrokkenheid van de burgers bij de lokale politiek..$^{6}$ 
Een tweede mogelijkheid om de relatie tussen kiezers en gekozenen te versterken is het invoeren van een districtenstelsel op lokaal niveau. Het zal duidelijk zijn dat dit met name in grotere gemeenten een interessante mogelijkheid is. In dit kader kan ook gewezen worden op de grote interesse van burgers in de gemeente Eindhoven voor het kiezen van gemeenteraadsleden uit hun wijk (65\%) en de steun voor een wijkwethouder in Utrecht (47\% positief en $32 \%$ gematigd positief). De invoering van districten kan gekoppeld worden aan de invoering van het zogenaamde Duitse kiesstelsel. Op nationaal niveau wordt op dit moment naar aanleiding van de voorstellen van de commissie-Deetman gestudeerd op de mogelijkheid van de invoering van dit kiesstelsel (de commissie de Koning). De essentie van dit kiesstelsel is dat men zowel de mogelijkheid heeft om op een landelijke (lokale) lijst van een partij te stemmen als de mogelijkheid om in het eigen district (wijk) op een persoon te stemmen. De beschikbare zetels worden verdeeld op basis van de stemmen op de lijst, waarbij de in de districten gekozen kandidaten voorrang hebben. Het voordeel van dit stelsel is dat de representativiteit van het vertegenwoordigend orgaan niet wordt aangetast terwijl via de kandidaten uit de districten de band tussen kiezer en gekozene meer inhoud kan krijgen. In het verlengde van de discussie over verandering van het landelijk kiesstelsel is het daarom nuttig ook de mogelijkheid van een dergelijkeverandering in (grotere) gemeenten aan de orde te stellen.

\section{Het verbieden van de deelname van landelijke partijen}

Een vergaande maatregel om het lokale karakter van de gemeenteraadsverkiezingen te versterken door het kiesstelsel aan te passen, is het verbieden van landelijke partijen om aan de gemeenteraadsverkiezingen mee te doen. ${ }^{7}$ Een voordeelvan deze benadering is ondermeer dat de gemeenteraadsverkiezingen niet meer gebruikt kunnen worden als opiniepeilingen voor de landelijke partijen. Tevens zouden zij niet meer sterk beïnvloed worden door landelijke politieke ontwikkelingen. Kiezers zouden gedwongen worden een keuze te maken uit lokale lijsten en partijen. De landelijke politieke partijen zouden niet meer de mogelijkheid hebben om met hun landelijk imago de lokale politieke verhoudingen te bepalen. Zo zou er ruimte komen om de lokale (politieke) verhoudingen tot zijn recht te laten komen.

Tegen deze benadering zijn bezwaren van praktische en principiële aard aan te voeren. In de eerste plaats zal het onmogelijk zijn om (leden van) landelijke partijen te verbieden om onder een andere naam mee te doen aan de gemeenteraadsverkiezingen. Vooral als partijen op basis van de landelijke politieke ontwikkelingen electorale winst verwachten, zal de neiging bestaan om de band met landelijke partijen te benadrukken, al was het alleen maar in de naamgeving. Daarmee wordt een groot deel van het effect van het verbieden van de landelijke partijen bij de gemeenteraadsverkiezingen teniet gedaan. Het is wel mogelijk om de Kieswet zo te veranderen dat er niet meer de mogelijkheid is voor lijsten om hun naam boven het stembiljet te zetten. Maar een dergelijke maatregel kan natuurlijk in het verkiezingsmateriaal ontdoken worden. Daarbij is van groot belang dat een verbod op het gebruik van namen en/of aanduidingen van partijen in verkiezingsmateriaal niet mogelijk is vanwege de vrijheid van meningsuiting.

Het belangrijste bezwaar tegen het verbieden van de deelname van landelijke partijen aan de gemeenteraadsverkiezingen is van principiële aard. In een democratie, waar een vrije keuze van volkvertegenwoordigers centraal staat, dienen kiezers uit te maken wie in een vertegenwoordigend orgaan worden gekozen en niet een wettelijk verbod. ${ }^{8}$ Daarbij is het aan de kiezers om te bepalen of men bij de gemeenteraadsverkiezingen op landelijke partijen stemt. Bij een 
verbod ontstaat de eigenaardige situatie dat partijen gestraft worden voor de omstandigheid dat zij kiezers de gelegenheid geven te stemmen op de partij van hun keuze. Nog los van de onwaarschijnlijkheid dat de partijen in het parlement akkoord zullen gaan met een verbodvan deelname van deze partijen bij de gemeenteraadsverkiezingen, is op basis van praktische en principiële bezwaren een dergelijk verbod onwenselijk.

\section{Spreiding van de gemeenteraadsverkiezingen}

Vooral het voorstel om de gemeenteraadsverkiezingen te spreiden kent veel aanhangers. De discussie over het lokale karakter van de gemeenteraadsverkiezingen is zelfs begonnen met een voorstel van P. Scholten (1986), de toenmalige burgemeester van Soest en huidige burgemeester van Arnhem, om de gemeenteraadsverkiezingen niet meer in alle gemeenten op één dag te laten plaatsvinden maar te spreiden over meerdere data. Onderdeel van zijn voorstel was om de gemeenten de mogelijkheid te geven om eens in de vier á zes jaar gemeenteraadsverkiezingen te houden. Later heeft hij dit voorstel aangepast door te pleiten voor gemeenteraadsverkiezingen perWGR-regio (Scholten, 1987a).$^{9}$ Verschillende deelnemers aan deze discussie over de versterking van het lokale karakter van de gemeenteraadsverkiezingen ondersteunden zijn voorstel (Elzinga, 1986; Drijber, 1987; Derksen, 1990a; Tops, 1990:219; Onderzoeksgroep Lokale Democratie, 1991:111). De vraag is echter of de spreiding van de gemeenteraadsverkiezingen een groot effect zal hebben op het lokale karakter van de gemeenteraadsverkiezingen. ${ }^{10}$ Deze verwachting is vooral gebaseerd op de verondersteiling dat de landelijke media en de landelijke partijen op deze manier minder aandacht aan de gemeenteraadsverkiezingen zullen en kunnen besteden, waardoor de kiezers in de gemeenten voornamelijk geconfronteerd worden met informatie over de lokale politiek. Wij kunnen echter vraagtekens zetten bij dit verwachte effect omdat een spreiding van de verkiezingen betekent immers ook dat de media en de landelijke partijen hun aandacht kunnen spreiden." Dat betekent bijvoorbeeld dat landelijke kopstukken nog gemakkelijker ingezet kunnen worden bij de campagnes van de landelijke partijen bij de gemeenteraadsverkiezingen. En omdat bij spreiding van de gemeenteraadsverkiezingen regelmatig verkiezingen zullen plaatsvinden, waarbij meestal ook grotere gemeenten betrokken zijn, kunnen deze gemeenteraadsverkiezingen gebruikt worden als opiniepeilingen voor de landelijke politieke verhoudingen. Mocht een spreiding van de gemeenteraadsverkiezingen toch de door de voorstanders verwachte effect hebben, dan zal dat waarschijnlijk leiden tot een daling van de opkomst bij de gemeenteraadsverkiezingen. Door de verminderde aandacht van de landelijke media en de landelijke partijen zal een deel van de kiezers waarschijnlijk uit desinteresse niet gaan stemmen, hetgeen juist een verzwakking van de legitimiteit van de de lokale politiek ten gevolge heeft.

Hiermee wordt duidelijk dat een spreiding van de gemeenteraadsverkiezingen als zelfstandig fenomeen niet de essentie van de zaak raakt, namelijk het versterken van het lokale karakter van de gemeenteraadsverkiezingen door de betrokkenheid van de kiezers bij de lokale politiek te vergroten. Natuurlijk heeft de aandacht van de landelijke media en de landelijke campagnes van de landelijke partijen bij de gemeenteraadsverkiezingen een negatieve invloed op het lokale karakter van de gemeenteraadsverkiezingen. $Z$ ij kan deze rol echter met name spelen vanwege de geringe betrokkenheid van de kiezers bij de lokale politiek. Daarom kan de spreiding van de gemeenteraadsverkiezingen hoogstens een aanvulling zijn op maatregelen die deze betrokkenheid vergroten. Zij kan wel een rol spelen als zij gekoppeld wordt aan het functioneren van de lokale politiek. Dit is bijvoorbeeld het geval als na het uiteenvallen van een 
college van $B \& W$ nieuwe verkiezingen uitgeschreven zouden kunnen worden. In de verkiezingscampagnes bij dergelijke gemeenteraadsverkiezingen zal in ieder geval een lokaal politiek item centraal staan, waardoor lokale kiezers op een duidelijke manier geconfronteerd worden met de lokale politiek. Een dergelijke 'politisering'van de gemeenteraadsverkiezingen vergroot aldus de mogelijkheid van de burgers om daadwerkelijk invloed uit te oefenen op de lokale politiek. In de huidige politieke situatie komen collegecrises weinig voor, maar dat kan veranderen als een aantal maatregelen worden ingevoerd om de lokale politiek te 'personaliseren' en te 'politiseren'. ${ }^{12}$

\subsubsection{Meer verkiezingen}

Delokale kiezer kan meer betrokken worden bij de lokale politiek door hem meer mogelijkheden te geven om op een eenvoudige en interessante wijze invloed uit te oefenen op de lokale politiek. Eén van deze mogelijkheden is het houden van een lokaal referendum. Formeel bestaat er op dit moment niet de mogelijkheid om een bindend referendum te houden. Wel is het mogelijk kiezers een uitspraak te vragen over een politiek onderwerp waarbij mogelijk van te voren een meerderheid van de gemeenteraad zich moreel heeft verplicht om elke beslissing van de kiezers te accepteren. In een aantal gemeenten zijn dan ook al dergelijke referenda gehouden. ${ }^{13}$ Een voordeel van een referendum is dat kiezers uiteindelijk zelf de mogelijkheid hebben om een beslissing te nemen. Daarmee verdwijnt de onzekerheid of de lokale politiek bereid is de door kiezers gewenste beslissing te nemen. De vraag is echter of na een referendum, dus op langere termijn, de betrokkenheid van de burgers met de lokale politiekvergroot is. Onderzoek naar aanleiding van de referenda in Leiden en Haarlem wijzen uit dat dat niet het geval is. Tenminste, na eén experiment met het houden van een referendum is dat niet het geval. De onderzoekers stellen dan ook dat "als het referendum een positieve invloed invloed op de betrokkenheid bij de politiek heeft, dan zou zulks pas op langere termijn en mogelijk na het houden van meerdere referenda echt totuitdrukking kunnen komen (van Holsteyn/Hillebrand, 1991:115). Het houden van een referendum stelt wel een aantal eisen aan het onderwerpen het draagvlak hiervan. Het is ondermeer noodzakelijk dat het onderwerp zich leent voor een duidelijke vraagstelling. En het moet een onderwerp betreffen dat door een groot deel van de burgers als belangrijk en interessant wordt gezien. Tenslotte is het noodzakelijk dat duidelijk is dat een meerderheid van de gemeenteraad bereid is om de uitslag daarvan te accepteren, hoe deze ook luidt. Daardoor wordt niet het risico gelopen dat de uiteindelijke beslissing van de gemeenteraad niet de uitspraak van de kiezers volgt. Dat zou immers tot gevolg hebben dat kiezers zich in nog sterkere mate zullen afkeren van de lokale politiek. Uit het onderzoek van de onderzoeksgroep Lokale Democratie blijkt in ieder geval dat er bij een grote meerderheid van de kiezers de bereidheid is om aan een referendum mee te doen. De opkomst van 26,7 procent bij het in 1991 in Amsterdam gehouden referendum, geeft echter aan dat men in de praktijk geen al te hoge verwachtingen moet hebben van de opkomst bij een lokaal referendum. ${ }^{14}$

\section{De gekozen burgemeester}

Naast het houden van referenda staat met name de verkiezing van de burgemeester in de belangstelling in de discussie over het betrekken van burgers bij de lokale politiek. ${ }^{15}$ Zoals uit het lokaal kiezersonderzoek blijkt, is de burgemeester veel bekender dan de (overige) lokale 
politici. Met name in de grote steden lijkt het persoonlijk element in de lokale politiek nauwelijks aan bod te komen. Dit is vooral van belang in een tijd waarin personen de samenbindende rolvan ideologieën lijken over te nemen. Een verkiezing van de burgemeester kan leiden tot een versterking van het lokale politieke profiel van de lokale politiek. Zoals Tops (1992:185) stelt kan een zekere personalisering van de lokale verkiezingsstrijd en een toespitsing van de verkiezingen op de vraag wie burgemeester wordt, de eigenstandigheid van de lokale verkiezingen versterken. Er kan een sterkere samenhang ontstaan tussen de verrichtingen van de lokale politici en de winst of hetverlies bij de gemeenteraadsverkiezingen.

\subsubsection{Inhoudelijke verkiezingen}

Wij kunnen ons echter afvragen in hoeverre er mogelijkheden zijn voor de lokale politiek groeperingen om zich te profileren, gezien het beperkte takenpakket en de geringe financiële beleidsruimte van de gemeenten. Een vergroting van het takenpakket en de financiële beleidsruimte van gemeenten, gepaard aan een afname van de verschillende regels dienaangaande zal de eigen beslissingsruimte van gemeenten vergroten. Dit kan op twee manieren van belang zijn voor de versterking van het lokale karakter van de gemeenteraadsverkiezingen. In de eerste plaats worden daarmee de beslissingen van het gemeentebestuur belangrijker voor de burgers, hetgeen de betrokkenheid van de kiezers bij de lokale politiek kan vergroten. In de tweede plaats kan het vergroten van de eigen beslissingsruimte van de gemeenten leiden tot een vergroting van de partijpolitieke verschillen, hetgeen voor een deel van de kiezers interessant is, zoals wij reeds eerder zagen. ${ }^{16}$ De achtergrond hiervan is dat bij een grotere eigen beslissingruimte van de gemeente, politiek-inhoudelijke argumenten een grotere rol kunnen gaan spelen bij de politieke besluitvorming. Daardoor kunnen verschillende lokaalpolitieke items ontstaan waarop de partijen met elkaarvan mening verschillen. Kiezers worden daardoor niet alleen geconfronteerd met het politieke karakter van de gemeentelijke besluitvorming, maar tevens komen de politieke verschillen tuissen de partijen pregnanter naar voren. Daarmee is de basis gelegd voor een meer eigenstandig lokaal kiesgedrag bij de gemeenteraadsverkiezingen.

Het is de vraag of op korte termijn een vergroting van de beslissingsruimte van de gemeenten door een vergroting van het takenpakket en de financile beleidsruimte gerealiseerd kan worden. Ondanks de beleden steun voor de decentralisatie van taken naar gemeenten en provincies, is daar de afgelopen jaren weinig van terecht gekomen (Heij/ Schrijver, 1991:62-73). Wellicht dat de door het kabinet voorgestelde Decentralisatie-Impuls er wel in zal slagen om een substantieel deel van rijkstaken over te hevelen naar de gemeenten. Gezien de daarbij gehanteerde efficiencykorting zijn er wat de vergroting van de financiële beleidsruimte betreft, weinig positieve ontwikkelingen te bespeuren. Dat geldt met name ook voor de vergroting van het gemeentelijk belastinggebied. Ondanks het voorstel van de commissie-Christiaanse om de onroerend goedbelasting te verdubbelen lijkt op korte termijn alleen het overhevelen van de overdrachtsbelasting naar de gemeenten een kans van slagen te hebben. ${ }^{17}$ De vraag is of de voorstellen van de commissie-De Kam voor het invoeren van opcenten op de loon- en inkomstenbelasting, het invoeren van het zogenaamde koppengeld en een aanpassing van de onroerend goedbelasting meer kans van slagen hebben. 
Bovenstaande voorstellen zijn bedoeld om de betrokkenheid bij de lokale politiek te vergroten waardoor het lokale karakter van de gemeenteraadsverkiezingen versterkt wordt. Deze benadering stelt in wezen hoge eisen aan de kiezer. Uitgangspunt is namelijk dat in principe de kiezer geïnteresseerd is in politiek en dat deze interesse zich niet alleen zal uitstrekken over de landelijke politiek maar ook over de lokale politiek. Zoals bijvoorbeeld Berelson constateerde beantwoordt deze zienswijze niet aan de realiteit (Berelson, 1962:305-323). Daarmee wordt duidelijk dat wij niet al te hoge verwachtingen moeten hebben van het effect van de voorgestelde maatregelen. Slechts een deel van de kiezers zal op basis van deze maatregelen bij de gemeenteraadsverkiezingen een meer bewuste lokale partijkeuze maken. Aangezien een geringe betrokkenheid van de kiezers bij de lokale politiek en het daarmee samenhangende geringe lokale karakter van de gemeenteraadsverkiezingen vanuit democratisch oogpunt een onbevredigende situatie is, blijft het echter wenselijk te streven naar een zodanige verandering van het lokale politieke systeem dat een bijdrage wordt geleverd aan het versterken van het lokale karakter van de gemeenteraadsverkiezingen. 


\section{NOTEN}

' Hierbij gaan wij voorbij aan het feit dat in verschillende provincies bij de verkiezingen voor de Provinciale Staten de mogelijkheid bestaat om op samenwerkingsverbanden van lokale lijsten te stemmen. Tevens houden wijgeen rekening met het feit dat niet alle kiezers bij de gemeenteraadsverkiezingen op de partij van hun keuze kunnen stemmen aangezien deze partij in de betreffende gemeente niet aan de verkiezingen deelneemt. Aangezien in 1990 echter bijna alle kiezers hun stem konden uitbrengen op én van de drie politieke hoofdstromingen, is deze factor slechts van gering belang. Anders gezegd, slechts weinig kiezers werden gedwongen op een lokale lijst te stemmen omdat in de betreffende gemeente geen partij deelnam die in het politieke spectrum dicht bij de eigen partij stond.

${ }^{2}$ Zoals in hoofdstuk 5 is aangegeven kan dit gedeeltelijk het gevolg zijn van het relateif grote verschil tussen de data van de gemeenteraadsverkiezingen van 1990 en de Tweede Kamerverkiezingen van 1989.

${ }^{3}$ Daarbij moeten wij ons wel realiseren dat deze gegevens enkel afkomstig zijn van kiezersonderzoeken uit 1986 en 1991 .

' Harrop en Miller merken in dit kader op:

"But their is no point in castigating the voters failing to hold their elected representatives responsible. They use elections to send a message to what is, in their (and our) view, the real seat of government power. Criticism should be reserved for those who set up elected offices which lack real discretionary power."

Harrop en Miller (1987:94).

${ }^{5} \mathrm{Bij}$ het overzicht van maatregelen ter versterking van het lokale karakter van de gemeenteraadsverkiezingen moeten wijons raliseren dat met name de maatregelen die het politieke karaktervan degemeenteraadsverkiezingen versterken, een groter effect zullen hebben op de betrokkenheid van de kiezers bij de lokale politiek in grote gemeenten dan in kleine gemeenten. Gezien de aard van de problemen in de steden, zal een maatregel zoals bijvoorbeeld de vergroting van de gemeentelijke beleidsruimte van groter belang zijn in deze gemeenten dan in kleinere gemeenten.

${ }^{6}$ Gezien het feit dat bij de laatste herziening van de Kieswet een voorstel tot verlaging van de voorkeursrempel tot 25 procent van de kiesdeler met grote meerderheid verworpen is, lijkt een dengelijke wijziging op korte termijn niet, te realiseren. Een amendement van die strekking van het D66-Kamerlid Kohnstamm kreeg alleen de steun van de fracties van D66, PPR en PSP.

${ }^{7}$ Met name Bordewijk (1991:58) heeft de positieve effecten van een dergelijke maatregel naar voren gebracht. Zie ook Derksen (1990b:12), die sterk de nadelige gevolgen van de deelname van landelijke partijen aan de gemeenteraadsverkiezingen benadrukt.

'Zelfs ten aanzien van niet-democratische partijen ken men zich afvragen of de democratie ermee gediend is als deze partijen worden verboden, waardoor zij niet aan de verkiezingen kunnen deelnemen. Zie hiervoor onder meer: Elzinga (1982:143-147) en Eskes (1988:565-588).

Indeling van de Nederlandse gemeenten in 59 samenwerkingsgebieden op grond van de Wet gemeenschappelijke regelingen.

${ }^{10}$ Wij gaan hier voorbij aan de de omstandigheid dat slechts een kleine minderheid van de Tweede Kamer bij de herziening van de Kieswet in 1989 een voorstel voor een onderzoek naar de spreiding van de gemeenteraadsverkiezingen ondersteunde, waardoor op korte termijn een verandering in die richting niet reell lijkt. Het betreffende voorstel, ingediend door het D66-kamerlid Kohnstamm, kreeg de steun van de fracties van D66, PPR en PSP.

${ }^{11}$ Dat de verschillende gemeenten door de spreiding van de gemeenteraadsverkiezingen meer aandacht zullen krijgen van de landelijke media wordt door Bordewijk (1991:58) als een voordeel beschouwd. Daarvoor moet volgens hem wel de gemeentelijke issues centraal staan in de berichtgeving.

12 In dit opzicht is het interessant dat in Amersfoorten Utrecht, twee steden waarbij de gemeenteraadsverkieizngen inhet teken stonden van een belangrijk lokaal politiek item, in 1991 te maken kregen met een collegecrisis. In beide gevallen werd D66 die zich in beide steden gekeerd had tegen bestaande plannen om respectievelijk het Amersfoortse centrum grootschalig te vernieuwen en een sneltram door de Utrechtse binnenstad te laten lopen, na een grote winst bij de verkiezingen inhet college van $B \& W$ opgenomen. In Amersfoort trad men zelf uit het college, terwijl men in Utrecht uit het college werd verwijderd.

${ }^{3}$ In 1990 is in de kern Welsum van de gemeente Olst via een referendum aan de kiezers voorgelegd of men tot de provincie Overijssel of Gelderland wilde behoren. In 1991 is er in Haarlem gestemd over de bestemming van een polder voor woningbouw; in Leiden over de openingstijden van de horeca in de binnenstad; en in Vlaardingen 
over het houden van referenda. In 1992 is in Amsterdam een refendum gehouden over het toelaten van autoverkeer in de binnenstad.

${ }^{14}$ Men kan zich echter afvragen of de gebrekkige onganisatie van het. referendum in Aimsterdam niet mede geleid heeft tot de lage opkomst. Zie hiervoor bijvoorbeeld: Elzinga (1992a) „De: Amsterdarnse mislukking zal andere experimenten besmetten.

${ }^{15}$ Naar aanleiding van de bespreking van het rapport Deetman in de Tweede Kamer staat dit punt momenteel nog op de politieke agenda. Het maakt deel uit van het werk van de cornmissie van Thijn die zich beraad over het functioneren van de lokale democratie.

${ }^{15}$ Een stimulerende rol kan hierbii gespeeld worden door de lokale radio en met name de lokale TV. De lokale radio en TV kunnen immers de zichtbaarheid van lokale politici vergroten, waardonr de afstand tussen burgers en lokale politici verkleind kan worden. De lokale politiek krijgt daarmee een eigengezicht. Tegelijkertijd worden daarmee de lokale politici gedwongen zich meer rekenschap te geven van de manier waarop zij zich presenteren aan de burgers. De indruk bestaat dat de lokale politici zich door de sterke nadruk op de bestuursinterne activiteiten een 'beleidstaal' hebben eigen gemaakt waardoor communicatie met de burgers een probleem is geworden (Onderzoeksgroep Lokale Damocratie, 1991:106-108). Tevens kan de lokale TV ingeschakeld worden om de participatie van de burgers te vergroten (van Engelen, Experiment met lokale TV in Dordrecht prikkelt de participatie, 1990; Mendel, Experimenten met teledemocratie noodzakelijk voor moderne democratie, 1992). "Gebaseerd op: Havermans (1989:99-100) en: Europese eenwording leidt tot zwaardere lokale lastendruk, Binnenlands Bestuur, nr. 47, 22-11-1991, p.8. 



\section{SUMMARY}

During the municipal elections of 1986 a discussion arose about the local character of these elections. The main question in this discussion was whether or not, over the heads of local politicians, through municipal elections an opinion was expressed about the performance of national politicians. If this would be the case local elections could be described as a rather arbitrary intervention in the local political balance. Basically this means that the electorate would give a formal instead of a material mandate to their representatives to implement their political program. Proceeding from this point of view, it is important to determine the local character of municipal elections in the dutch municipalities. Hence the central thesis of this dissertation is: to what extent are the municipal elections of the period 1974-1990 determined by local voting behaviour that is characteristic for these elections.

Chapter 1 , which is the introductionary part of this study, will focus on the above-mentioned setting of the study. Furthermore, the central thesis will be formulated and the set-up of the research will be presented. There are only relatively few useful results of local electorate survey available. Therefore an analysis of the results of the municipal elections will be used to determine to what extent one can speak of a local character of municipal elections. The results of local electorate survey that are available though, will be used to gain an insight into the engagement of the electorate in local politics.

Chapter 2 will subsequently draw the formal framework in which municipal elections take place. For the purpose of analysis an overall picture of the arrangement of municipalities ( 841 in 1974 and 647 in 1990) according to province and size of municipality is included. Furthermore, the list of candidates is divided into local and national lists. In regard to the national lists we subsequently characterize confessional, progressive, and liberal lists. As to the local lists specific attention will be given to the different ways in which local lists are classified in literature.

The central issue in the second part of this study is the electoral position of local and national lists. The background of this overview is that by definition local lists are a local element in municipal elections. Chapter 3 will first of all pay attention to the participation of local and national lists to municipal elections. In general various lists and parties do not participate in the elections in all the municipalities. Therefore participation influences the election results and hence the degree of which one can speak of local voting behaviour which is characteristic for municipal elections. The research shows that within the period examined the percentage of local lists has decreased in relation to the total number of participating lists. Furhtermore, it shows that local lists have participated in the local elections in relatively less municipalities. In this regard we can speak of a delocalization of municipal elections during 1974-1990. Likewise we can assess a process of nationalization of municipal elections. This is because, in addition to the rise of the national lists in the total number of participating lists, national lists have started to participate in more municipalities. This increase has particularly been identified in NoordBrabant and Limburg, the two southern provinces where local lists are strongly represented from way back. In addition it turns out that each of the three different national political movements participate in relatively more municipalities. Since more voters are able to make 
a choice out of one of these political movements we can speak of a party political pluralization of municipal elections.

In chapter 4 we will fix our attention on the election results of the local and national lists. The research results indicate that during 1974-1990 the election results of local lists deteriorated in favor of national lists. This nationaliztion of municipal elections happened not only in regard to the compound election results on the national level but also on the local level. After all, there are more municipalities where the local lists got a lower percentage of votes in 1990 compared with 1974 than there are municipalities where these local lists got a higher percentage of votes. This picture prevails very strongly in Noord-Brabant and Limburg.

The electoral position of the local and national lists is not the only element which gives an insight into the local character of municipal elections. The local percentages and trends of the national political parties can also show local voting behaviour in relation to municipal elections. That is why part 3 of this study analyses the local election results of the three largest national political parties, which are the christian-democratic CDA, the social-democratic PvdA and the liberal VVD. Chapter 5 presents first of all an analysis of the local voting percentages. This analysis is established by a comparison of the local voting percentages in local and non-local elections. Therefore it is important to determine more explicitly which factors play a part in the differences between the local voting percentages of both types of elections. Particularly the participation of the local lists seems to be an important factor in explaining this difference. Subsequently the local character of the municipal elections has been mapped by various methods. The results of these analyses show that the influence of local factors on the local voting percentages is rather small. For example, there seems to be a very strong correlation between the local voting percentages in local and non-local elections. The connection is almost perfect in municipalities where local lists do not participate in municipal elections. As a result, the local element in the local voting percentages of the three national parties is for a relatively large part determined by the participation of local lists. This goes to a larger degree for the CDA than for the two other parties. In regard to the investigated period one can determine however a slightly rising tendency regarding the local contents of municipal elections.

Subsequently, in chapter 6 the local trends of the three national political parties will be analyzed. Also regarding this analysis several methods of research have been used. The results of these various interpretations support the main features of the conclusions which are based on the analysis of the local voting percentages in the previous chapter. This means that only to a small degree one can speak of a local character of the municipal elections. It also means that an important part of the local element in these elections is caused by the participation of local lists in municipal elections.

Contrary to the preceding sections part 4 of the dissertation focuses on the anlysis of local electorate survey. Thereby we concentrate on the behaviour of the individual voter in local elections. An additional analysis of the available electorate survey shows that in 1986 about 70 percent of the voters voted for the same party in municipal and parliamentary elections. Leaving local lists aside this percentage turns out to be 80 to 90 percent. Research in seven large municipalities in 1991 provide similar percentages. It also turns out that for only a minority of the voters the local policy of the party of their choice was decisive with respect to their party choice in municipal elections. In sum, the results of the available local electorate research als 0 
sustain the conclusion that for only a relatively small section of the voters local politics was of overriding importance concerning their party choice in municipal elections.

Such a conclusion arises the question as to what extent citizens are concerned with local politics. Chapter 8 presents an overview of the available electorate research in order to offer more insight into this question. Among other things this overview shows a distinctively lower interest in local politics compared with national politics, though voters show a relatively large interest in news from their own municipality. The knowledge of local politics is also minor, allthough this is contrasted with more confidence in local politics than in national politics. Furthermore, people expect to be able to exert more influence on politics on the local level. The available information shows though that in smaller municipalities the involvement in local politics is higher than in larger municipalities. The identified differences, however, are not large and it is impossible to establish a clear connection between the differences in the municipalities with respect to the different aspects of involvement of the citizens into local politics. Therefore we cannot identify various local political cultures.

The last chapter, which is chapter 9, presents an overview of the conclusions drawn in the other chapters. The final conclusion is that only to a small degree one can speak of a local voting behaviour which is characteristic for municipal elections for the period 1974-1990. Particularly the participation of local lists is an important local factor in municipal elections. Futhermore, it appears that in regard to the above no large differences exist between the three largest national political parties. Then, based on the results of the available electorate survey the hypothesis is formulated that the involvement in local politics and thereby the local character of municipal elections can be raised by increasing the party political differences at the local level and by paying more attention to the connection between local politicians and citizens. Starting from this point of view various proposals which could enhance the local character of municipal elections are discussed. 


\section{BIBLIOGRAFIE}

Aarts, C.W.A.M., Politici: bekendheid en sympathie, in: J.J.M. van Holsteijn, G.A. Irwin en C. van der Eijk, De Nederlandse kiezer '86, Steinmetzarchief/SWIDOC, Amsterdam, 1987, pp. 8091.

Aarts, K en Horstman, R (1991), Political Change and the Electoral Geography of the Netherlands, Paper prepared for the ECPR Joint Sessions of Workshop, Enschede 1991.

Achen, C.H. (1977), Measuring representation: perils of the correlation coefficient, in: American Journal of Political Science, volume 23, no. 4, 1977, pp. 805-815.

Amersfoort, J.J.M. van, W.F. Heinemeyer en H.H. van der Wusten (1981), Een wereld van staten, Samson, Alphen a/d Rijn, 1981.

Amsterdams bureau voor Onderzoek en Statistiek (1991), Verslag nulmeting referendum, Amsterdam, 1991.

Andeweg, R.B. (1982), Dutch Voters adrift; On Explanations of Electoral Change (1963-1977), proefschrift, Rijksuniversiteit Leiden, 1982.

Andeweg, R.B. (1989), De burger in de Nederlandse politiek, in: RB. Andeweg, A. Hoogerwerf en J.J.A Thomassen (red.), Politiek in Nederland, Samson, Alphen aan den Rijn, 1989, derde druk.

ANP (1990), Officieuze uitslagen gemeenteraadsverkiezingen 21 maant 1990, Amsterdam, 1990.

AVRO/NIPO (1990), Politieke voorkeurgegevens en de komende gemeenteraadsverkiezingen, NIPO, Amsterdam, 1990.

Berelson, B.R., P.F. Lazarsfeld en W.N. McPhee, Voting; A Study of Opinion Formation in a Presidential Campaign, The University of Chicago Press, Chicago, 1954.

Biemans, P.J.M. e.a. (1982), Rondom de Nijmeegse gemeenteraadsverkiezingen 1982, Nijmegen, 1982.

Biemans, P.J.M. en J.J.J. van der Putten (1990), Gemeenteraadsverkiezingen Nijmegen 1990. Nijmegen, 1990.

Bjorkland, T. (1988), The 1987 Norwegian Local Elections: A Protest Election with a Swing to the Right, in: Sandinavian Political Studies, vol. 11, no. 3, 1988, pp. 211-234. 
Blalock, H.M. (1979), Social statistics, McGraw-Hill Kogakusha, Tokyo, 1979, revised second edition.

Boaden, N., M. Goldsmith, W. Hampton and P. Stringer (1982), Public Participation in Local Services, Longman, London, 1982.

Bock, A de en A van der Veen (1986), Gemeenteraadsverkiezingen Breda, Tabellenrapport, Ansterdam, 1986.

Boer, C. de e.a. (1990), Verkiezingsonderzoek in Leeuwarden naar aanleiding van de gcmeenteraadsverkiezingen van 21 maant 1990, onderzoeksverslag Thorbecke Academie, Leeuwarden, 1990.

Boogers, M. en R. Keizers (1991), Een verdeelde eenheid; Lokale politiek in Sittard tussen 1900 en 1991, Margraten Magazine, Sint Geertruid, 1991.

Boosten, C.A.M. (1990), Migranten op komst, Onderzoek naar de opkomst van buitenlandse kiczers bij de gemeenteraadsverkiezingen van 21 maart 1990, gemeente Enschede, Enschede, 1990.

Bordewijk, P. (1990a), Wethouders moeten geen raadslid zijn: verkiezingsuitslag ondergraaft legitimatie gemeentebesturen, in: Binnenlands Bestuur, 30-1-1990, p. 31.

Bordewijk, P. (1990b), Om participatie te vergroten: raadsverkiezingen zonder landelijke partijen beter af, Binnenlands Bestuur, 18-5-1990, p. 27.

Bordewijk, P. (1991), Het nut van wethouders; Opstellen over lokale politiek en burcaucratie in Nederland en Europa, Samson H.D. Tjeenk Willink, Alphen a/d Rijn, 1991.

Braat, H. en L. Gerrichhauzen (1986), Onderzoek burgers en gemeentepolitiek in Ronsendaal 1986, Erasmus Universiteit Rotterdam, 1986.

Brasz, H.A. (1960), Veranderingen in het Nederlandse communalisme; De gemeentebesturen als element in het Nederlandse stelsel van sociale beheersing, Vuga-boekerij, Arnhem, 1960.

Bruce, A. and G. Lee (1982), Local election campaigns, in: Political Studies, vol. 30, no. 2, 1982, pp. 247-261.

Burkens, M.C., S.W. Couwenberg, H. Franken en L.J. Brinkhorst (1991), Staatsrechtelijkc vemicuwingen; Commentaren op het rapport van de commissie-Deetman, W.E.J. Tjeenk Willink, Zwolle, 1991.

Buijs, F.en J. Rath (1986), Destem van de migranten en werklozen, Degcmecnteraadsverkiezingen van 19 maan 1986 te Rooterdam, C.O.M.T. Rijksuniversiteit Leiden, Leiden, 1986. 
Centraal Bureau voor de Statistiek, Statistieken der verkiezingen 1974, 1978, 1982, 1986, 1990 (gemeenteraden), Den Haag, 1975-1991.

Centraal Bureau voor de Statistiek, Statistieken der verkiezingen 1974, 1978 (Provinciale Staten), Den Haag, 1975-1979.

Centraal Bureau voor de Statistiek, Statistieken der verkiczingen 1982, 1986, 1989 (Twecde Kamer), Den Haag, 1983-1990.

Centraal Bureau voor de Statistiek (1990), Nationaal Kiezersonderzoek 1989, Kerncijfers, deel 1. Den Haag, 1990.

Cohen, M.J. en KL.L.M. Dittrich (1982), De Limburgse gemeenteraadsverkiezingen, Het probleem van het stemmen bij volmacht, in: NJB 1982, pp. 347-351.

Commissie Vraagpunten (1990), cie. Deetman, Vraagpunten staatkundige, bestuurlijke en staatsrechtelijke vernieuwing, 's-Gravenhage, 1990.

Custers, J. (1988), Macht en Meerderheid; Lokale politiek in Sint-Geentruid tussen 1919 en 1982 , Sint Geertruid, 1988.

Daalder, H. (1974), Politisering en lijdelijkheid in de Nederlandse politiek, van Gorcum, Assen, 1974.

Dah], RA (1984), Modern Political Analysis, Prentice-Hall, Englewood Cliffs, 1984, fourth edition.

Dahl, RA en E.R. Tufte (1974), Size and Democracy, Stanford Úniversity Press, Stanford, 1974.

Daudt, H. (1977), Winst en verlies van de partijen, in: G.A. Irwin, J. Verhoef en C.J. Wiebrens (red.), De Nederlandse kiezer '77, NKO, 1977.

Dekker, P. (1988), Lokale en regionale verscheidenheid in politieke cultuur in Nederland, in: Geografisch Tijdschnift, 1988, nr. 3, p. 256-271.

Denters, S.A.H. (1987), Partijen, kiczers en gemeentelijk beleid, een empirische toetsing van een politiek-economische theorie, CT Press, Amsterdam, 1987.

Denters, S.A.H., Towards a Conditional Model of Coalition Behaviour, in: European Journal of Political Research, volume 13, 1985, pp. 295-309.

Denters, S.A.H., Jong de, H.M. en Thomassen, J.J.A. (1990), Kwaliteit van gemeenten, Vuga, s-Gravenhage, 1990. 
Depla, P. en K. Schalken (1991), Bestuurlijke vernieuwing belicht, paper voor de workshop 'Lokale democratie en bestuurlijke vernieuwing' van het politicologenetmaal 1991, Tilburg, 1991.

Denver, D. (1987), Scottish Local Elections 1974-86: the Growth of Partisan Politics, Paper prepared for the joint Sessions of Workshops ECPR, Lancaster, 1987.

Derksen, W. (1989a), Nationalisering van de lokale politiek, in: De Nederlandse Gemeente, nr. 10, 10 maart 1989, p.269.

Derksen, W. (1989b), Gemeentelijke herindeling en pluriformiteit, in: W. Derksen en A.F.A. Korsten (red.), Lokaal bestuur in Nederland, Inleiding in de gemeentekunde, Sarnson H.D. Tjeenk Willink, Alphen a/d Rijn, 1989, 2e druk, pp. 414-428.

Derksen, W. (1990a), Elke gemeente moet zelf verkiezingsdatum bepalen, in: NG-magazine, n.. 7, 1990, p.8.

Derksen, W. (1990b), Lokale politiek: wie niet sterk is, moet slim zijn, het ontnationaliseren van de raadsverkiezingen, in: NG-magazine, nr. 8, 1990, p. 12.

Derksen, W. (1990c), Institutionele normen in het lokaal bestuur, Wolters Noordhof, Leiden, 1990.

Derksen, W., J.A van der Drift, R. Gibels en C. Terbrack (1987), De bestuurskracht van kleive gemeenten, beleidsrapport, Meppel, 1987, tweede druk.

Derksen, W. en A.F.A. Korsten (red.) (1989), Lokaal bestuur in Nederland; Inleiding in de gemeentekunde, Samson H.D. Tjeenk Willink, Alphen aan den Rijn, 1989, tweede herziene druk.

Deth van J.W. en R. Horstman (1989), Dutch Parliamentary Election Studies Data Source Book 1971-1986, Steinmetzarchief/SWIDOC, Amsterdam, 1989.

De Vos Hindriks Consultants (1991), Onderzoek invloed en macht, Veere, 1991.

Dijk, J.M.A van (1987), Politiek zelfvertrouwen en cynisme, in: J.J.M. van Holsteijn, G.A. Irwin en C. van der Eijk (red.), De Nederlandse kiezer '86, Steinmetzarchief/SWIDOC, Amsterdam, 1987, pp. 27-41.

Dittrich, KL.L.M. (1978), Partij-politieke verschoudingen in Nederlandse gemeenten; Een analyse van de gemeenteraadsverkiezingen 1962-1974, proefschrift, Rijksuniversiteit Leiden, 1978.

Dittrich, K.L.L.M. (1983), Limburg en de gemeentepolitiek- een analyse van de gemeenteraadsverkiezingen van 21 oktober 1981, in: F.H. van der Burg en M.A. van der Ham 
(red.), Gemeentelijke vrijheden, opstellenbundel aangeboden aan prof.mr. M. van Vliet, Alphen aan den Rijn, 1983.

Dittrich, K.L.L.M. en R van der Helm (1977), Gemeenteraadsverkiezingen 1974, in: Acta Politica, 1977, nr. 2, pp. 207-230.

Dittrich, K.L.L.M., P.W. Tops en R.G. Welten (1986), Het gebeurde in het Zuiden, Politieke veranderingen sedert 1966, in: Socialisme en Democratie, nr. 10, 1986, pp. 295-303.

Dolive, L.L. (1976), Electoral Politics at the Local Level in the German Federal Republic, The University Presses of Florida, Gainesville, 1976.

Drijber, J. (1987), Plaatselijke verkiezingen spreiden en regionaliseren, in: Namens, jrg. 2, afl.2, pp. $67-70$.

Eijk, C. van der, I, van Geest, P. Kramer en L. Tiddens (red.), Verkiezingen zonder mandaat; Politieke communicatie en provinciale verkiezingen, SDU, Den Haag, 1992.

Eijk, C. van der, M.J. Koopman en B. Niemöller (1983), Dutch Parliamentary Election Study 1982, CT Press, Amsterdam, 1983.

Eijk, C. van der en B. Niemöller (1983), Stemmen op godsdienstige partijen sinds 1967, in: C. van der Eijk en $\mathrm{B}$ Niemöller (red.), In het spoorvan de kiezer, aspecten van 10 jaarkiezersgedrag. themanummer Acta Politica, Boom, Meppel, 1983, pp. 169-182.

Eijk, C. van der en M. Visser (1992), Eén uitslag, twaalf spiegelbeelden, in: C. van der Eijk e.a. (red.), Verkiezingen zonder mandaat; Politieke communicatie en provinciale verkiezingen, SDU, Den Haag, 1992, pp. 83-93.

Elzinga, D.J. (1979), Politieke kontrole in de lokale democratie, Kluwer, Deventer, 1979.

Elzinga, D.J. (1982), De politieke partij en het constitutionele recht, Ars Aequi Libri, Nijmegen, 1982.

Elzinga, D.J. (1986), Elke provincie een eigen tijdstip voor raads- en statenverkiezingen, in: Binnenlands Bestuur, 3-9-1986, p. 29.

Elzinga, D.J. (1989a), Regeling voorkeurstemmen beperkt politieke partijen, in: Binnenlands Bestuur, 28-4-1989, p.31.

Elzinga, D.J., (1989b) Animo voor voorkeursacties zal bij grotere effectiviteit toenemen, in: Binnenlands Bestuur, 16-6-1989, p. 26.

Elzinga, D.J. (1989c), Het Nederlandse kiesrecht, W.E.J. Tjeenk Willink, Zwolle, 1989. 
Elzinga, D.J. (1992a), De Amsterdamse mislukking zal andere experimenten besmetten, in: Binnenlands Bestuur, 3-4-1992, p.35.

Elzinga, D.J. (1992b), Aanbevelingsrecht voor raad verheldert rol vertouwenscommissie, in Binnenlands Bestuur, 17-4-1992, p. 29.

Engelen, G. van (1990), Experiment met lokale TV in Dordrecht prikkelt de participatie, in: Binnenlands Bestuur, 6-4-1990, p.11.

Eskes, J.A.O. (1988), Repressie van politieke bewegingen in Nederland; Een juridisch-historische. studie over het Nederlandse publiekrechtelijke verenigingsrecht gedurende het tijdsvak 17981988, Tjeenk Willink, Zwolle, 1988.

Gallagher, M. (1987), Sub-national Elections and Electoral Behaviour in the Republic of Ireland, Paper presented to the ECPR workshop on Sub-national Government Elections en Electoral Behaviour, Dublin, 1987.

Gemeente Delft (1990), Basisrapport stadpanel resultaten meting najaar 1990, Delft, 1990, pp. 80.

Gemeente Zaanstad (1990), Omnibusonderzoek 1990, Zaanstad, 1991.

Gerrichhauzen, L.G. (1986), Communalisme en makelaardij in de gemeentepolitif $k$, in: Namens, jrg.1, afl.1, 1986, pp. 23-27 en 48.

Grünfeld, F. en R. Meijer (1977), Politieke opvattingen in Lelystad, Amsterdam, 1977.

Haagsche Courant (1990), Wegblijven stemmers geen politiek protest, 24-3-1990.

Hảkansson, A. (1987), The Relationship between Results in Local and National Elections, Paper prepared for ECPR Joint Sessions of Workshops, Lund, 1987.

Harrop, M. and W.L Miller (1987), Elections and Voters; A Comparative Introduction, Mac Millan education, London, 1987.

Havermans, AJ.E. (1989), Gemeentelijke taken en gemeentefinanciën, in: W. Derksen en AF.A. Korsten (red.), Lokaal bestuur in Nederland; Inleiding in de gemeentekunde, Samson H.D. Tjeenk Willink, Alphen a/d Rijn, 1989, 2e druk, pp. 93-113.

Heij, P.R en J.F. Schrijver (1991), Decentralisatie, in: C.A de Kam en J. de Haan (red.), Terugtredende overheid: realiteit of retoriek?; Een evaluatie van de grote operaties, Academic Service, Schoonhoven, 1991, pp. 55-76.

Hendrikx, J.A.M. (1987), Landelijke partijen en media moeten lokale verkiezingen met rust laten, in: Namens, 1987, afl. 2, pp. 71-74. 
Hessing, RC. (1989), Te hoge voorkeursdrempel: nieuwe regeling voorkeurstemmen beperkt kiezers corrigerend op te treden, in: Binnenlands Bestuur, 26-5-1989, p. 25.

Hill, D.M. (1974), Democratic Theory and Local Government, Geoge Allen en Unwin, London, 1974.

Hillebrand, R en J.J.M. van Holsteyn (1991), Haarlem geraàdpleegd; Evaluatie van het referendum van 6 maart 1991, Leiden, 1991.

Hoekema, AJ. (1978), De uitgespeelde gemeenteraad, Kluwer, Deventer, 1978.

Hofstee, E.W. (1962), De groei van de Nederlandse bevolking, in: AN.J. den Hollander e.a., Drift en Koers, een halve eeuw sociale verandering in Nederland, Assen, 1962, 2e druk, pp. 1385.

Holsteyn, J.J.M. van en R. Hillebrand (1991), Leiden geraadpleegd; Evaluatie van het referendum van 6 maant 1991, Leiden, 1991.

Hond, M. de (1990), De afgang van de opkomst, in: Het Parool, 22-3-1990.

Hond, M. de en M. Bank (1986), Prognose gemeente Nijmegen, Tabellenrapport, Amsterdam, 1986.

Irwin, G.A (1983), De invloed van kandidaten op stemgedrag, in: C. van der Eijk en B. Niemöller (red.), In het spoor van de kiezer, aspecten van 10 jaar kiezersedrag, themanummer Acta Politica, Boom, Meppel, 1983, 183-200.

Irwin, G. en R Andeweg (1990), PvdA verliest extra door thuisblijvers, in: De Volkskrant, 233-1990.

Irwin, G.A., R.B. Andeweg en W. Braak (1974), Waarheen waarvoor, voor wie?, in: Bestuurswetenschappen, jrg. 28, nr. 1, 1974, pp. 3-18.

Irwin, G, en K. Dittrich (1984), And the Walls came tumbling down: Party Dealignment in the Netherlands, in: RJ. Dalton, S.C. Flanagan en P.A. Beck, Electoral Change in Advanced Industrial Democracies, Princeton University Press, Princeton, 1984, pp. 267-298.

Irwin, G.A. en J.J.M. van Holsteyn (1989), Decline of the Structured Model of Electoral Competition, in: West European Politics, volume 12, january 1989, nr. 1, 1989, pp. 21-42.

Johnston, R.J., A.B. O'Neill en P.J. Taylor (1983), The changing Electoral Geography of the Netherlands: 1946-1981, in: Tijdschrift voor Economische en Sociale Geografie, jrg. 74, nr. 3, 1983. pp. $185-195$. 
haap, H.G. van der (1987), Partijvoorkeur voor de verkiezingen, in: J.J.M. van Holsteyn, G.A. Irwin en C. van der Eijk, De Nederlandse kiezer'86, Steinmetzarchief/SWIDOC, Amsterdam, $198 \%$.

Kemenade, J.A. van (1990), Bezinning op het duaal stelsel is goed ais dat niet tot vertraging geldt, in: Binnenlands Bestuur, 27-4-1990, p. 25.

Key, V.O. (1961), Public Opinion and American Democracy, Alfred. A Knopf, New York, 1961.

Knippenberg, E. (1988), Het gedwongen ontslag van wethouders in Limburgse gemeenten, in : Ti O, jrg. 14, nr. 1, 1988, pp. 4-9.

Knippenberg, H. en B. de Pater (1988), De eenwording van Nederland; Schaalvergroting en integratie sinds 1800, SUN, Nijmegen, 1988.

Kursten, A.F.A en W. Kuiper (red.) (1991), Limburg kiest; Ontwikkelingen in de lokale politiek rondom de gemeenteraadsverkiezingen van maant 1990, Kerckebosch, Zeist, 1991.

Kuiper, W. (1986), Het democratisch gehalte van communalistische politiek, een terreinverkenning, Paper ten behoeve van de workshop 'lokale politiek', Politicologenetmaal, 1986.

Kuiper, W. (1987), Verslag van ecn enquete onder lijsttrekkers bijgemeenteraadsverkiezingen in 1981/1982 in de provincie Limburg, paper Werkgroep Lokale Politiek, Maastricht, 1987.

Kuiper, W. (1988), Verdwijnen van lokale lijsten is verlies voor democratie in Limburg, in: Namens, jrg. 3, nr. 1988, pp. 19-22.

Kuiper, W. en E. Knippenberg (1990), Het CDAen de lokale lijsten in Limburg, in: Bestuursforum, mei 1990, pp. 146-148.

Kuiper, W. (1991), De speleres in de verkiezingsarena, in: A.F.A. Korsten en W. Kuiper (red.), Limburg Kiest, Ontwikkelingen in de lokale politiek rondom de gemeenteraadsverkiezingen van maart 1990, Kerckebosch, Zeist, 1991, pp.105-117.

Kuiper, W. en H. Koning (1991), Kiezersvolmachten en voorkeursstemmen, in: A.F.A. Korsten en W. Kuiper (red.), Limburg Kiest, Ontwikkelingen in de lokale politiek rondom de gemeenteraadsverkiezingen van maart 1990, Kerckebosch, Zeist, 1991, pp.189205.

Kuiper, W., M.F.J. van Tilburg en A.F.A. Korsten (1991), Politieke verhoudingen voor en na de herindeling, Een analyse van de gemeenteraadsverkiezingen in Midden-Limburg van 28 november 1990, in: Korsten, A.F.A., W. Kuiper en F.P.C.L Tonnaer (red.), Gemeentelijke herindeling, keuzen en kansen, Lessen uit Midden-Limburg, Kerckebosch, Zeist, 1991, pp.5175.

Laan van der J.H. (1990), Wisselende verkiezingsdata ontzettend onpraktisch, in: NG magazine, nr. 9, 1990, p.21. 
Lieske, J.C. (1986), Landspolitiek vervuilt gemeenteraadsverkiezing, in: De Nederiandse Gemeente, nr. 9, 28 februari 1986, p. 162.

Lijphart, A (1979), Verzuiling, pacificatie en kentering in de Nederlandse politiek, J.H. de Bussy, Amsterdam, 1979, derde herziene druk.

Löffler, B. en W. Rogg (1991), Kommunalwahlen und kommunales Wahlverhalten, in: Th. Pfizer en H. Wehling (red.), Kommunalpolitik in Baden-Wünttemberg, W. Kohlhammer, Stuttgart/Berlin/Köln, 2e druk, 1991, pp.108-124.

Loo, H. van der en W. van Reijen (1990), Paradoxen van modermisering: een sociaalwetenschappclijke benadering, Coutinho, Muiderberg, 1990.

Luijten, H. (1990), Schaduwverkiezingen '90: migranten meningen, Regionaal centrum buitenlanders Zuid-Holland west, Den Haag, 1990.

Mabileau, A, G. Moyser, G. Parry en P. Quantin (1989), Local politics and Participation in Britain and France, Cambridge University Press, Cambridge, 1989.

Meijervan Meybeek, F.A.C. (1987), Verminder invloed landspolitiek op raadsverkiezingen, in: De Nederlandse Gemeente nr. 4, 23-1-1987, p. 52.

Mendel, R (1992), Experimenten met teledemocratie noodzakelijk voor moderne democratie, in: Namens, jrg. 6, afl. 8, 1992, pp. 25-30.

Miller, W.L. (1988), Irrelevant Elections?; The Quality of Local Democracy in Britain, Clarendon Press, Oxford, 1988.

Morlan, RL. (1974), Gemeentepolitiek in debat; Opvattingen van burgers en bestuurders, Samson, Alphen aan den Rijn, 1974.

Niezing, J. (1966), Inleiding tot de politieke sociologie, van Gorcum, Assen, 1966.

Onderzoeksgroep Lokale Democratie (1991), P.W. Tops e.a., Lokale democratie en bestuurlike vernicuwing in Amsterdam, Eburon, Delft, 1991.

Praag van P. jr. (1987), Verkiezingscampagnes in de afdelingen, in: Jaarboek 1986 Documentatiecentrum Nedenlandse politieke partijen . Rijksuniversiteit Groningen, 1987.

Rath, J. (1990), Deelname migranten aan gemeenteraadsverkiezingen, in: Namens, jrg 5, afl. 11/12. pp.46-51.

Riker, W.H. (1982), Liberalism against Populism; A Confrontation between the Theory of Democracy and the Theory of Social Choice, W.H. Freeman, San Francisco, 1982. 
Ringeling, A.B. (1989), De gemeenteraad, in: W. Derksen en A.F.A Korsten (red.), Lokaal bestuur in Nederland, Inleiding in de gemeentekunde, Samson H.D. Tjeenk. Willink, Alphen a/ d Rijn, 1989, 2e druk, pp. 115-127.

Rose, R. and D.W. Urwin, Regional Differentiation and Political Unity in Western Notions, Sage publications, London, 1975.

Scholten, P. (1986), Gemeenteraadsverkiezing losvan de landelijke politiek, in:NRC-Handelsblad, 7 augustus 1986.

Scholten, P. (1987a), Verfinde Gemeenteraadsverkiezingen, in: NRC-Handelsblad', 5 januari 1987.

Scholten, P. (1987b), Nationalisatie van verkiezingen in gemeente en provincie, in : Namcns, jrg. 2, afl. 2, 1987, p. 66.

Snippenburg, L.B. van (1986), Modernisering en sociaal beleid; Een landenvergelijkende studie, proefschrift, Nijmegen, 1986.

Sociaal en Cultureel Planbureau (1987), Gemeente, burger, klant, Rijswijk, 1987.

Sociaal Geografisch Bureau Gemeente Dordrecht (1989), Relatie burgers-lokale overheid, Dordrecht, 1989.

Sociologisch Instituut en IVA (1982), Lokaal kiczersonderzock n.a.v. degemeenteraadsverkiezingen in 1982, in opdracht van het Nieuwsblad voor het Zuiden, Tilburg, 1982.

Spoormans, H. (1988), Met uitsluiting van voorrecht; Het ontsiaan van liberale democratie in Nederland, SUA, Amsterdam, 1988.

Staatscommissie van advies inzake de relatie kiezers-beleidsvorming (1984), cie. Biesheuvel, Relatie kiezers-beleidsvorming, 's-Gravenhage, 1984.

Stanyer, J. (1980), Understanding Local Government, Martin Robertson, Oxford, 1980.

Taylor, P.J. and RJ. Johnston (1979), Geography of Elections, Croom Helm, London, 1979.

Terpstra, P.R.A. en Wouters, J. (1991), Bestuurlijke vernieuwing: gemeentelijke beleidsvoornemens 1990-1994, in: Openbaar Bestuur, 1991, pp. 9-12.

Thomassen, J.J.A. (red.) (1991), Hedendaagse democratie, Sarnson H.D. Tjeenk Willink, Alphen aan den Rijn, 1991.

Thomsen, S.R. (1991), Comparative Electoral Dymamics, Paper prepared for the workshop Analysing Voting Behaviour using Election Results, Essex, 1991. 
Tilburg van, M.F.J. (1991), Provinciaal of nationaal? Het provinciale en democratische karakter van Statenverkiezingen, in: Jaarboek 1990 Documentatiecentrum Nederlandse Politieke Partijen, Rijksuniversiteit Groningen, 1991, pp. 154-167.

Tilburg, M.F.J. van en E.T.C. Knippenberg (1989), Het PvdA-voorstel om de kiesdrempel bij de gemeenteraadsverkiezingen te verhogen, toegepast op de gemeenteraadsverkiezingen van 1986 , onderzoeksrapport, 1989.

Tilburg, M. van en M. Ohlenforst (1991), De neergang van de opkomst: afgang van de politiek, in: A.F.A. Korsten en W. Kuiper (red.), Limburg kiest, ontwikkelingen in de lokale politiek rondom de gemeenteraadsverkiezingen van 21 maart 1990, Kerckebosch, Zeist, 1991, pp. 171188.

Tilburg, M.F.J. van en P.W. Tops (1990), Partijen en lijsten in Nederlandse gemeenten (19461986), in: Jaarboek 1989 Documentatiecentrum Nederlandse Politieke Pantijen, Rijksuniversiteit Groningen, 1990, pp. 73-92.

Tilburg, M. van, P. Tops en E. Knippenberg (1990), Analyse collegevorming 1990, in: Binnenlands Bestuur, 1990, nr. 19, pp. 18-24.

Toonen, T.A.J. (1987), Denken over Binnenlands Bestuur; Theorieën van de gedecentraliseerde eenheidsstaat bestuurskundig beschouwd, VUGA, 's-Gravenhage, 1987.

Toonen, T.AJ. (1981), Gemeentelijke invloed in een vervlochten bestuur, de relatie tussen nationale en lokale overheden, in: Beleid en Maatschappij, 1981, pp. 334-342.

Tops, P.W. (1990), Afspiegeling en afspraak, proefschrift, Rijksuniversiteit Leiden, 1990.

Tops, P.W. (1991), Coalitievorming in communale gemeenten, in: A.F.A. Korsten en W. Kuiper (red.), Limburg Kiest, Kerckebosch, Zeist, 1991.

Tops, P.W. (1992), Modernisering van de lokale democratie en de aanstelling van de burgemeester, in: A.F.A. Korsten, H. Spoormans, F.A.M. Stroink, F.P.C.L. Tonnaer en R. Vaarkamp (red.), De benoemde of gekozen burgemeester, van Gorcum, Maastricht/Assen, 1992, pp. 175-186.

Tops, P.W. en P. Depla (1992), Modernisering van de lokale politiek, in: Openbaar bestuwr, 1992, nr4. pp. 20-29.

Tops, P.W., P. Depla en K. Schalken, Bestuurlijke vernieuwing, bedoeld om burger en gemeente weer bij elkaar te brengen, blijft nog teveel een zaak van navelstaren, in: Binnenlands Bestuur, 5-3-1991, pp. 22-25, 27.

Tops, P.W., E.T.C. Knippenberg en M.F.J. van Tilburg, De A-politieke gemeente? (1989), in: Bestuur, 1989, nr. 2, pp. 43-47. 
Tops, P.W. en C. Kommers (1991), Lokale democratie, bestuurijke vemicuwing en informatisering; Een terreinverkenning, papervoor de workshop 'Lokale democratie en bestuurlijkevernieuwing" politicologenetmaal 1991, Tilburg/Rotterdam, 1991.

Tops, P.W. en M.F.J. van Tilburg (1989), Partijen en lijsten in Nederlandse gemeenten (19461986), papervoor de workshop 'Deveranderende rolvan depolitieke partijen' politicologenetmaal 1989, Maastricht, 1989.

Tufte, E.R, Data-analysis for Politics and Policy, Prentice-Hall, New York, 1974.

Veldkamp marktonderzoek b.v. (1974), Onderzoek naar de relatie burger -gemeentelijke overheid, deel 3, Amsterdam, 1974.

Veldkamp marktonderzoek b.v. (1986), Gemeenteraadsverkiezingen en ethnische minderheden, Een onderzoek naar de factoren die van invloed zijn geweest op de participatie van ethnische. minderheden bij de gemeenteraadsverkiezingen van 19 maart 1986, uitgevoerd in opdracht van het Ministerie van Binnenlandse Zaken, Amsterdam, 1986.

Vereniging van Nederlandse Gemeenten (1991), Bouwstenen voor bestuurlijke vernieuwing, Politieke en maatschappelijke betrokkenheid van inwoners van Almere bij de gemeente, Den Haag, 1991.

Verhoef, J. (1977), Bekendheid van politici, in: G.A Irwin, J. Verhoef en C.J. Wiebrens (red.), De Nederlandse Kiezer' '77, NKO, 1977.

Verplanke, C.J. (1986), Kan de gemeenteraad zelf zijn zittingsduur bepalen?, in: De Nederlandse Gemeente, 12 september 1986, nr. 7, p. 641.

Verplanke, C.J. (1990), Idee van Derksen is niet nieuw, in: NG-Magazine, nr. 9, 1990, p.152.

Visscher, G. (1989), Weinigverandering onder de electorale zon, in: Namens, jrg. 4, afl. 6, pp.5056.

Vught, G.W.M. van, Naar een sterke gemeenteraad, Tjeenk Willink, Zwolle, 1987, 2e druk.

Waller, R (1980), The 1979 Local and General Elections in England and Wales: is there a Local/ National Differantial? in: Political Studics, Vol. XXVIII, no. 3, 1980, pp. 443-450.

Welten, R.G. (1987a), Nationalisering en professionalisering in de Limburgse gemeentepolitiek, in: De Europese gemeente, Maastricht, 1986, pp. 43-48.

Welten, R.G. (1987b), Limburg en de voorkeurstem, lezing D66-Maastricht, Maastricht, japer werkgroep lokale politiek RL, 18-5-1987.

Werkgroep Lokale Politiek Rijksuniversiteit Limburg (1986), Lokale politiek in Limburg, een menu met 69 variaties, Maastricht, 1986. 


\section{Bijlage 1}

\section{EXTRA TABELLEN HOOFDSTUK 3}

In deze bijlage zijn een aantal tabellen opgenomen met gegevens over de verkiezingen van 1978, 1982 en 1986. Deze gegevens zijn vanwege de overzichtelijkheid niet opgenomen in de tabellen van hoofdstuk drie. De nummers van de tabellen in deze bijlage corresponderen met de overeenkomstige tabellen in hoofdstuk drie.

Tabel 3.2: Gemiddeld aantal deelnemende lokale en nationale lijsten per gemeente, per provincie, 1978-1986.

lok. nat. $\begin{array}{r}1978 \\ \mathrm{~N}\end{array}$ lok. nat. $\stackrel{1982}{\mathrm{~N}} \quad$ lok. nat. $\stackrel{1986}{\mathrm{~N}}$

$\begin{array}{lrrrrrrrrr}\text { Gr. } & 0,84 & 4,02 & 51 & 0,96 & 4,34 & 50 & 0,78 & 4,04 & 50 \\ \text { Fr. } & 1,48 & 3,93 & 44 & 1,48 & 4,27 & 44 & 1,52 & 4,19 & 31 \\ \text { Dr. } & 1,00 & 4,09 & 34 & 1,15 & 4,23 & 34 & 0,85 & 3,94 & 34 \\ \text { Ov. } & 1,15 & 4,47 & 47 & 1,06 & 4,85 & 47 & 0,76 & 4,56 & 45 \\ \text { Gl. } & 1,78 & 3,76 & 104 & 1,52 & 4,19 & 93 & 1,24 & 4,15 & 86 \\ \text { Ut. } & 0,81 & 4,81 & 48 & 0,65 & 4,83 & 48 & 0,58 & 4,69 & 48 \\ \text { NH. } & 1,05 & 4,30 & 95 & 1,11 & 4,75 & 81 & 1,12 & 4,53 & 81 \\ \text { ZH. } & 0,79 & 4,38 & 151 & 0,76 & 4,59 & 144 & 0,84 & 4,93 & 103 \\ \text { Zl. } & 1,37 & 3,97 & 30 & 1,07 & 4,47 & 30 & 0,87 & 4,23 & 30 \\ \text { NB. } & 3,73 & 2,55 & 131 & 3,08 & 2,98 & 131 & 2,77 & 3,07 & 131 \\ \text { Lb. } & 5,18 & 1,18 & 103 & 4,16 & 2,83 & 69 & 3,39 & 2,68 & 69 \\ \text { Fl. } & 1,00 & 7,00 & 1 & 1,00 & 6,67 & 3 & 1,50 & 6,17 & 6\end{array}$

Bron: Databestand CELS.

Tabel 3.3: Gemiddeld aantal deelnemende lokale en nationale lijsten per gemeente, per gemeentegrootte, 1978-1986.

\begin{tabular}{|c|c|c|c|c|c|c|c|c|c|c|c|}
\hline \multirow{3}{*}{$\begin{array}{l}\text { inwoners } \\
\text { x1000 }\end{array}$} & & & \multicolumn{3}{|c|}{1978} & \multicolumn{3}{|c|}{1982} & \multicolumn{3}{|c|}{1986} \\
\hline & & & lok. & nat. & $N$ & lok. & nat. & $\mathrm{N}$ & lok. & nat. & $N$ \\
\hline & & & & & & & & & & & \\
\hline & $<$ & 3 & 1,80 & 2,05 & 148 & 1,60 & 2,34 & 112 & 1,77 & 1,92 & 65 \\
\hline 3 & . & 10 & 2,25 & 2,81 & 359 & 1,60 & 3.33 & 311 & 1,38 & 3,23 & 282 \\
\hline 10 & - & 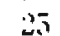 & 1.97 & 4.28 & 209 & 1.76 & 4.66 & 225 & 1,55 & 4.27 & 239 \\
\hline 25 & . & 50 & 1,42 & 5.92 & 71 & 1,44 & 5,98 & 81 & 1,30 & 5,48 & 77 \\
\hline 50 & - & 100 & 1,69 & 7,42 & 26 & 1,43 & 7,54 & 28 & 1,79 & 7,12 & 34 \\
\hline & $\therefore$ & 100 & 3,24 & 8,65 & 17 & 4,00 & 8,41 & 17 & 3,41 & 9,35 & 17 \\
\hline
\end{tabular}


Tabel 3.5: Spreidingscijfers voor lokale en nationale lijsten, per provincie, 1978-1986, in procenten.

\begin{tabular}{|c|c|c|c|c|c|}
\hline \multicolumn{2}{|r|}{1978} & \multicolumn{2}{|c|}{1982} & \multicolumn{2}{|c|}{1986} \\
\hline lok. nat. & N & lok. & $\mathrm{N}$ & lok. & $\mathrm{N}$ \\
\hline $68,6100,0$ & 51 & $70,0100,0$ & 50 & $64,0100,0$ & 50 \\
\hline $95,5 \quad 97,7$ & 44 & $100,0 \quad 97,7$ & 44 & $100,0 \quad 96,8$ & 31 \\
\hline $82.4100,0$ & 34 & $79,4 \quad 100,0$ & 34 & $76,5100.0$ & 34 \\
\hline $72,3 \quad 100,0$ & 47 & $68,1 \quad 97,9$ & 47 & $57,8 \quad 100,0$ & 45 \\
\hline $72,6 \quad 91,6$ & 95 & $75,3 \quad 97,9$ & 93 & $66,3100,0$ & 86 \\
\hline $60,4100,0$ & 48 & $58,3100,0$ & 48 & $47,9100,0$ & 48 \\
\hline $73,7 \quad 100,0$ & 95 & $70,4 \quad 98,8$ & 81 & $67,9 \quad 98,8$ & 81 \\
\hline $58,9100,0$ & 151 & $56,9100,0$ & 144 & $56,3 \quad 100,0$ & 103 \\
\hline $66,7100,0$ & 30 & $53,3100,0$ & 30 & $43,3 \quad 100,0$ & 30 \\
\hline $96,2 \quad 78,6$ & 131 & $96,2 \quad 84,0$ & 131 & $97,7 \quad 93,1$ & 131 \\
\hline $100,0 \quad 45,6$ & 103 & $100,0 \quad 82,6$ & 69 & $94,2 \quad 88,4$ & 69 \\
\hline $100,0100,0$ & 1 & $100,0100,0$ & 3 & $83,3100,0$ & 6 \\
\hline
\end{tabular}

Bron: Databestand CELS.

Tabel 3.6: Spreidingscijfers van lokale en nationale lijsten, per gemeentegrootte, 1978-1986, in procenten.

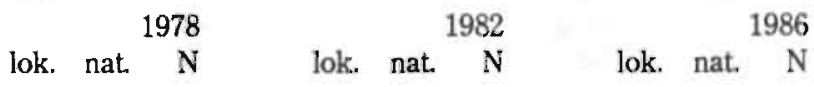

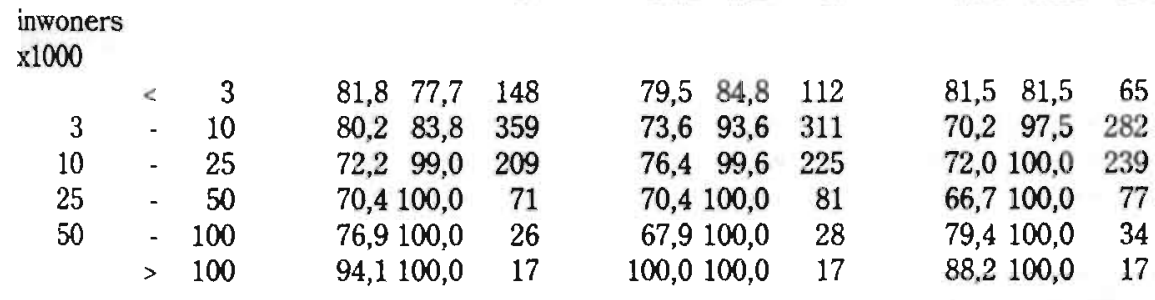


Tabel 3.8: Spreidingscijfers voor de landelijke politieke stromingen, per provincie, 1978-1986, in procenten.

\begin{tabular}{|c|c|c|c|c|c|c|c|}
\hline & \multicolumn{3}{|c|}{ Confessionelen } & \multicolumn{3}{|c|}{ Progressieven } & \\
\hline & 1978 & 1982 & 1986 & 1978 & 1982 & 1986 & \\
\hline Gr. & 92,2 & 92,0 & 88,0 & 100,0 & 100,0 & 100,0 & \\
\hline Fr. & 93,2 & 97,7 & 93,5 & 97,7 & 97,7 & 96,8 & \\
\hline Dr. & 97,1 & 94,1 & 97,1 & 97,1 & 100,0 & 100,0 & \\
\hline Ov. & 100,0 & 97,9 & 100,0 & 91,5 & 93,6 & 97,8 & \\
\hline Gl. & 87,3 & 95,7 & 97,7 & 91,6 & 94,6 & 100,0 & \\
\hline Ut. & 100,0 & 100,0 & 100,0 & 87,5 & 87,5 & 87,5 & \\
\hline NH. & 93,7 & 96,3 & 96,3 & 95,8 & 97,5 & 96,3 & \\
\hline $\mathrm{ZH}$. & 96,0 & 97,9 & 100,0 & 92,7 & 93,1 & 95,1 & \\
\hline $\mathrm{Zl}$. & 96,7 & 100,0 & 100,0 & 90,0 & 86,7 & 86,7 & \\
\hline NB. & 61,1 & 79,4 & 91,6 & 66,4 & 70,2 & 73,3 & \\
\hline Lb. & 15,5 & 81,2 & 85,5 & 35,9 & 63,8 & 69,6 & \\
\hline \multirow[t]{3}{*}{ F1. } & 100,0 & 100,0 & 100,0 & 100,0 & 100,0 & 83,3 & \\
\hline & \multicolumn{3}{|c|}{ Liberalen } & \multicolumn{3}{|c|}{$\mathrm{N}$} & \\
\hline & 1978 & 1982 & 1986 & 1978 & 1982 & 1986 & \\
\hline Gr. & 60,8 & 62,0 & 62,0 & 51 & 50 & 50 & \\
\hline Fr. & 79,5 & 88,6 & 96,8 & 44 & 44 & 31 & \\
\hline Dr. & 91,2 & 94,1 & 100,0 & 34 & 34 & 34 & \\
\hline Ov. & 78,7 & 83,0 & 88,9 & 47 & 47 & 45 & \\
\hline Gl. & 81,1 & 85,0 & 94,2 & 95 & 93 & 86 & \\
\hline Ut. & 87,5 & 91,7 & 91,7 & 48 & 48 & 48 & \\
\hline $\mathrm{NH}$. & 85,3 & 93,8 & 96,3 & 95 & 81 & 81 & \\
\hline $\mathrm{ZH}$. & 87,4 & 91,7 & 96,1 & 151 & 144 & 103 & \\
\hline Zl. & 66.7 & 83.3 & 86,7 & 30 & 30 & 30 & \\
\hline NB. & 67,9 & 68,7 & 72,5 & 131 & 131 & 131 & \\
\hline Lb. & 34,0 & 56,5 & 63,8 & 103 & 69 & 69 & \\
\hline Fl. & 100,0 & 100,0 & 83,3 & 1 & 3 & 6 & \\
\hline
\end{tabular}

Bron: Databestand CELS. 
Tabel 3.9: Spreidingscijfers voor de landelijke politieke stromingen, per gemeentegrootte, 1978-1986, in procenten.

\begin{tabular}{cccccc}
\multicolumn{4}{c}{ Confessionelen } & \multicolumn{3}{c}{ Progressiven } \\
1978 & 1982 & 1986 & 1978 & 1982 & 1986
\end{tabular}

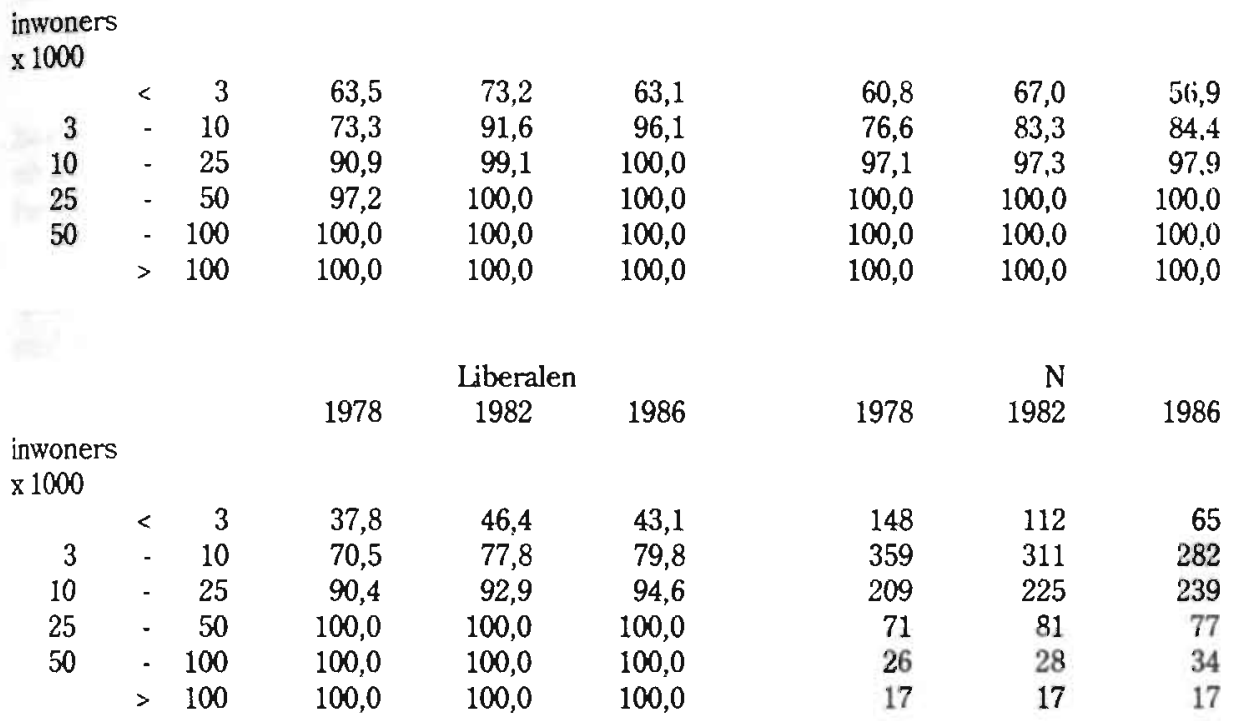

Bron: Databestand CELS. 


\section{Bijlage 2}

\section{EXTRA TABELLEN HOOFDSTUK 4}

In deze bijlage zijn een drietal tabellen opgenomen met gegevens over de verkiezingen van 1978,1982 en 1986. Deze gegevens zijn vanwege de overzichtelijkheid niet opgenomen in de tabellen van hoofdstuk vier. De nummers van de tabellen in deze bijlage corresponderen met de overeenkomstige tabellen in hoofdstuk vier.

Tabel 4.10: Percentage stemmen op de drie politieke stromingen, per categorie van gemeentegrootte, 1978-1986.

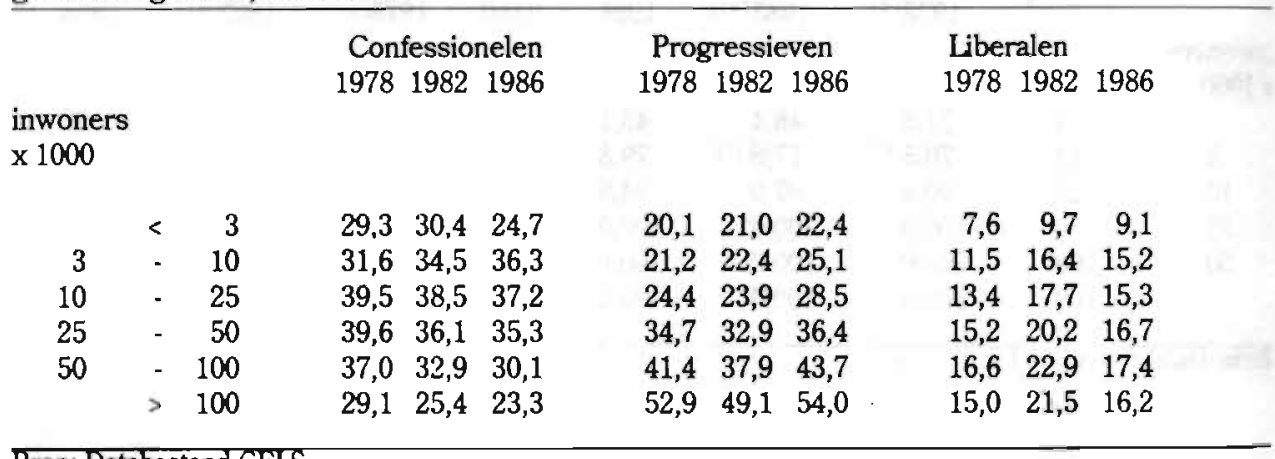

Bron: Databestand CELS.

Tabel 4.13: Percentage communale en nationale gemeenten, per provincie, 1978-1986.

\begin{tabular}{|c|c|c|c|c|c|c|}
\hline & \multicolumn{3}{|c|}{1978} & 1982 & \multicolumn{2}{|c|}{1986} \\
\hline & com. nat. & $\mathrm{N}$ & com. nat. & $\mathrm{N}$ & com. nat. & $\mathrm{N}$ \\
\hline Gr. & $-100,0$ & 51 & $-100,0$ & 51 & $-100,0$ & 51 \\
\hline Fr. & $6,8 \quad 93,2$ & 44 & $2,3 \quad 93,2$ & 44 & $3,2 \quad 93,5$ & 31 \\
\hline Dr. & $-94,1$ & 34 & $-97,1$ & 34 & $-100,0$ & 34 \\
\hline Ov. & $-100,0$ & 47 & $2,1 \quad 97,9$ & 47 & $-100,0$ & 45 \\
\hline Gl. & $12.680,0$ & 95 & $6,5 \quad 82,8$ & 93 & $1,2 \quad 88,4$ & 86 \\
\hline C"t. & $2,193,8$ & 48 & $2,1 \quad 97,9$ & 48 & $2,1 \quad 97,9$ & 48 \\
\hline $\mathrm{NH}$. & $4,2 \quad 87,4$ & 95 & $2,5 \quad 95,1$ & 81 & $1,2 \quad 95,1$ & 81 \\
\hline $\mathrm{ZH}$. & $1,3 \quad 92,7$ & 151 & $1,4 \quad 96,5$ & 144 & - 98,1 & 103 \\
\hline Zl. & $6,7 \quad 86,7$ & 30 & $3,3 \quad 80,0$ & 30 & $3,3 \quad 83,3$ & 30 \\
\hline NB. & $48.1 \quad 35,9$ & 131 & $32,8 \quad 42,0$ & 131 & $22,1 \quad 43,5$ & 131 \\
\hline Lb. & $86,4 \quad 8,7$ & 103 & $46,4 \quad 31,9$ & 69 & $37,7 \quad 42,0$ & 69 \\
\hline Fl. & $-100,0$ & 1 & $-100,0$ & 3 & $-100,0$ & 6 \\
\hline
\end{tabular}


Tabel 4.14: Percentage communale en nationale gemeenten, per categorie van gemeentegrootte, 1978-1986.

com. nat. $\begin{array}{r}1978 \\ \mathrm{~N}\end{array}$ com. nat. $\mathrm{N} \quad$ com. ${ }^{1982}$ nat. $\mathrm{N}$

inwoners

$\mathrm{x} 1000$

\begin{tabular}{|c|c|c|c|c|c|c|c|}
\hline & 3 & 57,4 & 148 & 26,8 & 112 & $32,3 \quad 50,0$ & 24 \\
\hline 3 & 10 & $28,1 \quad 46,2$ & 359 & 14,5 & 311 & 10,3 & 282 \\
\hline 10 & 25 & $12.0 \quad 80,4$ & 209 & 82,7 & 225 & 84,5 & 239 \\
\hline 25 & $-\quad 50$ & $2,8 \quad 93,0$ & 71 & $-93,8$ & 81 & $-96,1$ & 77 \\
\hline 50 & - 100 & $-100,0$ & 26 & $-100,0$ & 28 & -100.0 & 34 \\
\hline & $>100$ & $-100,0$ & 17 & $-100,0$ & 17 & $-100,0$ & 17 \\
\hline
\end{tabular}

Bron: Databestand CEIS. 
Bijlage 3

EXTRA TABELLEN HOOFDSTUK 5

Tabel 1: Standaardafwijking van het gemiddelde stempercentage bij de lokale- en niet-]okale verkiezingen, 1974-1990.

\begin{tabular}{lrrrrrr}
\hline & \multicolumn{2}{c}{ CDA } & \multicolumn{2}{c}{ PvdA } & \multicolumn{2}{c}{ VVD } \\
& Lok & N-Lok & Lok & N-Lok & Lok & N-Lok \\
1974 & 14,85 & 12,92 & 11,80 & 10,09 & 7,65 & 7,30 \\
1978 & 13,52 & 13,68 & 11,67 & 10,50 & 7,32 & 7,13 \\
1982 & 12,25 & 12,17 & 10,58 & 9,68 & 8,23 & 6,83 \\
1986 & 11,51 & 12,79 & 11,10 & 10,65 & 7,56 & 6,72 \\
$1989 / 90$ & 11,26 & 12,48 & 9,14 & 9,36 & 7,16 & 6,03
\end{tabular}

Bron: Databestand CELS.

Tabel 2: Standaardafwijking van het gemiddelde stempercentage bij de lokale- en niet-lokale verkiezingen, in gemeenten zonder lokale lijsten, 1974-1990.

\begin{tabular}{lrrrrrr} 
& \multicolumn{2}{c}{ CDA } & \multicolumn{2}{c}{ PvdA } & \multicolumn{2}{c}{ VVD } \\
& Lok & N-Lok & Lok & N-Lok & Lok & N-Lok \\
1974 & 15,13 & 12,07 & 10,47 & 9,48 & 7,65 & 7,51 \\
1978 & 13,27 & 12,21 & 10,10 & 9,72 & 7,07 & 6,68 \\
1982 & 11,74 & 9,78 & 9,09 & 8,50 & 7,97 & 6,81 \\
1986 & 11,51 & 11,20 & 9,82 & 10,34 & 7,76 & 7,06 \\
$1989 / 90$ & 11,91 & 10,94 & 8,49 & 9,31 & 7,77 & 6,36 \\
\hline
\end{tabular}

Bron: Databestand CELS. 
Tabel 3: Correlatie tussen de plaatselijke stempercentages bij lokale-en niet-lokaleverkiezingen, per gemeentegrootte, 1974-1990.

\begin{tabular}{llllllllllll}
\hline $\mathrm{CDA}$ & 1974 & $\mathrm{~N}$ & 1978 & $\mathrm{~N}$ & 1982 & $\mathrm{~N}$ & 1986 & $\mathrm{~N}$ & 1990 & $\mathrm{~N}$
\end{tabular}
aantal inwoners $\times 1000$

$\begin{array}{rrrrrrrrrrr}<3 & .82 & 98 & .73 & 83 & .73 & 80 & .66 & 39 & .55 & 14 \\ 3-10 & .82 & 227 & .72 & 257 & .59 & 277 & .66 & 268 & .68 & 214 \\ 10-25 & .71 & 160 & .71 & 186 & .69 & 211 & .65 & 235 & .70 & 228 \\ 25-50 & .82 & 58 & .83 & 68 & .90 & 77 & .88 & 76 & .82 & 81 \\ 50-100 & .75 & 25 & .88 & 26 & .97 & 26 & .89 & 34 & .89 & 36 \\ >100 & .91 & 15 & .98 & 15 & .99 & 17 & .97 & 17 & .97 & 17\end{array}$

$\begin{array}{lllllllllll}\text { PvdA } & 1974 & \mathrm{~N} & 1978 & \mathrm{~N} & 1982 & \mathrm{~N} & 1986 & \mathrm{~N} & 1990 & \mathrm{~N}\end{array}$ aantal inwoners $\mathrm{x} 1000$

\begin{tabular}{|c|c|c|c|c|c|c|c|c|c|c|}
\hline$<3$ & .83 & 86 & .80 & 85 & .83 & 64 & .83 & 39 & .79 & 14 \\
\hline $3 \cdot 10$ & .86 & 198 & .83 & 234 & .85 & 213 & .80 & 197 & .66 & 166 \\
\hline $10-25$ & .88 & 121 & .78 & 160 & .80 & 177 & .70 & 206 & .69 & 211 \\
\hline $25 \cdot 50$ & .94 & 47 & .90 & 58 & .91 & 67 & .80 & 71 & .75 & 77 \\
\hline $50-100$ & .94 & 18 & .89 & 24 & .97 & 26 & .82 & 34 & .82 & 36 \\
\hline$>100$ & .90 & 13 & .93 & 16 & .94 & 16 & .86 & 17 & .66 & 17 \\
\hline
\end{tabular}

$\begin{array}{llllllllllll}\text { VVD } & 1974 & \mathrm{~N} & 1978 & \mathrm{~N} & 1982 & \mathrm{~N} & 1986 & \mathrm{~N} & 1990 & \mathrm{~N}\end{array}$ aantal inwoners $\times 1000$

\begin{tabular}{rrrrrrrrrrr}
$<3$ & .73 & 41 & .76 & 56 & .63 & 52 & .60 & 39 & .67 & 14 \\
$3-10$ & .78 & 206 & .86 & 252 & .81 & 237 & .82 & 23 & .72 & 176 \\
$10-25$ & .90 & 164 & .94 & 185 & .90 & 199 & .90 & 222 & .84 & 217 \\
$25-50$ & .93 & 61 & .97 & 70 & .92 & 77 & .96 & 76 & .94 & 81 \\
$50-100$ & .97 & 24 & .98 & 26 & .92 & 26 & .96 & 34 & .93 & 36 \\
$>100$ & .89 & 15 & .94 & 17 & .90 & 17 & .94 & 17 & .88 & 17 \\
\hline
\end{tabular}


Tabel4: Correlatie tussen de plaatselijke stempercentages bij lokale-en niet-lokaleverkiezingen in gemeenten zonder lokale lijsten, per gemeentegrootte, 1974-1990.

$\begin{array}{llllllllllll}\text { CDA } & 1974 & N & 1978 & N & 1982 & N & 1986 & N & 1990 & N\end{array}$
aantal inwoners

$\mathrm{x} 1000$

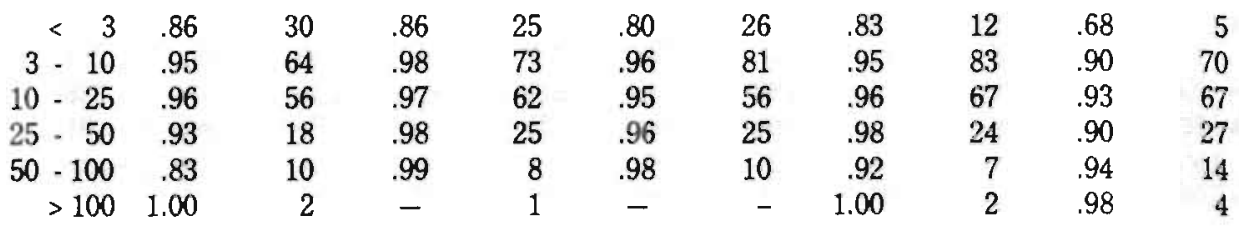

$\begin{array}{llllllllllll}\text { PudA } & 1974 & \mathrm{~N} & 1978 & \mathrm{~N} & 1982 & \mathrm{~N} & 1986 & \mathrm{~N} & 1990 & \mathrm{~N}\end{array}$ aantal inwoners $\times 1000$

$\begin{array}{rrrrrrrrrrr}<3 & .90 & 31 & .86 & 30 & .91 & 26 & .97 & 10 & .90 & 5 \\ 3-10 & .95 & 52 & .97 & 58 & .89 & 68 & .89 & 69 & .89 & 60 \\ 10-25 & .96 & 40 & .96 & 50 & .92 & 44 & .95 & 60 & .88 & 61 \\ 25-50 & .97 & 16 & .95 & 21 & .95 & 22 & .96 & 23 & .96 & 27 \\ 50-100 & .97 & 6 & .99 & 8 & .96 & 10 & .99 & 7 & .90 & 14 \\ >100 & - & 1 & - & 1 & - & - & 1.00 & 2 & .60 & 4\end{array}$

$\begin{array}{llllllllllll}\text { VVD } & 1974 & \mathrm{~N} & 1978 & \mathrm{~N} & 1982 & \mathrm{~N} & 1986 & \mathrm{~N} & 1990 & \mathrm{~N}\end{array}$ aantal inwoners $\mathrm{x} 1000$

$\begin{array}{rrrrrrrrrrr}<3 & .88 & 26 & .92 & 29 & .91 & 29 & .86 & 13 & .98 & 5 \\ 3-10 & .91 & 57 & .92 & 69 & .91 & 80 & .93 & 84 & .84 & 69 \\ 10-25 & .94 & 54 & .98 & 58 & .96 & 54 & .97 & 64 & .91 & 65 \\ 25-50 & .98 & 18 & .97 & 25 & .97 & 25 & .99 & 24 & .97 & 27 \\ 50-100 & .98 & 10 & 1.00 & 8 & .95 & 10 & .98 & 7 & .93 & 14 \\ >100 & 1.00 & 2 & - & - & - & - & 1.00 & 2 & .93 & 4\end{array}$

Bron: Databestand CELS. 


\section{Bijlage 4}

\section{EXTRA TABELLEN HOOFDSTUK 6}

Tabel 1: Correlatie tussen de plaatselijke stempercentages bij twee opeenvolgende gemeenteraadsverkiezingen, per gemeentegrootte, 1974-1990.

\begin{tabular}{lllllllllll}
\hline $\mathrm{CDA}$ & $74-78$ & $\mathrm{~N}$ & $78-82$ & $\mathrm{~N}$ & $82-86$ & $\mathrm{~N}$ & $86-90$ & $\mathrm{~N}$
\end{tabular}

aantal inwoners

$\mathrm{x} 1000$

\begin{tabular}{|c|c|c|c|c|c|c|c|c|c|}
\hline & $<$ & .75 & 77 & .77 & 65 & $.95^{\circ}$ & 37 & .92 & 13 \\
\hline 3 & 10 & .88 & 212 & .89 & 228 & .88 & 245 & .91 & 209 \\
\hline 10 & 25 & .83 & 163 & .93 & 189 & .93 & 219 & .91 & 224 \\
\hline 25 & - 50 & .94 & 64 & .95 & 72 & .96 & 75 & .94 & 79 \\
\hline 50 & -100 & .84 & 26 & .86 & 26 & .93 & 34 & .93 & 36 \\
\hline & $>100$ & .94 & 17 & .99 & 17 & .96 & 17 & .97 & 17 \\
\hline
\end{tabular}

PvdA

$\begin{array}{llllllll}74-78 & \mathrm{~N} & 78-82 & \mathrm{~N} & 82-86 & \mathrm{~N} & 86-90 & \mathrm{~N}\end{array}$

aantal inwoners

$\times 1000$

\begin{tabular}{|c|c|c|c|c|c|c|c|c|c|}
\hline & $<$ & .89 & 76 & .90 & 60 & .92 & 32 & .77 & 10 \\
\hline 3 & 10 & .92 & 181 & .93 & 197 & .93 & 176 & .92 & 154 \\
\hline 10 & 25 & .94 & 118 & .93 & 147 & .94 & 180 & .92 & 194 \\
\hline 25 & 50 & .93 & 49 & .98 & 61 & .97 & 64 & .95 & 7 \\
\hline 50 & -100 & .94 & 20 & .95 & 24 & .92 & 32 & .91 & 3 \\
\hline & $>100$ & .95 & 15 & .96 & 16 & .90 & 16 & .73 & 1 \\
\hline 7 & & 74.78 & $\mathrm{~N}$ & $78-82$ & $\mathrm{~N}$ & 82.86 & $N$ & $86-90$ & \\
\hline
\end{tabular}

aantal inwoners

$\mathrm{x} 1000$

\begin{tabular}{|c|c|c|c|c|c|c|c|c|c|}
\hline & 3 & .93 & 35 & .81 & 40 & .88 & 24 & .96 & 13 \\
\hline 3 & 10 & .90 & 191 & .91 & 217 & .90 & 204 & .88 & 172 \\
\hline 10 & 25 & .96 & 163 & .95 & 184 & .94 & 204 & .94 & 209 \\
\hline 25 & 50 & .96 & 69 & .97 & 74 & .98 & 75 & .96 & 79 \\
\hline 50 & $=100$ & .97 & 25 & .96 & 26 & .96 & 34 & .92 & 36 \\
\hline & $>100$ & .91 & 17 & .94 & 17 & .93 & 17 & .92 & 17 \\
\hline
\end{tabular}

Bron: Databestand CELS. 
Tabel 2: Correlatie tussen de plaatselijke stempercentages bij twee opeenvolgende niet-lokale verkiezingen, per gemeentegrootte, 1974-1990.

$\begin{array}{llllllllll}\mathrm{CDA} & 74.78 & \mathrm{~N} & 78-82 & \mathrm{~N} & 82-86 & \mathrm{~N} & 86-89 & \mathrm{~N}\end{array}$

aantal inwoners

$\times 1000$

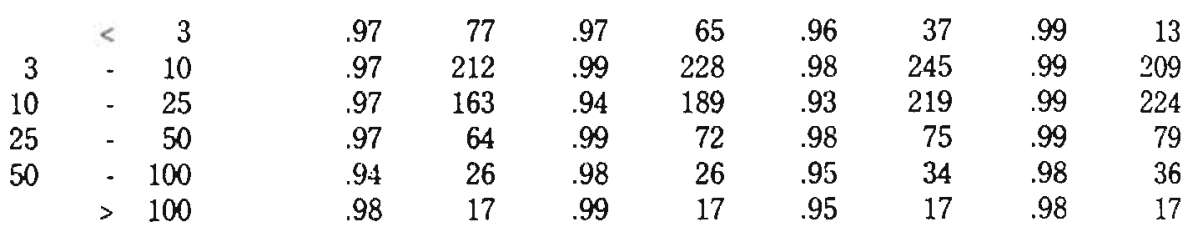

PvdA

$\begin{array}{llllllll}74.78 & \mathrm{~N} & 78-82 & \mathrm{~N} & 82-86 & \mathrm{~N} & 86-89 & \mathrm{~N}\end{array}$

aantal inwoners

$\mathrm{x} 1000$

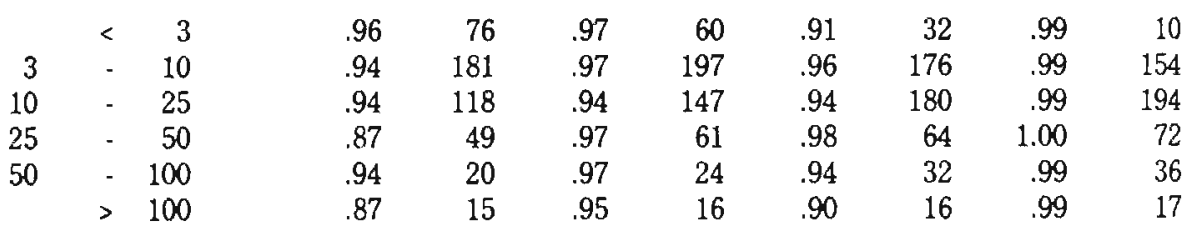

VVD

$\begin{array}{llllllll}74-78 & \mathrm{~N} & 78-82 & \mathrm{~N} & 82-86 & \mathrm{~N} & 86-89 & \mathrm{~N}\end{array}$

aantal inwoners

$\times 1000$

\begin{tabular}{|c|c|c|c|c|c|c|c|c|c|}
\hline & $<3$ & .89 & 35 & .88 & 40 & .92 & 24 & .98 & 13 \\
\hline 3 & 10 & .93 & 191 & .91 & 217 & .95 & 204 & .97 & 172 \\
\hline 10 & 25 & .96 & 163 & .91 & 184 & .95 & 204 & .98 & 209 \\
\hline 25 & 50 & .97 & 69 & .94 & 74 & .97 & 75 & .98 & 79 \\
\hline 50 & . 100 & .97 & 25 & .96 & 26 & .97 & 34 & .96 & 36 \\
\hline & $>100$ & .88 & 17 & .91 & 17 & .96 & 17 & .96 & 17 \\
\hline
\end{tabular}

Bron: Databestand CELS. 
Tabel 3: Correlatie tussen de plaatselijke stempercentages bij twee opeenvolgende gemeenteraadsverkiezingen in gemeenten zonder lokale lijsten, per gemeentegrootte, 19741990 .

\begin{tabular}{lllllllllll}
\hline $\mathrm{CDA}$ & 7478 & $\mathrm{~N}$ & $78-82$ & $\mathrm{~N}$ & $82-86$ & $\mathrm{~N}$ & $86-90$ & $\mathrm{~N}$
\end{tabular}

aantal inwoners

$\times 1000$

\begin{tabular}{|c|c|c|c|c|c|c|c|c|c|}
\hline & 3 & .93 & 17 & .94 & 19 & .89 & 10 & .93 & 5 \\
\hline 3 & 10 & .95 & 43 & .96 & 54 & .96 & 60 & .94 & 61 \\
\hline 10 & 25 & .97 & 42 & .96 & 42 & .97 & 48 & .97 & 52 \\
\hline 25 & $\begin{array}{l}-\quad 50 \\
\end{array}$ & .96 & 11 & .91 & 15 & .98 & 18 & .97 & 22 \\
\hline 50 & -100 & .91 & 7 & .88 & 4 & 1.00 & 5 & .98 & 6 \\
\hline & $>100$ & - & 1 & - & - & - & - & - & 1 \\
\hline
\end{tabular}

$\operatorname{PvdA}$

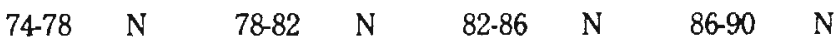

aantal inwoners

$\mathrm{x} 1000$

\begin{tabular}{|c|c|c|c|c|c|c|c|c|c|}
\hline & 3 & .94 & 22 & .92 & 21 & .97 & 9 & .95 & 5 \\
\hline 3 & 10 & .95 & 34 & .95 & 45 & 97 & 48 & .92 & 48 \\
\hline 10 & 25 & .95 & 27 & .91 & 28 & .91 & 38 & .91 & 44 \\
\hline 25 & 50 & .98 & 10 & .98 & 12 & .97 & 15 & 96 & 20 \\
\hline 5 & - 100 & .92 & 6 & .95 & 4 & .97 & 5 & .96 & $\epsilon$ \\
\hline & $>100$ & - & 1 & - & - & - & - & - & \\
\hline
\end{tabular}

WD

$\begin{array}{llllllll}74-78 & \mathrm{~N} & 78-82 & \mathrm{~N} & 82-86 & \mathrm{~N} & 86-90 & \mathrm{~N}\end{array}$

aantal inwoners

$\times 1000$

\begin{tabular}{|c|c|c|c|c|c|c|c|c|c|}
\hline & 3 & .95 & 19 & .93 & 20 & .95 & 11 & 1.00 & 5 \\
\hline 3 & 10 & .94 & 41 & .93 & 52 & .94 & 60 & .91 & 60 \\
\hline 10 & 25 & .97 & 41 & .97 & 40 & .97 & 47 & .95 & 50 \\
\hline 25 & 50 & .96 & 11 & .96 & 15 & .99 & 18 & .97 & 22 \\
\hline 50 & -100 & .99 & 7 & .67 & 4 & .96 & 5 & .97 & 6 \\
\hline & $>100$ & - & 1 & - & - & - & - & - & - \\
\hline
\end{tabular}

Bron: Databestand CELS. 
Tabel 4: Correlatie tussen de plaatselijke stempercentages bij twee opeenvolgende niet-lokale verkiezingen in gemeenten zonder lokale lijsten, per gemeentegrootte, 1974-1990.

\begin{tabular}{llllllllll}
\hline $\mathrm{CDA}$ & $74-78$ & $\mathrm{~N}$ & $78-82$ & $\mathrm{~N}$ & $82-86$ & $\mathrm{~N}$ & $86-89$ & $\mathrm{~N}$
\end{tabular}

aantal inwoners

$\times 1000$

\begin{tabular}{|c|c|c|c|c|c|c|c|c|c|}
\hline & $<$ & .97 & 17 & .95 & 19 & .99 & 10 & .96 & 5 \\
\hline 3 & 10 & .98 & 43 & .99 & 54 & .98 & 60 & .99 & 61 \\
\hline 10 & 25 & .96 & 42 & .98 & 42 & .97 & 48 & .99 & 52 \\
\hline 25 & 50 & .97 & 11 & .96 & 15 & .96 & 18 & .99 & 22 \\
\hline 50 & -100 & .97 & 7 & .96 & 4 & .97 & 5 & .98 & 6 \\
\hline & $>100$ & .- & 1 &.- & - & .- & - & .- & 1 \\
\hline
\end{tabular}

PvdA

$\begin{array}{llllllll}74-78 & \mathrm{~N} & 78-82 & \mathrm{~N} & 82-86 & \mathrm{~N} & 86-89 & \mathrm{~N}\end{array}$

aantal inwoners

$\mathrm{x} 1000$

\begin{tabular}{|c|c|c|c|c|c|c|c|c|c|}
\hline & 3 & .97 & 22 & .96 & 21 & .99 & 9 & 1.00 & 5 \\
\hline 3 & 10 & .96 & 34 & .98 & 45 & .96 & 48 & .99 & 48 \\
\hline 10 & 25 & .97 & 27 & .98 & 28 & .98 & 38 & .99 & 44 \\
\hline 25 & -50 & .92 & 10 & .98 & 12 & .99 & 15 & 1.00 & 20 \\
\hline 50 & -100 & .99 & 6 & .99 & 4 & .99 & 5 & .98 & 6 \\
\hline & $>100$ &.- & 1 &.- & - &.- & - &.- & 1 \\
\hline
\end{tabular}

VVD

$\begin{array}{llllllll}74-78 & \mathrm{~N} & 78-82 & \mathrm{~N} & 82-86 & \mathrm{~N} & 86-89 & \mathrm{~N}\end{array}$

aantal inwoners

$\times 1000$

\begin{tabular}{|c|c|c|c|c|c|c|c|c|c|}
\hline & 3 & .92 & 19 & .94 & 20 & .95 & 11 & 1.00 & 5 \\
\hline 3 & 10 & .93 & 41 & .93 & 50 & .97 & 60 & .98 & 60 \\
\hline 10 & 25 & .97 & 41 & .97 & 40 & .98 & 47 & .99 & 50 \\
\hline 25 & 50 & .97 & 11 & .97 & 15 & .98 & 18 & .99 & 22 \\
\hline 50 & -100 & 1.0 & 7 & .98 & 4 & .95 & 5 & .97 & 6 \\
\hline & $>100$ & . & 1 & . - & - & - & - &. & - \\
\hline
\end{tabular}

Rron: Databestand CELS. 


\author{
Bijlage 5
}

\title{
EXTRA TABELLEN HOOFDSTUK 7
}

Tabel 1: Vergelijking van het stemgedrag bij de gemeenteraads- en de Tweede Kamerverkiezingen in 1986, met de Tweede Kamerverkiezingen als uitgangspunt.

NKO

Gemeen-

CDA PvdA VVD $\quad$ D66 $\quad$ Tweede Kamer $\quad$ CR. $\quad$ ov. NG

teraad

$\begin{array}{lrrrrrrrr}\text { CDA } & 58,9 & 2,1 & 5,8 & 9,4 & 3,8 & 12,5 & 5,6 & 11,7 \\ \text { PvdA } & 6,9 & 67,4 & 2,9 & 21,2 & 9,6 & 2,5 & 16,7 & 1,1 \\ \text { WVD } & 5,3 & 0,9 & 67,3 & 4,7 & 1,9 & 0,0 & 0,0 & 4,3 \\ \text { D66 } & 2,0 & 0,9 & 1,9 & 32,9 & 1,9 & 0,0 & 0,0 & 2,1 \\ \text { GL } & 0,8 & 3,0 & 0,5 & 0,0 & 40,4 & 0,0 & 11,1 & 1,1 \\ \text { CR } & 1,5 & 0,2 & 0,5 & 0,0 & 0,0 & 75,0 & 5,6 & 0,0 \\ \text { Lok/ov. } & 11,2 & 9,3 & 10,6 & 16,5 & 30,8 & 2,5 & 38,9 & 5,3 \\ \text { NG } & 13,5 & 16,2 & 10,6 & 11,5 & 11,5 & 7,5 & 22,2 & 74,5 \\ \text { Tot. } & 100,1 & 100,0 & 100,1 & 100,0 & 100,1 & 100,0 & 100,1 & 100,1 \\ & & & & & & & & \\ \text { N } & 439 & 394 & 208 & 85 & 52 & 40 & 18 & 94\end{array}$

AVRO-NIPO

\section{Gemeen-}

Tweede Kamer

teraad

CDA

PudA

VVD

GL $\quad \mathrm{CR}^{\prime}$

ov. NG

D66

GL

$$
65,7
$$

2,2

1,0

\section{1,8}

4,5

0,0

5,0

$0,0 \quad 6,3$

$0,4 \quad 1,1$

2,3

0,7

60,8

50,0

15,8

0,0

$33,3 \quad 9,0$

2,6

0,0

$0,0 \quad 2,1$

$\begin{array}{ll}2,0 & 0,7 \\ 0,9 & 0,5\end{array}$

1,3

0,0

2,6

0,0

$0,0 \quad 2,6$

CR

0,0

1,6

0,0

0,0

36,8

0,0

$0,0 \quad 3,4$

Lok/ov.

0,0
19,7

r,

17,0

0,0

67,5

$0,0 \quad 1,1$

$\mathrm{NG}$

16,6

13,8

16,7

25,0

23.7

22,5

$33,3 \quad 19,0$

Tot

$$
100,0
$$

99,9

99,9

99,9

18,4

$33,3 \quad 56,5$

$$
\text { N }
$$

446

674

227

$99,9 \quad 100,0$

$99,9100,0$

Bron: Secundaire analyse NKO 1986 en AVRO-NIPO 1986.

Tcelichting: $\quad$ GL $=$ Groen-Linkse partijen (PPR,PSP,CPN,EVP)

$\mathrm{Lok} / \mathrm{ov} .=$ Lokale lijsten en overige partijen

$\mathrm{CR}=$ Kleinere christelijke partijen $(\mathrm{SGP}, \mathrm{GPV}, \mathrm{RPF})$

$\mathrm{NG}=$ Niet gestemd

Leesvoorbeeld: Volgens het NKO heeft 85,9 procentvan de de CDA-stemmers bij de Tweede Kamerverkiezingen ook bij de gemeenteraadsverkiezingen op het CDA gestemd. Bij de AVR:O-NIPO is dit percentage 87,7 procent. 
Tabel 2: Vergelijking van het stemgedrag bijde gemeenteraads-en Tweede Kamerverkiezingen in 1986, met de gemeenteraadsverkiezingen als uitgangspunt.

NKO

Tweede Kamer

CDA PvdA VVD D66 GL CR ov. NG Tot. N

Gemeen-

teraar

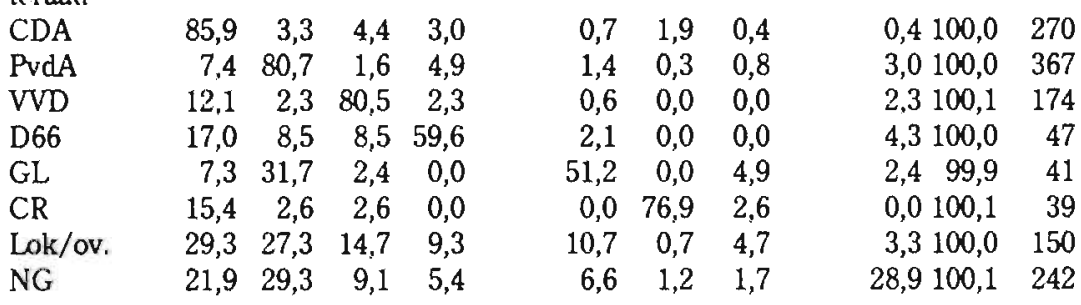

AVRO-NIPO

Tweede Kamer

\begin{tabular}{lrrrrrrrrrr} 
& \multicolumn{1}{c}{ CDA PvdA VVD } & D66 & & GL & CR & ov. & NG & Tot. & N \\
Gemeen- \\
teraad
\end{tabular}

Bron: Secundaire analyse NKO 1986 en AVRO-NIPO 1986.

Toelichting: $\quad$ GL = Groen-Linkse partijen (PPR,PSP,CPN,EVP)

Lok/ov. = Lokale lijsten en overige partijen

$\mathrm{CR}=$ Kleinere christelijke partijen (SGP,GPV,RPF)

$\mathrm{NG}=$ Niet gestemd

Leesvoorbeeld: Volgens het NKO heef 85,9 procent van de de CDA-stemmers bij de Tweede Kamerverkiezingen ook bij de gemeenteraadsverkiezingen op het CDA gestemd. Bij de AVRO-NIPO is dit percentage 87,7 procent. 


\section{Bijlage 6}

\section{OVERZICHT GEBRUIKT KIEZERSONDERZOEK}

Het in deze bij]age gepresenteerde lokale kiezersonderzoek is waarschijnlijk het merendee] van het lokale kiezersonderzoek dat in de periode 1974-1991 verricht is. Het bevat in ieder geval de kiezersonderzoeken waarvan in hoofdstuk zeven en acht de resultaten gebruikt zijn. Allereerst zal een overzicht worden gegeven van het kiezersonderzoek op nationaal niveau.

\section{Culturele veranderingen in Nederland 1975-1989}

Doel van dit onderzoek van het Sociaal en Cultureel Planbureau is in eerste instantie niet het in kaart brengen van ontwikkelingen in politieke gedragingen en opvattingen maar vooral het bestuderen van algemene culturele en sociale veranderingen in Nederland. Het onderzoek is in 1970 gestart. In hoofdstuk zeven is alleen gebruik gemaakt van de door het SCP aangeleverde gegevens uit de onderzoeken in de periode 1975-1989. Het gaat hierbij met name om de vragen omtrent politieke interesse, politiek (zelf)vertrouwen, politieke activiteiten en het belang van de lokale en landelijke politiek voor het dagelijkse leven van de kiezers. Een groot deelvan deze gegevens is tevens gepubliceerd in: Sociaal en Cultureel Planbureau, Gemeentc, burger, klant, Rijswijk, 1989, p77-78. In de regel werden de gebruikte vragen brantwoord clour ongeveer 1800 respondenten.

\section{Nationale Kiezers Onderzoeken 1977-1989}

Sinds 1967 wordt bij elke verkiezing voor de Tweede Kamer een kiezersonderzoek gehouden omtrent de gedragingen, houdingen en opvattingen van de kiezers in verband met de landelijke politiek. Met name wordt gelet op de vergelijkbaarheid van de verschillende onderzoeken zodat veranderingen in electoraal gedrag van kiezers in kaart kunnen worden gebracht Een interuniversitaire werkgroep is verantwoordelijk voor het opleveren van de data. De gegevens zijn verkregen in een vraaggesprek waarbij de gebruikte vragen gesteld zijn aan ongeveer 1500 respondenten. Van belang is met name het onderzoek naar de partijkeuze bij gemeenteraads- en Tweede Kamerverkiezingen in 1986. Hiervoor is gebruik gemaakt van het databestand van het NKO uit 1986 in het Steinmetzarchief (nr. P0866). Daarnaast is in hoofdstuk zeven de vraag naar contacten met lokale en landelijke politici in de periode 1977 1989 gebruikt. Zie hiervoor: J.W. van Deth en R Horstman, Dutch Parliamentary election studies dat source book 1971-1986, Steinmetzarchief/SWIDOC, Amsterdam, 1989.

\section{AVRO/NIPO-enquêtes 1982-1990}

Naar aanleiding van de gemeenteraadsverkiezingen heeft het NIPO in 1982, 1986 en 1990 in opdracht van de AVRO in haar weekenquetes een aantal vragen opgenomen over de opvattingen en houdingen van de kiezers ten opzichte van de lokale en de landelijke politiek en de gemeenteraadsverkiezingen. De resultaten zijn verkregen via vraaggesprekken waar in 1982 en 1990 ongeveer 1100 respondenten aan meewerkten en in 1986 ongeveer 2000 . In 
hoofdstuk zeven maken wij met name gebruik van de vragen naar de interesse in de lokale en de landelijke politiek en de lokale en nationale overwegingen bij de partijkeuze bij de gemeenteraadsverkiezingen. Tevens is de partijkeuze bij de gemeenteraads- en Tweede Kamerverkiezingen in 1986 met behulp van de gegevens van de NIPO-enquête onderzocht. Daarbij is gebruik gemaakt van de databestanden in het Steinmetzarchief. Resultaten van de onderzoeken in de drie verkiezingsjaren zijn ook gepubliceerd in: AVRO/NIPO,Politieke voorkeurgegevens en de komende Gemeenteraadsverkiezingen, NIPO, Amsterdam, 1990.

\section{Onderzoek dagblad Trouw 1991}

Naar aanleiding van Prinsjesdag 1991 is in opdracht van het dagblad Trouw een representatief onderzoek verricht naar de mening van de kiezers over macht- en invloedsverhoudingen in de Nederlandse politiek. Via een telefonisch vraaggesprek is medewerking verleend door 600 kiezers. In dit onderzoek zijn tevens een aantal vragen opgenomen met betrekking tot de lokale politiek. In hoofdstuk zeven is met name gebruik gemaakt van de vraag naar de politike betrokkenheid en het politiek zelfvertrouwen op lokaal niveau. Het merendeel van de resultaten van het onderzoek zijn op 17 september 1991 gepubliceerd in Trouw. Een volledig verslag is te vinden in: De Vos Hindriks Consultants, Onderzoek invloed en macht, Veere, 1991.

Naast bovenstaande landelijke kiezersonderzoeken met betrekking tot de lokale politiek, zijn in hoofdstuk zeven ook een groot aantal plaatselijke kiezersonderzoeken gebruikt. Deze zullen thans in chronologische volgorde gepresenteerd worden.

\section{Onderzoek naar de relatie burger-gemeentelijke overheid 1974}

Begin jaren zeventig is in een twaalftal gemeenten een onderzoek verricht met het doel inzicht te verschaffen in de relatie tussen burgers en de gemeentelijke overheid, zodat bepaald kon worden in hoeverre beleidsmaatregelen zinvol zijn en maatregelen voorgesteld kunnen worden welke met name kunnen leiden tot een verkleining van de afstand tussen de burgers en de overheid. Het betreft de gemeenten Den Haag, Utrecht, Leiden, Gouda, Haarlemmermeer, Voorburg, Bussem, Zoetermeer, Leidschendam Enschede, Breda en Dordrecht. Het onderzoek dat uitgevoerd is door Veldkamp marktonderzoek b.v. bestond uit drie delen. Allereerst werd er een kiezersonderzoek gehouden onder de burgers. Op basis hiervan zijn gesprekken gevoerd met gemeentelijke gezagsdragers uit de ambtenarij en de politiek. Tenslotte zijn ook nog de rol van de intermediare kaders onderzocht. Voor dit onderzoek hebben wij alleen gebruik gemaakt van de gegevens van het kiezersonderzoek in elf van de twaalf deelnemende gemeenten. De gegevens van de gemeente Dordrecht konden niet achterhaald worden. Het veldwerk voor deze onderzoeken heeft zich medio 1973 voltrokken, en de rapportage vond in 1974 plaats. Het aantal respondenten in de gemeenten variëerde van 205 in Bussem tot 681 in Den Haag. In hoofdstuk 8 hebben wij gebruik gemaaktvan gegevens omtrent de interesse voor en kennis van de lokale politiek, de politieke activiteiten op lokaal niveau en het lokale politieke (zelf)vertrouwen van de kiezers. Zie voor een overzicht van de resultaten van dit onderzoek: Veldkamp marktonderzoek b.v., Onderzoek naar de relatie burger-gemeentelijke overheid, deel 3, Totaal overzicht van de resultaten in negen gemeenten, Amsterdam, 1974. Daarnaast is gebruik gemaakt van de afzonderlijke rapporten voor de gemeenten Enschede en Breda. 


\section{Lelystad 1974}

In april 1974 is in opdracht van de Stichting voor het Bevolkingsonderzoek in de drooggelegde Zuiderzeepolders een enquete gehouden onder de inwoners van de gemeente Lelystad, waaraan 304 inwoners hebben meegewerkt. De aanleiding van het onderzoek waren de Adviesraadsverkiezingen die in mei 1974 in Lelystad werden gehouden. De toenmalige Adviesraad in Lelystad is te vergelijken met de gemeenteraad. Een belangrijk verschil is echter, zoals de naam al aangeeft, dat de Adviesraad geen beslissende stem heeft. In de regel werd wel het advies van de Adviesraad overgenomen door de Landdrost. Zie hiervoor: F. Grünfeld en R. Meijer, Politieke opvattingen in Lelystad, Amsterdam, 1977, p. 39. Uit deze publicatie zijn ook de in hoofdstuk zeven gebruikte gegevens overgenomen. Ondanks de andere bestuursstructuur in Lelystad zijn de resultaten van dit onderzoek in hoofdstuk zeven aan de orde gesteld omdat het én van de weinige lokale kiezersonderzoeken is in de periode 1974-1980.

\section{Tilburg 1982}

In 1982 werd in opdracht van het Nieuwsblad van het Zuiden naar aanleiding van de gemeenteraadsverkiezingen in 1982 een lokaal kiezersonderzoekverricht door het Sociologisch Instituut en het IVA in Tilburg. 381 kiezers hebben via een vraaggesprek aan dit onderzoek meegewerkt. Verschillende aspecten van de betrokkenheid en het stemgedrag van de burger worden in dit onderzoek aan de orde gesteld. In hoofdstuk zeven is met name gebruik gemaakt van de vragen naar de politieke kennis van de respondenten. Gebruik is gemaakt van de rechte tellingen van de antwoorden op de vragen zoals deze door de KU.B. zijn verstrekt.

\section{Nijmegen 1982}

In Nijmegen is naar aanleiding van de gemeenteraadsverkiezingen van 1982 door het Sociologisch instituut in opdracht van de Stichting Politiek Kafee Nijmegen een onderzoek verricht naar de meningen van de Nijmeegse kiezers over een aantal aspecten van de lokale politiek in Nijmegen. Het onderzoek is verricht in mei 1982 via een telefonische enquête waar 433 kiezers aan meewerkten. De gebruikte gegevens zijn afkomstig uit: P.J. M. Biemans e.a.,Rondom de Nijmeegse gemeenteraadsverkiezingen 1982, Nijmegen, 1982.

\section{Nijmegen 1986}

In februari/maart 1986 is in opdracht van het dagblad de Gelderlander door het bureau Inter/ View een telefonisch enquête gehouden waaraan 332 kiezers hebben meegewerkt. De vragen hadden betrekkeing op het stemgedrag en een aantal actuele zaken in Nijmegen. De gemeenteraadsverkiezingen van 19 maart 1986 waren de aanleiding voor dit onderzoek. De resultaten van dit onderzoek zijn grotendeels gepubliceerd in de Gelderlander van 15 maart 1986. De gebruikte gegevens zijn gebaseerd op: M. de Hond en M. Bank, Prognose gemeente Nijmegen, Tabellenrapport, Amsterdam, 1986.

\section{Breda 1986}

Door Inter/View is in februari 1986 eveneens een onderzoekverrichtonder de kiesgerechtigde burgers van Breda. Deze keer in opdracht van de Veronica Omroep Organisatie. Aan dit onderzoek werd meegewerkt door 600 kiezers. De in hoofdstuk zeven gebruikte gegevens 
stammen uit: H. de Bock en A. van der Veen, Gemeenteraadsverkiezingen Breda, tabellenrapport, Amsterdam, 1986.

\section{Roosendaal 1986}

In 1986 is in een wijk in Roosendaal op de dag van de Tweede Kamerverkiezingen een lokaal kiezersonderzoek gehouden om meer inzicht te krijgen in de opvattingen van de burgers over de gemeentepolitiek. Het onderzoek werd uitgevoerd door medewerkers van de vakgroep politicologie van de Erasmus Universiteit Rotterdam. De betreffende wijk werd gekozen omdat daar betrekkelijk veel stemmen werden uitgebracht op lokale lijsten. Iedere derde kiezer werd verzocht aan de enquête mee te werken. In totaal hebben 203 kiezers aan het onderzoek meegewerkt. De resultaten van dit onderzoek kunnen niet als representatief voor de hele gemeente Roosendaal worden beschouwd. De gebruikte gegevens zijn afkomstig uit: H. Braat en L. Gerrichhauzen, Onderzoek burgers en gemeentepolitiek in Roosendaal 1986, Rotterdam, 1986.

\section{Dordrecht 1989}

In april 1988 is door de gemeente Dordrecht een lokaal kiezersonderzoek verricht. Doel van het onderzoek was het verschaffen van inzicht in de relatie tussen burgers en de lokale overheid en het geven van handvaten om die relatie te verbeteren. Met name wordt aandacht geschonken aan klantgerichtheid en benvloedingsmogelijkheden van de burger op de lokale politiek. Aan het onderzoek is meegewerkt door 1375 huishoudens die een schriftelijke vragenlijst hebben ingevuld. De resultaten van het onderzoek zijn gepubliceerd in: Sociaal (ieografisch Bureau Gemeente Dordrecht, Relatie burgers-lokale overheid, Dordrecht, 1989.

\section{Nijmegen 1990}

Evenals in 1982 is in 1990 door de K.U.N., deze keer door de vakgroepen sociologie en methoden van onderzoek, in samenwerking met de Stichting Politiek Kafee Nijmegen een lokaal kiezersonderzoek verricht naar aanleiding van de gemeenteraadsverkiezingen. Via een telefonische enquète werden 1118 Nijmeegse kiezers bereikt. De gebruikte gegevens van dit onderzoek zijn gebaseerd op een perspublicatie: P.J.M. Biemans en J.J.J. van der Putten, Gcmeenteraadsverkiezingen Nijmegen 1990, Nijmegen, 1990.

\section{Leeuwarden 1990}

In februari/maart 1990 is door een aantal studenten van de Thorbecke Academie een representatiefkiezersonderzoek gehouden naar aanleiding van de gemeenteraadsverkiezingen. Het onderzoek is met name gericht op het peilen van de bekendheid van de lokale politici en wil tevens een prognose geven van de uitslag van de komende gemeenteraadsverkiezingen. Via een telefonische enquête hebben 499 inwoners van Leeuwarden aan het onderzoek meegewerkt. De resultaten van dit onderzoek zijn gepubliceerd in: C. de Boer e.a., Verkiezingsonderzoek in Leeuwarden naar aanleiding van de gemeenteraadsverkiezingen van 21 maant 1990, onderzoeksverslag Thorbecke Academie, Leeuwarden. 1990. 


\section{Delft 1988 en 1990}

In Delft wordt regelmatig via een stadspanel nagegaan wat de meningen en houdingen van burgers zijn ten aanzien van een aantal actuele zaken opverschillende beleidsterreinen. In deze onderzoeken wordt tevens aandacht geschonken aan de relatie tussen de burger en de lokale overheid. Het onderzoek bestaat uit mondelinge vraaggesprekken met vertegenwoordigers van Delftse huishoudens en schriftelijke vragenlijsten die door leden van deze huishoudens zijn ingevuld. In hoofdstuk zeven is gebruik gemaakt van de reacties op enkele voorgelegde stellingen omtrent het politiek zelfvertrouwen van de ondervraagden. In 1988 reageerde 992 huishoudrepresentanten via de schriftelijke enquête op de voorgelegde stellingen. In 1990 betrof het 1007 respondenten. Zie hiervoor: Gemeente Delft, Basisrapport stadspanel resultaten meting najaar 1990, Delft, 1990, p.80.

\section{Zaanstad 1990}

In december 1990 is aan 2515 inwoners van Zaanstad gevraagd een schriftelijke enquête in te vullen omtrent verschillende actuele zaken in de gemeente en de relatie burger-gemeente. In totaal werden 1831 enquêtes teruggestuurd. De gestelde vragen omtrent de relatie tussen de burgers en de gemeenten betroffen met name de politieke betrokkenheid van de kiezers en het politiek (zelf)vertrouwen. De in hoofdstuk zeven gebruikte gegevens zijn afkomstig uit: Gemeente Zaanstad, Omnibusonderzoek 1990, Zaanstad, 1991.

\section{Haarlem en Leiden 1991}

In Haarlem en Leiden is door leden van de vakgroep politieke wetenschappen van de Rijksuniversiteit Leiden in opdracht van de gemeentebesturen van de betreffende gemeenten een evaluatie-onderzoek gehouden naar de in deze gemeenten georganiseerde referenda. Het doel van deze onderzoeken was na te gaan of en in welke mate de verwachtingen met betrekking tot het refendum (zoals een toename van de politieke betrokkenheid en participatie) gerechtvaardigd zijn geweest. In het kader van dit onderzoek zijn een aantal vragen gesteld omtrent de politieke betrokkenheid van de kiezers. Aan het kiezersonderzoek datvoorafgaande aan het referndum werd gehouden, werkten via een telefonische enquête in Leiden 930 en in Haarlem 849 kiezers mee. Zievoor de volledige resultaten van deze onderzoeken: R. Hillebrand en J.J.M. Holsteyn, Haarlem geraadpleegd, evaluatie van het referendum van 6 maart 1991, Leiden. 1991; en: J.J.M. Holsteyn en R Hillebrand, Leiden geraadpleegd, evaluatie van het referendum van 6 maart 1991, Leiden, 1991.

\section{Almere 1991}

In 1991 heeft de afdeling sociaal-geografisch en bestuurskundig onderzoek van de VNG in opdracht van de gemeente Almere een kiezersonderzoek verricht naar de politieke alsmede de sociale en maatschappelijke betrokkenheid van de inwoners van Almere. Tevens werd de waardering van de gemeentelijke dienstverlening onderzocht. Aan het onderzoek hebben 1001 inwoners meegewerkt. In hoofdstuk zeven zijn alleen de gegevens omtrent de politieke betrokkenheid gebruikt. Zie hiervoor. VNG, Bouwstenen voor bestuurlijke vernieuwing, Politieke en maatschappelijke betrokkenheid van inwoners van Almere bij de gemeente, Den Haag, 1991. 


\section{Amsterdam 1991}

In Amsterdam is voorafgaande aan het in 1992 gehouden referendum over het autoverkeer in de binnenstad in juni 1991 in samenwerking met de Universiteit van Amsterdam een kiezersonderzoek verricht. Bedoeling van dit onderzoek was om de politieke betrokkenheid van de burgers te meten voor het referendum, zodat na het referendum kon worden nagegaan of en in hoeverre hierin verandering is gekomen. Tevens werd via een panel nagegaan hoe in de aanloop naar het referendum kiezers door de voorlichting en discussie van mening of houding veranderde. De gebruikte gegevens van dit onderzoek zijn afkomstig van de nulmeting waarbij 868 kiesgerechtigden hebben meegewerkt aan een telefonisch vraaggesprek. Zie voor de resultaten van dit onderzoek: Het Amsterdamse bureau voor Onderzoek en Statistiek, Verslag nulmeting referendum, Amsterdam, 1991

\section{Onderzoek lokale democratie en bestuurlijke vernieuwing 1991}

In 1991 is in opdracht van zeven gemeenten in deze gemeenten een grootschalig kiezersonderzoek verricht naar de relatie tussen de burgers en de lokale overheid. De betrefffende gemeenten zijn: Amsterdam, Den Haag, Eindhoven, Nijmegen, Tilburg, Utrecht en Zwolle. Het onderzoek werd uitgevoerd door de interuniversitaire onderzoeksgroep 'lokale democratie'. De aanleiding voor het onderzoek was delage opkomstcijfers bij de gemeenteraadsverkiezingen van 1990. Doel van het onderzoek was de relatie tussen de burgers en de lokale overheid in kaart te brengen zodat op basis hiervan strategieën van bestuurlijke vernieuwing gemaakt konden worden. In hetonderzoek is naast deverschillende aspecten van politieke betrokkenheid, de motieven voor het stemgedrag ook aandacht geschonken aan de de waardering van de dienstverlening van de overheid en de maatschappelijke betrokkenheid van de burgers. Ter vergelijking is tevens aandacht geschonken aan de betrokkenheid van de burgers bij de landelijke politiek. De resultaten van het onderzoek zijn gebaseerd op ongeveer 400 vraaggesprekken in elk van de gemeenten, behalve in Den Haag waar 800 vraaggesprekken zijn afgenomen. In hoofdstuk zeven zijn gegevens van deze onderzoeken gebruikt ten aanzien van alle aspecten van de betrokkenheid van kiezers bij de lokale politiek alsmede het lokale karakter van het stemgedrag bij de gemeenteraadsverkiezingen. De gebruikte gegevens zijn afkomstig uit de afzonderlijke rapporten voor de zeven gemeenten. Zie hiervoor bijvoorbeeld: Onderzoeksgroep Lokale Democratie, Lokale democratie en bestuurlijke vermieuwing in Amsterdam, Delft, 1991. 
Bijlage 7

\section{OVERZICHT VERKIEZINGSUITSLAGEN 1974-1990}

Tabel 1: Percentage stemmen op politieke groeperingen en landelijke politieke stromingen bij de gemeenteraadsverkiezingen, 1974-1990.

\begin{tabular}{lrrrrr}
\hline & 1974 & 1978 & 1982 & 1986 & 1990 \\
CDA & 27,1 & 31,7 & 28,9 & 28,0 & 29,0 \\
CR & 3,6 & 3,2 & 4,5 & 4,2 & 4,9 \\
Tot. conf. & 30,7 & 34,9 & 33,4 & 32,2 & 33,9 \\
PvdA & 21,6 & 24,4 & 20,9 & 29,0 & 22,0 \\
PAK & 4,4 & 2,8 & 1,8 & 1,2 & 0,8 \\
GL & 7,1 & 4,7 & 6,5 & 4,2 & 5,3 \\
D66 & 0,5 & 3,7 & 4,0 & 3,6 & 8,7 \\
Tot. prog.33,6 & 35,6 & 33,2 & 38,0 & 36,8 & \\
VvD & 14,8 & 14,8 & 19,5 & 16,0 & 13,5 \\
Lok. & 18,9 & 14,1 & 13,0 & 12,0 & 13,3 \\
Ov. & 2,0 & 0,6 & 0,9 & 1,8 & 2,4 \\
Tot. & 100,0 & 100,0 & 100,0 & 100,0 & 99,9 \\
\hline
\end{tabular}

Bron: Databestand CEIS.

Toelichting: $\mathrm{CR}=$ Gezamenlijke kleinere christelijke partijen (SGP, GPV, RPF)

conf. = Confessionele stroming

PAK $=$ Progressief AKkoord

GL = Gezamenlijke Groen-Linkse lijsten (CPN, PSP, PPR, EVP, Groen Links)

prog $=$ Progressieve stroming

Lok. $=$ Gezamenlijke lokale lijsten

Ov. = Overige partijen en lijsten 


\section{Bijlage 8}

\section{OVERZICHT METHODEN DEEL III}

In deel III van dit onderzoek wordt door middel van een analyse van de plaatselijke stempercentages en trends van de drie grootste landelijke partijen het lokale karakter van de gemeenteraadsverkiezingen bepaald. In deze bijlage zal een overzicht worden gegeven van de methoden die in de hoofdstukken 5 en 6 zijn gebruikt. De nadruk ligt daarbij op de methoden van hoofdstuk 5 . De reden hiervoor is dat de methoden die gebruikt worden bij de analyse van de plaatselijke trends in hoofdstuk 6 in grote lijnen overeenkomen met de methoden die gebruikt worden bij de analyse van de plaatselijke stempercentages in hoofdstuk 5 .

Er is echter één belangrijk verschil tussen de gebruikte methoden in hoofdstuk 5 en hoofdstuk 6. Bij de analyse van de plaatselijke stempercentages worden in elke gemeente de plaatselijke stempercentages bij de lokale verkiezingen in relatie wordt gebracht met de plaatselijke stempercentages bij de niet-lokale verkiezingen. Bij de analyse van de plaatselijke trends daarentegen wordt afzonderlijk voor de plaatselijke tends bij de lokale verkiezingen en de plaatselijke trends bij de niet-lokale verkiezingen een analyse uitgevoerd, waarna de de resultaten hiervan worden vergeleken. Omdat in hoofdstuk 6 in tegenstelling tot hoofdstuk 5 de plaatselijke uitslagen bij de lokale verkiezingen niet direct worden vergeleken met de plaatselijke uitslagen bij de niet-lokale verkiezingen, zijn de gebruikte methoden in hoofdstuk 6 in wezen minder robuust dan de gebruikte methoden in hoofdstuk 5.

In hoofdstuk 5 worden in essentie drie methoden gebruikt om de invloed van lokale factoren op de plaatselijke stempercentages van de drie grote landelijke partijen bij de gemeenteraadsverkiezingen te meten. In de eerste plaats wordt de correlatie berekend tussen de plaatselijke stempercentages bij de lokale-en de niet-lokaleverkiezingen. Vervolgens wordt de zogenaamde lokale factor berekend, waarna tenslotte de uitzonderlijk plaatselijke stempercentages worden geanalyseerd. Voor elk van deze methoden zullen wij aangeven waarom zij gebruikt zijn, en wat de voor- en nadelen zijn van de betreffende methode.

\section{De correlatie tussen de plaatselijke stempercentages}

De correlatie tussen de plaatselijke stempercentages bij de lokale-en niet-lokale verkiezingen is berekend om daarmee de samenhang tussen de plaatselijke stempercentages bij de lokaleen niet-lokale verkiezingen te kunnen bepalen. De achtergrond hiervan is dat als lokale factoren een rol van betekenis spelen bij de gemeenteraadsverkiezingen, dit tot uitdrukking moet komen in de plaatselijke stempercentages bij deze verkiezingen. In sommige gemeenten zal een partij hierdoor een hoger stempercentage halen bij de gemeenteraadsverkiezingen in vergelijking met de niet-lokale verkiezingen. In andere gemeenten kan het omgekeerde het geval zijn. Daardoor wordt de samenhang tussen de plaatselijke stempercentages bij de lokaleen niet-lokale verkiezingen verminderd.

Een voordeel van het gebruik van correlatiecoëfficiënten is dat deze veel gebruikt worden in de sociale wetenschappen. Samen met de omstandigheid dat de correlatiecoëfficiënt een 
schaal kent die tussen 0 en 1 ligt, zijn de resultaten van de berekening van de correlatiecofiënten relatief gemakkelijk te interpreteren. Daar staat echter tegenover dat de hoogte van de correlatiecoëfficiënten mede beïnvloed wordt door de mate van spreiding van de variabelen die de basis vormen van de berekening van de correlatiecoëfficiënt (Achen, 1977). Tevens kan men zich afvragen of het mogelijk is dat de plaatselijke stempercentages bij de twee soorten verkiezingen helemaal geen samenhang vertonen. Anders gezegd, waarschijnlijk is het bij een vergelijking van de plaatselijke uitslagen bij lokale- en niet-lokale verkiezingen niet mogelijk dat de correlaties onder een bepaald basis-niveau uitkomen. Het onderscheidend vermogen van deze methode wordt daarmee aangetast. Op basis van bovenstaande twee kanttekeningen zijn de resultaten van de berekende correlaties te beschouwen als een aanwijzing van het lokale karakter van de gemeenteraadsverkiezingen. De vergelijking van de onderzoeksresultaten tussen de partijen en over de verschillende verkiezingen geeft daarbij aan wat de verschillen tussen de partijen zijn en welke ontwikkelingen zich voordoen ten aanzien van het lokale karakter van de gemeenteraadsverkiezingen.

\section{De berekende lokale factor}

Het belang van de berekende lokale factor bij de plaatselijke stempercentages is dat duidelijk wordt wat de invloed van lokale factoren op de hoogte van een plaatselijk stempercentage van een partij is geweest. Anders gezegd, daarmee wordt in concreto aangegeven hoeveel hoger of lager een plaatselijk stempercentage zou zijn geweest als lokale factoren geen invloed hadden uitgeoefend.

Eén van de voordelen van deze methode is dat het onderscheidend vermogen in vergelijking met de berekende correlatiecoëficienten groot is omdat de verschillen tussen de berekende plaatselijke lokale factoren relatief groot kunnen zijn. Tevens kunnen wij met het berekenen van de lokale factor op een eenvoudige manier inzicht krijgen in de invloed van extreme waarden op de resultaten. Daarnaast is een voordeel dat niet alleen de resultaten per partij maar ook de resultaten per gemeente op een eenvoudige manier te berekenen zijn.

Een nadeel is echter dat het berekening van de lokale factor een nieuwe en daarmee onbekende methode is binnen de sociale wetenschappen, hetgeen de interpretatie van de onderzoeksresultaten kan bemoeilijken. Daarbij speelt ook een rol dat met name de berekende relatieve lokale factoren extreem hoog kunnen zijn. Door echter uit te gaan van de mediane waarde in plaats van de gemiddelde waarde van de berekende plaatselijke relatieve lokale factoren is het wel mogelijk om de invloed van deze extreme waarden tot een minimum te beperken.

\section{Analyse van de uitzonderlijke plaatselijke stempercentages}

Via een analyse van de uitzonderlijke plaatselijke stempercentages bij de gemeenteraadsverkiezingen wordt op een eenvoudige manier duidelijk welke lokale factoren een rol spelen bij de gemeenteraadsverkiezingen. Het gaat dus niet meer om de invloed van de lokale factoren maar om de inhoud. Welke lokale factoren met name van belang zijn, wordt bepaald door een eenvoudige analyse van de gevonden uitzonderlijke plaatselijke stempercentages op basis van de uitslagen van de gemeenteraadsverkiezingen. Daarmee hebben de resultaten van deze analyse slechts een "face-validiteit". Aangezien wij via deze uitslagen een beperkt beeld krijgen van de plaatselijke politieke verhoudingen, is het niet in alle gevallen mogelijk te bepalen welke lokale factor van invloed is op de gemeente- 
raadsverkiezingen. Alleen door case-studies is het mogelijk een completer beeld te krijgen van de lokale factoren die in de betreffende gemeenten een rol van betekenis spelen, waardoor tevens de geldigheid van de in dit deel van het onderzoek gepresenteerde onderzoeksresultaten duidelijk wordt.

In de inleiding is reeds gesteld dat de gebruikte methoden in hoofdstuk 5 in grote lijnen overeenkomen met die in hoofdstuk 6. Immers, in hoofdstuk 6 berekenen wij ook correlaties en worden ook uitzonderlijke plaatselijke uitslagen (in dit geval trends) geanalyseerd. De in hoofdstuk 6 berekende afwijking van de plaatselijke trends komt in sterke mate overeen met de berekende lokale factor in hoofdstuk 5 . Het belangrijkste verschil is dat de laatste stap bij de berekening van de lokale factor in hoofdstuk 5 , het leggen van een relatie tussen de plaatselijke uitslag bij de lokale verkiezingen met die van de niet-lokale verkiezingen, wordt overgeslagen. In hoofdstuk 6 wordt daarentegen gebruik gemaakt van de spreiding in de plaatselijke trends bij de lokale-en niet-lokale verkiezingen. Deze methode is toegevoefd omdat $z$ ij op een heldere manier duidelijk maakt dat lokale factoren invloed uitoefenen op de plaatselijke trends van de partijen bij de gemeenteraadsverkiezingen. Dit is met name van belang omdat het onderscheidend vermogen van de berekende correlaties tussen de plaatselijke stempercentages bij twee opeenvolgende verkiezingen betrekkelijk gering is. 


\section{CURRICULUM VITAE}

Mario van Tilburg werd op 6 september 1961 geboren te Helmond. In 1979 haalde hij het VWOdiploma aan het Peelland College te Deurne. In dat jaar begon hij met de studie politicologie aan de Katholieke Universiteit Nijmegen en koos na het kandidaatsexamen in 1983 voor de afstudeerrichting bestuurskunde. In januari 1987 legde hij het doctoraal examen af. Vervolgens trad hij in februari 1987 als Assistent In Opleiding (AIO) in dienst van de Faculteit der Rechtsgeleerdheid van de Rijksuniversiteit Limburg. Aldaar heeft hij als lid van de Werkgroep lokale politiek en later als lid van het Centrum voor Euregionale, Lokale en Provinciale Studies (CELS) tot februari 1992 het in dit proefschrift beschreven onderzoek verricht. Sinds november 1992 is hij assistent van het College en de secretaris van de Algemene Rekenkamer. 
In de discussie over de afstand tussen kiezers en gekozenen op lokaal niveau speelt het geringe lokale karakter van de gemeenteraadsverkiezingen een belangrijke rol. Immers, wat is de relatie tussen kiezers en lokale poli. tici als de kiezers bij de gemeenteraadsverkiezingen op basis van landelijke politieke verhoudingen hun stem uitbrengen. In deze studie wordt nagegaan in welke mate de gemeenteraadsverkiezingen in de periode 1974 1990 een lokaal karakter dragen. Zo wordt een overzicht gegeven van de electorale positie van de lokale lijsten. Tevens worden uitslagen en trends bij de gemeenteraadsverkiezingen geanalyseerd. Vervolgens wordt nagegaan hoe groot de betrokkenheid van burgers bij de lokale politiek is. Afgesloten wordt met een actueel overzicht van de voorstellen om de gemeenteraadsverkiezingen lokaler te maken. 